\title{
Salas abertas
}

formação de professores e práticas pedagógicas em comunicação alternativa e ampliada nas salas de recurso multifuncionais

\section{Leila Regina d'Oliveira de Paula Nunes \\ Carolina Rizzotto Schirmer}

(orgs.)

\section{SciELO Books / SciELO Livros / SciELO Libros}

NUNES, L. R. O. P., and SCHIRMER, C. R., orgs. Salas abertas: formação de professores e práticas pedagógicas em comunicação alternativa e ampliada nas salas de recurso multifuncionais [online]. Rio de Janeiro: EDUERJ, 2017, 357 p. ISBN: 978-85-7511-452-0. Available from: doi:

$\underline{10.7476 / 9788575114520}$. Also available in ePUB from: http://books.scielo.org/id/xns62/epub/nunes9788575114520.epub.

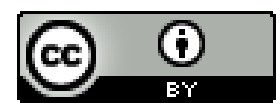

All the contents of this work, except where otherwise noted, is licensed under a Creative Commons Attribution 4.0 International license.

Todo o conteúdo deste trabalho, exceto quando houver ressalva, é publicado sob a licença Creative Commons Atribição $\underline{4.0}$.

Todo el contenido de esta obra, excepto donde se indique lo contrario, está bajo licencia de la licencia $\underline{\text { Creative Commons }}$ Reconocimento 4.0. 


\section{SALAS ABERTAS:}

Formação de Professores

e Práticas Pedagógicas

em Comunicação Alternativa e Ampliada nas Salas de Recursos

Multifuncionais 


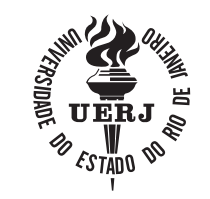

UNIVERSIDADE DO ESTADO DO RIO DE JANEIRO

\author{
Reitor \\ Ruy Garcia Marques
}

Vice-reitora

Maria Georgina Muniz Washington

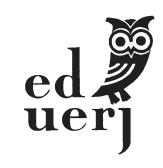

EDITORA DA UNIVERSIDADE DO
ESTADO DO RIO DE JANEIRO

\title{
Conselho Editorial
}

\author{
Bernardo Esteves \\ Erick Felinto \\ Glaucio Marafon (presidente) \\ Jane Russo \\ Maria Aparecida Ferreira de Andrade Salgueiro \\ Italo Moriconi \\ Ivo Barbieri (membro honorário) \\ Lucia Bastos (membro honorário)
}




\section{SALAS ABERTAS: Formação de Professores \\ e Práticas Pedagógicas em Comunicação Alternativa e Ampliada nas Salas de Recursos Multifuncionais}

Organização

Leila Regina d'Oliveira de Paula Nunes

Carolina Rizzotto Schirmer

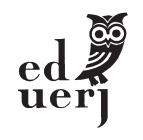

Rio de Janeiro

2017 
Copyright (c) 2017 dos autores.

Todos os direitos desta edição reservados à Editora da Universidade do Estado do Rio de Janeiro. É proibida a duplicação ou reprodução deste volume, ou de parte do mesmo, em quaisquer meios, sem autorização expressa da editora.

EdUERJ

Editora da UNIVERSIDADE DO ESTADO DO RIO DE JANEIRO

Rua São Francisco Xavier, 524 - Maracanã

CEP 20550-013 - Rio de Janeiro - RJ - Brasil

Tel./Fax.: 55 (21) 2334-0720 / 2334-0721

www.eduerj.uerj.br

eduerj@uerj.br

$\begin{array}{ll}\text { Editor Executivo } & \text { Glaucio Marafon } \\ \text { Coordenadora Administrativa } & \text { Elisete Cantuária } \\ \text { Coordenadora Editorial } & \text { Silvia Nóbrega } \\ \text { Assistente Editorial } & \text { Thiago Braz } \\ \text { Coordenador de Produção } & \text { Mauro Siqueira } \\ \text { Supervisor de Revisão } & \text { Elmar Aquino } \\ \text { Revisão } & \text { Erika Neusghwang } \\ \text { Capa, Projeto Gráfico e Diagramação } & \text { Elmar Aquino } \\ & \text { Thiago Netto }\end{array}$

CATALOGAÇ̃̃O NA FONTE

UERJ/REDE SIRIUS/NPROTEC

S161 Salas abertas : formação de professores e práticas pedagógicas em comunicação alternativa e ampliada nas salas de recurso multifuncionais / organizadoras, Leila Regina d'Oliveira de Paula Nunes e Carolina Rizzotto Schirmer. - Rio de Janeiro : EdUERJ, 2017.

$358 \mathrm{p}$.

ISBN 978-85-7511-450-6

1. Educação. 2. Prática de ensino. 3. Professores - Formação. I. Título... 
A todos os professores

das salas de recursos multifuncionais.

A meus netos, Bady, Elias, Julia, Paula, Henrie e Vicente, que dão sentido à minha vida. Ao meu filho João, que enche minha vida de alegria. 


\section{Agradecimentos}

A todos os professores das salas de recursos multifuncionais que participaram desta formação.

À equipe de Oficina Vivencial pelo convite e parceria.

À Direção do Instituto Helena Antipoff, da Secretaria Municipal de Educação do Rio de Janeiro.

Aos nossos bolsistas e assistentes de pesquisa, alunos da UERJ. 


\section{Sumário}

Lista de Abreviaturas

Apresentação

Leila Regina d'Oliveira de Paula Nunes e Carolina Rizzotto Scbirmer

Capítulo 1 - Salas de Recursos Multifuncionais de Referência em

Comunicação Alternativa : caminhos possíveis de uma parceria entre instituição e universidade.

Janaina Larrate, Maristela C. Dias Siqueira, Vera Val de Casas Pimentel, Gabriela Ferreira Ramiro de Souza e Leila Regina d'Oliveira de Paula Nunes

Capítulo 2 - Salas de Recursos Multifuncionais de Referência no Rio de Janeiro: análise de conteúdo das reuniões de pesquisa - 2013- 2016

Leila Regina d'Oliveira de Paula Nunes, Stefhanny Paulimineytrick Nascimento Silva e Carolina Rizzotto Schirmer

Capítulo 3 - Quem são as professoras e quem são os alunos atendidos nas Salas de Recursos Multifuncionais

Leila Regina d'Oliveira de Paula Nunes, Carolina Rizzotto Schirmer, Stefhanny Paulimineytrick Nascimento Silva e Maria Gabriela Lopes Araúijo 
Capítulo 4 - Levantamento das habilidades pedagógicas e das conceituações das professoras das

Salas de Recursos Multifuncionais

Carolina Rizzotto Schirmer, Leila Regina d'Oliveira de Paula Nunes e Stefhanny

Paulimineytrick Nascimento Silva

Capítulo 5 - Análise da formação continuada em serviço sobre Comunicação Alternativa para professores de Sala de Recursos Multifuncionais de Referência: abordagem problematizadora

Carolina Rizzotto Schirmer, Leila Regina d'Oliveira de Paula Nunes

Capítulo 6 - O uso da autoscopia como aliada na formação continuada de professores de Salas de Recursos Multifuncionais 138

Thatyana Machado Silva e Leila Regina d'Oliveira de Paula Nunes

Capítulo 7 - A importância da formação continuada para ampliar os conhecimentos dos professores do Atendimento Educacional Especializado em Comunicação Alternativa e Ampliada

Cláudia Mibaru Togashi, Thatyana Machado Silva e Carolina Rizzotto Schirmer

Capítulo 8 - Relatando a experiência com a Comunicação Alternativa e Ampliada a partir da participação em curso de formação continuada para professores de Salas de Recursos Multifuncionais 177 Gabriela Ferreira Ramiro de Souza e Carolina Rizzotto Schirmer

Capítulo 9 - Comunidade on-line de professores das Salas de Recursos Multifuncionais de Referência Carolina Rizzotto Schirmer 
Capítulo 10 - Material pedagógico adaptado ou especialmente elaborado e os recursos de Comunicação Alternativa e Ampliada postados no WhatsApp

Carolina Rizzotto Schirmer, Luciana Meira Ferreira Pinto e Ana Caroline Rached

Capítulo 11 - Ampliando o olhar sobre o programa de formação continuada de professores das Salas de Recursos Multifuncionais da cidade do Rio de Janeiro

Patrícia Fernandes Ferreira, Leila Regina d'Oliveira de Paula Nunes e Carolina Rizzotto Schirmer

Capítulo 12 - Vamos brincar? O uso da Comunicação

Alternativa para favorecer a brincadeira de crianças com dificuldade na comunicação oral

Leila Ferreira Andrade, Vanessa Queiroz Costa e Carolina Rizzotto Schirmer

Capítulo 13 - Salas Abertas: estratégias de funcionamento das

Salas de Recursos Multifuncionais de Referência 272

Leila Regina d'Oliveira de Paula Nunes, Carolina Rizzotto Schirmer, Luciana Meira Ferreira Pinto e Luiz Eduardo Veras Lopes Pontes

Capítulo 14 - Os encontros de Salas Abertas e seus desdobramentos 293

Majui Menezes de Souza e Carolina Rizzotto Scbirmer

Capítulo 15 - Linguagem, interação e comunicação: competências para o desenvolvimento da criança com deficiência não oralizada 300

Debora Deliberato

Capítulo 16 - PECS - Adaptado na sala de Atendimento

Educacional Especializado 


\section{Lista de Abreviaturas}

AC - Adaptação Curricular

AEE - Atendimento Educacional Especializado

AH/SD - Altas Habilidades/Super Dotação

ARASAAC - Portal Aragonês de Comunicação Alternativa e Ampliada

CAA - Comunicação Alternativa e Ampliada

CBE - Congresso Brasileiro de Educação

CRE - Coordenadoria Regional de Educação

DF - Deficiência Física

DI - Deficiência Intelectual

DV - Deficiência Visual

FAPERJ - Fundação Carlos Chagas Filho de Amparo à Pesquisa do Estado do Rio de Janeiro

IHA - Instituto Helena Antipoff

ISAAC - International Society for Augmentative and Alternative Comunication

MEC - Ministério de Educação e Cultura

NEE - Necessidades Educacionais Especiais

ONEESP - Observatório Nacional de Educação Especial

OV - Oficina Vivencial

PC - Paralisia Cerebral

PCS - Picture Communication System

PECS - Picture Exchange Communication System

PECS-Adaptado - Pessoas Engajadas Comunicando-se Socialmente Adaptado

PEI - Plano Educacional Individualizado

PROPED - Programa de Pós-Graduação em Educação

RAC - Recursos de Acessibilidade do Computador

SDP - Speaking Dinamically Pro

SRM - Sala de Recursos Multifuncionais

SME - Secretaria Municipal de Educação

TA - Tecnologia Assistiva

TEA - Transtorno do Espectro Autista

TGD - Transtorno Global do Desenvolvimento

UERJ - Universidade do Estado do Rio de Janeiro 


\section{Apresentação}

Leila Regina d'Oliveira de Paula Nunes Carolina Rizzotto Schirmer

Em janeiro de 2013, fomos procuradas pela equipe da Oficina Vivencial de Ajudas Técnicas para Ação Educativa, do Instituto Municipal Helena Antipoff - SME, no Rio de Janeiro, que estava interessada em desenvolver uma parceria com a universidade para uma pesquisa que envolveria a formação de professores, com a ideia de realizar um trabalho inovador na área de Tecnologia Assistiva (TA), principalmente na Comunicação Alternativa e Ampliada (CAA). O principal objetivo seria formar uma equipe de professores de Atendimento Educacional Especializado (AEE) para ampliar o trabalho da Oficina Vivencial (OV) por meio das Salas de Recursos Multifuncionais de Referência.

O extenso acervo de estudos sobre a formação continuada de professores e seus achados levou-nos à reflexão de que, mesmo diante das práticas inclusivas e de toda a informação disponível, o professor necessita de conhecimentos específicos, atualizados e fundamentados teoricamente, que deem suporte à resolução dos problemas vivenciados no dia a dia na escola. Esses estudos ainda criticam os modelos de formação continuada adotados pela 
maioria das instituições e defendem que essa formação deveria ser oferecida utilizando-se modelos alternativos, uma vez que os tradicionais são formatados para repassar conhecimentos de caráter meramente informativos, desvinculados da realidade de sala de aula, que não contemplam as necessidades dos professores e dos alunos, e que, por isso, pouco contribuem para a modificação das concepções e práticas destes.

Outro ponto importante a ser pensado é a separação entre a pesquisa e a prática educacional e entre os planejadores e executores das ações educativas, o que torna a função do professor esvaziada e desqualificada, já que sua missão se resume a validar, na prática, o conhecimento científico previamente elaborado por pesquisadores fora do contexto escolar (Machado, 1999). Zeichner (1992) e Nóvoa (1992) argumentam que, além de apresentar críticas ao modelo da racionalidade técnica, Schön apontou possibilidades de mudança, introduzindo a necessidade de repensar-se a epistemologia da prática, fundamentada na reflexão a partir de situações concretas. Dessa maneira, a formação de professores ganha outra dimensão, passando a ser centrada na investigação do próprio trabalho no contexto escolar. Esse modelo ficou conhecido como modelo da prática reflexiva, e há um consenso na literatura sobre a relevância de sua incorporação nas formações inicial e continuada de professores.

Partindo dessas ideias de que o modelo de formação deveria estar vinculado à realidade da sala de aula, atendendo às necessidades dos professores e pensando no modelo da prática reflexiva, surgiu a nossa proposta de formação continuada em serviço de professores de Salas de Recursos Multifuncionais para atuar com TA, principalmente a CAA, que é o tema principal deste livro.

Esta publicação apresenta a pesquisa desenvolvida por nós, não apenas pesquisadores e assistentes de pesquisa vinculados ao grupo de pesquisa Comunicação Alternativa do Programa de Pós-Graduação em Educação da UERJ e seus colaboradores, mas também a equipe da OV e, é claro, todas as professoras que se envolveram com o projeto ao longo dos quatro anos de formação. A pesquisa foi financiada com a bolsa Cientista do Nosso Estado para Leila Regina d'Oliveira de Paula Nunes (FAPERJ - Proc. 102.319/2013) e bolsa de pós-doutorado para Carolina Rizzotto Schirmer (CNPq - Proc. 501388/2013-3). 
O livro oferece ao leitor contribuições teórico-práticas relativas às áreas de Educação Especial, Formação de Professores, Tecnologia Assistiva, Comunicação Alternativa e Ampliada, além de constituir um trabalho de grande importância para a consulta por parte daqueles que atuam ou pretendem atuar nas áreas da Educação Especial e da CAA. Ao longo dos dezesseis capítulos são discutidas questôes relativas à formação continuada em serviço de professores, comunicação alternativa e ampliada, materiais pedagógicos e lúdicos adaptados, informática acessível, entre outros.

Esperamos que este livro contribua para a área da Educação Especial e CAA, e que as metodologias, os conteúdos e as atividades descritas e discutidas na presente obra possibilitem aos professores e aos demais profissionais e interessados uma revisão de suas concepções e práticas pautadas na diversidade.

Leila Regina d'Oliveira de Paula Nunes Carolina Rizzotto Schirmer 


\title{
Capítulo 1 - Salas de Recursos Multifuncionais de Referência em Comunicação Alternativa: caminhos possíveis de uma parceria entre instituição e universidade
}

\author{
Janaina Larrate ${ }^{1}$ \\ Maristela C. Dias Siqueira ${ }^{2}$ \\ Vera Val de Casas Pimentel 3 \\ Gabriela Ferreira Ramiro de Souza ${ }^{4}$ \\ Leila Regina d'Oliveira de Paula Nunes
}

1 Secretaria Municipal de Educação do Rio de Janeiro. E-mail: ofvivencialiha@rio.rj.gov.br

2 Secretaria Municipal de Educação do Rio de Janeiro. Mestranda em Educação pelo Programa de Pós-Graduação em Educação da UERJ. E-mail: ofvivencialiha@rio.rj.gov.br

3 Secretaria Municipal de Educação do Rio de Janeiro. E-mail: ofvivencialiha@rio.rj.gov.br

4 Secretaria Municipal de Educação do Rio de Janeiro. E-mail: ofvivencialiha@rio.rj.gov.br

5 Professora titular da Faculdade de Educação e do Programa de Pós-Graduação em Educação da UERJ. E-mail: leilareginanunes@terra.com.br 


\section{Quem somos?}

A Oficina Vivencial de Ajudas Técnicas para a Ação Educativa (OV) é um serviço oferecido pelo Instituto Municipal Helena Antipoff (IHA) ${ }^{6}$, voltado para a orientação e formação continuada de professores que atuam com alunos com deficiência, matriculados na rede pública municipal de ensino do Rio de Janeiro, no que se refere à avaliação, uso, pesquisa e produção de Tecnologia Assistiva $(\mathrm{TA})^{7}$, direcionado àqueles que apresentem prejuízos na comunicação e na mobilidade. Uma das suas principais vertentes de trabalho está na orientação e na formação continuada dos professores do Atendimento Educacional Especializado $(\mathrm{AEE})^{8}$, principalmente dos que atuam nas Salas de Recursos Multifuncionais (SRMs).

\section{Nossa História}

Criada em 1994 - época em que se vivia intensamente a mudança de paradigma de uma educação baseada no modelo integracionista, em transição para uma educação inclusiva -, a Oficina Vivencial chegou com uma

6 IHA - Órgão da Secretaria Municipal de Educação (SME) da cidade do Rio de Janeiro, responsável pela implementação das políticas públicas que normatizam a Educação Especial na perspectiva da Educação Inclusiva, no âmbito da rede municipal de ensino, atuando em consonância com as legislações federal e internacional para garantir os direitos dos alunos com deficiência, Transtorno Global do Desenvolvimento (Transtorno de Espectro Autista) e altas habilidades/superdotação, no que tange ao acesso e permanência nas turmas comuns, em igualdade de condiçôes com os demais.

7 "Área do conhecimento, de característica interdisciplinar, que engloba produtos, recursos, metodologias, estratégias, práticas e serviços que objetivam promover a funcionalidade, relacionada à atividade e participação, de pessoas com deficiência, incapacidade ou mobilidade reduzida, visando à sua autonomia, independência, qualidade de vida e inclusão social” (CORDE, 2007).

8 "Realiza o Atendimento Educacional Especializado, disponibiliza os recursos e serviços e orienta quanto à sua utilização no processo de ensino e aprendizagem nas turmas comuns do ensino regular" (MEC, 2008, p. 10). 
proposta inovadora de oferecer recursos e serviços da TA aos alunos com deficiência física, incluídos nas turmas comuns das escolas municipais, para atender às suas necessidades de acessibilidade ao espaço escolar, de comunicação, informação e de conhecimento.

Figura 1. Áreas de abrangência das Coordenadorias Regionais de Educação da cidade do Rio de Janeiro

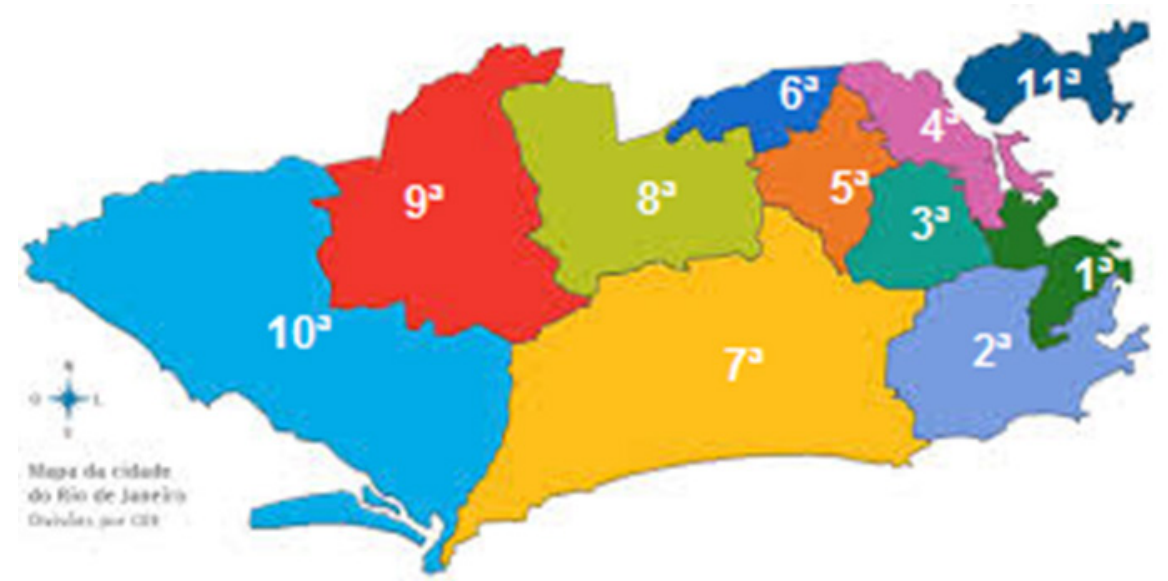

Fonte: escolasdoamanha.rioeduca.rio.gov.br/AreaPublica/Escolas.aspx.

Paulatinamente, no decorrer da última década, a OV rediscute seu papel e amplia sua atuação, consolidando-se como referência em Comunicação Alternativa e Ampliada (CAA) ${ }^{9}$ para as escolas da rede municipal. O foco do trabalho, antes restrito ao aluno com deficiência física/neuromotora, passa a abranger todos aqueles que podem se beneficiar do seu uso, independentemente da deficiência que possui. Acompanhando professores e alunos de uma das maiores redes de ensino da América Latina, observa-se a necessidade da ampliação das formas de ofertar formação continuada em serviço aos professores.

Distribuídos pelas 1.013 escolas de ensino fundamental e 514 unidades de Educação Infantil, nas 11 Coordenadorias Regionais de Educação (CREs), a cidade do Rio de Janeiro, no ano de 2016, possuía, aproximada-

9 É toda forma de comunicação que complementa ou substitui a linguagem oral e/ou escrita. 
mente, 650 mil alunos. Desse total, 13 mil eram acompanhados pela Educação Especial, sendo cerca de 8 mil incluídos em turmas comuns e atendidos por 474 Salas de Recursos Multifuncionais em horário de contraturno.

Esses números refletem a proporção do desafio que se fazia presente "para garantir a aprendizagem, por meio da oferta de serviços e de recursos de acessibilidade que eliminem as barreiras e promovam a inclusão plena" (Brasil, 2015 - Cap. IV, Art. 27, \$2).

Para a OV, o desafio de oferecer serviços e recursos de acessibilidade que promovam a inclusão plena dos alunos com deficiência se refletia na procura de caminhos que auxiliassem a promoção da autonomia dos professores do AEE, na condução do seu fazer pedagógico, em relação à implementação do uso da CAA pelo alunado que não possui fala oral e/ou escrita funcional.

A experiência com a formação continuada, acumulada em vinte anos de existência do serviço, vinha demonstrando, ainda que intuitivamente, que a utilização da CAA por esses alunos era muito restrita se comparada ao universo daqueles que dela necessitavam. Quais seriam as razões? Levantamos algumas hipóteses: Os modelos de formação, até então oferecidos, organizados em cursos presenciais com temas pré-estabelecidos, não seriam suficientes à clientela? Demandavam outros formatos? Em caso afirmativo, quais poderiam ser estes?

Outra questão relevante seria a própria extensão da rede e o aumento progressivo no número de alunos incluídos, tornando necessária a ampliação do serviço da OV em espaços mais regionalizados pela cidade. De que forma promovê-la?

Buscando possíveis respostas aos problemas apresentados, firmamos parceria de pesquisa com as professoras pesquisadoras do Programa de Pós-Graduação em Educação da Universidade do Estado do Rio de Janeiro (ProPEd/UERJ). Em estudo iniciado em 2013, apresentado à Secretaria Municipal de Educação, o projeto "A Formação Continuada de Professores das Salas de Recursos Multifuncionais do Rio de Janeiro em Tecnologia Assistiva"10 teve como objetivo implementar e avaliar um programa de formação em

10 Projeto financiado com a bolsa "Cientista do Nosso Estado" para Leila Regina d'Oliveira de Paula Nunes (FAPERJ - Proc. 102.319/2013) e bolsa de pós-doutorado para Carolina R. Schirmer (CNPq - Proc. 501388/2013-3). 
serviço de professores para atuação em Sala de Recursos Multifuncionais de Referência.

Os professores seriam ensinados a planejar, utilizar e avaliar recursos e serviços da TA nas áreas ligadas à escola, sobre a CAA, o acesso ao computador a atividades e materiais pedagógicos adaptados para atender aos alunos que apresentassem severos comprometimentos em sua comunicação oral, como aqueles com paralisia cerebral, autismo e deficiência múltipla (Schirmer e Nunes, 2013).

As SRMs, onde os participantes do projeto atuavam, passariam a caracterizar-se como "Salas de Recursos Multifuncionais de Referência em Tecnologia Assistiva”, com ênfase em CA - espaços de difusão da TA, de estratégias pedagógicas e conhecimento para os demais professores das SRMs convencionais, na abrangência das 11 CREs. Dessa forma, buscava-se ampliar o alcance das ações da $\mathrm{OV}$, de modo a abarcar um maior número de professores do AEE, nas práticas que envolvessem o uso da TA, especialmente a CAA.

Como fios de uma peça tecida a várias mãos, foi organizado um projeto-piloto em que a instituição e a universidade uniram-se em suas propostas de formação continuada em serviço.

Neste capítulo, abordaremos os caminhos percorridos pela parceria da pesquisa iniciada em 2013 e finalizada em 2016. Todos os professores participantes foram indicados pelas Coordenadorias de Educação e Equipes de Acompanhamento do IHA, a partir dos seguintes critérios: ter formação na área de CAA, por meio dos cursos oferecidos pelo IHA ou demais instituições de ensino; atuar em uma Sala de Recursos que tenha recebido material disponibilizado pelo MEC; possuir conhecimentos básicos de informática; exibir habilidade para atuar como dinamizador de encontros e palestras e demonstrar interesse em fazer parte do projeto. A OV garantiu também a estrutura legal da certificação da presença na formação continuada da rede municipal, por meio de cursos anuais autorizados pela SME. 


\section{Desenvolvimento}

Ao longo desses quatro anos, participaram, em média, 18 professores ${ }^{11}$. As metodologias utilizadas delinearam-se de acordo com as necessidades do grupo. Inicialmente, utilizamos a Problematização, que possibilitou a identificação de situações-problema, mediante casos de alunos acompanhados pelos cursistas, para que fossem levantadas suas necessidades, habilidades e dificuldades. Esse levantamento foi a base para o desenvolvimento da estrutura do estudo, com a definição das temáticas que seriam abordadas daí em diante, com palestras de convidados ou da própria equipe OV/UERJ, oficinas e discussão de casos, alternando o formato, de individual, em pequenos grupos e coletivamente. Os conteúdos formativos foram organizados a partir das necessidades apontadas pelos participantes enfatizando o planejamento, a execução e a avaliação de serviços e dos recursos da CAA pertinentes ao trabalho realizado nas SRMs.

Entre os temas solicitados, os mais discutidos foram aqueles que estavam diretamente envolvidos com as atribuições do professor da SRM: linguagem e comunicação; estratégias de ensino e intervenção de CAA com os alunos; utilização de sistemas de CAA para alunos com Transtorno do Espectro Autista; Plano Educacional Individualizado (PEI); aplicativos de CAA para tablets; e adaptação de materiais pedagógicos.

Os encontros foram realizados na sala da OV, no IHA, e, eventualmente, no Laboratório de Tecnologia Assistiva da UERJ. Também foram utilizadas nas SRMs das professoras participantes em encontros específicos, totalizando 160 horas de formação em serviço.

Organizadas de modo a valorizar o conhecimento de todos os participantes, as atividades seguiram os pressupostos da Aprendizagem Colaborativa:

Parte da ideia de que o conhecimento é resultante de um consenso entre membros de uma comunidade de conhecimento, algo que as pessoas constroem conversando, trabalhando juntas direta ou indiretamente (i.e., resolução

11 Esse é o quantitativo mais frequente de professores. Alguns se ausentaram temporariamente da formação, enquanto outros ingressaram mais recentemente. 
de problemas, projetos, estudos de caso etc.) e chegando a um acordo (Torres et al., 2004, pp. 2-3).

Com efeito, uma das atividades que mais contribuiu para a pesquisa foi a de assistir a pequenos blocos de filmagens de quatro participantes que se voluntariaram para registrar sua atuação com os alunos sem comunicação oral nas suas Salas de Recursos. Tomadas como ponto de partida para as discussōes, acabaram por possibilitar aos professores a saída da condição de receptores passivos, valorizando seus próprios conhecimentos e construindo um arcabouço teórico sobre sua prática. Essas experiências permitiram um desdobramento da pesquisa com o aprofundamento das análises dessas filmagens, utilizando-se da metodologia de autoscopia ${ }^{12}$, com a participação de duas professoras em encontros que precediam os do grupo maior, mantendo-se, contudo, a proposta de estudarem os temas de interesse geral, de desenvolvimento da linguagem e comunicação.

De modo geral, os dois primeiros anos foram voltados a um conteúdo mais formativo, e os dois últimos, dedicados ao planejamento dos encontros das Salas Abertas ${ }^{13}$ para uma futura implementação das Salas de Recursos Multifuncionais de Referência em TA, com ênfase em CAA.

Abordando temas como "Começar do começo...", que discutia sobre quem eram os alunos que necessitavam de CAA e como se podia começar a desenvolver na escola a aplicação desta, especificamente, para crianças com autismo; esses encontros foram progressivamente ampliados à medida que as professoras participantes sentiam-se mais preparadas para assumirem a proposta.

Em 2015, foram realizados dois encontros das Salas Abertas em quatro CREs, com oito professoras, das quais metade optou por trabalhar em

12 A metodologia da autoscopia foi empregada quando as filmagens realizadas eram previamente vistas pela pesquisadora da UERJ, que selecionava trechos específicos das filmagens para serem analisados pelas professoras dos alunos, que faziam, em um primeiro momento, sua autoanálise e, a seguir, discutiam os pontos observados com o grupo de pesquisadores.

13 Encontros dos professores participantes com seus colegas de SRM, das suas respectivas CREs, destinados à troca de experiências, reflexão e oficinas pedagógicas para professores iniciantes de SRM e que tivessem alunos com necessidade de CAA. 
duplas. Em 2016, mais duas Salas Abertas aconteceram, envolvendo todas as professoras participantes, em todas as coordenadorias. Ao todo, dessas quatro Salas Abertas, participaram 333 professores.

\section{Conclusão}

De início, o que se observou ao verificar o perfil das professoras indicadas pelas CREs é que, embora apresentassem interesse e disponibilidade para participar da pesquisa, nem todas tinham experiência e conhecimento prévio sobre TA e CAA. A Metodologia da Problematização permitiu que se trouxesse o foco da formação continuada em serviço para as necessidades do grupo, não a enquadrando em uma proposta fechada.

Manter o grupo de pesquisa com todos os participantes por um período de tempo relativamente longo não é tarefa fácil na rede municipal como um todo. Durante esses quatro anos, tivemos a rotatividade de aproximadamente $30 \%$ das professoras participantes. Esse dado aponta a necessidade de se criarem estratégias para manter a unidade da proposta.

Durante o trajeto da pesquisa, foi possível verificar a mudança de atitude das professoras participantes em relação aos alunos com dificuldade ou ausência de fala oral e/ou escrita funcional, por meio dos relatos e da utilização mais frequente dos recursos e das estratégias de CAA no ambiente escolar. As trocas entre os membros do grupo e a participação no processo de análise da própria prática pedagógica contribuíram para sua percepção como parte de um processo maior: entenderem que não estão sozinhos para enfrentar as dificuldades encontradas e que podem compartilhar o que sabem com seus pares.

As Salas Abertas se configuraram como um momento de troca de conhecimento e experiência bem avaliado não apenas pelas professoras participantes da pesquisa, como também por aquelas que foram convidadas, cujos relatos estão ilustrados a seguir:

Professora C (3. $\left.{ }^{\text {a }} \mathrm{CRE}\right)$ : "Desde o primeiro encontro, utilizo as imagens para CAA em SR, mas este foi mais produtivo sobre a forma de como produzir e 
aplicar. Consegui tirar várias dúvidas e, devido a isso, acho que seria ótimo vários encontros".

Professora A (1. $\left.{ }^{\text {a }} \mathrm{CRE}\right)$ : "Foi muito bom estar aqui, neste encontro, trocando experiências e sendo incluída neste universo da Educação Especial. O filme, os slides e a produção de material. Tudo muito proveitoso! Obrigado por me oportunizar momentos de crescimento como esse".

Professora D (4. $\left.{ }^{\mathrm{a}} \mathrm{CRE}\right)$ : “Gostei muitoooo! Adorei este e quero outros, como são boas estas trocas! Descobrimos que não estamos sós nesta missão, que estas pessoas (profissionais) sofrem das mesmas angústias, mas que também compartilham de sucessos. Estarei em todas que for convocada ou convidada. Parabéns!”.

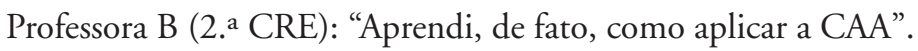

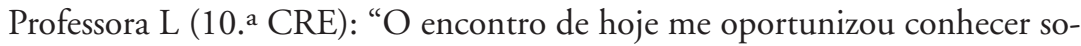
bre Comunicação Alternativa e com essa experiência saio daqui bastante motivada para buscar mais conhecimento e poder aplicar nas minhas práticas".

Professora C (5. $\left.{ }^{a} \mathrm{CRE}\right)$ : "O fortalecimento do grupo de AEE perpassa por esses encontros, assim como uma melhor qualificação da equipe. A generosidade da V. assim como seus conhecimentos e humildade nos enriquece e simplifica o que possa parecer demasiadamente complexo. Os encontros foram bem produtivos e numa linguagem bem próxima à nossa realidade cotidiana. Fui capaz de fazer links e pensar em atividades para alunos específicos que atendo na Sala de Recursos Multifuncional".

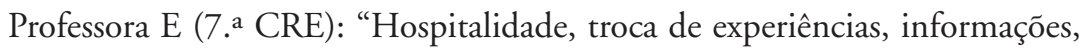
praticidade, novas ideias e cooperação". 
Professora F (9. $\left.{ }^{a} \mathrm{CRE}\right)$ : "Tudo foi positivo: troca de experiência, elaboração do PEI, oficina, material disponibilizado e a dinamizadora".

Professora G (11. a CRE): "Amei o encontro! Amei as trocas, Amei fazer o jogo cara a cara. Precisamos sempre de encontros assim!”.

Professora M (10. $\left.{ }^{\text {a }} \mathrm{CRE}\right)$ : "Eu achei interessante, pois o momento foi de compartilhar experiências e ideias, importantes para o desenvolvimento do trabalho do professor".

Professora $\mathrm{G}$ (8. $\left.{ }^{\mathrm{a}} \mathrm{CRE}\right)$ : $\mathrm{O}$ encontro foi produtivo, à medida que favoreceu $o$ acesso dos professores que ainda não conhecem a fundo a importância da Comunicação Alternativa como um importante recurso a ser utilizado com alunos não oralizados, e também um momento de troca, que, com certeza, enriqueceu a todos".

Avaliamos, ao final desse processo, que a implementação das Salas de Recursos Multifuncionais de Referência em TA, com ênfase em CAA, é viável e poderá trazer ganhos à formação continuada em serviço da rede municipal de professores do AEE e, especialmente, no que se refere à ampliação da acessibilidade de comunicação e informação aos seus alunos incluídos com dificuldade ou impossibilidade de fala oral e/ou escrita funcional. Sem esquecer, no entanto, que é preciso que se garantam as condições necessárias de tempo, recursos humanos e materiais, bem como a sistematização dos encontros com a OV, com permanente estudo, para manter e ampliar os resultados até aqui alcançados. 


\section{Capítulo 2 - Salas de Recursos Multifuncionais de Referência no Rio de Janeiro: análise de conteúdo das reuniões de pesquisa - 2013-2016}

Leila Regina d'Oliveira de Paula Nunes ${ }^{1}$ Stefhanny Paulimineytrick Nascimento Silva ${ }^{2}$ Carolina Rizzotto Schirmer ${ }^{3}$

\section{Introdução}

O processo de inclusão escolar de alunos com deficiência e com Transtorno do Espectro Autista (TEA) resultou na presença crescente desse alunado nas salas de aula regulares nas últimas décadas. De modo a favorecer esse processo, o Atendimento Educacional Especializado foi instituído pelo MEC em 2008. O AEE, ofertado preferencialmente nas SRMs, tem como função

1 Professora titular da Faculdade de Educação e do Programa de Pós-Graduação em Educação da UERJ. E-mail: leilareginanunes@terra.com.br.

2 Mestranda em Educação pelo Programa de Pós-Graduação em Educação da UERJ. E-mail: stefhannyp@gmail.com.

3 Professora adjunta da Faculdade de Educação da UERJ. E-mail: ead.carolina@gmail. com. 
complementar ou suplementar a formação do aluno por meio da disponibilização de serviços, recursos de acessibilidade e estratégias que eliminem as barreiras para sua plena participação na sociedade e desenvolvimento de sua aprendizagem.

O município do Rio de Janeiro possui 1.013 escolas de Ensino Fundamental e 514 unidades de Educação Infantil, onde são atendidos 13.336 alunos especiais. Desses, 8.758 frequentam as 474 SRMs. Considerando a complexidade do cotidiano escolar, o Instituto Helena Antipoff ${ }^{4}$, por meio da Oficina Vivencial 5 , e a UERJ desenvolveram um projeto para a implantação de Salas de Recursos Multifuncionais de Referência em cada uma das 11 Coordenadorias Regionais de Educação (CREs). O propósito último é que tais salas constituam-se, no futuro, em polos de referência no desenvolvimento e na disseminação dos procedimentos e recursos de TA, da CAA, da informática acessível e demais estratégias pedagógicas, com o intuito de apoiar os demais professores que trabalham nas SRMs convencionais.

O objetivo da pesquisa foi planejar, implementar e avaliar um programa de formação continuada em serviço de professores das SRMs da rede pública de ensino do município do Rio de Janeiro para atuação nessas Salas. Mais especificamente, esses professores foram ensinados a planejar, implementar e avaliar recursos e serviços da TA nas áreas ligadas à escola, tais como CAA, acesso ao computador e, ainda, atividades e materiais pedagógicos adaptados para atender alunos do ensino fundamental que apresentassem

4 O Instituto Municipal Helena Antipoff (IHA) é o órgão da Secretaria Municipal de Educação do Rio de Janeiro que tem sob sua responsabilidade a implementação de políticas públicas voltadas à educação de alunos com deficiência, transtorno global do desenvolvimento e altas habilidades, incluindo o acompanhamento de propostas promotoras do desenvolvimento e aprendizagem dos alunos público-alvo da Educação Especial na perspectiva da educação inclusiva.

5 A Oficina Vivencial de Ajudas Técnicas para Ação Educativa é um serviço promovido pelo Instituto Helena Antipoff e destina-se aos alunos com deficiência e transtorno global do desenvolvimento, direcionando seu trabalho na busca de estratégias e recursos da TA que facilitem a participação desses educandos nas atividades escolares cotidianas e contribuindo para a inclusão escolar. 
severos comprometimentos em sua comunicação oral, como aqueles com paralisia cerebral, TEA e deficiência múltipla.

Os pressupostos da ação educativa, implementada nessa formação continuada de professores, encontram-se na abordagem denominada "Problematização", segundo a qual os conteúdos de ensino não são oferecidos aos alunos (no caso, as professoras da SRM) em sua forma acabada, mas na forma de problemas extraídos da realidade, cujas relaçōes devem ser descobertas e construídas pelo aluno, que reorganiza o material, adaptando-o à sua estrutura cognitiva prévia, para descobrir relaçóes, leis ou conceitos que precisará assimilar (Cyrino e Toralles-Pereira, 2004).

\section{Método}

O projeto original, do qual o presente estudo faz parte, constituiu-se em uma pesquisa quali-quantitativa, com diversos objetivos específicos e um conjunto de vários procedimentos. $\mathrm{O}$ presente estudo envolveu uma pesquisa qualitativa centrada na análise de conteúdo das sessões de pesquisa realizadas de forma sistemática ao logo desses quatro anos:

Participantes: dezoito ${ }^{6}$ professores de SRM, pesquisadoras da UERJ e a equipe da $\mathrm{OV}$.

Local e instrumentos: Oficina Vivencial de Ajudas Técnicas para Ação Educativa do IHA. Os instrumentos utilizados foram os seguintes: questionários para descrever o perfil e o conhecimento das professoras acerca de diversos temas, a clientela dos alunos sem fala articulada atendidos, os recursos físicos e humanos das escolas (adaptaçóes do material escolar, recursos de informática acessível e de CAA) e o diário de campo das pesquisadoras (que continha suas impressões e anotações). Além desses, filmadora e gravadores de voz digitais foram utilizados, assim como computadores/notebooks, plastificadora e impressoras. Figuraram ainda softwares e aplicativos de CAA, sistemas de CAA de baixa tecnologia, recursos de acessibilidade ao computador,

6 Este é o quantitativo mais frequente de professores. Alguns se ausentaram temporariamente da formação, enquanto outros ingressaram mais recentemente. 
bem como materiais escolares e pedagógicos adaptados. O software Atlas $\mathrm{TI}^{7}$ foi utilizado para auxiliar na análise de conteúdo das sessões filmadas.

Procedimentos gerais: o projeto foi submetido à direção do IHA e à Comissão de Ética em Pesquisa da UERJ, sendo aprovado (Parecer Coep n.o 336.622 - 11/07/2013).

Procedimentos específicos: todo o estudo envolve um conjunto de diversas atividades, a saber: aplicação de questionários para caracterizar as professoras de SRM e suas concepções acerca da deficiência, TA e CAA, características do alunado atendido, entrevistas acerca das relações desses professores com as professoras das salas regulares, oferta do curso de formação com metodologia problematizadora, elaboração de estudos de caso pelas professoras, oferta de palestras com especialistas acerca de Comunicação e Interação, Comunicação Alternativa e Linguagem, Salas de Recursos Multifuncionais e Atendimento Educacional Especializado, PECS-Adaptado ${ }^{8}$ - CAA para pessoas com Transtornos do Espectro Autista -, software Boardmaker',

7 Poderosa ferramenta de análise de dados dinâmicos da atualidade, pois opera com praticamente qualquer tipo de arquivo ou mídia, cruzando dados sem restrições de tamanho ou extensão dos arquivos que analisa e produzindo relatórios e sistemas de dados claros e objetivos a partir dos critérios estabelecidos pelo próprio usuário.

8 PECS-Adaptado é um sistema de comunicação alternativa por meio do intercâmbio de figuras destinado a pessoas com autismo. $\mathrm{O}$ indivíduo oferece o cartão pictográfico ao seu interlocutor para receber o item desejado. Esse sistema consiste em uma adaptação do PECS [Picture Exchange Communication System] ao contexto brasileiro e possui flexibilidade para os diferentes contextos: escolar, familiar e especializado.

9 Programa utilizado para a criação de pranchas, cartôes de comunicação e também para material lúdico e pedagógico. É um banco de dados gráficos que contém mais de 8.000 símbolos do Picture Communication System. 
software Speaking Dinamically Pro ${ }^{10}$, TICO ${ }^{11}$, ARASAAC $^{12}$ e estudo do desempenho das professoras em atendimento a seus alunos por meio da autoscopia $^{13}$. Mais recentemente, planejamento e implementação das chamadas Salas Abertas, com oferta de palestras e workshops aos demais professores das SRMs tradicionais pelas professoras participantes desse estudo.

Trinta e cinco sessões da pesquisa foram conduzidas nos anos de 2013, 2014, 2015 e 2016, durante as quais foram desenvolvidas as atividades listadas anteriormente. Tais sessōes foram filmadas, transcritas e submetidas à análise de conteúdo, contando com o auxílio do Atlas TI. O foco principal do presente trabalho é a análise de conteúdo dessas sessōes.

10 Programa que permite a criação de pranchas dinâmicas, no qual o aluno visualiza sua prancha principal no monitor do computador e, ao acessar um símbolo, que representa outro tema, automaticamente acontece a mudança da prancha, para que ele possa falar sobre o assunto desejado. Também pode ser utilizado para a realização de atividades pedagógicas interativas.

11 Aplicação livre de pranchas de comunicação interativas. Pode ser usado em celulares smartphone e/ou tablet, tendo uma mobilidade muito grande.

12 ARASAAC -Portal Aragonês de Comunicação Alternativa e Ampliada, desenvolvido e mantido pelo Centro Aragonés de Tecnologías para la Educación (CATEDU) que disponibiliza um sistema de livre distribuição de pictogramas, ferramentas e softwares para a construção de recursos de Comunicação Alternativa e Ampliada - CAA (Portal Arasaac, 2013). Esse sistema foi desenvolvido com o objetivo de garantir a comunicação como direito universal, a difusão e o uso em qualquer contexto, como educativo, terapêutico e outros.

13 Uma ação na qual o eu analisa-se em torno de uma finalidade, a partir de um objetivo específico. Trata-se de um procedimento de coleta de dados que registra, por meio da videogravação, a ação do sujeito e, em sequência, coloca-o como avaliador de seu próprio desempenho. 


\section{Resultados}

No quadro a seguir, estão apresentados o número de sessões de pesquisa conduzidas, filmadas e transcritas nos anos de 2013, 2014, 2015 e 2016 e os temas nelas discutidos.

\begin{tabular}{|c|c|c|}
\hline Ano & Número de sessões & Temas tratados \\
\hline 2013 & 12 & $\begin{array}{l}\text { Descrição dos casos estudados } \\
\text { Dificuldades } \\
\text { Inclusão } \\
\text { Recursos para o aluno } \\
\text { Sugestões de práticas instrucionais } \\
\text { Dúvidas teórico-práticas } \\
\text { Concepçōes de comunicação }\end{array}$ \\
\hline 2014 & 9 & $\begin{array}{l}\text { Recursos da CAA } \\
\text { Comunicação e interação } \\
\text { Linguagem, fala e pensamento } \\
\text { CAA e inclusão } \\
\text { AEE } \\
\text { Família } \\
\text { Relação entre as professoras } \\
\text { Desempenho das professoras } \\
\text { Dificuldades administrativas } \\
\text { Estudos de caso } \\
\text { Adaptações curriculares } \\
\text { Plano Educacional Individualizado (PEI) } \\
\text { Metodologia da problematização } \\
\text { Leitura e escrita } \\
\text { Ensino naturalístico } \\
\text { Projeto das salas abertas } \\
\text { Análise de dados na pesquisa }\end{array}$ \\
\hline
\end{tabular}




\begin{tabular}{|l|l|l|}
\hline Ano & Número de sessôes & Temas tratados \\
\hline 2015 & 8 & Comunicação e interação \\
& & Relação entre as professoras \\
& & Dificuldades administrativas \\
& & Desempenho das professoras \\
& & Metodologia da problematização \\
& & Adaptações curriculares \\
& & PEI \\
& & Família \\
& & Estudo de caso \\
& Leitura e escrita \\
\hline & 7 & Comunicação \\
& & Desempenho das professoras \\
& Dificuldades administrativas \\
& Relação entre as professoras \\
& Família \\
& Estudo de caso \\
& Projeto de pesquisa \\
& Comunicação Alternativa: conversa \\
& Comunicação: aplicativos \\
& Salas abertas \\
& PEI \\
\hline
\end{tabular}

Serão apresentados, a seguir, os conteúdos tratados nas sessões em cada ano.

\section{Sessões de 2013}

Em 2013, as atividades da pesquisa concentraram-se na oferta de palestras sobre Comunicação e Interação, Comunicação Alternativa e Linguagem e PECS-Adaptado, e de workshops sobre emprego dos softwares Boardmaker e Speaking Dinamically Pro. No curso de formação com a metodologia problematizadora, as professoras formaram grupos de três a quatro participantes, observaram e registraram o desempenho de um aluno com deficiência em seu conteúdo, problematizando-o. Elegeram o foco do estudo, redigiram e justificaram a escolha do problema pertinente à educação, referente ao caso 
do aluno. Elas ainda identificaram possíveis fatores associados ao problema e seus determinantes ${ }^{14}$.

As professoras procederam a uma reflexão, captando os vários aspectos envolvidos no problema e verificando o que pertencia à escola e, mais especificamente, ao AEE. Elegeram, com critérios, os aspectos que serão estudados na etapa seguinte e redigiram os pontos-chave de aprofundamento teórico-prático. Em seguida, elas elaboraram as hipóteses de solução para o problema, com base na teorização e nas etapas anteriores. Aprenderam a utilizar o software Boardmaker para produzir e pensar nos recursos adaptados e em estratégias. As docentes explicaram e argumentaram sobre as hipóteses elaboradas. Foram apresentadas ao software Speaking Dinamically Pro com o objetivo de utilizá-lo nos casos estudados. Apresentaram os casos com a análise da aplicabilidade das hipóteses levantadas ou em prática - planejamento da execução das ações - e a análise dos resultados.

Alguns aspectos dessas propostas e discussões merecem destaque e são apresentados a seguir.

Quando discutiam sobre os alunos não oralizados que já estão no segundo segmento do ensino fundamental e que não estão alfabetizados, as professoras questionaram sobre o que ensinar na SRM: acompanhar os referenciais curriculares da série escolar, como as professoras fazem para todos os alunos da turma, ou seguir o plano de trabalho individualizado para o aluno especial? Como disse uma professora, "até que ponto o papel da sala de recursos, nesse momento, é investir na alfabetização, fazer um trabalho paralelo de alfabetização ou de adequação dessa proposta”. Se o aluno tem de responder às perguntas de compreensão de um texto lido, como ele o fará? Por meio de imagens em uma prancha? Mas é importante que haja sempre mais de duas opções de resposta.

As adaptações são necessárias para ajustar as necessidades do aluno especial às exigências dos referenciais curriculares. Ressalte-se que a professora deve dar prioridade ao que é funcional para a vida do aluno. "Só vale a pena a gente seguir ali o que está no currículo, para uma criança que é integrada,

14 Uma descrição detalhada desses estudos de caso é apresentada no capítulo "Análise da formação continuada em serviço sobre comunicação alternativa para professores de Salas de Recursos Multifuncionais de Referência: abordagem problematizadora”. 
se a gente realmente tiver certeza que aquilo ali pra ele vai ser significativo ou não”. Qual a função do mediador junto a professores que atendem alunos do sexto ao nono ano. Para quem priorizar o mediador?

Para tornar o uso das pranchas em sala de aula mais aceitável e interessante, as professoras sugerem uma "semana da inclusão", durante a qual elas ensinariam os outros alunos a usarem a prancha. Surgem alternativas para o aluno com deficiência motora grave, sobretudo nos membros superiores - "utilizar um adaptador para o pé e usar a boca como mais um recurso, já que usar a mão é mais difícil". O importante é que o aluno possa escolher o recurso ou a forma de comunicação que seja mais adequada para ele.

$\mathrm{O}$ relacionamento das professoras das SRMs com as professoras das salas comuns foi igualmente alvo de discussão, como afirmou uma participante: "Já aconteceram casos de professores da sala de recursos dar material e a professora da sala de aula comum não usar". E completa: "no olhar das professoras é possível identificar seus pensamentos como: Ela não faz nada, vem pra cá e quer que a gente faça. Esse é o meu desafio diário”.

As falas das professoras sobre os recursos de CAA, sejam os de baixa tecnologia, como pranchas, e de alta tecnologia - recursos computadorizados -, revelam que eles ainda se sentem pouco à vontade com seu uso em sala de aula. Por vezes, destacam que o aluno não oralizado tem dificuldade de aceitar suas limitações, sentindo-se muito diferente de seus colegas por estar empregando este recurso da CAA. Em outros alunos, o uso de "plaquinhas ${ }^{15}$ " (sic) nas séries mais adiantadas parece ser dispensável se ele puder se comunicar mais rapidamente com gestos e sons. Algumas professoras ressaltam que muitos alunos são hábeis em acessar músicas e imagens em smartphones, como se isso implicasse em comunicação. Outras ressaltam que o plano do aluno deveria destacar, inicialmente, a comunicação e a convivência social. O PECS-Adaptado foi apresentado como fator facilitador para efetivar a comunicação do aluno com TEA, que, rapidamente, conseguiu entender e utilizar a lógica da troca dos cartôes para obtenção do objeto de desejo.

15 A forma como a professora se referia à prancha de comunicação. 


\section{Sessões de 2014}

No ano de 2014, foram realizadas oito sessões de pesquisa em que todo o grupo de professoras esteve presente junto com as pesquisadoras.

Os temas da comunicação, interação, linguagem e CAA foram prevalentes nas discussões de todas as sessões. Foi dada bastante ênfase aos componentes da comunicação: "algo a comunicar, alguém com quem se comunicar, meios de se comunicar, razão para se comunicar, expectativa para se comunicar e oportunidade de se comunicar". Carolina Schirmer sugeriu que a CAA deva ser contextualizada, funcional e envolver os componentes citados anteriormente. A atividade de comunicação em sala de aula não precisa ser estruturada, começa-se o trabalho conversando simplesmente. A professora precisa ter disponibilidade para fazê-lo. A comunicação, contudo, não deve resumir-se a uma série de perguntas que a professora formula, pois, ainda que, inicialmente, essa tática seja válida, sua persistência restringe a comunicação. A professora deve exibir fala adequada ao nível de compreensão do aluno e, para favorecê-la, falar e apontar para os cartões de comunicação. Outro aspecto que mereceu destaque refere-se à alternância ou troca de turno na interação com o aluno - dar tempo para o aluno responder e não invadir seu turno. É importante que o interlocutor do indivíduo não oralizado indique quando a mensagem deste não for entendida. Essa quebra na comunicação exige que o usuário de CAA melhore e amplie seu vocabulário. Tratou-se também da relevância da terapeuta/professora desenvolver aspectos primários da comunicação, como capacidade de manter o tópico, intencionalidade, troca de turno e acréscimo de informaçōes. A espera da troca de turno na interação precisa ser feita de forma adequada para que o enunciado seja compreendido com eficácia. Na verdade, a expectativa da professora em relação à comunicação do aluno pode ser um fator que dificulte esse processo de interação, de tal modo que muitos alunos acabam não expressando seus desejos devido à constante interpelação e impaciência da docente. É importante também perceber o momento em que o aluno expressa algum tipo de intenção de falar, pois, muitas vezes, as suas atitudes podem expressar e explicar seus comportamentos.

Deve-se evitar a conversa vazia, na qual não há troca de informação. $\mathrm{O}$ uso de recurso de CAA não é tudo na comunicação; o elemento-chave é a 
interação. Para desenvolver a conversa, pode-se usar o reconto de histórias, em que cada interlocutor tem sua vez. Foi enfatizado que a comunicação ocorre com a troca de mensagens entre dois interlocutores. $\mathrm{O}$ código usado pode ter diferentes modalidades - oral, gestos, libras, simbologia gráfica ou um misto de tudo. A linguagem tem diversos componentes: semântica, fonologia, sintaxe e a pragmática. Esse último componente deve ser priorizado no atendimento aos alunos sem fala articulada, pois se trata do uso da linguagem no contexto social, em que é dado ênfase à intencionalidade. A linguagem é própria e essencial ao homem. Para que a comunicação se efetive, é preciso que a linguagem se desenvolva. Na CAA, deve-se pensar nas habilidades linguísticas dos alunos e de seus interlocutores. Comunicação é troca e, portanto, não depende somente do aluno. A ausência de fala não significa ausência de linguagem, porque esta se expressa de diferentes formas ou modalidades. É lembrado que as professoras precisam explorar outras formas de comunicação com seus alunos, visto que, muitas vezes, a comunicação ocorre mediante o uso de gestos, sons etc. Mas, para poder reconhecer esses outros sinais de comunicação, os educadores precisam deixar de lado suas expectativas e ansiedades.

Além dos aspectos interacionais da comunicação, as professoras e as pesquisadoras ressaltaram que a CAA favorece a inclusão, porque garante o questionamento e a expressão do alunado sem fala articulada em diferentes ambientes e em interação com diversas pessoas. A professora do atendimento educacional especializado tem papel ímpar no desenvolvimento da linguagem, da comunicação e do pensamento do aluno.

Outro tema de destaque é a adequação dos recursos de $C A A$ à realidade do aluno. Sendo assim, é importante que o docente perceba que os materiais e as atividades devem ser flexibilizados e adaptados às peculiaridades do educando. Durante os atendimentos nas SRMs, alguns alunos fazem uso do computador, porém é preciso explicar que esse não é o único recurso, não devendo ser usado ad eternum, e que há outros materiais para facilitar a aprendizagem/comunicação. Recursos de baixo custo, como os kits com figuras/cartóes, podem ser uma ferramenta facilitadora, visto que esse material, posteriormente, pode ser trabalhado e compartilhado com outras pessoas da comunidade escolar. A construção dos kits exige desempenho e interesse do docente. A CAA pode ser vista como um mecanismo capaz de auxiliar as professoras na estruturação da rotina dos alunos, contribuindo para a or- 
ganização do pensamento, da linguagem e da aprendizagem. As professoras afirmam também que a falta de conhecimento sobre o uso da prancha de comunicação e a dificuldade de avaliar o aluno têm prejudicado o processo de aprendizagem. As professoras relatam que têm tido dificuldade em utilizar o sistema de varredura, a prancha e o acionador, por isso, é importante que eles conheçam bem os recursos da CAA para que sua funcionalidade seja completa.

A professora precisa perceber que alguns alunos com TEA utilizam a imaginação, a linguagem oral e a gestual para se expressarem e que o uso da CAA pode auxiliá-los na produção e ampliação dos enunciados verbais. A intenção comunicativa do aluno com dificuldade na fala também deve ser observada, e, nesse sentido, o uso do PECS-Adaptado pode ser um grande aliado no processo de interação com o aluno com TEA que apresenta frequentemente déficits na intenção comunicativa. Estruturar a rotina de sala de aula por meio dos cartôes tem contribuído para o desenvolvimento da comunicação e interação desses sujeitos, sendo assim, é preciso aproximar cada vez mais as atividades cotidianas das propostas pedagógicas e comunicativas. É importante que a professora tenha conhecimento das fases do PECS-Adaptado. Todavia, o grande embate parece estar em compreender e utilizar esse sistema de troca de figuras. As professoras ainda têm dúvidas em relação ao uso dos cartões de CAA, alegando que muitas informações podem confundir os alunos.

Foi mencionada a criação espontânea do grupo no WhatsApp pelos participantes, em outubro de 2014, como forma de favorecer a interação das professoras. Com isso, a comunicação entre elas foi bastante estimulada, pois passaram a compartilhar informações diversas, materiais e dificuldades ${ }^{16}$.

Outro tema discutido foi a sobrecarga de atendimentos nas SRMs, o que tem prejudicado, em certa medida, o desempenho das professoras. Uma das soluções imediatas tem sido a criação de figuras de comunicação em conjunto com os alunos no decorrer dos atendimentos. Outra queixa formulada

16 Uma descrição detalhada do conteúdo do grupo de WhatsApp pode ser encontrada nos capítulos "Comunidade on-line de professores de Salas de Recursos Multifuncionais de Referência” e "Material pedagógico adaptado ou especialmente elaborado e a comunicação alternativa e ampliada”. 
pelos participantes foi referente à falta recorrente de comunicação entre a equipe da Oficina Vivencial, a direção da escola e as CREs.

A importância da família no desenvolvimento do aluno tem sido uma preocupação das professoras. $\mathrm{O}$ trabalho interdisciplinar contando com o apoio da família é imprescindível para uma formação de qualidade. A família é um dos primeiros ambientes sociais em que a criança se insere, por isso, é essencial a participação dos familiares - no caso, as mães -, no processo de adaptação do aluno. Para as professoras, as mães dão muitas informações a respeito da criança, o que tem facilitado a busca por melhores práticas em sala de aula; portanto, o diálogo entre os pais e os docentes faz-se necessário. Todavia, ainda que as famílias tenham limitações em relação às técnicas, estratégias e metodologias, incluí-las no processo de desenvolvimento escolar da criança pode ser um fator positivo na aprendizagem do aluno.

Entre as dificuldades administrativas enfrentadas pelas professoras, destaca-se a não compreensão do papel das professoras das SRMs pelas escolas. É preciso entender que o sucesso escolar do aluno com dificuldade é responsabilidade de todos. Muitas vezes, o educador não tem a quem recorrer quando existem dúvidas de como proceder com um aluno, um familiar etc., e a falta de apoio da própria escola, como também das CREs, tem prejudicado esse diálogo. Outro fator a ser observado é a falta de tempo para conversar e/ou esclarecer dúvidas, compartilhar materiais pedagógicos adaptados e informações a respeito do aluno com outros docentes. $\mathrm{O}$ trabalho da professora na sala de recursos tem sido prejudicado por inúmeros fatores, como: falta de recursos e materiais, excesso de alunos, tempo limitado para adaptar as provas, capacitação informal do estagiário, falta de apoio da própria escola e das CREs e acúmulo de funções extras (atender pais, professores, diretores), ou seja, há uma sobrecarga desses docentes, contribuindo para a concepção de que as atividades realizadas no AEE são extremamente árduas e cansativas.

As ações possíveis do AEE devem ser contempladas pelas professoras de SRM, ou seja, elas devem solucionar os problemas que estão ao seu alcance, dando ênfase à construção de um Plano Educacional Individualizado (PEI) que contemple as necessidades dos alunos quando são atendidos nessas salas. Antes de elaborar o PEI, no entanto, faz-se necessário pensar e discutir as atividades pedagógicas que, de fato, atenderão às reais necessidades educativas $\mathrm{e}$ comunicativas dos alunos. 
Ao tratar dos estudos de caso, por meio da metodologia da problematização, a pesquisadora Carolina Schirmer aponta que é extremamente importante registrar e considerar as potencialidades dos alunos, pois essas são peças-chave no desenvolvimento das soluções. Muitos problemas não poderão ser resolvidos pelo atendimento educacional especializado (saúde, família etc), mas deverão aparecer na lista de informações do caso-aluno. A professora deve buscar conhecimentos diversos, a fim de encontrar soluçōes para os problemas levantados, propondo o PEI, cujo objetivo é o de listar, de forma clara e rápida, as atividades que eram desenvolvidas/ensinadas para os alunos durante os atendimentos, elencando os materiais que seriam necessários para a intervenção pedagógica e detalhando os resultados alcançados com cada sujeito. É de grande importância que a escola compreenda a proposta do PEI para melhor auxiliar seus professores e alunos. As dificuldades do PEI estão relacionadas à elaboração de material, provas e adaptações e, ainda, à troca de informaçôes entre os docentes da sala de recursos e da sala comum.

As professoras concordam que as adaptaçôes curriculares são essenciais para que o aluno compreenda os conteúdos pedagógicos, todavia, muitas docentes têm dificuldade para elaborá-las. Antes, é preciso compreender as necessidades do aluno, a fim de propor as adaptações e conhecer os recursos certos que possam dar suporte às suas peculiaridades. Outro ponto bastante discutido refere-se às adaptaçôes feitas mediante o uso do caderno pedagógico. É sabido que os conteúdos desse caderno são extremamente limitados, se considerarmos as reais necessidades dos educandos. Verificou-se que muitas professoras têm usado os recursos da CAA para fins pedagógicos. Vale destacar que, quanto mais o recurso de CAA for utilizado pelo aluno, maiores são as chances de aumentar seu vocabulário e sua autonomia. É preciso considerar o interesse e a idade do aluno, pois, para ele, pode ser mais interessante usar um IPad do que um comunicador para expressar-se. Outro ponto fundamental é verificar se os recursos são utilizados em outros ambientes naturais, já que o aluno precisará comunicar-se em diferentes espaços, como casa, consultório etc. Procedimentos do ensino naturalístico, como colocar os objetos desejados pelo aluno fora do seu alcance (arranjo ambiental), podem estimulá-lo a solicitar o objeto por meio do cartão de comunicação nesses diversos ambientes.

As professoras expressaram o sentimento de frustração quando um aluno não desperta interesse por alguma atividade, sendo assim, é preciso 
imediatamente redirecionar as tarefas a fins pedagógicos e comunicativos que sejam da escolha do aluno. A dificuldade de comunicação entre as professoras tem prejudicado o desempenho da criança com deficiência e TEA. Por essa razão, é importante haver meios de comunicação que as aproximem, para que, juntas, consigam elaborar estratégias de ensino que contemplem as especificidades do educando.

Outro tema debatido foi o emprego dos cartóes de CAA para estimular a leitura e a escrita. A complexidade das atividades de ler e escrever palavras mediante o uso dos cartóes de CAA tem chamado a atenção de muitas professoras, na medida em que é possível observar que os alunos decoram as palavras sem relacioná-las aos seus significados. Também é comum pensar que o usuário da CAA refere-se apenas a indivíduos sem fala. Todavia, o aluno que tem dificuldade de ler e escrever também necessita do suporte para desempenhar melhor suas habilidades comunicativas e pedagógicas em sala de aula. Alguns alunos têm dificuldade em contextualizar a própria fala, por isso é fundamental que a professora desenvolva atividades de leitura que os auxiliem na organização do pensamento. Quando o aluno demonstra ter muita resistência em utilizar os cartões, é preciso que a docente mostre para ele a sua funcionalidade. Por exemplo: ensinar o aluno a pedir um item desejado, mostrando que sua solicitação se faz necessária para que haja entendimento entre ambas as partes. Softwares que permitem criar símbolos podem ajudar o aluno com deficiência na produção da escrita, principalmente quando está presente a opção de ouvir o que foi escrito. O software permite ainda trabalhar com soletração. Combinar música e desenho também pode favorecer a comunicação do aluno.

As questôes burocráticas das escolas e das CREs podem impedir as professoras de participar do projeto-piloto de Salas de Recursos Multifuncionais de Referência, que prevê a criação das chamadas "Salas Abertas". Uma professora da Oficina Vivencial afirma que, no primeiro momento, é preciso ter cautela na implementação do projeto-piloto, visto que há uma demanda muito significativa de alunos com deficiência e TEA nas escolas. Vale lembrar que em uma sala pode haver cinco alunos e, em outra, pode haver trinta, ou seja, é fundamental uma reorganização desses estudantes para que o projeto seja realizado de forma satisfatória.

Finalmente, foi tratada a questão da coleta e análise dos dados da pesquisa que está em curso. É por meio desses procedimentos que o pesquisador 
pode ter um parecer positivo ou negativo sobre o andamento da pesquisa. É preciso também compreender o que as professoras apreenderam no curso de formação para dar seguimento a possíveis ajustes no projeto. Questionários - fundamentais para o pesquisador, principalmente pelo fato de permitirem a constatação da ocorrência ou não de mudanças significativas no estudo foram utilizados para fazer uma análise comparativa dos dados coletados em momentos diferentes do estudo. $\mathrm{O}$ uso dos gráficos pode auxiliar no controle dos dados.

Foi solicitado que as professoras dessem seguimento às filmagens de suas interaçôes com o aluno, a fim de que os dados fossem descritos com fidedignidade e, posteriormente, analisados. Algumas docentes controlaram os dados coletados, ligando e desligando a câmera. Contudo, é lembrado que as filmagens deveriam ser as mais naturais possíveis, para não haver manipulação dos dados.

Para fazer uma análise de conteúdo, antes de tudo, é preciso ter a transcrição das sessões da pesquisa em mãos. $\mathrm{Na}$ transcrição, é possível ver os temas mais recorrentes para, assim, criar categorias que são fundamentais para comparação dos dados, caso haja mudanças de comportamento e de opinião dos sujeitos.

No decorrer da formação, as análises de comportamento e de discurso puderam ser realizadas. Reaplicar os questionários para a construção dos dados e nomear as categorias é extremamente importante para a condução da pesquisa.

As professoras parecem não ter compreendido muito bem a proposta do projeto de pesquisa em curso, que sugere a criação de Salas de Recursos Multifuncionais de Referência em cada CRE, com o objetivo de divulgar de forma mais adequada os procedimentos e os recursos voltados para a população de alunos não oralizados. É fundamental que a professora compreenda, de fato, a proposta do projeto e queira apreender os conteúdos ofertados nessa formação. Ela precisa entender que faz parte, ativamente, do seu processo de formação. 


\section{Sessões de 2015}

Em 2015, houve oito sessōes de pesquisa, cujo conteúdo é apresentado a seguir.

O tema recorrente da comunicação e dos recursos de TA e CAA foram trazidos à tona, recomendando-se que, para ter entendimento sobre a TA, é fundamental estar junto do aluno, ou seja, é preciso que ambos os interlocutores (professor/aluno) estejam envolvidos na realização da tarefa. Vale destacar que a observação da própria prática pode contribuir para o desempenho das professoras. Interagir com o aluno mediante o uso dos cartóes pictográficos, das pranchas, pode ser um diferencial na formação da professora, contudo, muitos educadores ainda têm dificuldade em manusear esses recursos.

Recomendou-se ainda que, em sala de aula, a professora atente cuidadosamente ao processo inicial de comunicação do aluno, sobretudo quando este for solicitado a responder algo. Isso significa dizer que é preciso valorizar os momentos de interação, objetivando explorar melhores formas de expressão, seja verbal, gestual, corporal etc. Também é necessário mostrar à criança que há outras formas de comunicação (sinalização), isto é, para que seja compreendida e o aluno seja atendido em seu pedido, torna-se fundamental a compreensão do interlocutor.

Vale destacar que o uso do ensino incidental pode melhorar a comunicação do aluno sem fala funcional, especialmente quando as situaçôes (pedagógicas, jogos, lanche etc.) são vivenciadas em um ambiente onde a criança esteja engajada. Em primeiro lugar, são exibidos itens que a criança deseja, colocando-os, contudo, fora do seu alcance, a fim de incentivar o ato comunicativo. Emprega-se, então, o procedimento do "mando-modelo", segundo o qual a professora pergunta ou solicita que a criança indique o que ela quer. Se ela o fizer, o objeto lhe é fornecido. Caso contrário, a professora fornece o modelo "quero o jogo" e aguarda a criança imitá-lo. O terceiro procedimento é a espera, ou seja, a professora segura o objeto de desejo da criança próximo ao seu (da professora) rosto e aguarda que ela responda usando o cartão para solicitar o que deseja. Cabe aqui ressaltar que compartilhar o mesmo foco de atenção com a criança é essencial, e que a professora também precisa aceitar a resposta dela - criança - por mais primitiva que seja, exigindo, com o passar do tempo, respostas mais elaboradas. Vale lembrar que o uso de recursos tec- 
nológicos de alto ou baixo custo em sala de aula é importantíssimo, mas nada substitui as técnicas e atitudes das educadoras perante os seus alunos, pois a interação humana está no esteio da comunicação.

O uso do PECS-Adaptado foi mais um tema abordado. É preciso ambientar e organizar a sala antes de utilizá-lo com o seu educando, principalmente para evitar comportamentos de agressividade. As professoras também apontam que a Comunicação Alternativa tem que ser utilizada de acordo com a singularidade do aluno, ou seja, são "mundos extremamente diferentes". Antes de utilizar a CAA, é preciso que a professora faça um levantamento dos alunos que precisam dos recursos, a fim de auxiliá-los de forma mais significativa. Vale destacar a necessidade de entender o conceito de interlocutor e locutor para que as mensagens sejam mutuamente transmitidas e recebidas. Também é importante estimular o aluno a ser emissor, ou seja, iniciador do diálogo, corroborando com a ideia de que é preciso haver uma troca. Isso significa dizer que se o aluno não entender que ele precisa ser emissor, essa troca não será possível. $\mathrm{O}$ aluno também pode experimentar outras formas de comunicação e, nesse sentido, os símbolos podem ser utilizados. Mas para que isso aconteça, é preciso que a professora busque mecanismos que auxiliem o aluno nesse processo de comunicação/interação. Para tanto, os conteúdos pedagógicos também podem ser trabalhados com o uso de imagens, principalmente quando a educadora usa palavras para instigar o aluno ("Olhe aqui", "Veja”) para que ele fique atento ao que está sendo proposto. Alguns professores não sabem usar ou têm ainda dúvidas em relação ao uso da CAA.

Às vezes, para atrair a atenção do aluno que não fala ou não quer falar, as professoras apontam que se fazer de desentendido pode ser uma boa solução. Elas precisam conhecer o aluno para escolher o método que atenda às suas reais necessidades. Quando a educadora compreende que tem dificuldade de comunicar-se com o aluno, torna-se mais fácil viabilizar estratégias que melhorem seu desempenho para com esse alunado. A troca de informações/ parceria entre as docentes pode agregar a construção do conhecimento acerca da Comunicação Alternativa.

Nas sessóes de 2015, foram apresentados alguns softwares, como o TICO, usado para a produção de pranchas. Foi recomendado que, para usá-lo, são necessários sintetizador de voz, tablet, notebook etc. Ele conta com a opção de varredura (o programa reconhece os comandos, independentemente do local onde a professora e o aluno toquem na tela). Vale destacar 
que o processo de abertura de caixas de diálogo do TICO é semelhante ao do Boardmaker. As professoras mostraram-se bastante interessadas pelo uso do programa e chegaram a elaborar pranchas com ele. Contudo, algumas apresentaram dúvidas em relação às células acumuladas e compreenderam que o ato de passar para a outra tela não influencia na imagem seguinte. As explicações dadas no curso de formação também orientaram as educadoras na configuração e no manuseio das células.

Outro software apresentado foi o ARASAAC - um dos recursos que despertou bastante interesse nas professoras, visto que, nos encontros, foram discutidas as suas possibilidades de facilitar a comunicação do aluno. Já em relação ao PECS-Adaptado, elas afirmaram ter dificuldade em utilizá-lo em sala de aula, e que é preciso estruturar o ambiente antes de propô-lo ao aluno. Também foi percebido que os docentes tinham pouco conhecimento em relação à Comunicação Alternativa e que, muitas vezes, utilizavam cartóes e pranchas de comunicação, mas não sabiam a sua real funcionalidade.

Foi mostrado que o uso do tablet é extremamente importante, já que pode melhorar a comunicação entre a professora e os alunos com deficiência e TEA, além de fazer com que estes entendam os conteúdos com mais eficiência. No tablet, a docente pode usar os aplicativos interativos para despertar o interesse do discente por determinada situação ou tarefa. Destaca-se, ainda, que o uso do tablet pode melhorar a coordenação motora de alunos com dificuldades diversas, e muitas professoras têm utilizado o TICO (cria tabelas, por exemplo: "Como estou?". E o aluno pode visualizar uma carinha de triste, feliz etc.) e o ARASAAC (organiza a rotina do aluno, por exemplo: imagem do shopping, escola etc.) para melhorar a aprendizagem e a comunicação. Assinale-se que a maioria das professoras ganhou um tablet do município ou da pesquisadora com verba da FAPERJ. No entanto, as docentes apontaram três dificuldades: diretoras que não deixam o tablet sair da escola, prejudicando o aprendizado de alunos que necessitam de Comunicação Alternativa e Ampliada em outros ambientes; desorganização da CRE em relação ao calendário escolar; e falta de interesse de alguns professores no que concerne ao início das salas abertas, devido ao fato de determinadas escolas estarem localizadas em áreas de risco. É preciso compreender que as pranchas de comunicação podem ser utilizadas em outros ambientes naturais, ou seja, a inclusão transcende os muros das escolas, e que a CAA é um recurso do usuário de TA, ou seja, o aluno com deficiência ou TEA. 
A despeito do interesse das docentes, ficou claro que elas ainda encontram bastante dificuldade em manusear os recursos tecnológicos, principalmente aqueles que favorecem a CAA com alunos com dificuldades diversas. É preciso destacar que a CAA não se refere apenas ao uso dos recursos, mas também a um jeito diferente de olhar para o indivíduo que apresenta dificuldades na fala. Cabe aqui frisar que alguns educadores até fazem cursos com ênfase em CAA, mas, por falta de prática e de recursos tecnológicos, acabam esquecendo o conhecimento adquirido. Eles ainda têm receio de utilizar a tecnologia, e isso, de certa forma, tem prejudicado o desempenho quanto ao manuseio dos recursos da Comunicação Alternativa e Ampliada.

A relação entre as professoras também foi colocada em pauta. A troca de informações entre elas é fundamental, sobretudo quando as Salas de Recursos Multifuncionais de Referência estiverem funcionando. Os docentes dessas salas poderão ajudar os demais professores de salas de recursos nos momentos de dúvidas, mostrando que têm consciência de determinadas situaçôes, devido à vivência que tiveram em suas práticas. As educadoras demonstraram interesse em continuar os encontros e relataram que há uma necessidade de trocar informações entre elas, pois, muitas vezes, passam por angústias e precisam compartilhar umas com as outras. Isso quer dizer que essa troca é bastante rica e fundamental para o aprendizado dessas docentes. Esse intercâmbio de informações é muito importante, pois mostra o quanto todos têm problemas semelhantes no cotidiano escolar, e que compartilhar conhecimento, sentimentos e percepções com o colega de grupo é um grande aprendizado, visto que os deixam mais seguros em relação ao trabalho realizado na sala de recursos.

Entre as dificuldades administrativas, as professoras reportaram que a falta de apoio da coordenação pedagógica e de outras professoras tem prejudicado o trabalho dos educadores da sala de recursos. Outro fator que dificulta o trabalho é a falta de preparo e formação dos estagiários para lidar com alunos com deficiências e TEA. Vale lembrar que o tempo limitado para realizar as adaptações para as provas e o número excessivo de alunos em sala de aula têm sido um desafio para muitas docentes, principalmente pelo fato de não conseguirem elaborar e se dedicar às especificidades dos educandos. Muitas escolas veem a sala de recursos como um cantinho ou depósito. Isso quer dizer que é preciso que a direção da escola tenha mais consideração pelo trabalho desses docentes. Destaca-se que a falta de comunicação entre diver- 
sos setores da escola também pode ser um fator prejudicial ao desempenho das professoras na sala de recursos.

Foram feitos relatos da realização das Salas Abertas (SAs). As docentes lembraram que as dinâmicas realizadas nessas sessōes de pesquisa podem ser empregadas nos encontros das SAs. Uma professora abordou a questão dos estudos de casos e disse que as professoras participantes das SAs, assim como ela, gostariam de ensinar também a elaborar PEI, pranchas. Entre os desafios enfrentados pelas professoras nesses encontros, estão: a) professoras insatisfeitas com o "sistema" educacional; b) a escola não proporciona espaço e tempo para interação entre os docentes, a fim de que estes possam trocar informaçóes acerca do aluno e sobre como adaptar provas e recursos; c) o desinteresse e a insatisfação mostrados por algumas professoras que participavam das SAs; e d) encontros que focalizam muito a discussão dos estudos de casos e não avançam.

Finalmente, tratou-se do PEI. Observou-se que, para realizá-lo, antes de mais nada, é preciso ter planejamento. As professoras alegam que encontram dificuldade em fazer o PEI porque as salas de recursos são vistas pela escola como uma válvula de escape, isto é, quando um professor de sala comum ou diretor não consegue dar conta da demanda pedagógica ou comunicativa dos alunos com deficiência e TEA, encaminham-nos à sala de recursos para que desta docente apresente uma solução. Vale lembrar também que muitas professoras reclamam da falta de auxílio para elaborar o PEI.

\section{Sessões de 2016}

No ano de 2016, houve sete reuniões de pesquisa, cujos conteúdos são apresentados abaixo.

Já nos primeiros encontros, foi destacado que a elaboração expressiva de materiais pedagógicos adaptados pelas participantes tem ofuscado a questão da comunicação: "não sobra tempo para conversar". As professoras alegaram que o tempo limitado e o excesso de demandas em sala de aula para obter resultados positivos no atendimento às exigências curriculares têm provocado essa conduta. Contudo, compreendem que, apesar do desafio em interagir com o aluno sem fala funcional e da falta de experiência teórico-prática acerca 
da Comunicação Alternativa e Ampliada, é preciso envidar esforços, a fim de favorecer a comunicação desse discente, criando atividades pedagógicas que potencializem as questôes comunicativas do aluno sem fala funcional. Algumas professoras relataram que ainda sentem dificuldade em usar os cartôes de comunicação e que os alunos parecem ainda não compreender o uso do PECS-Adaptado. Assim, elas acreditam que para desenvolver continuamente um trabalho pedagógico, a despeito das dificuldades administrativas e da falta de apoio da escola e da CRE, é preciso buscar mecanismos e recursos, como o celular e o tablet. Nesse sentido, o compartilhamento de informaçóes acerca de materiais postados em sites especializados em deficiências diversas com as colegas, por meio do WhatsApp e do Facebook, tem-se constituído em um plus promovido pela participação nesta pesquisa. Foi enfatizado que o diálogo entre as professoras pode melhorar o desempenho dos alunos incluídos.

Outro obstáculo apontado refere-se à falta de estagiários para auxiliar as professoras das salas comuns. Não obstante, quando esses estão presentes e trabalham com o aluno incluído, observa-se a falta de base teórica sobre as deficiências, as técnicas de ensino, os métodos de aprendizagem e a CAA.

As professoras queixam-se das familias, que parecem perceber a escola como um espaço de descanso. Assim, é perturbador para os pais ouvirem da educadora que devem participar dos momentos pedagógicos do filho como mediadores. Eles alegam sentir dificuldade em usar o PECS-Adaptado com a criança. Segundo as docentes, os pais de alunos com deficiência e TEA têm levado seus filhos à escola devido à obrigatoriedade dos programas sociais.

A mestranda Thatyana Machado Silva apresentou seu projeto de pesquisa, que se constituiu em sua dissertação de mestrado, acerca do emprego da autoscopia na formação de duas participantes dessa pesquisa, a fim de incrementar a aprendizagem e a comunicação de seus alunos com autismo nas SRM. A autoscopia é um procedimento que permite visualizar o indivíduo em ação, o que proporciona ao ator ver a si próprio, aumentando, desse modo, sua capacidade de modificar sua atuação pela tomada de consciência de seu desempenho. $\mathrm{Na}$ fase de linha de base, as professoras não tinham dificuldade em usar os cartôes de comunicação e, na maioria das vezes, sua utilização era restrita a práticas pedagógicas. $\mathrm{O}$ planejamento também era engessado e rígido. Depois do procedimento da autoscopia, as docentes mu- 
daram suas concepções e ações pedagógicas em face dos alunos incluídos, e estes tornaram-se mais participativos ${ }^{17}$.

Esse tema da reflexão sobre a própria prática pedagógica voltou à baila nos encontros seguintes, sendo considerado bastante promissor para o andamento da pesquisa. As professoras enfatizaram a importância dessa atitude reflexiva. A filmagem da prática permite uma discussão crítica e diferenciada sobre o modo de perceber e atuar perante o aluno incluído. Em decorrência dessa constatação, o registro filmado do próprio desempenho será proposto às educadoras das Salas Abertas.

As pesquisadoras da UERJ ficaram surpresas quando algumas mestras sugeriram que os materiais/recursos precisariam ser produzidos de acordo com as demandas dos alunos, favorecendo não apenas os quesitos pedagógicos, mas também as questôes comunicativas e funcionais para a vida dos discentes. Vale lembrar que muitos docentes tendiam a produzir materiais e a ofertar atividades estritamente pedagógicas, devido à falta de experiência ou habilidade em se comunicar com o aluno sem fala funcional. Eles costumavam dizer: "Mas eu não vou ter Comunicação Alternativa e Ampliada, eu não sei pra que isso serve, eu não quero aprender”. Diante disso, faz-se mister convocar toda a escola para que o trabalho com CAA envolva todos - as docentes, os estagiários, os diretores etc.

As pesquisadoras da UERJ e as demais profissionais do IHA já haviam conversado com as professoras a respeito de uma moça - Lívia (nome fictício) -, que seria recebida em uma das reuniões com o propósito de promover uma conversa descontraida com uso da CAA entre ela e as professoras de SRM. A pesquisadora Carolina explicou como conduziria a sessão, e Lívia ficou atenta, escutando e, por vezes, concordando com o que estava sendo exposto. Lívia utilizou uma ponteira para Ipad como aparelho para iniciar o diálogo com a pesquisadora e dizer que estava feliz. Uma professora respondeu oralmente que o grupo estava feliz em recebê-la. A pesquisadora explicou para Lívia em que consistia a sala de recursos e, em seguida, as professoras começaram a formular perguntas sobre as preferências da visitante e sobre os temas que ela

17 Este estudo de Thatyana Machado Silva é apresentado, neste livro, no capítulo intitulado "O uso da autoscopia como aliada na formação continuada de professores de Sala de Recursos Multifuncionais”. 
gostaria de abordar. A garota perguntou às professoras se todas trabalhavam com Comunicação Alternativa, obtendo uma resposta positiva.

Lívia usava os seguintes gestos e movimentos corporais para se comunicar: mexia a cabeça para cima e para baixo (concordar); apontava para a prancha; inclinava o corpo para frente; mexia no tablet com as pontas dos dedos; balançava a cabeça para um lado e para outro (discordar); colocava duas mãos no ouvido (não querer escutar); apontava para letras/nomes/ imagens; balançava-se na cadeira; levantava a mão; sorria; balançava a mão fazendo sinal de não; fazia sinal com o polegar (está legal); levantava a mão até o pescoço, fazendo gesto de enforcamento (tem raiva da pessoa); colocava as mãos nas axilas (rindo) quando perguntada se estava de namorado; fechava os braços (rígidos) quando falavam de Saquarema (onde vai com frequência, mas não gosta); e olhava indicando para alguém ${ }^{18}$.

${ }_{18} \quad$ Um recorte da conversação com Lívia: "Quanto tempo que usa a CAA? Cinco anos. A pesquisadora diz que não. $\mathrm{O}$ que você mais gostava de fazer no tempo da escola, em especial na sala da professora Clotilde? Livia aponta para o caderno. Todos ficam sem saber o que é e começam a rir no final, pois compreenderam que a menina gostava do momento em que a professora ficava escrevendo no caderno. Qual o colega de sala que você mais gostava? Livia teve que utilizar o alfabeto, no caso apontar para a letra inicial do nome da pessoa. A pesquisadora ajudou a garota a responder (apoio físico). Qual o aluno que te tirava do sério? Livia respondeu que era X porque o mesmo comia o biscoito e sujava tudo. Para chegar até a essa resposta a garota precisou de apoio físico e de dicas da professora (a ex-professora estava presente). Você gosta de passear? A garota respondeu que sim e que o lugar que mais frequenta é Saquarema e que já estava enjoada porque a mãe só queria ir pra lá. O sim dela foi balançando a cabeça. Ficou procurando a resposta no álbum de comunicação. Você gosta de ir ao supermercado e por quê? Livia responde que gosta de ir tomar café no Guanabara e que vai com o pai. Também aponta que não vai apenas ao aniversário do estabelecimento, mas que costuma ir em dias de quarta-feira. Ela afirma que às quartas-feiras tem promoção de frutas e verduras. Você quer café? Grande ou pequeno e pedem para a garota apontar. A menina pega o grande e fala que tomava café na escola também. O que você faz em casa? A garota aponta para as figuras, tira o lixo de casa, cozinha. Com quem você gostava de ir para a escola? Livia responde dizendo que adorava voltar da escola com o irmão porque ele a levava para o shopping. Não tinha esses pictogramas na prancha. Ela teve que usar outro sinal de comunicação para explicar do porque gostava de sair com o irmão, visto que só a 
As professoras mostraram-se muito animadas com a conversa com Lívia, ao observarem que ela fazia uma comunicação multimodal - usando gestos, expressões corporais e gestuais, escrita e pictogramas. Algumas vezes,

sua ex-professora conhecia gestos. Por que você está zangada? Livia explica que está zangada porque não gostava de ir para Saquarema. Desconversou quando perguntada se gostava da cunhada e se a mesma ia pra Saquarema. Nessa oportunidade leva a mão até o pescoço fazendo gesto de enforcar (tem raiva da cunhada)! Você já conheceu o novo Guanabara? Não. Você gosta de novela, jornal, etc.? Livia folheia a prancha várias vezes para falar que gosta de uma determinada novela. Depois as professoras ficaram perguntando se ela gostaria que um personagem namorasse outra pessoa. E ela respondeu que sim. Ela indica que gosta de Malhação, Vale a pena ver de novo. Fala que o pai gosta de ver jornal. Livia inicia uma conversa com a pesquisadora fazendo um sinal com a mão e apontando para o dia da semana. Também diz que a fonoaudióloga e a fisioterapeuta não estão em casa (aponta). Quando você vai para Saquarema? Livia coloca as mãos no ouvido para falar que não vai para Saquarema e faz um pequeno gesto de repulsa quando perguntaram desde quando ela costumava ir para Saquarema. O que você gosta de comer? A menina aponta na prancha para o macarrão, mamão, cenoura, purê de batata. Você tem facebook? Livia aponta para a prancha de comunicação digital e mexe com a própria mão e coloca no Facebook. Em seguida, aponta para a prancha para falar que era triste e que agora é feliz. Livia abraça a pesquisadora. Você gosta de ir à UERJ trabalhar com os alunos da Pedagogia na disciplina Pesquisa e Prática Pedagógica (PPP)? Livia fala que os alunos são da faculdade. A garota balança a cabeça, fazendo gesto de sim para falar que gosta de ensinar para aos alunos que vão à PPP. Ela pega o tablet e mexe sozinha. Depois, ela aponta para ela mesma para indicar que se formou e usa o tablet para responder. Ela fez um discurso na formatura, mas apagou o material do tablet. Qual a disciplina que você mais gostava no tempo de escola? Livia não soube responder, porque o material tinha sido excluido. A pesquisadora fala que isso foi bom para ela aprender que precisa de memórias. A garota aponta para as letras A e I e as professoras ficaram deduzindo... Artes e Inglês. Você gosta de música? A garota balança a cabeça para falar que gosta de música. As professoras falam de vários estilos musicais e ela fica mexendo a cabeça um pouco agitada e mexendo na prancha. Você tem celular? Livia fica um pouco desatenta quando perguntam se ela tem celular. A pesquisadora chama a sua atenção e ela responde que não. No final da sessão, depois de ter ganhado um chocolate, a garota em tom de risadas diz que não vai compartilhar com todo mundo!!!" 
usava o próprio corpo e, em outras, valia-se do álbum de comunicação com fotos, figuras e letras e do IPad.

O encontro com Lívia parece ter sensibilizado positivamente as professoras, que revelaram, em sessōes posteriores, que aquela conversa fez a diferença. Elas consideraram que a Comunicação Alternativa e Ampliada é extremamente importante, principalmente no que concerne ao desenvolvimento da linguagem da criança. Posto isso, torna-se fundamental trabalhar a CAA desde cedo, diminuindo os riscos de o indivíduo sem fala funcional ter problemas acerca dos processos de alfabetização e qualidade de vida. Outro aspecto bastante discutido foi a respeito do preconceito e/ou crença que alguns professores manifestam a respeito dos alunos sem fala funcional mais velhos: "Não usou até hoje e se virou com o gestual, então não será agora que irá precisar de Comunicação Alternativa”.

Uma das professoras apresentou alguns aplicativos para comunicação, como DosVox, ARASAAC etc., e explicou a possibilidade de fazer download, pela internet, informando que eles poderiam favorecer os processos de alfabetização e de aprendizagem do aluno com algum tipo de comprometimento oral. No decorrer da apresentação, muitas docentes tiveram dúvidas a respeito dos aplicativos: Onde usar? Como funciona? Baixa pela internet? Ajuda no processo de aquisição da leitura? Limpa as pranchas? etc. Cabe registrar que, apesar de alguns sites disponibilizarem gratuitamente determinados aplicativos, muitos ainda têm de ser comprados. As docentes ficaram um pouco frustradas com essa notícia, tendo em vista que o MEC pouco (ou nada) investe na compra desses recursos. Em relação aos jogos, a professora salientou que são muito rápidos, não sendo possível desenvolver/trabalhar estímulo-resposta com o aluno em sala de aula. Alguns jogos não funcionam no tablet, mas podem ser usados no Ipad, inclusive fazendo sistema de varredura. Há jogos que já vêm com o acionador.

Tratou-se, posteriormente, das Salas Abertas, que constituem um espaço de troca entre as professoras. Foi explicado às pesquisadoras que muitas professoras entraram e saíram das CREs e que o critério de seleção para participar da Sala Aberta não tem considerado o conhecimento do educador acerca da CAA. É importante ressaltar que alguns professores ainda se sentem confusos a respeito da proposta das SAs. Durante a sessão, as professoras perguntaram às pesquisadoras se seria pertinente apresentar, nas SAs, um recorte da conversa que tiveram com a Lívia, acreditando ser importante mostrar 
como ocorre o diálogo com uma pessoa não oralizada, mediante os recursos da Comunicação Alternativa.

Em geral, as professoras relataram que o primeiro encontro com as colegas nas Salas Abertas foi gratificante. Nessa oportunidade, elas iniciaram com um vídeo que explanava os conceitos da comunicação e da CAA. Após o vídeo, mostraram alguns materiais que produziram em suas salas de recursos, bem como o uso de alguns aplicativos. Algumas delas falaram que tiveram problemas para filmar e mostrar as fotos de determinados alunos, pois muitos faltavam aos atendimentos pedagógicos. Elas tiveram dúvidas de como seria a organização das próximas Salas Abertas: as professoras que iriam participar; por que há professoras que possuem muita experiência em sala de recursos, mas não conhecem a CAA (há também aquelas com bastante teoria, mas não têm aluno com dificuldade de comunicação); o local onde seria realizada a Sala Aberta; e a questão do número de professoras, que tem de ser controlado, porque não se pode configurar como palestra. As professoras salientaram a importância de produzir $\mathrm{CDs}$, visto que só os vídeos não darão conta dos conteúdos diversos que as educadoras de Salas Abertas precisam conhecer. Vale ressaltar que elas querem mostrar a importância de se comunicar/interagir com o aluno, isto é, de trocar experiências com ele, e que se o recurso não for usado de forma correta, não adianta tê-lo, pois é preciso dominar sua funcionalidade. A pesquisadora ressaltou que o vídeo e as Salas Abertas não serão apenas uma sensibilização, mas um aprendizado para todas as professoras.

Ao observar os estudos de casos que as professoras das SRMs apresentaram nas SAs, a audiência ficou surpresa com as mudanças de comportamento dos alunos, ou seja, os cartões estimularam não apenas a comunicação e a interação, mas também o comportamento, a aprendizagem e a vida cotidiana do aluno.

Uma das professoras que promoveram o encontro da SA relatou que ainda tem dificuldade de usar o PECS-Adaptado e que tem procurado conhecer mais as suas fases. Ela relatou que, diante da dificuldade de fazer com que o aluno usasse a prancha de comunicação, passou a copiar as imagens do Google no Word, em vez de utilizar pranchas de comunicação. Então, fotografou as imagens que estavam no Word e enviou aos pais para que as usassem no próprio celular com a criança. Isto é, quando a ela quisesse pedir algo, o pai, ou a própria criança, poderia procurá-las na galeria de fotos do aparelho. 
Contudo, antes de iniciar essa "prancha" no celular, a professora precisou saber dos interesses da criança.

As educadoras relataram também dificuldades nos encontros das Salas Abertas, a saber: falta de interesse de algumas professoras que participaram como audiência no encontro das Salas Abertas. Elas sugeriram que o IHA ofertasse encontros mais específicos sobre determinadas temáticas. Ainda confessaram que têm bastante dificuldade em organizar o material e preencher os documentos. Algumas professoras que dirigiram a Sala Aberta tiveram dificuldade em filmar o encontro. Havia muitas professoras novas no terceiro encontro da SA, de modo que o embasamento teórico acerca da CAA teve que ser ofertado.

Para os próximos encontros, o que as professoras estão planejando? Elas irão continuar com o mesmo grupo no próximo encontro da Sala Aberta, mas gostariam que professoras novatas, sobretudo as que não têm experiência com alunos não oralizados, participassem do encontro. Alguns tópicos a serem tratados são os seguintes: confecção de pranchas, PECS-Adaptado, exemplos de provas adaptadas por meio do uso de imagens, elaboração do PEI, emprego de cartôes de comunicação e estratégias para favorecer a comunicação, comportamento e aprendizagem do aluno, softwares, aplicativos com jogos, estudos de casos, contação de histórias, adaptação de pranchas com o uso do Word e celular e produção de materiais mediante o uso de computador (sem internet).

$\mathrm{O}$ aluno tende a regredir quando deixa de utilizar a Comunicação Alternativa em sala de aula. O vínculo com a criança é estabelecido por meio do diálogo. Se ninguém faz isso ou se há dificuldade em ter profissionais na escola, o vínculo não é constituído. Mesmo que o aluno esteja um pouco mais velho ou fora de faixa etária, é preciso acreditar que a CAA seja possível e que ele poderá mudar sua forma de interagir e se comportar no mundo, ainda que no começo encontre alguma resistência. É importante que o aluno não oralizado interaja com o restante da turma. Os alunos tendem a ficar surpresos quando veem a criança não oralizada usando a prancha de comunicação: "Ele consegue responder o que é perguntado". É importante destacar que é preciso utilizar a CAA com a família e os amigos em contextos naturais além da escola. Jogos interativos podem estimular a comunicação da criança, mas é fundamental conhecer e entender o funcionamento do jogo, bem como adaptá-lo, a fim de facilitar a compreensão da criança. 
Finalmente, no último encontro, a professora Maristela Siqueira, da OV, propôs a leitura de um texto baseado em uma resolução das Salas de Leitura Pólos, da prefeitura do Rio de Janeiro. Ela explicou que a Sala de Recurso de Referência em CAA poderia funcionar da mesma forma que essa sala de leitura e que precisaria da opinião das professoras presentes no encontro para discutir o que poderia ser colocado ou não nos parágrafos da possível "resolução". A equipe da OV, por meio desse texto base, quer apresentar à direção do IHA uma proposta de regulamentação da Sala de Recurso de Referência em Comunicação Alternativa (SRRCA). Essa iniciativa objetiva garantir ao professor de sala de recurso formação específica em Comunicação Alternativa para que ele possa atuar com alunos sem fala funcional e com dificuldade na escrita. Nessa reunião, foi enfatizado que a SRRCA irá atender professores que tenham alunos que necessitem da Comunicação Alternativa. Isso também elucida que a sala de recurso de referência exercerá a função de formadora/multiplicadora, visando a alcançar mais alunos e professores da rede.

Ao final da reunião, as professoras compartilharam os conteúdos e os materiais apresentados no encontro das $S A s$ realizado no dia 9 de novembro, a saber: manuseio do Boardmaker, prancha temática e curso básico sobre o PECS-Adaptado, oficina de jogos, elaboração do PEI, uso de aplicativos, provas adaptadas, filmagens de sua própria aluna, slides com vídeos, jogo da velha, TA, recursos de alta e baixa tecnologia, uso do vídeo da Lívia, estudos de casos, dicas, estratégias de como trabalhar com alunos vistos nos vídeos, materiais lúdicos e de CAA, aplicativos, aplicação do software Prancha Fácil, adaptações de pranchas com o jogo Cara a Cara, casos de alunos hipotéticos para as professoras, vídeos das professoras que passaram pelo processo de autoscopia, dinâmica pelo WhatsApp e as possibilidades de CAA pelos emoticons. As docentes relataram que muitas professoras novas participaram do encontro e solicitaram que essas Salas Abertas continuassem a ser ofertadas.

\section{Discussão}

Quatro questôes ganharam destaque na análise das falas das professoras e das pesquisadoras nas sessões de pesquisa, a saber: 


\section{Condições de trabalho nas SRMs}

Com o propósito de consolidar a educação inclusiva em nosso país, o MEC propôs, em 2008, a Política Nacional de Educação Especial na Perspectiva da Educação Inclusiva, considerada um novo parâmetro para as ações na educação brasileira. De acordo com essa nova concepção, o público alvo da educação especial, ou seja, alunos com deficiência, transtorno global do desenvolvimento ${ }^{19}$ e altas habilidades/superdotação estarão incluídos nas turmas comuns do ensino regular (Brasil, 2008, p. 15). Em seguida, foi publicado o Decreto n. ${ }^{\circ}$ 6.571, de 17 de setembro de 2008, que trata do Atendimento Educacional Especializado (AEE), o qual deverá ocorrer, preferencialmente, nas Salas de Recursos Multifuncionais, cabendo ao MEC prover apoio técnico e financeiro para a implementação de tais salas, assim como a formação continuada de professores para o AEE. Em 2 de outubro de 2009, a Resolução n. ${ }^{\circ}$ 04, que instituiu as "Diretrizes Operacionais para o Atendimento Educacional Especializado na Educação Básica, na modalidade Educação Especial”, estipula que "a elaboração e a execução do Plano de AEE são de competência dos professores que atuam na Sala de Recursos Multifuncionais (SRM) ou centros de AEE, em articulação com os demais professores do ensino regular e com a participação das famílias" (Brasil, 2009, p. 2). Fica claro, nesses documentos legais, que as atribuiçõos dos professores são numerosas e diversificadas. Esse professor passa a ser o principal agente da política de inclusão escolar, responsável por prover atendimento direto ao público-alvo da educação especial e às suas famílias, bem como articular ações junto aos educadores das classes comuns, ao pessoal da escola e às agências da comunidade.

Uma das queixas frequentes das professoras participantes da atual pesquisa refere-se ao excesso de atribuições impostas a esse cargo. Espera-se que essa docente seja uma superespecialista, preparada para atender a toda gama de dificuldades dos alunos com diferentes condições especiais. No dizer de uma das participantes desses estudos nacionais, "a sala é multifuncional, mas o professor não é” (Mendes et al., 2015, p. 522). Além da demanda excessiva, elas ressentem-se do baixo reconhecimento de seu trabalho por parte dos demais agentes escolares, dos gestores e mesmo das CREs, além da sensação

19 Atualmente denominado de Transtorno do Espectro Autista 
de isolamento e minus valia. Esses dados são corroborados pelo conjunto de estudos desenvolvidos por 76 pesquisadores oriundos de 21 universidades, localizadas em 38 municípios brasileiros, com a participação de 596 professores das Salas de Recursos Multifuncionais e coordenados pela professora Enicéia Gonçalves Mendes, no Observatório Nacional de Educação Especial, iniciado em 2010 e finalizado em 2015 (Mendes et al., 2015).

\section{Recursos da Comunicação Alternativa: Adaptações pedagógicas $x$ Comunicação}

Observou-se, ao longo das sessões, a ênfase no uso dos recursos da CAA na elaboração do material adaptado para fins pedagógicos. Esse fato não pode ser apontado como uma interpretação equivocada das professoras. Muito pelo contrário, os recursos pictográficos favorecem a linguagem receptiva (compreensão) do aluno, assim como a expressão de seu pensamento, em tarefas acadêmicas por excelência. Adicionalmente, como muitas educadoras atendem em suas salas de recursos alunos com deficiência, mas capazes de se expressarem oralmente, é justificável que elas tenham aprimorado seus materiais adaptados também para esse alunado, fazendo uso das figuras das pranchas de comunicação.

No entanto, faz-se mister lembrar que os recursos de CAA devem priorizar a comunicação social do aluno sem fala. Segundo as professoras participantes, a conversação entre professores e alunos, e alunos entre si, não é enfatizada no cotidiano escolar: "Não há tempo para as conversas, é preciso dar conta do programa curricular". Essa afirmativa remete-nos ao terceiro tópico, que é a relação entre a CAA e a linguagem.

\section{Comunicação Alternativa e Ampliada (CAA) e Linguagem}

A aquisição da competência comunicativa por indivíduos não oralizados está relacionada a vários aspectos e, dentre eles, destaca-se o domínio 
linguístico, considerado crítico para tal desenvolvimento. Ainda que algum nível de comunicação seja possível sem a competência linguística, a profundidade e a amplitude dessa comunicação estariam severamente prejudicadas pela ausência do significado simbólico. Em outras palavras, pessoas com competência linguística mínima conseguem expressar necessidades básicas por meio de habilidades não simbólicas, como o choro, o olhar e as expressões faciais, mas seriam incapazes de compartilhar ideias, sentimentos e pensamentos mais complexos com outros interlocutores (Light, 2003, p. 3; Deliberato et al., 2014).

Assim como a capacidade de representação simbólica mostra-se essencial para a comunicação, nas suas diversas modalidades - orais, gestuais e gráficas -, a comunicação interpessoal favorece sobremaneira o próprio desenvolvimento da linguagem e da cognição. Segundo a perspectiva vygotskiana, a linguagem e outras funções mentais são construídas no âmago das interações sociais da criança, ou seja, no plano interpsicológico, neste espaço compartilhado entre sua mente e a de seus interlocutores mais experientes. Os processos que emergem desse espaço coletivo, aparentes na fase das primeiras palavras e frases, vão, aos poucos, transferindo-se para um locus privado, constituindo, assim, a "fala" interior, que não é simplesmente uma fala sem som. Ela possui uma sintaxe especial, simplificada e condensada, representando a junção de dois processos que, até então, vinham correndo paralelamente: o pensamento e a fala. Nesse ponto, a fala passa a ser racional e o pensamento, verbal (Nunes, 2003). Com efeito, pesquisas têm mostrado que o uso de um sistema pictográfico com crianças com severos distúrbios de comunicação pode estimular o desenvolvimento das funçôes cognitivas, particularmente, da linguagem (Chun, 2003; Trevisor e Chun, 2004) ${ }^{20}$.

20 Estas questôes encontram-se mais desenvolvidas, neste livro, no capítulo redigido por Debora Deliberato, intitulado "Linguagem, interação e comunicação: competências para o desenvolvimento da criança com deficiência não oralizada”. 


\section{Interação humana e Comunicação Alternativa e Ampliada}

Atualmente, as Tecnologias de Informação e Comunicação (TICs) estão inseridas em quase todos os aspectos da vida cotidiana, inclusive na escola (Monteiro da Cruz e Monteiro, 2013). O emprego dessas inovaçōes tecnológicas têm se difundido exponencialmente na Comunicação Alternativa e Ampliada, com o desenvolvimento de softwares sofisticados, mouses adaptados, recursos de acionamento, pranchas com recursos de voz digitalizada ou sintetizada e, mais recentemente, as tecnologias móveis (tablets, Ipads e telefones celulares), que dispóem de tela sensível ao toque. $\mathrm{Na}$ formação oferecida às participantes da presente pesquisa, esses recursos e sistemas ganharam, de fato, destaque, e as professoras dedicaram-se sobremaneira a adquirir habilidades de identificar, manusear e dominar tais recursos para empregá-los junto a seus alunos. Assim, a Comunicação Alternativa e Ampliada vem sendo reduzida, gradativamente, à sua dimensão técnica. Essa constatação já havia sido denunciada por Paul (1997), ao assinalar que o emprego de tais recursos de alta tecnologia não promovem necessariamente melhores interações comunicativas. Com efeito, o encantamento com esses gadgets e o consequente foco apenas na tecnologia podem levar os profissionais a negligenciarem o que realmente importa: a comunicação e a interação do usuário desses recursos e seus interlocutores (Light e McNaughton, 2013).

O emprego da Comunicação Alternativa em sala de aula, ou em qualquer outro ambiente, conduz-nos a refletir sobre em que consiste a comunicação humana. Segundo Fogel (1993), a comunicação constitui um processo contínuo no qual interlocutores mutuamente corregulam seus comportamentos, isto é, alteram suas ações em virtude das açōes atuais e antecipadas do parceiro, possibilitando a criação conjunta de sentido. Assim, é fundamental destacar a presença do outro. Ora, nós nos comunicamos para afetar o comportamento, o pensamento e o sentimento do nosso parceiro e com ele negociarmos o sentido de nosso ato comunicativo. Assim, para garantir a comunicação do indivíduo com severa limitação na fala funcional, não basta a oferta de recursos de Comunicação Alternativa, como pranchas e cartóes de comunicação, comunicadores portáteis, computadores e softwares especiais. $\mathrm{Na}$ medida em que consideramos que comunicar seja uma ação existencial e vital na relação humana, a ênfase na interação humana deve anteceder qual- 
quer procedimento ou técnica. A comunicação não é feita somente de conteúdos, mas também de aspectos emocionais, de movimentos e expressões faciais que complementam e direcionam o rumo da conversa em questão, e isso é fortemente determinado pela relação entre os interlocutores. Assim, tão ou mais importante do que o emprego dos recursos tecnológicos é a presença do interlocutor interessado e preparado para acolher e responder às mensagens da pessoa não oralizada e que respeite e utilize, ele próprio, essas modalidades alternativas de comunicação. O processo de aquisição da competência comunicativa não depende somente da inserção de linguagens alternativas na rotina das pessoas, ele também implica a mudança de atitude dos interlocutores diante das diversas possibilidades para tornar a comunicação entre duas pessoas significativa e efetiva. Isso significa que não é apenas inserir um código comunicativo, mas também favorecer a ampliação e encorajar necessidades emergentes de comunicação e o uso de funções comunicativas mais sofisticadas. É preciso lembrar, em suma, que competência comunicativa não é um traço intrapessoal, mas um constructo interpessoal (Lund e Light, 1997; Nunes e Walter, 2014). 


\title{
Capítulo 3 - Quem são as professoras e quem são os alunos atendidos nas Salas de Recursos Multifuncionais
}

\author{
Leila Regina d'Oliveira de Paula Nunes ${ }^{1}$ \\ Carolina Rizzotto Schirmer ${ }^{2}$ \\ Stefhanny Paulimineytrick Nascimento Silva ${ }^{3}$ \\ Maria Gabriela Lopes Araújó
}

\section{Introdução}

Educadores e pesquisadores em Educação e Educação Especial concordam que a perspectiva atual da inclusão exige o repensar da escola, com o objetivo de proporcionar um ensino de qualidade para todos os alunos, sem exceção. Para que isso ocorra, a formação de professores torna-se essencial nesse processo, e várias são as ações políticas e os estudos voltados para a atua-

1 Professora titular da Faculdade de Educação e do Programa de Pós-Graduação em Educação da UERJ. E-mail: leilareginanunes@terra.com.br

2 Professora adjunta da Faculdade de Educação da UERJ. E-mail: ead.carolina@gmail. com

3 Mestranda em Educação pelo Programa de Pós-Graduação em Educação da UERJ. E-mail: stefhannyp@gmail.com

4 Graduanda em Pedagogia pela UERJ. E-mail: gabiaraujo11@hotmail.com 
ção tanto em sala de aula como no atendimento educacional especializado (Martins, 2003; Oliveira, 2003; Lauro et al., 2003; Gomes e Barbosa, 2006; Pelosi, 2008; Pletsch, 2009; Bersch, 2009; Nunes, 2009; Lourenço, 2012; Veltrone e Mendes, 2011).

Para que se possa garantir a acessibilidade do aluno com deficiência e Transtorno do Espectro Autista (TEA) ao conhecimento, ao espaço físico, às interações e à comunicação, é necessário que os professores de Salas de Recursos Multifuncionais (SRM), principais interlocutores e modelos, tenham conhecimento sobre a Tecnologia Assistiva (TA) e, especialmente, sobre a Comunicação Alternativa e Ampliada (CAA). Porém, para que a TA e a CAA façam parte do cotidiano da SRM e da escola, é fundamental que os professores da Educação Especial que trabalham com os alunos sejam capazes não apenas de implementar seus recursos, como também de favorecer interações ricas em comunicação. Esse conhecimento exige que, em sua formação, os professores sejam levados a refletir e a repensar sua prática, assim como trabalhar colaborativa e criativamente (Schirmer, 2012).

A formação continuada em serviço de professores constituiu-se como tema e foi o objeto desta pesquisa, que teve como objetivos planejar, implementar e avaliar a eficácia do programa de formação continuada em serviço de professores sobre TA, com ênfase na CAA, por intermédio de uma metodologia problematizadora, a fim de favorecer as interações sociais e o uso desses recursos por alunos com deficiência e TEA. Tanto para o planejamento quanto para a implementação, foi essencial conhecer as professoras de SRM e seus alunos, assim como envolvê-los no planejamento do curso. Por isso, este capítulo apresenta quem são as professoras das SRM e quem são os alunos atendidos por elas.

No início da pesquisa, um questionário e uma ficha foram aplicados a 18 educadoras das SRMs, que aceitaram participar deste projeto. O questionário teve por objetivo traçar o perfil dessa população, e a ficha visava a identificar quem são os alunos atendidos nas SRMs por essas professoras. O questionário, respondido na segunda sessão da pesquisa, realizada no dia 22/05/2013, era composto de 19 questóes abertas e foi respondido na sala da Oficina Vivencial do Instituto Helena Antipoff. Todos os respondentes eram do sexo feminino. 
A seguir, serão apresentados em forma de gráfico os dados coletados.

Gráfico 1 - Idade das Professoras

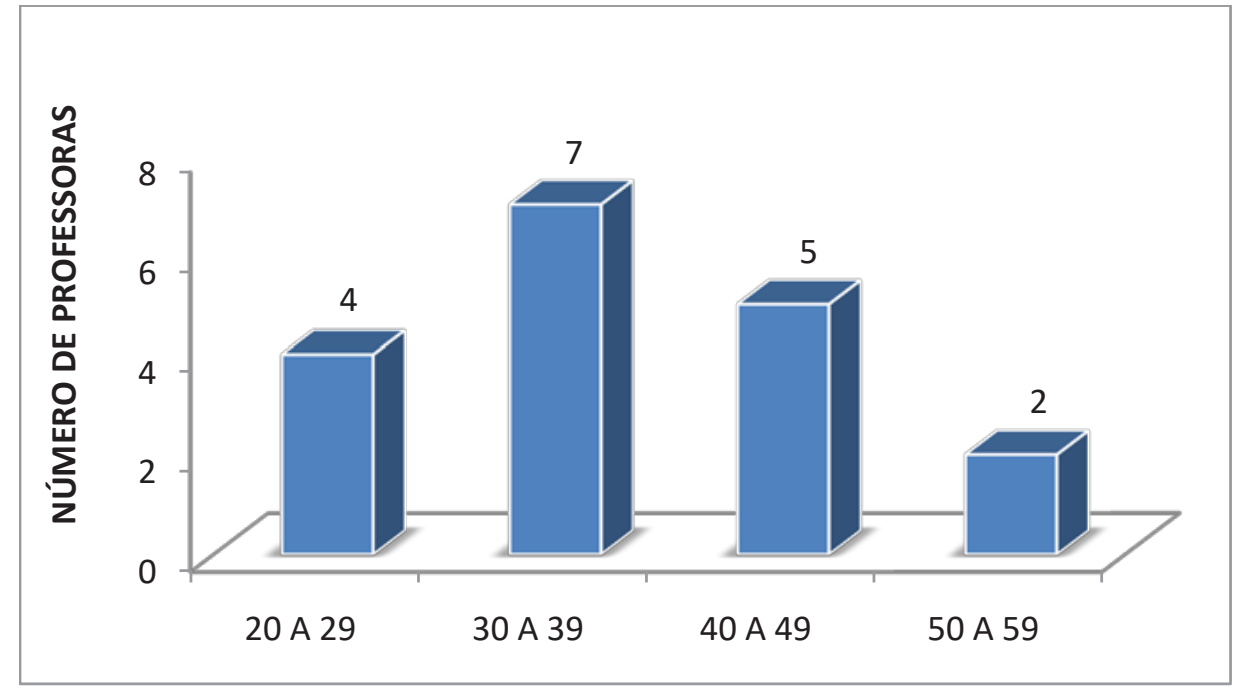

Trinta e nove por cento das professoras tinham a idade entre 30 e 39 anos e, em 28\%, a idade variava entre 40 e 49 anos.

Gráfico 2 - Tempo de magistério nas escolas da Secretaria Municipal de Educação

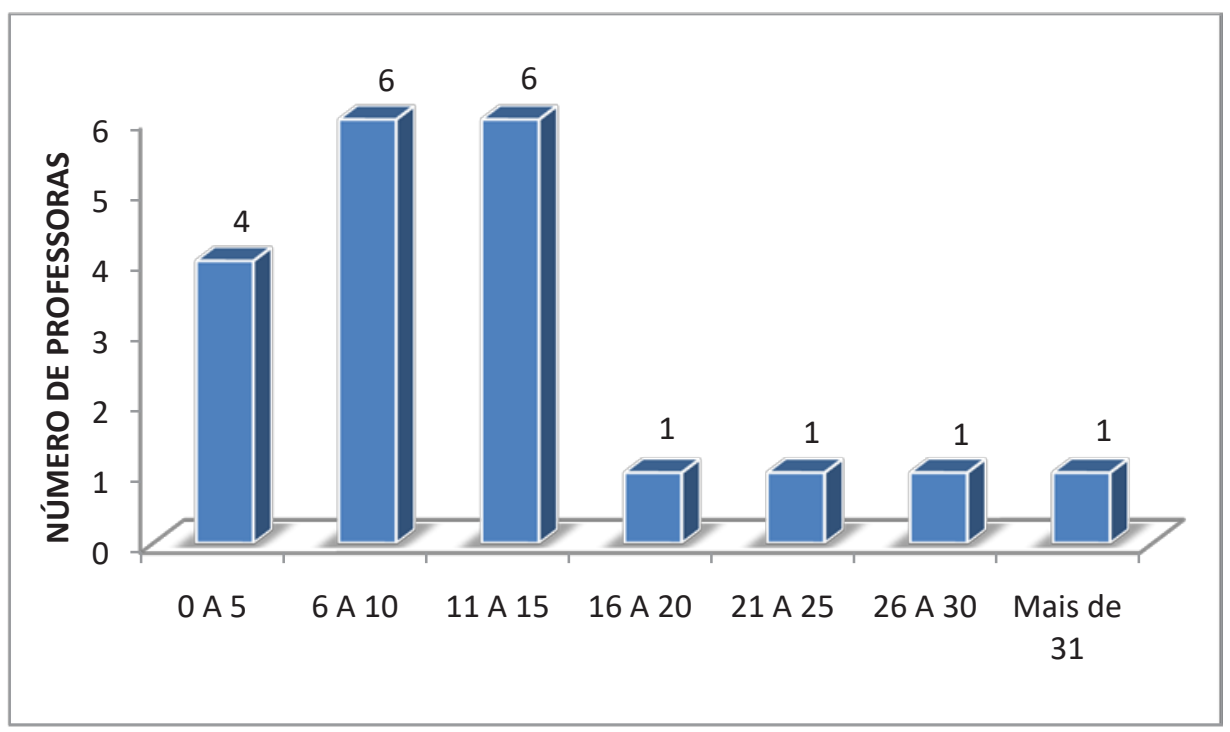


O tempo de magistério de $67 \%$ das respondentes variou entre seis e 15 anos.

Gráfico 3 - Tempo de atuação em Educação Especial

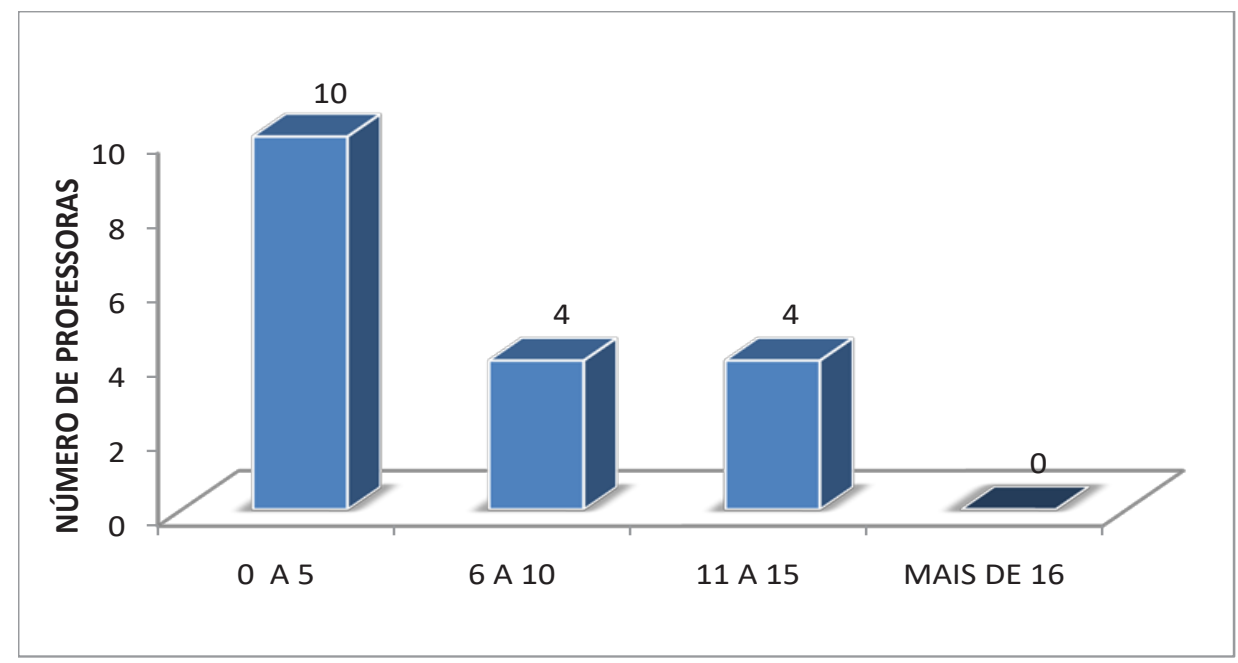

Cinquenta e seis por cento das professoras trabalhavam em um período de cinco anos, ou menos, em Educação Especial.

Gráfico 4 - Tempo de atuação nas Salas de Recursos Multifuncionais

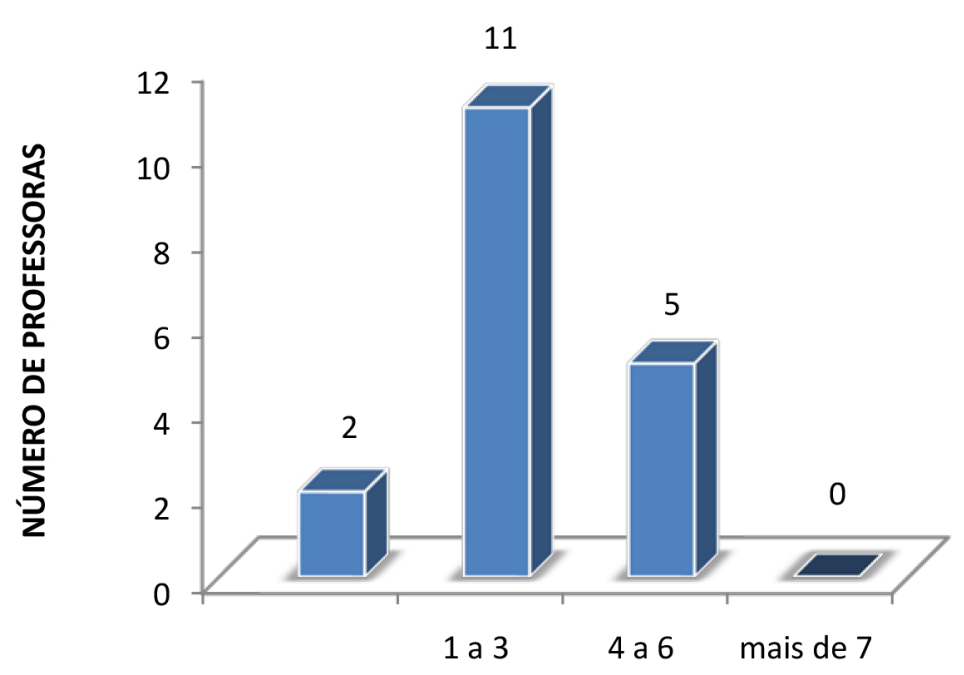


Setenta e dois por cento das professoras trabalhavam nas SRMs por um período igual ou menor que três anos.

Gráfico 5 - Funções exercidas anteriormente à SRM

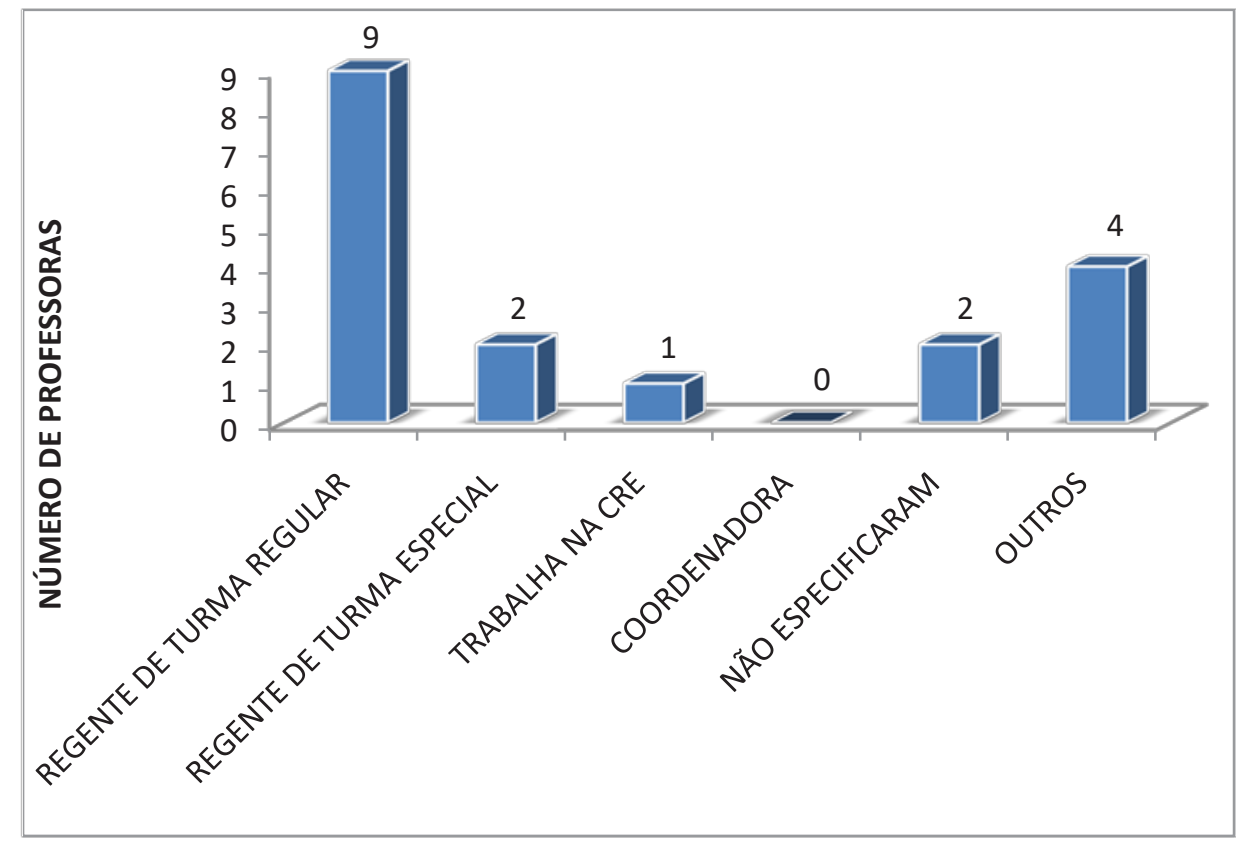

Cinquenta por cento atuavam como regente de turma comum antes da SRM. 
Gráfico 6 - Outras funções exercidas atualmente pelas professoras

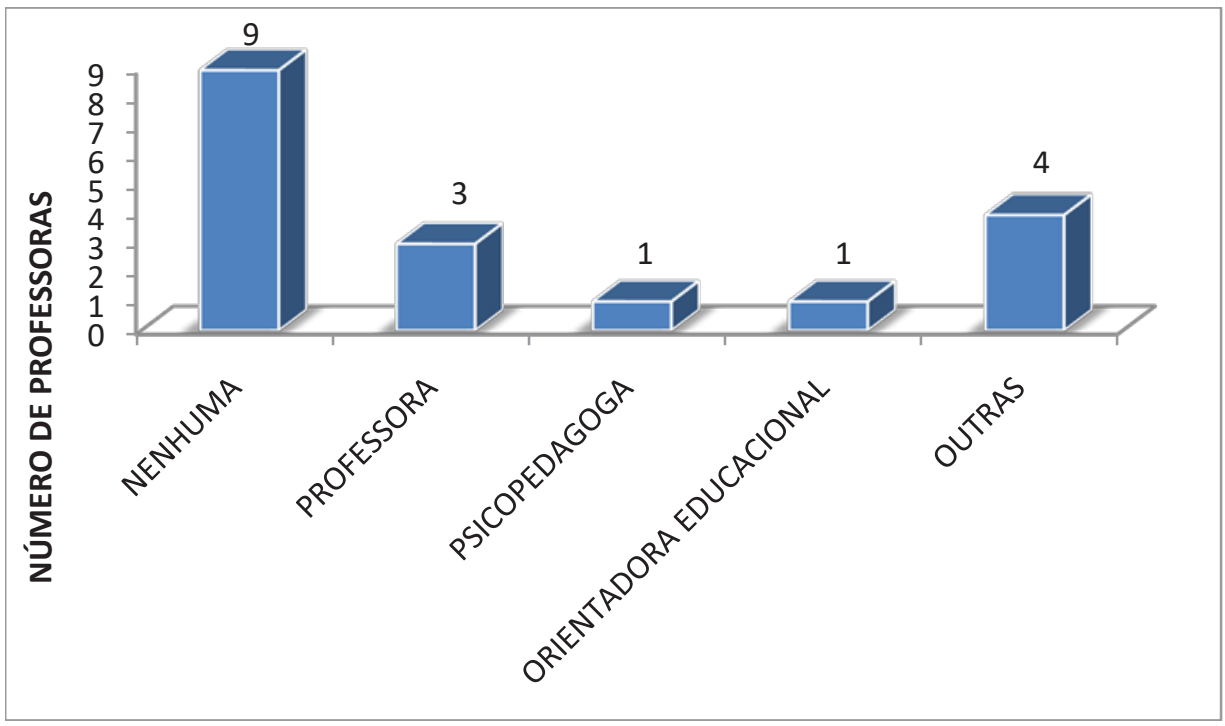

Cinquenta por cento das professoras não exerciam outra função além da SRM. 
Gráfico 7 - Graduação cursada

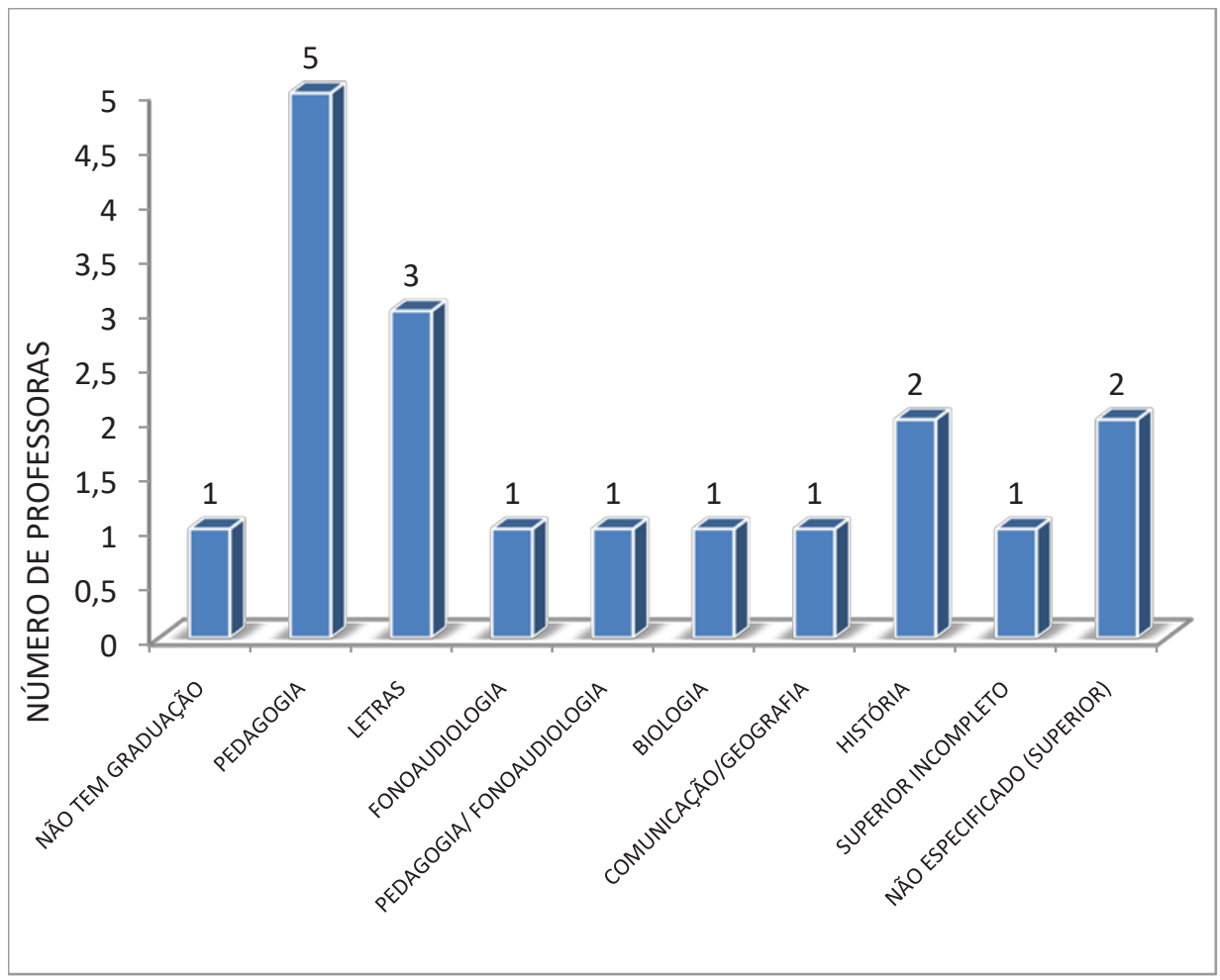

Vinte e oito por cento das participantes haviam cursado graduação em Pedagogia. Apenas 6\% das professoras não possuíam graduação. 
Gráfico 8 - Ano de conclusão da graduação

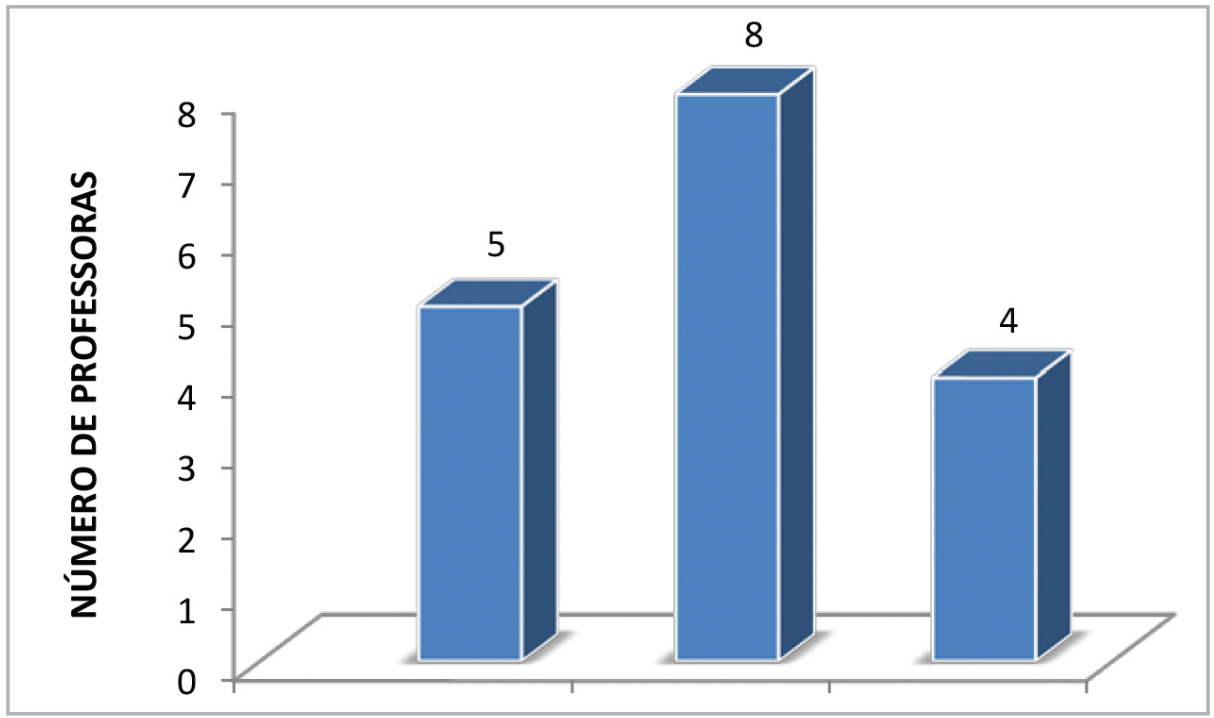

Quarenta e quatro por cento das professoras concluíram a graduação entre 2006 e 2010.

Gráfico 9 - Curso de especialização

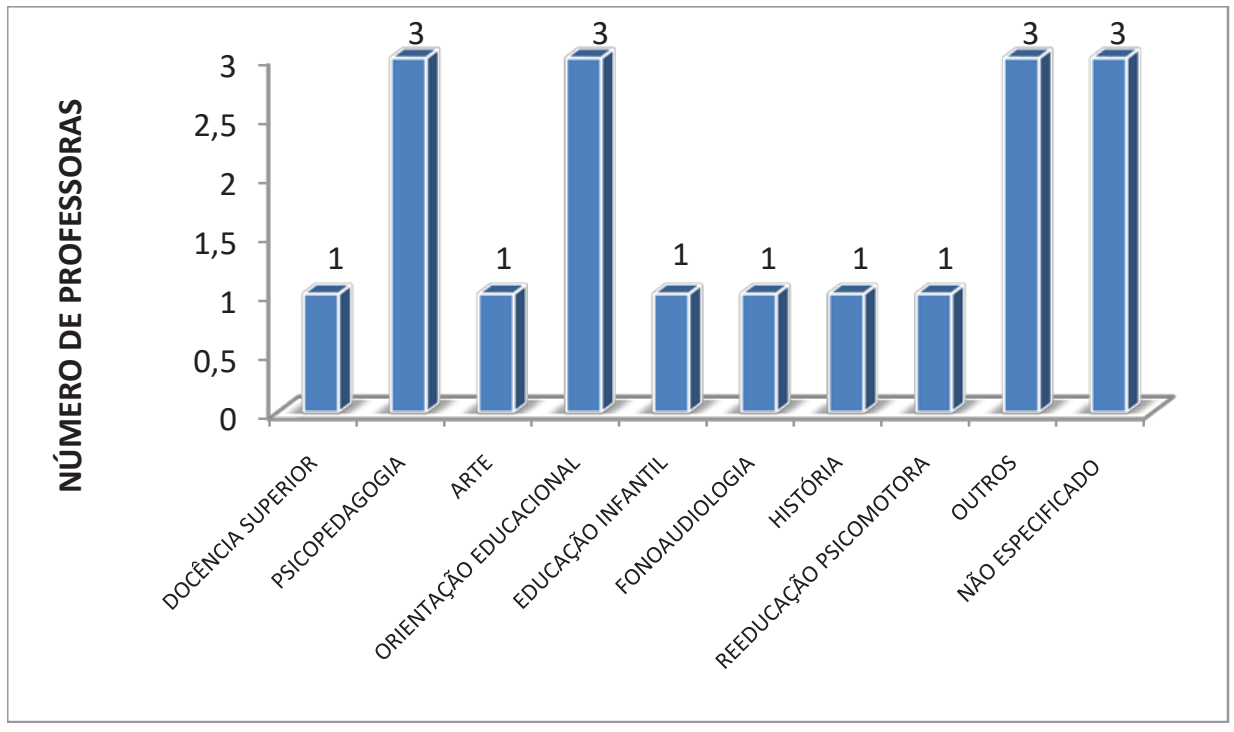


Cem por cento das participantes frequentaram cursos de especialização. Trinta por cento cursaram Psicopedagogia ou Orientação Educacional. Gráfico 10 - Cursos de mestrado e doutorado

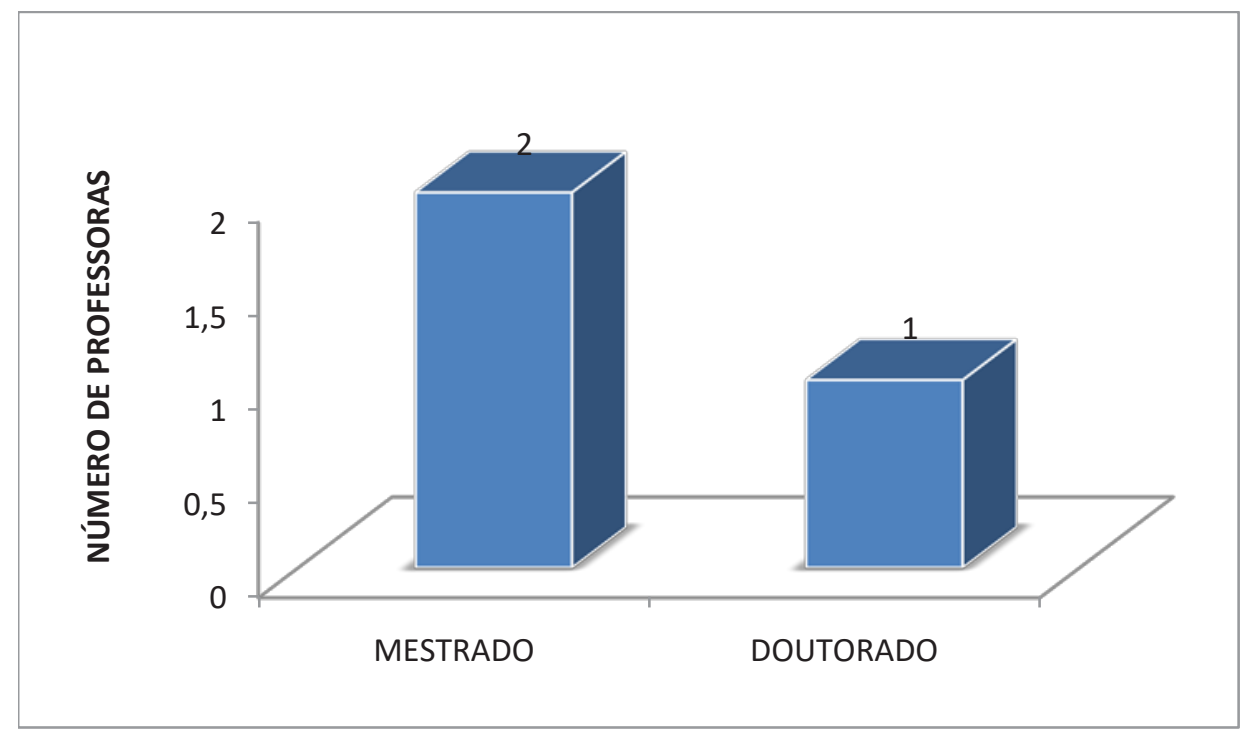

Entre as 18 participantes, apenas duas tinham mestrado e uma cursava doutorado.

Gráfico 11 - Ano de conclusão do curso sobre Comunicação Alternativa e Ampliada

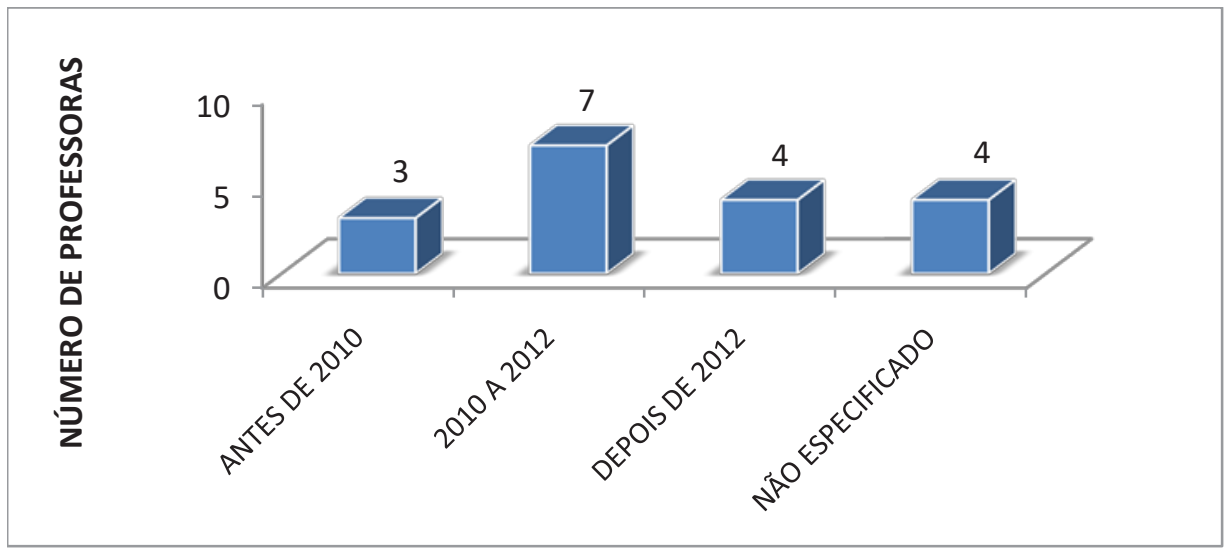


Todas as professoras já haviam frequentado curso sobre Comunicação Alternativa e Ampliada. Trinta e nove por cento no período compreendido entre 2010 e 2012.

Gráfico 12 - Duração do curso sobre Comunicação Alternativa e Ampliada

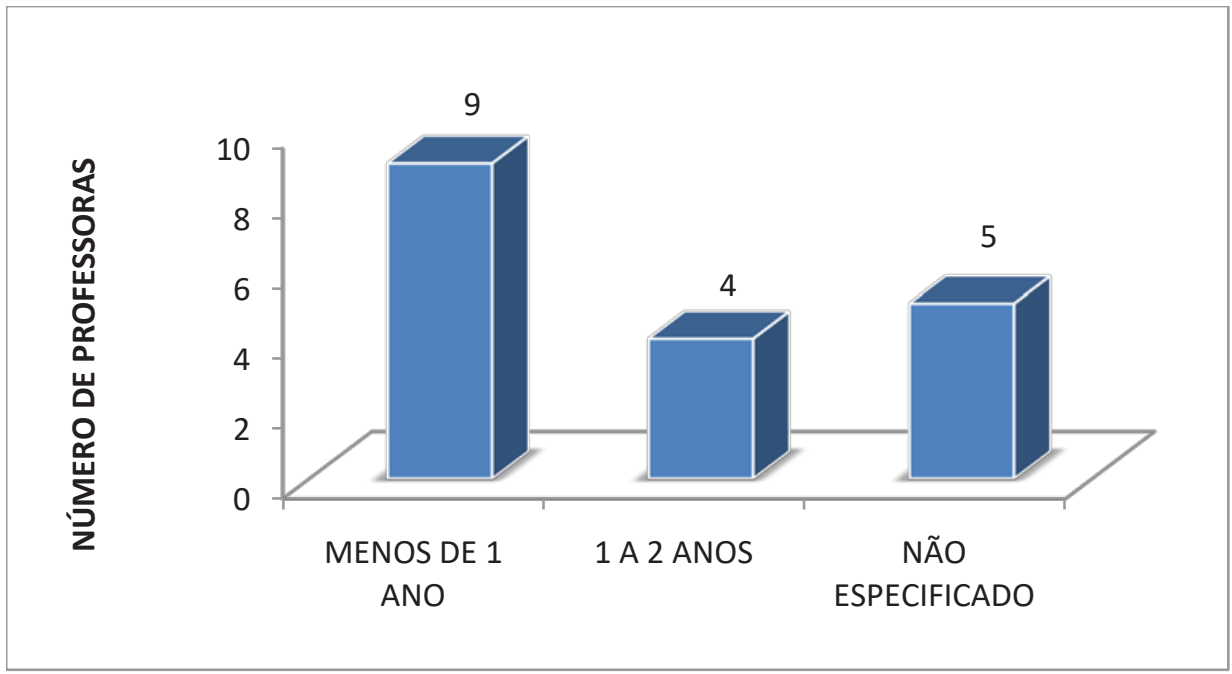

Cinquenta por cento das professoras completaram o curso sobre CAA em menos de um ano.

Gráfico 13 - Instrutores dos cursos de CAA

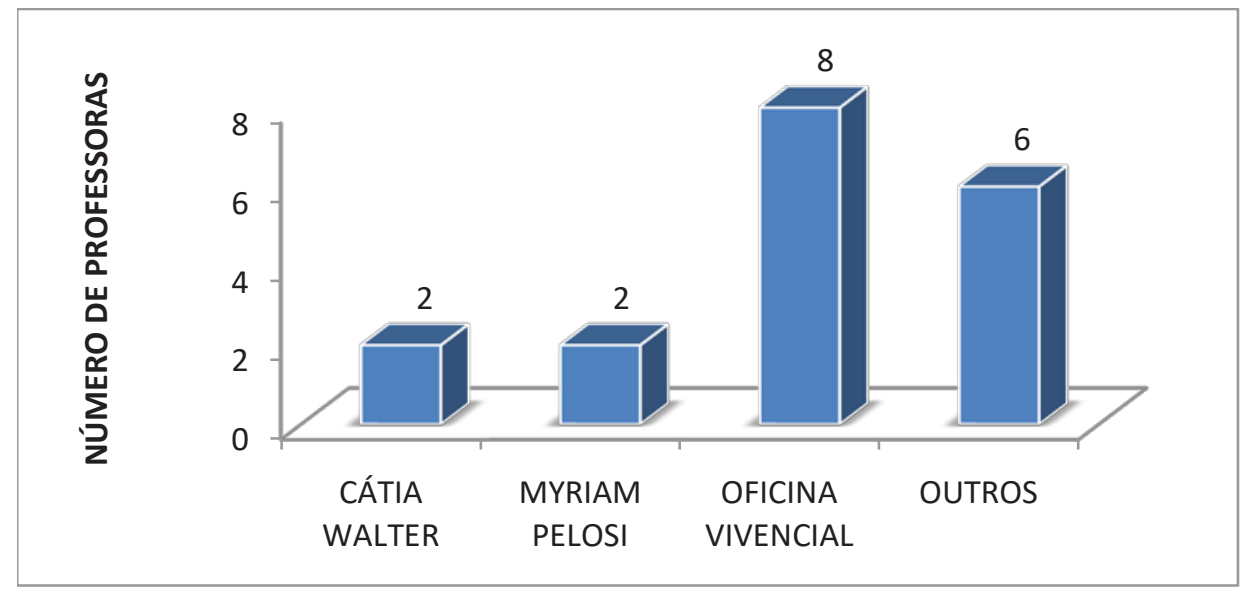


Quarenta e quatro por cento das participantes frequentaram o curso de CAA ofertado pelas professoras da OV do IHA.

Gráfico 14 - Frequência a curso de formação em Educação Especial nos últimos três anos

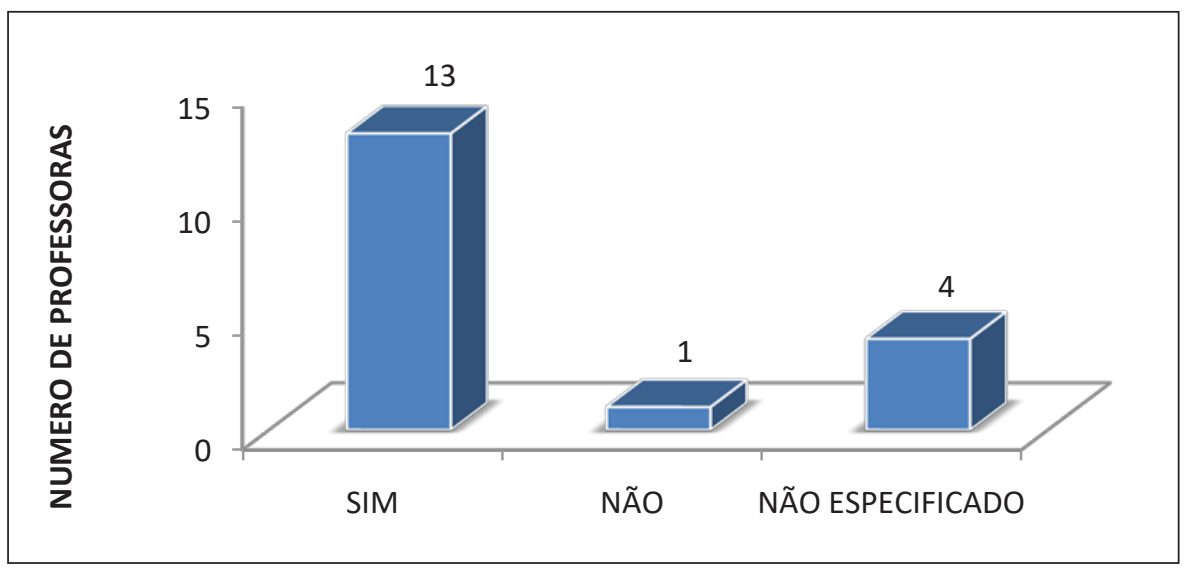

Setenta e dois por cento das professoras frequentaram curso de formação em Educação Especial nos últimos três anos.

Gráfico 15 - Temas dos cursos de formação em Educação Especial nos últimos três anos

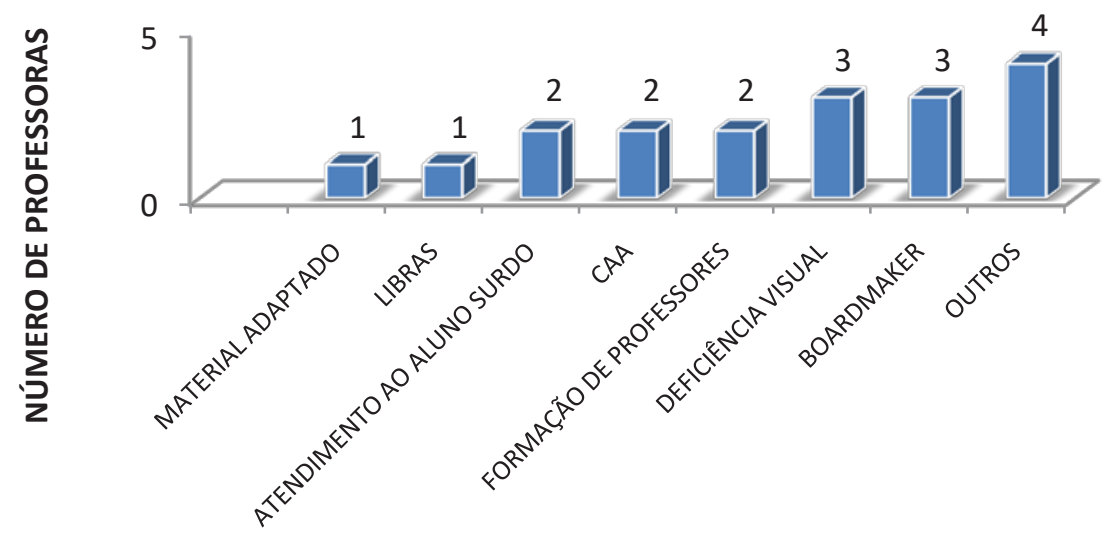


Vinte e oito por cento das participantes frequentaram cursos ligados à CAA e ao software Boardmaker.

Gráfico 16 -Frequência em eventos científicos em Educação Especial nos últimos dois anos

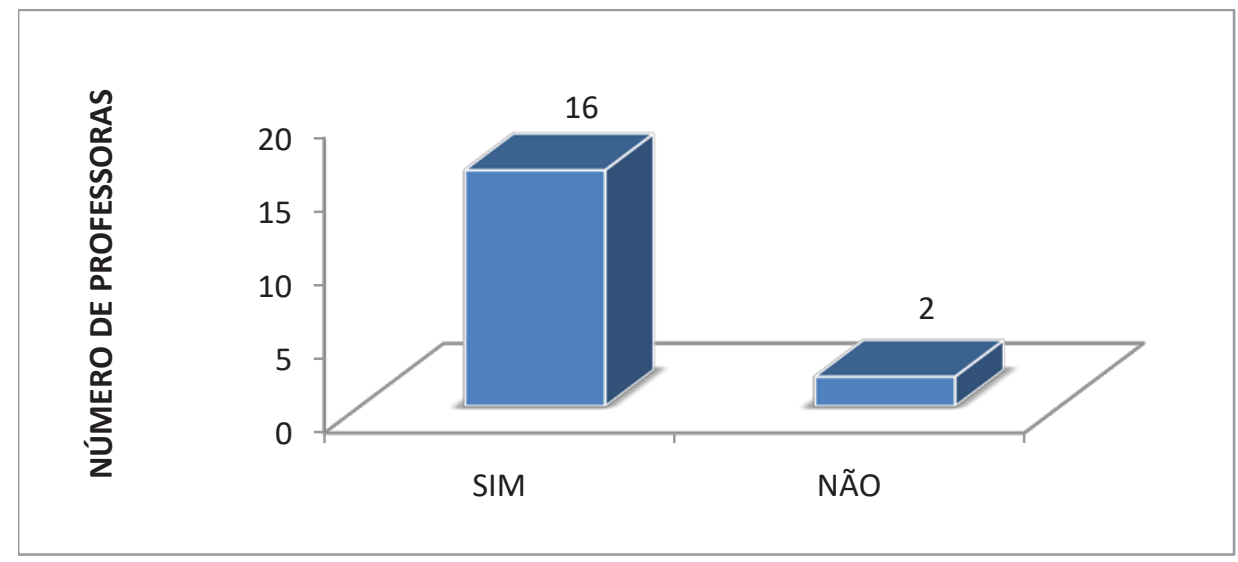

Oitenta e nove por cento das professoras frequentaram eventos científicos em Educação Especial nos últimos dois anos.

Gráfico 17 - Eventos científicos em Educação Especial, nos últimos dois anos, dos quais participaram as professoras

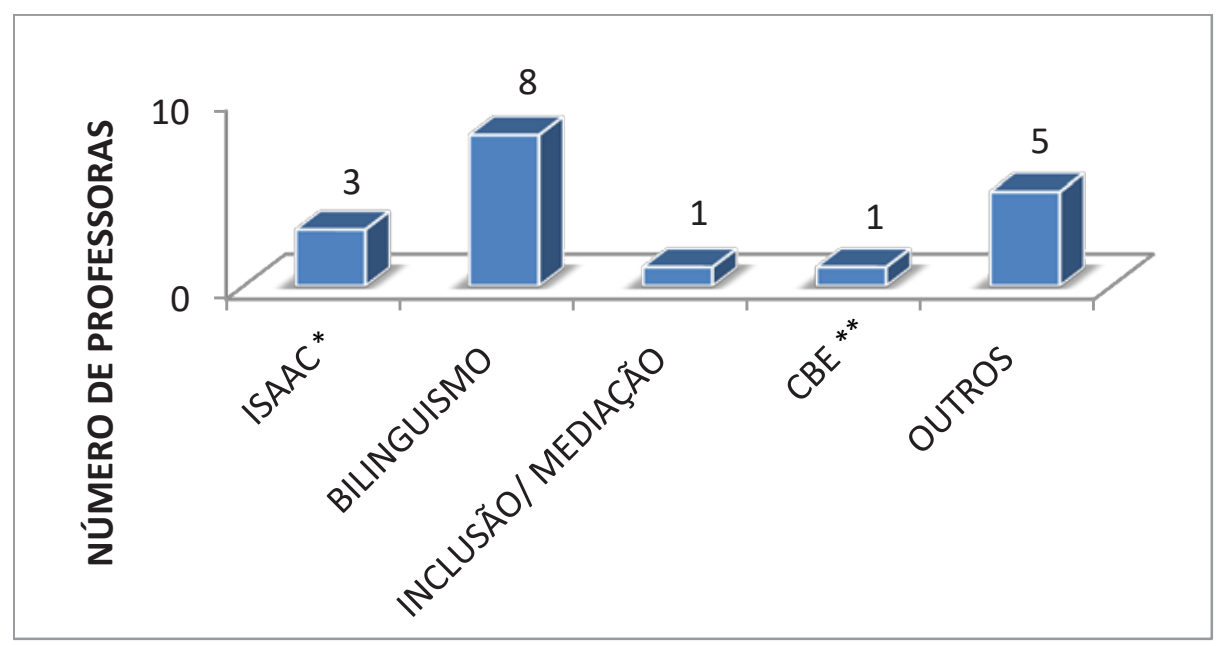

* ISAAC - International Society for Argumentative and Alternative Comunication

** CBE - Congresso Brasileiro de Educação 
Apenas $17 \%$ das professoras frequentaram eventos científicos ligados à CAA.

Gráfico 18 - Temas das leituras feitas pelas participantes

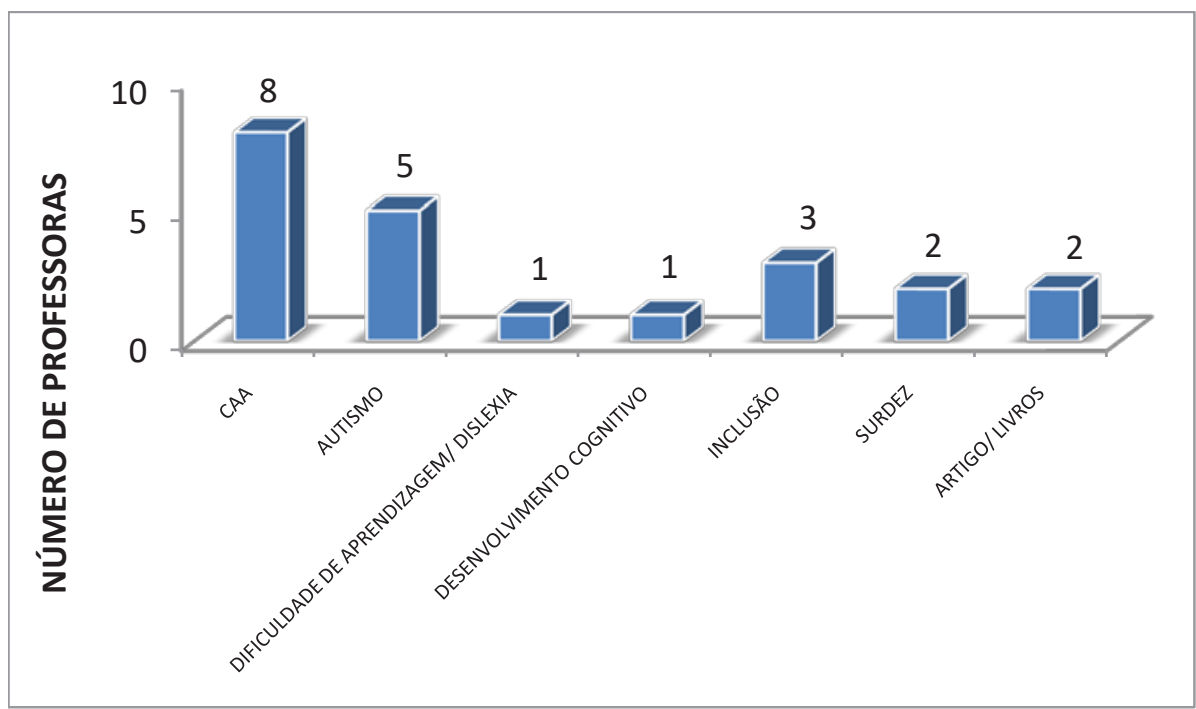

Quarenta e quatro por cento das participantes reportaram leituras sobre Comunicação Alternativa e Ampliada, e 27,5\% das participantes realizaram leitura sobre o Transtorno do Espectro Autista.

\section{Quem são os alunos atendidos por essas professoras}

Uma ficha contendo 12 itens foi preenchida por 17 professoras, informando as características dos 262 alunos atendidos por elas nas SRMs entre 2015 e 2016. Os dados coletados serão apresentados a seguir.

As 17 professoras atendem, em média, 15 alunos em suas SRMs, e a variação é de seis a 24 alunos.

No gráfico19, apresenta-se a informação sobre o sexo dos alunos atendidos. 
Gráfico 19 - Sexo dos alunos atendidos

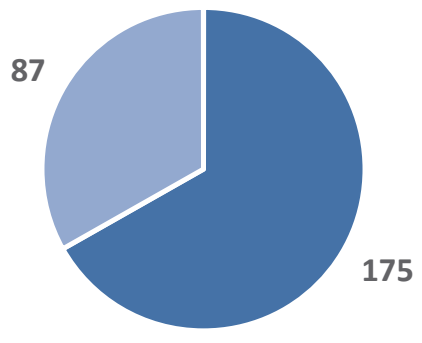

- Masculino - Feminino

Do total de 262 alunos, $67 \%$ são do sexo masculino.

No gráfico 20, apresenta-se a idade dos alunos.

Gráfico 20 - Idade dos alunos

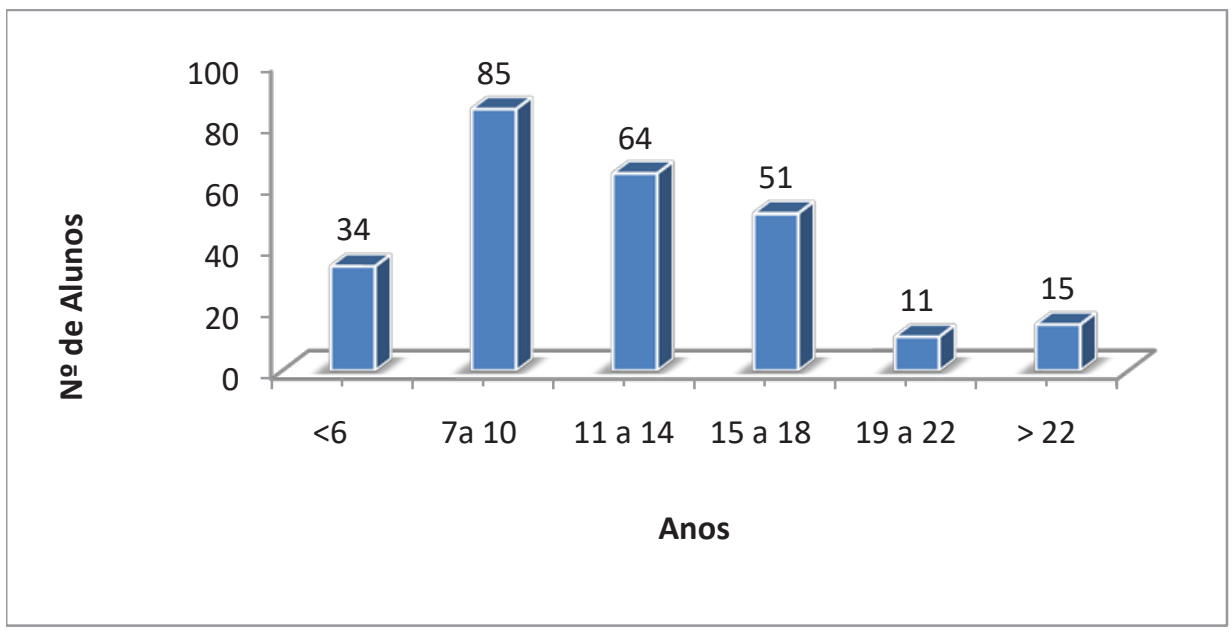

Trinta e dois por cento dos alunos têm idade entre sete e 10 anos.

No gráfico 21, identifica-se o tipo de deficiência dos alunos. 
Gráfico 21 - Tipo de deficiência dos alunos

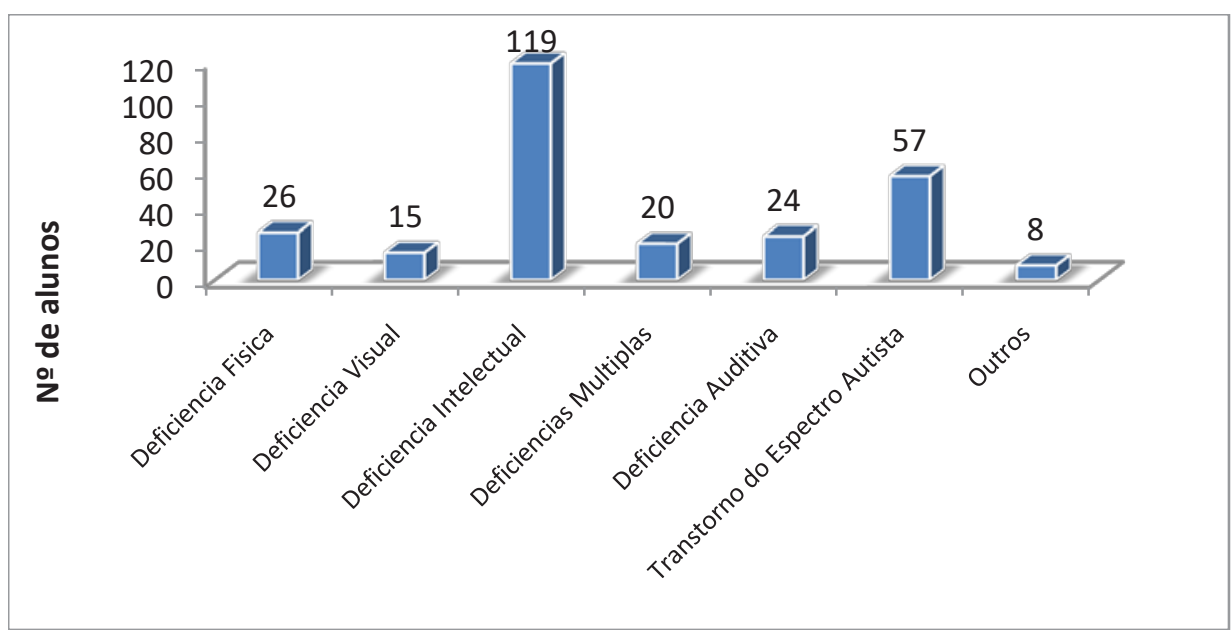

Observa-se que 45\% dos alunos atendidos apresentam deficiência intelectual e $22 \%$ apresentam TEA.

No gráfico 22, está apresentada a frequência semanal dos alunos nas Salas de Recursos.

Gráfico 22 - Frequência dos alunos

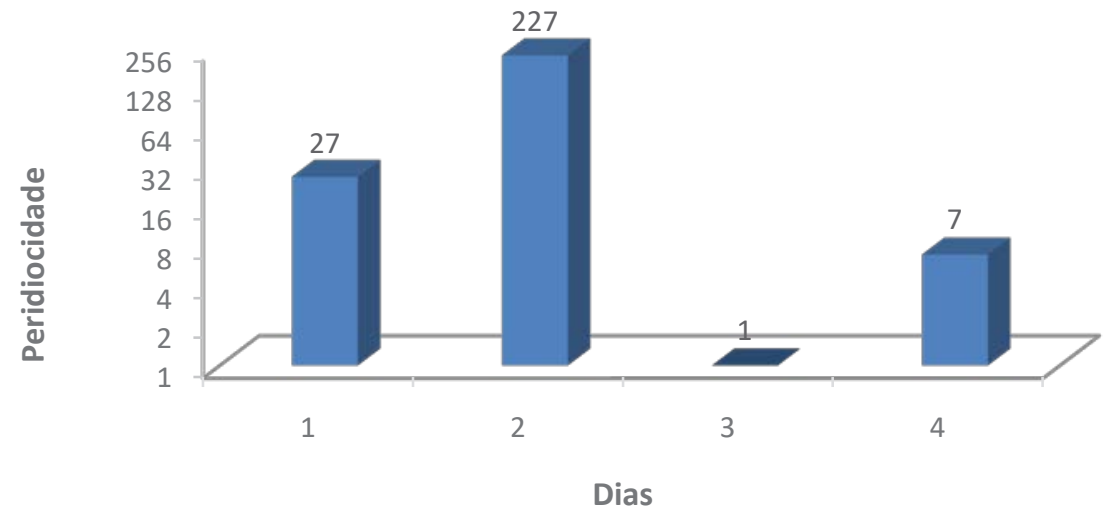

A maioria dos alunos, $87 \%$, é atendida duas vezes por semana nas salas de recursos. 
No gráfico 23, apresenta-se a série escolar desses alunos.

Gráfico 23 - Série escolar dos alunos

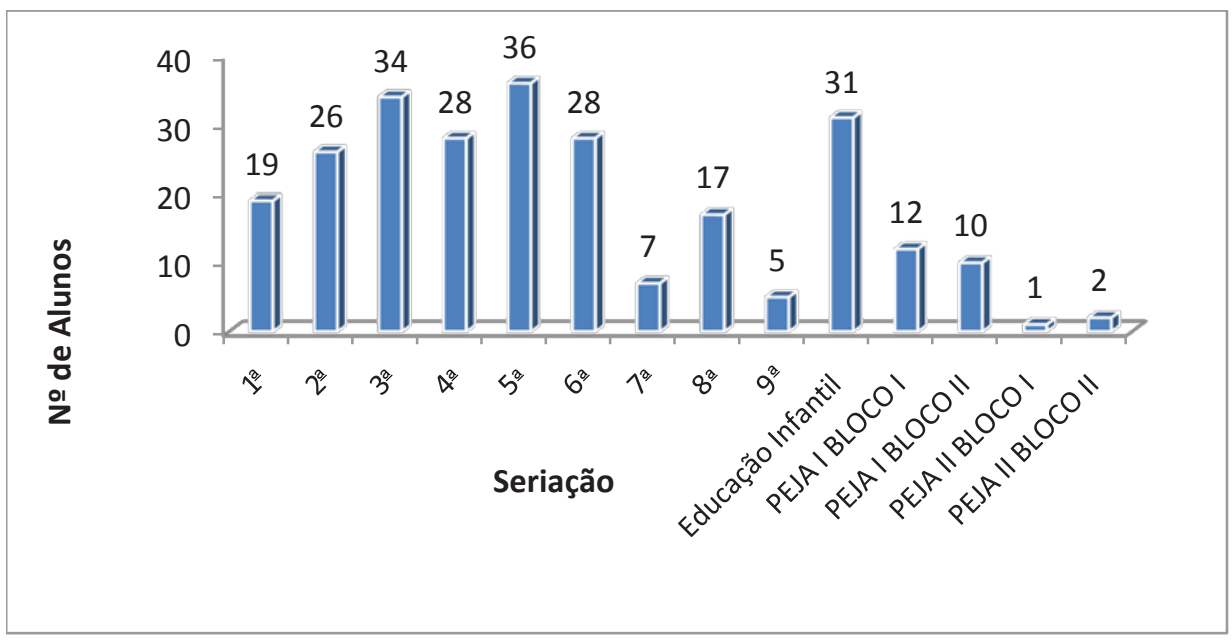

Observa-se que $27 \%$ dos alunos frequentam a $3 .^{\mathrm{a}}$ e a $5 .^{\mathrm{a}}$ séries.

No gráfico 24, mostra-se o número de professoras que contam com estagiário nas Salas de Recursos Multifuncionais.

Gráfico 24 -Número de professoras que contam com estagiário nas salas de recursos

- Sim Não 
Verifica-se que apenas 35\% das professoras contam com a colaboração de estagiário.

No gráfico 25, é exibido o número de alunos considerados assíduos nas sessões ocorridas nas salas de recursos.

Gráfico 25 - Número de alunos considerados assíduos nas sessões nas Salas de Recursos

\section{Assiduidade}

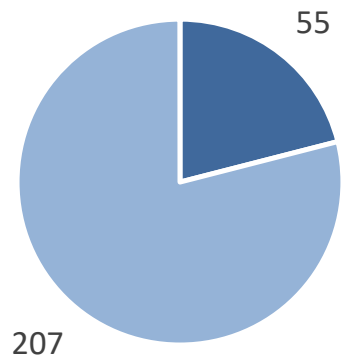

- Não assíduo

Assíduo

Setenta e nove por cento dos alunos atendidos nas sessões nas Salas de Recursos são considerados assíduos por suas professoras.

No gráfico 26, são exibidos os objetivos dos atendimentos ofertados aos alunos pelas professoras das Salas de Recursos. 
Gráfico 26 - Objetivos dos atendimentos ofertados aos alunos pelas professoras das Salas de Recursos

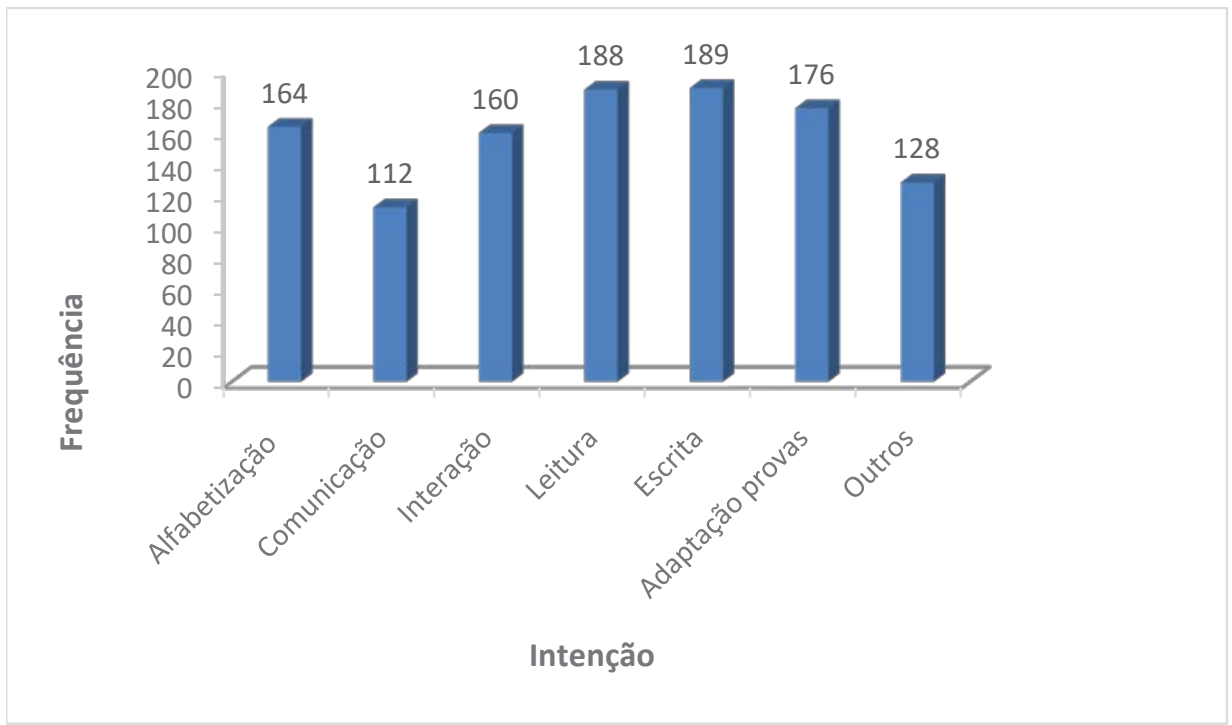

A seguir, no quadro 1, estão listados todos os objetivos categorizados como "Outros" pelas professoras. 
Quadro 1 - Objetivos categorizados como "Outros” pelas professoras

\begin{tabular}{|l|c|}
\hline Objetivos & Número de respondentes \\
\hline Ensino dos conceitos escolares bimestrais & 20 \\
\hline Autonomia nas atividades de vida diária & 11 \\
\hline Braille & 1 \\
\hline Prova individual diferente do ano da turma comum & 1 \\
\hline Organização do material de estudo & 1 \\
\hline Estimulação visual & 1 \\
\hline Conceitos matemáticos & 1 \\
\hline Matemática & 5 \\
\hline História & 1 \\
\hline Ciências & 1 \\
\hline Geografia & 1 \\
\hline Ensino PECS5 & 1 \\
\hline Adaptação do caderno & 2 \\
\hline Adaptação de atividade pedagógica & 1 \\
\hline Adaptação de conteúdo & 1 \\
\hline Raciocínio lógico & 15 \\
\hline Raciocínio lógico-matemático & 2 \\
\hline Percepção & 1 \\
\hline Memorização & 1 \\
\hline Atenção & 1 \\
\hline Concentração & 1 \\
\hline Redução de questões & 3 \\
\hline Figura & 1 \\
\hline Ampliação & 3 \\
\hline Flexibilização curricular & 1 \\
\hline Atividades e recursos & 1 \\
\hline Coordenação motora fina & 3 \\
\hline Coordenação motora & 1 \\
\hline Habilidades cognitivas e não cognitivas & 1 \\
\hline Interpretação de texto & 1 \\
\hline
\end{tabular}

5 Picture Exchange Comunication System 
Alfabetização, leitura e escrita são os objetivos mais frequentes no atendimento ofertado.

No gráfico 27, são apresentados os recursos usados pelas professoras nas Salas de Recursos.

Gráfico 27 - Recursos usados pelas professoras nas Salas de Recursos

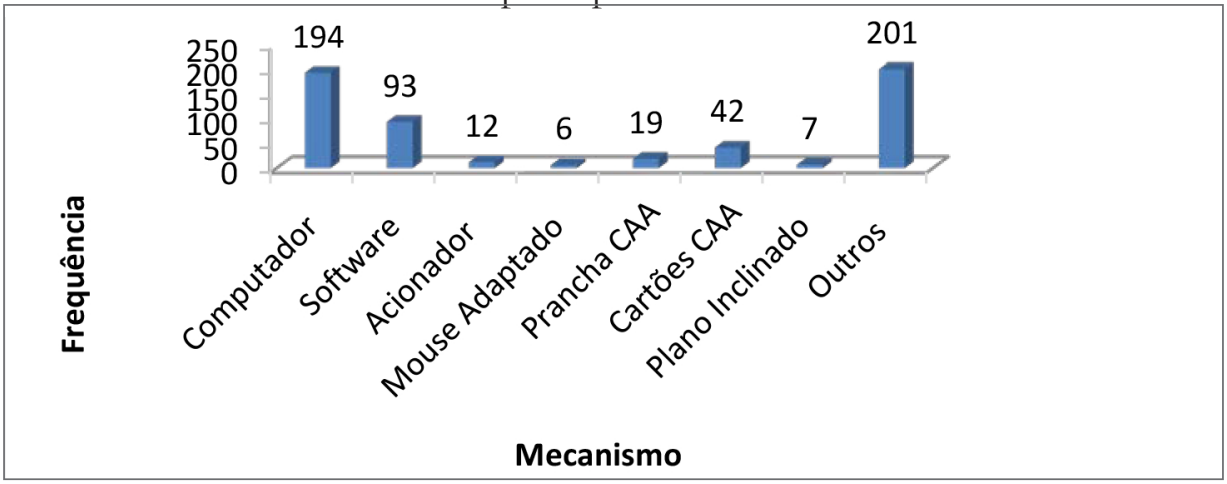

Computadores são os recursos mais usados pelas professoras em suas Salas de Recursos.

No quadro 2, estão listados todos os softwares indicados pelas professoras.

Quadro 2 - Softwares usados

\begin{tabular}{|l|c|}
\hline Software & Número de respondentes \\
\hline Boardmaker & 20 \\
\hline Alfa & 6 \\
\hline Participar & 11 \\
\hline Prancha Fácil & 1 \\
\hline Fono Tico & 1 \\
\hline Dosvox & 16 \\
\hline Aventuras & 19 \\
\hline Abc & 1 \\
\hline Educativo & 11 \\
\hline Pranchas Pedagógicas & 1 \\
\hline Contos Infantis 1 & 1 \\
\hline
\end{tabular}


No Quadro 3, estão listados os recursos classificados pelas professoras como "Outros".

Quadro 3 - Recursos classificados pelas professoras como "Outros"

\begin{tabular}{|c|c|}
\hline Recurso & Número de respondentes \\
\hline Libras & 3 \\
\hline Alfabeto em Libras & 2 \\
\hline Tablet & 26 \\
\hline Jogos educativos & 19 \\
\hline Jogos e materiais adaptados & 25 \\
\hline Jogos pedagógicos & 17 \\
\hline Lupa eletrônica & 2 \\
\hline Letras e números móveis e ampliados & 17 \\
\hline Programa Sebran & 9 \\
\hline Site estudamos.com & 6 \\
\hline Programa Pé de Vento & 4 \\
\hline Coleção Fono na Escola & 13 \\
\hline Brinquedos & 4 \\
\hline Pesquisa & 10 \\
\hline Gravuras variadas & 1 \\
\hline Miniaturas & 2 \\
\hline Jogos didáticos & 2 \\
\hline Material concreto & 14 \\
\hline Ampliação & 1 \\
\hline Material dourado & 1 \\
\hline Maquetes & 1 \\
\hline Materiais tridimensionais & 1 \\
\hline Brinquedos adaptados & 2 \\
\hline Brinquedos com acionador & 1 \\
\hline Caixa de antecipação & 1 \\
\hline Sistema de calendários & 1 \\
\hline Jogos & 3 \\
\hline Brincadeiras & 1 \\
\hline Oficinas de produção de texto & 2 \\
\hline
\end{tabular}




\begin{tabular}{|l|c|}
\hline Recurso & Número de respondentes \\
\hline Rodas de leitura & 1 \\
\hline Oficinas pedagógicas & 1 \\
\hline Calculadora & 1 \\
\hline Cartão com opção de resposta & 1 \\
\hline Letras móveis & 1 \\
\hline Figuras e palavras com velcro & 2 \\
\hline Conhecimentos matemáticos & 1 \\
\hline Mesa adaptada & 2 \\
\hline Caderno pedagógico adaptado & 1 \\
\hline Material diversificado & 1 \\
\hline Teclado adaptado & 7 \\
\hline Jogos online & 2 \\
\hline Atividades adaptadas & 1 \\
\hline História adaptada & 1 \\
\hline Adaptaçóes escritas & 6 \\
\hline Material adaptado & 4 \\
\hline Pasta de vocabulário & \\
\hline
\end{tabular}

Cento e sessenta em cinco, ou seja, 63\% do total de 262 alunos são atendidos nas 17 escolas onde estão lotadas as 17 professoras. Os demais (37\%) recebem atendimento em outras escolas (escolas extras). O número médio de escolas extras atendidas pelas professoras é três e a variação é de uma a seis escolas. 


\section{Discussão}

Os dados fornecidos pelas participantes acerca de seu perfil profissional mostram que se trata de um grupo relativamente jovem, mas com razoável tempo de magistério e de dedicação ao ensino da população-alvo da Educação Especial. Sua atuação, contudo, nas Salas de Recursos Multifuncionais é igual ou inferior a três anos. A maioria, quase absoluta, tem curso superior e, além disso, muitas delas frequentaram cursos de especialização. Todas, sem exceção, fizeram curso de Comunicação Alternativa antes de ingressar nesta pesquisa. Este foi um dos critérios para ser participante dessa formação. Muitas frequentam eventos na área e costumam ler sobre assuntos relacionados à educação do aluno especial.

A análise dos dados acerca dos alunos atendidos por essas professoras confirma muitas das conclusóes obtidas pelo conjunto de estudos desenvolvidos por 76 pesquisadores oriundos de 21 universidades localizadas em 38 municípios brasileiros. Com a participação de 596 professores das Salas de Recursos Multifuncionais, o projeto coordenado pela professora Enicéia Mendes, no Observatório Nacional de Educação Especial, foi iniciado em 2010 e finalizado em 2015 (Mendes et al., 2015).

No atual estudo, o número médio de alunos atendidos por docente é de 15 , com variação entre seis e 24 . No conjunto de estudos coordenados por Mendes et al. (2015), esse quantitativo variou entre um e 23. Corroborando os achados de Mendes, há, no presente estudo, predominância de alunos com deficiência intelectual. Essa concordância estende-se para as séries escolares dos alunos. Ou seja, são atendidos alunos desde o ensino infantil até o ensino médio, com maior representatividade de estudantes do ensino fundamental. Observe-se que a maioria dos atendimentos (63\%) é ofertada na própria escola onde as professoras estão lotadas. Contudo, todas elas deslocam-se para outros estabelecimentos escolares no âmbito de sua CRE para oferecer esse atendimento especializado.

A periodicidade dos encontros dos alunos com a professora da SRM é bastante semelhante àquela relatada por Mendes et al. (2015). Essa autora e colaboradores informam que os alunos pesquisados frequentavam de uma até cinco vezes por semana, com predomínio de dois atendimentos semanais. $\mathrm{Na}$ atual pesquisa, há uma variação entre um e quatro vezes, com maior frequência de dois atendimentos por semana. 
Outro aspecto em que houve concordância entre os estudos coordenados por Mendes et al. (2015) e a presente investigação diz respeito às atividades conduzidas nas SRM. Atividades ligadas à alfabetização, leitura e escrita ganharam destaque na agenda das professoras que ofertam atendimento educacional especializado, assim como o ensino de uso de hardwares, como computadores e tablets e softwares com jogos pedagógicos, materiais adaptados e atividades lúdicas.

Os dados coletados por meio dessa ficha dos alunos atendidos não permitem, infelizmente, concluir se as atividades conduzidas pelas professoras atendem ou não à orientação do MEC, que recomenda que o atendimento educacional especializado deva constituir-se como complementar ou suplementar ao ensino comum e não como substitutivo. 


\title{
Capítulo 4 - Levantamento das habilidades pedagógicas e das conceituações das professoras das Salas de Recursos Multifuncionais
}

\author{
Carolina Rizzotto Schirmer \\ Leila Regina d'Oliveira de Paula Nunes ${ }^{2}$ \\ Stefhanny Paulimineytrick Nascimento Silva ${ }^{3}$
}

\section{Objetivos}

Este estudo teve como objetivo identificar as habilidades das professoras acerca do emprego de recursos de Comunicação Alternativa e Ampliada (CAA) e de conhecimentos sobre temas afins antes e após o curso de formação continuada em serviço.

1 Professora adjunta da Faculdade de Educação da UERJ. E-mail: ead.carolina@gmail. com.

2 Professora titular da Faculdade de Educação e do Programa de Pós-Graduação em Educação da UERJ. E-mail: leilareginanunes@terra.com.br.

3 Mestranda em Educação pelo Programa de Pós-Graduação em Educação da UERJ. E-mail: stefhannyp@gmail.com. 


\section{Procedimentos}

O presente estudo foi desenvolvido na Oficina Vivencial, no Instituto Helena Antipoff. A coleta de dados foi realizada por meio de dois questionários, aplicados em duas ocasiōes. O primeiro continha 25 questões de múltipla escolha - que envolveram o emprego de recursos de CAA e de acesso ao computador - e tinha como objetivo identificar as habilidades dos professores. Sua elaboração foi baseada no questionário validado por Pelosi (2008). O segundo questionário era composto de 11 questóes abertas e pretendia verificar o conhecimento e a percepção dos professores sobre temas como deficiência, CAA, Informática Acessível e outros. A elaboração desse questionário foi fundamentada no instrumento validado por Schirmer (2012).

A primeira aplicação ocorreu em maio de 2013 , bem no começo da pesquisa, e a segunda, em dezembro de 2014, ao final do segundo ano de formação.

Foram realizadas análises quantitativas das questōes de múltipla escolha e de conteúdo das questôes descritivas. Utilizou-se a técnica de análise categorial, que funciona por operações de desmembramento do texto em categorias, segundo reagrupamentos analógicos (Bardin, 1977). A análise de conteúdo foi organizada em três etapas: a pré-análise, a exploração do material e o tratamento dos resultados que envolveram a inferência e a interpretação. Os dados coletados foram organizados em banco de dados, usando-se o software Microsoft Office Excel, o que auxiliou na organização dos dados em categorias para facilitar a análise, bem como na quantificação dos resultados, possibilitando a criação de gráficos ilustrativos.

Como nem todas as 18 professoras participantes do estudo responderam aos questionários nas duas datas, optou-se, para fins de comparação, por apresentar os dados de dez professoras que cumpriram o agendamento. 


\section{Resultados}

A seguir, são apresentados os dados do primeiro questionário analisado.

Gráfico 1 - Professora é capaz de determinar respostas afirmativas e negativas do aluno que não tem comunicação oral

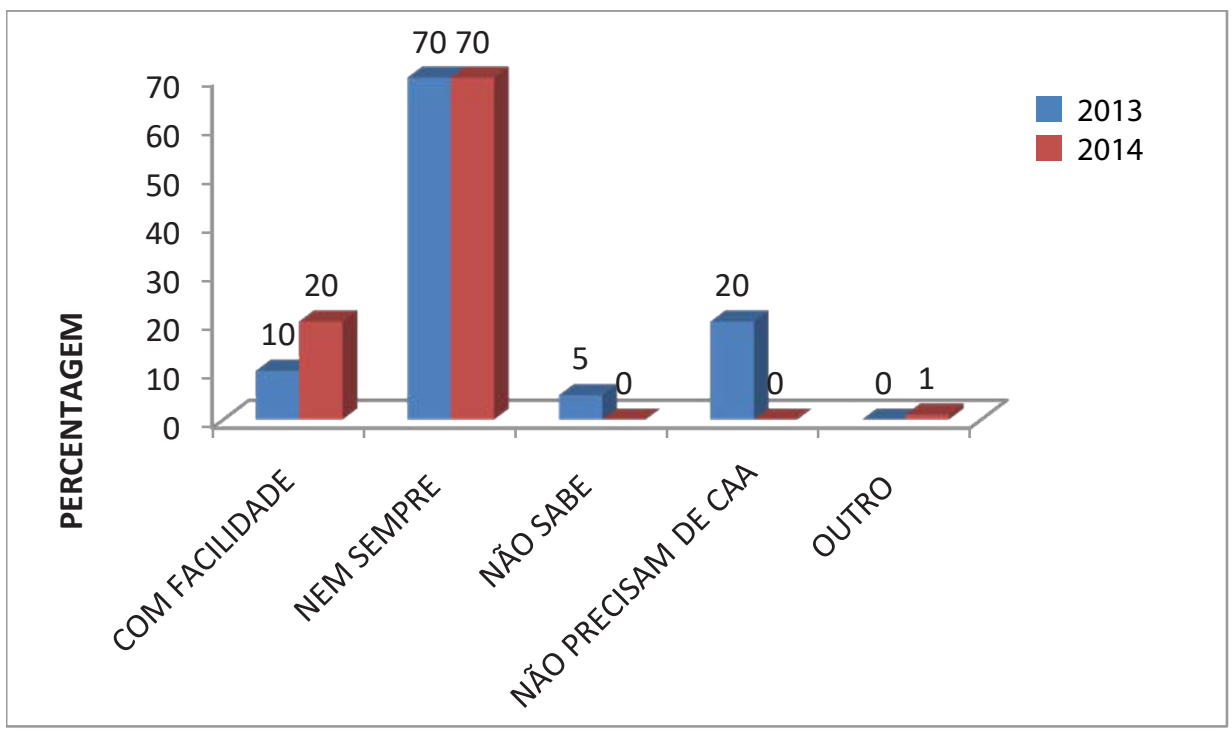

O número de docentes que sabiam determinar respostas afirmativas e negativas do aluno não oralizado aumentou levemente depois da formação de professoras. 
Gráfico 2 - Professora sabe utilizar adaptações para escrita (engrossadores, lápis especiais, órteses)

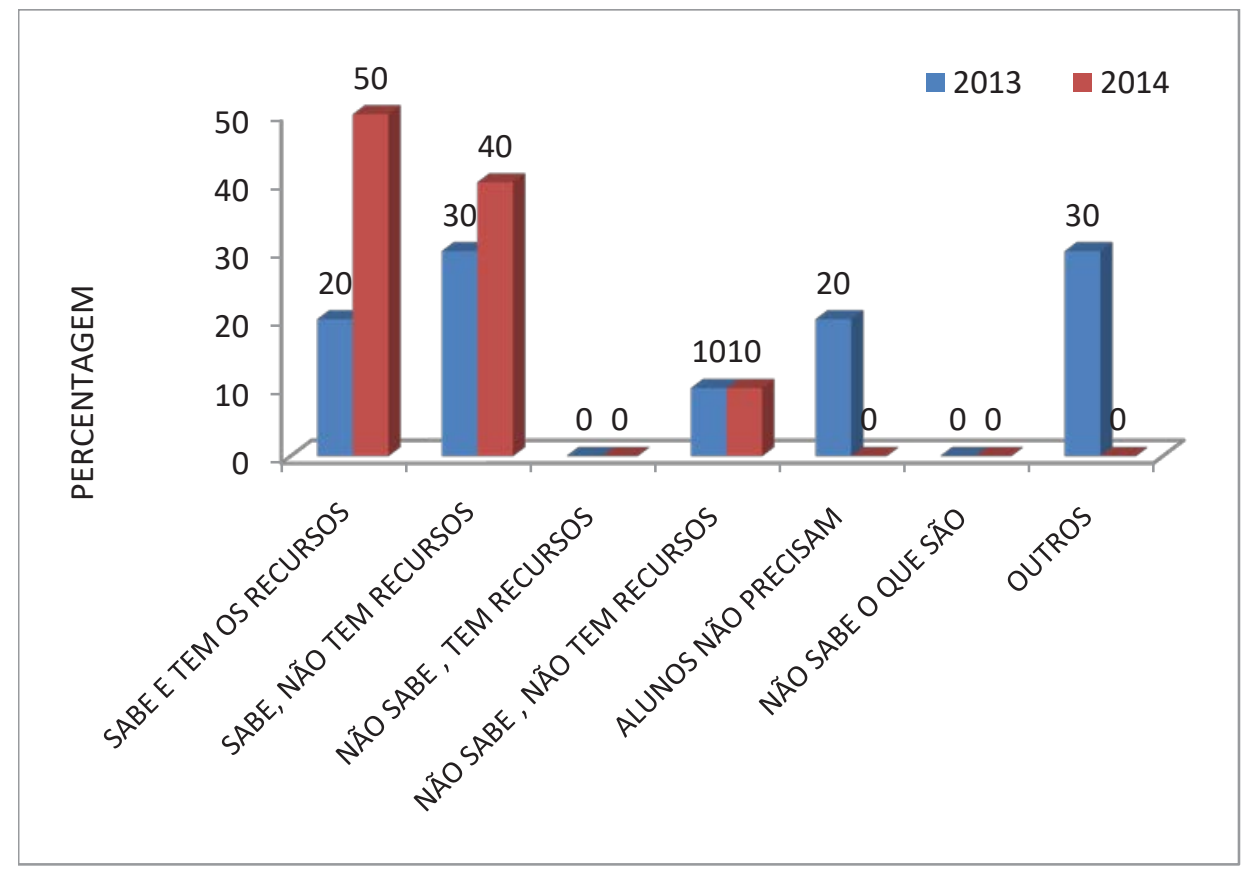

Após a formação, aumentou o número de professoras que informaram saber mais e ter mais recursos para fazer adaptações para a escrita. 
Gráfico 3 - Professora é capaz de elaborar prancha de comunicação

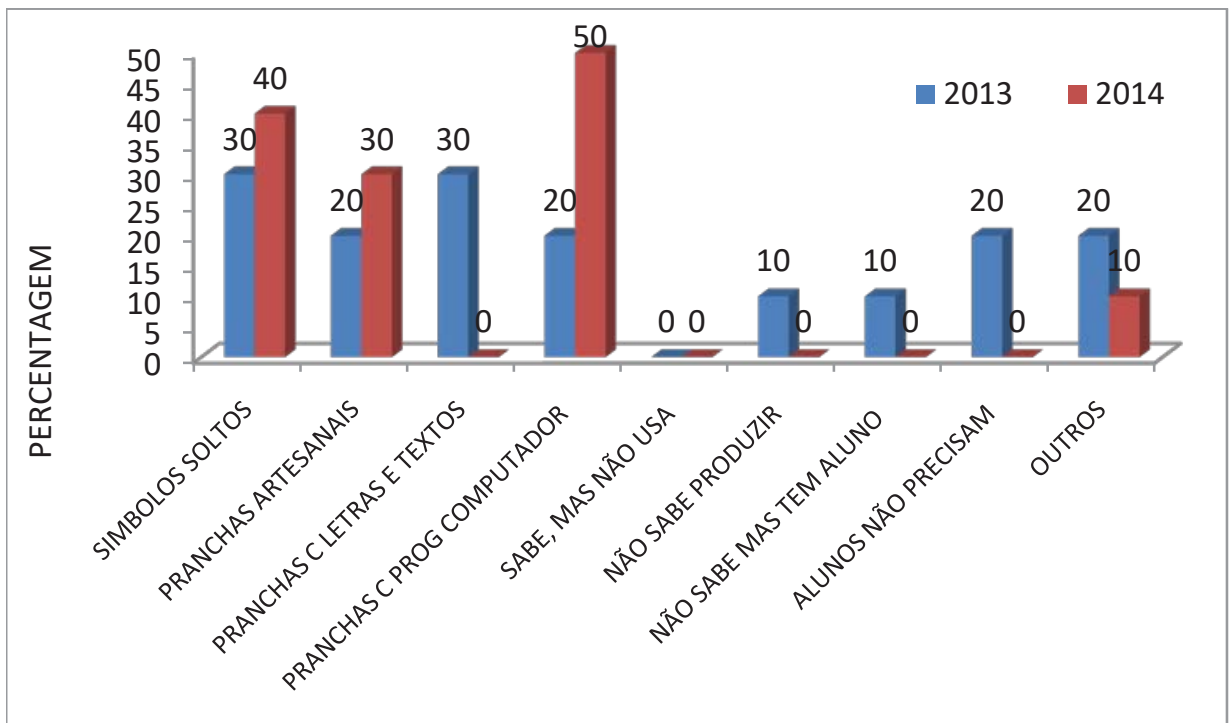

Aumentou o número de professoras que, após receberem a formação, passaram a elaborar recursos diversos de Comunicação Alternativa e Ampliada.

Gráfico 4 - Professora utiliza pranchas de comunicação socialmente

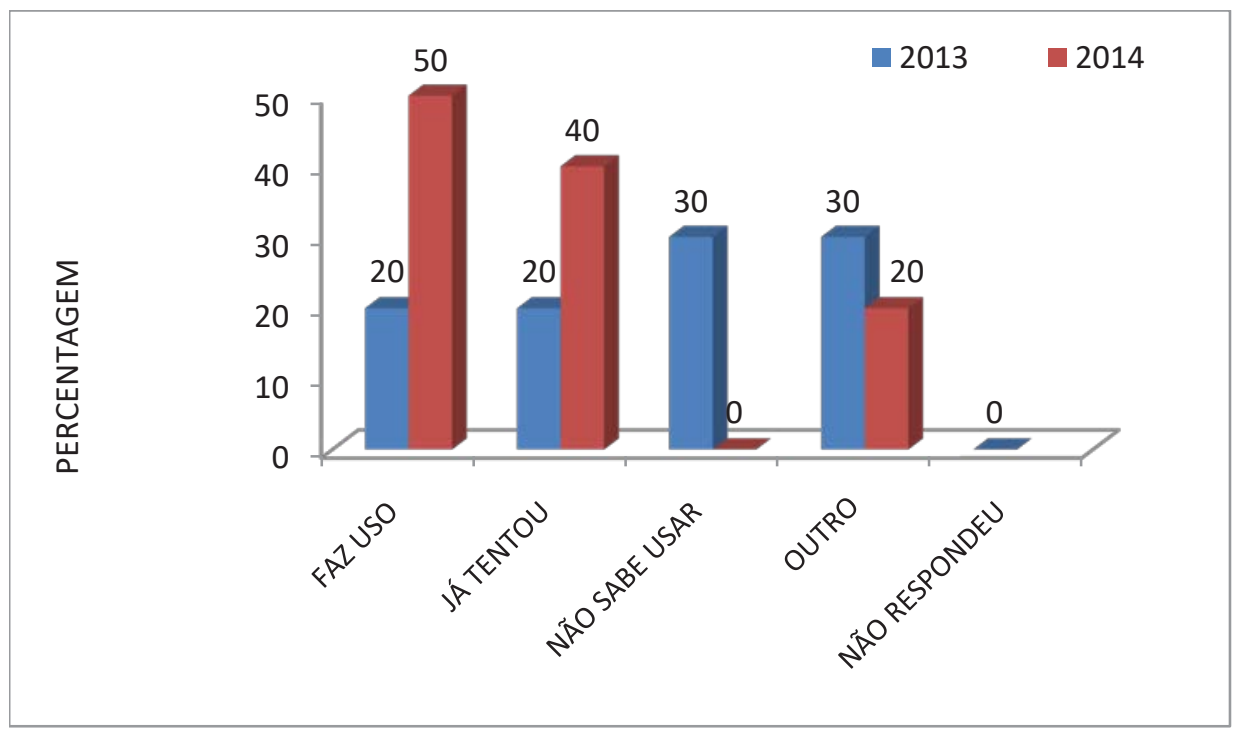


Maior número de professoras passou a usar ou a tentar usar a prancha de comunicação socialmente, após a formação.

Gráfico 5 - Professora utiliza prancha de comunicação para auxiliar no trabalho escolar

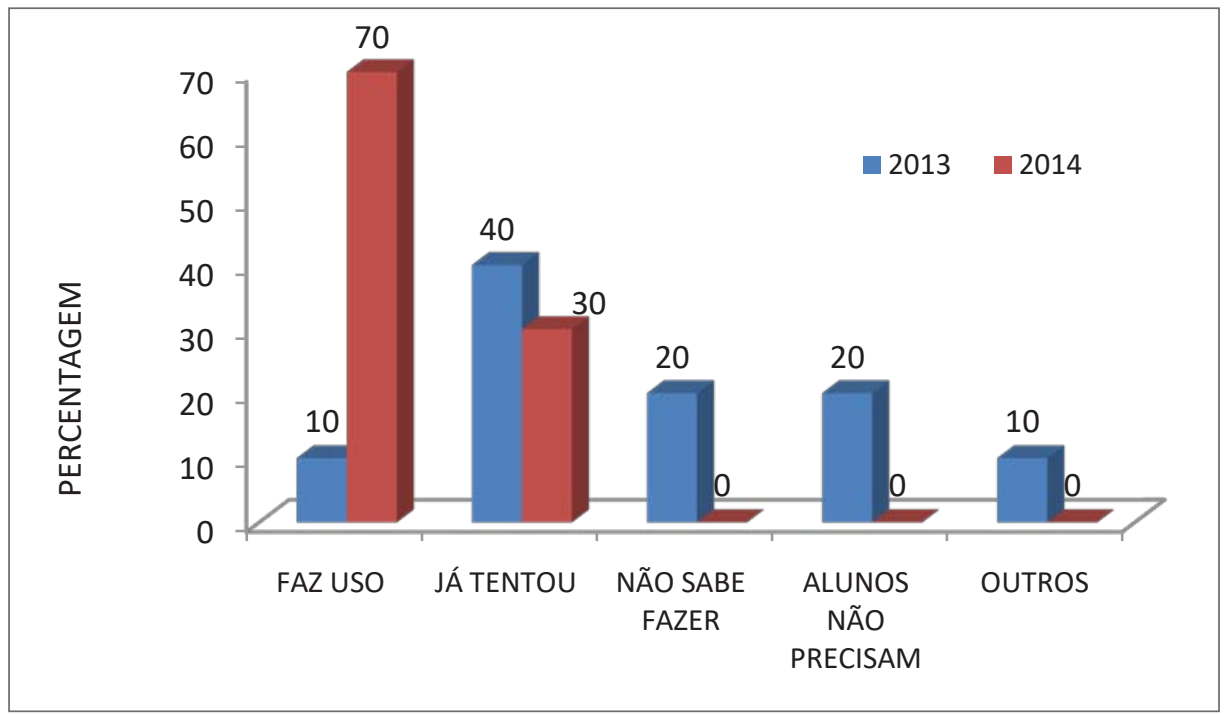

Houve um aumento considerável do número de professoras que passaram a usar pranchas de comunicação para fins acadêmicos após a formação.

Gráfico 6 - Professora faz adaptação de trabalhos escolares

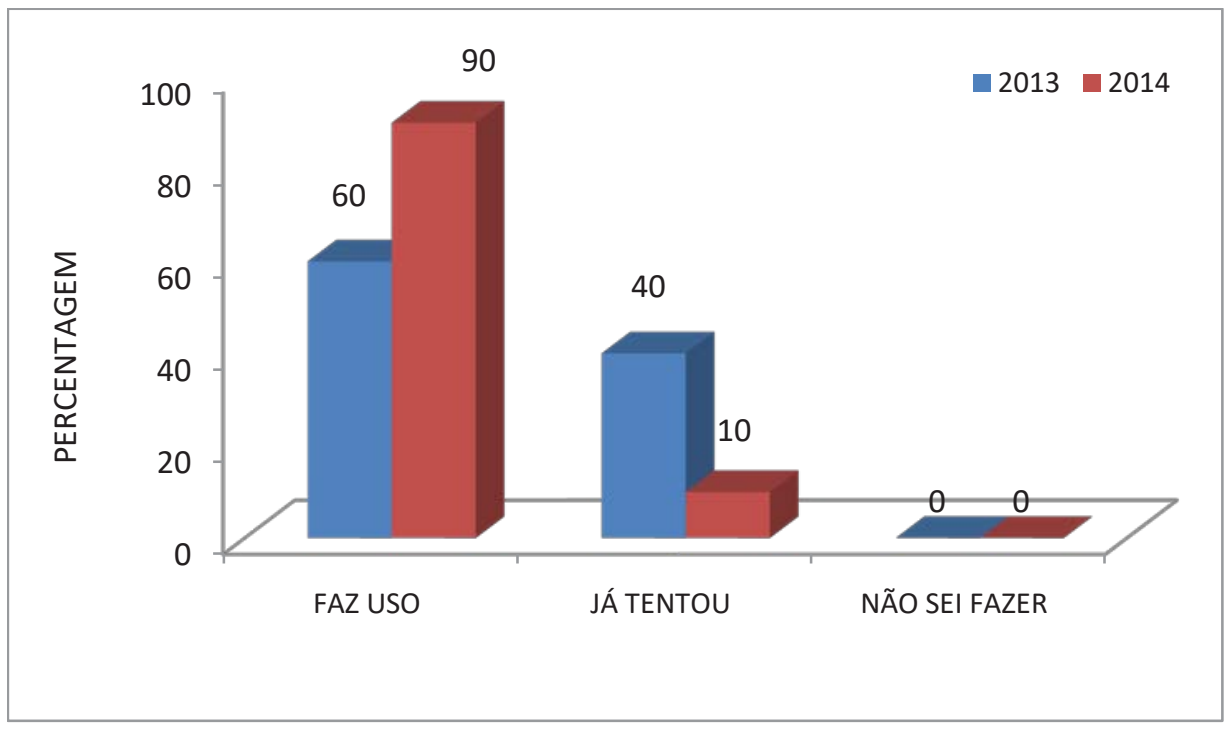


Com a formação, mais professoras passaram a fazer adaptação de trabalhos escolares.

Gráfico 7 - Professora usa letras emborrachadas e outros materiais adaptados para facilitar a escrita de alunos com dificuldade motora

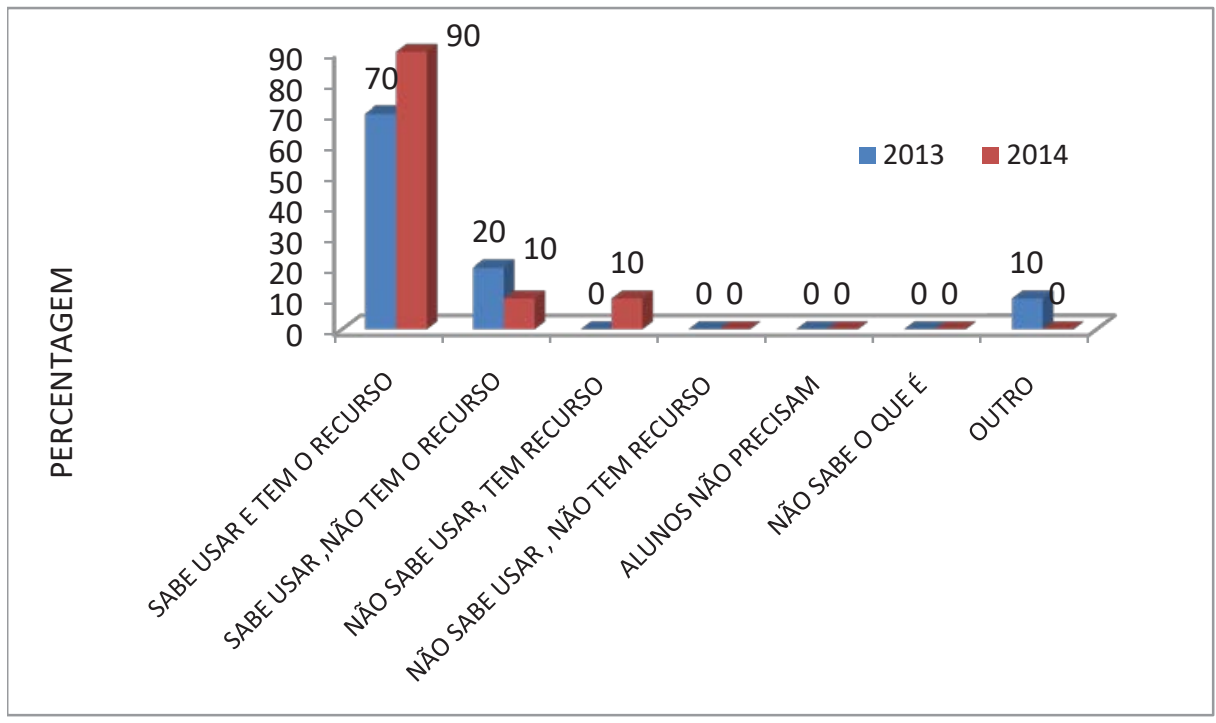

Após a formação, mais professoras passaram a empregar letras emborrachadas e outros materiais adaptados, a fim de facilitar a escrita de alunos com dificuldade motora. 
Gráfico 8 - Professora sabe avaliar o aluno para uso do acionador

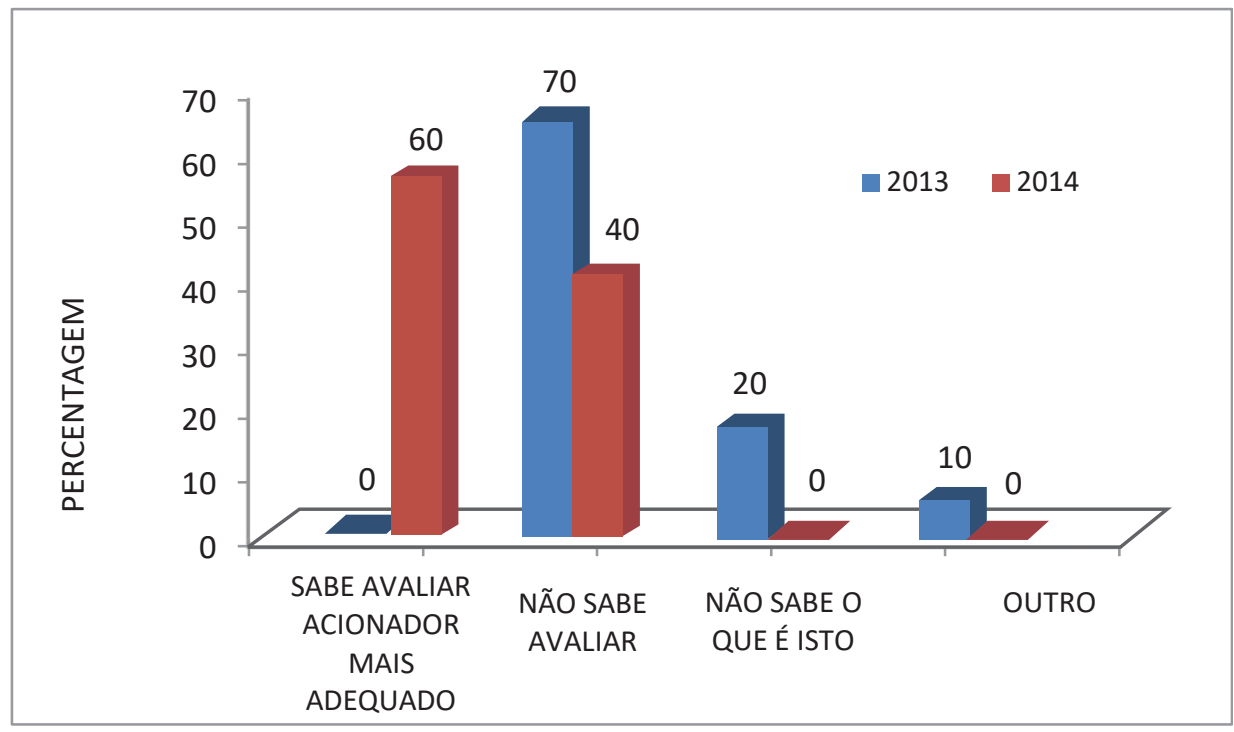

Após o curso de formação, um maior número de professoras passou a avaliar o aluno a fim de selecionar o melhor acionador. 
Gráfico 9 - Professora usa acionador

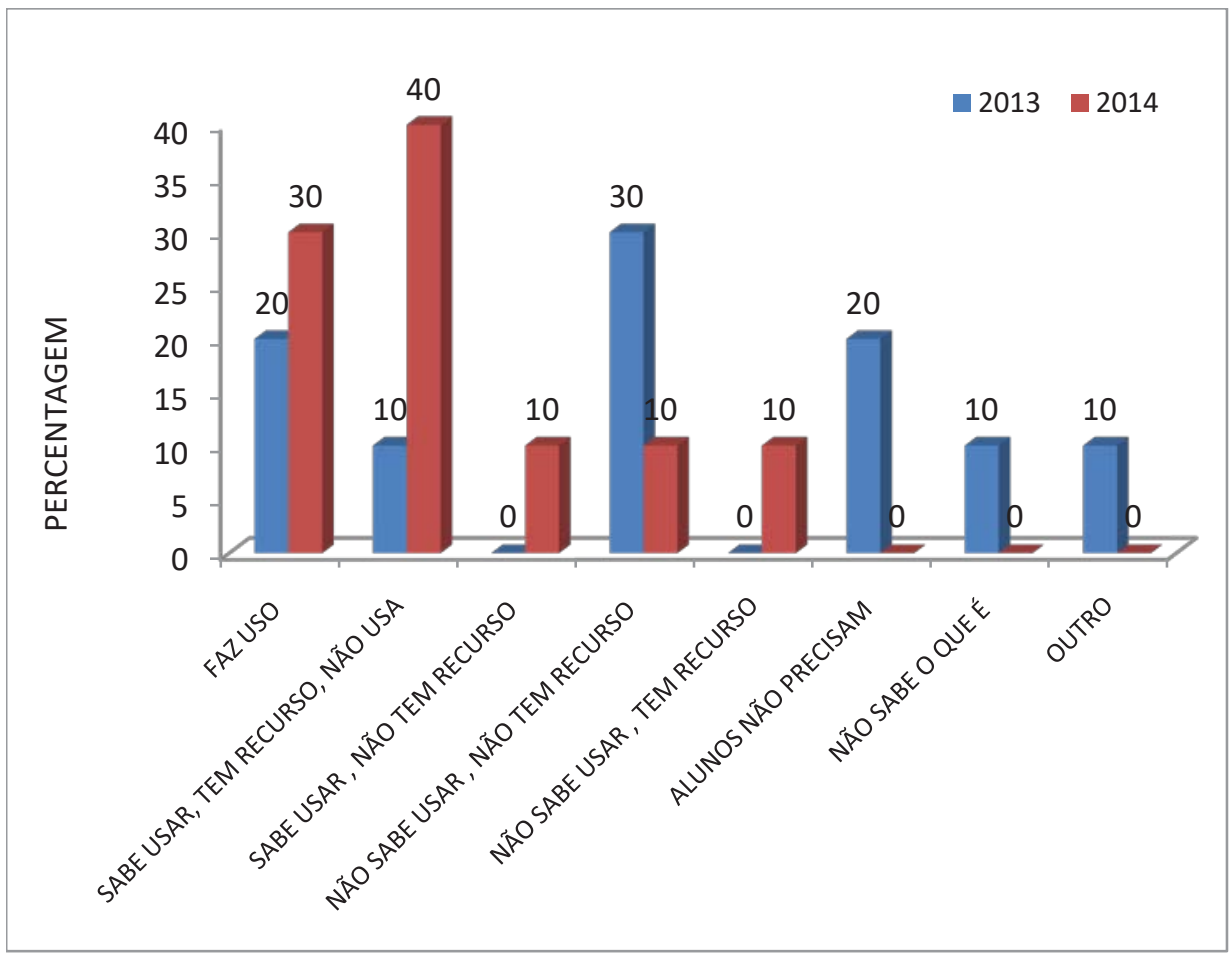

Mais professoras passaram a usar o acionador após a formação. No entanto, aquelas que não o usavam em 2013 continuaram a não fazê-lo em 2014. 
Gráfico 10 - Professora usa brinquedo adaptado (com interruptor de pilha)

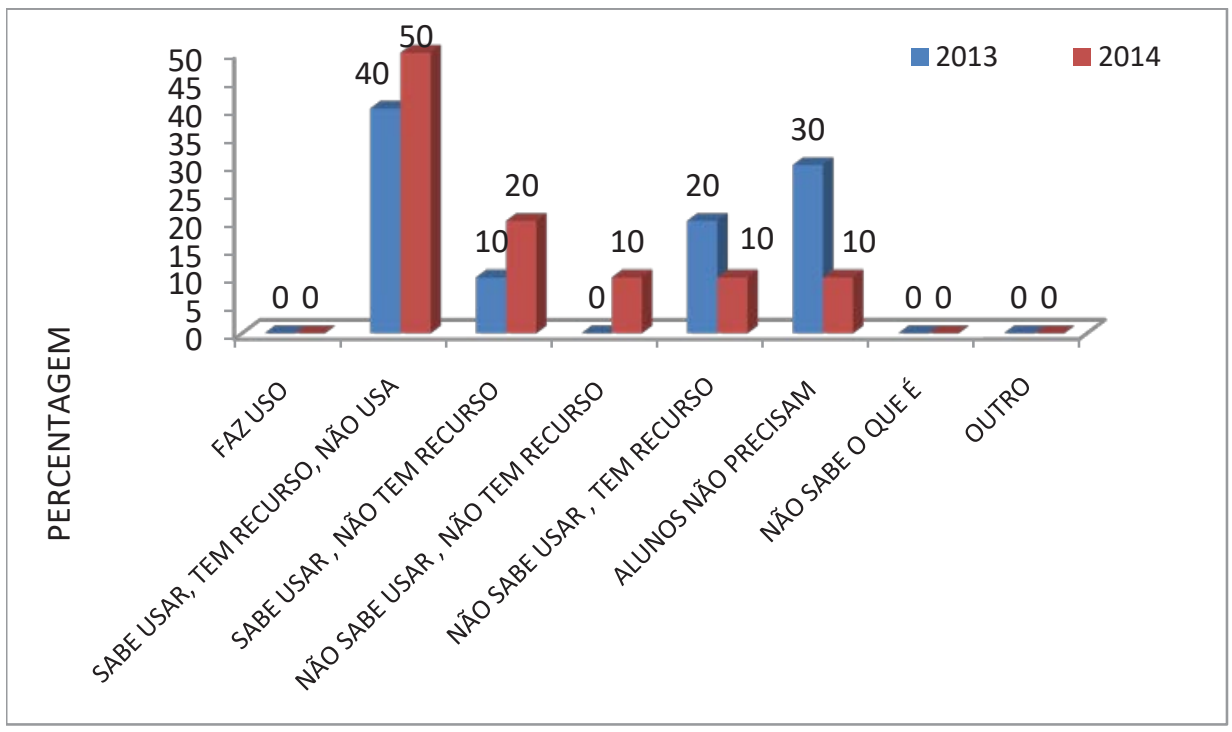

As professoras que possuem brinquedo adaptado não fazem uso deste. 
Gráfico 11 - Professora usa comunicador com voz

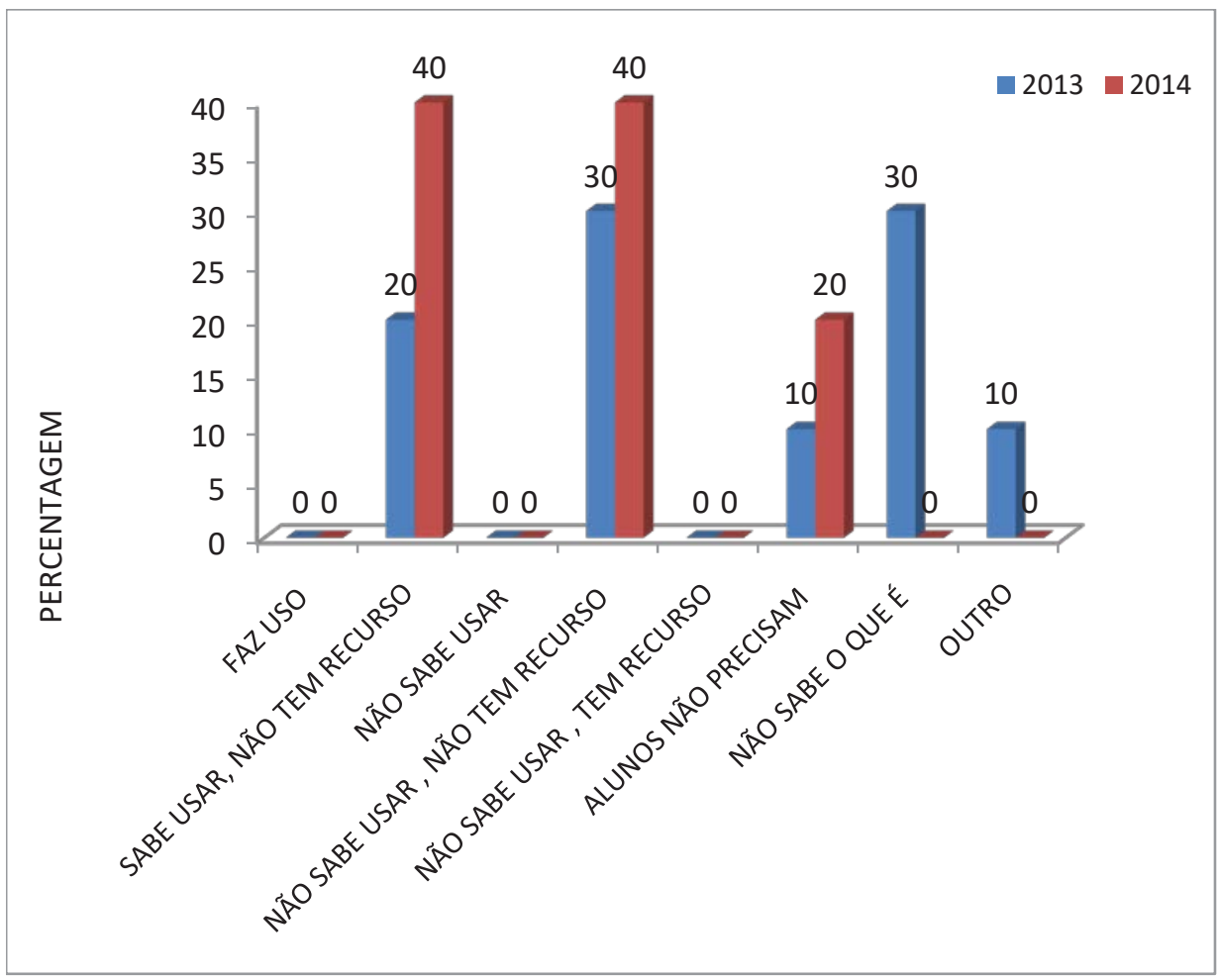

Professoras não possuem o comunicador com voz em suas salas. 
Gráfico 12 - Professora avalia aluno e determina a melhor forma de acesso ao computador

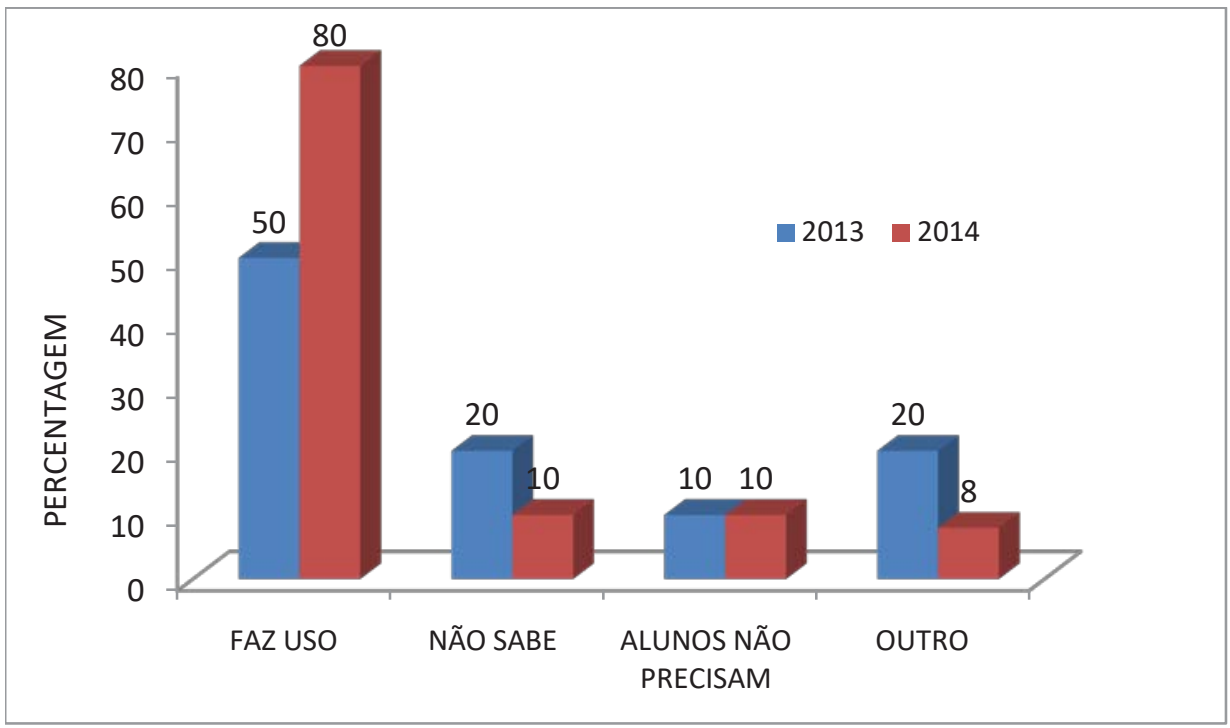

Mais professoras, após a formação, exibiram capacidade de avaliar o aluno e determinar a melhor forma de acesso ao computador.

Gráfico 13 - Uso de computador com software educativo

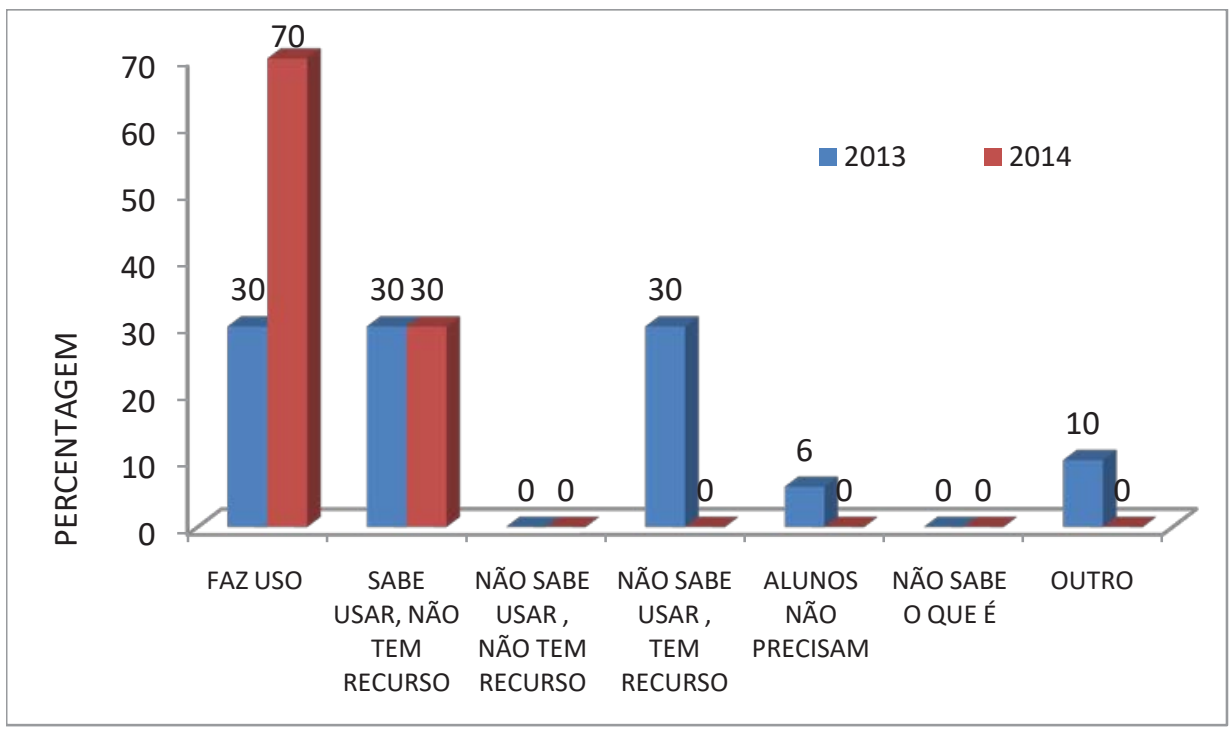


Maior número de professoras passou a usar o computador com software educativo após a formação.

Gráfico 14 - Professora usa adaptações, como órteses, pulseira de peso etc.,para facilitar o teclar.

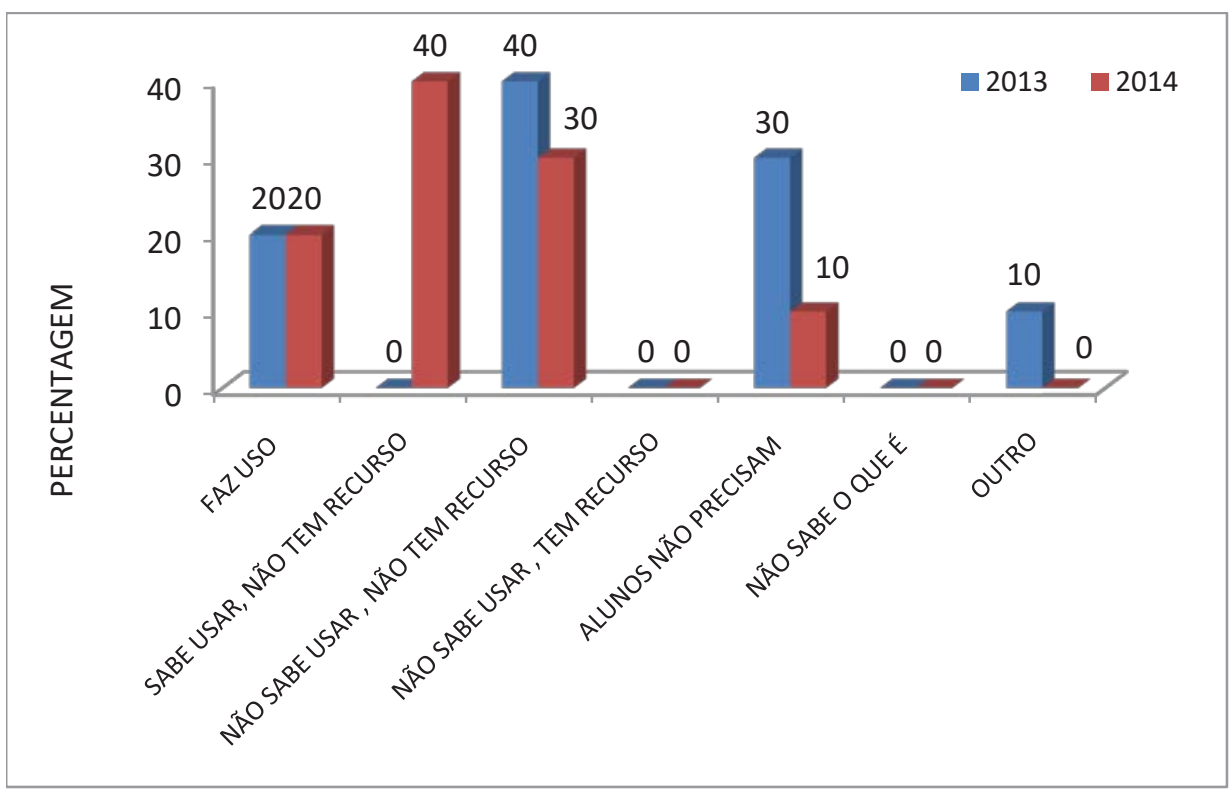

Não foi alterado, a partir da formação, o número de professoras que usam adaptaçóes para facilitar o teclar. 
Gráfico 15 - Professora usa a colmeia para teclado

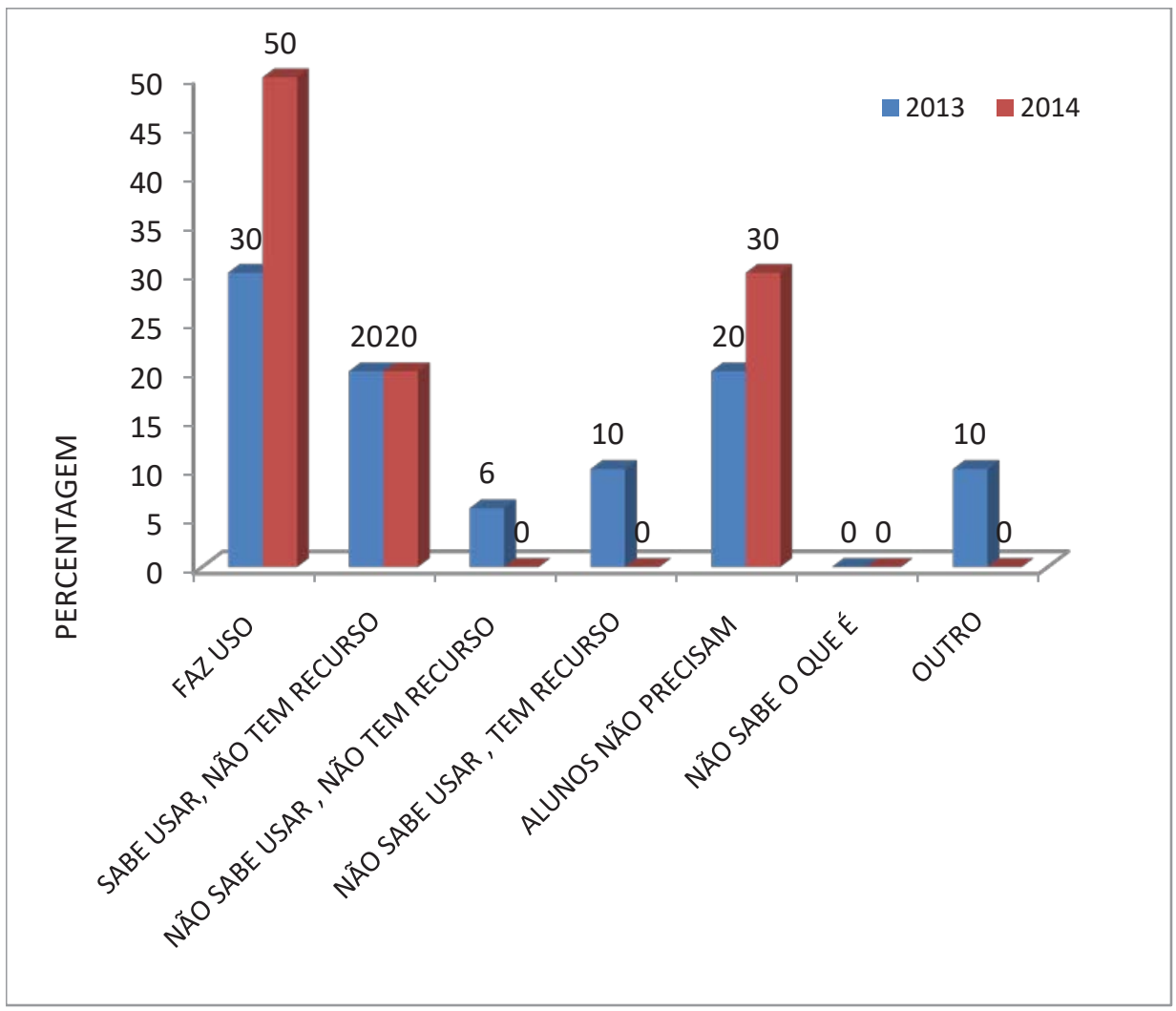

Aumentou o número de professoras que usa a colmeia para teclado após a formação. 
Gráfico 16 - Professora usa o computador com teclado expandido

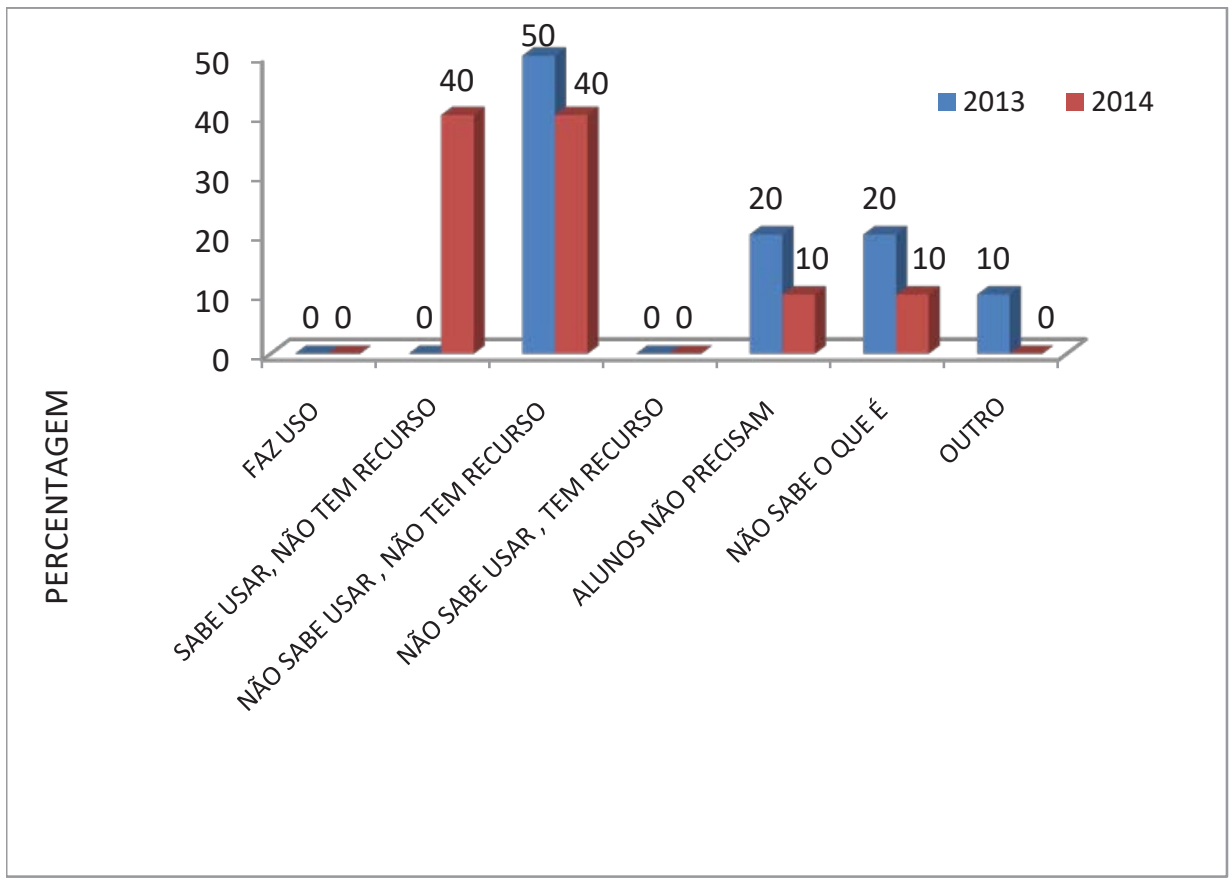

Professoras não possuem o teclado expandido em suas salas.

Gráfico 17 - Professora usa o computador com mouse adaptado

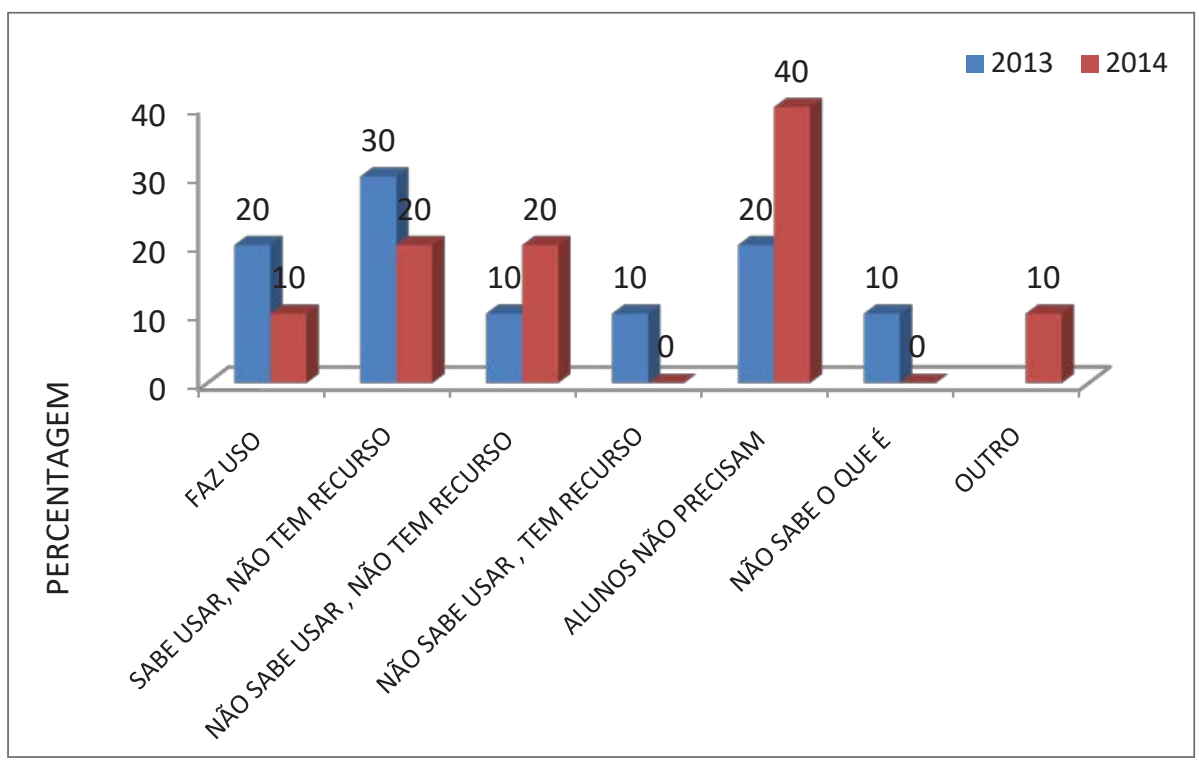


Diminuiu o número de professoras que usam o computador com mouse adaptado. Quarenta por cento das professoras não possuem mouse adaptado em suas salas.

Gráfico 18 - Professora usa computador com softwares especiais para escrita

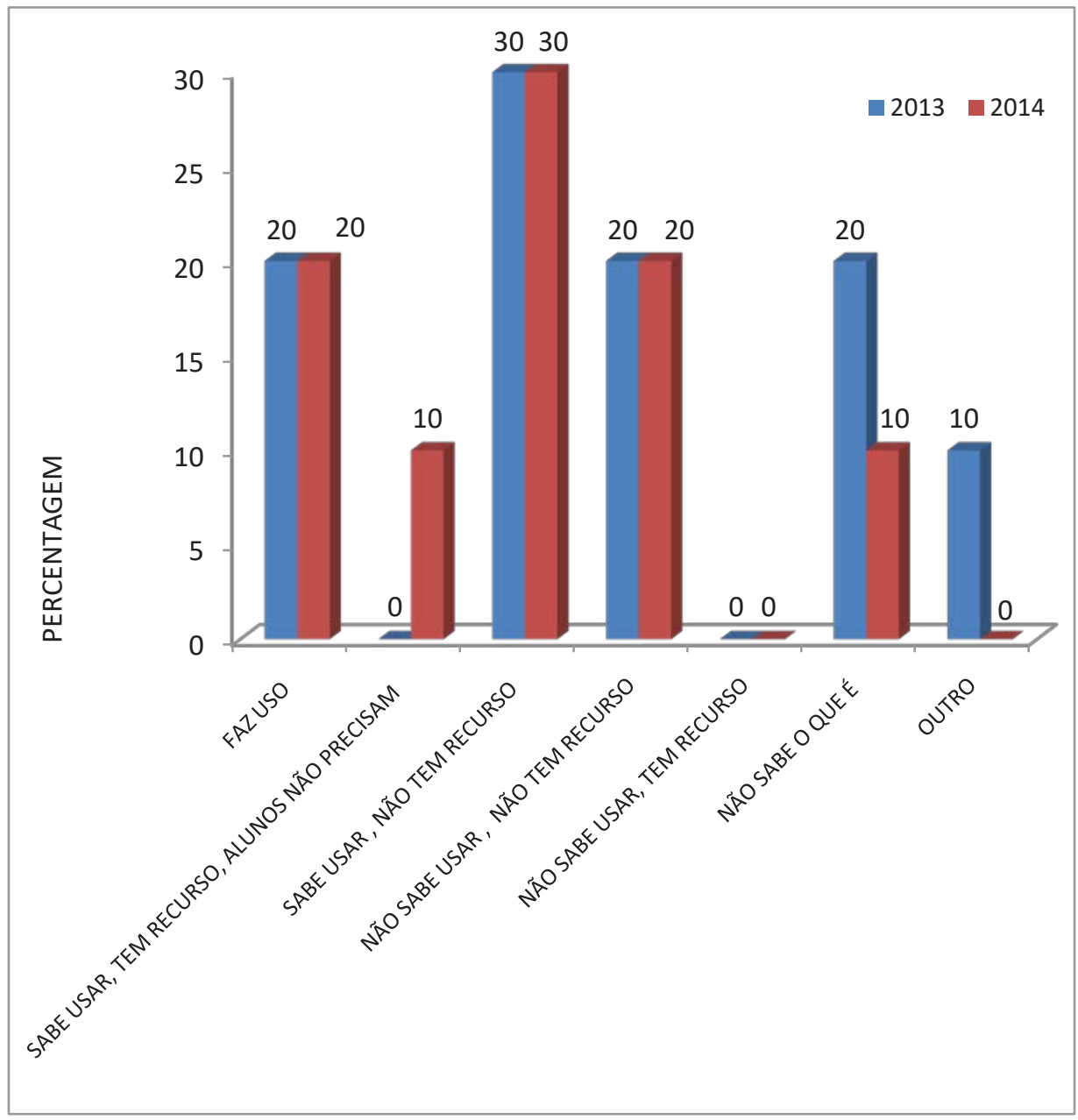

Não se alterou o número de professoras que usam o computador com softwares especiais para escrita. Cinquenta por cento das professoras não têm softwares especiais para escrita em suas salas. 
Gráfico 19 - Professora identifica as necessidades específicas do aluno diante das atividades propostas para o seu grupo de referência

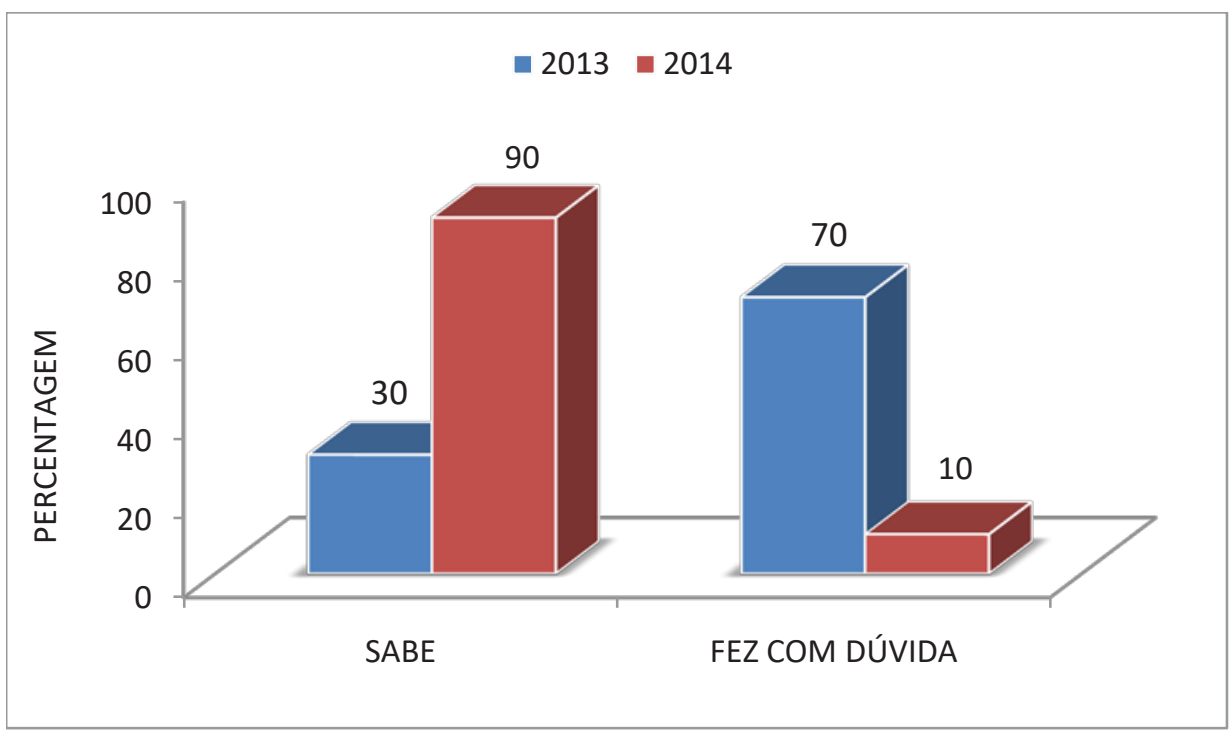

Após a formação, aumentou o número de professoras que se consideram capazes de identificar as necessidades específicas do aluno ante as atividades propostas para o seu grupo de referência. 
Gráfico 20 - Professora propõe as adaptações pedagógicas necessárias

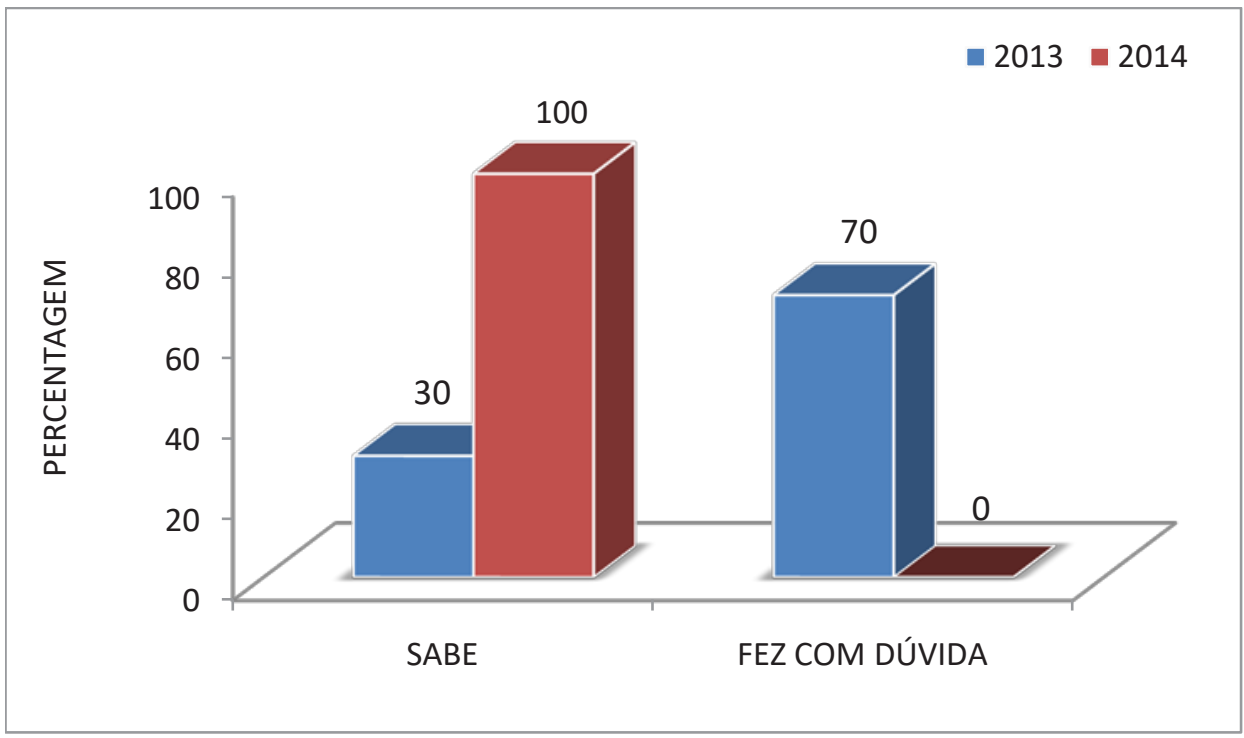

Ao final da formação, todas as professoras afirmaram saber propor as adaptações pedagógicas necessárias.

Gráfico 21 - Professora produz recursos pedagógicos adaptados às necessidades específicas dos alunos

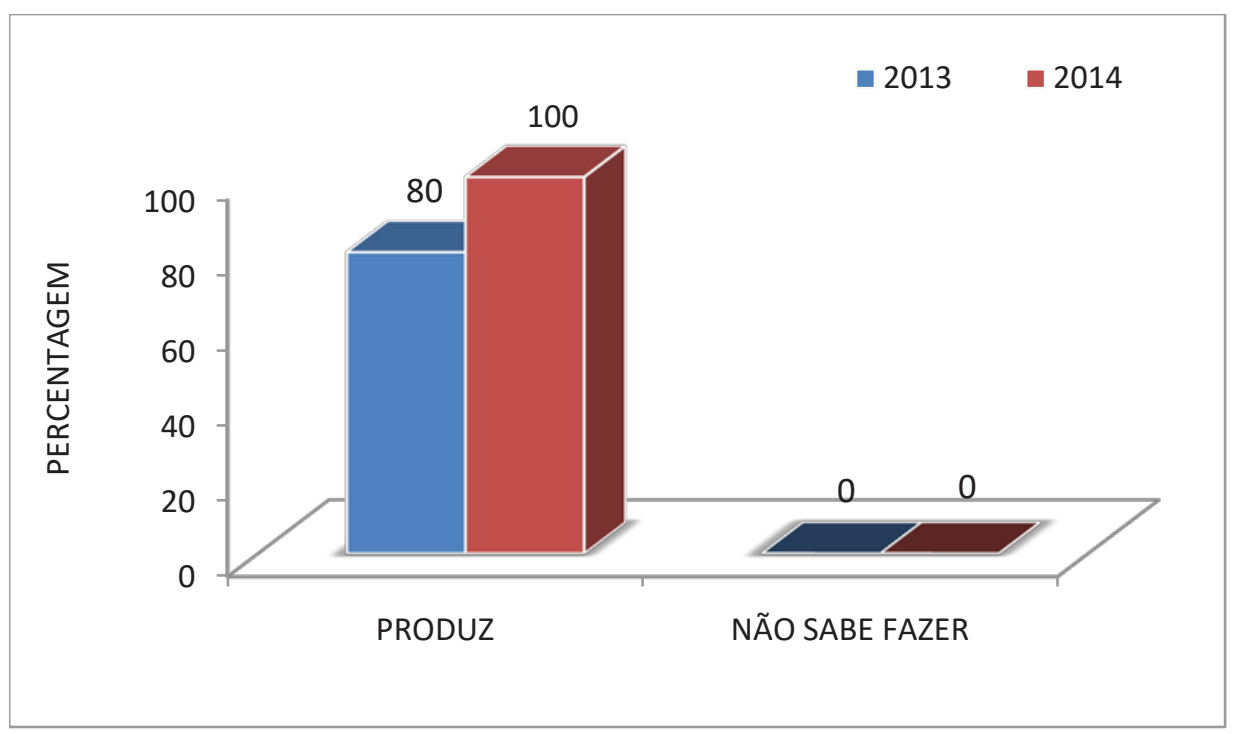


Após a formação, aumentou o número de professoras que produzem recursos pedagógicos adaptados às necessidades específicas dos alunos.

Gráfico 22 - Professora avalia o estágio de alfabetização em que o aluno se encontra (pré-silábica, silábica, alfabética ou fases de transição)

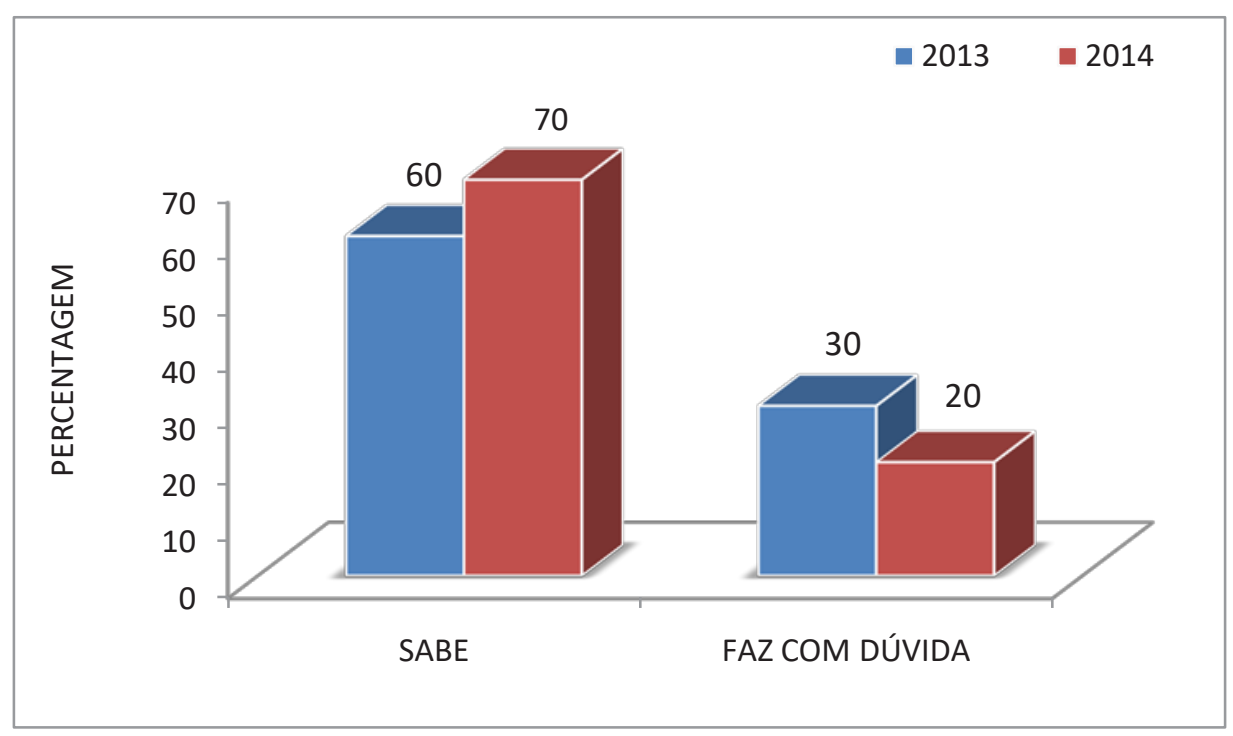

Aumentou levemente o número de professoras que sabem avaliar o estágio de alfabetização em que o aluno se encontra. 
Gráfico 23 - Professora adapta atividades de leitura e escrita

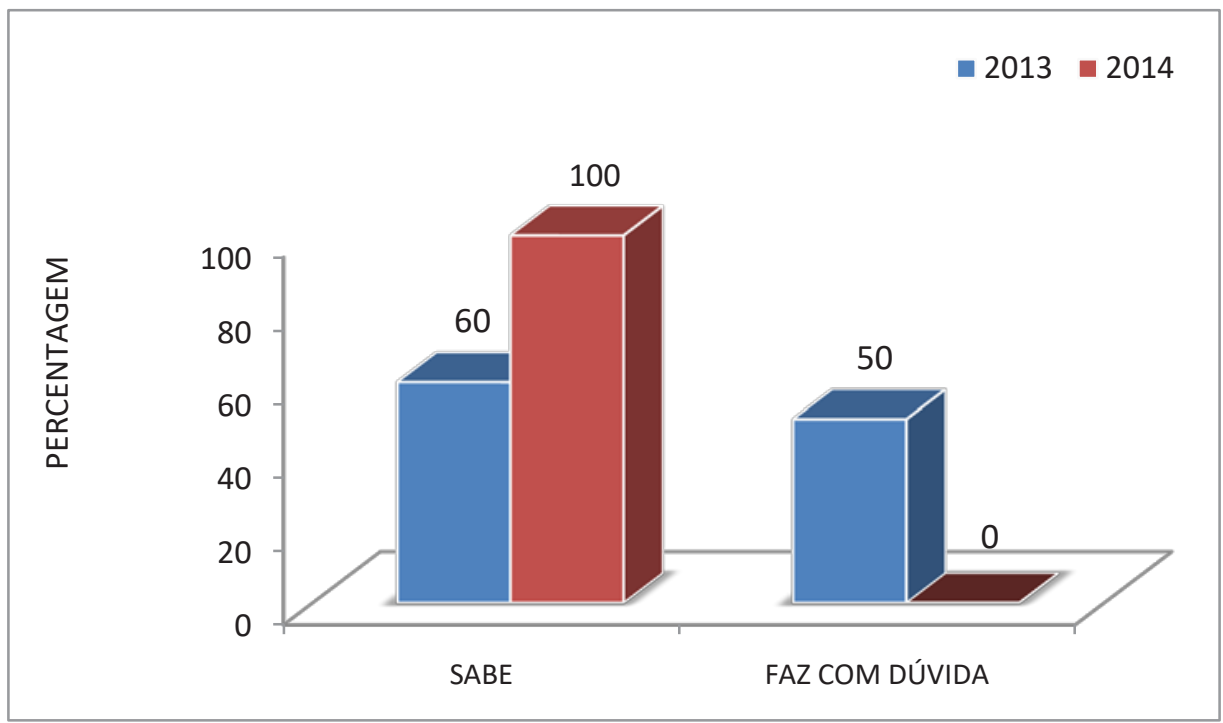

Aumentou o número de professoras capazes de adaptar atividades de leitura e escrita após a formação. Ao final de 2014, todas as professoras afirmaram saber adaptar as atividades de leitura e escrita.

Gráfico 24 - Professora adapta as atividades de matemática

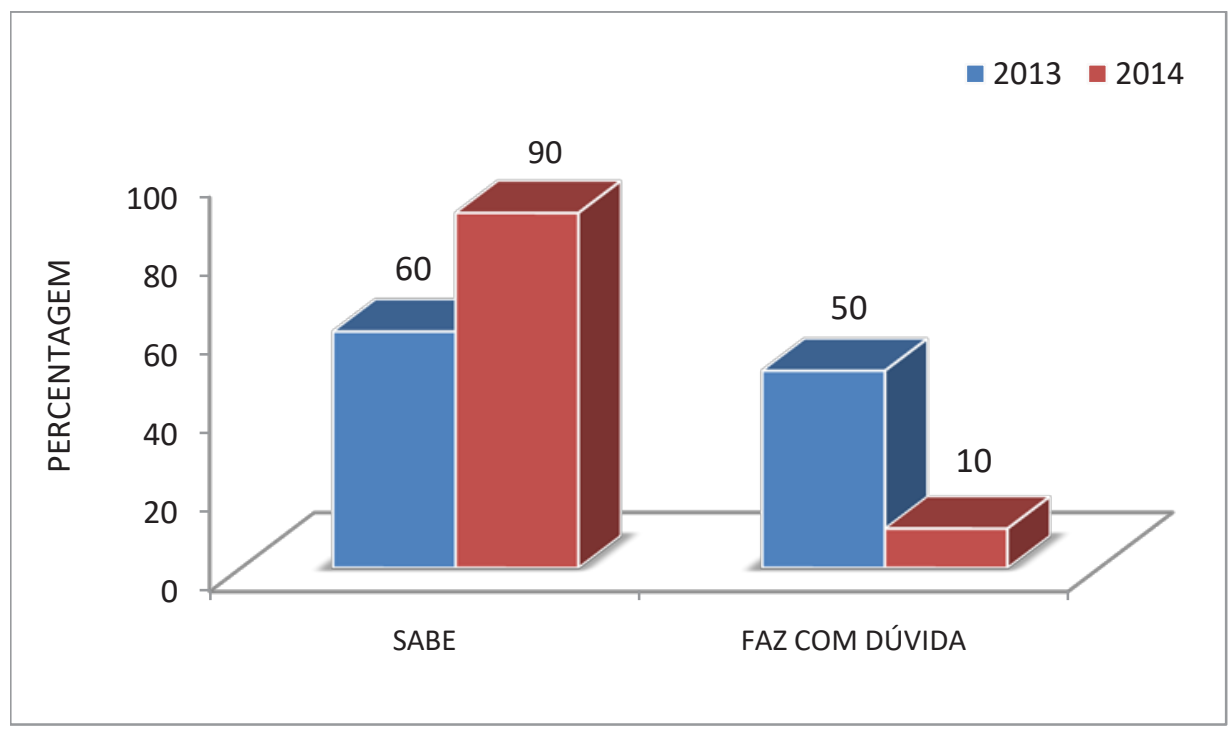


Após a formação, aumentou o número de professoras capazes de adaptar atividades de matemática.

Gráfico 25 - Professora é capaz de adaptar provas

$2013-2014$

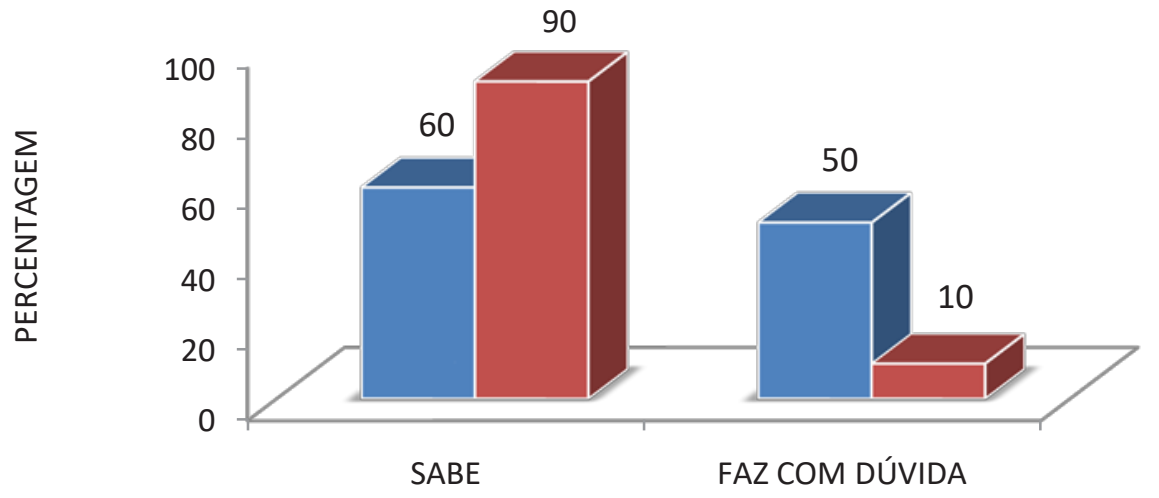

Após a formação, o número de professoras capazes de adaptar provas aumentou.

\section{Concepções e conhecimentos}

A seguir, são apresentados os dados do segundo questionário analisado. Esse instrumento teve como objetivo verificar as concepçóes e o conhecimento das professoras sobre os temas: deficiência, tecnologia assistiva, CAA, trabalho do professor com o aluno sem fala articulada ou funcional, o brincar, sugestões e comentários. Os dados resumidos estão expressos nos quadros. 


\section{Deficiência: conceito}

2013 - Alteração/prejuízo; impossibilidade; dificuldade; disfunção; área afetada; limitação, falta de habilidade e incapacidade.

2014 - Comprometimento, ausência ou limitação sensorial, intelectual, motora e comunicativa.

\section{TA: conceituação, modalidades e aplicabilidade}

2013 - Recursos ou materiais adaptados que facilitam a comunicação e a inclusão, de modo a eliminar barreiras que os alunos com deficiência encontram em sala de aula. Um dos recursos da tecnologia assistiva que favorece a comunicação e aprendizagem de alunos com dificuldades é a Comunicação Alternativa e Ampliada, contudo, há outras modalidades, tais como: pranchas de comunicação, computadores, softwares, engrossadores, lupa, colmeia, mouse adaptado e aranha-mola.

2014 - Recursos tecnológicos de alto e baixo custos que podem ser adaptados tanto para o aprendizado do aluno com deficiência, como para o favorecimento da sua comunicação, sua autonomia e independência. A CAA, as pranchas de comunicação, o Boardmaker, o lápis engrossador, os comunicadores de voz, os jogos pedagógicos e os recursos tecnológicos são modalidades de tecnologia assistiva. 
CAA: conceito, importância para inclusão, auxílio para aluno com deficiência

2013 - CAA é uma área da tecnologia assistiva que objetiva a comunicação, a leitura e a escrita do aluno mediante o manuseio de pranchas, fotos e gravuras. O seu uso é extremamente importante, pois possibilita a interação e a socialização, de maneira a favorecer a comunicação, a autonomia e a inclusão da pessoa com deficiência.

2014 - CAA é uma área de TA que proporciona a "linguagem oral" do sujeito sem fala, oportunizando outras formas de comunicação. Os recursos de CAA, como imagens, figuras, pranchas, softwares e símbolos de comunicação interativa, facilitam a comunicação do aluno especial. O Boardmaker é um programa pouco conhecido. A Comunicação Alternativa e Ampliada é fundamental para a comunicação do aluno sem fala, pois facilita/permite conhecimento, expressão e compreensão do aluno em sala de aula. $\mathrm{O}$ indivíduo que usa a CAA participa e interage mais com os seus interlocutores, utilizando cartões e símbolos para se comunicar, bem como expressa suas opiniōes com o professor e o grupo, de forma a garantir sua socialização, inclusão e independência. 


\section{Trabalho do professor junto aos alunos sem fala articulada}

2013 - Para planejar uma atividade adaptada utilizando a CAA, faz-se necessário avaliar o conhecimento do aluno, seu cotidiano e suas especificidades, com o intuito de elaborar estratégias que alcancem o aluno com ou sem deficiência. O diálogo com os profissionais do AEE é imperativo, pois, em geral, eles observam a progressão do uso do material adaptado. As angústias e apreensões fazem parte do planejamento, visto que muitos educadores encontram dificuldades em desenvolver atividades para o discente incluído. Devem ser desenvolvidas atividades que possibilitem momentos de interação, a fim de que o aluno sem comunicação oral e sem escrita funcional desperte o interesse em se relacionar. Não é uma tarefa fácil, muitas vezes angustiante, porém, o professor pode iniciar um trabalho de intensa mediação, usando pranchas de CAA e recursos adaptados para eliminar os entraves relacionados à comunicação. A interação depende do grupo, do contato estabelecido com os alunos e do planejamento pedagógico do professor.

2014 - É imperativo que o professor esteja disposto a adaptar as atividades pedagógicas para que, assim, possa atender às especificidades do alunado, e é cabível que o profissional do AEE esteja junto, apoiando-o quando necessário. $\mathrm{O}$ material adaptado chama a atenção dos outros alunos, que acabam interagindo com o aluno incluído, o que facilita sua inclusão e aprendizagem. O planejamento deve estar de acordo com a temática que está sendo dada em sala de aula e com o material específico de CAA. 
Forma de brincar e interagir do aluno com deficiência com seus pares e professores

2013 - Alguns alunos interagem de forma espontânea, já outros apresentam dificuldades de interagir e expressar seus desejos, sendo esse, talvez, um dos principais desafios enfrentados pelo professor. As dinâmicas, os jogos e as brincadeiras podem instigar o aluno a querer se relacionar, entretanto, para que funcionem, o docente precisa planejar suas atividades de modo que os objetivos propostos sejam alcançados.

2014 - Em geral, os alunos sem comunicação oral e sem escrita manual funcional estão perdidos e desinteressados. Os professores encontram muitas dificuldades, mas é preciso que se mantenham empenhados e dispostos a trabalhar com o discente incluído. No que concerne à interação, é importante avaliar as necessidades do grupo, objetivando planejar mediaçôes e adaptaçôes que contemplem todos, e que os alunos, assim como os professores resistentes, coloquem-se no lugar do outro, pois, apesar das limitações, os alunos devem brincar juntos e de maneira prazerosa. Além disso, cabe ao professor elaborar estratégias, como jogos, imagens e brincadeiras adaptadas para o aprendizado e para a inclusão da criança, provendo aulas mais dinâmicas e atividades em grupo. 
Sugestões (2013) e avaliação (2014) do trabalho na Oficina Vivencial 2013 - A proposta do projeto é interessante e animadora, pois aprofundar os conhecimentos sobre a CAA pode acarretar o aprimoramento de suas práticas. Como críticas, as professoreas salientaram que o questionário estava longo e repetitivo.

2014 - Os conteúdos teóricos contribuíram de forma significativa, pois houve uma evolução positiva, comprometimento e vontade de melhorar a prática em sala de aula. A partir da avaliação, pôde ser realizada a análise de casos por grupo, propondo alteraçôes no material que estava sendo usado em tempo real. Algumas expressaram sentimentos de dedicação, confiança, superação, desafio, decepção, amor, entre outros, acreditando que a teoria as auxiliaram na prática.

\section{Comentários adicionais}

2013 - O tempo para atender os professores, assim como a falta de recursos, ainda são as maiores dificuldades.

2014 - A experiência foi extremamente gratificante, pois apreenderam conhecimentos teóricos sobre recursos de CAA etc., todavia, faz-se necessário compreender melhor a utilização do Boardmaker e de outros sistemas e sinais de CAA, bem como entender de que maneira funcionará o projeto SRM de referência e como pô-lo em prática.

\section{Discussão}

Em síntese, após o curso de formação continuada em serviço em TA, com ênfase na CAA, percebemos modificações significativas quanto às habilidades relatadas pelos professores. Houve um aumento nas habilidades em relação ao aluno, tais como: identificação de respostas afirmativas e negativas do aluno não oralizado, identificação das necessidades específicas do aluno 
ante as atividades propostas para o seu grupo de referência, avaliação do estágio de alfabetização em que se encontra o discente e proposição das adaptações pedagógicas necessárias.

Também houve um aumento nas habilidades das professoras em relação aos recursos e materiais, como produção e uso de recursos e adaptações para a escrita, elaboração e uso social e acadêmico de pranchas de comunicação, bem como outros recursos de CAA. As professoras afirmaram que passaram a fazer adaptação de trabalhos escolares e provas.

Assim como nos estudos realizados por Ascenção (2007) e Zuttin (2008), verificamos que recursos de média e alta tecnologia, bastante necessários ao atendimento de pessoas com deficiências física e múltipla, como comunicador de voz, mouse adaptado, teclado expandido e softwares especiais para a escrita, não estão presentes em todas as SRMs. Esse talvez tenha sido um fator que contribuiu para o não desenvolvimento das habilidades para seu uso. Em contrapartida, outros recursos, como acionador de pressão e teclado com colmeia, que vêm no kit disponibilizado pelo MEC para as SRMs, passaram a ser usados por um maior número de professoras.

Em relação ao conhecimento e às concepções das professoras, percebeu-se que, no início do curso, os professores conceituaram a deficiência utilizando termos como "prejuízo, impossibilidade e incapacidade", mas, ao final do segundo ano de formação, o conceito estava associado a "comprometimento, ausência ou limitação sensorial, intelectual, motora e comunicativa”. Segundo Bersch (2007), as terminologias não definem nossa atitude perante uma pessoa com deficiência. A mesma autora destaca que a deficiência é marcada pela perda de uma das funções do ser humano, seja ela física, psicológica ou sensorial. E que um indivíduo pode ter uma deficiência, mas isso não significa necessariamente que ele seja incapaz. A incapacidade poderá ser minimizada quando o meio lhe possibilitar acessos, e a TA, principalmente a modalidade da CAA, tão enfatizada na formação, é um desses. Segundo o Comitê de Ajudas Técnicas (2007), a Tecnologia Assistiva é uma área do conhecimento, de característica interdisciplinar, que engloba produtos, recursos, metodologias, estratégias, práticas e serviços.

Em 2013 e 2014, as professoras associaram as modalidades de TA apenas aos recursos, deixando de citar que a TA também envolve estratégias, metodologias e serviços. Esses últimos são ou deveriam ser prestados por elas. Também existe uma dificuldade em distinguir as modalidades da TA. Elas 
citam, como exemplo, a CAA e seus recursos, e isso provavelmente ocorreu porque o curso enfatizou a CAA e os alunos. Com efeito, os sujeitos dos estudos de caso utilizados na formação possuíam, todos, necessidades de comunicação. Em 2014, as professoras associaram os termos "autonomia" e "independência” ao termo Tecnologia Assistiva, cujo objetivo é promover a funcionalidade, relacionada à atividade e à participação de pessoas com deficiência, incapacidades ou com mobilidade reduzida, visando a sua autonomia, independência, qualidade de vida e inclusão social (CAT, 2007).

Manzini (2013) afirma que várias pesquisas têm instigado e revelado questôes que precisam ser discutidas na formação de professores, sendo que o tema da formação de professores especialistas para pôr em uso os recursos de TA presentes nas SRMs tem recebido bastante destaque. Algumas pesquisas têm demonstrado que nem sempre os professores estão preparados para usar os recursos de TA na escola (Pelosi, 2008; Galvão Filho, 2009; Versussa e Manzini, 2009; Lourenço, 2012).

No estudo realizado por Manzini (2012), constatou-se que, dos 32 recursos apresentados no questionário aplicado, em relação ao conhecimento dos recursos e equipamentos de Tecnologia Assistiva para alunos com deficiência física, apenas 14 deles são conhecidos por pelo menos $50 \%$ dos professores das salas de recursos.

Em relação ao uso e à importância da CAA para a inclusão, as professoras declararam que a consideram fundamental para o desenvolvimento, a comunicação e a autonomia do aluno sem fala, e reconhecem-na como uma área/modalidade de TA.

Quanto ao trabalho do professor junto a aluno sem fala articulada ou funcional em 2013, as professoras reconheceram a importância da avaliação das necessidades e especificidades deste para o trabalho com a CAA, porém, consideram-na como uma "tarefa difícil e angustiante". São muito comuns, em um primeiro momento, os sentimentos de angústia, de incapacidade e de medo perante a necessidade de atendimento a um aluno com deficiência sem fala articulada, por exemplo. Esse desconhecimento a respeito dos aspectos peculiares da deficiência e de suas potencialidades pode afastar o professor desse tipo de experiência por lhe suscitar estranheza (Correia, 1999; Beyer, 2003; Rocha et al., 2003), impedindo-o de desenvolver uma prática pedagógica sensível às necessidades do aluno especial incluído (Pletsch, 2009). Diferentemente do que revelaram no início do curso, as professoras ressalta- 
ram em 2014 que a CAA precisa constar no planejamento do professor e que as adaptações devem estar de acordo com as especificidades dos alunos, pois acabam por beneficiar a turma toda.

Atuar com alunos que necessitam de conhecimentos sobre educação especial exige do professor maior atenção em relação à sua prática. Além de adaptações do espaço físico, de serviços de apoio, de um material pedagógico adequado, dos recursos e serviços de TA ou de qualquer alteração necessária para facilitar o processo de aprendizagem, o discente usuário de CAA necessita de intervençóes e de algumas adaptações na apresentação dos conteúdos. Assim, o professor que possui um aluno incluído em sua sala de aula não pode deter-se em planejamentos padronizados de ensino. Ao contrário, as necessidades específicas também criam a essencialidade de novas e diferentes formas de apresentar o conteúdo escolar, ação que proporciona maior compreensão por parte desse aluno e dos demais.

No entanto, nem todos os professores estão preparados para adequar a sua forma de ensinar às características e necessidades particulares desses discentes ou não possuem um serviço de apoio de um profissional especializado, que os auxilie no atendimento em sala de aula. Assim, alunos que precisam de intervençóes específicas ou de suporte imediato não são logo atendidos, o que prejudica ainda mais seu entrosamento na dinâmica da turma (Macedo, 2009). Galvão Filho (2009), em tese de doutorado desenvolvida em Salvador, referiu que os participantes da pesquisa também careciam de informações sobre os recursos de Tecnologia Assistiva, sendo necessário investimento e formação profissional continuada desses docentes.

Quanto à avaliação da proposta, comentários e sugestôes, as professoras, em 2013, avaliaram o projeto como "interessante e animador" e, em 2014, afirmaram que os conteúdos e a metodologia haviam contribuído para a melhora de sua prática.

Estudos desenvolvidos por Martins (2003), Oliveira (2003), Lauro et al. (2003), Gomes e Barbosa (2006), Mori (2003), Pelosi (2008), Pletsch (2009), Galvão Filho (2009) e Schirmer (2012) apontam para a necessidade de formação continuada em serviço, informação e apoio aos educadores, bem como mudanças nos processos avaliativos, maior envolvimento da família e de outros profissionais, melhora dos recursos materiais e das condições de trabalho para o professor e abordagens de formação que utilizem metodolo- 
gias diferenciadas. Mas também mostram que a inclusão responsável e gradativa é possível e pode ser bem-sucedida.

\section{Conclusão}

O levantamento das habilidades e o conhecimento do grupo de professores participantes do projeto foi muito importante na elaboração do curso. A formação ofertada nos anos de 2013 e 2014 foi estruturada de maneira a possibilitar aos participantes a reflexão de suas práticas pedagógicas cotidianas, tendo como abordagem educacional uma metodologia problematizadora. Os conteúdos formativos foram organizados a partir das necessidades apontadas pelos professores nos estudos de caso e filmagens e enfatizaram o planejamento, a execução e a avaliação de serviços e dos recursos da Tecnologia Assistiva, com ênfase na CAA, pertinentes ao trabalho realizado pelo Atendimento Educacional Especializado. Percebe-se, com os resultados, que houve uma apropriação pelos professores com relação à avaliação, ao planejamento, à elaboração e ao uso de recursos de baixa tecnologia, sobretudo na CAA e no material pedagógico adaptado ou especialmente produzido.

Diante disso, acreditamos que um importante fator que pode prejudicar o processo de inclusão é a ausência de uma formação inicial e continuada adequada. Essa formação pode oferecer ao professor - tanto o que atuará na rede de ensino comum como o especializado -, entre outras coisas, prática e conhecimentos consistentes sobre o processo de ensino e de aprendizagem de alunos com deficiência, bem como a compreensão das inúmeras possibilidades e potencialidades de cada aluno, principalmente quando este recebe o apoio dos recursos de Tecnologia Assistiva. 


\title{
Capítulo 5 - Análise da formação continuada em serviço sobre Comunicação Alternativa para professores de Sala de Recursos Multifuncionais de Referência: abordagem problematizadora
}

\author{
Carolina Rizzotto Schirmer ${ }^{2}$ \\ Leila Regina d'Oliveira de Paula Nunes ${ }^{2}$
}

\section{Introdução}

Educadores e pesquisadores brasileiros concordam que a perspectiva atual da inclusão dos alunos com deficiência exige o repensar da escola, de modo a proporcionar ensino de qualidade para todos os alunos, sem exceção. Para que isso ocorra, a formação de professores torna-se essencial. A preocupação com essa formação tem estado presente em todos os esforços de renovação pedagógica promovidos pelo sistema de ensino ao longo dos tempos. No entanto, é possível identificar a perspectiva clássica, na maioria dos projetos de renovação pedagógi-

1 Professora adjunta da Faculdade de Educação da UERJ. E-mail: ead.carolina@gmail. com.

2 Professora titular da Faculdade de Educação e do Programa de Pós-Graduação em Educação da UERJ. E-mail: leilareginanunes@terra.com.br. 
ca propostos, cuja ênfase é dada à "reciclagem” dos professores (Candau, 1996). Cunha et al. (2001), estudando os processos de mudanças em diferentes áreas do ensino superior, destacam experiências inovadoras no limite de uma disciplina ou entre disciplinas de um mesmo curso que podem contribuir para a melhoria do ensino e da aprendizagem. Na perspectiva desenvolvida por eles, a inovação pode colaborar para a "ruptura do paradigma dominante, fazendo avançar, em diferentes âmbitos, formas alternativas de trabalhos que quebram com a estrutura tradicional". Os autores observam, contudo, que uma inovação não se caracteriza simplesmente pelo uso de novos elementos tecnológicos no ensino, "a menos que estes representem novas formas de pensar o ensinar e o aprender, numa perspectiva emancipatória" (Cunha et al., 2001, p. 44).

A prática reflexiva é enfatizada nos estudos de muitos autores. Schön (1995) propõe a formação de professores, valorizando a experiência e a reflexão na experiência pela prática na formação profissional, mas uma prática refletida, que lhes possibilite responder a questôes novas, nas situações de incertezas e indefinições. Zeichner (1992), por meio de pesquisas desenvolvidas junto a professores, aponta três perspectivas a serem acionadas: a prática reflexiva centrada no exercício profissional dos professores por eles mesmos e nas condições sociais em que este ocorre; o reconhecimento pelos professores de que seus atos são fundamentalmente políticos e, portanto, podem direcionar-se a objetivos democráticos emancipatórios; e a prática reflexiva, como prática social, que só pode realizar-se no coletivo, o que leva à necessidade de transformar as escolas em comunidades de aprendizagem, nas quais os professores apoiem-se e estimulem-se mutuamente. Zeichner (1993) interpreta o movimento da prática reflexiva como: uma reação a imposições de cima para baixo sobre as questôes de ensino; uma percepção de que a geração de conhecimento acerca do bom ensino não é de propriedade exclusiva de acadêmicos e pesquisadores de universidades; o reconhecimento da riqueza da expertise, que reside na prática dos bons professores (noção de "conhecimento na ação", de Schön); e o reconhecimento de que aprender a ensinar é um processo que se dá ao longo de toda a carreira do professor, e, sendo assim, os cursos de formação de professores têm como tarefa prepará-los para "começar" a ensinar e tentar comprometê-los com a disposição de estudar seu ensino e desenvolver a habilidade necessária para isso, assumindo, dessa forma, responsabilidade pelo seu próprio desenvolvimento.

No entanto, a formação de professores enfrenta alguns desafios críticos: o de atribuir ao docente um papel ativo no processo de ensino-aprendizagem; o de 
favorecer que ele realize um trabalho em colaboração com os colegas ou com as pessoas envolvidas em determinado projeto; e o de proporcionar oportunidades significativas de aplicação teórico-prática relacionadas à realidade escolar (Nóvoa, 1992; Duek e Martins, 2010; Rodrigues e Rose, 2010).

Para que se possa garantir o acesso do aluno com deficiência ao conhecimento, ao espaço físico, às interações e à comunicação, é necessário que os professores, principais interlocutores e modelos, tenham conhecimento sobre a Tecnologia Assistiva (TA) e, especialmente, sobre a Comunicação Alternativa e Ampliada (CAA). Porém, para que a TA e a CAA façam parte do dia a dia da escola, é fundamental que os professores que atendem esse aluno sejam capazes não apenas de implementar seus recursos, mas também de trabalhar em parceria com colegas, assim como com outros profissionais envolvidos com o discente, além de favorecer interações ricas em comunicação. Esse conhecimento exige que, em sua formação, os professores sejam levados a refletir e a repensar sua prática, assim como trabalhar colaborativa e criativamente.

É crescente o número de pesquisas que propõem e avaliam os efeitos da oferta de cursos de formação para professores voltados à inclusão dos alunos com deficiência severa de comunicação que necessitam de recursos da CAA e de informática acessível em suas salas de aula (Pelosi, 2000, 2008; Lauand, 2005; Nunes, 2009, 2010; Galvão Filho, 2009; Nunes e Danelon, 2009; Schirmer, 2012; Araújo, 2012; Rocha e Deliberato, 2012; Lourenço, 2012; Correa Netto, 2012; Pelosi e Souza, 2012; Givigi, 2012; Nunes e Gomes, 2013). Tal acervo fundamentou a proposta do presente estudo.

Este estudo visou à implementação e à avaliação de um programa de formação continuada de professores da rede pública de ensino municipal para atuação nas Salas de Recursos Multifuncionais de Referência, as quais funcionarão como agentes multiplicadores das ações formativas da Oficina Vivencial (OV) Mais especificamente, esses professores serão ensinados a planejar, implementar e avaliar, nas áreas ligadas à escola, recursos e serviços da TA, como: CAA, acesso

\footnotetext{
3 A Oficina Vivencial de Ajudas Técnicas para Ação Educativa é um serviço ligado à Secretaria Municipal de Educação de uma grande capital brasileira e destina-se aos alunos com deficiência e transtorno global do desenvolvimento, direcionando seu trabalho à busca de estratégias e recursos - TA - que facilitem a participação desses educandos nas atividades escolares cotidianas, contribuindo para a inclusão escolar.
} 
ao computador e a atividades e materiais pedagógicos adaptados para atender alunos do ensino fundamental que apresentem severos comprometimentos em sua comunicação oral, como aqueles com paralisia cerebral, autismo e deficiência múltipla.

\section{Objetivo}

Planejar, implementar e avaliar os efeitos da oferta de uma formação continuada em serviços para professores de Sala de Recursos Multifuncionais, por meio da abordagem problematizadora sobre a área de Tecnologia Assistiva, com ênfase na Comunicação Alternativa e Ampliada, junto a alunos com deficiência e transtornos do espectro autista.

\section{Método}

Participantes: participaram do estudo dezoito professores de Salas de Recursos Multifuncionais (SRMs), selecionados pelas equipes ligadas às onze CREs de um município do estado do Rio de Janeiro; cinco alunos sem fala articulada ou funcional, acompanhados por esses professores de AEE; duas pesquisadoras ligadas à Faculdade de Educação de uma universidade pública; e a equipe de professores da OV, composta por três professoras.

Foram indicados, em média, dois professores por CRE. Os critérios de inclusão foram: a) ter formação na área de CAA, por meio de cursos oferecidos pelo IHA ou demais instituições de ensino; b) atuar em uma Sala de Recursos que já tenha recebido o material disponibilizado pelo MEC; c) ter conhecimento básico de informática; d) ter disponibilidade para participar dos encontros no horário da tarde; e) ter habilidade para atuar como dinamizador de encontros e palestras; e f) ter interesse em fazer parte do projeto. 
Local: o estudo foi desenvolvido na sala da Oficina Vivencial de Ajudas Técnicas para Ação Educativa, serviço ligado ao Instituto Municipal Helena Antipoff (IHA) $)^{4}$, e também no auditório do IHA.

Instrumentos: nesse estudo, foram utilizados os seguintes instrumentos: roteiro de observação, diário de campo, filmagens e fotografias. A seguir, no quadro 1, há uma breve descrição dos instrumentos utilizados.

Quadro 1 - Instrumentos empregados no estudo

\begin{tabular}{|c|c|c|c|}
\hline $\begin{array}{l}\text { Número do } \\
\text { Instrumento }\end{array}$ & $\begin{array}{l}\text { Tipo de } \\
\text { Instrumento }\end{array}$ & Características & Observações \\
\hline Instrumento 1 & $\begin{array}{l}\text { Roteiro de Plano de } \\
\text { Observação e Estrutu- } \\
\text { ração para o trabalho } \\
\text { na SRM }{ }^{1}\end{array}$ & $\begin{array}{l}\text { O Roteiro era composto } \\
\text { por três partes: a primeira } \\
\text { era composta pelas informa- } \\
\text { ções sobre o(s) aluno(s); a } \\
\text { segunda constava de dados } \\
\text { para a solução do problema } \\
\text { e de relação dos principais } \\
\text { tópicos para a sua resolução; } \\
\text { e a terceira era o Plano de } \\
\text { Intervenção, no caso, plano } \\
\text { de atendimento educacional } \\
\text { individualizado. }\end{array}$ & $\begin{array}{l}\text { Produzidos pelas } \\
\text { professoras em } \\
\text { grupo }\end{array}$ \\
\hline Instrumento 2 & Diário de Campo & $\begin{array}{l}\text { Anotações realizadas pelas } \\
\text { pesquisadoras }\end{array}$ & $\begin{array}{l}\text { Produzidos pelas } \\
\text { pesquisadoras }\end{array}$ \\
\hline Instrumento 3 & $\begin{array}{l}\text { Vídeos, fotografias e } \\
\text { slides das apresentações }\end{array}$ & $\begin{array}{l}\text { Vídeos e fotografias feitos ao } \\
\text { longo da formação e as apre- } \\
\text { sentaçōes em PowerPoint. }\end{array}$ & $\begin{array}{l}\text { Produzidos pelas } \\
\text { pesquisadoras, } \\
\text { professores e pa- } \\
\text { lestrantes }\end{array}$ \\
\hline
\end{tabular}

4 O Instituto Municipal Helena Antipoff (IHA) é o órgão da Secretaria Municipal de Educação que tem sob sua responsabilidade a implementação de políticas públicas voltadas à educação de alunos com deficiência, transtorno global do desenvolvimento e altas habilidades, incluindo o acompanhamento de propostas promotoras do desenvolvimento e aprendizagem dos alunos público-alvo da Educação Especial na perspectiva da Educação Inclusiva. 
Foram utilizados também recursos de Tecnologia Assistiva, câmera digital, filmadora e audiogravadores digitais, assim como computadores/notebooks, plastificadora e impressoras.

Procedimentos gerais: o projeto foi submetido à apreciação da direção do Instituto Helena Antipoff, que o aprovou. Após esse aceite, o projeto foi submetido à Comissão de Ética em Pesquisa (COEP) da UERJ e foi aprovado segundo o Parecer de número 336.622, exarado em 11 julho de 2013.

Após a apresentação do projeto e da equipe aos professores, estes foram convidados a participar da pesquisa. Todos os envolvidos assinaram um Termo de Consentimento Livre e Esclarecido (TCLE).

Procedimentos específicos: o estudo foi desenvolvido no ano de 2013, em duas etapas, a saber:

\section{I etapa - Planejamento do curso de formação:}

Nesta etapa, que ocorreu de março a abril de 2013, houve o envolvimento apenas da equipe da OV e das duas pesquisadoras. Foram realizados três encontros para seleção dos instrumentos que seriam utilizados na coleta de dados. Entre os dias 08/05/2013 e 22/05/2013, os dados foram analisados e nortearam a organização do curso. Em abril de 2013, após o convite para participação, os professores também foram convidados a falar sobre suas expectativas em relação à formação e que temas gostariam de aprofundar.

\section{II etapa - Oferta do curso de formação (maio a dezembro de 2013):}

Oferta de curso de formação, que envolveu aulas teóricas e práticas, com 44 horas de duração.

Desenvolvimento e apresentação de estudos de caso por grupos de professores: cada grupo escolheu um ou dois alunos com deficiência sem fala e/ou escrita funcional e procurou identificar um problema relevante no ensino. Após a observação, cada grupo apresentou para todo o grupo de professores os alunos-alvo e descreveu um problema que julgaram pertinente ao ensino deles. A seguir, as equipes levantaram hipóteses para a resolução do problema e buscaram referencial teórico que as ajudasse a estabelecer objetivos da ação 
pedagógica. Daí, selecionaram as estratégias de atuação e os materiais didáticos e tecnológicos necessários para a resolução do problema, implementaram o plano instrucional, avaliaram os resultados e propuseram nova ação, dando continuidade ao processo.

As atividades planejadas e organizadas foram realizadas em 12 sessões de formação continuada em serviço no ano de 2013. E a abordagem educacional eleita foi a Problematização ${ }^{5}$.

O quadro 2, a seguir, descreve a organização da pesquisa realizada e o instrumento de coleta das informações:

5 Os pressupostos da ação educativa desenvolvida encontram-se na abordagem denominada Problematização, segundo a qual os conteúdos de ensino não são oferecidos aos alunos em sua forma acabada, mas na forma de problemas extraídos da realidade, cujas relaçôes devem ser descobertas e construídas pelo aluno, que reorganiza o material, adaptando-o à sua estrutura cognitiva prévia, para descobrir relações, leis ou conceitos que precisará assimilar (Cyrino e Toralles-Pereira, 2004). Por tratar do estudo da realidade dinâmica e complexa, essa metodologia é propícia para encorajar os alunos, em cada etapa de sua experiência de aprendizagem, a refletir sobre a situação global de estudo de uma realidade concreta, com seus conflitos e contradiçóes (Berbel, 1998, 1999, 2001; Batista et al., 2005). A problematização estimula o aprender a aprender e, consequentemente, a metacognição do estudante, ou seja, as habilidades de automonitoramento de seu processo de aprendizagem. A metacognição é elemento essencial da aprendizagem bem-sucedida e envolve o estabelecimento do objetivo da ação, a seleção das estratégias e a avaliação dos resultados por parte do aprendiz. Na problematização, a relação ação-reflexão-ação transformadora é o eixo básico de orientação do processo (Berbel, 1999). 
Quadro 2 - Descrição das atividades, tempo de observação e instrumentos de registro

\begin{tabular}{|c|c|c|c|c|}
\hline Sessão & Atividades & \begin{tabular}{|c|}
$\begin{array}{c}\text { Tempo de } \\
\text { observa- } \\
\text { ção }\end{array}$ \\
\end{tabular} & $\begin{array}{l}\text { Instru- } \\
\text { mento de } \\
\text { registro }\end{array}$ & $\begin{array}{c}\text { Etapas } \\
\text { da pes- } \\
\text { quisa } \\
\end{array}$ \\
\hline \multicolumn{4}{|c|}{$\begin{array}{l}\text { Período para as pesquisadoras conseguirem a autorização para a realização do } \\
\text { projeto junto à Prefeitura e para que as Coordenadorias Regionais de Educação } \\
\text { (CRE) indicassem os professores. }\end{array}$} & Etapa I \\
\hline 1 & $\begin{array}{l}\text { Contato com as professoras para explicar o } \\
\text { projeto e obter as autorizaçôes } \\
\end{array}$ & $3 \mathrm{~h} 30 \mathrm{~min}$ & $\begin{array}{l}\text { Diário de } \\
\text { Campo }\end{array}$ & \multirow[t]{2}{*}{ Etapa I } \\
\hline 2 & $\begin{array}{l}\text { Apresentação do projeto na íntegra e con- } \\
\text { versa com professores }\end{array}$ & $3 \mathrm{~h} 30 \mathrm{~min}$ & $\begin{array}{l}\text { Gravação } \\
\text { Diário de } \\
\text { Campo }\end{array}$ & \\
\hline 3 & $\begin{array}{l}\text { Curso de Formação com Metodologia } \\
\text { Problematizadora (CFMP) - Observação } \\
\text { da realidade - (Identificação do problema) } \\
\text { Professores realizaram, registraram e analisa- } \\
\text { ram a observação de um aluno com defici- } \\
\text { ência em seu conteúdo, problematizando-o. } \\
\text { Elegeram o foco do estudo, redigiram e jus- } \\
\text { tificaram a escolha do problema pertinente à } \\
\text { educação, referente ao caso do aluno. }\end{array}$ & $3 \mathrm{~h} 30 \mathrm{~min}$ & $\begin{array}{l}\text { Gravação } \\
\text { Diário de } \\
\text { Campo } \\
\text { Roteiro de } \\
\text { observação }\end{array}$ & Etapa II \\
\hline 4 & $\begin{array}{l}\text { CFMP - Pontos-chave } \\
\text { Professores identificaram possíveis fatores } \\
\text { associados ao problema e seus determi- } \\
\text { nantes; analisaram a reflexão, captando os } \\
\text { vários aspectos envolvidos no problema, } \\
\text { verificando o que pertence à escola e, mais } \\
\text { especificamente, ao AEE; e elegeram, com } \\
\text { critérios, aqueles aspectos que serão estuda- } \\
\text { dos na etapa seguinte, redigindo os pontos- } \\
\text {-chave de aprofundamento teórico-prático. }\end{array}$ & $3 \mathrm{~h} 30 \mathrm{~min}$ & $\begin{array}{l}\text { Gravação } \\
\text { Diário de } \\
\text { Campo } \\
\text { Roteiro de } \\
\text { observação }\end{array}$ & \multirow[t]{3}{*}{ Etapa II } \\
\hline 5 & $\begin{array}{l}\text { CFMP - Teorização } \\
\text { Estudo sobre Comunicação e Interação }\end{array}$ & $3 \mathrm{~h} 30 \mathrm{~min}$ & $\begin{array}{l}\text { Gravação } \\
\text { Diário de } \\
\text { Campo } \\
\text { PowerPoint }\end{array}$ & \\
\hline 6 & $\begin{array}{l}\text { CFMP - Teorização } \\
\text { Estudo sobre Comunicação Alternativa e } \\
\text { Linguagem }\end{array}$ & $3 \mathrm{~h} 30 \mathrm{~min}$ & $\begin{array}{l}\text { Gravação } \\
\text { Diário de } \\
\text { Campo } \\
\text { PowerPoint }\end{array}$ & \\
\hline
\end{tabular}




\begin{tabular}{|c|c|c|c|c|}
\hline Sessão & Atividades & $\begin{array}{l}\text { Tempo de } \\
\text { observa- } \\
\text { ção }\end{array}$ & $\begin{array}{l}\text { Instru- } \\
\text { mento de } \\
\text { registro }\end{array}$ & $\begin{array}{l}\text { Etapas } \\
\text { da pes- } \\
\text { quisa }\end{array}$ \\
\hline 7 & $\begin{array}{l}\text { CFMP - Teorização } \\
\text { Estudo sobre Salas de Recursos Multi- } \\
\text { funcionais e Atendimento Educacional } \\
\text { Especializado }\end{array}$ & $3 \mathrm{~h} 30 \mathrm{~min}$ & $\begin{array}{l}\text { Gravação } \\
\text { Diário de } \\
\text { Campo } \\
\text { PowerPoint }\end{array}$ & \multirow{6}{*}{ Etapa II } \\
\hline 8 & $\begin{array}{l}\text { CFMP - Teorização } \\
\text { Estudo sobre o PECS-Adaptado - CAA } \\
\text { para pessoas com Transtornos do Espectro } \\
\text { Autista (TEA). }\end{array}$ & $3 \mathrm{~h} 30 \mathrm{~min}$ & $\begin{array}{l}\text { Gravação } \\
\text { Diário de } \\
\text { Campo } \\
\text { PowerPoint }\end{array}$ & \\
\hline 9 & $\begin{array}{l}\text { CFMP - Teorização } \\
\text { Estudo sobre o PECS-Adaptado - CAA para } \\
\text { pessoas com TEA }\end{array}$ & $3 \mathrm{~h} 30 \mathrm{~min}$ & $\begin{array}{l}\text { Gravação } \\
\text { Diário de } \\
\text { Campo } \\
\text { PowerPoint }\end{array}$ & \\
\hline 10 & $\begin{array}{l}\text { CFMP - Hipóteses de solução } \\
\text { Os professores elaboraram as hipóteses de } \\
\text { solução para o problema com base na Teo- } \\
\text { rização e nas etapas anteriores; aprenderam } \\
\text { a utilizar o software Boardmaker para pro- } \\
\text { duzir e pensar nos recursos adaptados e em } \\
\text { estratégias; e explicaram e argumentaram } \\
\text { acerca das hipóteses elaboradas. }\end{array}$ & $3 \mathrm{~h} 30 \mathrm{~min}$ & $\begin{array}{l}\text { Gravação } \\
\text { Diário de } \\
\text { Campo } \\
\text { Roteiro de } \\
\text { observação }\end{array}$ & \\
\hline 11 & $\begin{array}{l}\text { CFMP - Hipóteses de solução } \\
\text { Aprenderam a utilizar o software Speaking } \\
\text { Dinamically Pro com o objetivo de empre- } \\
\text { gá-lo nos casos estudados }\end{array}$ & $3 \mathrm{~h} 30 \mathrm{~min}$ & $\begin{array}{l}\text { Gravação } \\
\text { Diário de } \\
\text { Campo } \\
\text { Roteiro de } \\
\text { observação }\end{array}$ & \\
\hline 12 & $\begin{array}{l}\text { CFMP - Aplicação à realidade (prática) } \\
\text { Apresentação dos casos com análise da } \\
\text { aplicabilidade das hipóteses que colocaram } \\
\text { em prática; planejamento da execução das } \\
\text { açôes; e análise dos resultados. }\end{array}$ & $3 \mathrm{~h} 30 \mathrm{~min}$ & $\begin{array}{l}\text { Gravação } \\
\text { Diário de } \\
\text { Campo } \\
\text { Roteiro de } \\
\text { observação }\end{array}$ & \\
\hline \multicolumn{4}{|c|}{ Período para a análise dos dados } & Etapa III \\
\hline
\end{tabular}




\section{Análise dos Dados}

Neste estudo, foram realizadas análises qualitativas. A inferência foi fundamentada na presença do tema ou palavra, e não sobre a frequência de sua aparição. Foram analisados apenas os dados pertinentes a essa fase do estudo.

As sessões filmadas com as professoras ao longo do curso de formação foram transcritas na íntegra e, após a estruturação e a organização das informações em um texto escrito, foram identificados os temas segundo Bardin (1997).

O presente estudo foi realizado a partir de uma triangulação de dados em um processo que contempla sua análise, cruzando as informações obtidas com os roteiros, as transcriçôes das filmagens e o diário de campo. As unidades significativas selecionadas foram definidas como tema.

Nesse caso, as respostas dos participantes foram classificadas em cinco categorias: metodologia da problematização, descrição dos casos, motivação para escolha do caso, problemas elencados no caso e recursos e estratégias desenvolvidos para o caso.

\section{Resultados e Discussão}

Os resultados sobre o conhecimento dos professores, colhidos por meio dos Instrumentos 1, 2 e 3, estão expressos nas categorias a seguir. Responderam ao Instrumento 18 professores.

\section{Categoria: Metodologia da Problematização}

No primeiro dia do curso, que correspondeu à terceira sessão da pesquisa, foram organizados cinco grupos, com uma média de três a quatro professoras em cada. Formaram-se de acordo com a proximidade por região e pelas CREs nas quais os professores estavam lotados. Essa organização estava prevista, visto que, dentro da abordagem utilizada, valoriza-se o trabalho colaborativo com os demais professores do grupo, assessorado pelas pesqui- 
sadoras e pela equipe da OV e desenvolvido nos contextos reais em que o docente trabalha (Cyrino e Toralles-Pereira, 2004). Pensou-se em grupos com, no máximo, quatro professores para favorecer a troca de conhecimento e o envolvimento de todos.

A proposta com a Metodologia da Problematização prevê que os professores em formação tenham contato com as situações-problema em um cenário real (Berbel, 1999). Em nosso estudo, os cenários foram a SRM e a escola. Sendo assim, envolveu também o aceite da direção da escola, o convite e o aceite dos professores, dos alunos com deficiência e dos seus responsáveis.

$\mathrm{Na}$ sessão número 2, foi solicitado que os professores trouxessem para a sessão 3 um breve relato de um caso de aluno com deficiência ou TEA que eles atendessem em SRM e no qual estivessem enfrentando problemas. $\mathrm{Na}$ sessão 3, os grupos foram organizados e os casos discutidos. Solicitou-se que o grupo elegesse um caso para ser utilizado em estudo durante a formação. Os professores receberam o roteiro de plano de observação e estruturação para o trabalho na SRM. Esse roteiro, que foi discutido na sessão 3 com todo o grupo, orientava o trabalho no campo. Nele, constavam os seguintes pontos:

- Informações sobre o(s) aluno(s): resumo do caso, tipo de problema identificado, potencialidades/habilidades, dificuldades e interesses;

- Solução do problema e relação dos principais tópicos para a sua resolução: relação do que existe em termos de acessibilidade arquitetônica realizada no ambiente escolar, materiais e equipamentos utilizados pelo aluno, recursos disponíveis no ambiente escolar e outros, como, por exemplo, recursos humanos;

- Plano de Intervenção: são as ações desenvolvidas para atender às necessidades do(s) aluno(s), com base nas suas potencialidades e no(s) objetivo(s) do plano e das atividades a serem desenvolvidas no atendimento ao aluno — CAA, RAC, adequação de mobiliário etc.;

- Resultados obtidos ou esperados.

O roteiro foi utilizado até o final da formação, em dezembro de 2013. 


\section{Categoria: Descrição dos Casos}

Quanto à descrição dos casos pelos professores, foi possível constatar que, no roteiro preenchido ao final do curso, os grupos conseguiram descrever o caso resumidamente, determinando, com clareza, o tipo de problema identificado, as potencialidades, as dificuldades e os interesses dos alunos. Alguns trechos com o resumo dos casos podem ser vistos no quadro 4, a seguir.

Quadro 4 - Resumo dos Estudos de Caso

\begin{tabular}{|l|l|}
\hline Caso & Breve descrição \\
\hline Caso 1 & $\begin{array}{l}\text { Tem paralisia cerebral, } 15 \text { anos, está no 6.o ano, "até hoje ele não conseguiu se } \\
\text { alfabetizar de uma forma concreta", não faz contas, fala não funcional, somente } \\
\text { pessoas próximas conseguem entendê-lo. A professora, ao se referir ao não uso } \\
\text { da CAA, diz: "O que eu sinto é que ele tem dificuldade de aceitar que ele tem } \\
\text { essas limitações. Então ele quer estar sempre mais próximo dos outros". "Ele } \\
\text { quer ser igual a todos". O menino usa o computador com dificuldade para } \\
\text { fazer cópias (só consegue se a letra usada for bastão), não quer segurar o lápis. } \\
\text { Anda sozinho com dificuldade, não quis usar cadeira de rodas. É independente, } \\
\text { come e vai ao banheiro sozinho. }\end{array}$ \\
\hline José & $\begin{array}{l}\text { Tem paralisia cerebral, 7 anos, está no 2.o ano. Não possui fala articulada. Faz } \\
\text { uso de cadeira de rodas somente para ir à escola ou para ir ao tratamento. Em } \\
\text { casa, ele rasteja e tenta se locomover. Segundo a mãe dele, existe em casa uma } \\
\text { cadeira (como se fosse uma poltrona antiga de carro) na qual ele gosta muito } \\
\text { de se sentar. José faz tudo com os pés porque não tem coordenação com as } \\
\text { mãos. "Ãs vezes se bate e como é muito branquinho, fica vermelhinho". João faz } \\
\text { fisioterapia, terapia ocupacional e fonoaudiologia. Os profissionais que fazem } \\
\text { tratamentos adicionais com ele queriam prender os pés de José para estimular } \\
\text { as mãos e os braços dele. José é muito esforçado e encantador. A professora } \\
\text { relata que José não é da escola onde ela trabalha. Ele estuda em uma turma } \\
\text { regular que é uma escola próxima e faz a sala de recursos com ela de manhã } \\
\text { duas vezes na semana. José entrou na escola em outubro de 2012, frequentou } \\
\text { muito pouco porque a mãe trabalha e não estava conseguindo levar o aluno à } \\
\text { escola. Ele este ano está conseguindo frequentar a escola e a sala de recursos. }\end{array}$ \\
\hline
\end{tabular}




\begin{tabular}{|c|c|}
\hline Caso & Breve descrição \\
\hline $\begin{array}{l}\text { Caso } 3 \\
\text { Benicio }\end{array}$ & 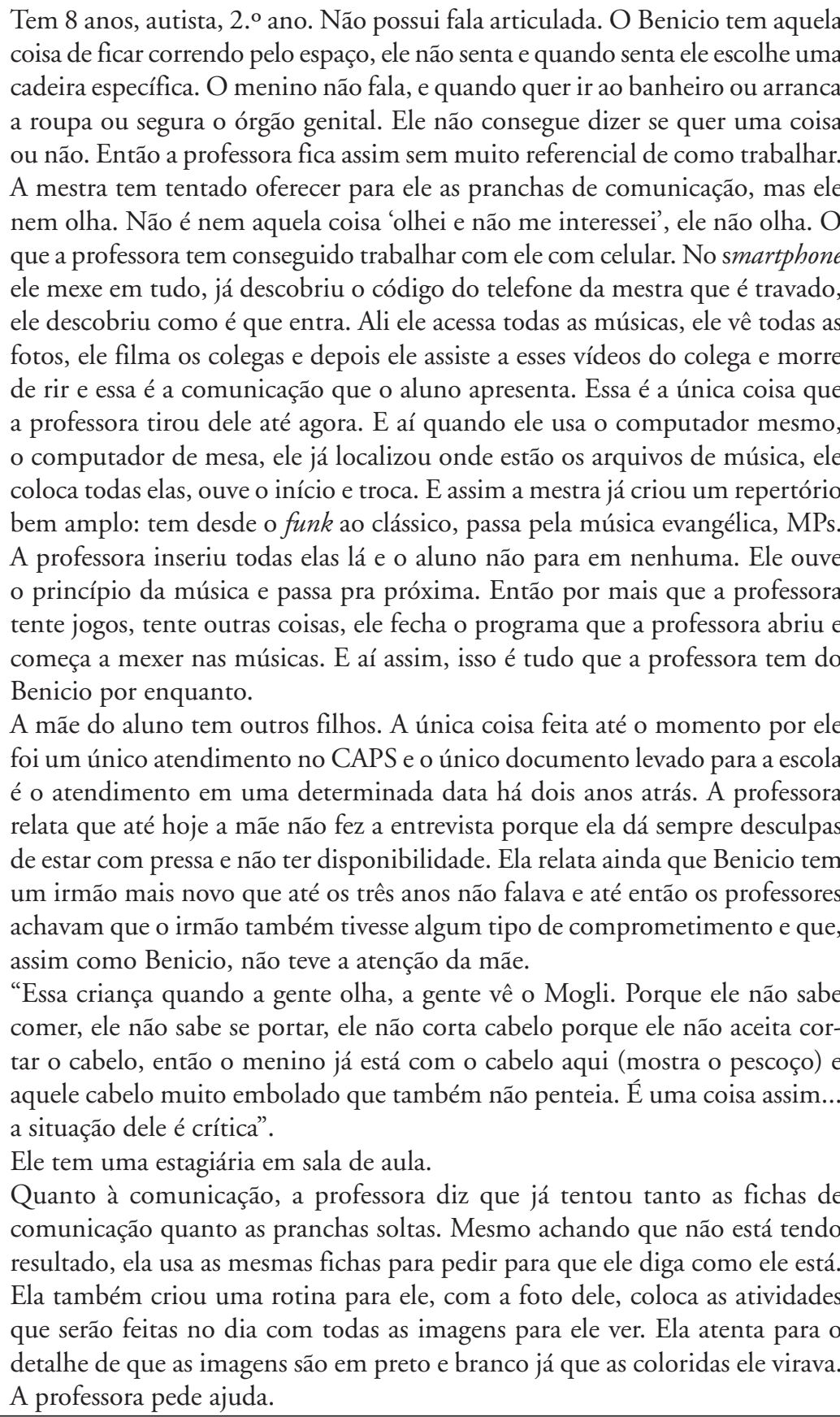 \\
\hline
\end{tabular}




\begin{tabular}{|l|l|}
\hline Caso & Breve descrição \\
\hline Caso 4 & Tem 5 anos, autista. Não possui fala articulada. Está na educação infantil. \\
& $\begin{array}{l}\text { É um menino que não brinca e suas únicas respostas são sorrir quando está } \\
\text { gostando e fazer um barulho para demonstrar irritação. Ainda recorre à chupeta } \\
\text { e a professora diz que está "cortando a chupeta”. Ela diz que a chupeta é um } \\
\text { anestésico. Segundo a mestra: "Ele chupa a chupeta e vai para o mundo dele e á́ } \\
\text { não consigo despertá-lo para nada. Então eu estou apresentando para ele várias } \\
\text { coisas para ver se ele me dá resposta. Eu tenho uma caixa de brinquedos. E ele } \\
\text { tem fixação por simetrias. Então o ventilador... ele fica ali no ventilador. A mesa } \\
\text { tem... o pé da mesa tem um metal que faz isso aqui, então ele fica com dedo } \\
\text { ali (movimentos de cima pra baixo e de baixo pra cima). A minha sala de aula } \\
\text { é de tijolinhos aparente, então ele vai com o dedo (faz movimentos de ir e vir). } \\
\text { Quando está mais agitado, ele não abraça } e \text { rola pelo chão e grita". A professora } \\
\text { relata que um dia disse com um tom bem impositivo para parar de fazer aquilo } \\
\text { e o aluno parou, se levantou e a abraçou. } \\
\text { O aluno começou a fazer fonoterapia e vai a um neurologista de tempos em } \\
\text { tempos. A professora descreve a mãe do aluno como ótima por ser participa- } \\
\text { tiva e foi até escolhida como mãe representante. Cita uma crise de birra que o } \\
\text { aluno teve porque tirou a sandália. Ela coloca: "Ele está sendo o meu desafio". } \\
\text { A professora relata ainda a tentativa de brincar com lego, mas ele não teve } \\
\text { interesse. Ela não sabe dizer os interesses do aluno e nem a mãe. Colocou que } \\
\text { o pai interage com o aluno em brincadeiras de luta. O aluno não tem interesse } \\
\text { em televisão, nem em computador porque ela mesma baixou vídeos e ele não } \\
\text { se interessou. } \\
\text { Em casa ele gosta de pular em cima da cama, vai para o sofá e interage com os } \\
\text { avós e fazem todas as vontades dele. } \\
\text { Em sala de aula ele anda pela sala e quando é pedido para que sente, ele se senta } \\
\text { por pouco tempo e depois não faz absolutamente nada. }\end{array}$ \\
\hline
\end{tabular}




\begin{tabular}{|c|c|}
\hline Caso & Breve descrição \\
\hline $\begin{array}{l}\text { Caso } 5 \text { - } \\
\text { Eduardo }\end{array}$ & 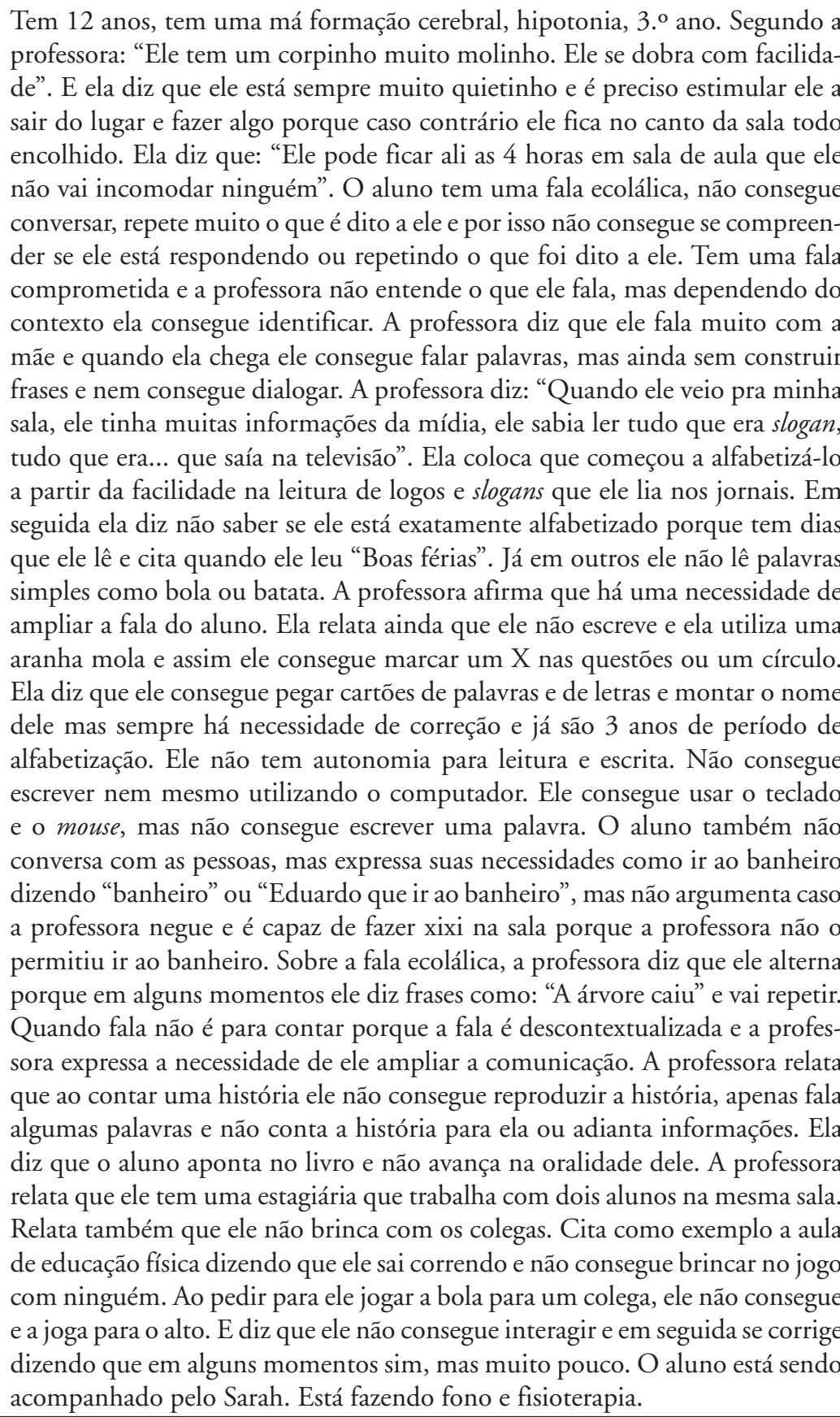 \\
\hline
\end{tabular}


As informações sobre o(s) aluno(s) e o campo foram obtidas pelas professoras por meio do contato com os pais ou cuidadores, professores e também com os próprios alunos com deficiência. $\mathrm{O}$ roteiro foi importante no trabalho, pois conduziu os professores a levantar os problemas e a buscar soluçôes para os discentes.

Antes de redigirem os estudos de caso, percebeu-se que, no discurso, as professoras davam muita importância para informações clínicas, como diagnósticos, por exemplo, ignorando ou desmerecendo informações educacionais. Isso ocorre, provavelmente, porque a Educação Especial se constituiu originalmente como campo de saber e área de atuação, a partir de um modelo médico ou clínico. A cientificidade nas décadas de 1960 e 70, que fez com que predominasse o modelo médico e fosse instituído um diagnóstico-padrão classificatório ao aluno com distúrbios psicomotores e de aprendizagem, até hoje predomina em nossa cultura (Glat, 1995). Portanto, mesmo nas áreas educacional e psicopedagógica, essa visão médica diagnóstica era e ainda é hegemônica. Essa questão foi discutida com os professores ao longo da formação.

Verificou-se que, nas sessões seguintes, os dados educacionais foram mais enfatizados na descrição do caso e os pontos elencados para o estudo passam a ter relação mais direta com temas como a Educação Especial, Educação Inclusiva, TA e CAA.

\section{Categoria: Motivação para escolha do caso}

No quadro 5, estão resumidas as motivações dos grupos para a escolha dos casos. As dificuldades em avaliar e o que esperar do aluno aparecem em todas as falas. 
Quadro 5 - Motivação a para escolha dos casos

\begin{tabular}{|l|l|}
\hline Caso & Motivação para a escolha do caso \\
\hline $\begin{array}{l}\text { Caso 1 } \\
\text { Cláudio }\end{array}$ & $\begin{array}{l}\text { Dificuldade em fazer as adaptações para o aluno por ser adolescente e estar } \\
\text { no 6.0 ano. } \\
\text { Não sabe como avaliar e o que esperar do aluno. }\end{array}$ \\
\hline $\begin{array}{l}\text { Caso 2 } \\
\text { José }\end{array}$ & $\begin{array}{l}\text { "A escolha por esse caso porque, em entrevista com a mãe, ela descobriu que } \\
\text { os profissionais que fazem tratamentos adicionais com ele queriam prender os } \\
\text { pés de José para estimular as mãos e os braços dele. Refere que ficou chocada". } \\
\text { Não sabe como avaliar e o que esperar do aluno. } \\
\text { Professora preocupada em relação à alfabetização: Como ele irá escrever? Com } \\
\text { letras móveis, emborrachadas? }\end{array}$ \\
\hline $\begin{array}{l}\text { Caso 3 } \\
\text { Benicio }\end{array}$ & $\begin{array}{l}\text { Está com muita dificuldade em relação ao caso. Descreve que "está se des- } \\
\text { cabelando". } \\
\text { Não sabe como avaliar e o que esperar do aluno. }\end{array}$ \\
\hline $\begin{array}{l}\text { Caso 4 } \\
\text { Paulo }\end{array}$ & $\begin{array}{l}\text { Dificuldade da professora em avançar com o caso. } \\
\text { Não sabe como avaliar e o que esperar do aluno. }\end{array}$ \\
\hline $\begin{array}{l}\text { Caso 5 } \\
\text { Eduardo }\end{array}$ & $\begin{array}{l}\text { Aluno muito passivo. } \\
\text { Não sabe como avaliar e o que esperar do aluno. }\end{array}$ \\
\hline
\end{tabular}

\section{Categoria: Problemas elencados no caso}

Essa primeira etapa de conhecimento do aluno e dos problemas identificados ocupou três encontros da formação. No quadro 6, apresentam-se os problemas elencados pelos grupos de acordo com o caso estudado.

Quadro 6 - Problemas elencados

\begin{tabular}{|l|l|}
\hline Caso & Problemas Elencados \\
\hline Caso 1 - Cláudio & Alfabetização e comunicação \\
\hline Caso 2 - José & Alfabetização e comunicação \\
\hline Caso 3 - Benicio & Comunicação e comportamento \\
\hline Caso 4 - Paulo & Comunicação e comportamento \\
\hline Caso 5 - Eduardo & Alfabetização e comunicação \\
\hline
\end{tabular}

Com essas informações em mãos, os grupos discutiram com a equipe da $\mathrm{OV}$ e as pesquisadoras quais seriam as possíveis soluções dos problemas identificados, relacionando os principais tópicos para a sua resolução. Nessa etapa, foi necessário que as professoras buscassem aprofundamento teórico, 
o que envolveu textos e aulas teóricas e práticas. Como a comunicação foi um dos problemas elencados por todos os grupos, os temas tratados foram: interação e comunicação, linguagem e comunicação, função do professor de AEE, recursos de comunicação para alunos com autismo e softwares de CAA - Boardmaker, Speaking Dinamically Pro e TICO.

Posteriormente, a orientação que receberam foi a de que todos deveriam propor um plano de intervenção, escolhendo um dos problemas, traçando objetivos e pensando em pelo menos uma atividade para alcançar esse objetivo, bem como recursos e estratégias a serem desenvolvidos.

\section{Categoria: Recursos e estratégias desenvolvidos para o caso}

Durante o ano de 2013, os professores receberam indicações bibliográficas e oficinas sobre os recursos de CAA, conheceram alunos com deficiência e TEA, por meio de estudos de caso compartilhados, filmagens e conversas compartilhadas nas sessões de pesquisa em grupo. A partir das observações feitas pelas colegas professoras, equipe da OV e pesquisadoras, as docentes foram levadas a refletir e conhecer problemas que esses alunos vivenciam no seu cotidiano escolar. Ao longo da formação, aprenderam a identificar as habilidades, potencialidades e interesses dos seus alunos e, a partir desse conhecimento, destacaram problemas, estudaram, buscaram soluções relacionadas, em sua maioria, a estratégias e recursos de baixa tecnologia, principalmente nas modalidades de CAA e materiais pedagógicos, escolares e lúdicos adaptados.

Alguns professores tiveram dificuldades na organização inicial desse plano de atendimento educacional. A maior delas foi quanto à redação dos objetivos do plano de intervenção, que às vezes não estavam relacionados aos problemas identificados ou eram redigidos em forma de atividades. Os professores conseguiram compreender as necessidades e potencialidades dos alunos e, principalmente, entender que isso não é uma tarefa simples quando estamos tratando de alunos sem fala articulada e/ou funcional, porém, é de fundamental importância para o estabelecimento de programas educacionais que efetivamente contribuam para o seu aprendizado (Bueno, 1999; Omote, 2001). O modelo proposto pelo Council for Exceptional Children (CEC, 2008) recomenda o desenvolvimento da competência em relação ao planejamento instrucional e, com isso, propõe que o professor desenvolva habilida- 
des em: elaborar um plano de instrução individualizada geral com objetivos a longo prazo; traduzir esses planos individualizados em objetivos de curto prazo cuidadosamente selecionados, levando em consideração as habilidades e necessidades dos indivíduos, e os múltiplos fatores culturais e linguísticos; e avaliar continuamente o progresso da aprendizagem do indivíduo. Além disso, o professor deve ajudar na facilitação desse plano instrucional em um contexto colaborativo, incluindo o aluno com deficiência, sua família e os outros profissionais que atuem com esse aluno especial.

A maioria das professoras elencou como principal problema dos alunos com deficiência e TEA as dificuldades de comunicação e, consequentemente, de interação. Em alguns casos tiveram a oportunidade de fazer a intervenção. No quadro 7, estão expressos os recursos e as estratégias pensados por elas.

Quadro 7 - Recursos e estratégias desenvolvidos

\begin{tabular}{|l|l|}
\hline Caso & Recursos e estratégias desenvolvidos \\
\hline $\begin{array}{l}\text { Caso 1 } \\
\text { Cláudio }\end{array}$ & $\begin{array}{l}\text { Professoras dizem que o importante para este aluno é o cotidiano, é a indepen- } \\
\text { dência e a ampliação da questão do uso do dinheiro. Professora pensa no futuro } \\
\text { do aluno e diz que, quando mais velho, aprendendo a lidar com o dinheiro, ele } \\
\text { poderá trabalhar em uma "tendinha". } \\
\text { Desenvolver a leitura e a escrita funcional mediante o uso de pictogramas. }\end{array}$ \\
\hline $\begin{array}{l}\text { Caso 2 } \\
\text { José }\end{array}$ & $\begin{array}{l}\text { Usar cartôes com simbologia pictográfica para ampliar a comunicação e a in- } \\
\text { teração do aluno. } \\
\text { Utilizar letras móveis para promover a escrita. }\end{array}$ \\
\hline $\begin{array}{l}\text { Caso 3 } \\
\text { Benicio }\end{array}$ & $\begin{array}{l}\text { Aplicar a metodologia do PEC-Adaptado - utilizar cartões com simbologia } \\
\text { pictográfica para a comunicação e a interação. } \\
\text { Organizar uma rotina visual com cartões com simbologia gráfica. } \\
\text { Organizar o ambiente com apoio de pictogramas. }\end{array}$ \\
\hline $\begin{array}{l}\text { Caso 4 } \\
\text { Paulo }\end{array}$ & $\begin{array}{l}\text { Esse foi o único grupo que não conseguiu avançar na metodologia e, assim, não } \\
\text { chegou a desenvolver recursos e estratégias. } \\
\text { Professora responsável pelo caso faltou muito. }\end{array}$ \\
\hline $\begin{array}{l}\text { Caso 5 } \\
\text { Eduardo }\end{array}$ & $\begin{array}{l}\text { Usar a comunicação alternativa para expandir a fala e a escrita. } \\
\text { Usar a simbologia pictográfica como apoio para a leitura. }\end{array}$ \\
\hline
\end{tabular}




\section{Conclusão}

Em síntese, esse trabalho proporcionou aos professores uma oportunidade real de exercer na prática a sua formação, com as seguintes características, partindo da observação da realidade de sua SRM: identificação dos problemas pedagógicos e escolha de um deles como foco de uma investigação; reflexão sobre os possíveis fatores e determinantes maiores do problema selecionado e definição dos pontos-chave do estudo; investigação desses pontos-chave, buscando informações onde quer que elas se encontrem, analisando-as para responder ao problema e compondo, assim, a teorização; elaboração de hipóteses de solução para o problema; e, por fim, aplicação de uma ou mais hipóteses de solução, como um retorno do estudo à realidade investigada. Colombo e Berbel (2007) explicam que, na Problematização, a pesquisa se dá a partir de um determinado aspecto da realidade. Então, a primeira etapa é a da observação da realidade e definição do problema. É o início de um processo de apropriação de informações pelos participantes, que são levados a observar a realidade em si, com seus próprios olhos, e a identificar as suas características, a fim de, mediante os estudos, poder contribuir para a transformação da realidade observada.

As professoras, apoiadas por suas colegas, equipe da OV e pesquisadoras, selecionaram situações e as problematizaram. Nesse estudo, a maioria dos grupos apontou como o principal problema as dificuldades de comunicação e de interação vividas pelos alunos e professores. Dessa forma, foram instigados a aprofundar seus conhecimentos nas áreas de TA, principalmente de CAA, para propor hipóteses de soluções para os casos estudados e até mesmo implementar as intervenções descritas nos resultados.

Por fim, a última etapa — a da aplicação à realidade — é aquela que possibilitou às professoras a intervenção, o exercício e o manejo de situações associadas à solução do problema. Para Moraes e Berbel (2006), a aplicação permite fixar as soluções geradas e contempla o comprometimento do pesquisador para voltar à mesma realidade, transformando-a em algum grau. Foi possível observar essa transformação por parte das professoras não só em relação à sua postura (tanto pessoal e acadêmica quanto de pesquisa), como também ao seu conhecimento e às suas concepções. 


\title{
Capítulo 6-O uso da autoscopia como aliada na formação continuada de professores de Sala de Recursos Multifuncionais
}

\author{
Thatyana Machado Silva ${ }^{1}$ \\ Leila Regina d'Oliveira de Paula Nunes ${ }^{2}$
}

$\mathrm{Na}$ última década, o governo federal buscou propagar os referenciais da educação inclusiva em todo o país, a fim de estabelecer um novo marco organizacional na educação brasileira (MEC/SEESP, 2008, p. 15). Diante de tantas mudanças, é essencial que haja uma reestruturação na postura dos professores, que não podem mais olhar a escola de maneira homogênea, mas precisam dar início a um processo crítico-reflexivo de modo a fazer valer o direito de educação para todos.

Ao pensar na Política Nacional de Educação Especial na Perspectiva da Educação Inclusiva (MEC/SEESP, 2008), pesquisas do Observatório Nacional de Educação Especial (Oneesp) ${ }^{3}$ apontam que há uma grande escassez

1 Mestre em Educação pelo Programa de Pós-Graduação em Educação da UERJ. Secretaria Municipal de Educação de Rio das Ostras. E-mail: thatyana.ms@gmail.com.

2 Professora titular da Faculdade de Educação e do Programa de Pós-Graduação em Educação da UERJ. E-mail: leilareginanunes@terra.com.br.

3 O Oneesp é um grupo de pesquisa em nível nacional, iniciado em 2011, cujos primeiros estudos foram realizados em 56 municípios provenientes de 17 estados brasileiros, 
de professores habilitados a trabalhar nas Salas de Recursos Multifuncionais (SRMs) e a exercer o Atendimento Educacional Especializado (AEE). As pesquisas do Oneesp (2014) confirmam, ainda, que os professores de SRM não se sentem aptos para oferecer o AEE a toda demanda que foi estabelecida como público-alvo da educação especial - o que inclui o trabalho não só com os diferentes tipos de deficiência, mas também com pessoas de diferentes faixas etárias, visto que a educação inclusiva perpassa da educação infantil até o ensino superior. Isso faz com que os professores assumam um problema de cunho político-administrativo como se fosse uma falha pessoal por ter uma formação precária.

Mendes, Vilaronga e Zerbato (2014) tecem uma enorme crítica ao modelo de Sala de Recursos vigente, referindo-se a ele como sendo um modelo econômico para o governo, pois centraliza diversos materiais, equipamentos e outros apoios em um mesmo local. Segundo as autoras, "esse modelo coloca obstáculos instransponíveis à formação dos professores, pois esses são obrigados a dominar conhecimentos e habilidades de ensino de diferentes populaçōes da Educação Especial" (Mendes et al., 2014, p. 25).

A angústia causada nos professores de Sala de Recursos, ao perceberem a enorme lista de suas atribuiçóes, faz com que, muitas vezes, eles assumam para si aquilo que é papel do governo como um todo. Mendes et al. (2015, p. 30) afirmam que "predomina no discurso político a responsabilidade deste profissional em adquirir múltiplas competências”, como se o professor fosse

a saber: Alagoas, Amapá, Bahia, Espírito Santo, Goiás, Maranhão, Mato Grosso do Sul, Minas Gerais, Rio de Janeiro, Rio Grande do Norte, Rondônia, São Paulo, Santa Catarina, Sergipe, Paraíba e Paraná. A princípio, o projeto foi composto por 25 pesquisadores que faziam parte de 22 universidades e de 18 programas de pós-graduação. Com o passar do tempo, esse número alastrou-se de modo que, em 2014, haviam participado do projeto 808 pessoas, sendo 203 pesquisadores (49 da rede nacional, 72 das redes estaduais de pesquisa, 77 pesquisadores colaboradores e 5 em estágios de pós-doutorado); 217 estudantes (115 alunos de 22 cursos de graduação, 55 de 14 diferentes programas de pós-graduação, 10 de cursos de especialização e 37 de graduação envolvidos em dois Programas de Incentivo à Docência - PIBID - de suas universidades); 446 professores especializados de SRM dos vários estados; e 36 gestores municipais da educação especial (Mendes e CIA, 2014, p. 20). 
o responsável por buscar sua própria formação a fim de cumprir com todas as especificidades exigidas pelo MEC. Em outas palavras, pode-se dizer que há sobre o professor do AEE a expectativa de que ele seja multifuncional em suas atribuições e açôes pedagógicas; sendo essa uma exigência que deveria pertencer ao espaço físico da Sala de Recursos, e não ao profissional que nela atua.

Ao observar tais questôes e considerar a urgência em discutir assuntos relacionados à educação inclusiva e à formação exigida dos professores para trabalhar nessa área específica, um grupo de pesquisadores ligados ao grupo de pesquisa do Laboratório de Tecnologia Assistiva da Universidade do Estado do Rio de Janeiro (LATECA) desenvolveu, junto à Oficina Vivencial de Ajudas Técnicas (um dos serviços oferecidos pelo Instituto Helena Antipoff), um processo de formação continuada para professores que trabalham nas Salas de Recursos Multifuncionais do Rio de Janeiro.

Foi assim que, em 2013, Schirmer e Nunes iniciaram uma pesquisa intitulada "A Formação Continuada de Professores das Salas de Recursos Multifuncionais do Rio de Janeiro em Tecnologia Assistiva”, financiada pela FAPERJ e pelo CNPq. A pesquisa teve como objetivo principal formar professores de SRM em Tecnologia Assistiva (TA) para que, ao estarem devidamente preparados, tivessem condiçóes de atender a seus alunos e dar o suporte necessário para o corpo docente da escola, bem como para os professores de SRM que fazem parte de suas Coordenadorias Regionais de Educação (CRE).

A pesquisa teve início com um curso de capacitação em TA e CAA para os professores participantes. Logo após a oferta do curso, Schirmer levou para o grupo de pesquisa um vídeo que mostra a conversa com um de seus pacientes durante o atendimento em seu consultório de fonoaudiologia e solicitou aos professores que analisassem o modo como ela interagiu com seu paciente, bem como os recursos que ela usou para conduzir a conversa e possibilitar uma comunicação autônoma daquele sujeito. Após isso, foi proposto que os professores filmassem o atendimento que realizavam na Sala de Recursos com os alunos que não apresentavam linguagem oral e levassem o vídeo para a próxima reunião de pesquisa, com a finalidade de exibir e avaliar como estavam suas práticas pedagógicas em relação aos conteúdos que foram experimentados no curso frequentado.

Essa proposta foi lançada de modo que os professores tivessem a liberdade de escolher participar ou não desse momento da pesquisa, não sendo 
eles obrigados a filmar suas aulas. Inicialmente, três professoras aceitaram participar dessa etapa e levaram suas experiências registradas em gravações de vídeo. Esse momento da pesquisa foi considerado como "Análise de Desempenho" e era realizado de maneira que todos assistissem juntos ao vídeo e analisassem a atuação da professora com o aluno que apresentasse dificuldade na linguagem oral.

Essa fase da pesquisa ocorreu em meados de 2014, e a intenção era que, no ano seguinte, os professores dessem continuidade ao emprego da Análise de Desempenho; no entanto, encontramos algumas dificuldades nesse processo. Percebemos que o processo de autoavaliação da prática pedagógica do sujeito que estava em evidência no vídeo ficava um pouco prejudicado, pois todos os participantes assistiam juntos ao vídeo e comentavam suas impressões ao mesmo tempo, não havendo espaço para o professor em cena falar de que forma ele foi impactado ao assistir ao vídeo.

Outra dificuldade encontrada é que, como todos assistiam juntos ao material gravado, não era dado o tempo hábil para que o vídeo chegasse ao final antes de iniciarem os comentários. Dessa forma, apenas um pequeno trecho do vídeo era analisado e logo as professoras começavam a comentar sobre ele, sem esperar para observar o modo como o professor conduzia o desfecho das atividades realizadas. Além dessas questôes relatadas, também houve dificuldade para realizar a análise dos vídeos, pois as três professoras que se propuseram a participar da Análise de Desempenho gravaram cenas com diferentes períodos de duração, não apresentando um padrão para a tabulação dos dados.

A observação desses obstáculos ocorridos durante a Análise de Desempenho possibilitou a elaboração de uma nova pesquisa, que se constitui em uma ramificação do estudo conduzido por Schirmer e Nunes. O trabalho aqui apresentado utilizou a experiência ocorrida durante a Análise de Desempenho das educadoras, em 2014, para propor uma metodologia que favorecesse a formação em serviço de professores.

A principal justificativa de um novo estudo foi a necessidade de uma abordagem que viabilizasse o registro das práticas educativas dos professores de SRM, para que eles pudessem adentrar no cotidiano de sua sala de aula e realizar um processo reflexivo acerca de suas práticas com alunos que não apresentam fala funcional. 


\section{O uso da autoscopia como aliada no processo de formação de professores}

Pensar em um processo de formação de professores que tenha a sala de aula como principal laboratório para que a formação aconteça não é tarefa fácil. Conforme vivencia as questôes que emergem de seu cotidiano, o professor mergulha e envolve-se em sua prática pedagógica, de modo que se torna difícil perceber, por si só, as mudanças necessárias. Desse modo, faz-se necessário utilizar uma ferramenta que permita uma observação com o devido distanciamento, possibilitando que ele reveja suas posturas e (re)formule o modo como ensina e planeja suas aulas.

Sendo assim, ao perceber todas as dificuldades encontradas durante a etapa da Análise de Desempenho, a pesquisadora (primeira autora) aprofundou-se nos estudos sobre a autoavaliação, realizada a partir de um conteúdo videogravado, e utilizou-se dessa técnica para que os professores pudessem meditar sobre suas ações e realizar a avaliação de suas práticas pedagógicas. Foi assim que a pesquisadora encontrou estudos que utilizavam a autoscopia como forma de avaliação docente e, a partir dessa técnica, iniciou a construção de uma pesquisa de dissertação derivada dos estudos de Schirmer e Nunes, cujo objetivo principal foi analisar como o processo de autoscopia na formação continuada dos professores de Salas de Recursos Multifuncionais influencia suas práticas pedagógicas.

Os objetivos específicos foram os seguintes: descrever e analisar a interação de dois professores com os alunos atendidos nas SRMs e verificar os efeitos da introdução da autoscopia (como procedimento para efetivar a formação continuada desses professores) nas interações professor-aluno em situação de ensino.

Em sua origem literal, a palavra "autoscopia" é composta pelos termos "auto" e "scopia". O termo "auto" é empregado quando uma ação é realizada pelo próprio sujeito, e "scopia" refere-se a escopo (do grego skoppós e do latim scopu), que significa objetivo, finalidade, meta, alvo ou mira. Portanto, ao realizar a autoscopia, o participante terá oportunidade de avaliar sua prática pedagógica após a observação de seu próprio desempenho ao interagir com um desses alunos na SRM. Essa tarefa foi possibilitada pelo registro em vídeo de trechos de seu atendimento a esses alunos. 
Sadalla e Laroca (2004) descrevem a autoscopia como uma técnica que se faz em dois momentos: o primeiro ocorre durante a gravação do vídeo e o segundo acontece quando o sujeito assiste ao material gravado para, então, realizar a análise do que foi visto.

De acordo com as autoras, o processo de autoscopia pode ser descrito da seguinte maneira: vale-se do recurso de videogravação de uma prática, visando à análise e à autoavaliação por um ou mais protagonistas dessa prática. Por meio da videogravação, objetiva-se apreender as ações do ator (ou atores), o cenário e a trama que compõem uma situação. O material videogravado é submetido a sessões de análise a posteriori da ação, o qual se destina à apreensão do processo reflexivo do ator (ou atores), por meio de suas verbalizações durante a análise das cenas videogravadas (2004, p. 421).

Segundo Leite (2012), “a Autoscopia é um procedimento de coleta de dados conhecido como confrontação de si na tela”, no qual, por intermédio das gravações realizadas e após a edição do material, o sujeito "é colocado em uma situação para observar o material gravado, sendo estimulado verbalmente pelo pesquisador para emitir comentários em razão dos objetivos da pesquisa" (Leite, 2012, p. 358).

\section{Participantes e local do estudo}

A pesquisa foi realizada com duas professoras que estão lotadas nas SRMs do município do Rio de Janeiro, que também fazem parte da pesquisa coordenada por Schirmer e Nunes, e com dois alunos que não possuem a fala funcional. As duas educadoras participantes são do sexo feminino e, neste trabalho, serão identificadas como Célia (C) e Glória $(\mathrm{G})$. A professora Célia tem 30 anos de idade e seis anos de experiência no magistério, sendo quatro anos com atuação em SRM; cursou faculdade de Pedagogia, fez especialização em Psicopedagogia, mestrado em Educação e, no momento, está cursando o doutorado em Educação. Glória tem 29 anos e sua experiência no magistério é de cinco anos, sendo três deles dedicados à atuação na SRM; concluiu recentemente a graduação em Ciências Biológicas.

Os alunos de Célia e Glória serão identificados, respectivamente, como Arthur e Heitor. Os dois são do sexo masculino e possuem laudo de autismo 
infantil. Eles estão matriculados em duas escolas distintas de ensino comum da Secretaria Municipal do Rio de Janeiro. Na época da pesquisa, Arthur encontrava-se com onze anos e estava matriculado no terceiro ano do ensino fundamental. Já Heitor, com sete anos, frequentava o segundo ano.

Os vídeos utilizados na pesquisa foram coletados na SRM de duas escolas públicas da rede municipal do Rio de Janeiro. As sessões de autoscopia ocorreram na OV do IHA e no Laboratório de TA da UERJ, conforme disponibilidade de espaço para os encontros.

Para realizar a filmagem dos atendimentos aos alunos, as professoras utilizaram seus próprios celulares e, para gravar as sessões de autoscopia, uma filmadora digital.

Como esta pesquisa é uma ramificação do estudo conduzido por Schirmer e Nunes (2013), os procedimentos aqui empregados já contavam com a aprovação do Comitê de Ética em Pesquisa da UERJ (número 336.622, de $11 / 7 / 2013)$. As professoras participantes da pesquisa preencheram o Termo de Consentimento Livre e Esclarecido (TCLE) e solicitaram que os responsáveis legais dos dois alunos também o fizessem.

\section{Procedimentos específicos da autoscopia}

\section{Organização prévia:}

A organização dessa etapa envolveu dois momentos: primeiramente, foi solicitado aos professores participantes que filmassem as sessões de atendimento aos seus alunos na Sala de Recursos. As sessões deveriam conter de trinta a trinta e cinco minutos, e a gravação deveria ocorrer de forma ininterrupta. Após a gravação dos atendimentos feitos com alunos sem fala funcional, os professores deveriam enviar os vídeos para a pesquisadora analisá-los previamente, possibilitando, assim, que a totalidade do material fosse contemplada, e não apenas uma pequena parte.

Após assistir ao vídeo por completo, a pesquisadora selecionou algumas cenas contendo situações importantes para a discussão, nas quais a ocorrência das variáveis do estudo pudesse ser mensurada. As cenas elencadas pela pesquisadora tinham, em média, a duração de dez a doze minutos. $\mathrm{O}$ vídeo entregue pelos professores foi editado e recortado, contendo apenas 
as cenas escolhidas pela pesquisadora. A edição do material não continha o mesmo número de cenas para cada vídeo, pois a duração padronizada de cada uma delas não seria relevante para a análise. Em vez de determinar o mesmo número de cenas para serem expostas durante a autoscopia, a pesquisadora decidiu por determinar o tempo de recorte dos vídeos. Portanto, dos trinta minutos contidos em cada gravação, a pesquisadora separou algumas cenas, que totalizaram de dez a doze minutos, e foram essas as que os professores assistiram durante as sessões de autoscopia.

Após fazer o recorte das cenas, a pesquisadora analisou-as cuidadosamente a fim de observar e tomar nota dos pontos que seriam discutidos com os professores durante as sessões de autoscopia.

\section{Realização da autoscopia}

Após a análise e o recorte das cenas, os participantes e os agentes de intervenção encontraram-se para realizar as sessões de autoscopia. Durante as sessões, a apresentação dos vídeos para todos os participantes foi igualmente filmada, para posterior análise da fala emitida pelas professoras ao observarem o modo como realizavam suas práticas pedagógicas e se relacionavam com seus alunos. Nesses encontros, a autora de cada vídeo foi solicitado a avaliar seu próprio desempenho, assim como o de seu aluno. Os demais professores e agentes de intervenção foram igualmente estimulados a comentar sobre o vídeo assistido e dar sugestóes.

O estudo realizado constituiu-se em duas fases, descritas a seguir:

\section{Linha de Base}

As sessōes de Linha de Base foram filmadas pelas duas professoras em seus locais de trabalho. Na primeira fase, foram realizadas três gravações consecutivas das aulas ocorridas nas SRMs (com média de 30 minutos de duração em cada sessão), em que as próprias professoras filmaram os atendimentos aos alunos. Ao se decidir que cada professora realizaria a sua filmagem, foi considerada a interferência que uma pessoa estranha poderia causar ao aluno observado e, com isso, modificar as respostas dele e da própria professora na situação de ensino. Essas três primeiras gravações aconteceram sem que as professoras recebessem qualquer tipo de instrução ou sugestão da pesquisa- 
dora. No entanto, vale ressaltar que, embora as professoras não tenham sofrido intervenção direta durante essa fase, elas já haviam participado do curso de formação continuada oferecido por Schirmer e Nunes junto à OV do IHA. Sendo assim, as duas já apresentavam conhecimento prévio em relação à comunicação alternativa e ao atendimento de alunos com TEA.

Após o término das sessões de Linha de Base, as professoras entregaram o material para a pesquisadora analisar e realizar o recorte das cenas, conforme o que foi descrito anteriormente.

\section{Intervenção}

A realização da Intervenção ocorreu após a pesquisadora editar os vídeos da Linha de Base. Nessa etapa da pesquisa, as professoras deram início ao processo de autoscopia, observando suas práticas pedagógicas por meio do material videogravado. A pesquisadora, a professora Leila Nunes e os membros que compunham a OV estavam presentes nas sessões e a eles foi dada a liberdade de tecer comentários durante o processo de análise do material das professoras.

A Intervenção foi dividida em dois momentos: Autoscopia de Treinamento e Autoscopia Orientada. O primeiro teve a duração de três encontros (ocorridos no período de um mês, sendo um a cada semana), nos quais foi analisado e discutido um vídeo da Linha de Base. As sessões duraram, em média, três horas cada, e as professoras realizaram o exercício de treinar o olhar para perceber as diversas situações cotidianas da sala de aula. Nesse momento, as educadoras foram convidadas a verbalizar sobre o modo como conduziam o atendimento aos seus alunos e como eles respondiam às propostas feitas por elas. Os encontros foram filmados e, posteriormente, transcritos, com o objetivo de analisar a fala das professoras ao perceberem-se atuando com seus alunos.

Após o término da última sessão da Autoscopia de Treinamento, as professoras filmaram uma de suas aulas e entregaram o vídeo para a pesquisadora fazer a seleção de cenas e, assim, dar início ao processo de Autoscopia Orientada. Nessa etapa, em vez de gravarem um conjunto de sessões consecutivas, as professoras passaram, inicialmente, pelo processo de autoscopia e, após, elas retornaram às suas salas para realizarem novas filmagens, de modo 
que, depois de cada gravação, era realizado um encontro para a realização da autoscopia, e assim por diante.

Nesse momento da pesquisa, as professoras receberam orientação direta da pesquisadora, focalizando as variáveis dependentes escolhidas para compor o estudo. Em vez de observarem o vídeo livremente, como foi feito na etapa da Autoscopia de Treinamento, o material foi analisado de acordo com o direcionamento e a orientação dados pela pesquisadora, sendo, por isso, essa etapa considerada como uma Autoscopia Orientada. Os encontros foram filmados e transcritos a fim de exibir a riqueza de detalhes contidos na fala das professoras ao se observarem nos vídeos. Cada sessão de Autoscopia Orientada teve a duração de, aproximadamente, três horas, estando presentes apenas as professoras e a pesquisadora.

Para realizar a edição das cenas dessa fase, a pesquisadora seguiu os mesmos passos descritos anteriormente.

\section{Delineamento da pesquisa}

Com o objetivo de verificar os efeitos do emprego da autoscopia no desempenho das professoras e dos seus respectivos alunos, foi empregado no estudo um delineamento quase experimental intrassujeitos - linha de base e intervenção. Essa metodologia "realiza uma avaliação individual e rigorosa dos efeitos das intervençóes ou tratamentos para cada participante, ou seja, a análise dos efeitos da(s) Variável(eis) Independente(s) em cada caso individual" (Nunes e Walter, 2014, pp. 4-5).

\section{Variáveis}

O emprego dos procedimentos da autoscopia constituiu a Variável Independente (VI).

Baseando-se nos estudos de Nunes et al. (2013), Corrêa Netto (2012), Feuerstein (1980) e Lidz (1991), a pesquisadora propôs cinco categorias de respostas como Variáveis Dependentes (VD), sendo elas: 1) professora favorece a comunicação do aluno; 2) aluno se comunica com a professora; 3) aluno faz uso de diferentes funções comunicativas; 4) desempenho acadêmico do aluno; e 5) prática pedagógica do profissional. 
A pesquisa desenvolveu-se de modo a verificar se VI afeta as VDs, ou seja, se a autoscopia provoca modificações nas práticas do professor e se isto influencia o comportamento e a comunicação dos alunos. Cada VD envolvia um conjunto de respostas, conforme a descrição a seguir:

1. Professora favorece a comunicação do aluno. Os seguintes comportamentos integram esta categoria:

- utilização de cartões para incentivar a comunicação da criança - o profissional faz uso de cartóes de Comunicação Alternativa para elaborar as perguntas e estabelecer algum diálogo com a criança, de modo que ela tenha condições de se expressar;

- utilização de cartões para mediar atividades pedagógicas - o profissional faz uso de recursos de Comunicação Alternativa para adaptar materiais e conduzir atividades de cunho pedagógico, a fim de facilitar a aprendizagem da criança, mas sem a intenção de estabelecer um diálogo com ela;

- espera da resposta da criança - o profissional aguarda a resposta da criança ao se dirigir a ela, dando o tempo necessário para ela conseguir se expressar;

- resposta às perguntas/solicitações da criança - o profissional está atento aos sinais verbais e não verbais emitidos pela criança, de modo a poder responder àquilo que a criança deseja, pergunta ou solicita. O professor percebe o que a criança solicita e dá a ela um feedback, independentemente de atender ou não ao pedido.

2. Aluno comunica-se com a professora. Os seguintes comportamentos integram esta categoria:

- iniciativa de interação com o profissional de modo autônomo - se o aluno inicia o ato comunicativo com o profissional a partir de atitude e interesse próprios, podendo ser de modo verbal ou não verbal;

- resposta ao diálogo iniciado pelo profissional - se o aluno faz uso de elementos verbais e não verbais para responder às perguntas e estabelecer algum diálogo com o profissional; 
- resposta ao direcionamento dado pelo profissional - o aluno entende a solicitação do profissional e responde à atividade proposta por meio de elementos verbais ou não verbais.

3. Desempenho acadêmico do aluno. Os seguintes comportamentos integram esta categoria:

- permanência na tarefa - o aluno mantém-se envolvido na tarefa acadêmica proposta;

- comportamento desafiador e/ou provocativo - o aluno apresenta comportamentos, tais como gritar e olhar para o interlocutor; colocar objetos na boca como se fosse engolir; subir na mesa ou cadeira; levantar com frequência para ser abordado; correr pela sala para ser abordado; fugir da sala para ser seguido; dar leves tapas para ser inquirido; apagar a luz como forma de finalizar a atividade; jogar objetos no chão como forma de recusar a atividade proposta; virar-se de costas para o professor e colocar os dedos no ouvido na tentativa de ignorar o que ele fala etc. Sem cunho de agressividade, mas para ter a atenção voltada para si.

4. Aluno faz uso de diferentes funções comunicativas. Os seguintes comportamentos integram esta categoria:

- pedido de objeto - se o aluno realiza algum ato ou emissóes verbais, ou se utiliza cartôes de comunicação para solicitar um objeto concreto desejado;

- pedido de ação/consentimento - se o aluno realiza algum ato ou emissões verbais, ou se utiliza de cartôes de comunicação para solicitar a execução de uma ação. Inclui pedido de ajuda e outras ações que envolvem outra pessoa, fazendo com que o aluno interaja com o interlocutor.

5. Categorias pedagógicas do profissional. Os seguintes aspectos integram estas categorias, de acordo com Lidz (1991):

- funcionalidade: o professor se preocupa em oferecer uma atividade que possa ser aplicada na vida diária do aluno, dando 
significado/função aos conteúdos pedagógicos apresentados - o conteúdo e a atividade aplicados podem ser generalizados pelo aluno e utilizados em seu cotidiano;

- intencionalidade: o professor fornece mensagem clara para os alunos com a intenção de envolvê-los em uma lição - estar ciente daquilo que pretende ensinar, demonstrando clareza durante a atividade;

- motivação: o professor mantém, com sucesso, a atenção dos estudantes ao longo da atividade, despertando o seu interesse e sua percepção naquilo que lhe está sendo oferecido - consegue motivar a atenção do aluno por meio do uso de voz, gestos, expressões afetivas e material concreto;

- flexibilização: a organização ou o plano de aula do professor podem sofrer alteraçôes de acordo com o comportamento demonstrado pelo aluno - abrir mão de uma atividade planejada ao perceber outro assunto que exija mais atenção e tendo mais significado para o aluno.

As variáveis foram mensuradas com três instrumentos diferentes para que os dados da pesquisa fossem explorados de acordo com suas especificidades. A maior parte das VDs foi mensurada de acordo com a frequência ocorrida em intervalos de três minutos, totalizando 21 minutos de análise para cada variável.

As variáveis que identificam o rendimento acadêmico do aluno (mantém a atenção durante a realização da atividade e apresenta comportamento desafiador) foram medidas em termos de sua duração. Tal medida permite verificar se houve aumento ou diminuição da duração de tais comportamentos.

As quatro subcategorias da variável referentes ao planejamento e à prática pedagógica do professor (Funcionalidade, Intencionalidade, Motivação e Flexibilização) foram mensuradas por meio de uma Escala Ordinal do tipo Likert, pontuada de 1 a 4, proposta por Lidz (1991). No quadro abaixo, estão descritas as categorias. 
Figura 1 - Escala ordinal utilizada por Lidz (1991)

\begin{tabular}{|c|c|c|c|}
\hline 4 & 3 & 2 & 1 \\
\hline $\begin{array}{c}\text { Comportamento } \\
\text { evidente em alto } \\
\text { grau }\end{array}$ & $\begin{array}{c}\text { Comportamento } \\
\text { evidente de forma } \\
\text { moderada }\end{array}$ & $\begin{array}{l}\text { Comportamento } \\
\text { evidente de forma } \\
\text { emergente }\end{array}$ & $\begin{array}{l}\text { Comportamento } \\
\text { não evidente }\end{array}$ \\
\hline
\end{tabular}

Ao lado de cada subcategoria analisada, foi apresentada uma escala ordinal, conforme figura anterior. Ao observar a variável de "funcionalidade", por exemplo, a pesquisadora avaliou se esse comportamento apresentou-se de forma evidente em alto grau, em grau moderado, de forma emergente ou não evidente nas gravaçõos realizadas pelos professores.

\section{Resultados da Autoscopia de Treinamento}

O cotidiano dinâmico da sala de aula exige do professor um constante planejamento de suas açóes. Conforme assume uma postura rotineira e reproduz suas atitudes de maneira automática, corre o risco de seguir acreditando que não há nada a mudar em sua prática pedagógica. A proposta para essa etapa da pesquisa foi descortinar o olhar das professoras, fazendo com que elas tivessem a coragem de olhar para seu próprio desempanho, sendo capazes de identificar os desafios que emergem da prática pedagógica.

Durante essa etapa, foi possível perceber a dificuldade de as professoras considerarem a necessidade de mudanças em suas práticas e posturas. No início da pesquisa, elas apresentavam um planejamento rígido e engessado, de modo que não havia espaço para a flexibilização da rotina e das atividades propostas, mas, aos poucos, as duas professoras saíram da posição de ensinantes para assumirem, também, a posição de aprendizes, de modo que uma prática retroalimentasse a outra.

Pouco a pouco, foi possível perceber que as professoras adentraram na proposta da autoanálise e no processo reflexivo de suas práticas pedagógicas.

Para ilustrar tal postura, vejamos agora uma das cenas selecionadas pela pesquisadora para a análise autoscópica. Ela foi apresentada no primeiro 
encontro da Autoscopia de Treinamento e fazia referência a uma atividade conduzida pela professora Célia (C) com seu aluno Arthur (A).

A cena tem início com a professora apresentando para o aluno três copos, numerados de 1 a 3, e um pote com tampinhas de refrigerante. A atividade consistia em identificar o numeral nos copos e colocar dentro deles a quantidade de tampinhas correspondente:

C: Olha aqui o que a gente vai fazer (mostrando a caixa com tampinhas).

O aluno brinca com uma boneca e não olha para a professora.

C: Não é a boneca não. Olha, são essas pecinhas aqui. Tá vendo? Tem tampinhas.

O aluno continua brincando com a boneca, sem prestar atenção na professora.

A professora mostra os copos para o aluno e diz:

C: Vamos colocar as tampinhas aqui dentro.

O aluno insiste em brincar com a boneca, e a professora retira o brinquedo de suas mãos.

O aluno pega a caixa com tampinhas, e a professora diz:

C: Assim você vai derrubar [...] Você não quer deixar eu te ajudar? Primeiro, vamos parar a teimosia e depois, a gente vai fazer direito.

O aluno coloca as tampinhas dentro do copo de modo indiscriminado e deixa os copos caírem no chão.

C: Pode guardar tudo porque não quero mais fazer isso não. Porque não é assim que se faz. Você tá vendo como tá tudo errado? Não tá nem na hora de brincar. Eu sei que você quer brincar com a boneca, mas eu já disse que não. 
Ao iniciar o processo de autoscopia, a professora alegou que aquele foi o primeiro dia em que esteve sozinha com o aluno, por isso, ele ainda não estava habituado à rotina e não respeitou a ordem dada por ela. Após ouvir a fala da professora, a pesquisadora disse que o que mais chamou sua atenção durante a cena foi a insistência em fazer com que o aluno se envolvesse com uma atividade que parecia não fazer sentido para ele. A outra professora sujeito da pesquisa (Glória - G.) também estava presente e, ao ouvir o comentário da pesquisadora, questionou sobre o limite entre insistir com o aluno e deixar que ele faça apenas aquilo que quiser. Célia concordou com o comentário feito por sua colega e acrescentou que abrir mão da atividade é "dar margens para que o aluno faça apenas aquilo que ele tiver interesse e vontade". A partir dessas falas, a pesquisadora aproveitou para trabalhar o conceito de "funcionalidade", utilizado por Suplino (2005).

Com essa visão de educação centrada no professor, os atendimentos das professoras eram inflexíveis, e não havia espaço para a troca de saberes com os alunos, fazendo até mesmo com que eles apresentassem poucas intenções comunicativas devido a essa postura rígida assumida por elas.

Em algumas situações, os alunos conseguiram demonstrar iniciativa na comunicação e sinalizavam seus interesses particulares. As professoras costumavam dar atenção e respondiam às solicitações feitas por eles, mas as respostas eram, na maioria das vezes, uma negação ao pedido dos alunos e, com isso, elas perdiam a oportunidade de estimular a autonomia comunicativa deles. Quando a professora apresenta uma fala do tipo "Eu sei que você quer brincar com a boneca, mas eu já disse que não", ela não cria a possibilidade de o aluno se expressar, pois não há uma devolutiva de modo que ele entenda o porquê daquilo não ser permitido.

O próximo exemplo, refletido junto às professoras durante o primeiro dia da Autoscopia de Treinamento, também retrata um momento no qual a professora não considerou o pedido do aluno e manteve o planejamento que havia feito. A cena teve início quando a professora Glória $(G)$ apresentou para seu aluno uma garrafa de plástico e propôs que ele pintasse o objeto fazendo uso de cola colorida e pincel. Esse seria um presente a ser entregue como lembrança do Dia das Mães. 


\section{Presente para a mamãe}

A professora inicia a atividade entregando para o aluno um pincel para que ele pintasse um objeto que seria entregue como presente de dia das mães. $\mathrm{O}$ aluno estava bastante inquieto e não demonstrava interesse pela atividade. Ele soltou todo o material e olhou fixamente na direção da parede.

G: Eu sei que você tá querendo fazer outras coisas. Eu sei o que você quer. Você quer o livro. Você quer usar o computador. Mas, só vamos usar o livro e o computador, depois que pintar o presente da mamãe. Vamos terminar de pintar?

O aluno pega o pincel e volta a pintar a garrafa.

G: Isso! Muito bem. Pega mais tinta.

Ao ouvir isso, o aluno coloca as mãos no ouvido e emite um suspiro que indica cansaço

G: É, não adianta tampar os ouvidos, vamos terminar de pintar. Segura aí o pincel e vamos continuar a atividade.

Vale a pena ressaltar que, durante a cena apresentada, o aluno já havia pintado a garrafa quase em sua totalidade, mas a professora insistia para que ele pintasse mais. Após assistir ao vídeo, a professora explicou a nós que o seu objetivo era trabalhar a mistura de cores, pois ela havia colocado duas tintas no potinho e pedido para que o aluno misturasse. Como o aluno se manteve disperso durante a maior parte do tempo, ao assistir a cena, a professora percebeu que seu objetivo não tinha sido alcançado, pois o aluno demonstrava estar interessado em outras coisas.

A pesquisadora chamou a atenção para a seguinte fala da professora: "Eu sei o que você quer". Glória usou essa frase quando o aluno apontou para a parede na tentativa de mostrar algo a ela. Em seguida, a pesquisadora perguntou como a professora poderia ter tanta certeza, como ela realmente sabia o que o aluno desejava. A fala da professora continha a informação de que era preciso terminar de pintar a garrafa para mudar a atividade, mas 
talvez o aluno considerasse que a atividade já estivesse concluída e, naquele momento, ele tentava expressar que desejava fazer outra coisa.

Ao ouvir essa fala, Célia comentou que caímos na mesma questão da cena em que o aluno recusava a atividade das tampinhas: "Quem deve decidir o tempo da atividade? Somos nós ou é o aluno? Se ele apontar para a rotina e quiser mudar, a gente deve deixar que ele faça o que quer?”.

Por meio dos comentários das professoras, podemos, mais uma vez, perceber o quão inflexível elas eram no início da pesquisa. Heitor apontou para outro objeto e demonstrou uma clara intenção de se comunicar, mas a professora não reconheceu essa possibilidade e insistiu na atividade de pintura. A cena também retrata que, no princípio, as professoras utilizavam os cartôes de CAA apenas como meio de organização pedagógica na condução de atividades, não havendo espaço para o desenvolvimento e a expansão da linguagem.

Ao final da terceira Autoscopia de Treinamento, foi solicitado às professoras que partilhassem a experiência vivida ao longo dos três encontros - o que elas sentiram ao se olharem nos vídeos e como elas se percebiam. Por meio de suas respostas, foi possível perceber a proporção da importância de ter uma prática crítico-reflexiva, visto que esse processo torna viável a mudança de atitude e a postura pedagógica.

A professora Célia respondeu à pergunta com lágrimas nos olhos. Ela ficou muito emocionada ao relatar como foi difícil esse processo de deixar que entrássemos em sua sala de aula para observarmos, juntos, o cotidiano de sua prática. Célia chorou ao contar que a observação de suas ações fez com que ela percebesse que é preciso mudar a cada dia e que não podemos ser sempre os mesmos:

C: No início da proposta da pesquisa eu estava toda animada, mas depois me bateu uma depressão, me veio uma tristeza, e eu pensei: 'Caramba, o que eu estava fazendo com esse menino?'. [...] 'Por que eu estou levando tampinha se o menino não gosta nem de tampinha?' [...] Aos poucos eu fui percebendo que a prática é muito mais ampla do que eu focava, a prática de comunicação alternativa é uma imensidão. [...] Isso é bom, pra gente tomar uma rasteira. Eu pensei: 'Está vendo como não adianta fazer iniciação cientifica? Se você, na prática, não mudar, não vai adiantar nada o conhecimento teórico que você tem. E se não fosse a sua 
pesquisa e a oportunidade que eu tive de me olhar através dos vídeos, talvez eu estaria batendo na mesma tecla das tampinhas até agora'.

O depoimento da professora Célia causou um grande impacto na equipe de pesquisa, pois, durante o processo do estudo, não conseguimos contemplar em sua totalidade o quanto os procedimentos adotados puderam contribuir para a formação humana e profissional do docente. Após a partilha de Célia, foi a vez da professora Glória nos contar como foi a sua experiência durante essa etapa de treinamento:

G: Desde a primeira filmagem que passou eu morri de medo e vergonha, mas hoje eu só tenho a agradecer pela autoscopia. Porque na hora a gente não percebe aquela tentativa incessante de tem que dar certo e ai continuamos a insistir na atividade que planejamos, sem levar em consideraçāo a possibilidade de mudança. Durante todo esse tempo eu só tenho a agradecer às mudanças que a pesquisa causou no meu trabalho. Porque eu não conseguia perceber a quantidade de formas que você tem de chegar no aluno. Hoje eu percebo que, por mais que a minha mudança seja uma coisa sutil, isso modifica muito a vida da criança e ela pode aprender melhor de acordo com o modo que vou ensiná-la.

Dessa forma, terminamos a etapa da Autoscopia de Treinamento e combinamos como seria o prosseguimento da pesquisa. Após o terceiro encontro, depois de terem passado pela experiência de observar suas práticas, foi solicitado às professoras que gravassem novas sessões para análise. Ao contrário da etapa anterior, os novos vídeos não deveriam ser gravados em sequência, pois, antes de coletar novos dados em seus locais de trabalho, as professoras passariam pelo processo de análise do material. ${ }^{4}$

Essa etapa fomentou nas professoras a importância da formação continuada baseada em um processo de autoanálise. A prática da autoscopia propiciou que elas experimentassem o processo de reelaboração de suas práticas pedagógicas a partir do confronto criado entre a imagem retratada no vídeo e o cotidiano da sala de aula.

4 Essas novas sessões de análise foram observadas e mensuradas e constituíram a fase de Intervenção. 


\section{Resultado da Autoscopia Orientada}

Até o presente momento, foram apresentados alguns relatos verbais feitos pelas professoras ao se observarem atuando nos vídeos. Podemos perceber, pela fala delas, o movimento feito na tentativa de melhorar suas práticas pedagógicas. No entanto, para ter maiores evidências de como ocorreu esse processo, foi realizada a mensuração das seguintes variáveis diretas: 1) professora favorece a comunicação do aluno; 2) aluno comunica-se com a professora; 3) aluno faz uso de diferentes funções comunicativas; 4) desempenho acadêmico do aluno; e 5) prática pedagógica do profissional.

Embora a pesquisadora tenha realizado a edição dos vídeos e feito o recorte de algumas cenas a fim de serem analisadas durante a autoscopia, foi considerada a totalidade de cada vídeo para o momento de mensuração das variáveis.

As três variáveis referentes à comunicação foram mensuradas de acordo com a frequência do comportamento ocorrida em intervalos de três minutos. As gravações realizadas pelas professoras tinham a duração aproximada de trinta minutos. As variáveis foram medidas até o sétimo intervalo, totalizando 21 minutos (contínuos) de análise para cada variável. As variáveis continham algumas subcategorias, o que contabilizou o total de nove categorias observadas em cada sessão.

Ao averiguar a variável referente ao modo como as professoras favorecem a comunicação do aluno, foi possível perceber que, no início da pesquisa, na maioria das vezes, os cartóes de CAA eram utilizados apenas com a intenção de mediar e adaptar atividades pedagógicas, não considerando as questôes mais abrangentes de comunicação. Havia uma acentuada dificuldade para usar o cartão como forma de comunicação e promoção do diálogo com os alunos. Após o processo de intervenção, observamos o aumento das tentativas em fazer com que a CAA favorecesse a comunicação de forma efetiva, sendo os cartôes usados como um instrumento que possibilitasse a interação dos alunos com o meio e com seus pares, por meio da expressão de seus pensamentos e desejos.

Ao refletirem como realizavam suas práticas pedagógicas e como se relacionavam com seus alunos, as professoras perceberam a necessidade de voltar o olhar para aquilo que eles tentavam comunicar por meio de suas ações. 
Mediante essa nova postura, é possível observar na Tabela 1, a seguir, as mudanças que ocorreram na frequência média do comportamento de espera das respostas dos alunos pelas professoras na Linha de Base e na Intervenção.

Tabela 1 - Frequência média do comportamento de espera das respostas dos alunos pelas professoras na Linha de Base e na Intervenção

\begin{tabular}{|l|l|l|}
\hline & Linha de Base & Intervenção \\
\hline Célia & 10 & 24 \\
\hline Glória & 7 & 18 \\
\hline
\end{tabular}

A Tabela 1 revela que houve um aumento no tempo de espera que as professoras ofereciam para as crianças responderem às atividades propostas. Foi possível identificar que as duas mostraram-se mais pacientes e perceberam a importância de saber aguardar a resposta dos alunos, possibilitando que eles se expressassem mais vezes. Ao dar mais tempo para os alunos elaborarem suas respostas, estes tinham mais condições de expressar não só o que as professoras perguntavam, mas também conseguiam manifestar aquilo que desejavam.

Essa atitude de espera por parte das professoras implicou até mesmo o número de vezes que elas atendiam às solicitações das crianças. Na Tabela 2, a seguir, conseguimos observar esse dado de modo concreto:

Tabela 2 - Frequência média das respostas da professora às perguntas/solicitações das crianças na Linha de Base e na Intervenção

\begin{tabular}{|l|l|l|}
\hline & Linha de Base & Intervenção \\
\hline Célia & 18 & 25 \\
\hline Glória & 11 & 20 \\
\hline
\end{tabular}

A partir dos números apresentados, é possível afirmar que as professoras mostraram-se mais atentas aos sinais dados pelas crianças e passaram a responder com maior frequência às perguntas e às solicitaçôes recebidas.

A mudança na postura profissional das professoras permitiu que se percebesse que o comportamento dos alunos tem uma ligação direta com o 
comportamento apresentado pelas docentes, como se uma prática alimentasse a outra. Ao analisar a variável referente à comunicação estabelecida entre o aluno e o profissional, foi possível verificar que as professoras modificaram o seu modo de agir, e os alunos, por sua vez, apresentaram mais respostas e mais intenções comunicativas.

Durante a realização da autoscopia, foi possível acompanhar o gradual empenho das professoras ao buscarem um modo de ensino que fosse agradável aos alunos. No início da pesquisa, as aulas eram centradas no objetivo estipulado por elas e mesmo que os alunos demonstrassem outro tipo de interesse durante a realização das atividades, as professoras insistiam no planejamento preparado e não modificavam a estratégia de ensino.

A maioria das interações estabelecidas pelas professoras visava a conduzir atividades pedagógicas, não havendo espaço para a troca por meio de diálogos. Conforme elas mudavam suas posturas e passavam não só a conversar com os alunos, mas também a ensinar-lhes a fazer escolhas por intermédio dos cartôes de comunicação, era possível perceber o aumento das respostas dadas por eles.

Além da postura dos professores, avaliamos também o comportamento autônomo dos alunos no processo de comunicação. Em relação à variável referente ao uso das funções comunicativas iniciadas pelos alunos, foi possível observar que, no decorrer da pesquisa, os alunos apresentaram um aumento de tais funçôes. A Tabela 3 mostra a frequência média das interações iniciadas pelos alunos de modo autônomo com as professoras nas fases de Linha de Base e de Intervenção.

Tabela 3 - Frequência média das interações que os alunos iniciaram de modo autônomo com as professoras nas fases de Linha de Base e de Intervenção

\begin{tabular}{|l|l|l|}
\hline & Linha de Base & Intervenção \\
\hline Arthur & 6 & 15 \\
\hline Heitor & 4 & 13 \\
\hline
\end{tabular}

É possível perceber que, nas sessões de intervenção, os alunos apresentaram mais autonomia na comunicação, aumentando o número de interações iniciadas por eles. Isso é consequência de todas as mudanças apresentadas anteriormente. Como as professoras apresentaram novos cartôes e construí- 
ram junto aos alunos o significado daqueles símbolos, elas demonstraram a funcionalidade social que os cartões representavam, e os alunos tiveram mais possibilidades de solicitar objetos e açôes que fossem do seu interesse.

Nas sessões gravadas durante a Linha de Base, as professoras ofereceram poucas possibilidades para os alunos realizarem escolhas. Geralmente, elas direcionavam as atividades de modo que os alunos tivessem apenas que executá-las, sem haver espaço para que eles decidissem o que queriam fazer. Dessa maneira, eles não foram estimulados a solicitar os objetos ou ações que desejavam e, quando o faziam, não recebiam um retorno positivo. Fato este que pode ter contribuído para que eles não entendessem o significado do uso dos cartões de CAA.

Após o término da Autoscopia de Treinamento, as professoras passaram a usar os cartôes de CAA como mediadores entre aquilo que elas propunham e a escolha das crianças. Com isso, pudemos perceber o aumento da autonomia comunicativa dos alunos.

Para analisar o desempenho acadêmico dos alunos, optou-se por medir sua duração, de modo a verificar com mais precisão se houve o aumento ou a diminuição dessas respostas. Para isso, foram considerados os primeiros 21 minutos de cada vídeo, de modo que a pesquisadora pudesse observar a frequência de envolvimento dos alunos nas atividades propostas e de emissão de comportamentos desafiadores. Após identificar o número de ocorrências desses eventos, a pesquisadora fez uma breve descrição deles e cronometrou a duração de cada ocorrência.

Para obter o percentual de duração de envolvimento dos alunos com a tarefa, a pesquisadora considerou o tempo total das atividades realizadas e o tempo total em que eles se mantiveram envolvidos na tarefa.

Quadro 2 - Equação realizada para obter a percentagem de duração do envolvimento do aluno na tarefa

Tempo de envolvimento na tarefa/tempo total da tarefa X $100=$ Percentual de duração de envolvimento na tarefa.

Dessa maneira, foi possível organizar os dados com a duração dos comportamentos, de modo a perceber a evolução apresentada pelos alunos ao 
longo da pesquisa. A seguir, encontram-se os dados relacionados à percentagem da duração do envolvimento de Arthur e de Heitor com as tarefas propostas durante as fases de Linha de Base e Intervenção.

Gráficos 1 e 2 - Percentual de duração do envolvimento dos alunos na tarefa durante as fases de Linha de Base e Intervenção
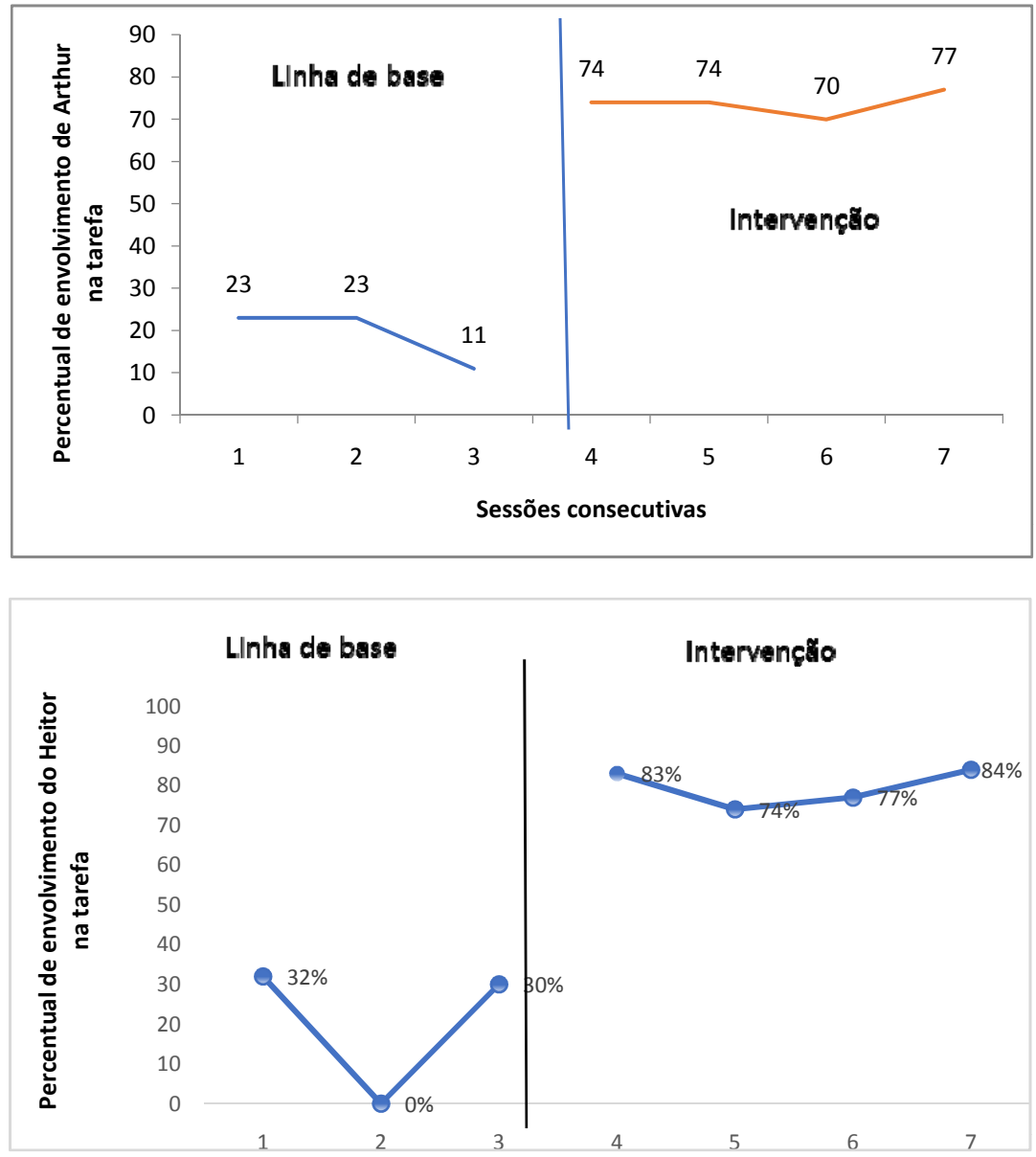

Observando todo o percurso realizado pelos alunos ao longo do ano letivo, pode-se perceber que o aumento do envolvimento nas atividades propostas pareceu ser decorrente do modo como as professoras passaram a conduzir as aulas. Dois fatores podem ter contribuído para isso: a funcionalidade empregada nas atividades, tornando-as úteis para os alunos, e a busca de 
conhecer melhor o gosto deles para, então, oferecer atividades que estivessem no centro de seus interesses.

Paralelamente ao aumento do tempo de envolvimento na tarefa dos alunos, houve a diminuição dos comportamentos desafiadores apresentados por eles. Para obter o percentual do tempo em que os alunos apresentaram esse tipo de comportamento, a pesquisadora considerou a duração total da sessão e a duração dos comportamentos desafiadores, o que resultou na seguinte equação:

Figura 2 - Equação realizada para obter a percentagem de duração dos comportamentos desafiadores dos alunos durante as atividades

\begin{tabular}{|ccc|}
\hline Tempo total de comportamento desafiador & $100=\begin{array}{c}\text { Percentual } \\
\text { de duracão } \\
\text { Tempo total da sessão }\end{array} \begin{array}{c}\text { domportamentos } \\
\text { desafiadores }\end{array}$ \\
\hline
\end{tabular}

Nos Gráficos a seguir, está apresentado o percentual de duração dos comportamentos desafiadores/provocativos dos alunos durante as tarefas na Linha de Base e na Intervenção. 
Gráficos 3 e 4 - Percentual de duração dos comportamentos desafiadores/ provocativos dos alunos durante as tarefas das fases de Linha de Base e Intervenção
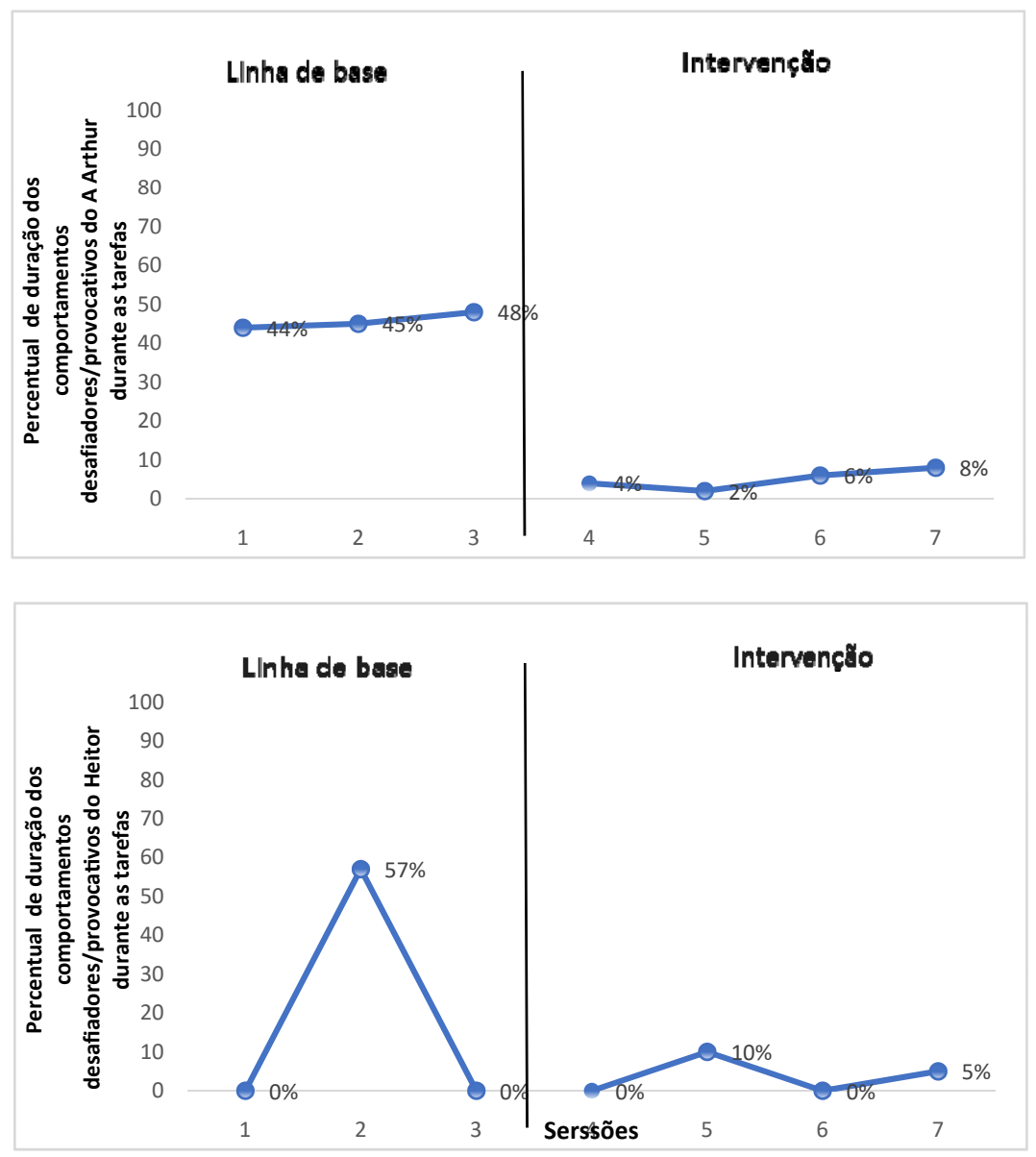

A análise desses dados permite-nos concluir que os alunos passaram a ocupar mais o tempo com a realização de atividades e, com isso, não desafiavam tanto as professoras; pelo contrário, eles começaram a estabelecer uma relação de parceria e troca. Foi justamente na fase de Intervenção que as professoras aumentaram as possibilidades de trabalho com a CAA, incentivando os alunos a usarem novos cartôes e a aumentarem o vocabulário. Dessa maneira, eles começaram a expor seus desejos por intermédio dos 
cartôes, não sendo necessário chamar a atenção por meio de comportamentos desafiadores.

No início da pesquisa, não havia a preocupação das professoras com a funcionalidade das atividades propostas. $\mathrm{O}$ maior cuidado era fazer com que seus alunos acompanhassem o conteúdo curricular referente à turma comum na qual estavam matriculados. Com isso, elas desenvolviam atividades de cunho tradicional e não ampliavam a possibilidade de trabalhar tais conteúdos, de modo a serem aproveitados na vida cotidiana das crianças.

Ao se preocuparem em oferecer atividades que apresentassem alguma funcionalidade na vida dos alunos, as educadoras passaram a planejar melhor as tarefas, demonstrando uma maior clareza daquilo que pretendiam ensinar. Ao terem em mente o conteúdo que seria ensinado, elas começaram a buscar o melhor modo de desenvolver as atividades com os alunos.

Os dados referentes à intencionalidade das professoras durante a execução das propostas pedagógicas também apresentaram mudanças, conforme podemos observar no gráfico que mostra a intencionalidade exibida por Célia e Glória na Linha de Base e na Intervenção. 
Gráficos 5 e $\mathbf{6}$ - Avaliação da intencionalidade apresentada pelas professoras durante as fases de Linha de Base e de Intervenção
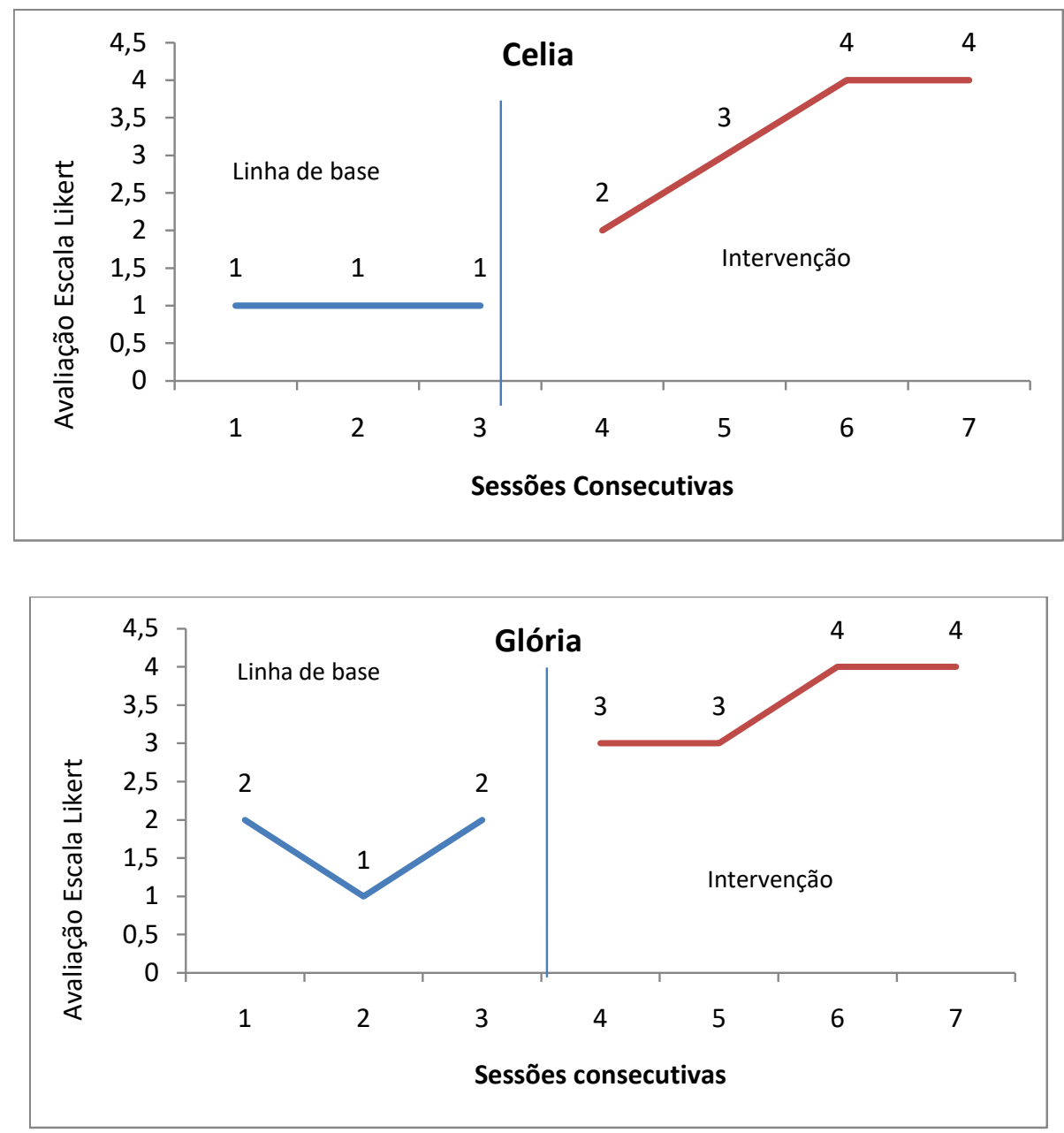

$\mathrm{O}$ aumento da intencionalidade perpassou até mesmo a reorganização do ambiente físico. A princípio, os objetos de interesse dos alunos estavam sempre ao alcance deles, não sendo necessário interagir com as professoras para conseguir aquilo que desejavam. Depois de passarem pelo processo de intervenção, as professoras começaram a deixar os objetos em locais onde os alunos não conseguissem alcançar, obrigando-os, assim, a estabelecerem 
algum tipo de interação ao solicitar aquilo que eles desejavam ${ }^{5}$. Dessa forma, elas demonstraram a intenção de se comunicar com os alunos em diferentes situaçōes, oferecendo pistas verbais e concretas (cartões de CAA) para que eles pudessem solicitar o que queriam.

Com todas essas mudanças atitudinais e físicas, os alunos passaram a se interessar mais pelas atividades propostas. $\mathrm{O}$ início da pesquisa retratou que a prática das professoras não motivava os alunos e que, por diversas vezes, eles reagiam de modo desafiador durante a realização das atividades, ou então, ainda que não apresentassem esse tipo de comportamento, eles não se interessavam por aquilo que era proposto e não conseguiam manter-se envolvidos com a atividade por muito tempo. Conforme as professoras buscaram o ponto de interesse dos alunos, foi possível perceber o aumento do envolvimento deles com o que lhes era proposto.

Ainda em relação às mudanças apresentadas pelas professoras em busca da motivação dos alunos, foi possível perceber que elas passaram a demonstrar mais afeto, usando um tom de voz menos agressivo e estabelecendo contato físico com eles por meio de beijos e abraços. Com essa postura, os alunos passaram a ficar mais motivados e, consequentemente, mantinham uma maior atenção no decorrer das atividades.

Para finalizar a avaliação do desempenho da prática pedagógica das professoras, apresentamos os dados referentes à flexibilização demonstrada por Célia e Glória durante a Linha de Base e a Intervenção.

5 Trata-se de um procedimento do Ensino Naturalístico. 
Gráficos 7 e 8 - Avaliação da flexibilização das propostas pedagógicas apresentadas pelas professoras durante as fases de Linha de Base e de Intervenção
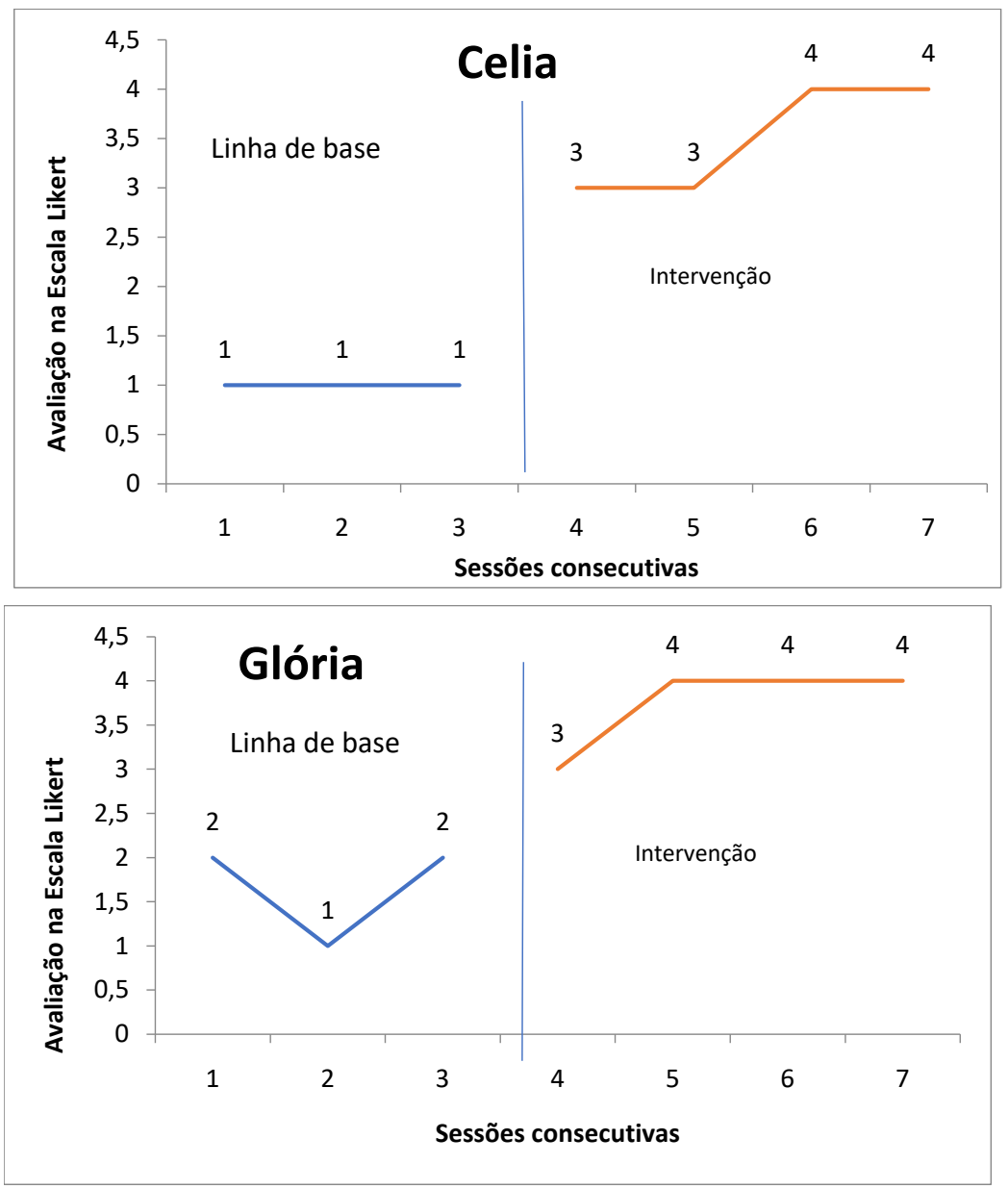

Todas as mudanças apresentadas em relação à prática pedagógica do profissional só foram possíveis porque, anteriormente a essas questões, as professoras decidiram abrir mão de um saber soberano e passaram a acreditar no saber compartilhado. Ao realizarem a autoscopia das sessões de Linha de Base e observarem as cenas que mostravam o modo enrijecido como conduziam suas propostas, as educadoras demonstraram bastante resistência à mudança e argumentaram como se tivessem certeza absoluta de que suas ações eram a melhor opção a seguir. Com o tempo, seus próprios relatos durante 
a autoscopia demonstraram uma abertura à mudança, e isso foi refletido em suas ações. Fato que resultou nos dados constantes nos gráficos anteriormente apresentados.

\section{Conclusão}

Segundo Nóvoa (1991), o desenvolvimento profissional do professor deve ocorrer mediante uma formação crítico-reflexiva, que propicie as dinâmicas de autoformação participada e que colabore para a construção da sua identidade como docente. De acordo com essa concepção de formação, a prática docente deve ir além dos procedimentos meramente didáticos para transformar-se em uma formação consciente e crítica.

$\mathrm{Na}$ tentativa de contribuir para tal, a autoscopia colocou os professores em posição de recomeço, de forma que eles assumissem a postura de rever suas práticas e percebessem a necessidade de estar em contínuo processo de aprendizagem. Aprendizagem esta que, segundo Freire (1997), requer a humildade de reconhecer que "não existe ensinar sem aprender".

Com o passar do tempo, as professoras compreenderam que, para o desenvolvimento de uma linguagem expressa por meio da CAA (e também da língua falada), não basta apenas aprender as correspondências entre os signos e os símbolos gráficos (ou palavras faladas), também é preciso entender como esses signos podem ser utilizados em diversas situaçóes da vida, dando-nos a possibilidade de expressar significados e manter comunicação com as pessoas com as quais convivemos (Von Tetzchner, 1996).

Aos poucos, foi possível perceber que as professoras passaram a considerar as intenções comunicativas das crianças, criando com elas esse caminho alternativo de constituição do sujeito. Conforme elas percebiam a necessidade de dar importância àquilo que os alunos demonstravam por meio de balbucios e gestos, foi possível identificar a diminuição dos comportamentos desafiadores apresentados. A respeito disso, Von Tetzchner et al. (2005) afirmam que, muitas vezes, algo é negado a uma criança que não consegue se comunicar de maneira oral sem que ela compreenda o motivo da negação, ou até mesmo sem que ela saiba se o seu desejo foi interpretado corretamente pelo outro. Segundo esses autores, a prática comunicativa colabora para a 
prevenção do desenvolvimento de comportamentos desafiadores, pois a falta de experiências comunicativas relevantes pode levar as crianças a reagirem emocionalmente às rejeiçôes.

Todas as mudanças ocorridas na postura das professoras, no que concerne ao modo como planejavam e executavam suas ações, podem ser atribuídas à prática da autoscopia. Em relação a isso, Sadalla (1997) preconiza que, por meio da autoscopia, os indivíduos que observam suas imagens no vídeo têm a chance de "alterar, reorganizar ou reformular suas ações, atitudes e posturas”, pois é possível, ao analisar o material gravado, observar o ambiente que o cerca e detectar as causas e efeitos de nossos comportamentos (p. 33).

Um dos grandes ganhos que se pode observar na mudança de atitude das professoras foi a importância que elas passaram a dar para a funcionalidade das atividades propostas. A respeito do currículo funcional, Suplino afirma que "é comum encontrar pessoas portadoras de retardo severo ou autismo que já alcançaram a idade adulta sem, no entanto, serem capazes de realizar tarefas mínimas relacionadas a autocuidados ou autoproteção, por exemplo" (Suplino, 2005, p. 33). Pensar na função e na contribuição que cada tarefa realizada exercerá na vida cotidiana dos alunos fez com que eles passassem a se interessar mais pelo que estava sendo proposto, pois, além de funcionais, as atividades tornaram-se prazerosas, sem o peso do conteúdo curricular que as professoras propuseram na Linha de Base.

Os resultados apresentados durante a realização desta pesquisa permite afirmar que a autoscopia é um meio eficaz para o processo de formação de professores, visto que a reflexão iniciada a partir da observação de suas atuaçôes contribui para a construção da consciência que constituirá a identidade docente. Identidade essa que se refaz a cada dia, em cada diálogo, em cada encontro, em cada experiência vivida com aquele que deve ser o principal motivo do exercício pedagógico: o aluno. 


\section{Capítulo 7 - A importância da formação continuada para ampliar os conhecimentos dos professores do Atendimento Educacional Especializado em Comunicação Alternativa e Ampliada}

Cláudia Miharu Togashi ${ }^{1}$

Thatyana Machado Silva ${ }^{2}$ Carolina Rizzotto Schirmer ${ }^{3}$

\section{Introdução}

Aprimorar a teoria e propor novas técnicas são importantes para a renovação dos conhecimentos de todo profissional. No caso dos profissionais da área da Educação, isso também se torna necessário a fim de aprimorar a

1 Doutoranda em Educação pelo Programa de Pós-Graduação em Educação da UERJ. Secretaria Municipal de Educação do Rio de Janeiro. E-mail: claudiatogashi@yahoo.com. br.

2 Mestre em Educação pelo Programa de Pós-Graduação em Educação da UERJ. Secretaria Municipal de Educação de Rio das Ostras. E-mail: thatyana.ms@gmail.com.

3 Professora adjunta da Faculdade de Educação da UERJ. E-mail: ead.carolina@gmail. com. 
prática pedagógica. Nesse sentido, a formação continuada em serviço é fundamental para que o professor se torne cada vez mais habilitado e seguro e, dessa forma, possa desenvolver a profissão docente.

Os desafios para lidar com os alunos que são público-alvo da Educação Especial são muitos no processo de inclusão escolar e vão desde a peculiaridade presente em cada indivíduo até as práticas pedagógicas necessárias para desenvolver-se juntamente com os alunos da classe regular. Daí a importância de estudar e buscar frequentemente novas práticas e saberes para conseguir atender às demandas desse alunado.

Especificamente quando falamos de indivíduos com Transtorno do Espectro do Autismo (TEA), verifica-se uma grande dificuldade para trabalhar no contexto escolar, por conta da natureza e da gravidade do transtorno (Simpson et al., 2004), em que o prejuízo na interação social acarreta deficiências na comunicação verbal e não verbal, limitação das atividades e interesses, além de padrões de estereotipias no comportamento (Zilbovicius et al., 2006).

Entre tantos outros importantes fatores que devem ser trabalhados e desenvolvidos em indivíduos com TEA, a comunicação é fundamental e necessária para favorecer seu processo de inclusão (Togashi, 2014). Portanto, o uso de recursos da Comunicação Alternativa e Ampliada (CAA) torna-se um forte aliado como instrumento para incrementar a interação entre o aluno com TEA e seus interlocutores.

O presente trabalho é um relato de experiência gerado a partir da minha participação como sujeito de uma pesquisa de mestrado de autoria de Thatyane Machado Silva, cuja proposta foi a formação continuada para professores do Atendimento Educacional Especializado (AEE) do município do Rio de Janeiro, tendo a autoscopia como um instrumento para avaliação e análise da prática pedagógica.

Para Sadalla e Laroca (2004), a autoscopia é um recurso de videogravação de uma prática, cujo objetivo é a autoavaliação por um ou mais protagonistas dessa prática, apreendendo, assim, as açōes do ator, o cenário e a trama que compõem uma situação. Como passos para a realização do procedimento de autoscopia, os referidos autores sinalizam que o material filmado "é submetido a sessões de análise a posteriori da ação, as quais se destinam à apreensão do processo reflexivo do ator (ou atores), através de suas verbalizações durante a análise das cenas videogravadas" (p. 421). Sendo assim, as 
sessões de formação continuada envolveram os procedimentos citados anteriormente, a fim de fomentar as discussões com a pesquisadora e a professora que foi sujeito da pesquisa.

\section{Objetivo}

Descrever as contribuições da autoscopia como ferramenta na formação continuada da professora de Atendimento Educacional Especializado, favorecendo o uso dos recursos da Comunicação Alternativa e Ampliada com o aluno com TEA.

\section{Método}

Participantes: a) $\mathrm{Célia}^{4}$, professora do AEE, com 30 anos de idade. Atuava no magistério há seis anos, sendo quatro desses atuando como AEE; b) Arthur ${ }^{5}$, aluno do $3 .^{\circ}$ ano do ensino fundamental, diagnosticado com TEA, sem fala articulada, apenas vocalizava alguns sons. Gritava muito em diversas situaçóes quando era contrariado, sendo agressivo com os seus interlocutores, e apresentava movimentos estereotipados quando estava ansioso e agitado.

Locais: as sessões de atuação da prática pedagógica de Célia com Arthur ocorreram na Sala de Recursos da professora Célia, em uma escola municipal da zona norte do Rio de Janeiro. As sessões de autoscopia para a formação continuada aconteceram no Instituto Helena Antipoff e no Laboratório de Tecnologia Assistiva da Universidade do Estado do Rio de Janeiro.

4 Nome fictício da autora do presente capítulo.

5 Nome fictício. 
Materiais utilizados: para registrar as sessões na Sala de Recursos, era usada a câmera digital do aparelho celular da professora de AEE. Além disso, também foram usados cartões de comunicação alternativa e diversos materiais pedagógicos adaptados para os atendimentos com o aluno Arthur e o PEI (Plano Educacional Individualizado), cujo modelo foi proposto pela SME/RJ.

Procedimentos gerais: envio do projeto ao comitê de ética e sua aprovação, no processo n. ${ }^{\circ}$ 336.622, de 11/07/2013, do COEP (UERJ) e preenchimento do Termo de Consentimento Livre e Esclarecido da professora participante e da responsável legal pelo aluno.

Procedimentos específicos: a professora Célia filmava as sessões de atendimento com o seu aluno na Sala de Recursos e enviava as filmagens para a pesquisadora analisá-las previamente. A escolha para que o registro em vídeo fosse realizado pela própria professora levou em consideração o possível estranhamento do aluno se a sessão fosse filmada por uma pessoa diferente na sala de aula. As sessões tinham em torno de trinta minutos de duração, dentre os quais a pesquisadora selecionava cenas que evidenciassem as seguintes categorias: 1) professora favorece a comunicação do aluno; 2) aluno se comunica com a professora; 3) aluno faz uso de diferentes funçóes comunicativas; 4) desempenho acadêmico do aluno; e 5) prática pedagógica do profissional. Posteriormente, os vídeos eram apresentados à professora Célia para a realização da sessão de autoscopia. Ao todo, foram praticadas sete sessões em que a professora assistia às cenas selecionadas e, logo após, era convidada a refletir e comentar sobre seus sentimentos e impressões ao ver o modo como conduzia sua prática pedagógica. Ao terminar o processo de autoavaliação da professora, a pesquisadora fazia os seus comentários e dava contribuições, possibilitando que Célia atentasse para os comportamentos e interesses de Arthur, que, até então, passavam despercebidos na correria do cotidiano escolar. 


\section{Resultados}

Por meio do procedimento de autoscopia, a professora Célia percebeu que era necessário mudar a sua prática pedagógica. A partir da percepção que teve da sua atuação, ela reconheceu a importância de utilizar mais os recursos da Comunicação Alternativa e Ampliada para que seu aluno tivesse condições de se comunicar e se expressar de modo autônomo. Isso afetou diretamente o comportamento e a relação que ela mantinha com Arthur.

A seguir, há um quadro que sinaliza alguns exemplos das mudanças pontuadas pela professora ao longo das sessóes de autoscopia:

\begin{tabular}{|l|l|l|}
\hline Situação & Sessōes iniciais & Sessões após a autoscopia \\
\hline $\begin{array}{l}\text { Organização da roti- } \\
\text { na do atendimento na } \\
\text { sala de recursos }\end{array}$ & $\begin{array}{l}\text { A professora usava cartões de CAA, } \\
\text { mas o aluno pegava e jogava no chão } \\
\text { ou tentava rasgar. }\end{array}$ & $\begin{array}{l}\text { A professora continuou fa- } \\
\text { zendo uso dos cartóes, e o } \\
\text { aluno começou a aceitá-los e } \\
\text { a entender sua função social. }\end{array}$ \\
\hline $\begin{array}{l}\text { Solicitação de algo } \\
\text { para o aluno, como } \\
\text { sentar-se à mesa para } \\
\text { a realização da ati- } \\
\text { vidade }\end{array}$ & $\begin{array}{l}\text { A professora ficava sentada à mesa, } \\
\text { chamando o aluno, sem ser atendi- } \\
\text { de costas para ele. }\end{array}$ & $\begin{array}{l}\text { A professora deslocava-se para } \\
\text { perto do aluno, abaixava-se e } \\
\text { usava o cartão de sentar para } \\
\text { se fazer entendida por ele. }\end{array}$ \\
\hline $\begin{array}{l}\text { Propostas de ativida- } \\
\text { des pedagógicas }\end{array}$ & $\begin{array}{l}\text { A professora realizava atividades } \\
\text { pouco atrativas e sem funcionalidade } \\
\text { para o aluno. }\end{array}$ & $\begin{array}{l}\text { A professora co meçou a } \\
\text { desenvolver atividades que } \\
\text { pudessem ser utilizadas no } \\
\text { cotidiano do aluno, dando } \\
\text { mais funcionalidade ao que } \\
\text { era proposto. }\end{array}$ \\
\hline $\begin{array}{l}\text { Agressividade do alu- } \\
\text { no }\end{array}$ & $\begin{array}{l}\text { O aluno era muito agressivo quando } \\
\text { contrariado. Por diversas vezes, a a } \\
\text { professora ficava com hematomas } \\
\text { nos braços. }\end{array}$ & $\begin{array}{l}\text { Com uso de cartões de co- } \\
\text { municação alternativa e ati- } \\
\text { vidades pedagógicas mais } \\
\text { interessantes para o aluno, } \\
\text { houve a diminuição dos com- } \\
\text { portamentos desafiadores } \\
\text { deste. Cartões com as frases } \\
\text { "Não pode bater" ou "Não } \\
\text { pode machucar" começaram } \\
\text { a ser usados. }\end{array}$ \\
\hline
\end{tabular}




\begin{tabular}{|l|l|l|}
\hline Situação & Sessões iniciais & Sessões após a autoscopia \\
\hline $\begin{array}{l}\text { Organização da sala } \\
\text { de recursos }\end{array}$ & $\begin{array}{l}\text { As mesas eram organizadas em dois } \\
\text { grupos, dificultando o acesso para } \\
\text { todos os cantos da sala e restringindo } \\
\text { o espaço para atividades mais livres. }\end{array}$ & $\begin{array}{l}\text { A sala foi reorganizada de } \\
\text { modo que houvesse maior } \\
\text { possibilidade de o aluno tran- } \\
\text { sitar por ela. Também foi } \\
\text { reservado um espaço para se- } \\
\text { rem feitas atividades lúdicas, } \\
\text { como uso da bola e do jogo } \\
\text { de boliche. }\end{array}$ \\
\hline $\begin{array}{l}\text { Uso dos recursos de } \\
\text { CAA }\end{array}$ & $\begin{array}{l}\text { A professora fazia uso da CAA com } \\
\text { o aluno, mas de forma instrutiva, } \\
\text { apenas para auxiliá-lo na organiza- } \\
\text { ção de rotina e oferta de atividades } \\
\text { pedagógicas dirigidas. Não havia o } \\
\text { objetivo de ampliar a comunicação } \\
\text { do aluno. }\end{array}$ & $\begin{array}{l}\text { O aluno passou a usar os } \\
\text { cartóes de CAA não somente } \\
\text { as organizar e realizar } \\
\text { para iniciar a comunicação } \\
\text { e responder às perguntas } \\
\text { feitas pela professora. Isso fez } \\
\text { com que os recursos de CAA } \\
\text { fossem usados para estabele- } \\
\text { cer uma comunicação mais } \\
\text { efetiva. }\end{array}$ \\
\hline
\end{tabular}

\section{Discussão}

A partir do quadro apresentado anteriormente, verifica-se a mudança na postura e no comportamento de ambos os participantes. Tanto a professora quanto o aluno tiveram ganhos, a partir da nova prática da professora Célia e das novas formas de comunicar e intereagir de Athur, que passou a se beneficiar do uso mais expressivo da comunicação alternativa e ampliada.

A formação continuada é um dos fatores que contribuem para a garantia do sucesso profissional e, principalmente, dos alunos no ambiente escolar. Além da formação continuada, ressalte-se ainda que esta pode estar aliada ao desejo do professor de querer desenvolver um trabalho pedagógico de qualidade, uma vez que a capacitação visa a oferecer novos conhecimentos, atualizações de conceitos e sugestóes de práticas cotidianas no contexto escolar.

Schirmer et al. (2011) defendem a importância da formação continuada como uma meta para todos os educadores, como forma de comprometimento profissional, a fim de oferecer educação de qualidade em todos os níveis de 
ensino. Para essas autoras, um professor que se atualiza e se informa constantemente, buscando formas novas na atuação pedagógica e acreditando no potencial dos seus alunos, terá maior satisfação, além de alcançar sucesso profissional.

Além disso, a autoscopia como uma ferramenta capaz de sensibilizar e auxiliar o professor em sua atuação de modo crítico e na construção da sua percepção e do seu conhecimento (Silva, 2016) foi de grande valia, constituindo um instrumento para a formação continuada do professor. Silva (2016) ressalta que essa técnica permite que "o professor consiga se observar com o distanciamento necessário para refletir sobre suas posturas e (re)formular suas práticas no modo de ensinar e planejar suas aulas" (p. 27).

A comunicação é imprescindível para o desenvolvimento de um ser humano, logo, uma pessoa que nasce ou torna-se desprovida dessa capacidade pode sofrer grandes impactos na sua qualidade de vida (Schirmer et al., 2007). Oferecer um sistema de CAA a alunos que apresentam dificuldades em se comunicar é, portanto, possibilitar novas formas de aproximação e interação social, facilitando desde as atividades desenvolvidas na escola às questôes práticas para a vida cotidiana, na relação com outras pessoas do seu círculo de convívio.

No caso de indivíduos com autismo, tais formas alternativas à fala são fundamentais à medida que possam ser um canal de comunicação em comum, diminuindo, assim, muitos distúrbios de condutas decorrentes das dificuldades comunicativas e sendo substituídos por comportamentos comunicativos claros, eficazes e mais adequados e socialmente aceitos (Walter, 2009).

\section{Conclusão}

Os estudos apresentados neste trabalho são fundamentais na medida em que contribuem para reforçar o papel da comunicação na inclusão de indivíduos com TEA no sistema comum de ensino. Além disso, oferecer recursos e meios alternativos que possam substituir ou ampliar a forma de interagir é benéfico não somente aos usuários da CAA, como também para todos os que pertencem ao mesmo meio social.

O ponto principal deste estudo, no entanto, foi perceber que é preciso voltar o olhar para nossos alunos. É preciso estar atento ao que eles querem nos 
dizer, mesmo com a falta de palavras articuladas, pois seus gestos nos revelam inúmeras possibilidades de trabalho.

Para que o professor tenha uma prática pedagógica que seja, de fato, qualitativa para o aluno, ele precisa sair de si e ir ao encontro daquilo que seja eficaz para o discente. Isso requer mudança de atitudes, de planejamento e de perspectiva. Silva (2016) afirma que a autoscopia é como uma janela, visto que "possibilita o professor a sair de si e a olhar as coisas exteriores que estão ao seu redor, de modo que ele não seja mais o único ser do universo". Nesse sentido, viver a experiência da autoscopia e ter a oportunidade de realizar um processo de reflexão profunda sobre a própria prática foi fundamental para que a professora Célia rompesse a barreira do imediatismo e flexibilizasse seu planejamento escolar.

No início da pesquisa, a professora comportava-se de maneira ansiosa e exigia, a todo tempo, que o aluno realizasse atividades que estivessem exatamente de acordo com aquilo que ela planejou. No decorrer do estudo, ela tornou-se mais flexível e se aproximou do aluno para perceber seus interesses, suas potencialidades e suas dificuldades.

Ao olhar para si própria, a docente acabou encontrando o seu aluno. Podemos, então, dizer que o comportamento e a intenção comunicativa de Arthur estão ligados ao modo como a professora planeja e executa o seu fazer pedagógico. Quanto mais o planejamento dela fosse adequado aos interesses do aluno, mais ele se mantinha envolvido com as atividades e diminuía o seu comportamento desafiador.

Com isso, ressalta-se a importância do AEE como parte fundamental no processo de inclusão escolar, dando suporte ao aluno na Sala de Recursos e na sala de aula. É preciso que o professor do AEE trabalhe em paralelo com o professor da turma comum, mesmo com todas as dificuldades e barreiras encontradas. E, em se tratando de alunos que não apresentem comunicação verbal, é imprescindível que o professor da Sala de Recursos oriente o professor da sala comum a utilizar a CAA como um meio de promover a inclusão e a autonomia desse aluno. Somente a partir do momento em que o discente conseguir expressar seus desejos, medos e angústias é que ele vai conseguir organizar seus sentimentos e diminuir seus comportamentos desafiadores/provocativos. 


\section{Capítulo 8 - Relatando a experiência com a Comunicação Alternativa e Ampliada a partir da participação em curso de formação continuada para professores de Salas de Recursos}

Gabriela Ferreira Ramiro de Souza Carolina Rizzotto Schirmer ${ }^{2}$

\section{Introdução}

Como professora de Sala de Recursos Multifuncionais (SRM) da Rede Municipal de Educação do Rio de Janeiro, e após uma experiência de seis anos, fui incentivada pela coordenadora da equipe de Educação Especial da CRE a participar, em 2013, do curso de Formação Continuada em Serviço, oferecido pela Universidade do Estado do Rio de Janeiro (UERJ) em parceria com a Oficina Vivencial (OV) do Instituto Municipal Helena Antipoff (IHA). Essa pesquisa foi aprovada pelo Co-

1 Secretaria Municipal de Educação do Rio de Janeiro. E-mail: ofvivencialiha@rio.rj.gov. br

2 Professora adjunta da Faculdade de Educação da UERJ. E-mail: ead.carolina@gmail. com 
mitê de Ética (Proc. 336.622, de 11/07/2013, do COEP/UERJ) e financiada pela FAPERJ e pelo CNPq. A formação, que ocorreu de maio de 2013 a dezembro de 2016, possibilitou-me o contato com discussões e a troca de vivências sobre questôes inquietantes a respeito do desenvolvimento dos alunos com deficiência e TEA.

As SRMs acompanham um diversificado grupo de alunos, abrangendo pessoas com deficiência, transtornos globais de desenvolvimento $(\mathrm{TGD})^{3}$ e altas habilidades/superdotação (AH/SD) (MEC, 2008). Para atuar no Atendimento Educacional Especializado (AEE), o professor precisa estar disposto a enfrentar os desafios de trabalhar com uma variedade de especificidades dentro de grupos com a mesma classificação, o que se torna possível quando o profissional adquire conhecimentos teóricos e práticos para dar conta de qualquer tipo de deficiência ou transtorno que façam parte desse público alvo (Pletsch, 2009).

Este capítulo tem por objetivo descrever a experiência que tive como participante da pesquisa e contar as mudanças ocorridas na minha prática pedagógica, bem como na postura pessoal diante das situaçôes cotidianas dos alunos com necessidades educacionais especiais e das especificidades de cada um. E isso modificou também a minha atuação como professora e a maneira como observo o desenvolvimento dos alunos que são acompanhados em SRMs.

\section{Metodologia}

Durante o curso de formação continuada, houve palestras ministradas por especialistas na área da Educação Especial, tais como Eduardo Manzini, Cátia Walter, Débora Deliberato, Leila Nunes e Carolina Schirmer, que dividiram com o grupo de professoras parte da vasta experiência que possuem nas áreas de Linguagem, Interação e Comunicação Aternativa e Ampliada (CAA), PECS-Adaptado, currículo funcional, políticas públicas, entre outros temas.

3 Atualmente, Transtornos do Espectro Autista (TEA) 
Em outro momento, durante a formação, foram utilizadas filmagens realizadas a partir do registro em vídeo das práticas pedagógicas vivenciadas pelos professores participantes do curso, bem como do cotidiano escolar de seus respectivos alunos. Essas filmagens serviram de base para o debate e para a construção de conhecimento. O estudo em grupo desse material possibilitou a criação de estratégias pontuais na busca por minimizar as barreiras do desenvolvimento dos alunos com deficiência e TEA, trazendo consequências benéficas para a vida do aluno não só na escola, como também fora do ambiente escolar. $\mathrm{O}$ ato de observar meu desempenho junto ao aluno propiciou mudanças em velhos hábitos antes imperceptíveis aos meus olhos, como, por exemplo, a aflição durante a espera da resposta do discente, quando, por precipitação, acabava por responder às minhas próprias perguntas sem dar tempo a ele. Depois que percebi essa dificuldade, passei a respeitar o tempo necessário do aluno. Por vezes, nas gravaçôes, pedia calma a ele quando, na realidade, o pedido era para mim mesma, buscando diminuir minha aflição.

No ano de 2014, ocorreu um desdobramento na pesquisa. Os vídeos da atuação da professora com seu aluno eram enviados para a pesquisadora Thatyana Machado Silva, que destacava trechos do vídeo a fim de direcionar a intencionalidade da prática do professor e estimular a autorreflexão deste ao confrontar suas ações com o objetivo proposto, bem como avaliar o desempenho de seu aluno. Essa prática é denominada de autoscopia (Sadalla e Larocca, 2004). A ação proporciona a troca de experiências a partir da observação das ações pedagógicas dos outros participantes, fomentando a criação de hipóteses e sugestôes com a intenção de melhorar as práticas cotidianas dos atendimentos.

$\mathrm{Na}$ busca por possíveis benefícios da utilização da CAA, foram selecionados casos de alunos sem fala funcional como participantes específicos da pesquisa para o estudo em formação. O caso acompanhado foi de um aluno com TEA que apresentava uma fala sem funcionalidade e não realizava trocas comunicativas. Respondia a tudo por meio da ecolalia, o que gerava dúvidas sobre se realmente desejava algo ou se era apenas uma reprodução do que ouvia. Após alguns anos acompanhando o desenvolvimento desse aluno, percebo o quanto a CAA ajudou na organização do pensamento e facilitou a expressão oral das informações 
que desejava transmitir, o que desmistificou a falsa impressão de que a utilização da CAA pudesse inibir a fala, sendo essa uma das primeiras dúvidas levantadas pela família. Vivenciar esse processo me tornou mais segura para a utilização com outras crianças.

Figura 1 - Aluno utilizando cartões de CAA no contexto da Sala de Recursos Multifuncionais

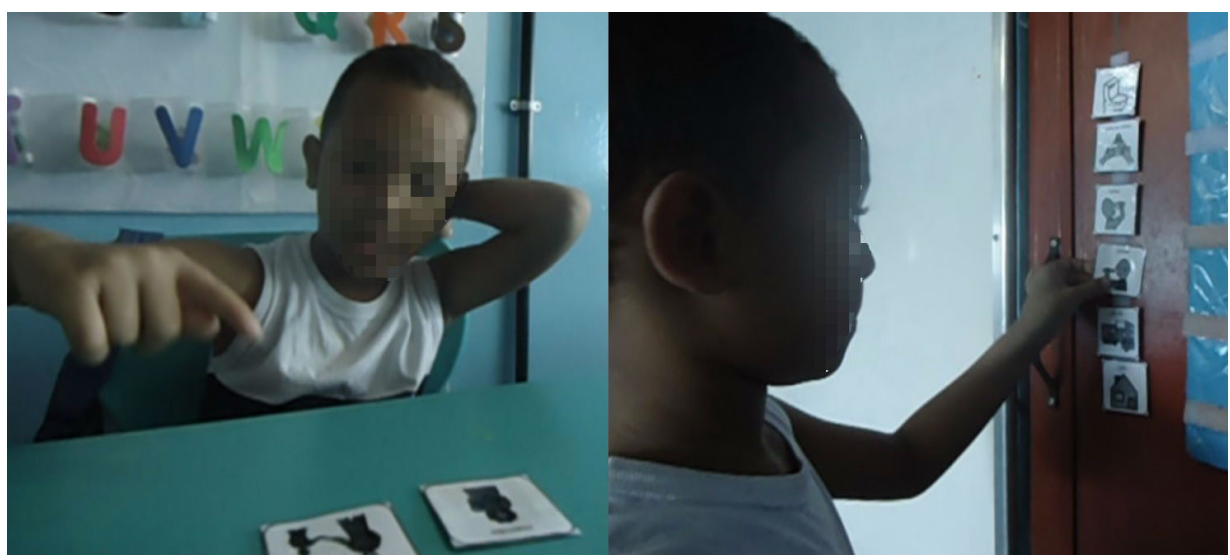

Fonte: G. R. F. Souza.

\section{Resultado}

O contato com a CAA ocorreu durante alguns anos de trabalho com Educação Especial, mas somente após a experiência do acompanhamento dos vídeos propostos pelo curso de formação superei minha insegurança ao implementar o uso da CAA, fortalecendo a sua utilização e desmistificando alguns medos, como: a incerteza de não ter todo o arsenal de vocabulário necessário para que uma criança sem fala comunique-se e a ideia de que o uso da CAA por crianças com fala, mas sem intenção comunicativa, possa inibir sua expressão oral.

$\mathrm{O}$ estudo gerou o meu empoderamento, distanciando a ideia de certo ou errado, uma vez que não há modelos prontos estabelecidas para 
todas as situações, muitas vezes novas, e somente por meio das tentativas pode-se encontrar um caminho. Para que a comunicação possa acontecer, é necessário que o professor coloque-se à disposição do aluno. Não basta usar o melhor recurso, o mais importante é permitir que o professor seja um mediador entre o aluno e esse recurso.

Com os resultados observados por mim na comparação entre duas crianças atendidas na SRM, utilizando a CAA, ficou evidente a importância da família na utilização dos cartôes de comunicação. Uma das crianças que passou a utilizar os cartões em sua casa, apropriou-se rapidamente deles, enquanto a outra criança, cuja família não colaborou para o uso efetivo da CAA, precisou ser lembrada como se estivesse sendo apresentada aos recursos pela primeira vez.

Como benefício da autoscopia para a prática pedagógica, percebo que professores que têm a oportunidade de receber a formação de acordo com os conflitos emergentes do cotidiano conseguem planejar, executar, autoavaliar-se e promover mudanças para alcançar os objetivos. Somente por meio da visualização de nossa prática podemos descobrir por que, mesmo quando temos um planejamento que parece estar perfeitamente adequado à necessidade do aluno, ainda assim não é possível dar conta das situações cotidianas. Portanto, a reflexão que os professores realizam favorece a criação de estratégias para melhorar o seu desempenho como docentes de Sala de Recursos.

\section{Conclusões}

As mudanças profissional e pessoal que o curso ofereceu são imensuráveis. Além de encorajar e proporcionar trocas riquíssimas, o trabalho de autorreflexão da autoscopia foi ótimo para o autoconhecimento. O olhar para mim mesma, o permitir-me ser avaliada e repensar as minhas próprias ações pedagógicas fizeram com que eu, professora e profissional, me conhecesse melhor. Agora, um ser humano capaz de ouvir críticas e de crescer com os erros. Lições como esperar o tempo do aluno só puderam ser observadas após as análises dos vídeos. Algumas açōes, como o pedido de compreensão por parte do discente, eram, na realidade, clara- 
mente um pedido de calma a mim mesma. A aflição da necessidade de um retorno rápido atropelava o momento do aluno. 


\section{Capítulo 9 - Comunidade on-line de professores das Salas de Recursos Multifuncionais de Referência}

Carolina Rizzotto Schirmer ${ }^{1}$

\section{Introdução}

As Tecnologias da Informação e da Comunicação (TIC) vêm se tornando, cada vez mais, importantes instrumentos de nossa cultura, e seu uso, um meio concreto de inclusão e interação no mundo (Lévy, 2000). Na educação, as TICs vêm modificando os ambientes e as formas habituais de nos relacionarmos com o ensino e a aprendizagem, inovando nas formas de interagirmos uns com os outros no acesso ao saber, bem como na produção do conhecimento (Ferreira e Silva, 2014). As possibilidades pedagógicas de uso da internet estão se tornando cada vez maiores e, a cada dia, surgem novas maneiras de usar a rede como um espaço virtual e formativo, o qual proporciona diferentes modos de ensinar, de aprender e de comunicar entre as pessoas (Miskulin et al., 2009).

Pesquisadores têm discutido a questão de que as condições atuais de trabalho dos professores dificultam, muitas vezes, a dedicação ao seu próprio

\footnotetext{
1 Professora adjunta da Faculdade de Educação da UERJ. E-mail: ead.carolina@gmail. com
} 
desenvolvimento profissional ou ao debate coletivo sobre os problemas da educação (Castells, 2004; Ferreira e Silva, 2014).

Este artigo visa a apresentar um estudo que resultou de uma ação proposta por um grupo de professores das Salas de Recursos Multifuncionais do município do Rio de Janeiro participantes da pesquisa "A formação continuada de professores das Salas de Recursos Multifuncionais do Rio de Janeiro em Tecnologia Assistiva". O produto analisado foi o chat do grupo de WhatsApp criado pelos próprios professores na tentativa de sanar uma angústia relatada por eles em vários momentos: o sentir-se só no trabalho e a necessidade de maior troca e colaboração com os colegas.

A pesquisa da qual esses professores participaram visou à implementação e à avaliação de um programa de formação continuada de professores da rede pública de ensino municipal para atuação nas Salas de Recursos Multifuncionais (SRM) de Referência. Mais especificamente, eles foram ensinados a planejar, implementar e avaliar recursos e serviços da Tecnologia Assistiva (TA) nas áreas ligadas à escola, como: Comunicação Alternativa e Ampliada (CAA), acesso ao computador e atividades e materiais pedagógicos adaptados para atender alunos de educação infantil e ensino fundamental que apresentem severos comprometimentos em sua comunicação oral, como aqueles com paralisia cerebral, autismo, deficiência intelectual e deficiência múltipla. Cabe ressaltar que a iniciativa da criação do grupo de WhatsApp partiu dos próprios professores em uma sessão de formação. Esses educadores, na etapa final da pesquisa, funcionarão como agentes multiplicadores das ações formativas da Oficina Vivencial ${ }^{2}-\mathrm{OV}$.

A Oficina Vivencial de Ajudas Técnicas para Ação Educativa é um serviço ligado ao Instituto Helena Antipoff da Secretaria Municipal de Educação de uma grande capital brasileira e destina-se aos alunos com deficiência e transtorno global do desenvolvimento, direcionando seu trabalho à busca de estratégias e recursos - TA - que facilitem sua participação desses educandos nas atividades escolares cotidianas e contribuindo para a inclusão escolar. 


\section{Desenvolvimento}

A formação continuada em serviço foi oferecida aos professores de SRM de Referência, de 2013 a 2016, na OV. Durante esse período, foram realizados 35 encontros presenciais. No decorrer desses encontros, os professores foram expostos a conteúdos teóricos sobre linguagem e comunicação, metodologias, estratégias e recursos de TA. Foram utilizadas filmagens, fotografias, entrevistas, questionários, serviços de armazenamento de arquivos em nuvens e tecnologia móvel.

Para o levantamento dos dados e posterior análise, foi realizado o download dos arquivos do chat, contendo os diálogos e o relatório das mídias compartilhados. Para esse estudo, foram analisados o conteúdo das mensagens escritas, trocadas durante o período de, aproximadamente, dois anos pelo grupo de WhatsApp. Após a leitura do material na íntegra, foram selecionados os posts que desencadearam diálogos entre os participantes. Cada postagem foi analisada e classificada entre duas categorias: 1) sociais e informativas; e 2) trabalho. Após essa primeira análise, foi realizada uma nova apreciação somente do conteúdo relativo a trabalho e uma organização dos dados em oito categorias: Feedback positivo sobre a formação; Dúvidas; Compartilhando Conquistas; Sugestôes; Material Adaptado; Comunicação Alternativa e Ampliada; Entraves e Feedback da Sala Aberta.

Entre 08/05/2013 e 23/07/2016, foram compartilhadas no chat 75.657 palavras, e consideradas como posts com conteúdo relativo a trabalho, 5.916 palavras. A seguir, a apresentação e discussão dos dados categorizados.

\section{Categoria: Feedback positivo sobre a formação}

Nesta categoria, foram postadas 1.137 palavras ao longo de dois anos. Porém, a maior parte dos comentários sobre a formação ocorrereu em dois momentos. O primeiro deu-se no início do grupo de WhatsApp (entre outubro e novembro de 2014), no qual os professores agradeceram a oportunidade de trabalho conjunto e falaram do seu crescimento profissional e pessoal. É importante ressaltar que esses professores já estavam em formação desde abril de 2013. Seguem algumas falas dos professores: 
P1: O espaço da oficina vivencial tem sido muito promissor, gosto muito dos nossos encontros e da riqueza das trocas (16/10/14 22:13:08).

P2: Durante as pesquisas que participei eu aprendi muitas coisas e não adianta guardar tudo pra mim... Que benefício isso traria????? Eu passo pra você e você passa pra outra que vai passar também e uma enorme teia se formará!!!! (16/10/14 22:16:38).

P3: Oi! Penso que seria interessante e bastante rico se pudéssemos marcar mais para o final da pesquisa um dos encontros para estas trocas. Nada com trabalharmos colaborativamente. Aprendi isso com suas pesquisas. $\mathrm{Bj}$

P4: Sua ideia dá ênfase ao que se propõem uma Sala de Referência, trocas ricas que redundam em benefício! (16/10/14 - 17/10/14 23:28:51-06:32:45).

P5: Nossa...Este nosso grupo de pesquisa estará terminando 2014 com enormes conquistas profissionais e pessoais. Lembrando o dia em que tudo começou penso no quanto crescemos, nos aprimoramos, buscamos novos horizontes e estamos começando a realização de uma nova fase... um novo ciclo que, como diz um antigo aluno chamado H. B., é só sucesso!!!!! Meninas que venha logo 2015 para que possamos continuar crescendo e conquistando coisas novas. Obrigada por terem nos oferecido mais essa grande oportunidade.[...] Bjks (11/11/14 00:24:48).

O segundo momento foi em 2016, após a sessão de formação realizada em 01/06/2016 na OV. Essa sessão foi especial para as professoras, pois uma jovem com deficiência física, usuária de CAA, ex-aluna de uma escola do município do Rio de Janeiro, foi conversar com os professores sobre a importância da CAA na sua vida. A maioria das professoras não havia tido contato com um usuário de CAA experiente, e uma pequena parte do grupo já conhecia a jovem. A seguir, a fala dos professores sobre a experiência de reencontrá-la e de conhecê-la. 
P1: Oi gente! Boa tarde! Infelizmente ontem fiquei muito pouquinho na reuniāo!!! Infelizmente, mas foi ótimo ter reencontrado a Lívia 3 !!! Acompanho ela desde os tempos de que eu era bolsista da graduação e hoje ela está muito melhor e mais resolvida, pois pode se comunicar. A C. A. pode falar muito bem, pois na época que ela era da escola, era muito triste, pois tem toda a capacidade de se expressar, como nos vimos, mas era pouco compreendida. Foi apresentada a comunicação alternativa há 9 anos, mas numa escola especial. Como ninguém antes disso conhecia tais recursos???? Por isso eu acho o nosso papel na sala de recursos fundamental para o trabalho com os alunos que precisam se comunicar! Foi uma ótima ideia trazer uma usuária da CAA para interagir conosco. Podemos também trazer mais pessoas que usam a CAA para comunicação. Que tal???

P2: C.... concordo com você plenamente!!!! Lívia era triste e deprimida e seu maior sonho era poder falar. Nunca irei esquecer o dia que entreguei o GoTalk a ela... depois de um longo e apertado abraço ela levou suas duas mãos ao pescoço numa tentativa de dizer que 'falar era a coisa que ela mais queria!' Temos, de fato, que tomarmos a consciência que nosso papel como AEE é fundamental, porém sem uma estrutura mínima favorável tudo que podemos e devemos fazer e transmitir vai pelo ralo... Não só a Lívia que se apropriou da CAA aos 22 anos, mas todos os usuários apresentam mudanças significativas em seus comportamentos e autoestima. Ontem eu saí daquela reunião de alma lavada e certa que escolhi o caminho certo e só tenho a agradecer todo o carinho, força e dedicação que recebi da Profa. L. e de todo grupo de pesquisa que, em muitas vezes, torna-se um grupo terapêutico diante das minhas necessidades. Obrigada, C. por tudo que você me ajudou e ensinou!

P3: A presença da Lívia impactou a todas nós! Foi muito bom perceber o quanto a CAA é essencial. Depois que ela foi embora conversamos um pouco sobre as Salas Abertas e surgiu a ideia de mostrar a Lívia usando a CAA para que outros professores percebam a importância de inserir esses recursos na vida de nossos alunos. Vê se ela nos autoriza a divulgar partes da filmagem.

3 Os nomes utilizados são fictícios. 
P4: Ontem eu tive o meu carro rebocado quando sai do curso..mas a alegria que senti ontem ao participar da reunião não tem preço. Parabéns por todos os envolvidos em ressignificar a história dela. Foi emocionante!

P5: Realmente é maravilhoso ver como os nossos alunos podem alçar novos voos e alcançarem objetivos maiores até do que achávamos que podiam. Acho que esse é o grande legado nos dado: poder participar das conquistas grandiosas, mesmo diante de todos os percalços, limitações, muitas vezes mais nossas e do sistema do que da deficiência. Parabéns a C. pelo belíssimo trabalho e a todas nós por escolhermos o melhor caminho, o de ver as possibilidades onde muitos só veem incapacidades.

P5: E eu que sempre chamei os poetas de artífices de palavras, hoje tenho a audácia de nos chamar de semeadores de palavras, aquelas nunca ditas com a voz 'natural', mas que ecoam de forma clara e absoluta, porque muito antes de faladas, são produzidas pelo coração. (02/06/16 12:08:47-13:54:50)

\section{Categoria: Dúvidas}

Nesta categoria, foram postadas 1.246 palavras. As dúvidas que apareceram no chat eram, em sua maioria, referentes ao trabalho desenvolvido por elas na prefeitura, mais especificamente ao Atendimento Educacional Especializado e à necessidade ou não de compartilhar informaçôes sobre o trabalho na Sala de Recursos Multifuncional (SRM), como nos diálogos abaixo:

P1: Oi, P2! boa noite! Eu queria te perguntar uma coisa e sempre acabo esquecendo... Tenho muitas fotos de atividades adaptadas que servem para DI, TGD, PC ${ }^{4}$ e acabam sendo de interesse até dos alunos das turmas regulares por ser muito colorido, com imagens, emborrachados etc. Você estaria interessada que eu postasse as fotos pra você? Eu tive quem me ensinasse e eu

4 DI - Deficiência Intelectual, TGD - Transtornos Globais do Desenvolvimento, PC Paralisia Cerebral. 
gosto muito de poder colaborar com as colegas. Mais cabeças pensando acaba sendo mais fácil... Bj!

P2: Claro! Obrigada por compartilhar comigo suas aquisições fico aguardando.

P2: O espaço da oficina vivencial tem sido muito promissor, gosto muito dos nossos encontros e da riqueza das trocas.

P1: Durante as pesquisas que participei eu aprendi muitas coisas e não adianta guardar tudo pra mim... Que benefício isso traria????? Eu passo pra você e você passa pra outra que vai passar também e uma enorme teia se formará!!!!

P3: P1 também quero ver as fotos

P3: Adoro trocar informações, ideias e sempre as utilizo em minha pessoa

P3: Prática

P1: P3 eu vou postar por aqui, mas como são muitas posso organizar num pen drive e a gente faz cópia na Oficina Vivencial. Que tal???!!!

P3: Ótimo

$(16 / 10 / 14$ 21:51:43-22:20:40)

P1: Gente! Ajudem-me! Será que alguém sabe dizer se é da competência da sala de recursos atender crianças com transtorno desafiador opositor??

P2: Não, C.! Isso é transtorno de comportamento

P3 : Oi.... Acho q sim, pois eu atendi um

P3 : No ano seguinte ele foi p classe 
P2: Não está dentro da categoria de TGD, deficiência e superdotação

P1: Pois é.. Eu estou com um caso desse! E ainda disseram que é um tipo de TGD. [...] mas não é mesmo!!!! TGD é outro transtorno

P3 : Isso TGD

P1: Só se tivesse isso associado a alguma deficiência ou

P1: TGD

P1: Mas não é o caso do meu aluno em questão

P2: La em TRo das Ostras batemos pé pra não atender. Porque teve uma época que foi uma enxurrada de Transtorno comportamental e isso foge aquilo que o MEC estipula

P5: E melhor VC ver c a C. M.

P1: Verdade! Não tenho competência para lidar com coisas que não cabem ao pedagógico

P2: Veja qual é a orientação, mas isso não está dentro de TEA

P1: Até porque nas disciplinas o garoto é ótimo

P1: Isso eu vi também... Pesquisei na literatura e não há nenhuma associação ao caso

P2: Exatamente! O trabalho precisa ser comportamental, primeiramente. Se o pedagógico vai mal, possivelmente é porque o comportamento dele não permite que ele fique em sala, que ele se concentre nas aulas etc. etc. etc.

P1: Amanhã tenho uma reunião na escola e a escola quer continuar enquadrando ele como educação especial

P1: E enquadraram como TGD 
P1: Mas eu discordo

P2: Tá errado!

P1: E não vou aceitar simplesmente porque não concordo em atender alguém que não seja público alvo da educação especial

P1: Nada contra o garoto, mas a família tem que procurar outro tipo de atendimento

P1: De ajuda

P1: Sei lá

P1: Mas não na sala de recursos e tirando vaga de quem poderia estar se beneficiando de fato

P2: Exatamente! As salas de recursos não são consultórios terapêuticos

$(18 / 11 / 15$ 15:10:40-15:20:42)

Também apareceram dúvidas sobre tecnologia, como nas falas seguir:

P1: Please. Alguém sabe mexer com variáveis do Boardmaker? (29/10/14 17:17:06)

P2: Se vocês souberem de um jogo legal que possa ser feito download me indiquem, pois, não tenho internet. Tenho que baixar em casa, por em pendrive e passar para o computador. Aff[...]

$(17 / 06 / 1611: 29: 58)$ 


\section{Categoria: Compartilhando Conquistas}

Nesta categoria, foram postadas apenas 49 palavras, mas as conquistas compartilhadas com os colegas referiam-se à busca por formação profissional, seja em cursos mais técnicos, como a P1, ou científicos, como a P2. Seguem os diálogos:

P1: Eu e V. conquistando mais um pouquinho de conhecimento pra fazer com que inclusão aconteça! Recebemos hoje nosso certificado de conclusão do módulo inicial de Braille!!! (26/09/14 20:57:14)

P2: Meu trabalho foi selecionado pra mostra cientifica. Tô besta bem. Rs $(14 / 05 / 15$ 18:38:17)

\section{Categoria: Sugestões}

Nessa categoria, foram postadas 686 palavras. As sugestões começaram com a proposta de criar uma conta em um serviço que permite o armazenamento de arquivos em nuvem, além de discussões sobre qual o serviço a ser escolhido. Como a seguir:

P1: Poderíamos montar alguma coisa onde todas nós postássemos o que temos, ou até mesmo as ideias para compartilharmos...

P2: Ou um momento de mostrar as ideias

P1: Aí poderíamos pensar neste momento mais para o formal do curso. Seriam as produçôes a partir das orientaçôes e consultorias da pesquisa. O que acha? 
P2: Acho ótimo... é sempre muito importante trocar ideias e partilhar experiências q deram certo...

P1: No próximo encontro a gente sugere isso para o grupo. Certo?

P1: Ficará ótimo!

$(16 / 10 / 14$ 22:22:40-22:29:00)

P1: Onde é este acervo?

P1: Podíamos criar um dropbox

P1: Pra postar algumas atividades

P1: Tenho algumas também pra compartilhar

P2: Que ótimo... Ficaremos com um mega arquivo

P3: Neste arquivo também podemos incluir as pranchas de Boardmaker

P1: É! O dropbox pode colocar varias pastas

P1: Vou criar um hoje à noite se der tempo

P1: Organizo as pastas

P1: E passo a senha e o login pra vocês

P2: Claro!!!! Até porque, V., temos as pranchas dos alunos e as temáticas para apoio das aulas.

P2: Tem ainda as pranchas que são as bases dos vocalizadores. As postarei também. (17/10/14 11:32:05-12:41:34) 
Foram postadas 434 palavras sobre sites, aplicativos e softwares relacionados à Educação, à Tecnologia Assistiva e à CAA.

P2: Arasaac? Eu tenho os pictogramas do Arasaac

P2: A biblioteca de imagens

P1: Acho que tem aplicativos também pra montar pranchas

P1: O site da Miryam Pelosi tem várias dicas

(29/10/14 17:21:54-17:30:04).

P1: Vocês conhecem o jogo Hidden Alphabet? Dá para jogar com o roller mouse. É para encontrar as letras do alfabeto em várias cenas, através da lupa. Muito legal. Joga-se online (17/06/16 10:57:24).

\section{Categoria: Material Adaptado}

Nessa categoria, foram postadas 555 palavras ao longo de dois anos. As professoras sugeriam com frequência materiais e atividades pedagógicas adaptadas ou especialmente desenvolvidas. Em geral, as falas, como no exemplo a seguir, eram para explicar os arquivos de imagens postados na sequência.

P1: Bom horário de verão, meninas!!!! Na falta de sono que tal postar mais algumas fotos. São alguns joguinhos adaptados também com o Boardmaker, livrinhos com personagens e objetos feitos com cartões soltos para que os alunos colem e atividades de leitura e escrita. (19/10/14 02:01:03)

No caso dessa professora, foram postadas 86 imagens.

P1: Meninas, vou tentar postar algumas fotos de uma história adaptada e questôes de múltiplas escolhas para compreensão leitora. Eu a utilizo com todos os meus alunos da SR e algumas colegas da escola levam para suas salas. Eles adoram. Não sei o que está acontecendo com a máquina. Algumas estão de cabe- 
ça pra baixo. Eu tenho tudo em pen drive e posso levar no próximo encontro. $(18 / 10 / 14$ 22:02:24)

No caso dessa professora, foram postadas nove imagens.

P1: Vou enviar os arquivos de imagem que criei para quem quiser confeccionar o jogo.

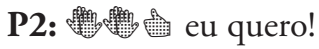

P1: Regras: Dividir as cartas entre os jogadores.

P1: As cartas metal, vidro, papel e plástico, devem ser colocadas em um saquinho, para que a cada jogada, o participante da vez, tire no saquinho qual a embalagem q deve reciclar. Se ele não tiver, passa a vez, se tiver faz o depósito no pote. $\mathrm{O}$ primeiro a terminar suas cartas é o vencedor.

$(10 / 05 / 16$ 11:35:37-11:38:33)

Mas também ocorreram momentos em que as professoras relataram a sua percepção em relação aos alunos com necessidades educativas especiais ante as propostas diferenciadas, como na fala a seguir:

P1: Tenho um aluno TGD que cada dia chega de um determinado jeito. É, extremamente, 'paparicado' pelos pais e irmãos. É temporão com diferença de 19 anos. São 3 filhos. O mais velho, hoje com 24. Meu planejamento, geralmente, tem que ser adaptado aos interesses, mas sem perder o foco do letramento. Esta atividade a seguir surgiu a partir de uma teimosia. Ele encontrava-se na janela olhando a chuva que caia na árvore. Diante sua resistência resolvi transformar aquele interesse em história. Sua participação foi efetiva e muito engraçada. (18/10/14 22:02:25) 


\section{Categoria: Comunicação Alternativa e Ampliada (CAA)}

Nessa categoria, foram postadas 1.148 palavras ao longo de dois anos. As professoras falaram sobre: seus alunos, o desenvolvimento de recursos de CAA de baixa, média e alta tecnologias e também expressaram seus sentimentos e percepções a respeito do trabalho com CAA.

Relatos sobre os alunos aconteceram em 388 palavras postadas, como na fala da professora, que relata a empolgação com a chegada do aluno que precisava de CAA, a seguir:

P1: Bom dia, gente!!!! Tô tão feliz!!!! Finalmente recebi um aluno que precise de CAA!!!! Peguei um aluno com TEA!!!! Tô feliz!!! Já vou começar a organizar a rotina dele, queria fazer linha de base (três dias de sessões) mas tô empolgada que queria começar já com a intervenção logo hoje...hehehe (10/03/15 07:58:12)

A mesma professora contando como está o aluno após o início do trabalho:

P1: Ai, gente...apanhei do autista

P1: :(2):웅ㅇㅇ

P1: Ele veio acompanhado de síndrome de príncipe

P1: Jogou os cartóes do PECs longe. Big desafio e eu to adorando isso

P2: Esses é q precisam mais do nosso amor e carinho!!!

P1: É! Mas dando limites né...rsrs. Eu tô adorando o desafio

P1: Por mais dolorida fisicamente que eu esteja, não fico com rancor dele... mas brigo firme e continuo

(10/03/15 16:47:40-17:08:50) 
P1: Hoje deu certo!!! Fiquei sozinha com Guilherme na sala, a sessão durou 40 minutos e ele começou a fazer uma atividade, mas no meio dela, a mãe chegou e desconcentrou o menino todo. Ai ela saiu, mas depois disso foi difícil voltar pra atividade, ele ficou só nos brinquedos. Depois ele pediu pra sair e descemos um ao lado do outro! Ele não gosta de dar as mãos, ai eu falei pra ele por a mão no meu ombro para descer as escadas e ele fez. Ai ele foi na quadra, e a mãe teve que pegar ele pra sair da quadra, senão eu ia apanhar de novo. Mas hoje não apanhei e ele já atende minhas solicitações!!! Aceitou a rotina e os cartões de CAA!

\section{P2 :}

P1: Chega de apanhar..hehehe

P2: Também levei um tapa de um menino autista na segunda... Está totalmente sem rotina e precisamos retomar o ritmo

\section{P1: Eita}

P1: Eu adoro esses desafios, mas dói muito né?! Rsrs

$(12 / 03 / 15$ 16:36:12-16:48:34)

Relato da professora um ano depois - evolução do aluno:

P2: O Guilherme iniciou os atendimentos na sala de recursos no início do ano passado em março.

P2: Era muito agressivo, sem comunicação oral

P2: A única forma de comunicação é a agressão física

P2: Muitas estereotipias, muita resistência a mudanças, muito teimoso. E partia pra cima mesmo, me deixando cheia de hematomas constantemente. Não aceitava os cartões de CAA no início. Rasgava e jogava longe. Não 
produzia nenhuma intenção comunicativa comigo, nem nas brincadeiras. Só ficava rodando seus bonequinhos. Quando contrariado, partia pra cima.

P3:

P1: Obrigada... qual ano ele estava no ano passado?

P1: Ainda usa CAA neste ano?

P1: Ainda está na sua sala de recursos?

P2: Ele era do terceiro ano

P2: Claro que usa comunicação alternativa

P2: Rsrs

P2: Ele não fala! Precisa usar comunicação alternativa

P2: Sim, ainda atendo ele

P1: Obrigada C.

$(12 / 07 / 16$ 19:19:13-22:58:30)

$\mathrm{Na}$ postagem a seguir, podemos perceber a prática da CAA no cotidiano do atendimento educacional especializado.

P1: Queria contar pra vocês que é uma pena não ter câmera na nossa sala, porque ontem tive uma experiência muito espontânea e bacana também enquanto resposta comunicativa do meu aluno Marcos. Um dos que faço uso dessa ferramenta, estávamos conversando e ele me mostrando a fruta da merenda que foi melancia. Daí eu precisei levantar para atender a coordenadora pedagógica na porta e ele ficou com o tablet. Lá tem um símbolo do pai que 'linka' com uma ação relacionada ao mesmo, daí quando voltei ele tinha 
achado essa prancha e me contou que o pai tinha batido nele... (07/06/16 19:07:40)

Novamente, a expressão de sentimentos com o início do trabalho com CAA e a possibilidade de trocas com o professor de sala de aula:

P1: Eu tenho um autista de 3 aninhos. Comecei o uso da CAA e fiquei emocionada ele respondeu no $1^{\circ}$ encontro na SR. (12/03/15 18:47:26)

P1: Houve uma mudança na minha escola e conversei com a nova professora da classe sobre um aluno não oralizado. Ela aceitou utilizar com ele a prancha de CAA. Estou muito feliz pois já havia tentado anteriormente com outras professoras e não tinha conseguido um sim. O encontro com a Lívia me fez muito bem e me motivou a tentar mais uma vez. (02/06/16 16:12:46)

A aluna Lívia, a que a professora se refere, foi a jovem usuária de CAA que participou de uma das sessões de formação em 01/06/2016.

Quanto aos recursos de CAA, geralmente, as falas acompanhavam imagens, como neste caso a seguir:

P1: Acabei de fazer

P1: Pro meu aluno com TEA

P1: Cartóes de CAA para a sala de aula, vou começar a implementar hoje (17/03/16 11:58:23-11:58:58)

Também encontramos falas sobre aplicativos e softwares de CAA.

P1: http://www.letmetalk.info/pt.html 
P1: Pessoal, esses são os links para baixar os aplicativos de CAA gratuitos, é só clicar no ícone do play store que já abre a tela para instalação, no caso de quem tem tablet que utiliza o Android

P1: http://acesstecnologia.blogs.sapo.pt/13377.html

P1: O Hermes é só clicar onde está escrito Google play

P1: http://pictovox.com.br

$(04 / 05 / 16$ 11:58:40-12:10:24)

P1: Eba finalmente minha primeira prancha TICO nasceu. Ela fala.... tô mega empolgada! (27/05/15 22:37:16)

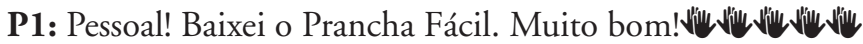

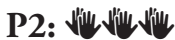

P1: Software livre e de fácil manuseio. Parabéns José Antônio e Júlio Tadeu. UFRJ. Nossos alunos agradecem(:) (-)

$(28 / 06 / 15$ 23:03:17-23:09:07)

\section{Categoria: Entraves}

Foram postadas 431 palavras sobre os entraves enfrentados pelos professores e alunos no cotidiano escolar. Alguns relataram que não conseguiam o apoio da escola para o desenvolvimento do trabalho, como a seguir:

P1: Muitos dirão: então você não acredita na escola que trabalha e no que realiza em prol do desenvolvimento dos alunos?! Mas meu papel aqui é esse provocar a reflexão e instigar se a escola que temos está preparada pra isso, ou se mais uma vez querem fazer cumprir a lei entregando na mão apenas dos professores a responsabilidade de estar com esses seres que precisam de muito mais!! (08/10/14 19:38:20) 
Outros citaram que a baixa frequência dos alunos no AEE e o pouco compromisso de algumas famílias atrapalham o processo:

P1: Ai, gente... É muito decepcionante ver o quanto o aluno deixa de evoluir depois que falta a tantos atendimentos. Tenho uma aluna que estava indo bem no processo de alfabetização, mas faltou o ultimo bimestre todinho. Hoje não fez nada do que aprendeu na prova adaptada da prefeitura.

P2: Passei por exatamente isso ontem na escola. Meu aluno não conseguiu fazer quase nada da prova de escrita... :

P3: Realmente uma grande pena... Naturalmente essas idas e vindas já ocorrem com eles, sem o atendimento então...

P1: E como tenho mães descompromissadas....infelizmente ...os alunos precisam de apoio dos pais. Alunos especiais, mais ainda. (:)

$(13 / 11 / 14$ 11:06:39-11:34:12)

Alguns professores relataram ainda a falta de estagiários/mediadores na escola:

P1: Não dá pra silenciar, precisamos pensar como agir, na Z CRE somente 120 estagiários foram contratados $:$

P2: Hoje tivemos reunião, na W CRE só 100 estagiários...cobranças e mais cobranças... Muito triste...

P1: :0 é lamentável

P2: Não devo falar certas coisas...aqui não seria o fórum adequado...

P3: Gente vocês estão reclamando de boca cheia. Na Y CRE só 20 estagiários. $\mathrm{Na}$ escola em que estou lotada há 1 por turno. 
$(04 / 03 / 15$ 16:20:29-19:42:07)

Categoria: Feedback "Sala Aberta" (SA)

Nesta categoria, foram compartilhadas 581 palavras sobre a dinâmica da "Sala Aberta". A meta maior da nossa pesquisa e formação era que esses professores de SRM pudessem ser multiplicadores do trabalho realizado na Oficina Vivencial de Ajudas Técnicas, tornando-se, assim, referência em suas regiôes de atuação. "Salas Abertas" foi o nome escolhido pelos professores participantes da pesquisa para a formação que eles ofereceram em 2015 e 2016 para os colegas professores de AEE das suas regiões. As falas a seguir retratam as percepções deles sobre essa dinâmica. As postagens, em geral, eram antecedidas ou precedidas por imagens do evento.

A professora postou quatro imagens da SA.

P1: Legal!!!!

P1: E como foi?

P1: A minha foi boa, mas estava vazia.... :-

P2: Boa tarde meninas! A nossa também foi boa e também foram poucas professoras, pois muitas estão envolvidas com outros cursos. (-)

P3: A da Z CRE foi muito boa também, mas poucas professoras (11/09/15 11:23:12-12:31:46)

Em 2015, ocorreram duas sessōes de SA em três coordenadorias e uma sessão em outra coordenadoria. Algumas professoras comentaram que nessas sessões de SA de 2015 o número de professores participantes foi abaixo do esperado. Constatou-se que isso estava ocorrendo por problemas internos de comunicação. Essa questão foi resolvida a partir de uma reunião com todos os diretores de escola das SRMs participantes, coordenadores pedagógicos e equipes ligadas ao IHA e às coordenadoras da pesquisa. Nesse encontro foi apresentado o projeto de pesquisa e os resultados preliminares e discutida 
a importância da participação de todos no trabalho. Nas SAs de 2016, o número de participantes aumentou, e as professoras de SRM de Referência sentiram-se mais apoiadas.

P1: [...] Muitos professores participaram, muita troca, um bom encontro!

P2: Saber que iniciamos um trabalho que produz: esperança, ânimo, reflexão e mudança na prática; nos faz perceber que estamos levando a sério a responsabilidade da INCLUSÃO. Parabéns para todas no grupo

P1: No momento só tenho essas fotos. Depois, envio outras do encontro acontecendo . (13/07/16 20:40:03-20:43:24)

Essa professora postou duas imagens da SA.

P1: Dia todo especial aqui na SRM! Nosso $2^{\circ}$ Encontro de Sala de Recursos Aberta, que faz parte do Projeto do IHA de SRM de Referência. Um grande orgulho e alegria poder multiplicar conhecimento. Hoje foi dia de aprender a fazer prancha de comunicação dinâmica no Pictorłme. Adorei o resultado dessa experiência!! As professoras de Atendimento Educacional Especializado ficaram muito satisfeitas e eu mais ainda!!! Porque cada passo que caminhamos em direção ao saber é uma porta que se abre para que o aluno incluído possa ser atendido nas suas especificidades!! Sou muito grata em ser um instrumento para repartir o que tenho aprendido com pessoas muito especiais. Meu agradecimento a AEE L. por ter ajudado a filmar esse processo de construção!! (09/12/15 16:52:03)

O chat também foi utilizado na organização das SAs, já que eram poucos os momentos que o grande grupo de professores em formação tinha para se encontrar.

P1: Oi pessoal, bom dia! Eu estava em dúvidas sobre o que trabalhar na próxima Sala Aberta, pois não sabia a demanda das professoras da minha equipe. Então eu perguntei no grupo de prof. da Z CRE. E elas estão sentindo falta de algo prático. Então eu resolvi fazer um workshop mais prático sobre como uti- 
lizar os recursos de comunicação alternativa com os alunos e também como ampliar para as adaptações pedagógicas com eles. Acho que vai ser interessante. $(24 / 06 / 16$ 10:43:48)

P1: Eu estarei junto com as professoras da classe especial realizando uma roda de conversa com os professores. Depois uma palestra com os responsáveis onde vamos apresentar trabalhos dos alunos incluídos e de alunos da turma regular mostrando que todos aprendem. E vamos finalizar com um curta para os alunos mostrando que todos somos diferentes. (22/07/16 21:27:05)

Nas falas, os professores também expressaram seus sentimentos em relação à experiência da SA: "privilegiada", "estou muito feliz", "momento maravilhoso", "sinto-me honrada e feliz", "realizada", "orgulhosa”.

\section{Discussão e Conclusão}

Com relação à participação das professoras no grupo, o conteúdo e a frequência das postagens analisadas sugerem que elas estavam bastante comprometidas com o projeto e com suas funções como professoras de AEE. Verificou-se que elas utilizaram o chat para trocar experiências (sobre o espaço educacional, principalmente na SRM) e conhecimentos (nas áreas da Educação Especial, CAA e Material Adaptado). Falaram também dos sentimentos e barreiras enfrentadas no dia a dia da escola, auxiliaram colegas e sugeriram soluçôes para os problemas enfrentados por elas, seus colegas, gestores, famílias e, principalmente, alunos. Essa atuação das professoras no grupo nos leva a pensar no conceito de Comunidade de Prática, concebido por Wenger (1998) como um grupo de indivíduos com distintos conhecimentos, habilidades e experiências, que participam de modo ativo em processos de colaboração, compartilhando conhecimentos, interesses, recursos, perspectivas, atividades e, sobretudo, práticas, para a produção de conhecimento tanto pessoal quanto coletivo. O conceito de comunidade de prática implica uma perspectiva da aprendizagem como atuação social, e não individual. 
Apesar de não terem sido analisadas de maneira mais aprofundada, as demais 69.741 palavras tratavam de temas relativos à vida social e outras informações ligadas ao dia a dia, como política, cultura, lazer e outros. Vavoula (2005) destaca que a aprendizagem não deve estar desconectada das atividades cotidianas, mas ligada aos processos mais comuns do dia a dia, como conversar, ler, fazer compras, enfim, entretenimento de modo geral.

Ainda que tenhamos identificado alguns participantes como mais ativos nas postagens de imagens e também nos comentários, as professoras, de um modo geral, atuavam bastante no grupo de WhatsApp. Quando não escreviam, utilizavam emojis (pictogramas ou ideogramas - imagens que transmitem a ideia de uma palavra ou frase completa) para comentar as postagens das colegas. Esse recurso foi o mais utilizado por todos. De um modo geral, assim como no estudo desenvolvido por Oliveira et al. (2014), os professores tiveram uma receptividade positiva em relação ao uso da aprendizagem móvel.

Cabe ressaltar que a ideia da criação do grupo de WhatsApp partiu das próprias professoras, que, sentindo necessidade de estarem mais próximas, escolheram essa ferramenta tecnológica a fim de solucionar essa questão. Segundo Castells (2004), existem vários fatores, desde os laborais, familiares, urbanísticos e políticos, que favorecem a instalação, na nossa sociedade, de um modelo de sociabilidade caracterizado pelo individualismo. Porém, as tecnologias digitais têm contribuído muito para que, nesse ambiente de trabalho, surjam novas formas de sociabilidade (Silva, 2008).

Tratando especificamente do uso do WhatsApp em educação, pesquisas descrevem a preferência de alunos por esse aplicativo como Ambiente Virtual de Aprendizagem (Bere, 2012), falam o quanto ele pode ajudar o estudante no acesso e na apropriação de recursos educacionais gerados de maneira coletiva (Rambe e Chipunza, 2013) e do seu uso como plataforma para desenvolvimento de trabalhos de pesquisa colaborativa (Ngaleka, 2013).

Os dados sugerem que o grupo estimulou a comunicação e a colaboração entre os participantes. Percebeu-se uma maior proximidade nas relaçôes, mesmo que essa proximidade se tenha dado vitualmente e não no contexto físico (geográfico). Segundo Ferreira e Silva (2014), com o advento das TICs, como a internet, houve uma multiplicidade de interaçōes entre pessoas. Para os autores, uma comunidade de prática pode ser chamada de comunidade on-line quando os participantes, alinhados em torno de um interesse comum, 
comunicam-se, interagem e constroem conhecimento, de forma síncrona ou assíncrona, utilizando as tecnologias digitais de comunicação, nomeadamente as interfaces de comunicação da internet. Para eles, nas comunidades on-line de aprendizagem, cada ator educativo pode contribuir e é convidado a fazê-lo, para a potencialização do trabalho do outro e do seu próprio. Segundo Wenger (1999), o desenvolvimento de uma prática exige a formação de comunidades nas quais seus membros devem se sentir engajados, bem como se reconhecerem como participantes competentes.

Sendo assim, os dados sugerem que o grupo de WhatsApp estudado constitui-se em uma comunidade on-line. Nela, os professores compartilharam saberes, desenvolveram a criatividade e a capacidade de resolver problemas não só do cotidiano e da tecnologia assistiva necessária à sua prática, como também diante das novas interfaces hipertextuais e interativas disponibilizadas pelas tecnologias móveis (Lucena, 2016).

Segundo Lucena (2016), essas práticas apontam para novas formas de interação com o conhecimento, oferecendo outras possibilidades de produção de saberes que ultrapassam a perspectiva convencional de sala de aula, da SRM e da universidade e que podem contribuir muito para a formação continuada de professores em serviço. Com esse estudo, percebemos que a formação continuada de professores parece ser mais um espaço para construir e experimentar processos de aprendizagem, utilizando as potencialidades das redes interativas para a realização de produções colaborativas e compartilhadas. 


\title{
Capítulo 10 - Material pedagógico adaptado ou especialmente elaborado e os recursos de Comunicação Alternativa e Ampliada postados no WhatsApp
}

\author{
Carolina Rizzotto Schirmer ${ }^{l}$ \\ Luciana Meira Ferreira Pinto ${ }^{2}$ \\ Ana Caroline Rached ${ }^{3}$
}

\section{Introdução}

Uma das grandes dificuldades para o ensino do aluno com deficiência e Transtorno do Espectro Autista (TEA) que não possui fala e/ou escrita funcional refere-se à utilização de recursos pedagógicos e de comunicação. Segundo Manzini (2009), vários pesquisadores têm estudado a viabilidade e as adaptaçôes para a utilização de jogos, brinquedos, brincadeiras e recursos para o ensinamento desse aluno, e a formação nessa área tem se tornado uma necessidade para o professor.

Alguns estudos têm demonstrado que a Tecnologia Assistiva, mais especificamente nas modalidades da Comunicação Alternativa e Ampliada (Nunes, 2007, 2009a), da adequação do material pedagógico e escolar

1 Professora Adjunta da Faculdade de Educação da UERJ. E-mail: ead.carolina@gmail. com.

2 Graduanda em Pedagogia da UERJ. E-mail: lucianapintop77@gmail.com.

3 Graduanda em Pedagogia da UERJ. E-mail: carol_r_ached@hotmail.com. 
(Bersch, 2007; Verussa e Manzini, 2009) e dos recursos de acesso ao computador (Cook e Hunsey, 1995; King, 1999; Lauand, 2005; Pelosi, 2008, Lourenço, 2012), constitui-se como elemento essencial no processo de inclusão (Pelosi, 2008; Bersch, 2009; Schirmer et al., 2009). E essas modalidades de TA são citadas nas recomendações da Procuradoria Federal dos Direitos do Cidadão (2004) sobre o acesso de alunos com deficiência às escolas e às classes comuns da rede regular (Zuttin e Manzini, 2009).

Outro aspecto importante é a forma como esses recursos serão utilizados. A escolha da TA deverá ser influenciada pelas características do usuário, bem como pelo ambiente físico e social em que se situa, e não dependerá unicamente dos recursos tecnológicos como se pensava anteriormente (Higginbotham et al., 2007). Por isso, devemos considerar que, para que o uso dos recursos seja funcional, os usuários devem ser encarados como protagonistas principais, pois são eles que têm a última palavra na escolha desses recursos e estratégias e, portanto, precisam participar dessa equipe, assim como seus cuidadores (Yeager et al., 2006; Blackstone et al., 2007).

Quando falamos de TA na escola, o recurso é o equipamento utilizado pelo aluno, que permite que ele realize tarefas escolares (como escrever, recortar, desenhar, conversar etc.), e o serviço é a ação de avaliar, indicar, treinar e acompanhar o uso desse recurso. Este pode ser prestado por vários profissionais, pois os serviços de TA têm um caráter interdisciplinar. Terapeutas ocupacionais, fonoaudiólogos, educadores, fisioterapeutas e psicólogos poderão contribuir, junto a engenheiros, arquitetos, designers e outros profissionais, no trabalho de identificação e ensino da tecnologia mais indicada (Pelosi, 2008). Porém, quando pensamos no espaço da escola, mais especificamente na Sala de Recursos Multifuncionais (SRM), o serviço será prestado pelo professor de Atendimento Educacional Especializado.

Estudos têm evidenciado que o professor, quando recebe o apoio de uma equipe interdisciplinar, na formação continuada, consegue ter mais sucesso em sua atuação e, consequentemente, apresentar melhor desempenho junto ao seu aluno com deficiência e TEA (Gomes, 2006; Cortelazzo et al., 2007; Pelosi, 2008; Schirmer et al., 2008; Nunes et al., 2009; Schirmer et al., 2009; Lourenço, 2010).

A literatura da área de CAA tem procurado alertar a respeito da importância de o aluno usuário desse sistema aprender a ler e a escrever, para que possa não só ampliar suas modalidades expressivas, como também ter acesso 
à língua escrita (Deliberato, 2009). Estudos apontam que o desenvolvimento de programas mais adequados à diversidade das necessidades dos alunos com pouca ou nenhuma fala funcional poderia garantir o aprendizado da leitura e da escrita, bem como outras áreas, e, assim, propiciar mais independência e favorecer a qualidade de vida dos usuários de CAA (Light e McNaughton, 1993; Hetzroni, 2004; Strum et al., 2005; Light e Drager, 2007). Dessa forma, destacamos a importância de o professor utilizar recursos como os softwares de CAA (Escrevendo com Símbolos, Comunicar com Símbolos e Boardmaker with Speaking Dynamically Pro) e os sistemas de símbolos gráficos, além de outros recursos, para adaptar ou elaborar o material didático, paradidático e lúdico.

O objetivo deste artigo é apresentar ao leitor a ampla gama de recursos de TA que os professores participantes dessa pesquisa produziram e utilizaram ao longo da sua formação. Espera-se, portanto, fornecer subsídios teóricos que fortaleçam a importância da TA para as pessoas com deficiência e TEA, bem como para aqueles que atendem esses sujeitos no âmbito educacional, discutindo a questão da formação profissional na área.

\section{Desenvolvimento}

Durante a formação continuada em serviço, oferecida aos professores de SRM de Referência, de 08/05/2013 a 23/07/2016, na Oficina Vivencial, foram realizados 35 encontros presenciais. Durante esses encontros, os professores foram expostos a conceitos teóricos sobre linguagem, comunicação, metodologias, estratégias e recursos de TA.

Em 03 de setembro de 2014, durante a sessão de formação, surgiu a ideia da criação de um grupo de WhatsApp em razão da necessidade de maior troca e colaboração entre os educadores, tendo em vista que esses encontros presenciais ocorriam, em média, uma vez por mês durante o ano letivo, o que era considerado pouco para o grupo. Nesse mesmo dia, o grupo foi criado e tem proporcionado uma maior aproximação e colaboração entre os professores.

Para o levantamento dos dados e posterior análise, foi realizado o download dos arquivos do chat, contendo os diálogos e o relatório das mídias 
compartilhados. Para esse estudo, foram analisadas as mídias (vídeos, som e imagens) trocadas durante o período de aproximadamente dois anos do grupo de WhatsApp. Após a leitura do material na íntegra, cada postagem foi analisada e classificada dentro de duas categorias: 1) sociais e informativas; e 2) trabalho. Deteremo-nos apenas no material relativo à categoria trabalho.

Durante o período de 08/05/2013 a 23/07/2016, foram compartilhadas 824 imagens, das quais 148 foram classificadas como referentes a trabalho. Dentro da categoria trabalho, houve uma subdivisão em outras categorias: CAA, Material Adaptado ou Especialmente Desenvolvido (MAED) e Acesso ao Computador (AC). Foram postadas 31 imagens de CAA, 112 de MAED e sete recursos de AC. Duas imagens continham recursos de CAA e MAED. Uma professora não compartilhou as imagens por meio do WhatsApp, pois preferiu levar os arquivos para os encontros de formação na OV. Essas imagens também foram analisadas, das quais 16 foram classificadas como de trabalho, todas de CAA. Sendo assim, foram 47 imagens de CAA.

Categoria: Comunicação Alternativa e Ampliada

Os tipos de recursos de CAA mais frequentemente desenvolvidos foram os cartões seguidos de pranchas.

Cartóes de Comunicação: são recursos simples para apresentar os símbolos gráficos ou fotografias em um espaço compacto. Geralmente são organizados em álbuns/fichários, em porta-cartôes ou caixas, de modo que o usuário, mediador e professor possam ter acesso rapidamente. São muito úteis na sala de aula e nas SRMs (na construção da rotina com o aluno e a turma, na adaptação de uma atividade avaliativa, pedagógica ou lúdica e para a comunicação, quando falta algum vocabulário no sistema do aluno), em oficinas (com tópicos de interesse dos discentes), e são facilmente organizados como uma prancha de vocabulário previamente selecionado (Schirmer e Bersch, 2007). Alguns exemplos desenvolvidos durante a formação são apresentados a seguir. 
Figura 1 - Álbum de comunicação com símbolos pictográficos

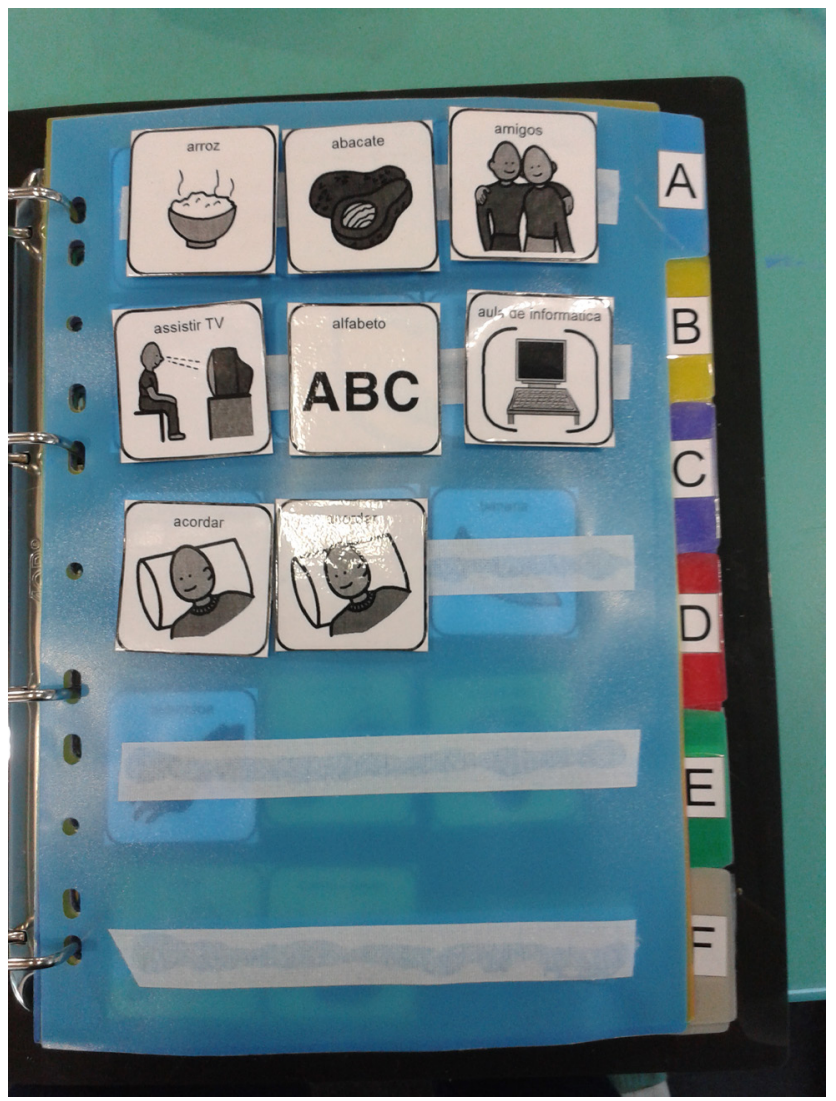

Fonte: G. F. R. Souza. 
Figura 2 - Álbum de comunicação com símbolos pictográficos

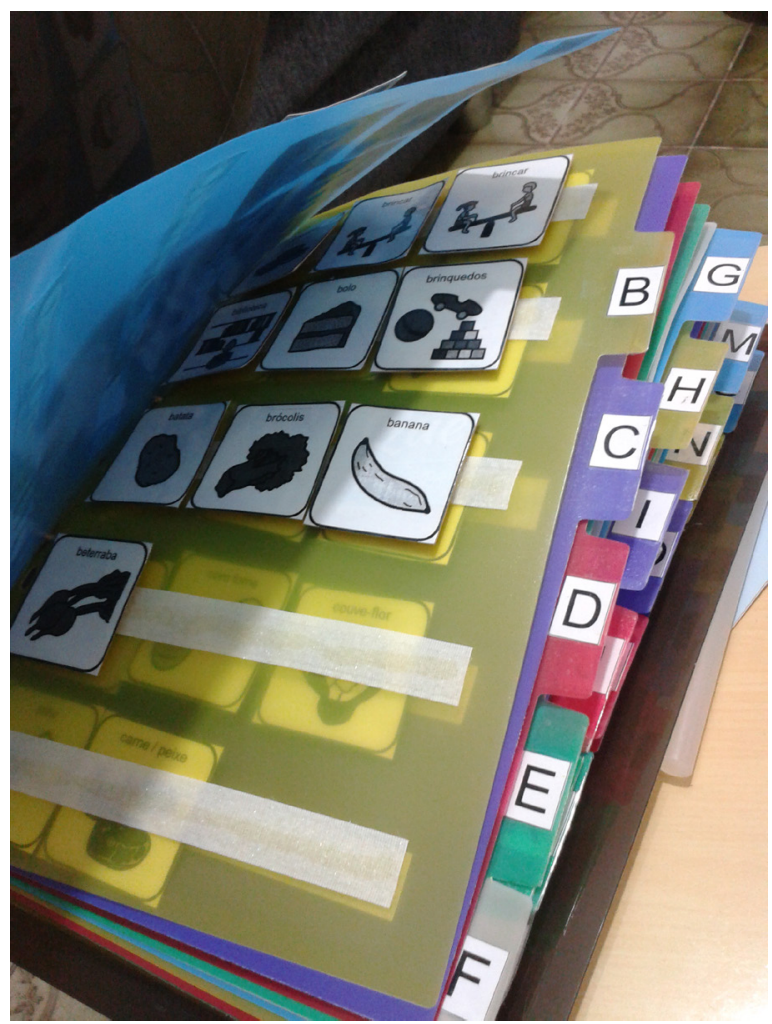

Fonte: G. F. R. Souza.

Professora sobre o recurso: “Álbum de comunicação com símbolos PCS organizados em ordem alfabética para utilizar na SRM, inicialmente para utilizar com aluno com Transtorno do Espectro Autista (TEA)" (Professora Gilda $\left.{ }^{4}-13 / 08 / 15\right)$.

4 Os nomes utilizados são fictícios. 
Figura 3 - Quadro com cartões de comunicação com símbolos pictográficos

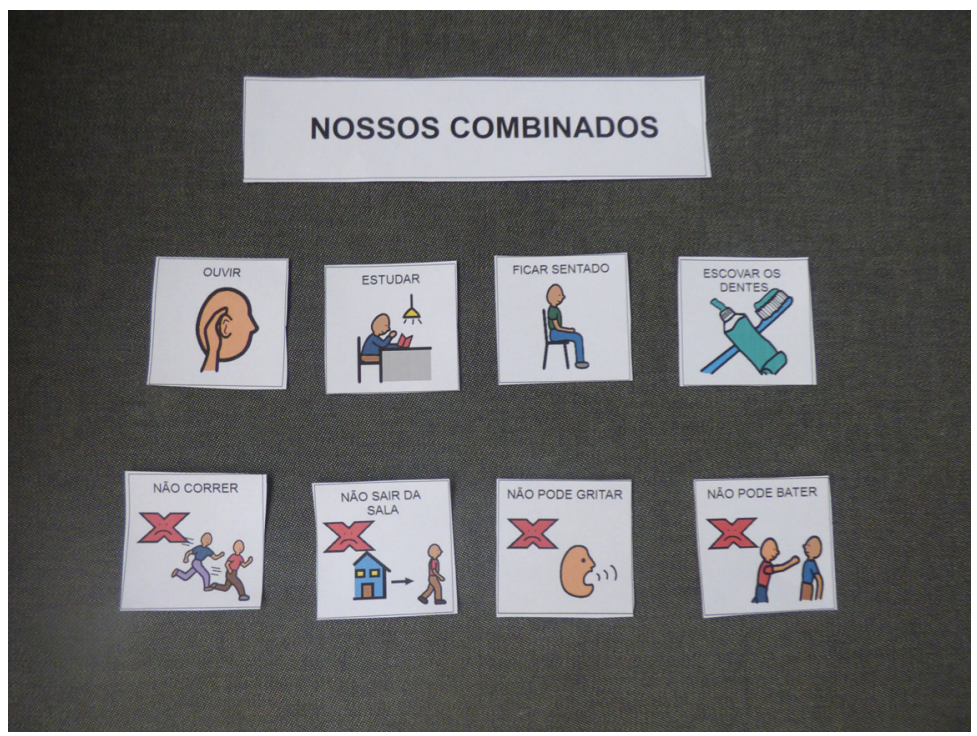

Fonte: C. A. Araújo, 2012.

Professora sobre o recurso: "Cartões de comunicação com símbolos PCS utilizados dentro da sala de aula. Primeiro utilizei com aluno com Paralisia Cerebral (PC) e depois com alunos com TEA. Utilizo também na SRM, são os combinados do que o aluno pode e não pode fazer" (Professora Clotilde - 19/10/14). 
Figura 4 - Cartões de comunicação com símbolos pictográficos

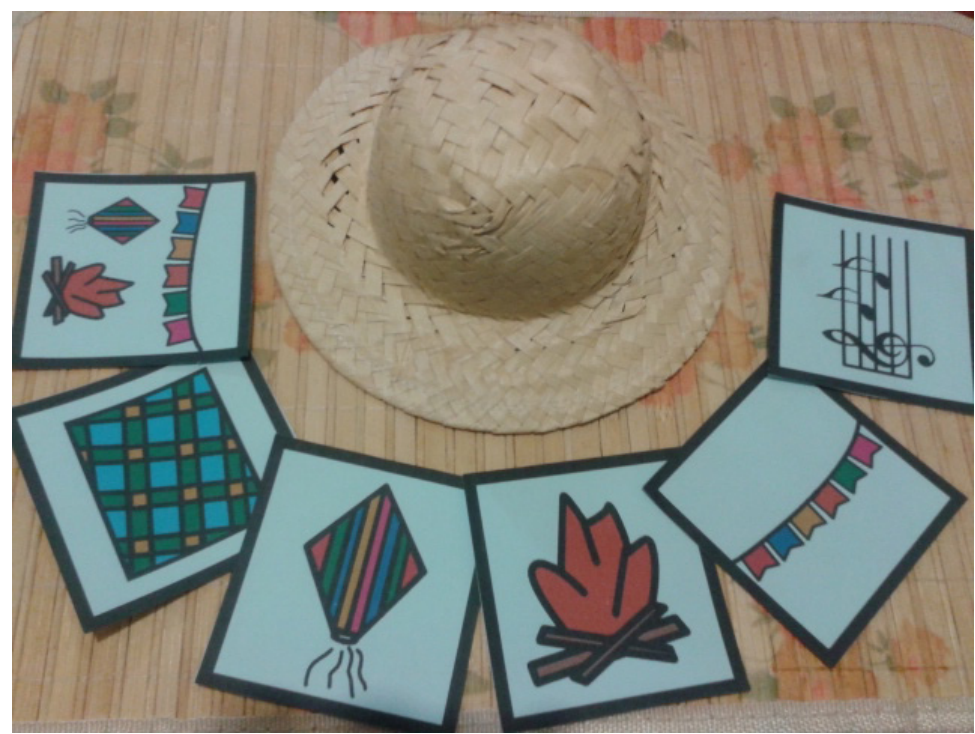

Fonte: V. Q. Costa.

Professora sobre o recurso: "Cartóes de comunicação com temática de festa junina. Utilizo com alunos com Deficiência Física (DF), TEA e Deficiência Intelectual (DI) na SRM" (Professora Vania - 13/06/2016).

Figura 5 - Bolas de brinquedo nos tamanhos grande e pequeno e cartões de comunicação com fotografias delas

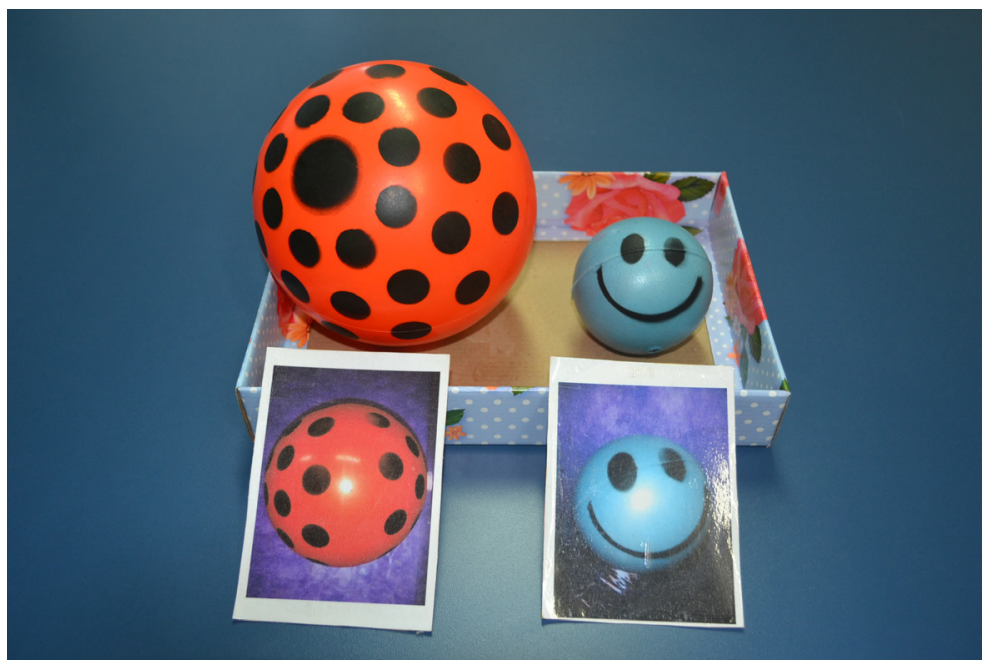


Fonte: J. B. S. Santos.

Professora sobre o recurso: "Uso de cartôes de comunicação com fotos e associação ao objeto concreto. Início do trabalho de comunicação com aluno com PC" (Professora Joana - 06/11/15).

Figura 6 - Cartões de comunicação com simbologia pictográfica e fotografias

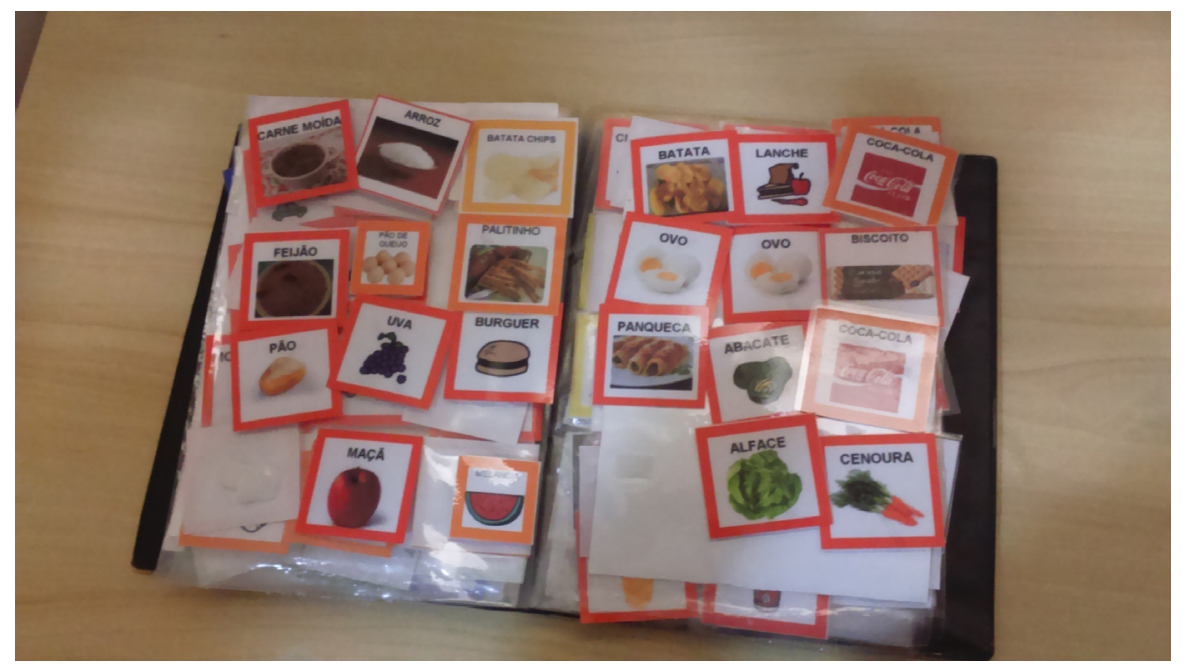

Fonte: J. B. S. Santos

Professora sobre o recurso: "Cartões de CAA com símbolos PCS e fotografias utilizados com alunos com PC e TEA na SRM” (Professora Joana - 13/07/2016). 
Figura 7 - Pasta com cartões de comunicação com simbologia pictográfica

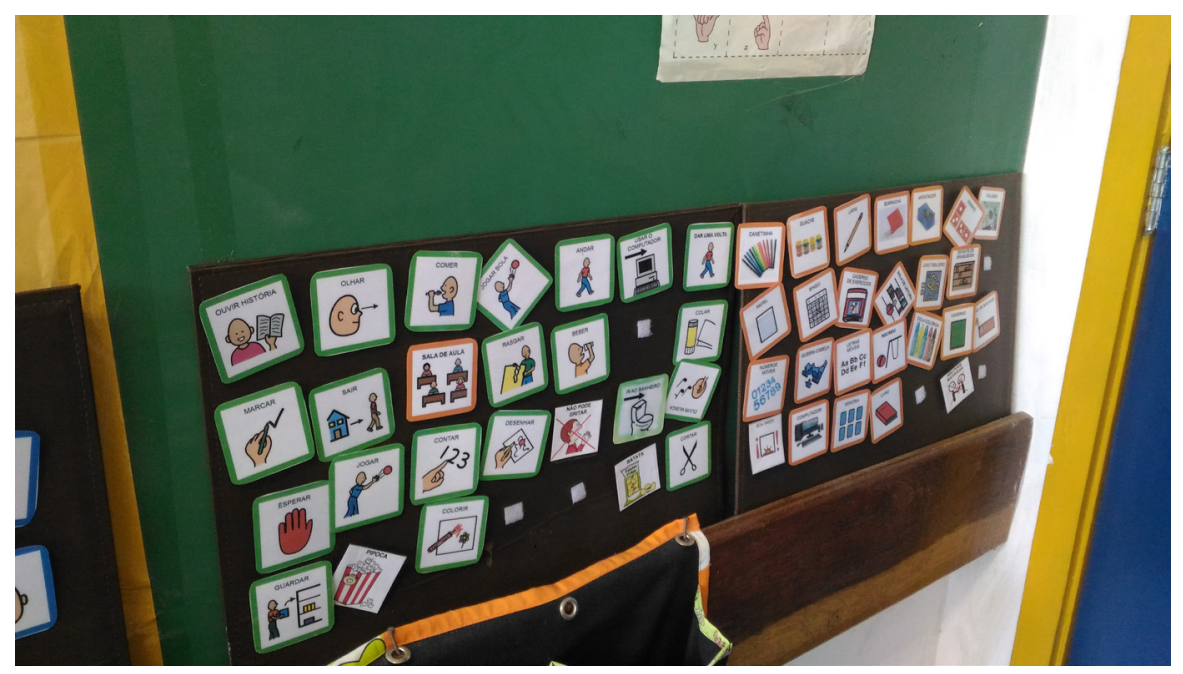

Fonte: C. M. Togashi.

Professora sobre o recurso: "Cartões de CAA com símbolos PCS para aluno com TEA utilizar em sala de aula. Trabalho com o PECS-Adaptado em SRM e sala de aula comum" (Professora Carmem - 17/03/2016).

No caso das professoras participantes do estudo, percebemos um grande uso dos cartôes de CAA, pois a maioria estava iniciando o uso de simbologia gráfica ou fotografias para a comunicação com seus alunos e estruturando esse trabalho nas suas SRM.

Prancha de CAA: é uma superfície que contém figuras, fotos, desenhos, letras, sílabas, palavras, frases ou números, podendo ser acoplada à cadeira de rodas ou se constituir em álbum ou caderno. A criança vai olhar, apontar ou ter a informação apontada pelo professor, dependendo de sua condição motora (Pelosi, 2008). Na sua confecção, são utilizados materiais variados, como folhas de papel, cartolina, isopor, madeira (Schirmer et al., 2007). Segundo Basil (1992), a prancha de comunicação alternativa não eletrônica pode ser considerada o principal auxílio técnico, por ser a mais usada tanto como recurso único quanto combinado (como o uso de um sistema computadorizado de comunicação), além de possuir baixo custo. 
Figura 8 - Prancha de comunicação com simbologia pictográfica

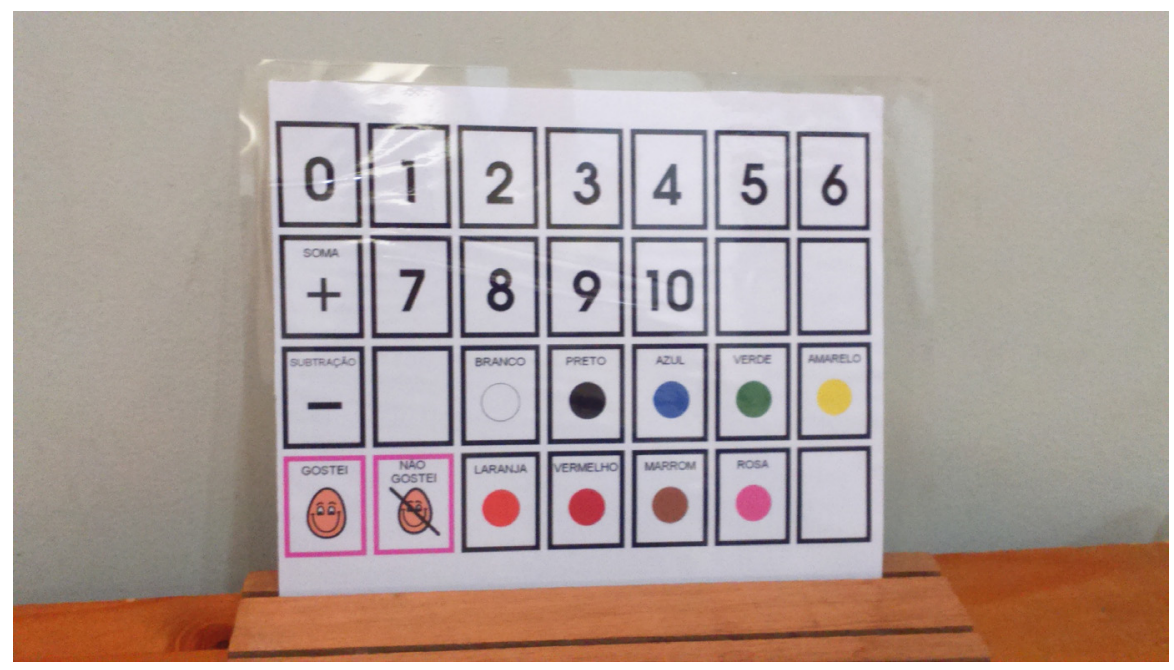

Fonte: C. A. Araújo.

Figura 9 - Prancha de comunicação com simbologia pictográfica

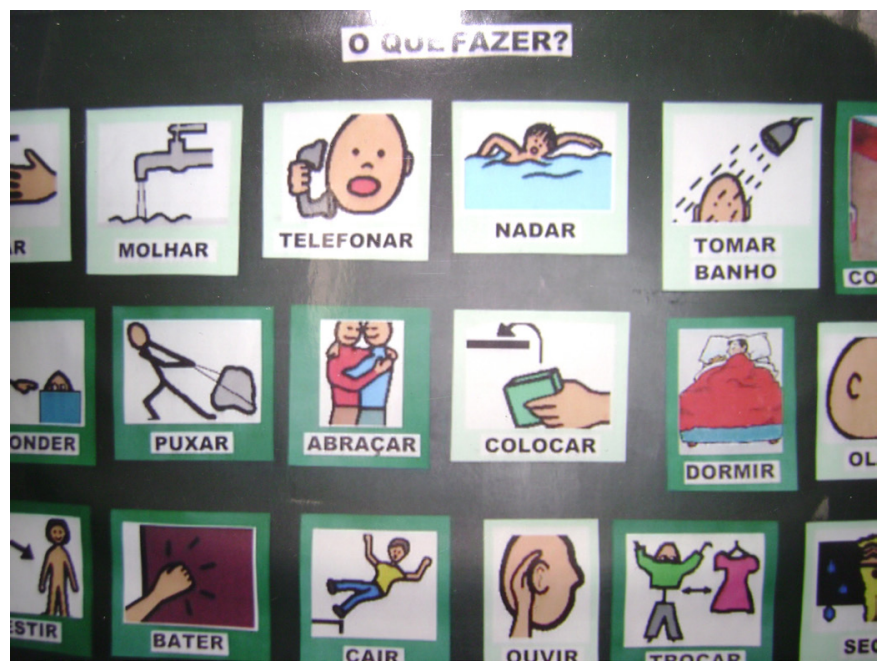

Fonte: C. A. Araújo. 
Professora sobre o recurso: "Pranchas de comunicação elaboradas com símbolos PCS. Utilizado com alunos com DF, TEA e DI na SRM” (Professora Clotilde - 19/10/14).

Figura 10 - Prancha temática de comunicação com simbologia pictográfica

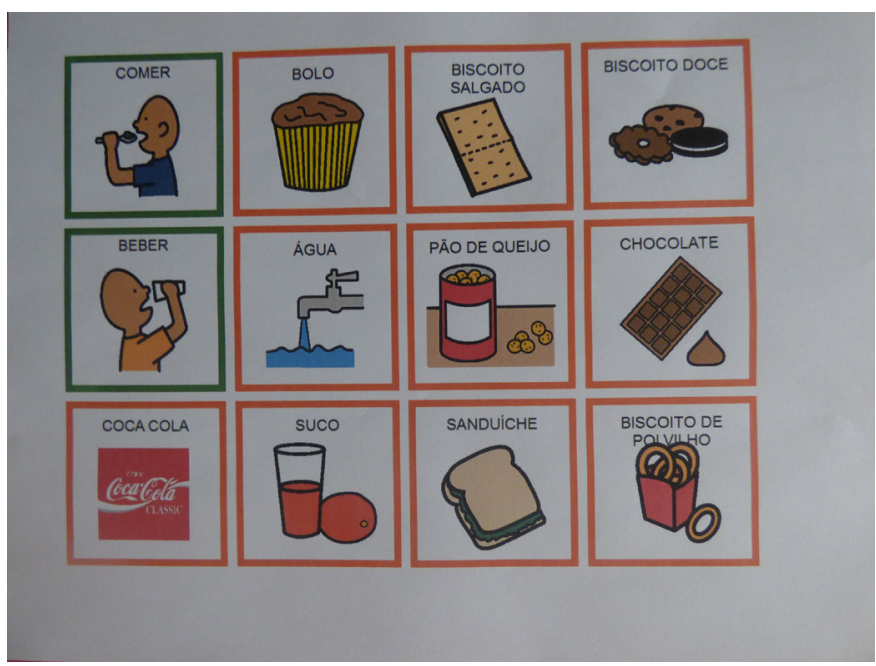

Fonte: C. M. Togashi.

Professora sobre o recurso: "Prancha de comunicação com o tema da alimentação. Elaborada com símbolos PCS para cinco alunos de Escola Especial com PC para utilizar em um lanche" (Professora Carmem - 21/10/14). 
Figura 11 - Prancha de comunicação com simbologia pictográfica e palavras em inglês

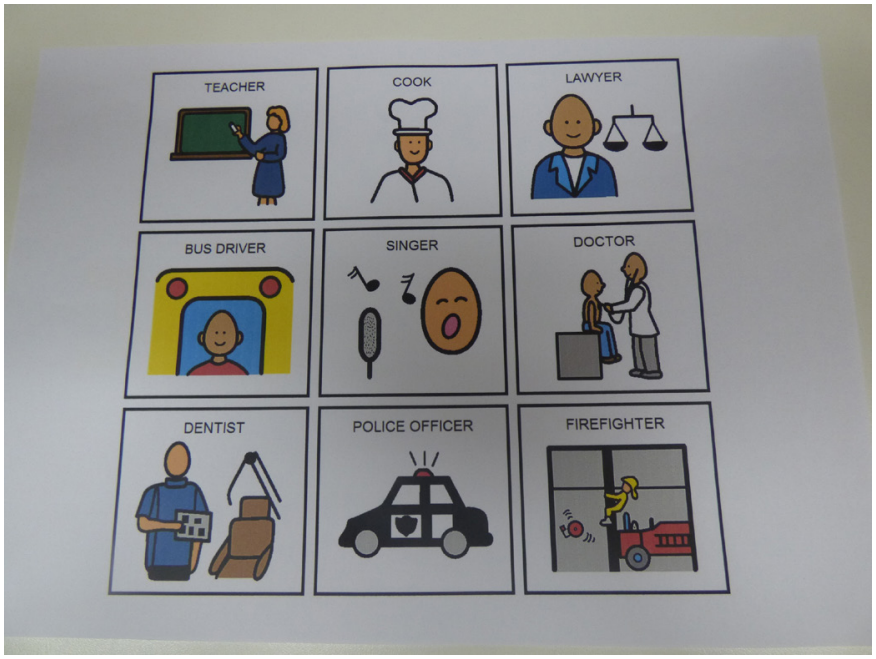

Fonte: V. Q. Costa.

Professora sobre o recurso: "Prancha de comunicação com símbolos PCS para a aula de inglês utilizada por aluno com DF" (Professora Vania 20/05/15).

As pranchas de comunicação compartilhadas foram as temáticas (sobre um livro, atividade ou aula específica) e, apesar de terem sido a princípio elaboradas para um determinado aluno, foram aproveitadas posteriormente por outros alunos na SRM. Nenhuma prancha de comunicação pessoal foi compartilhada no grupo de WhatsApp ou em sessão de formação.

Outro aspecto observado refere-se ao tipo de sistema de símbolos mais utilizado na confecção dos recursos, o sistema PCS, disponível no software Boardmaker ${ }^{5}$. Esse software tem acompanhado os materiais enviados para as Salas de Recursos Multifuncionais concedidas pelo Ministério da Educação

5 Software Boardmaker - Utilizado para a criação de pranchas e cartōes de comunicação e também para material lúdico e pedagógico, é um banco de dados gráfico que contém mais de 5.000 símbolos denominados Picture Communication Symbols (PCS) (Johnson, 1998). Os Símbolos de Comunicação Pictórica foram criados no início dos anos 1980 
nos últimos anos. Apenas cinco imagens de pranchas de CAA desenvolvidas em aplicativos para tablet utilizaram um sistema de símbolos diferente, conhecido como sistema ARASAAC ${ }^{6}$. Isso provavelmente se deve ao fato de os aplicativos serem disponibilizados gratuitamente com esse sistema. E, no caso do sistema PCS, só é possível utilizá-lo no computador, sendo mais trabalhoso transferir os arquivos de imagem do sistema PCS para o tablet.

Os aplicativos utilizados foram o Pictovox ${ }^{7}$ e o Adapt $^{8}$. Essa mesma professora postou uma imagem de uma prancha dinâmica programada no computador em um software chamado Araboard, que é um sistema dinâmico de pranchas que também utiliza o sistema ARASAAC.

\section{Categoria: Material Adaptado ou Especialmente Desenvolvido}

Para resolver os problemas funcionais de pessoas com deficiência e TEA, podemos introduzir o Material Escolar e Pedagógico Adaptado ou Especialmente Desenvolvido que favoreça o desempenho das atividades pretendidas (tesouras adaptadas, planos inclinados, engrossadores de lápis, pincéis, livros e atividades adaptadas com pictogramas, entre outros) (Pelosi, 2008). No caso da nossa pesquisa, os materiais adaptados ou especialmente elaborados para os alunos foram: livros, atividades pedagógicas, materiais escolares e jogos, como nos exemplos a seguir:

pela fonoaudióloga americana Roxanna Mayer Johnson e compõem, atualmente, o conjunto de símbolos mais difundido em todo o mundo.

6 Sistema ARASAAC - Trata-se de um conjunto em torno de 15.000 pictogramas, com licença livre. Por meio do Portal ARASAAC, é possível ter acesso aos símbolos e ferramentas, tais como o Gerador de Pranchas, específico para a produção de pranchas de comunicação impressas (Vieira e Pelosi, 2014).

7 Software PictoVox - É um aplicativo de CAA desenvolvido para auxiliar pessoas com deficiência, dificuldades ou limitações de comunicação. Como uma prancha de CAA, o PictoVox trabalha utilizando voz sintetizada e pictogramas - o usuário pode formar sentenças e se comunicar com as pessoas ao seu redor ou enviando as frases geradas por meio de outros aplicativos mensageiros.

8 Software Adapt - É um aplicativo de CAA criado para auxiliar crianças, adolescentes e adultos sem fala articulada e/ou funcional a se comunicarem com a família, amigos e pessoas próximas. 


\section{Atividades pedagógicas}

Figura 12 - Cartões de comunicação com desenhos e frações matemáticas

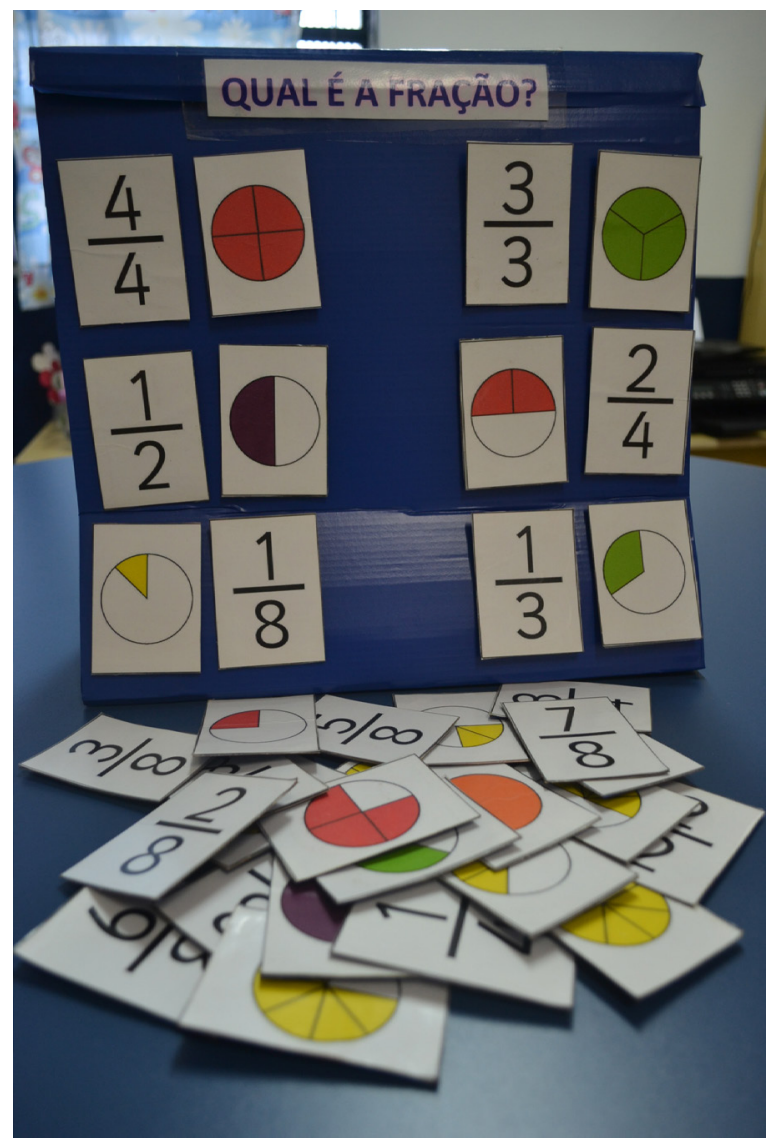

Fonte: J. B. S. Santos.

Professora sobre o recurso: "Atividade pedagógica de matemática, adaptada para alunos com DI. São descritores de fraçōes em cartôes móveis com imagens e números" (Professora Joana - 28/09/15). 
Figura 13 - Cartões com desenhos e sílabas

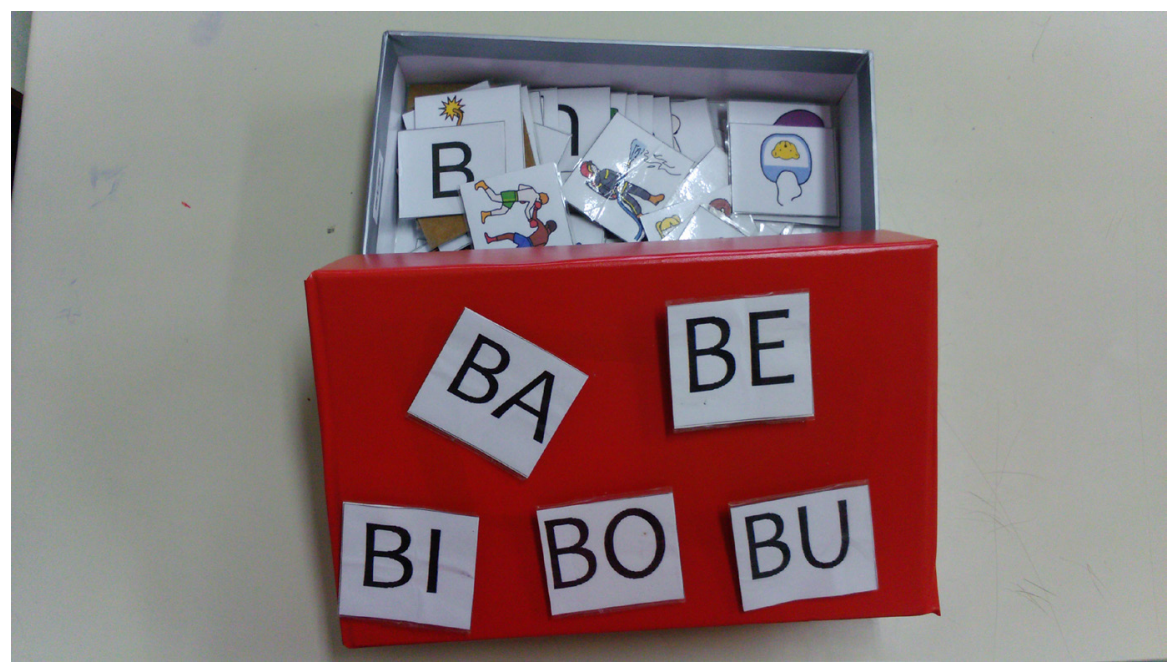

Fonte: C. M. Togashi.

Professora sobre o recurso: "Atividade pedagógica adaptada, correlacionando imagens, letras e sílabas. Trabalho o vocabulário que consta nos cadernos pedagógicos. Utilizo com alunos com Deficiência Física (DF), Transtorno do Espectro Autista (TEA) e Deficiência Intelectual (DI)" (Professora Carmem - 10/12/15).

Figura 14 - Cartões com simbologia pictográfica e tampinhas de garrafa coloridas

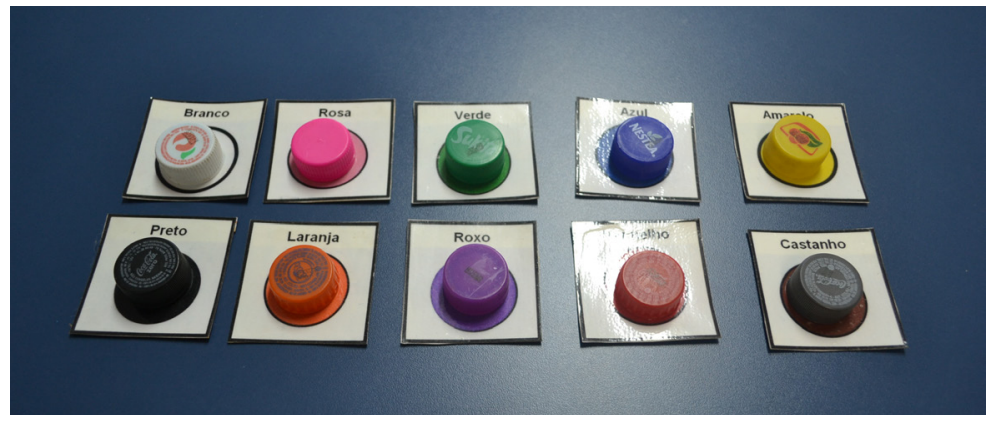

Fonte: J. B. S. Santos. 
Figura 15 - Caixa com cartões com simbologia pictográfica e tampinhas de garrafa coloridas

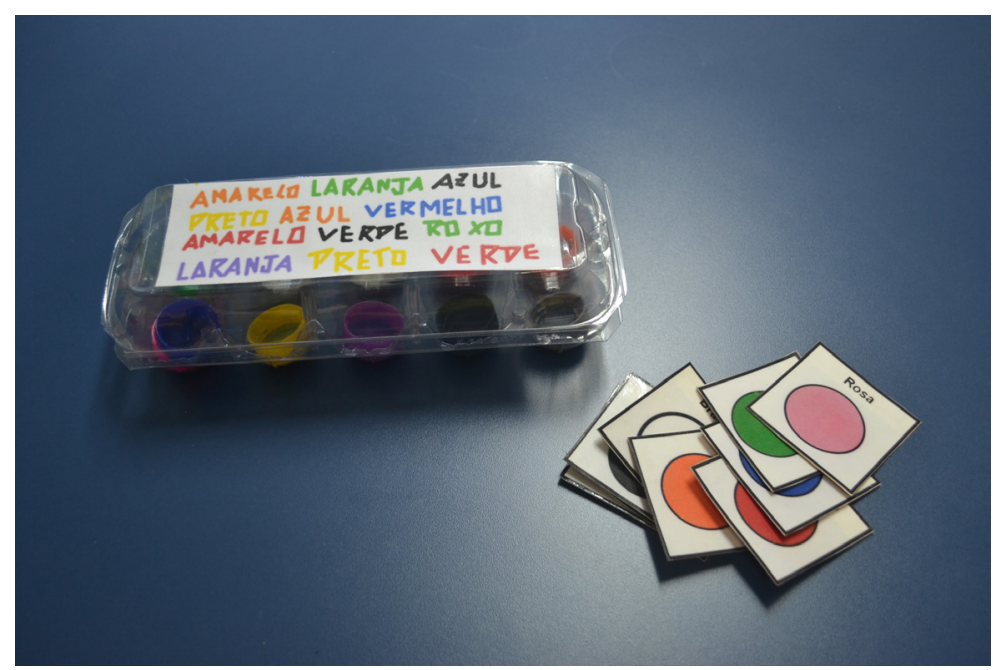

Fonte: J. B. S. Santos.

Professora sobre o recurso: "Atividade pedagógica adaptada - associação de cartôes com símbolos PCS, representando as cores, e tampinhas de garrafa coloridas. Também utilizo os cartões em jogo de memória e reconhecimento da escrita. Fiz para utilizar com um aluno com TEA" (Professora Joana - 23/02/16).

Figura 16 - Cartões com desenhos, palavras e sílabas

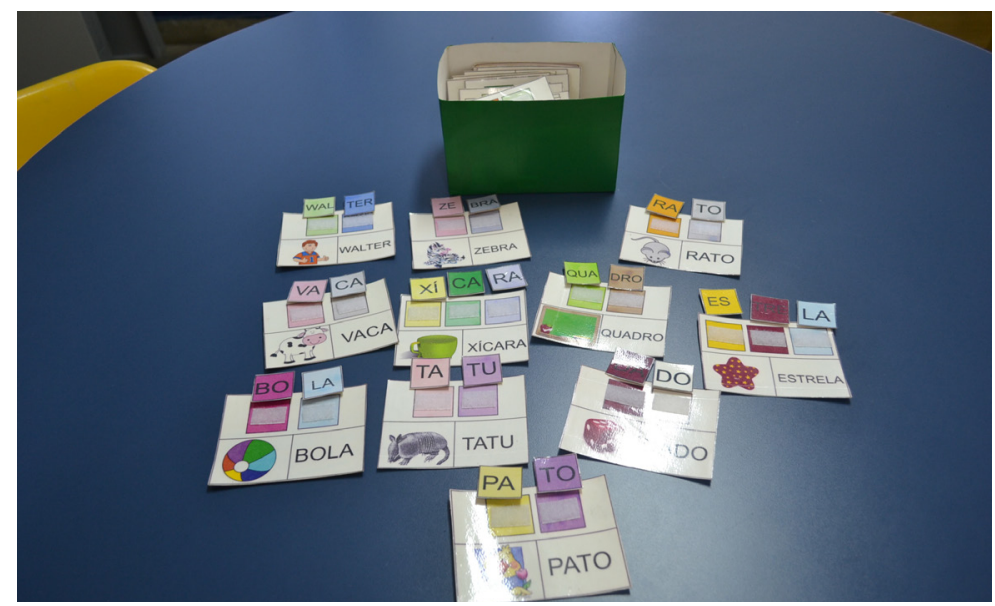


Fonte: J. B. S. Santos.

Professora sobre o recurso: "Atividade pedagógica adaptada para o trabalho na alfabetização. Utilizo cartões com imagens, palavras e sílabas móveis. Utilizo com aluno com TEA" (Professora Joana - 23/02/16).

Figura 17 - Caixa e fichas com cédulas de dinheiro pequenas

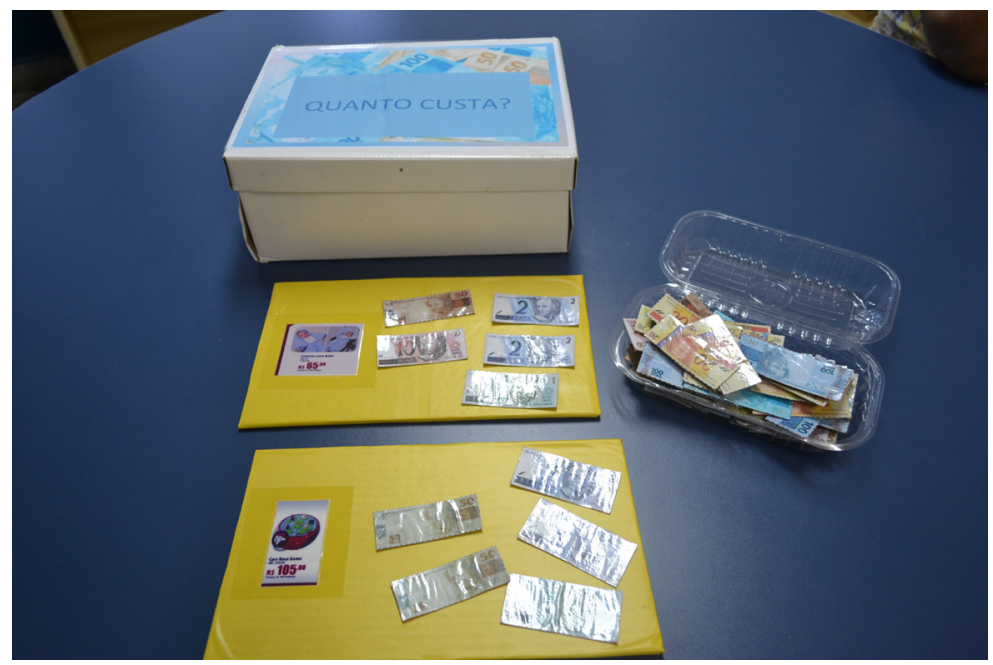

Fonte: J. B. S. Santos.

Professora sobre o recurso: "Atividade pedagógica adaptada para trabalhar contagem de moeda e dinheiro. Atividade funcional de criação de possibilidades de uso do dinheiro para aluno com DI" (Professora Joana 26/03/16). 
Figura 18 - Potes de plástico, que simulam miniaturas de latas de lixo de reciclagem, e cartões com fotografias

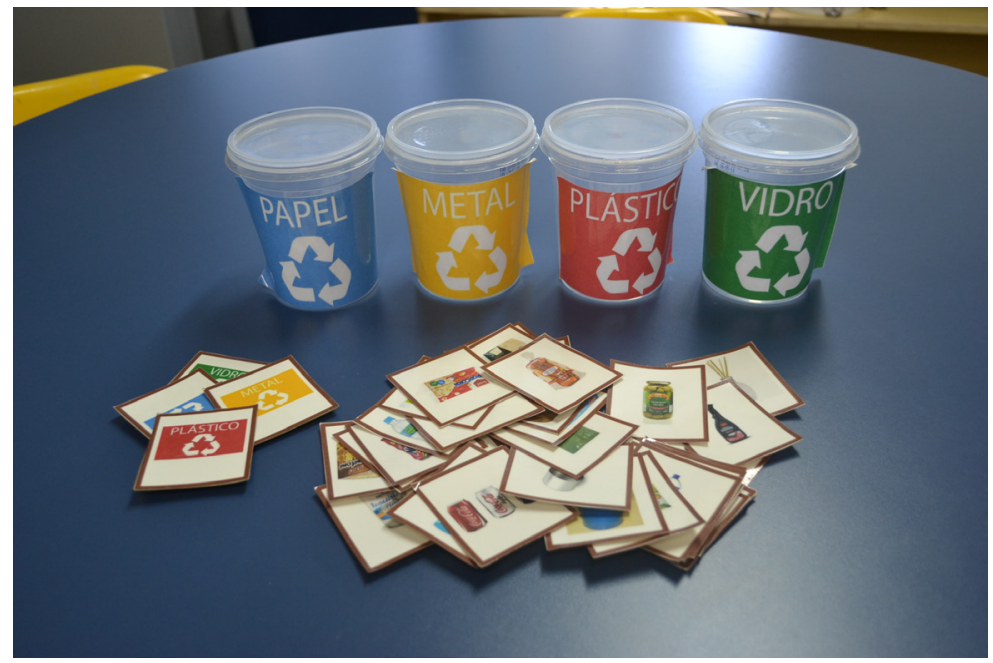

Fonte: J. B. S. Santos.

Professora sobre o recurso: “Atividade pedagógica adaptada. Foram utilizados símbolos e fotos. Atividade de reciclagem com cartões e potes de plástico representando cestos de lixo para aluno com DI" (Professora Joana - 26/03/16).

Livros adaptados: um exemplo de como a TA pode beneficiar as pessoas com deficiência é na habilidade de leitura. Alguns alunos apresentam dificuldades em acompanhar a turma, e seu ritmo para aprender a ler é diferenciado. Para auxiliá-los, o professor especializado poderá produzir, com os softwares de CAA, textos apoiados por símbolos gráficos e, assim, favorecer a compreensão dos discentes. Imerso no contexto de símbolos pictográficos e alfabéticos, o aluno poderá realizar leitura global e ter acesso a novos conhecimentos de forma mais autônoma (Schirmer e Bersch, 2007; Correia, 2007), ou, ainda, o professor poderá transcrever ou reescrever de forma simplificada e reimprimir o texto do livro com letra ampliada, para atender a alunos em início do processo de alfabetização ou que apresentem baixa visão. 
Figura 19 - Livro adaptado com simbologia gráfica PCS

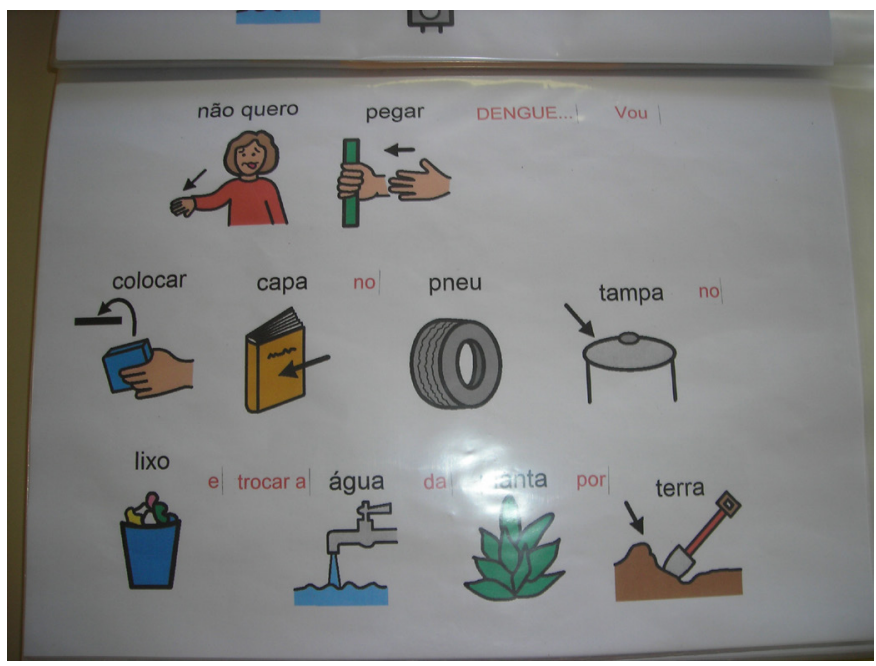

Fonte: C. A. Araújo.

Figura 20 - Atividade de interpretação do livro adaptada com simbologia gráfica PCS

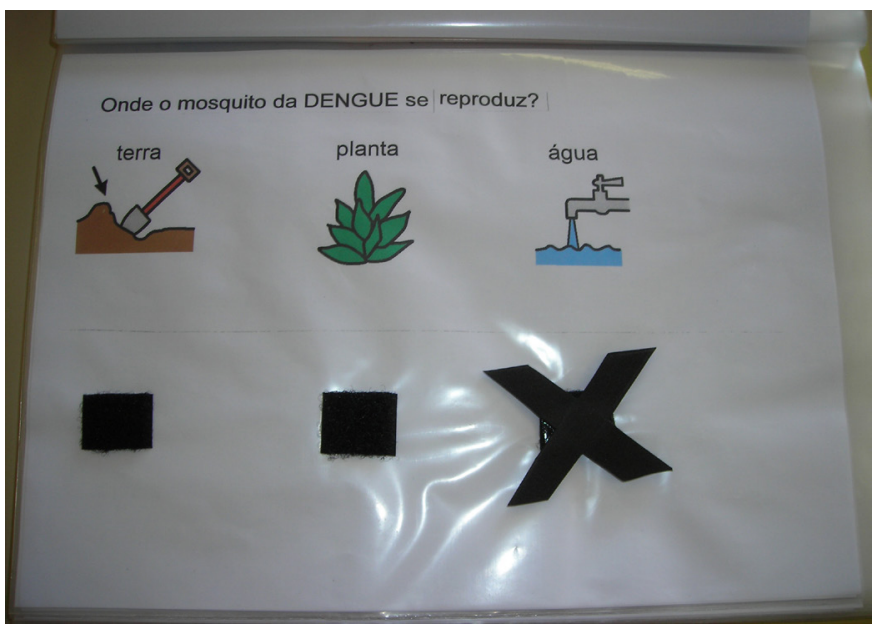

Fonte: C. A. Araújo. 
Professora sobre o recurso: "Livro e atividade de interpretação adaptados com sistema de símbolos PCS, velcro e marcador de EVA em forma de X. Recurso utilizado na SRM para desenvolver habilidades de leitura e interpretação de histórias com alunos com DF, TEA e DI" (Professora Clotilde - 18/03/16).

Figura 21 - Livro adaptado com simbologia gráfica PCS

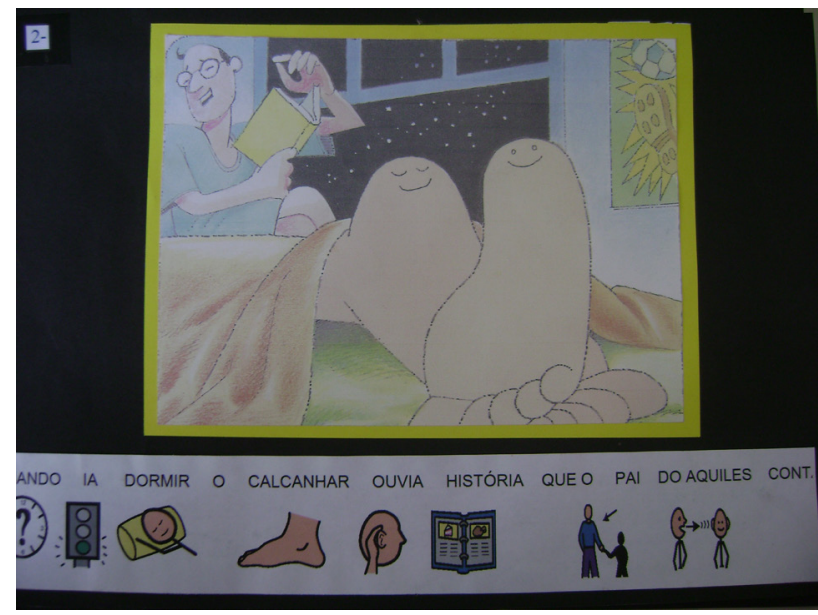

Fonte: C. A. Araújo.

Figura 22 - Atividade de interpretação do livro adaptada com simbologia gráfica PCS

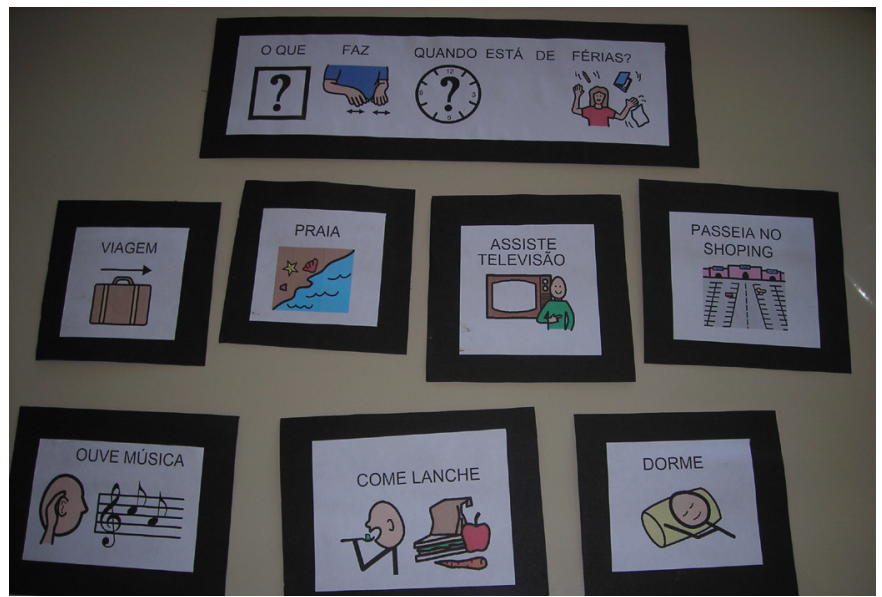

Fonte: C. A. Araújo. 
Professora sobre o recurso: "Atividade pedagógica, livro adaptado e interpretação da história através de símbolos PCS. Utilização para comunicação/interação. Atividade pedagógica, interpretação da história - adaptando perguntas com uso de símbolos PCS" (Professora Clotilde - 19/10/14).

Figura 23 - Atividade pedagógica adaptada com símbolos PCS perguntas com múltipla escolha

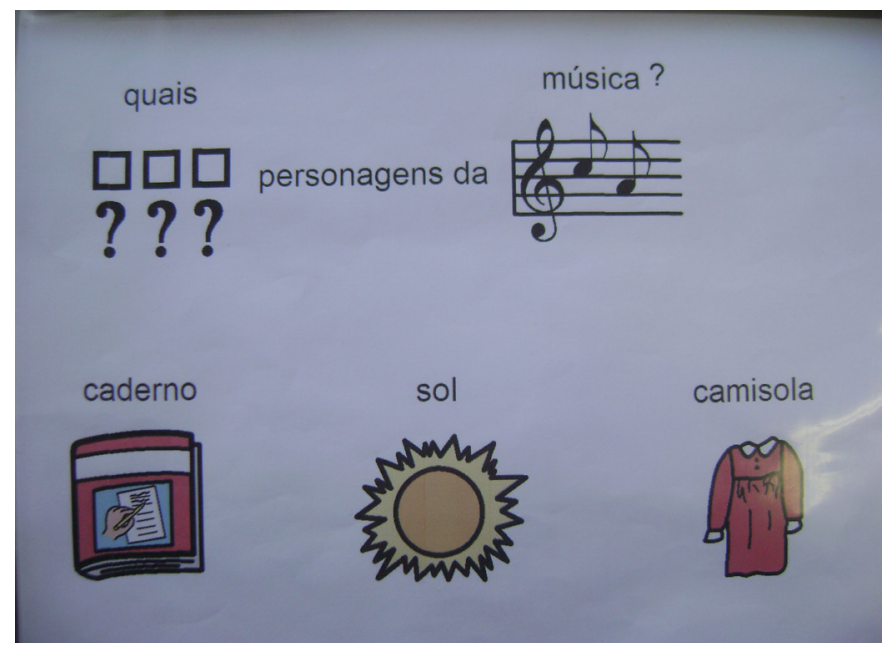

Fonte: C. A. Araújo. 
Figura 24 - Atividade pedagógica adaptada com símbolos PCS perguntas com múltipla escolha

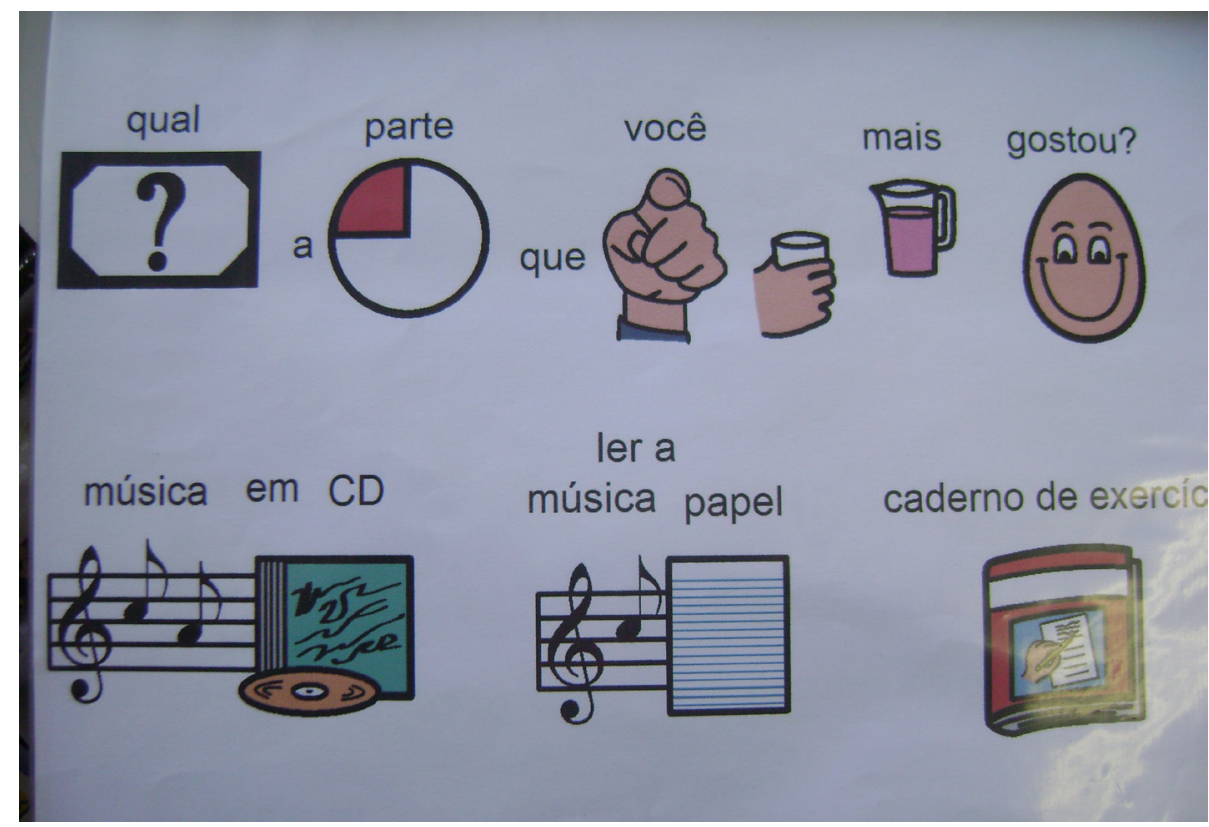

Fonte: C. A. Araújo.

Professora sobre o recurso: "Atividade pedagógica - perguntas com múltipla escolha - uso de símbolos PCS. Atividade na sala de recursos com participação ativa do aluno. Utilizo com alunos com Paralisia Cerebral (PC), DI e TEA" (Professora Clotilde - 19/10/14).

Outros exemplos de adaptações e adequações de material pedagógico são os livros eletrônicos, contando com o auxílio de voz gravada e músicas, ou mesmo livros adaptados, que fornecem feedback de voz para apoiar o processo de leitura, que são outros recursos que, sintonizados com os diferentes estágios de apropriação da leitura e da escrita e empregados de forma criativa pela professora, podem fazer a diferença na vida desses alunos (Pelosi et al., 2007); as folhas de exercícios e avaliações; os jogos e outras atividades lúdicas, utilizando-se esses ou outros recursos e estratégias citados anteriormente (Brando et al., 2011; Araújo, 2011; Quitério, 2011). 
Uma das professoras postou 23 imagens de atividades interativas desenvolvidas por ela no computador com o software Boardmaker with SDP9. Foram atividades pedagógicas que trabalham "percepção visual e contagem utilizando construção de história para alunos com DF, TEA e DI” (21/03/2016). Seguem algumas imagens sobre a atividade.

Figura 25 - Prancha dinâmica - atividade de percepção visual elaborada no software Speaking Dinamically Pro

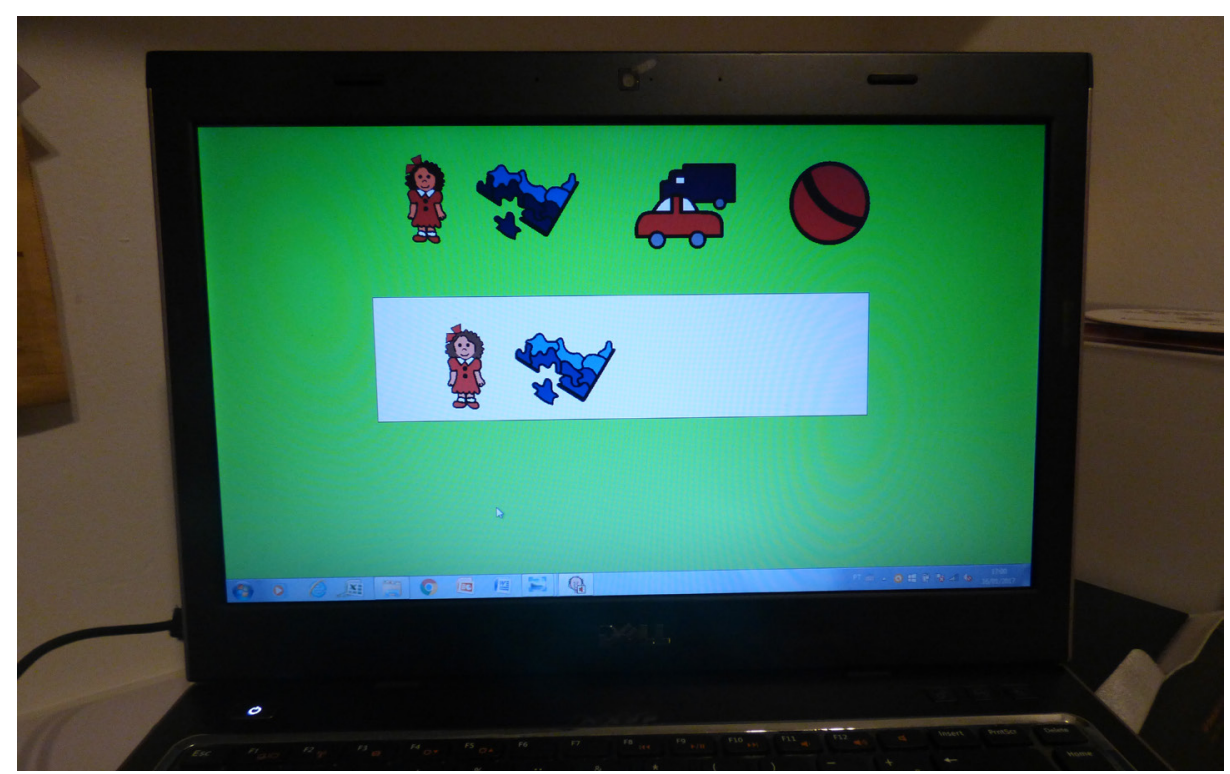

Fonte: C. A. Araújo.

9 Software Boardmaker with Speaking Dinamically (SDP) - É um software que transforma o computador em uma ferramenta de comunicação, a partir da seleção dos símbolos contidos em pranchas interligadas. Constitui um software de autoria no qual o professor, terapeuta ou familiar poderá criar inúmeras e atraentes atividades que instiguem o usuário ao raciocínio, à pesquisa, à expressão livre sobre temas, à leitura, a brincadeiras etc. Pode também ser usado na criação de atividades escolares interativas (Bersch e Schirmer, 2007). 
Figura 26 - Prancha dinâmica - atividade de percepção visual elaborada no software Speaking Dinamically Pro

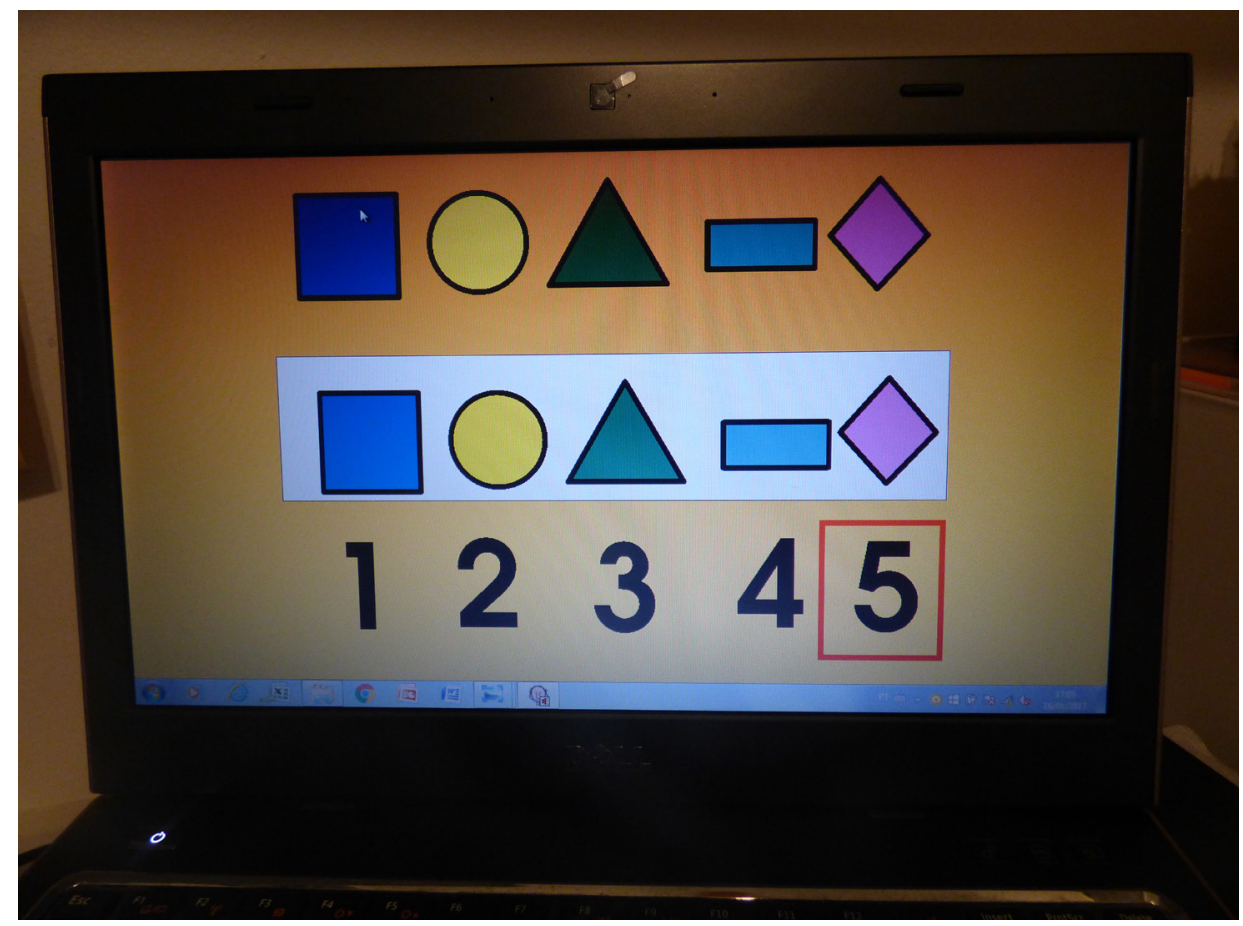

Fonte: C. A. Araújo.

Professora sobre o recurso: "Computador e software Boardmaker with SDP. Atividade interativa de percepção visual e contagem utilizando o software Boardmaker with SDP” (Professora Clotilde - 21/03/16). 
Figura 27 - Prancha dinâmica sobre corpo humano elaborada no software TICO

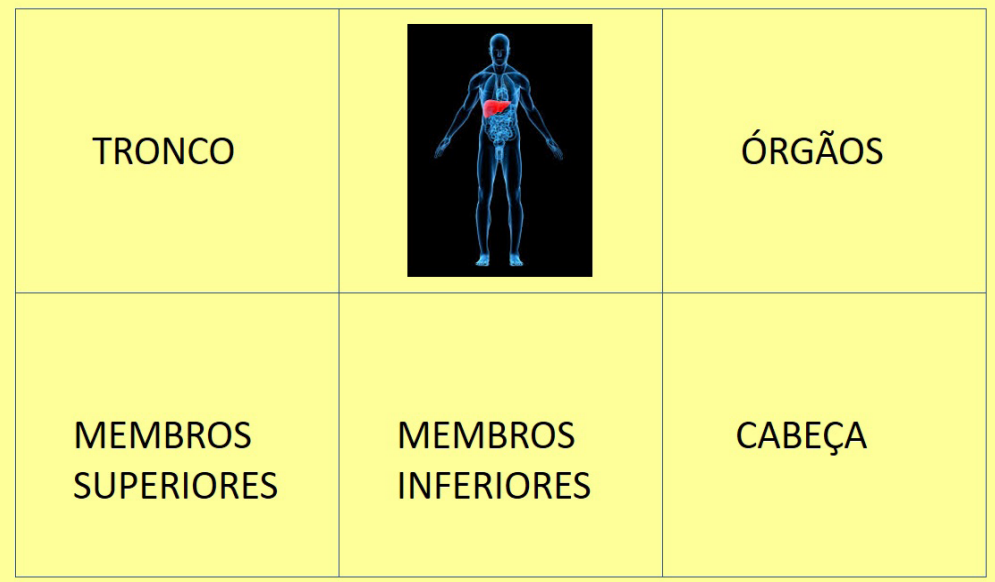

Fonte: A. C. P. Andrade.

Professora sobre o recurso: "Atividade pedagógica adaptada com fotos e palavras no software $\mathrm{TICO}^{10}$. Trabalhando corpo humano com aluno com PC” (Professora Anete - 27/05/15).

10 Software TICO de pranchas dinâmicas consiste em dois aplicativos: o primeiro, Editor, no qual são criadas as pranchas de comunicação com símbolos ARASAAC e imagens armazenadas no dispositivo, inserção de vídeos, vozes e sons gravados diretamente no programa, além de acumular células; e o segundo, Intérprete, que permite executar os recursos criados anteriormente. Esse programa possui a função de varredura sequencial, facilitando o acesso para pessoas com problemas motores que não podem usar o acesso direto, mas podem usar um acionador (Vieira et al., 2013). 


\section{Material Escolar}

Figura 28 - Atividade com símbolos pictográficos e letras móveis

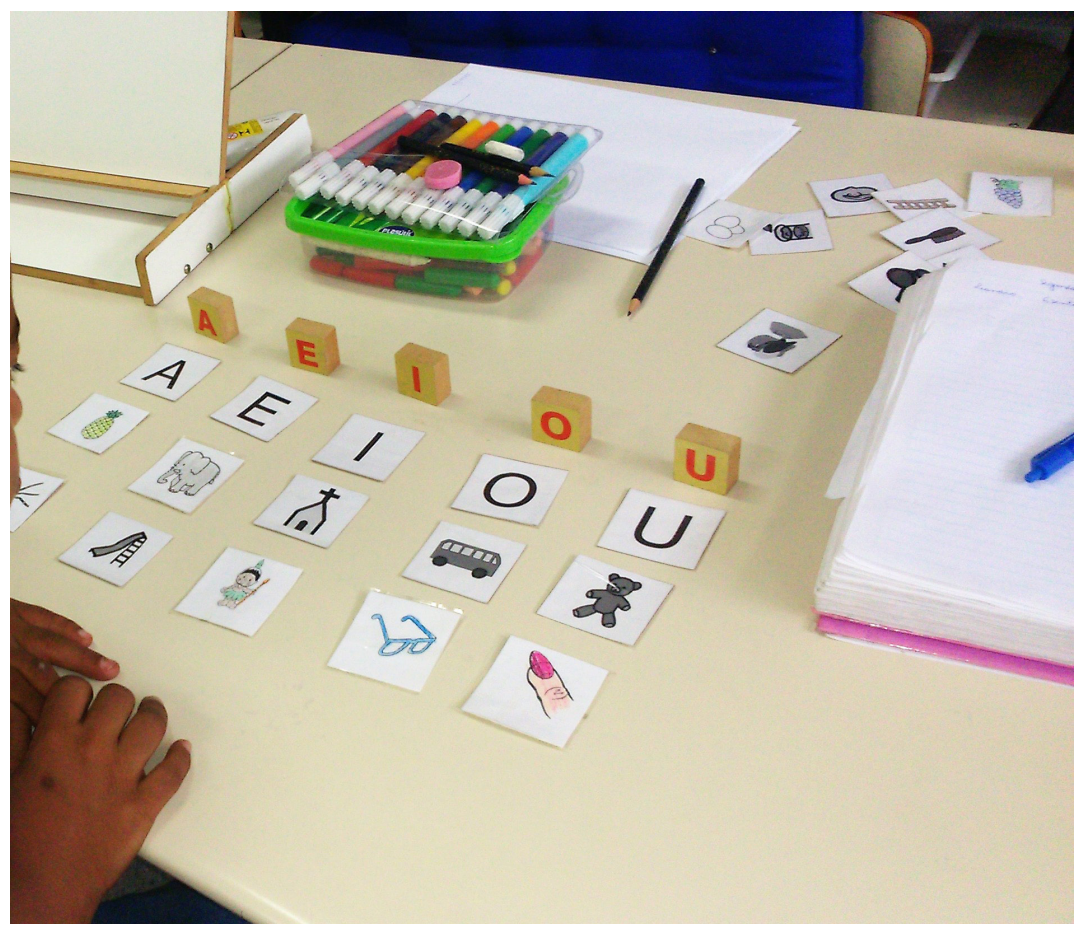

Fonte: V. Q. Queiroz.

Professora sobre o recurso: "A aluna está realizando uma atividade de escrita com letras móveis em papel e madeira, palavras e símbolos PCS” (Professora Vania - 30/09/14).

Alguns alunos apresentam dificuldades para executar a grafia. Isso pode ocorrer por motivos variados, como, por exemplo, cansar-se muito ou não conseguir escrever utilizando o lápis ou a caneta, mesmo adaptados. Nesses casos, será necessário que se pense em outras alternativas para a escrita: as letras em EVA (lâminas emborrachadas), em cubos de madeira, em cartões de papelão, coladas sobre tampinhas (Bersch, 2007) serão um recurso muito útil. 
Figura 29 - Caixas de "atividades" e “já acabou” para organização da rotina

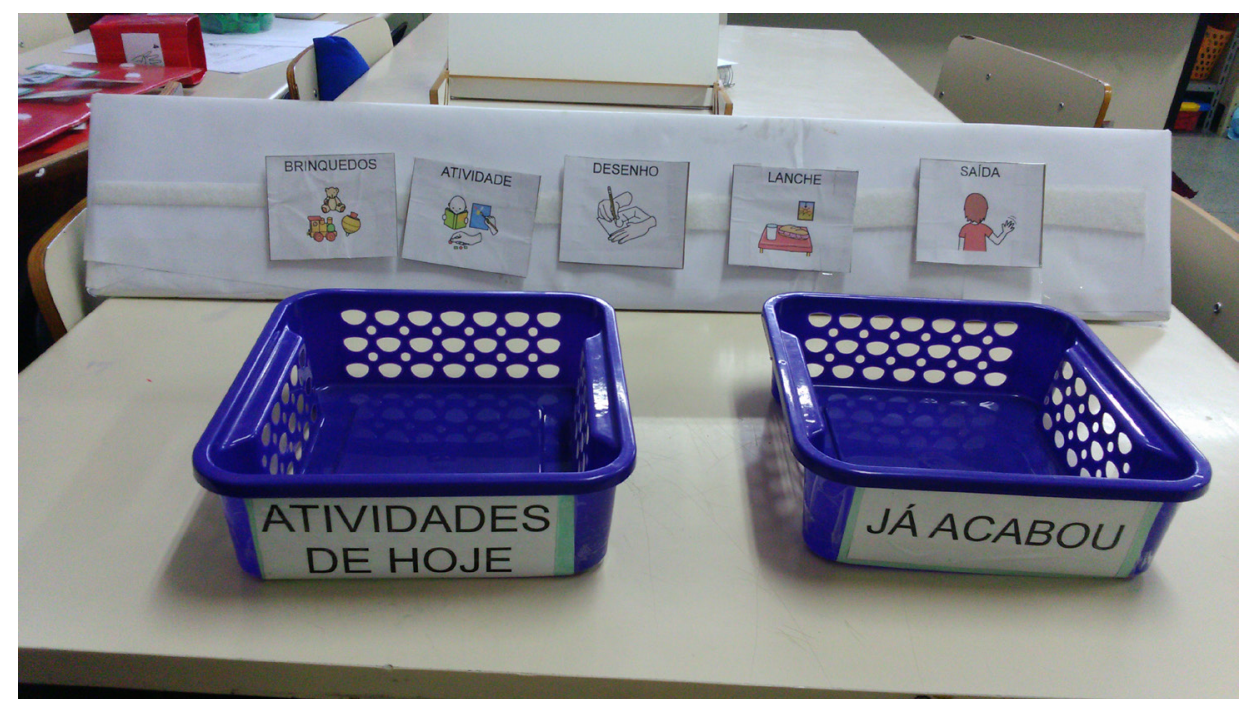

Fonte: C. M. Togashi.

Professora sobre o recurso: "Organização do ambiente - Caixas com 'as atividades de hoje' e o 'já acabou' e símbolos representando a atividade. Trabalho com rotina na sala de recursos multifuncionais com alunos com TEA" (Professora Carmem - 21/10/14).

Os recursos para organização do ambiente, como as caixas apresentadas anteriormente, agendas e calendários, são ótimos tanto para SRM quanto para uso em sala de aula, estimulando a organização espacial e temporal dos alunos. Essa organização pode ser utilizada para toda a turma e, quando associada aos símbolos da CAA, pode tornar-se um instrumento importante para a socialização de informações do aluno usuário desse sistema e seus colegas (Schirmer e Bersch, 2007). 
Figura 30 - Caixa com desenhos de figuras geométricas e sólidos geométricos

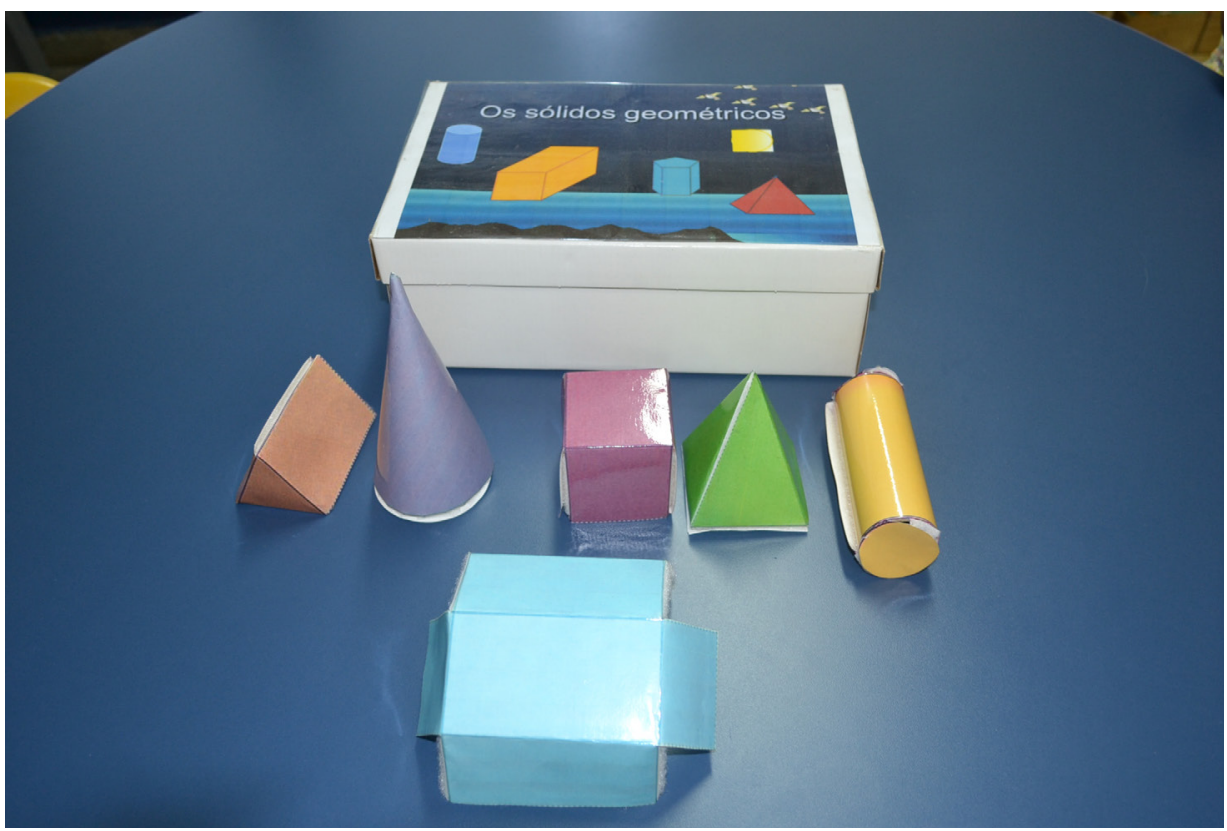

Fonte: J. B. S. Santos.

Professora sobre o recurso: "Material pedagógico adaptado - Sólidos geométricos com velcro autocolante para montagem. Utilizados no ensino descritor de sólido e geométrico para aluno com DI" (Professora Joana 26/03/16).

Uma prática para favorecer alunos com deficiência e TEA no processo de ensino-aprendizagem pode exigir a utilização de diferentes formas de linguagem. O professor deve explicar o conteúdo de forma visual e auditiva, utilizando recursos ilustrativos (concretos), de modo que ele possa compreender os conceitos básicos. O uso do material concreto facilita a aprendizagem por meio da sua manipulação. 
Figura 31 - Material para colorir feito de embalagens de desodorante

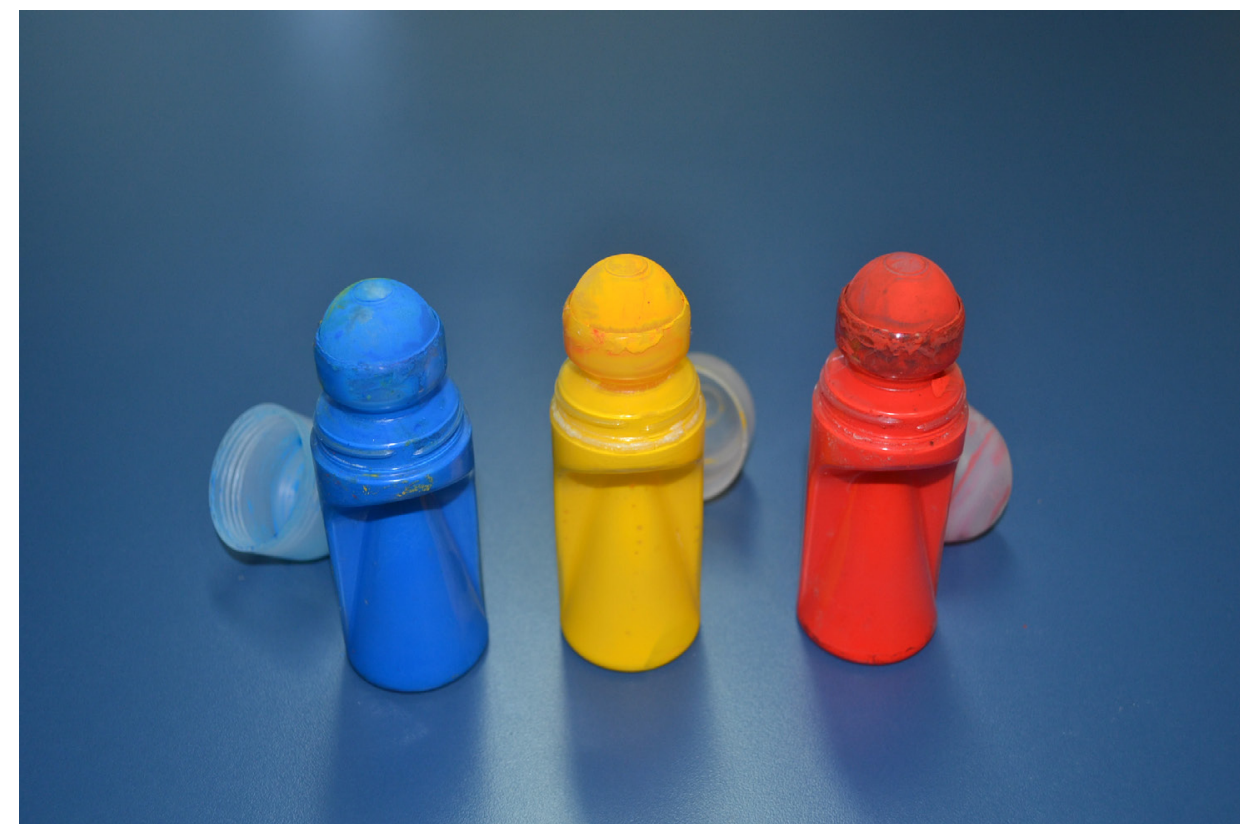

Fonte: J. B. S. Santos.

Professora sobre o recurso: “Adaptação para Trabalho com pintura com aluno com PC" (Professora Joana - 10/05/16).

Outras atividades muito frequentes na escola são a pintura e o desenho, por meio dos quais o aluno exercita o registro, além de fazer suas representações gráficas. Bersch (2007) fala que o professor poderá enfrentar o problema de manejo do lápis, giz de cera ou pincel, que exigem uma habilidade motora fina por meio de recursos alternativos, tais como engrossadores e órteses de posicionamento. Outro aspecto destacado pela autora é a necessidade de prender a folha mediante o uso de uma prancheta ou fita adesiva.

Jogos: o uso de jogos aparece como uma alternativa metodológica interessante, pois possibilita a construção de conhecimentos por intermédio do lúdico e de trocas sociais, que estimulam na criança o desenvolvimento cognitivo, social e moral (Fontes et al., 2007). Os alunos podem usar os jogos convencionais adaptados ou especialmente elaborados, conforme os desenvolvidos pelas professoras em formação. 
Figura 32 - Jogo de memória elaborado a partir de símbolos PCS

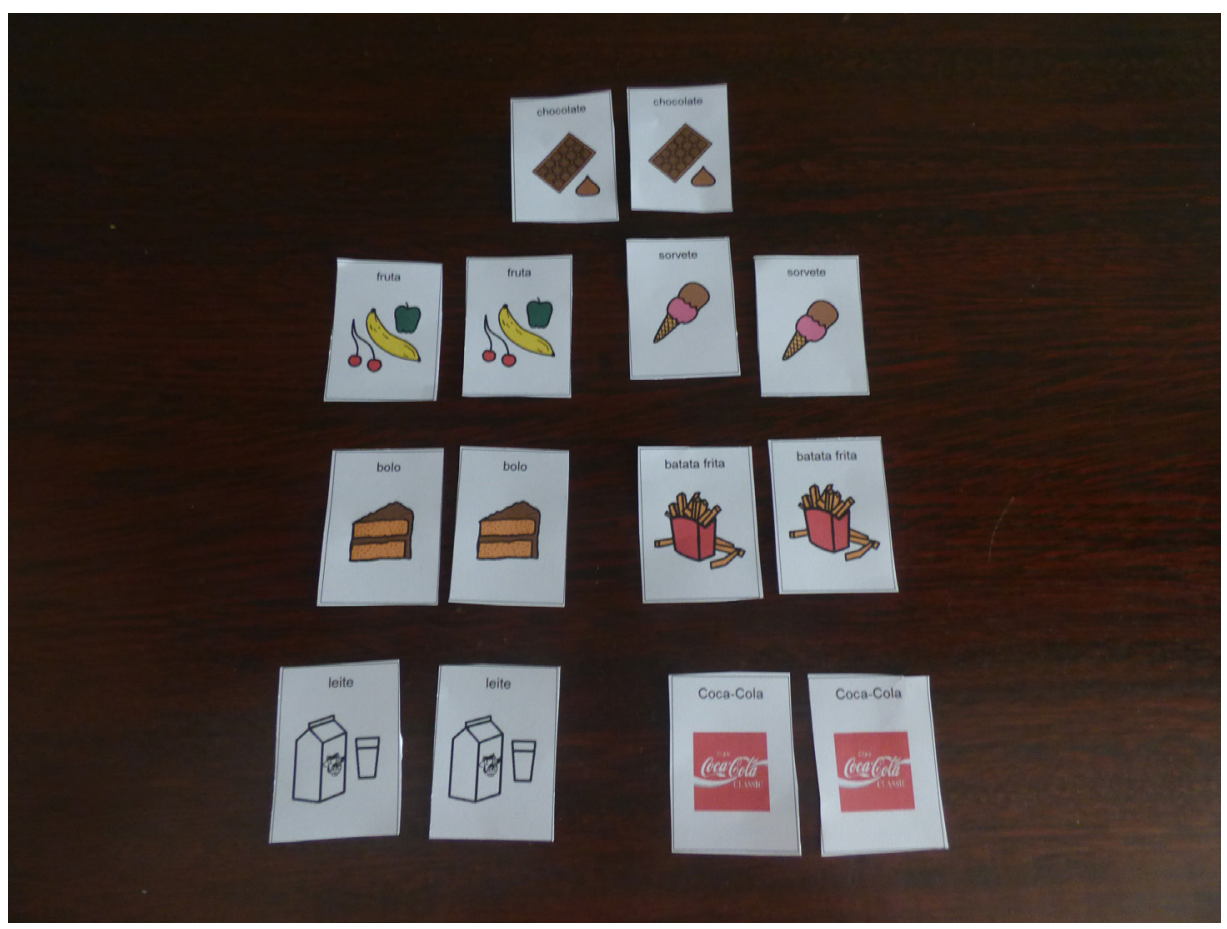

Fonte: C. A. Araújo.

Professora sobre o recurso: "Atividade lúdica - Jogos de memória com símbolos PCS com diferentes objetos para serem separados por categorias. Nessa imagem, a categoria: alimentos. Utilizo com alunos com PC, DI e TEA" (Professora Clotilde 18/03/16). 
Figura 33 - Jogo elaborado a partir de símbolos PCS

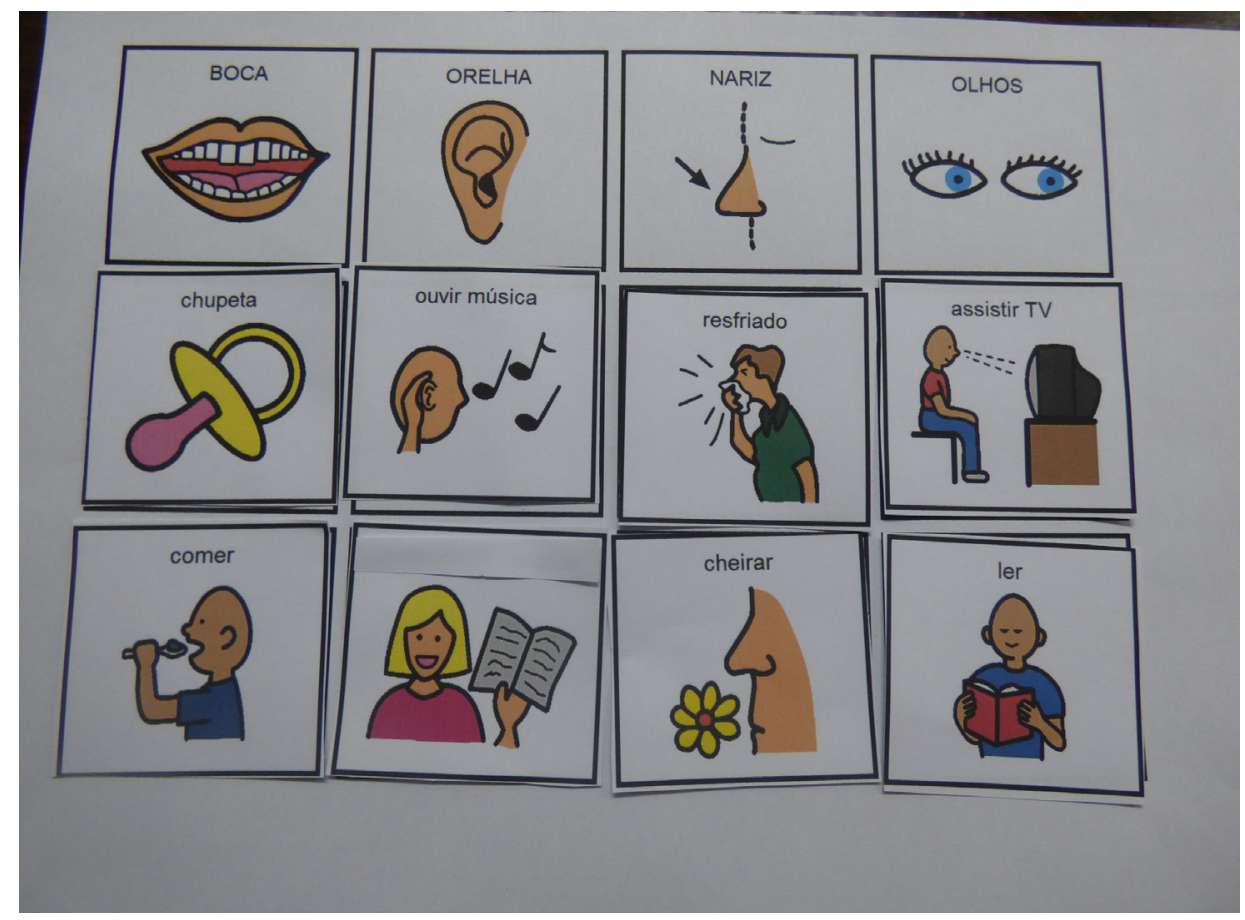

Fonte: C. A. Araújo.

Professora sobre o recurso: "Atividade pedagógica e lúdica adaptada construída com símbolos PCS dispostos em cartelas e cartóes. Jogos com diferentes objetos para serem separados por categorias. Utilizadas na SRM com alunos com DF, DI e TEA" (Professora Clotilde - 18/03/16).

Informática Acessível: trata-se de recursos, hardwares (teclados expandidos ou reduzidos, colmeias, tela de toque, acionadores de pressão, tração e sopro) e softwares (teclados programáveis e teclados virtuais com varredura, entre outros), que permitem a pessoas com deficiência utilizarem o computador de forma funcional (Bersch e Pelosi, 2008).

As professoras postaram fotos dos recursos que têm disponíveis em suas SRM. No quadro 1, é possível verificar qual o recurso postado e a descrição de uso dada pela professora. 
Quadro 1 - Recursos de acesso ao computador disponíveis na SRM

\begin{tabular}{|l|l|}
\hline Recurso & Descrição de uso dada pela professora \\
\hline Mouse adaptado RCT & $\begin{array}{l}\text { "Utilizo com alunos com PC e TEA que não conseguem utilizar } \\
\text { o mouse convencional" (Professora Joana, em 13/07/16). } \\
\text { "Utilido para facilitar o uso do computador por alunos com PC, } \\
\text { TEA, DV e DI" (Professora Vania, em 26/03/15). }\end{array}$ \\
\hline $\begin{array}{l}\text { Teclado Expandido } \\
\text { IntelliKeys }\end{array}$ & $\begin{array}{l}\text { "Utilizo para jogos e outras funções do computador, para fins } \\
\text { pedagógicos com alunos com PC" (Professora Joana em 13/07/16). } \\
\text { "Utilido para facilitar a escrita e o uso do computador por alunos } \\
\text { com PC, TEA, DV e DI" (Professora Vania, em 26/03/15). }\end{array}$ \\
\hline $\begin{array}{l}\text { Teclado convencional } \\
\text { com colmeia de acrílico }\end{array}$ & $\begin{array}{l}\text { "Utilizo para jogos e outras funções do computador, para fins pe- } \\
\text { dagógicos com alunos com PC" (Professora Joana, em 13/07/16). }\end{array}$ \\
\hline $\begin{array}{l}\text { Notebook convencio- } \\
\text { nal com acionador de } \\
\text { pressão }\end{array}$ & $\begin{array}{l}\text { "Acesso à prancha dinâmica pelo aluno com Paralisia Cerebral" } \\
\text { (Professora Joana, em 13/07/16). }\end{array}$ \\
\hline
\end{tabular}

O aluno com DF poderá ter a necessidade de adequação de recursos da informática para acessar o computador ou tablet em virtude da sua mobilidade reduzida, porém, outros alunos com diferentes NEEs podem se beneficiar do uso do computador ou tablet, como, por exemplo, nas atividades que envolvam escrita; para alunos com Distúrbios da Aprendizagem, DI ou TEA, digitar no computador ou tablet pode ser mais simples. Alunos com dislexia escrevem melhor quando digitam o que diminui o conflito gerado pelas questôes espaciais de traçar as letras.

Durante a análise das postagens e em entrevista com os professores, esses relataram que produziram os recursos para alunos com TEA (107), deficiência física (11), Paralisia Cerebral (85), deficiência intelectual (99) e outros (4); e que um mesmo recurso era muitas vezes pensado de maneira que pudesse contemplar várias necessidades educacionais especiais.

Numa abordagem de educação inclusiva, o conceito de Desenho Universal torna-se essencial. A diferença entre os estudantes será a norma que orienta a organização de objetivos, materiais instrucionais, métodos e avaliação, no sentido de promover o envolvimento de todos na construção de co- 
nhecimento. O objetivo é tornar os ambientes mais inclusivos, promovendo condições de acesso à locomoção, comunicação, informação e conhecimento para todas as pessoas.

\section{Conclusão}

No campo da inclusão das pessoas com deficiência e Transtorno do Espectro Austista, um currículo verdadeiramente inclusivo vem marcado por um aspecto essencial denominado Adaptação Curricular (AC). As ACs são os “ajustes" realizados no currículo para que ele se torne apropriado ao acolhimento das diversidades dos alunos. Envolvem modificações organizativas nos objetivos e conteúdos, nas metodologias e na organização didática, na organização do tempo e na filosofia e estratégias de avaliação, permitindo o atendimento às necessidades educativas de todos os alunos em relação à construção do conhecimento. São as transformaçōes que a escola precisa fazer para garantir a acessibilidade aos alunos quanto às adaptações pedagógicas ou curriculares propriamente ditas (Oliveira e Machado, 2007). A adequação dos recursos tem uma relação direta com o currículo escolar. Eles tanto são determinados pelos objetivos da intervenção de ensino, como são meio para que os objetivos se realizem (Araújo e Manzini, 2001).

Atuar com alunos que necessitam de conhecimentos sobre Educação Especial exige do professor mais atenção em relação à sua prática. Além de adaptaçóes do espaço físico, de serviços de apoio, de um material pedagógico adequado, dos recursos e serviços de TA ou de qualquer alteração essencial para facilitar o processo de aprendizagem, o aluno com necessidades educacionais especiais necessita de intervençóes e de algumas adaptaçóes na apresentação dos conteúdos. Assim, o professor que possui um aluno com NEEs em sua SRM ou sala de aula não pode deter-se em planejamentos padronizados de ensino. Ao contrário, as necessidades específicas do aluno especial também criam a necessidade de novas e diferentes formas de apresentar o conteúdo escolar, ação que proporciona mais compreensão por parte desse aluno e dos demais.

Apesar de encontrarmos nas postagens 31 imagens que se referem a recursos de CAA, percebemos que é muito inferior ao número de postagens 
sobre material pedagógico adaptado ou especialmente produzido. As professoras referiram que, devido à grande demanda de trabalho e à maneira como está pensado o currículo, não existe tempo para conversar com os alunos. Isso é preocupante, uma vez que sabemos que os recursos de CAA podem auxiliar no processo de aquisição e desenvolvimento da linguagem para o desenvolvimento da competência comunicativa, bem como também podem inserir o aluno com deficiência e TEA que possua necessidades complexas de comunicação em diferentes atividades pedagógicas e extracurriculares, colaborando, assim, para o processo de ensino e aprendizagem.

As adaptações nas atividades e nos materiais por meio de sistemas de comunicação suplementares e alternativos são importantes para trabalhar diversos conteúdos acadêmicos (Sameshima, 2011; Massaro et al., 2010; Deliberato et al., 2008; Deliberato et al. 2007; Paura e Deliberato, 2007). Na escola, o educador deve criar ambientes sociais e significativos que apoiem a aquisição de sistemas alternativos de comunicação, pois esses ambientes não se constituem naturalmente. A comunicação suplementar e alternativa não é uma forma natural de comunicação, assim, o desenvolvimento da linguagem demanda um processo de construção e planejamento (Von Tetzchner et al., 2005; Von Tetzchner, 2009; Downing, 2009). 


\title{
Capítulo 11 - Ampliando o olhar sobre o programa de formação continuada de professores das Salas de Recursos Multifuncionais da cidade do Rio de Janeiro
}

\author{
Patricia Fernandes Ferreira ${ }^{1}$ \\ Leila Regina d'Oliveira de Paula Nunes ${ }^{2}$ \\ Carolina Rizzotto Schirmer ${ }^{3}$
}

O Programa de Implantação de Salas de Recursos Multifuncionais (SRMs), instituído pelo Ministério da Educação, por intermédio da Secretaria de Educação Continuada, Alfabetização, Diversidade e Inclusão - SECADI, vem garantindo o atendimento educacional especializado, de forma complementar ou suplementar ${ }^{4}$ (atualmente, Transtornos do Espectro do Autismo), aos educandos com deficiência, transtornos globais do desenvolvimento, e altas habilidades matriculados no ensino regular. $\mathrm{O}$ professor do AEE deve considerar as habilidades e as necessidades educacionais específicas dos estudantes público-alvo da Educação Especial para oferecer um atendi-

1 Mestranda em Educação pelo Programa de Pós-Graduação em Educação da UERJ. Secretaria Municipal de Educação do Rio de Janeiro. E-mail:pferreira@rioeduca.net.

2 Professora titular da Faculdade de Educação e do Programa de Pós-Graduação em Educação da UERJ. E-mail: leilareginanunes@terra.com.br.

3 Professora adjunta da Faculdade de Educação da UERJ. E-mail: ead.carolina@gmail. com.

4 Atualmente Transtornos de Espectro do Autismo 
mento que elimine os obstáculos que impedem o desenvolvimento da sua aprendizagem e a participação na sociedade.

A ampliação da oferta do Atendimento Educacional Especializado na rede municipal de ensino do Rio de Janeiro pleiteia uma formação continuada que permita ao professor refletir sobre a sua ação, implementar melhores práticas pedagógicas e desenvolver um olhar sobre os processos educacionais que se assente no princípio de que toda criança pode aprender. Diante do exposto, o Instituto Helena Antipoff (IHA), por intermédio da Oficina Vivencial (OV) e da UERJ, vem desenvolvendo, desde o ano de 2013, um projeto para a implantação das Salas de Recursos Multifuncionais de Referência. Programa este que proporcionou a construção de espaços de multiplicação da Tecnologia Assistiva nas onze Coordenadorias Regionais de Educação do Rio de Janeiro.

As atividades desenvolvidas tiveram a finalidade de implementar e avaliar um programa de formação continuada de professores da rede pública de ensino municipal para atuação nas SRMs de Referência, que funcionarão como agentes multiplicadores das ações formativas da OV. Durante os quatro anos de realização do projeto, os docentes que atuam em SRMs foram ensinados a planejar, implementar e avaliar recursos e serviços de Tecnologia Assistiva (TA) e Comunicação Alternativa e Ampliada (CAA) para atender alunos do ensino fundamental que apresentem severos comprometimentos em sua comunicação oral.

No final de 2016, uma entrevista semiestruturada foi realizada com cada professor que participou do projeto. Esse procedimento de coleta de informações tem sido muito utilizado na pesquisa em educação, pois permite a descrição do fenômeno estudado por meio de perguntas principais que podem ser complementadas por outras questôes pertinentes ao assunto da investigação. As entrevistas foram realizadas pelas professoras da $\mathrm{OV}$ e pelas mestrandas da UERJ, Patrícia Ferreira e Stefhanny Silva.

As entrevistas tiveram como foco principal a compreensão do trabalho do professor que atende nas SRMs de Referência e sua relação com os professores das classes comuns, além da avaliação de todo o curso de formação ofertado ao grupo de docentes participantes desde 2013 pela OV, juntamente com professoras da UERJ. As entrevistas tiveram duração mínima de 30 minutos e máxima de 90 minutos, foram realizadas nas escolas em que as professoras são regentes e gravadas em áudio ou vídeo. 
Foi realizada uma análise de conteúdo preliminar das entrevistas, que mostraram, antes de tudo, que os professores e diretores da unidade escolar possuem demasiadas e equivocadas expectativas com relação ao trabalho na SRM, pois desconhecem as reais funções desse serviço e acreditam que o Atendimento Educacional Especializado deve assumir, solitariamente, o processo de desenvolvimento, ensino e aprendizagem dos alunos público-alvo da educação especial. Podemos confirmar o que foi declarado por meio das falas das professoras citadas abaixo e cujos nomes são fictícios:

Mariana: Pois é, as atribuiçōes da sala de recursos eu preciso sempre explicar, porque, às vezes, eles criam expectativas que vão além das atribuiçôes da sala de recursos. E o problema não é exatamente este, mas é que isto pode acabar prejudicando a inclusão de fato, porque senão o aluno passa a ser só da sala de recursos. [...] E aí assim, tem sempre que explicar o público-alvo, tem sempre que estar explicando. Ainda mais quando muda o professor e às vezes chega um professor que não conhece nada de autismo.

Como vimos, as incumbências dos professores que atendem nas Salas de Recursos Multifuncionais, assim como o seu público-alvo, ainda não estão claros para os docentes da turma regular. Esse desconhecimento acarreta um estado de apreensão e medo. Até certo ponto, essa reação é natural, sendo útil para o professor adaptar-se e reagir perante essa situação de grande expectativa. Contudo, quando ela atinge um nível que interfere no fazer pedagógico do docente, constrói uma barreira na construção de uma escola de qualidade para todos. O professor de SRM precisa estar, a todo momento, oferecendo assessoramento para esclarecer todas as peculiaridades que envolvem o seu ofício. Esse fato atrapalha o desenvolvimento das atividades com alunos, pois não há uma unidade no trabalho. Ele fica um tanto isolado dentro de um universo muito maior, que é a escola, como mostra o seguinte relato:

Karla: A ansiedade é total, por isso que eu faço questão de a primeira vez que eu vou conhecer, já vou assim cheia de documentos, com propostas, levo a maneira como trabalho, justamente para tentar minimizar isso e mostrar que a gente está junto, que fazemos parte de uma equipe e que vamos tentar com o objetivo de conseguir. 
O gestor, por sua vez, também não compreende as obrigações do AEE junto à sua comunidade escolar. De acordo com as informações coletadas nas entrevistas, esse profissional é visto como salvador, tranquilizador de alunos e professores, avaliador de alunos, um mágico que chega à escola e resolve todos os problemas, um fiscalizador do seu trabalho. Enquanto esse papel não estiver bem claro, ainda encontraremos instituições escolares com discurso inclusivo, mas com atitudes excludentes, pois estão sendo dirigidas por profissionais que não se apropriaram de todos os aspectos que envolvem o fazer pedagógico.

$\mathrm{O}$ desconhecimento e a falta de confiança que professores regulares e gestores mostram com relação ao papel do professor das salas de recursos multifuncionais, assim como o isolamento e o sentimento de desvalorização que esse professor vivencia, foram registrados igualmente pelo conjunto de estudos desenvolvidos por 76 pesquisadores oriundos de 21 universidades localizadas em 38 municípios brasileiros, com a participação de 596 professores das Salas de Recursos Multifuncionais e coordenados pela professora Enicéia Mendes, no Observatório Nacional de Educação Especial, iniciado em 2010 e finalizado em 2015 (Mendes et al., 2015a; Mendes et al., 2015b).

Carmen': Olha, tem diretor que, quando me recebe, acha que eu tenho que resolver. Tem diretor que acha que aluno é meu e não da escola. Tem diretor que acha que eu sou alguém do IHA e que eu tenho que resolver esse problema. Tem gente que fala assim 'Você como é lá do IHA, pode me ajudar'. Tem diretor que acha que eu sou avaliadora para avaliar o fulaninho que não é da sala de recursos.

O diretor da unidade escolar é personagem principal nesse processo de implantação de uma cultura educacional inclusiva e precisa estar preparado para articular conhecimentos, pessoas e processos. Entre as escolas participantes da pesquisa, também encontramos líderes que garantem a abertura de novos espaços de diálogo e parceria destinados à transformação do cotidiano escolar. Sua posição de autoridade, liderança e, principalmente, seu papel articulador dentro da escola foram fundamentais para a construção de um espaço de qualidade para todos.

5 Nome fictício. 
Eliane $^{6}$ : Eles dão total apoio. A direção tem essa visão de inclusão tanto que eu lhe falei que esse projeto é um ganho também de toda a escola que visa, que tem esse foco no aluno especial. $\mathrm{E}$ a direção tem dado todo apoio.

Anete: Eu acho que também tenho um trunfo muito grande que é a direção. Isso eu acho que é fundamental no trabalho. Eu mostrei o meu valor, elas acreditam nesse valor e elas compram a briga. Então, isso é um diferencial tanto aqui quanto na outra escola.

A inclusão educacional constitui um processo complexo e inovador que exige mudanças de atitude e uma reflexão permanente a respeito das lógicas que regem a reestruturação e o ordenamento das instituições escolares. O gestor, por meio de suas atitudes, pode facilitar ou dificultar o desenvolvimento de uma cultura na qual o diálogo e a parceria devam ser o carro chefe para a implantação de processos educativos e de relações que favoreçam ações e responsabilidades compartilhadas. Nos últimos anos, essa ideia de colaboração vem sendo defendida com muita propriedade por vários estudiosos da área da educação em geral e, mais especificamente, na prática do professor do atendimento educacional especializado. Este precisa realizar um trabalho articulado com o regente da turma comum para que se possa garantir o acesso do aluno com deficiência ao conhecimento, ao espaço físico, às interações e à comunicação.

De acordo com a análise do conteúdo das entrevistas, tem sido um grande desafio estabelecer uma relação de troca e colaboração com a maioria dos professores das turmas regulares, tencionando obter maiores informações sobre seus desempenhos e gerar maior probabilidade do que o trabalho desenvolvido nas Salas de Recursos Multifuncionais reflita nas classes comuns. Vários obstáculos têm se colocado no caminho dessa via de mão dupla: a ausência de uma Sala de Recursos Multifuncionais em cada escola; as inúmeras atribuições do professor do AEE; a resistência de alguns professores em aceitar o aluno com deficiência em sua turma; a rejeição das orientações de trabalho oferecidas pelo AEE; a falta de contato com todos os professores

6 Nome fictício 
que atuam no segundo segmento ${ }^{7}$; a falta de conhecimento do professor da turma regular e do diretor sobre a deficiência apresentada pelo aluno; a falta de espaço nas reuniões pedagógicas; a falta de relações interpessoais com os demais professores; a rotatividade de educadores e diretores; e o trabalho desarticulado com a proposta de uma educação inclusiva.

$\mathrm{O}$ professor especialista, aquele que atende às turmas de segundo segmento, constantemente questiona os regentes que atuam no Atendimento Educacional Especializado com relação às suas capacidades acadêmicas para realizar adaptações de aprendizagem para os alunos público-alvo da educação especial das disciplinas das quais não possuem formação. Ele sente-se afrontado e invadido quando alguém que, supostamente, tem um conhecimento inferior ao dele com relação àquela matéria tenta lhe dizer como trabalhar com determinado aluno. $\mathrm{O}$ educador do AEE aproveita todos esses momentos para estabelecer um diálogo colaborativo com esse docente. Investiga seus interesses em relação ao aluno com necessidades educacionais especiais para, a partir deles, tentar estabelecer uma comunicação, buscando a quebra das barreiras que impedem uma relação de parceria entre eles, mas nem sempre obtém sucesso. Alguns regentes, definitivamente, demonstram não desejar estabelecer essa parceria com o AEE.

Anete: Já fui questionada de qual é a minha formação várias vezes, principalmente pelo professor de Matemática. 'Ah, mas qual é a sua formação para você ensinar Matemática?' Eu falei que a minha formação era de Geografia, como PI, mas eu tinha estudado até o $9^{\circ}$ ano. Então, eu poderia não saber Matemática no mesmo nível que ele, mas no mesmo nível que o meu aluno precisava eu sabia. E que quando eu não soubesse eu pediria ajuda a ele.

Luana: Tem alguns que realmente são porta fechada, eles não querem. Porque o que eles querem é um professor de reforço. Não tem um professor de reforço, então a sua parceira não me interessa. E aí eu vou tentando abrir essa porta, eu vou forçando um pouquinho, mas sempre com muita leveza, com afetividade, porque eu sou muito afetiva. Essa coisa de criar laços, de carinho,

7 Professor do ensino fundamental do $2 .^{\circ}$ segmento (6. ${ }^{\circ}$ ao $9 .^{\circ}$ ano de escolaridade). 
de conversa, de dar atenção é minha característica. Então eu utilizo isso a meu favor.

Eliane: Para se aproximar do professor a gente até conversa com relação às aplicaçóes de provas, das dificuldades que eles têm nessas provas, das formas de avaliação. A gente conversa sobre provas orais, outros instrumentos que facilitem a prova, até mesmo uma adaptação dessa prova. Então, é muito mais complicado lidar com o PI quando você fala de adaptação, do que com o PII ${ }^{8}$. Eles já estão mais abertos a isso. O PI você encontra muita resistência.

Eliane: Muitas vezes, o professor sente que você está tentando mexer com aquilo que ele já preparou. Então, às vezes, ele fala 'Ah, eu vou facilitar muito para esse aluno' e não entende que é uma questão da deficiência dele que pede que seja mexido.

Alguns educadores da turma regular demonstram dificuldade em aceitar o aluno com deficiência em sua sala de aula. Não se sentem responsáveis pela aprendizagem e desenvolvimento desse estudante. $\mathrm{O}$ Atendimento Educacional Especializado precisa realizar um trabalho intenso de aceitação dessa criança ou adolescente por parte do professor. Quando isso acontece, o trabalho do AEE junto a esse profissional deve ser pautado na paciência e na flexibilidade, para que esse empecilho não atrapalhe o processo de inclusão do aluno.

Mariana: Isso depende muito de professor para professor. Tem professor que é mais resistente. Já teve professor que eu tive que estimular mais a aceitação da inclusão do aluno, porque, por exemplo, eu orientava e ele dizia que não estava conseguindo fazer. Aí eu montei um caderno para ela e o professor disse que ela não fazia nada. Aí eu falei 'Ué, mas ela não está usando o caderno?'. Aí ele me disse que ela não tirava o caderno da mochila. Então, a gente lida com a ansiedade do professor, porque se eu chegar com força vai ser uma relação que vai ficar cada vez mais difícil. Então, tem que ter um pouco de

8 Professor do ensino fundamental do $1 .^{\circ}$ segmento (1. ${ }^{\circ}$ ao $5 .^{\circ}$ ano de escolaridade). 
tolerância e falar 'Não, mas olha, se você puder, pede para ela tirar o caderno da mochila'. A menina além de ser DI tinha uma questão familiar bem grave sabe. Pai alcóolatra, a menina não dormia à noite por causa das brigas. Então ela chegava na escola sonolenta.

Outro fator que dificulta a relação dos professores da turma regular e do atendimento educacional especializado é a rotatividade de professores dentro da unidade escolar. Muitos não possuem a formação adequada para trabalhar na perspectiva da educação inclusiva, o que bloqueia o processo de aprendizagem dos alunos público-alvo da educação especial. Diante disso, o AEE é visto como o "salvador da pátria" e precisa desenvolver estratégias de atendimento tanto para esses alunos como para os professores. É um trabalho árduo que é afetado pela ausência de uma Sala de Recursos Multifuncionais em cada escola.

Anete: Essa coisa da visita no contra turno sem encontrar os professores é muito complicada. O meu trabalho flui muito melhor hoje enquanto sala de recursos dos alunos de dentro da escola $\mathrm{B}$ do que quando eu era da sala de recursos da escola $C$ e atendia a escola $B$, porque eu vinha de 15 em 15 dias, de mês em mês, o que desse eu vinha para visitar. Você não cria laços, você não cria amizade, você não tem o dia a dia.

Se, por um lado, ele é considerado a pessoa que é capaz de resolver qualquer coisa, por outro, é tratado pela gestão como um verdadeiro estranho, um visitante que vai até a sua unidade escolar, presta um serviço e depois vai embora. Não se percebe um esforço por parte da equipe gestora para inserir o AEE no planejamento, no dia a dia da escola. Percebe-se, com essa postura, uma total ausência de um trabalho pedagógico voltado para a inclusão, além de uma completa desvalorização do profissional.

Clotilde: E, em relação à direção, se você chegar na secretaria e falar assim 'Clotilde está aí hoje?', elas vão dizer 'Clotilde? Eu não sei te dizer'.

A análise dos dados também mostrou que existem escolas nas quais os professores do AEE conseguem estabelecer uma relação de colaboração, mesmo que parcial, com os docentes da turma regular. Alguns elementos 
facilitam esse vínculo: o atendimento e o suporte dado aos regentes da turma comum satisfazem as suas necessidades pedagógicas; a comunidade escolar compreende todas as singularidades do trabalho do AEE; a predisposição de alguns professores para o trabalho colaborativo; os professores de todas as turmas conhecem as necessidades e o trabalho desenvolvido pelo AEE junto aos estudantes; o fato de as turmas de primeiro segmento serem atendidas por um único educador; equilíbrio, resignação e perseverança por parte do AEE no trato com os demais profissionais; o fato de o AEE também atuar na turma regular em outro horário; o apoio da direção; e a participação do AEE na maioria das reuniões pedagógicas.

A professora de uma unidade escolar revelou que os docentes da turma comum sentem-se amparados com relação ao atendimento que é dado aos alunos e ao suporte que é oferecido a eles pelo AEE. A compreensão do papel desse profissional por todos os envolvidos no processo educacional, mais especificamente pelo professor que está atuando junto ao aluno que apresenta deficiência, respalda o trabalho desse regente e o deixa mais seguro e à vontade para buscar novas possibilidades de ajudar essa criança ou adolescente.

Alguns professores possuem uma predisposição, uma flexibilidade para o trabalho colaborativo. Eles interagem com o outro e criam uma ajuda mútua, bilateral, pois estão engajados em um processo conjunto de tomada de decisão, trabalhando em direção a um objetivo comum: o aprendizado e o desenvolvimento dos alunos com necessidades educacionais especiais. Compartilham metas, responsabilidades e recursos. Geralmente, são educadores novos na escola e na profissão. Diante desse cenário, os resultados não demoram muito a aparecer.

Clotilde: Eu tive uma colega ano passado que realmente trabalhou comigo colaborativamente. Nós pegamos uma menina que veio da Colômbia que não falava nada em Português, que não entendia nada. Venezuela, desculpe! Nós tivemos que alfabetizá-la em Português para poder trabalhar. E aí só para você ter uma ideia do que foi trabalhar colaborativamente, nós tínhamos um caderno só. As atividades que eu fazia colava no caderno. As atividades que ela produzia, a partir das orientações que eu dava de adaptação, ela colava no caderno. A mãe dela ficou radiante porque a menina ficou aqui na escola oito meses e ela saiu daqui, não lendo, mas sabendo as famílias silábicas. 
Mariana: Atualmente eu consigo. Teve um grupo aqui que era um pouco mais resistente, mas o grupo atual é um grupo de parceria. A gente consegue fazer uma parceria.

A professora Valéria contou que um aspecto que facilita a sua interação com os demais docentes da escola é o fato de conhecerem as especificidades de todos os alunos atendidos na Sala de Recursos Multifuncionais, pois as conversas que acontecem entre eles são coletivas, e não ficam centralizadas somente no professor de determinado aluno. Nesse panorama, o estudante é visto como da escola, e não como exclusividade do educador que o atende na turma regular. Um outro cenário vivenciado, agora, pela professora Eliane também auxilia na construção de um diálogo colaborativo: o fato de os professores atuarem em turmas de primeiro segmento, onde estão todos os dias, na instituição escolar, em contato diário com o aluno, o que não ocorre com o regente de segundo segmento, que frequenta a escola somente alguns dias da semana. Essa proximidade entre ele e o estudante acaba se perdendo.

Valéria: Todo mundo conhece todas as crianças aqui da escola, porque a gente conversa muito sobre cada criança da escola, independente daquele professor. Não fico centralizada naquele professor. Eu acho isso importante.

Eliane: Então, nas turmas menores a gente tem apoio dos professores, até porque tem essa proximidade do aluno com o professor. Nas turmas maiores são vários professores e esse contato diminui. Então, nem todos os professores a gente consegue entrar em contato, porque quando a gente vai visitar, geralmente, é aquele professor do dia e as conversas ficam mais com aquele professor. E assim essa proximidade acontece mais com os alunos em que a gente encontra o PII. O PI é sempre um pouco mais difícil de lidar também.

Os dados da entrevista mostraram que, quando a professora da Sala de Recursos Multifuncionais também atua na sala de ensino regular, há uma compreensão maior com relação aos medos e às dificuldades enfrentadas pelo docente da classe comum, o que facilita a construção de relaçôes colaborativas. 


\begin{abstract}
Alana: A relação é muito boa, até porque eu também sou professora de sala comum. Então, eu entendo muito bem os questionamentos do professor de sala comum. Há três anos eu não tenho alunos incluídos pelo fato de eu estar sempre com as maiores turmas do terceiro ao quinto ano, mas eu já trabalhei muito com crianças incluídas. Eu sei o que os colegas passam. Então, essa ponte de você também saber o que o outro lado está passando é legal.
\end{abstract}

Como pudemos perceber, os dados da entrevista mostraram que existem muitos fatores que dificultam a relação do professor da turma comum com o professor da Sala de Recursos Multifuncionais. Contudo, encontramos também várias realidades que expressam possibilidades reais de mudança em favor de uma educação que valorize a aprendizagem e o desenvolvimento de todos os alunos na classe comum. Para ajudar nesse processo de mudança de posturas, valores e práticas, é necessário investir na formação continuada desses professores. Formação esta que já vem sendo oferecida desde o ano de 2013 pela Oficina Vivencial, juntamente com as professoras da UERJ, aos docentes entrevistados.

As informações que serão apresentadas neste momento fazem parte da avaliação que as entrevistadas fizeram do curso de que participaram no período de 2013 a 2016. O grupo de professores que iniciou o curso de formação no primeiro ano da pesquisa não permaneceu junto até o final do projeto. Os participantes que entraram depois sentiram, inicialmente, certa dificuldade para compreender a proposta de trabalho. Houve uma perda no processo de construção de conhecimentos deles. Contudo, com o passar do tempo e dos encontros, os objetivos e as estratégias ficaram mais claras.

Valéria: Eu me senti muito perdida. Primeiro que eu não entendia muito
bem, eu não conseguia. Quando eu entrei, na verdade, eu não conhecia mui-
to a proposta do trabalho. Aos pouquinhos eu fui conseguindo entender e tal.
É difícil você entrar num trabalho que já está sendo desenvolvido desde 2013 .
Então, assim, é meio complicado. Agora eu estou me sentindo mais segura, já
estou entendendo qual é a proposta, mas no início foi bem difícil conseguir
entrar mesmo e conseguir caminhar junto.

As professoras que participaram dos quatro anos de formação acharam que o curso contribuiu muito para a sua prática pedagógica e para mudanças 
de posturas em relação ao trabalho desenvolvido nas Salas de Recursos Multifuncionais. Os encontros serviram para enriquecer as atividades desenvolvidas junto aos alunos com deficiência e ampliou a visão para a busca de novas estratégias. A sensação de que nada que estava fazendo era correto foi substituída pelo sentimento de fortalecimento diante das vivências relatadas pelas outras regentes. Os momentos de troca de experiências entre os docentes e os formadores foi um dos pontos-chave da formação, pois elas não tinham muita noção do que era comunicação alternativa, e esses momentos favoreceram o esclarecimento das dificuldades vividas no dia a dia dos atendimentos.

\begin{abstract}
Mariana: Assim, eu achei importante e foi uma coisa que foi se estendendo. Ia ser um ano, depois virou dois, depois três anos. Então, foi tendo movimento. Não sei se já vou começar a responder as outras perguntas sem querer. Foi legal também ver aquela coisa do espelhamento. Às vezes você passa uma situação na sua escola e aí você sente que tem que ter paciência e muita tolerância. Que não pode bater de frente e tal e, às vezes, você se sente sozinha.
\end{abstract}

Karla: Eu achei ótimo, porque eu acho que tudo que vem enriquecer o nosso trabalho, ampliar a nossa visão é sempre bem-vindo. O objetivo da sala de recursos inicial, achei interessantíssimo. Eu acho que é necessário as professoras de sala de recurso estarem sempre trocando.

Eliane: Quando eu comecei, tinha aquela visão da comunicação alternativa. Era como se eu fosse uma criança dando os primeiros passos. Mas a gente vê os colegas comentando a respeito de como é o lidar delas nas salas de recursos com as crianças que tem recebido. A gente vê que o trabalho é igual, que a gente tem também as nossas dificuldades. A gente vê que uma palavra de um colega, muitas vezes, vem contribuir com o nosso trabalho.

As palestras ofertadas aos professores foram muito interessantes e ministradas por profissionais que tinham bastante experiência de vida profissional e acadêmica para transmitir. Em um primeiro momento, alguns professores não possuíam alunos com necessidade de comunicação alternativa, mas esse fato não tirou o brilho e a importância dos conhecimentos trabalhados 
pelos palestrantes. A forma como o conteúdo das aulas foi trabalhado instigou a busca por novos conhecimentos.

Joana: Eu gostei bastante, porque a gente teve muitas palestras bacanas com pessoas bacanas que trouxeram muita bagagem para a gente de informação que a gente não tinha.

Anete: De uma certa forma, acho que foi muito proveitosa. Muita coisa que eu queria aprender ainda não sei, mas, pelo menos eu já sei que aquilo existe com certeza. Então, cabe a mim agora buscar um conhecimento maior. Eu fico muito contente quando eu vou a uma palestra e eu saio dali com um pouco de interrogação na cabeça. Isso para mim é o que vale.

Clotilde: $\mathrm{O}$ início, naquela parte mais teórica, onde os convidados foram para se apresentar foi um embasamento teórico que você acha que poderia procurar na internet. Mas não, porque é diferente você procurar na internet e ler e ter o profissional falando com você. Então, eu achei que foi extremamente válido.

Um dos pontos de maior expressão do curso de formação foi o fato de os formadores serem professores ainda atuantes na área da educação especial. Nesse caso, teoria e prática caminham juntas, uma complementando e respaldando a outra. O conteúdo que está sendo trabalhado ganha credibilidade e, quando isso ocorre, as pessoas se interessam mais, pois veem significado no que estão estudando. A atividade de autoscopia, na qual as professoras filmavam suas atividades e depois assistiam e avaliavam seus procedimentos, foi um dos instrumentos que ajudou a dar sentido, relevância e uma orientação para as experiências vividas diariamente nas salas de recursos.

Anete: Eu acredito muito no trabalho de formação em que o professor seja professor ainda atuante. [...] Eu acho que esse professor está certo. Ele tem que continuar atendendo, não pode sair do atendimento porque ele passa a falar de uma teoria, no meu entender. Ele não passa mais a viver aquela prática. E quando a gente deixa de praticar, a gente perde muito a referência. Eu 
penso assim. Então, eu acho que a formação feita com quem está ali no campo com você trabalhando, trocando, sentindo na pele as mesmas dificuldades que o outro sente, é fantástico. Eu acho que isso ajuda a aumentar muito a chance de dar certo.

Anete: Foi muito interessante a questão de se ver filmar, de ver a sua filmagem. Isso é uma coisa que para mim trouxe muita luz mesmo. Às vezes eu queria que o aluno fizesse aquilo daquele jeito. Se eu fosse mais flexível, ele faria. Mas na hora você não percebe, você está tão envolvido, que não percebe.

Com relação aos procedimentos de ensino empregados pelos professores/palestrantes, os dados da pesquisa mostraram que o modo como eles se organizaram para atingir os objetivos de estudo foi muito adequado e relevante, pois priorizaram a prática, o que possibilitou a troca de experiências, o diálogo e a construção de novas estratégias de ensino e aprendizagem.

$\mathrm{O}$ curso de formação oferecido pela Oficina Vivencial, em conjunto com as professoras da UERJ, foi um grande sucesso, teve grande relevância social e acadêmica. Durante esses quatro anos de formação, detectamos na fala dos entrevistados vários pontos fortes: amadurecimento dos participantes; oportunidade de participar de congressos na UERJ; exemplos práticos trazidos pelos palestrantes; compartilhamento das experiências com a comunidade escolar; conteúdo funcional; atividades de estudo de caso; utilização de tecnologia de ponta; implementação das Salas Abertas e os laços que foram criados com os professores de outras escolas. Tivemos, também, alguns pontos que necessitam de um olhar mais atencioso por conta de terem sido citados como pontos fracos na formação. São eles: conversas paralelas durante os encontros, o que atrapalha o desenvolvimento do trabalho; pouco tempo para o desenvolvimento das atividades das Salas Abertas; deslocamento da escola até o local de formação; encontros muito distantes um do outro; datas dos cursos que coincidiam com a semana de conselho de classe ou com a semana de prova; aplicativos difíceis de serem manejados; poucas intervenções teóricas na apreciação dos vídeos; pouco tempo para organizar os encontros das Salas Abertas; e formaçóes com temas voltados somente para o público infantil. 
Esse trabalho provocou impactos nas práticas pedagógicas dos professores junto aos alunos que são atendidos nas Salas de Recursos Multifuncionais, no sentido das estratégias, da postura, da seriedade e da autoestima. Percebe-se uma diferença entre as práticas pedagógicas e as posturas dos professores antes e depois da realização do curso de formação. Ele foi decisivo, um marco na vida profissional de muitos educadores. Possibilitou uma postura mais segura diante dos atendimentos que são dados aos responsáveis pelos alunos e aos profissionais de saúde que atendem os estudantes. $\mathrm{O}$ atendimento realizado pelo AEE teve uma melhora na qualidade, pois passou a ter um olhar diferenciado para a comunicação alternativa, assim como para as experiências vividas e ouvidas e para os materiais utilizados. Esse curso deu voz e vez aos professores carentes de uma formação que estivesse de acordo com suas necessidades, e também aos alunos, que sentiam a falta de práticas pedagógicas que os auxiliassem a aprender, a desenvolver-se socialmente e emocionalmente e a interagir com o mundo.

A continuidade do curso de formação é uma possibilidade, já que ele foi de extrema relevância e significação para professores, alunos e comunidade. Algumas sugestōes, fornecidas pelos participantes no momento da entrevista, dão algumas recomendaçôes que merecem destaque, a saber: continuidade, nas formações, do modelo que já vem sendo praticado; implementação das Salas Abertas em toda a rede municipal de ensino do Rio de Janeiro; revisão das excessivas atribuiçóes dos professores das Salas de Recursos Multifuncionais; reavaliação da quantidade de alunos que são atendidos pelo AEE; mais tempo para planejar e confeccionar o material necessário para o trabalho; que a Sala de Recursos Multifuncionais de Referência torne-se um espaço de formação e de troca de experiências em cada coordenadoria regional de educação; continuação do processo de autoscopia e de estudo de caso; ampliação dos espaços de troca de experiências; formações ministradas por professores que atuam nas SRMs e priorização de temas diversificados relacionados aos alunos com deficiência.

Pode-se afirmar que a parceria entre a Oficina Vivencial e a Universidade do Estado do Rio de Janeiro, no curso de formação continuada oferecido aos professores de Salas de Recursos Multifuncionais, alcançou os objetivos propostos, pois ampliou a compreensão de questôes políticas e educacionais que visam a garantir a educação inclusiva. $\mathrm{O}$ trabalho com os professores das Salas de Recursos Multifuncionais fomentou questionamentos e posiciona- 
mentos em relação à formação do docente e também às diferentes práticas pedagógicas e aos lugares em que elas acontecem, tencionando assegurar o direito de todas as pessoas à educação escolar de qualidade. As reflexões e os debates sobre o contexto social, a escola e a atuação do professor, tanto da classe comum quanto da Sala de Recursos Multifuncionais, indubitavelmente encontrarão repercussão naqueles que desejam e que se dedicam a construir uma sociedade solidária, em que os direitos humanos sejam promovidos e respeitados. 


\title{
Capítulo 12 - Vamos brincar? O uso da Comunicação Alternativa para favorecer a brincadeira de crianças com dificuldade na comunicação oral
}

\author{
Leila Ferreira Andrade ${ }^{1}$ \\ Vanessa Queiroz Costa ${ }^{2}$ \\ Carolina Rizzotto Schirmer ${ }^{3}$
}

Nosso percurso profissional sempre foi permeado por atividades lúdicas, cores, dança, livros e movimento, visto que atuamos durante muitos anos na educação infantil e na sala de leitura. Mas um novo caminho surgiu e nos desafiou: a educação especial! Uma novidade que requer novas leituras, especializações e olhares. Assim, chegamos à Pesquisa na Oficina Vivencial/ IHA, em parceria com a UERJ.

Antes de continuarmos nossa caminhada, foi preciso uma pausa. Estávamos nos sentindo como um lince, mas no seu início de vida: sem enxergar e sem ouvir. Como poderíamos ajudar crianças sem comunicação ou mesmo com uma oralidade reduzida se não conseguíamos ver ou ouvir?

À medida que a pesquisa se desenvolvia, mais queríamos compreender a comunicação com tais alunos. Assim, semelhante aos linces, nossos olhares

\footnotetext{
Secretaria Municipal de Educação do Rio de Janeiro. E-mail: leilaandrade@rioeduca.net.

2 Secretaria Municipal de Educação do Rio de Janeiro. E-mail: vaneqcosta@yahoo.com. br

3 Professora adjunta da Faculdade de Educação da UERJ. E-mail: ead.carolina@gmail. com
} 
também foram sendo abertos e nossos ouvidos, destampados, para ouvir, embora soe paradoxal, até mesmo o silêncio dos nossos alunos.

Nossos olhos estavam sendo abertos e, como no jogo "Olhos de Lince"4, precisávamos ser rápidas para atender às necessidades de nossos alunos. Os encontros iniciais propiciaram as formaçôes acadêmicas e as experiências de casos, embasando teoricamente nossa prática. Os exemplos mais citados e demonstrados para estabelecer a comunicação foram as pranchas de Comunicação Alternativa e Ampliada (CAA), confeccionadas com imagens, e o uso do PECS-Adaptado5. Foi esse novo caminho que ampliou nossos horizontes.

Em 2015, experimentamos a Análise de Desempenho ${ }^{6}$, que nos revelou muito sobre nossa prática. A cada ida aos encontros no IHA, até mesmo na viagem de retorno para casa, continuávamos discutindo o que havíamos ouvido e aprendido e, assim, novas ideias surgiam. Além das pranchas e do PECS, quais outras possibilidades seriam viáveis naquele momento? Esse era um de nossos maiores questionamentos.

Estávamos diante das necessidades e das possibilidades de construir novos caminhos. Decidimos, então, perguntar aos nossos alunos: "Vamos brincar?”. Quando usávamos a brincadeira como ferramenta pedagógica a cada encontro nas Salas de Recursos Multifuncionais (SRM), eles mesmos nos davam retorno ao apresentarem intencionalidade em se comunicar, propiciando, dessa forma, melhores condições de percebê-los e entendê-los. Assim,

${ }^{4}$ Jogo de tabuleiro em que três figuras são selecionadas e o participante tem um tempo curtíssimo para reencontrá-las no diagrama.

5 O PECS - Picture Exchange Communication System - é um sistema de intervenção de comunicação alternativa, criado por Bondy e Frost (1994), exclusivo para indivíduos com Transtorno do Espectro Autista, de modo que o usuário realize a troca do cartão de comunicação que está em suas mãos por um objeto ou ação desejado. Em 2000, Walter fez uma adaptação da versão original, denominando-a de PECS-Adaptado. A autora manteve o objetivo original, mas efetivou algumas adaptações, considerando uma maior interação entre os usuários baseada nas premissas do Currículo Funcional Natural.

6 Etapa da pesquisa em que os professores assistiam às suas aulas por meio de vídeos gravados e faziam o exercício de refletir em conjunto sobre o modo como exerciam suas práticas pedagógicas. Para maiores detalhes sobre a Análise de Desempenho e os desdobramentos que ela favoreceu à pesquisa, vide capítulo "O uso da autoscopia como aliada na formação continuada de professores de Sala de Recursos Multifuncionais”, de Silva e Nunes. 
nossos medos iam tornando-se menores e nos víamos olhando por diversos ângulos um mesmo recurso; sobrepondo um olhar inovador para estabelecer a comunicação com os alunos. Compreendíamos, conforme Vigotski (2014, p. 31), que

A existência de necessidades ou aspirações põe, desse modo, em movimento o processo imaginativo, revivendo as marcas das excitaçôes nervosas que fornecem material para seu funcionamento. Essas duas condiçôes são necessárias e suficientes para que compreendamos a atividade da imaginação e de todos os processos que a integram.

Para isso, precisávamos ficar bem atentas, pois qualquer intenção de comunicação não poderia passar despercebida pelos nossos olhos e ouvidos. Tínhamos a preocupação de organizar o ambiente de forma apropriada, usar recursos que estimulassem o seu desejo de comunicar e a segurança e a satisfação de estarem conosco na sala de recursos. Optávamos por estimular a comunicação dos nossos alunos por meio da brincadeira e do jogo, de acordo com os fatores expostos por Riper e Emerick:

Pelo menos três fatores ambientais são cruciais para se estimular o desenvolvimento da fala: (1) uma relação positiva sob o ponto de vista emocional com um tutor que incentive as iniciativas de comunicação da criança; (2) pelo menos um modelo de fala (uma pessoa) que utilize padróes de linguagem simples, porém bem-formados; e (3) oportunidades para a exploração e variação das experiências cotidianas que estimulem a necessidade de comunicação (Van Riper e Emerick apud Deliberato, 2007, p. ?).

Brincar era um desafio instigante, porque, brincando, desejávamos promover o desenvolvimento, o aprendizado, os interesses, o bem estar e estabelecer a comunicação. O lúdico tornara-se, então, nosso carro-chefe. Tínhamos necessidade de iniciar com o que nos era familiar, o que nos dava segurança, uma vez que nosso aluno já era, para nós, o desconhecido. Conhecíamos a realidade educacional em que, ao longo dos anos, o processo se tornaria mais árido e os estudos seriam, quase sempre, voltados exclusivamente para os conteúdos programáticos, rígidos e avaliativos, deixando o "brincar" para os anos inicias da vida escolar, especialmente nos Espaços de Desenvol- 
vimento Infantil (EDIS) ${ }^{7}$. Nesse modelo intransigente de educação, o brincar fica para trás e, assim também, o espaço para a criatividade espontânea.

A ausência da oralidade tirava das crianças a possibilidade de comunicar seus conhecimentos e pensamentos, fazendo com que elas ficassem isoladas e excluídas no espaço escolar, bem como em outros meios sociais. Sendo assim, percebemos a importância de resgatar o lúdico dentro de nossas salas, pois, por meio dele, a interação social é estabelecida e o comunicar vai além das palavras. Gestos, olhares, movimentos, risos... Por meio da brincadeira e das atividades lúdicas, o corpo todo fala. $\mathrm{E}$, assim, na tentativa de estabelecer a comunicação, vimos alunos sendo incluídos a partir da possibilidade de brincar em sala de aula com seus pares.

O relacionamento interpessoal é inerente ao ser humano e potencializa o aprendizado. No tocante a isso, o jogo foi tomado como base para a organização das atividades por ser um recurso não apenas atrativo, mas que também possibilita a expressão e comunicação.

A vida escolar exige da criança ler, escrever, pensar, perceber sons/estímulos visuais, entender símbolos e, depois de todas essas experiências, dar resultados. Mas, como responder a tudo isso sem antes estabelecer uma comunicação? Como diz Maia (2014, p. 53),

O jogo no ambiente escolar propicia a espontaneidade do aprender, facilita a integração e comunicação, criando, inevitavelmente, redes sociais e uma busca por responsabilidade e autonomia. $\mathrm{O}$ aprendizado se dá de forma natural, por meio de complexificação do pensamento e das ações de cada criança, cada uma ao seu tempo e também ajudada por todos.

A seguir, temos uma imagem que corrobora a ideia de Maia quanto ao processo de aprendizagem dos nossos alunos de forma natural.

Modelo de escola, criado na Prefeitura do Rio de Janeiro, que reúne, no mesmo ambiente, a creche e a pré-escola, atendendo crianças de seis meses a 5 anos e 11 meses de idade. 
Figura 1 - Crianças

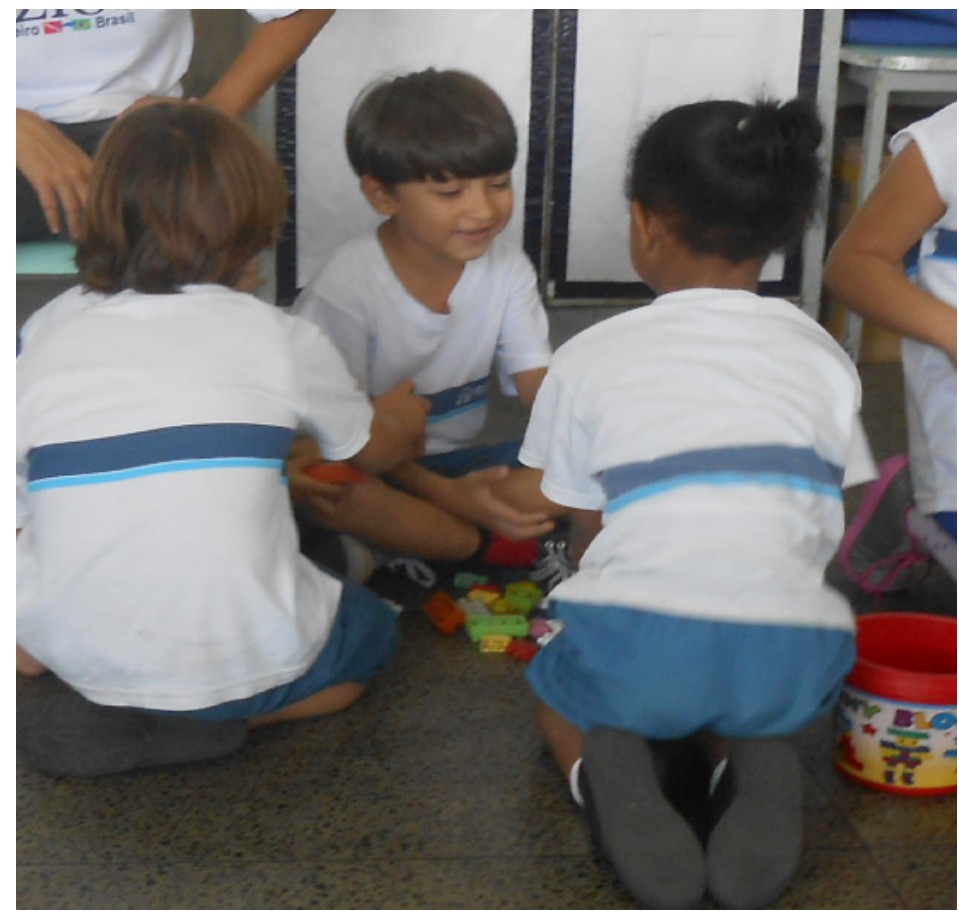

Fonte: L. F. Andrade e V. Q. Costa.

Logo no início do trabalho, os primeiros meses foram resumidos em choros, grunhidos, tentativas de fuga, lágrimas, suores escorrendo, olhares perdidos, mordidas, cuspes, agressões, corpo deitado no chão etc. Para conseguir os primeiros resultados em termos de comunicação, fizemos uso da caixa de antecipação - um recurso da Tecnologia Assistiva de baixo custo que possibilita a organização temporal do aluno. $\mathrm{O}$ recurso providenciado pela professora do Atendimento Educacional Especializado (AEE) era utilizado na Sala de Recursos, e a experiência era repetida na classe comum. Assim que chegava à sala de aula, o aluno era encaminhado pela professora até a caixa que continha as principais atividades do dia: rodinha, blocos de montar, videoteca, refeitório, descanso e saída. As atividades do dia estavam na caixa de antecipação, representadas por objetos tridimensionais que pudessem evidenciar o que teria de ser realizado.

Embora a sala de aula da educação infantil fosse um ambiente que favorece o estabelecimento da rotina de modo bem participativo, o aluno na 
imagem não conseguia, anteriormente, envolver-se com as atividades propostas. Sentar na rodinha para realizar a chamada, contagem de crianças presentes no dia, reconhecimento do nome, identificação do tempo, construção do calendário (dia, mês e ano), lançamento do conteúdo programático, atividades como essas eram sempre muito difíceis, e o aluno se negava a participar, pois queria mexer nos materiais da sala de aula, nos brinquedos, nos murais e ficava andando em círculos.

A caixa de antecipação foi pensada para estruturar a rotina do aluno, dando-lhe maior compreensão e previsibilidade do que ocorreria durante as aulas na sala comum ou durante os atendimentos na Sala de Recursos Multifuncionais. $\mathrm{O}$ uso da caixa de antecipação permitia redirecionar o aluno para a atividade proposta no momento, evitando, inúmeras vezes, comportamentos inadequados.

Aos poucos, conseguimos nos comunicar, e a brincadeira, inicialmente isolada, passou a ser compartilhada com a professora da Sala de Recursos e com seus amigos de turma. Com o passar do tempo, as interaçóes aumentaram e novas possibilidades surgiram: pique-pega, carrinho, bola, troca de brinquedos, jogo da memória, esconde-esconde. A partir dessas experiências, os cartôes com imagens eram introduzidos e o aluno os utilizava para indicar suas vontades, tais como: beber água, ir ao banheiro, sair da sala e pegar um brinquedo. Não havia fala, mas havia comunicação.

Estávamos diante de uma realidade que precisava ser pensada diariamente, porque trabalhávamos com o rompimento da homogeneidade.

O lúdico possibilita traduzir, a partir de linguagens simbólicas e sensíveis, experiências não traduzíveis em palavras. Quando temos o processo de aprendizagem paralisado, normalmente percebemos questóes emocionais associadas a esse processo. E, pela arte, pelo brincar e pela utilização de jogos em uma prática de intervenção na escola, podemos tentar ressignificar esse processo, desbloqueando o caminho que antes existia e fruía (Maia, 2009 apud Maia, 2014).

Utilizamos esse mesmo lúdico, mas com a sensação de estarmos muitas vezes no contrafluxo, porque desejávamos que a criança o utilizasse para traduzir suas experiências em palavras que lhes faltavam, por meio da CAA.

Buscamos nos aproximar de nossos alunos observando seus pontos fortes e realizando o planejamento do Plano Educacional Individualizado (PEI), 
objetivando estabelecer a comunicação com eles por intermédio de diferentes recursos lúdicos, pranchas e cartôes de CAA.

Tendo em vista que um dos interesses de uma aluna com quem trabalhávamos a comunicação alternativa na SRM era brincar de trocar as roupinhas das bonecas, utilizamos uma prancha de CAA confeccionada pela Oficina Vivencial do IHA com figuras das princesas existentes nas histórias de contos de fada.

Figura 2 - Atividade

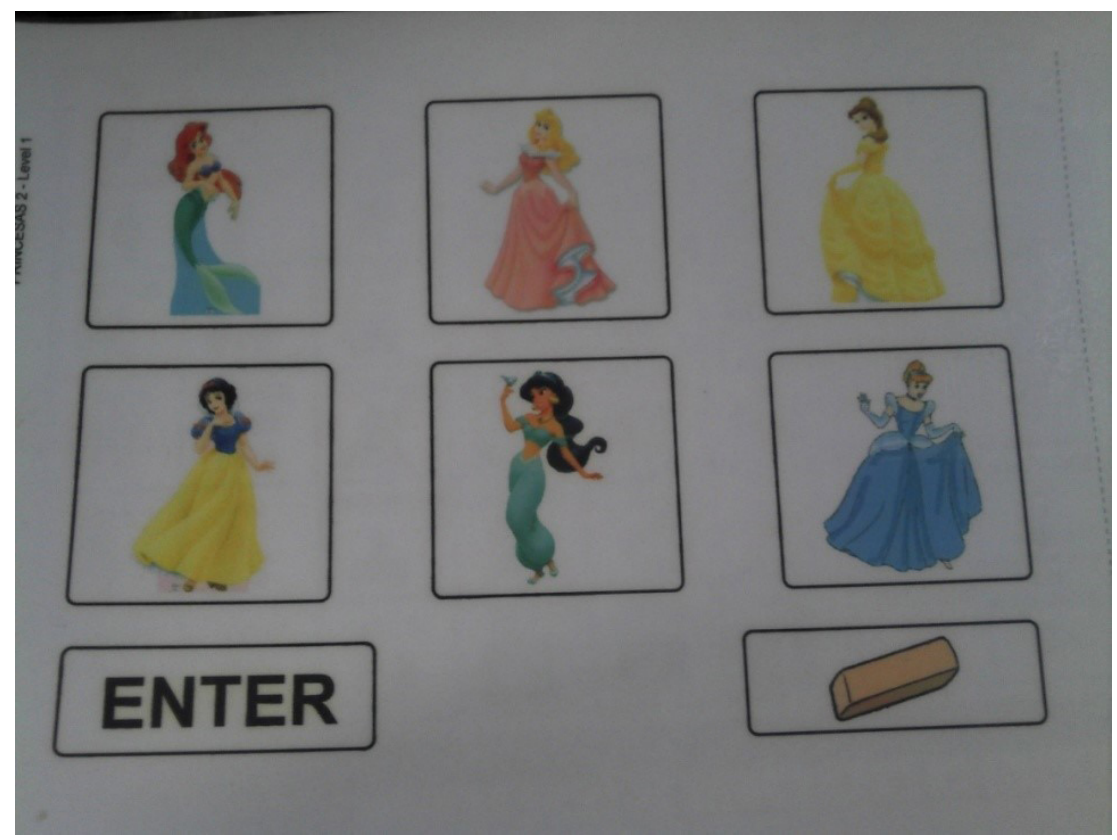

Fonte: L. F. Andrade e V. Q. Costa.

Nessa atividade foi iniciada pela professora da Sala de Recursos uma conversa sobre cada princesa, de modo que a aluna poderia responder de forma direta ou por meio dos cartões. Depois disso, realizava, brincando, o pareamento entre a cor da roupa e a do pregador (vide foto abaixo). 
Figura 3 - Atividade I

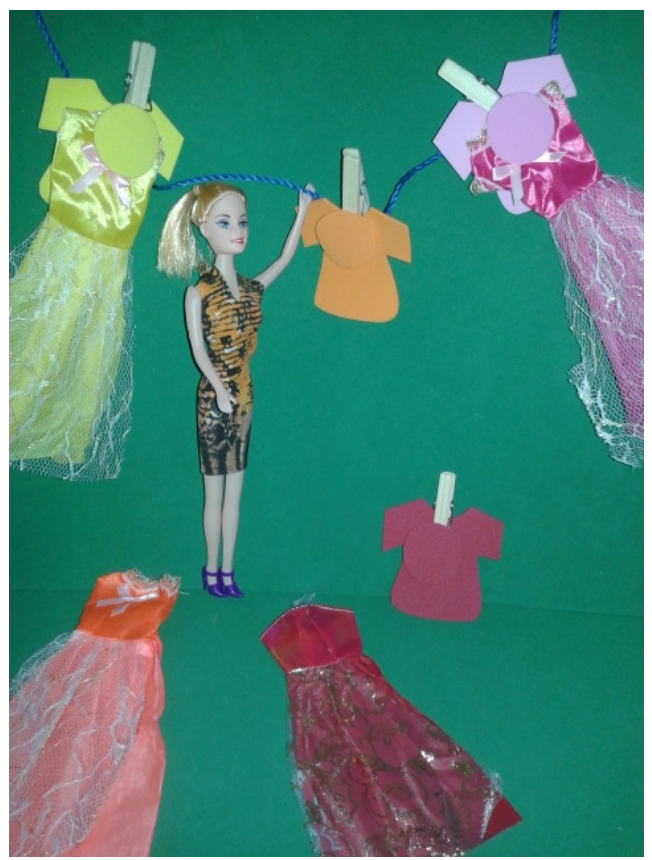

Fonte: L. F. Andrade e V. Q. Costa.

Quando a aluna percebeu que as atividades propostas eram de seu interesse, a interação social entre ela e a professora da Sala de Recursos foi aumentando. Havia o desejo de retornar para o próximo atendimento, pois aquele se tornou um local onde ela era compreendida mesmo sem a fala convencional.

$\mathrm{Na}$ experiência com outro aluno, foi revelado pelo processo de Análise de Desempenho que os sons por ele emitidos tratavam-se de melodias de músicas. Mantendo a perspectiva de valorizar aquilo que é de interesse do aluno e desejando oferecer uma prática pedagógica que fosse significativa e funcional para ele, demos continuidade ao planejamento do PEI. Utilizamos uma prancha de CAA confeccionada pela Oficina Vivencial com a música Dez indiozinhos e as luvas como recurso visual e tátil para propor a brincadeira. 
Figura 4 - Atividade II

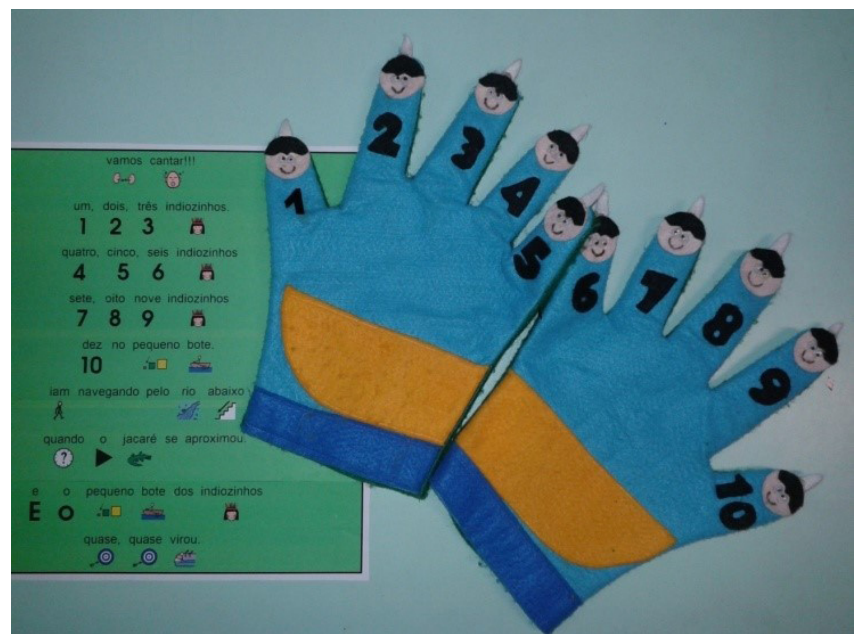

Fonte: L. F. Andrade e V. Q. Costa.

A alegria do aluno ao perceber que sua melodia foi compreendida representou para nós um momento indescritível. O que ouvimos diversas vezes nos encontros da reunião de pesquisa pela professora Carolina Schirmer "CAA é a voz do aluno não oralizado ou com fala reduzida" - estava acontecendo.

Figura 5 - Atividade III

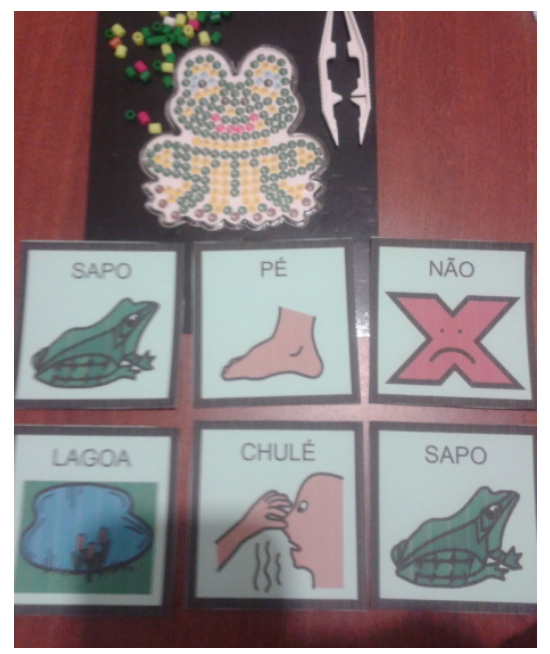

Fonte: L. F. Andrade e V. Q. Costa. 
Produzimos, então, mais recursos, a partir de outras melodias identificadas nos sons emitidos pelo aluno. A figura anterior corresponde à cantiga popular O sapo não lava o pé, com o uso de cartōes confeccionados no software Boardmaker, e o jogo de pixels com o sapinho.

Além do recurso da música, também utilizamos a leitura de livros como possibilidade de proporcionar momentos lúdicos para as crianças. Um dos livros utilizados foi o Era uma vez um ovo, adaptado pelo Centro de Transcrição a Braille (CTB)/IHA, conforme mostra a figura seguinte:

Figura 6 - Livro

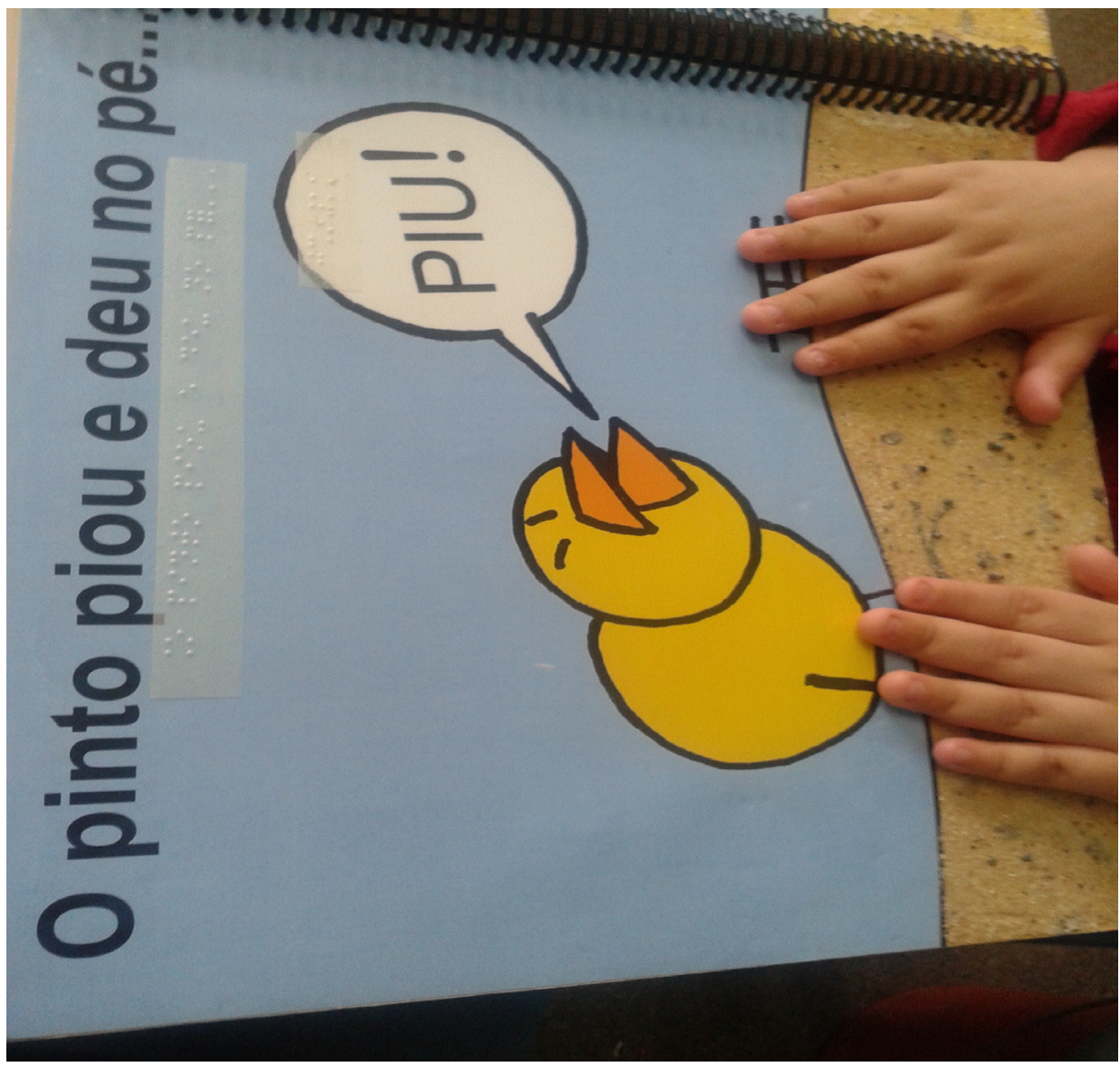

Fonte: L. F. Andrade e V. Q. Costa. 
A aluna a quem foi proposta a atividade já era alfabetizada. Ao se expressar oralmente, contudo, usava apenas palavras e não formava frases. A seguir, apresentaremos algumas atividades propostas a ela:

Figura 7 - Aluna

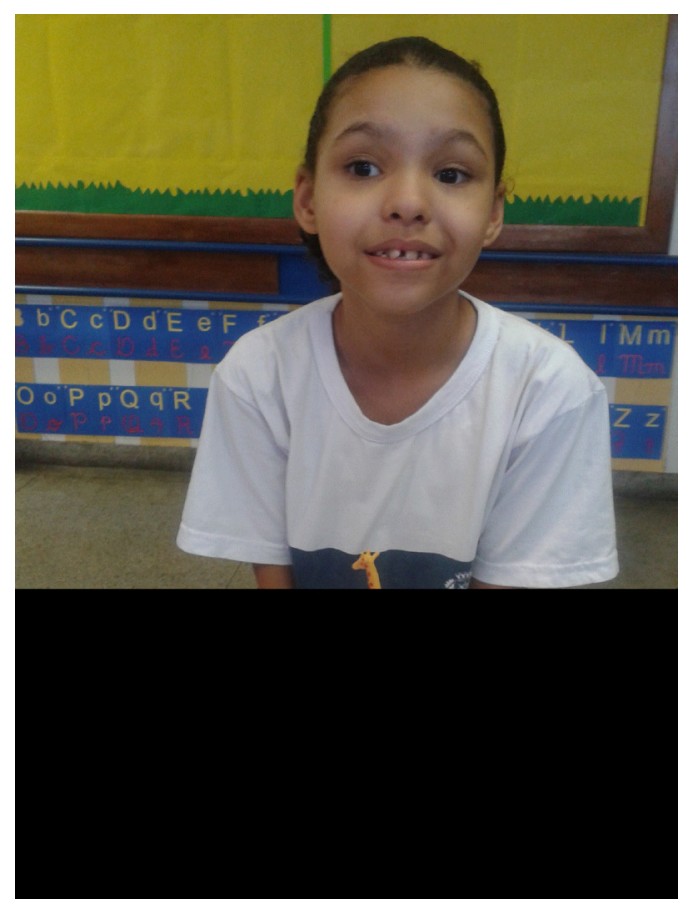

Fonte: L. F. Andrade e V. Q. Costa.

Propusemos que a aluna colocasse cada animal em miniatura no local correspondente a seu nome. Depois, conversávamos sobre algumas características desses animais e sustentávamos a comunicação com o uso do quebra-cabeça online no site Escola Games. Para as frases, utilizávamos os cartões confeccionados no software Boardmaker, tendo inicialmente três cartões para cada frase: sujeito (amarelo), ação (verde) e substantivo (laranja). Também utilizamos diferentes tipos de texturas, que podiam ser associadas a cada animal. 
Figura 8 - Atividade IV

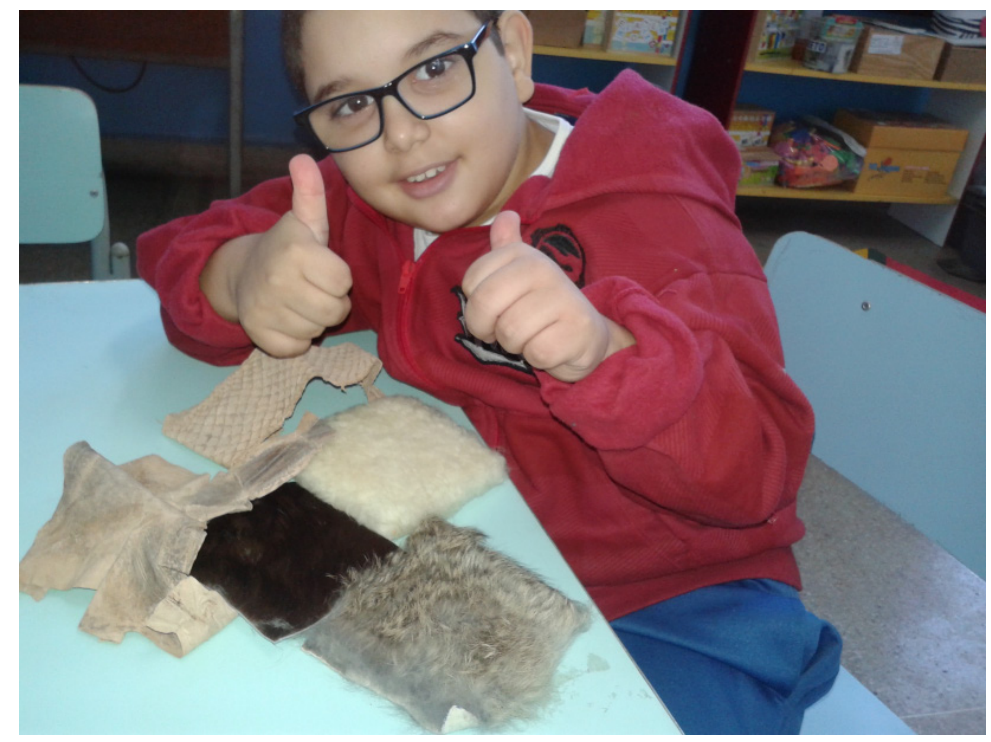

Fonte: L. F. Andrade e V. Q. Costa.

O tempo foi passando, a confiança da aluna foi aumentando, e aquele ambiente tornou-se prazeroso e de comunicação. Inicialmente, a discente possuía um vocabulário restrito e dizia uma única palavra para expressar o que queria. Por exemplo, se queria um brinquedo, apenas dizia "bingo" ou "minions", querendo, assim, ser atendida em suas necessidades. No decorrer do ano, sua fala passou a ter função social, houve a ampliação de seu vocabulário e, hoje, a aluna consegue formar frases. Pletsch (2010, p. 187) explica que "a aprendizagem não ocorre de maneira espontânea, mas sim a partir da interação e do desenvolvimento de práticas curriculares planejadas e sistematizadas de forma intencional".

E a busca continua...

Pudemos constatar em nossa caminhada que a CAA está para além do que podíamos imaginar e experimentar. Ao participarmos da pesquisa, nossas práticas pedagógicas foram ressignificadas e, com isso, passamos a estudar, fazer leituras, trocar ideias e até mesmo organizar um momento para confeccionarmos juntas os recursos que partissem do lúdico para as formalizações necessárias ao ambiente escolar. 
Desejamos que nossos olhares tornem-se como os de lince, pois queremos continuar acreditando que há algo além das nossas limitações. No trabalho desenvolvido, o que aparentava inicialmente inalcançável veio para nós por meio das respostas dos nossos alunos, era a dimensão do inimaginável tornando-se real.

Descobrimos, nesse caminho, que a criança não está fadada ao silêncio se houver quem queira se comunicar com ela. A afetividade, um planejamento individualizado e o querer são essenciais para estabelecer a comunicação com um indivíduo.

Pudemos sorrir enquanto caminhávamos, mas também encontramos diversas barreiras, inclusive atitudinais. $\mathrm{O}$ nosso olhar precisa ser como de lince para contemplar o horizonte, desvelando o que parece imutável. Por isso, convidamos-te, ao encontrar uma criança com quem você ainda não saiba se comunicar, que comece a comunicação brincando com ela. As Salas Abertas já estão abertas, então brinque e cante conosco a canção do Gonzaguinha: "Eu fico com a pureza das respostas das crianças: É a vida! É bonita e é bonita! Cantar, a beleza de ser um eterno aprendiz. Eu sei que a vida devia ser bem melhor e será. Mas isso não impede que eu repita: É bonita, é bonita e é bonita!". 


\title{
Capítulo 13 - Salas Abertas: estratégias de funcionamento das Salas de Recursos Multifuncionais de Referência
}

\author{
Leila Regina d'Oliveira de Paula Nunes ${ }^{1}$ \\ Carolina Rizzotto Schirmer ${ }^{2}$ \\ Luciana Meira Ferreira Pinto ${ }^{3}$ \\ Luiz Eduardo Veras Lopes Pontes 4
}

Salas Abertas foi o termo cunhado pelas professoras participantes desse estudo para se referirem aos encontros delas com seus colegas de SRM, das suas respectivas CREs, destinados a trocas de experiências, reflexão e oficinas pedagógicas com o intuito de melhor atender os alunos com necessidade de Comunicação Alternativa e Ampliada (CAA). As Salas Abertas representam, com efeito, a operacionalização do movimento de extensão das funções e atividades da Oficina Vivencial, desenvolvidas desde 1995, para atingir um número crescente de professores nas onze CREs do município do Rio de Janeiro.

Assim, a partir do segundo semestre de 2015, iniciou-se o planejamento para a oferta dessas Salas Abertas para os demais professores das SRM de

1 Professora titular da Faculdade de Educação e do Programa de Pós-Graduação em Educação da UERJ. E-mail: leilareginanunes@terra.com.br.

2 Professora adjunta da Faculdade de Educação da UERJ. E-mail: ead.carolina@gmail. com.

3 Graduanda em Pedagogia da UERJ. E-mail: lucianapintop77@gmail.com.

4 Graduando em Psicologia da UERJ. E-mail: luizulpontes@hotmail.com. 
suas respectivas CREs. Durante as reuniões de pesquisa, o grupo, juntamente com as professoras da Oficina Vivencial e as pesquisadoras da UERJ, iniciou a discussão sobre os temas e as atividades a serem desenvolvidas nesses encontros, os recursos a serem exibidos, assim como as providências para garantir a presença do maior número possível de docentes.

No quadro 1, estão apresentados os dados sobre as Salas Abertas conduzidas pelas participantes da pesquisa. Faremos, a seguir, uma exposição breve acerca desses encontros. Ao todo, foram realizados 30 encontros, coordenados pelas 16 participantes desse estudo, para uma audiência total de 333 professores representantes das 11 CREs. Oito professoras coordenaram juntas as reuniões.

$\mathrm{Na}$ primeira Sala Aberta de todas, as professoras participantes foram apresentadas à conceituação de CAA, seus recursos e a população que pode se beneficiar dessa prática. Nas seguintes, foram tratados e discutidos os seguintes temas: projeto de formação de professores para as SRM, processo de comunicação, Tecnologia Assistiva, acessibilidade, recursos de CAA de alta e baixa tecnologias, aplicativos para CAA, confecção de pranchas e de mensagens com emprego destas, comunicação funcional dentro e fora da escola, processo de autoscopia, conversação com uso de recursos de CAA, interação com alunos com autismo, jogos pedagógicos, materiais adaptados, ensino do PECS 5 -Adaptado, estudos de caso, Plano Educacional Individualizado (PEI) e provas adaptadas. Cabe destacar que os temas tratados foram frequentemente sugeridos pela própria audiência.

As coordenadoras das Salas Abertas conduziram diversas atividades nesses encontros, a saber: exposição oral com auxílio de data show, apresentação de vídeos de alunos fazendo uso de recursos de CAA de alta e baixa tecnologias, apresentação de materiais adaptados confeccionados por elas, apresentação de vídeos comerciais sobre comunicação, relato de casos de alunos com dificuldades de comunicação pelas palestrantes e pela audiência,

5 PECS-Adaptado é um sistema de comunicação alternativa destinado a pessoas com autismo, que promove a comunicação por intercâmbio de figuras. O indivíduo oferece o cartão pictográfico para seu interlocutor a fim de receber o item desejado. Esse sistema consiste em uma adaptação do PECS - Picture Exchange Communication System - ao contexto brasileiro e possui flexibilidade para os diferentes contextos: escolar, familiar e especializado (Walter, 2000, 2006). 
dinâmicas de grupo para discutir temas diversos e vivenciar a comunicação sem fala, elaboração coletiva de um PEI e confecção de jogos.

As professoras que frequentaram tais encontros avaliaram, de modo geral, como muito positivas as Salas Abertas. Ressaltaram, como aspectos especialmente produtivos, as dinâmicas de grupo, a troca de experiências, os relatos de casos, a apresentação e o ensino da elaboração de materiais adaptados e pranchas de comunicação, a aplicabilidade dos conteúdos tratados para seu trabalho de sala de aula, o acolhimento de suas dificuldades e angústias pelas palestrantes e o fato de estas serem como elas, professoras de SRM. A formação era mais horizontal - de igual para igual. A audiência demandou encontros mais longos e mais frequentes para tratar de aspectos teóricos da comunicação, da adaptação de provas, da elaboração do PEI e de procedimentos para alfabetização. Foram sugeridas oficinas para aprender a confeccionar materiais e brinquedos adaptados e pranchas de comunicação, elaborar adaptaçōes curriculares e usar softwares, aplicativos, recursos, estratégias e métodos de CAA (Boardmaker, Arasaac, PECS etc.). Algumas palestrantes criaram grupos de WhatsApp para manter o contato com as professoras que estiveram presentes nos encontros.

Schirmer (neste livro), ao apresentar a comunidade on-line criada pelas professoras participantes do estudo por meio do grupo de WhatsApp, considerou-a como uma comunidade de prática. Analogamente, as Salas Abertas também o são. $\mathrm{O}$ conceito de comunidade de prática foi cunhado por Wenger (1998), sob a perspectiva da teoria social da aprendizagem, para referir-se a configurações sociais que agregam valor aos empreendimentos de seus integrantes e reconhecem como competente sua participação. As comunidades caracterizam-se, assim, por atividades ou práticas específicas que definem limites de pertencimento e identidades (Schommer, 2005). O conhecimento coletivo resultante dessas práticas pertence a uma comunidade que possui um objetivo comum (Wenger, 1998). Assim, o conceito de comunidade de prática implica necessariamente uma perspectiva da aprendizagem como atuação social, e não individual (Schirmer, neste livro).

Em uma comunidade de prática, há participantes plenos e periféricos. Os primeiros são aqueles com maior experiência, que dominam os proce-

${ }^{6}$ Schirmer, C. R. "Comunidade on-line de professores das Salas de Recursos Multifuncionais de Referência". 
dimentos desenvolvidos pela comunidade. Os periféricos são os novos integrantes acolhidos pela comunidade para iniciar seu engajamento e participação e, desse modo, terem acesso aos saberes produzidos pelo grupo. A entrada de novos participantes ajuda a "oxigenar" o conhecimento constituído e promover a busca de novas soluçóes para os processos de aprendizagem, favorecendo, assim, a revisão das práticas dos veteranos (Reily, 2015).

Nessa experiência, percebemos as professoras das Salas de Recursos Multifuncionais de Referência, que coordenaram as Salas Abertas, como aqueles participantes plenos que acolheram as demais professoras, inicialmente consideradas como membros periféricos. Estes passaram gradativamente não somente a dominar o conhecimento produzido pela comunidade, mas também a favorecer a recriação de novas práticas, imprimindo, assim, um movimento contínuo na comunidade. Dessa forma, se no início da oferta das Salas Abertas, as professoras coordenadoras portavam-se mais como conferencistas, ao longo desses dois anos, elas tornaram-se gradativamente mais parceiras das participantes, mostrando-se mais permeáveis aos seus relatos de experiências em sala de aula e incentivando uma busca coletiva de soluçôes para as dificuldades apresentadas.

Destaca-se, assim, a extrema importância da continuidade dessas salas com participação crescente das professoras de SRM, sobretudo aquelas com menor experiência docente com alunos especiais. Acreditamos que a possibilidade de trocas sistemáticas e mais horizontais entre as professoras possa se configurar como uma forma de torná-las menos solitárias e mais empoderadas. 
Quadro 1 - Dados sobre as Salas Abertas conduzidas pelas participantes da pesquisa

\begin{tabular}{|c|c|c|c|c|}
\hline \multicolumn{5}{|c|}{ SALAS ABERTAS COORDENADAS PELA PROFESSORA CARMEN } \\
\hline$\underset{\widetilde{\pi}}{\tilde{\Xi}}$ & 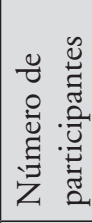 & $\underset{\overparen{E}}{\overparen{E}}$ & 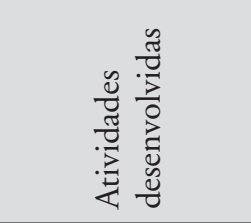 & 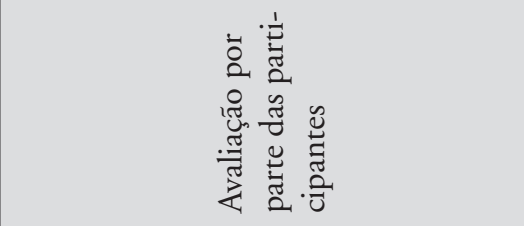 \\
\hline $09 / 09 / 15$ & 5 & $\begin{array}{l}\text { CAA e } \\
\text { Recur- } \\
\text { sos/ma- } \\
\text { teriais } \\
\text { adapta- } \\
\text { dos }\end{array}$ & $\begin{array}{l}\text { Apresentação } \\
\text { oral do tema; } \\
\text { Dinâmica de } \\
\text { grupo; } \\
\text { Apresentação de } \\
\text { materiais usados } \\
\text { por seus alunos. }\end{array}$ & $\begin{array}{l}\text { Poucas professoras, mas todas interes- } \\
\text { sadas na proposta. }\end{array}$ \\
\hline $09 / 12 / 15$ & 7 & $\begin{array}{l}\text { Dúvidas } \\
\text { e plane- } \\
\text { jamento } \\
\text { para o } \\
\text { próximo } \\
\text { ano }\end{array}$ & $\begin{array}{l}\text { Apresentação de } \\
\text { vídeos de alunos } \\
\text { com materiais } \\
\text { adaptados, } \\
\text { pranchas, cartões } \\
\text { e acionador; } \\
\text { Dinâmicas de } \\
\text { grupo. }\end{array}$ & $\begin{array}{l}\text { Cinco professoras - encontro posi- } \\
\text { tivo, com aprendizado por troca de } \\
\text { experiências entre elas; } \\
\text { Duas professoras - expectativa de aula } \\
\text { mais prática e necessidade de sanar } \\
\text { suas dúvidas; } \\
\text { Desejo de aprender Boardmaker e } \\
\text { sugestôes de atividades e vídeos. }\end{array}$ \\
\hline $04 / 10 / 16$ & 6 & $\begin{array}{l}\text { Impor- } \\
\text { tância } \\
\text { da } \\
\text { comu- } \\
\text { nicação } \\
\text { funcio- } \\
\text { nal fora } \\
\text { do am- } \\
\text { biente } \\
\text { escolar }\end{array}$ & $\begin{array}{l}\text { Apresentação de } \\
\text { vídeos cedidos } \\
\text { pelo IHA, de } \\
\text { alunos das pro- } \\
\text { fessoras do gru- } \\
\text { po de pesquisa. }\end{array}$ & $\begin{array}{l}\text { Para todas, o encontro foi bom; } \\
\text { Três queixaram-se da localidade, da } \\
\text { data do encontro e de sua pouca } \\
\text { duração; } \\
\text { Desejo de aprender mais sobre PECS- } \\
\text {-Adaptado. }\end{array}$ \\
\hline
\end{tabular}




\begin{tabular}{|l|l|l|l|l|}
\hline 09/11/16 & 11 & $\begin{array}{l}\text { Ensi- } \\
\text { no do } \\
\text { uso do } \\
\text { PECS- } \\
\text {-Adap- } \\
\text { tado }\end{array}$ & $\begin{array}{l}\text { Relato de caso } \\
\text { de aluno a di- } \\
\text { ficuldade da pro- } \\
\text { fessora Carmen } \\
\text { em se comunicar } \\
\text { com ele; } \\
\text { Ensino do uso } \\
\text { do PECS-Adap- } \\
\text { tado. }\end{array}$ & $\begin{array}{l}\text { As participantes consideraram o en- } \\
\text { contro muito bom, devido à troca de } \\
\text { experiências e ao aprendizado prático } \\
\text { sobre como usar a CAA; } \\
\text { Desejo de maior aprendizado sobre o } \\
\text { PECS e sobre outras formas de CAA, } \\
\text { mantendo a dinamização do encon- } \\
\text { tro. }\end{array}$ \\
\hline
\end{tabular}




\begin{tabular}{|c|c|c|c|c|}
\hline \multicolumn{5}{|c|}{ SALAS ABERTAS COORDENADAS PELA PROFESSORA PAULA } \\
\hline 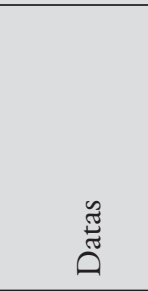 & 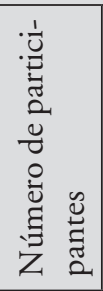 & $\underset{\widetilde{\Xi}}{\tilde{E}}$ & 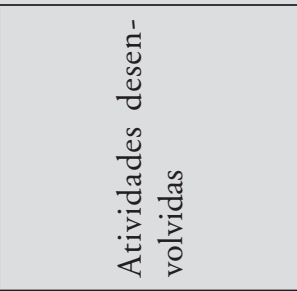 & 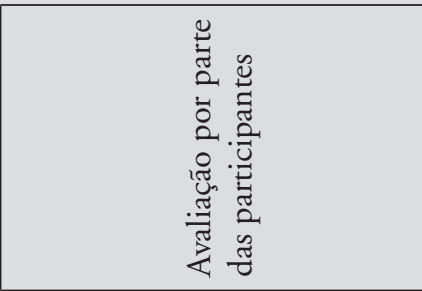 \\
\hline $13 / 07 / 16$ & 10 & $\begin{array}{l}\text { Uso de CAA } \\
\text { por alunos } \\
\text { Sala de re- } \\
\text { cursos com } \\
\text { materiais } \\
\text { adaptados e } \\
\text { pranchas de } \\
\text { comunicação }\end{array}$ & $\begin{array}{l}\text { Apresentação de } \\
\text { vídeos com alunos } \\
\text { usando CAA; } \\
\text { Apresentação de ma- } \\
\text { teriais adaptados e } \\
\text { pranchas de comu- } \\
\text { nicação. }\end{array}$ & $\begin{array}{l}\text { As dez professoras considera- } \\
\text { ram o encontro ótimo, enfa- } \\
\text { tizando o lado prático que a } \\
\text { palestrante priorizou; } \\
\text { Desejo de aprender adaptação } \\
\text { de provas, a montar cartões de } \\
\text { comunicação, iniciar o processo } \\
\text { de CAA; } \\
\text { Relação contínua sobre os as- } \\
\text { suntos trabalhados via internet. }\end{array}$ \\
\hline $09 / 11 / 16$ & 8 & $\begin{array}{l}\text { Confecção } \\
\text { de prancha } \\
\text { de CAA e } \\
\text { elaboração } \\
\text { de PEI por } \\
\text { meio de es- } \\
\text { tudo de caso. }\end{array}$ & $\begin{array}{l}\text { Dinâmica; } \\
\text { Confecção de pran- } \\
\text { cha de CAA; } \\
\text { Elaboração de PEI } \\
\text { por meio de estudo } \\
\text { de caso. }\end{array}$ & $\begin{array}{l}\text { Cinco professoras - encontro } \\
\text { esclarecedor; } \\
\text { Quatro professoras - encontro } \\
\text { produtivo; } \\
\text { Uma professora - encontro } \\
\text { bom; } \\
\text { Uma professora - encontro } \\
\text { criativo; } \\
\text { Desejo de um encontro volta- } \\
\text { do para a parte mais teórica e, } \\
\text { ainda, oficinas que englobassem } \\
\text { tais aplicativos, como: Arasaac, } \\
\text { Boardmaker e PECS-Adaptado. }\end{array}$ \\
\hline
\end{tabular}




\begin{tabular}{|c|c|c|c|c|}
\hline \multicolumn{5}{|c|}{ SALAS ABERTAS COORDENADAS PELA PROFESSORA VANIA } \\
\hline 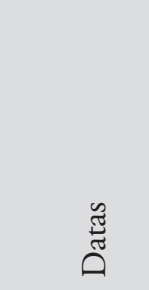 & 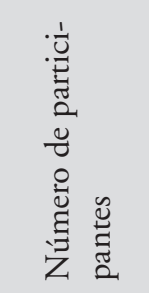 & 胥 & 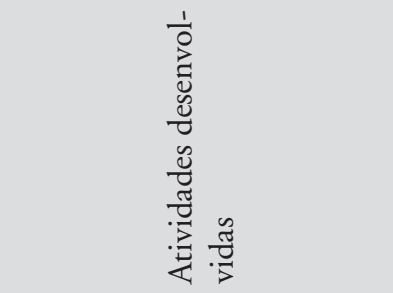 & 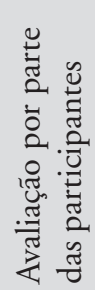 \\
\hline $09 / 11 / 16$ & $\begin{array}{l}10 \text {, e } \mathrm{m} \\
\text { dois tur- } \\
\text { nos }\end{array}$ & $\begin{array}{l}\text { Pranchas } \\
\text { Aplicativos } \\
\text { para CAA } \\
\text { Jogos }\end{array}$ & $\begin{array}{l}\text { Período da manhã: confecção } \\
\text { de pranchas no "prancha } \\
\text { fácil" para interpretação de } \\
\text { texto e manuseio de pranchas } \\
\text { com voz; Varredura; } \\
\text { Período da Tarde: apresenta- } \\
\text { ção de aplicativos para CAA } \\
\text { e jogos off-line, confecção } \\
\text { de pranchas, recursos como } \\
\text { varredura e utilização de voz. }\end{array}$ & \\
\hline
\end{tabular}




\begin{tabular}{|c|c|c|c|c|}
\hline \multicolumn{5}{|c|}{ SALAS ABERTAS COORDENADAS PELAS PROFESSORAS ELIANE E CELINA } \\
\hline ఏే & 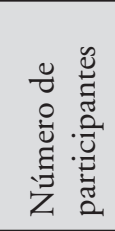 & $\underset{\tilde{\Xi}}{\tilde{E}}$ & 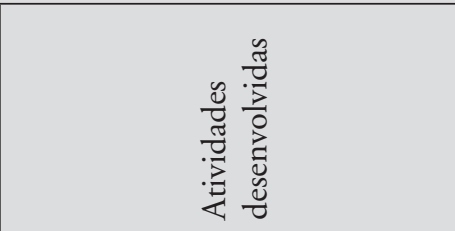 & 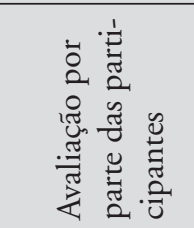 \\
\hline $09 / 12 / 15$ & 13 & $\begin{array}{l}\text { Conversa } \\
\text { sobre o pro- } \\
\text { jeto de Sala } \\
\text { de Recursos } \\
\text { Referência } \\
\text { Importância } \\
\text { da CAA }\end{array}$ & $\begin{array}{l}\text { Apresentação de vídeos de } \\
\text { alunos, usando diferentes tipos } \\
\text { de comunicação, e de YouTube, } \\
\text { sobre os processos de comuni- } \\
\text { cação; } \\
\text { Dinâmica com prancha de CAA } \\
\text { para descrever o final de semana. }\end{array}$ & \\
\hline $13 / 07 / 16$ & 14 & $\begin{array}{l}\text { Conversa } \\
\text { com uso de } \\
\text { recursos de } \\
\text { CAA } \\
\text { Autoscopia } \\
\text { Recursos } \\
\text { tecnológicos }\end{array}$ & $\begin{array}{l}\text { Apresentação do vídeo da Lívia, } \\
\text { uma moça usando vários recur- } \\
\text { sos na conversação para mostrar } \\
\text { as vantagens da utilização da } \\
\text { CAA dentro e fora do universo } \\
\text { escolar; } \\
\text { Discussão sobre a autoscopia } \\
\text { como estratégia de avaliação } \\
\text { contínua; } \\
\text { Apresentação de vídeos com } \\
\text { atendimento na sala de recursos. }\end{array}$ & $\begin{array}{l}\text { Sete profes- } \\
\text { soras consi- } \\
\text { deraram o } \\
\text { curso muito } \\
\text { bom, princi- } \\
\text { palmente pela } \\
\text { possibilidade } \\
\text { da troca. }\end{array}$ \\
\hline $09 / 11 / 16$ & 8 & $\begin{array}{l}\text { Vídeos } \\
\text { com uso de } \\
\text { recursos } \\
\text { Mostra de } \\
\text { material } \\
\text { confeccio- } \\
\text { nado }\end{array}$ & $\begin{array}{l}\text { Dinâmica de grupo; } \\
\text { Apresentação de vídeos; } \\
\text { Mostra de material confeccio- } \\
\text { nado; } \\
\text { Discussão; } \\
\text { Avaliação do encontro. }\end{array}$ & $\begin{array}{l}\text { Seis professo- } \\
\text { ras acharam } \\
\text { esclarecedor; } \\
\text { uma conside- } \\
\text { rou ser muito } \\
\text { importante; } \\
\text { Solicitação de } \\
\text { mais encon- } \\
\text { tros. }\end{array}$ \\
\hline
\end{tabular}




\begin{tabular}{|c|c|c|c|c|}
\hline \multicolumn{5}{|c|}{ SALAS ABERTAS COORDENADAS PELA PROFESSORA GILDA } \\
\hline & 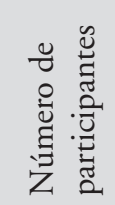 & $\underset{\Xi}{\overparen{E}}$ & 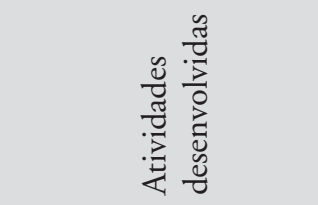 & 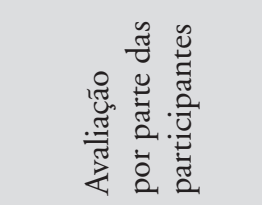 \\
\hline $09 / 09 / 15$ & 9 & $\begin{array}{l}\text { Uso de CAA, } \\
\text { relacionando com } \\
\text { suas reais necessi- } \\
\text { dades }\end{array}$ & $\begin{array}{l}\text { Palestra; } \\
\text { Exposição de } \\
\text { vídeos e slides. }\end{array}$ & $\begin{array}{l}\text { Todas as profes- } \\
\text { soras avaliaram o } \\
\text { curso positivamen- } \\
\text { te, dizendo que } \\
\text { favoreceu a troca } \\
\text { de experiências; } \\
\text { O curso ser regido } \\
\text { por uma pessoa } \\
\text { que também atua } \\
\text { na Sala de Recur- } \\
\text { sos é outro ponto } \\
\text { destacado; Foram } \\
\text { pedidos novos } \\
\text { encontros. }\end{array}$ \\
\hline $09 / 12 / 15$ & 9 & CAA & $\begin{array}{l}\text { Dinâmica; } \\
\text { Troca de experiências; } \\
\text { Apresentação de mate- } \\
\text { riais. }\end{array}$ & $\begin{array}{l}\text { Todas as professo- } \\
\text { ras relataram que o } \\
\text { encontro foi satis- } \\
\text { fatório, principal- } \\
\text { mente pela troca } \\
\text { de experiências; } \\
\text { Não houve relatos } \\
\text { negativos; } \\
\text { Interesse em apri- } \\
\text { morar o conheci- } \\
\text { mento sobre CAA, } \\
\text { confecção de brin- } \\
\text { quedos e materiais } \\
\text { adaptados. }\end{array}$ \\
\hline
\end{tabular}




\begin{tabular}{|c|c|c|c|c|}
\hline \multicolumn{5}{|c|}{ SALAS ABERTAS COORDENADAS PELA PROFESSORA GILDA } \\
\hline 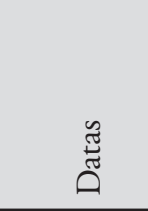 & 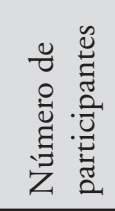 & 莺 & 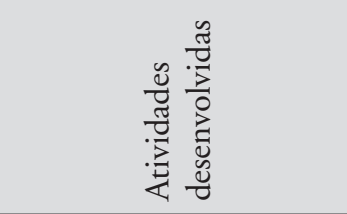 & 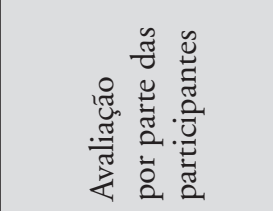 \\
\hline $13 / 07 / 16$ & 11 & $\begin{array}{l}\text { Uso da CAA e de } \\
\text { materiais adapta- } \\
\text { dos }\end{array}$ & $\begin{array}{l}\text { Apresentação de vídeos e } \\
\text { slides sobre o uso de CAA } \\
\text { com os alunos; Apresen- } \\
\text { tação de materiais adap- } \\
\text { tados e como usá-los; } \\
\text { Relato, pelas professoras, } \\
\text { de seus próprios alunos; } \\
\text { Palestrante acolheu a } \\
\text { angústia das professo- } \\
\text { ras quanto às suas difi- } \\
\text { culdades, procurando } \\
\text { dar algum respaldo por } \\
\text { meio dos ensinamentos } \\
\text { gerados pela sua própria } \\
\text { experiência. }\end{array}$ & $\begin{array}{l}\text { Todas as professoras } \\
\text { relataram ser um } \\
\text { encontro satisfató- } \\
\text { rio, principalmente } \\
\text { pela troca de ex- } \\
\text { periências, troca } \\
\text { de materiais e pela } \\
\text { dinamização da } \\
\text { sessão; } \\
\text { Demanda por mais } \\
\text { encontros. }\end{array}$ \\
\hline $09 / 11 / 16$ & 11 & $\begin{array}{l}\text { CAA } \\
\text { Provas adaptadas } \\
\text { Jogos com apoio } \\
\text { da CAA }\end{array}$ & $\begin{array}{l}\text { Apresentação oral sobre } \\
\text { CAA; } \\
\text { Apresentação de dois } \\
\text { casos; } \\
\text { Adaptação de provas. }\end{array}$ & $\begin{array}{l}\text { As participantes } \\
\text { consideraram o en- } \\
\text { contro muito pro- } \\
\text { veitoso. Em primei- } \\
\text { ro lugar, pela troca } \\
\text { de experiências e } \\
\text { pelo contato com } \\
\text { o dia a dia de pro- } \\
\text { fessoras que estão } \\
\text { passando por situa- } \\
\text { çôes similares. Em } \\
\text { segundo, pelas in- } \\
\text { formaçôes recebidas } \\
\text { que são muito úteis } \\
\text { para uma melhor } \\
\text { prática com seus } \\
\text { alunos. }\end{array}$ \\
\hline
\end{tabular}




\begin{tabular}{|c|c|c|c|c|}
\hline \multicolumn{5}{|c|}{ SALAS ABERTAS COORDENADAS PELA PROFESSORA JOANA } \\
\hline$\underset{\widetilde{\pi}}{\widetilde{\Xi}}$ & 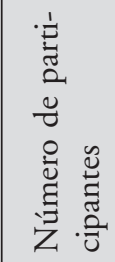 & 胥 & 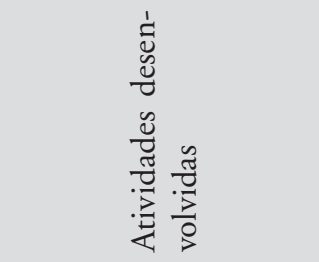 & 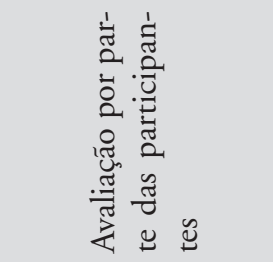 \\
\hline $09 / 09 / 15$ & 9 & $\begin{array}{l}\text { CAA } \\
\text { Recursos com } \\
\text { baixa e alta tecno- } \\
\text { logias }\end{array}$ & $\begin{array}{l}\text { Exibição dos slides e } \\
\text { vídeos; } \\
\text { Dinâmica de grupo; } \\
\text { Visita à Sala de Recur- } \\
\text { sos com } \\
\text { exposição dos mate- } \\
\text { riais de CAA de baixa } \\
\text { e alta tecnologias; } \\
\text { Relato de experiências } \\
\text { e necessidades. }\end{array}$ & $\begin{array}{l}\text { Seis professoras } \\
\text { consideraram o } \\
\text { curso ótimo e duas } \\
\text { o consideraram } \\
\text { bom, com ressalva } \\
\text { ao conteúdo do } \\
\text { curso; } \\
\text { Satisfação de suas } \\
\text { expectativas e ne- } \\
\text { cessidade e aplica- } \\
\text { bilidade do curso } \\
\text { em seu trabalho } \\
\text { diário; } \\
\text { Foi solicitada uma } \\
\text { Oficina de Pran- } \\
\text { chas de Comunica- } \\
\text { ção de alta tecno- } \\
\text { logia. }\end{array}$ \\
\hline $09 / 12 / 15$ & 6 & $\begin{array}{l}\text { Confecção de } \\
\text { pranchas software } \\
\text { Picto } 4 \mathrm{me}\end{array}$ & $\begin{array}{l}\text { Apresentação de vídeos } \\
\text { da Miryam Pelosi e } \\
\text { confecção de pranchas, } \\
\text { utlizando o software } \\
\text { Picto4me }\end{array}$ & $\begin{array}{l}\text { As professoras } \\
\text { demonstraram } \\
\text { satisfação ao reali- } \\
\text { zarem o curso, com } \\
\text { enfoque na troca } \\
\text { de experiências e } \\
\text { no aprendizado } \\
\text { no manuseio do } \\
\text { software; } \\
\text { Interesse na } \\
\text { continuidade dos } \\
\text { encontros e infor- } \\
\text { mação sobre como } \\
\text { trabalhar com alu- } \\
\text { nos com gagueira. }\end{array}$ \\
\hline
\end{tabular}




\begin{tabular}{|c|c|c|c|c|}
\hline \multicolumn{5}{|c|}{ SALAS ABERTAS COORDENADAS PELA PROFESSORA JOANA } \\
\hline$\stackrel{\underset{\mathbb{J}}{\tilde{\Xi}}}{\stackrel{\mathscr{0}}{0}}$ & 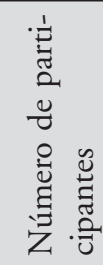 & $\underset{\tilde{E}}{\tilde{E}}$ & 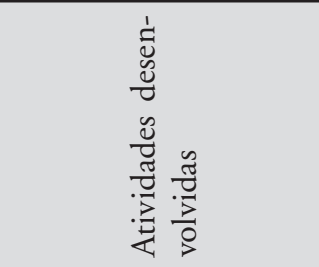 & 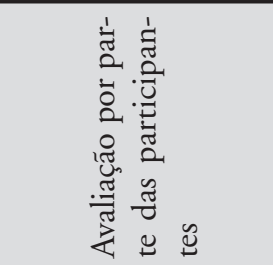 \\
\hline $13 / 07 / 16$ & 10 & $\begin{array}{l}\text { Comunicação sem } \\
\text { fala } \\
\text { CAA } \\
\text { Recursos de alta } \\
\text { tecnologia }\end{array}$ & $\begin{array}{l}\text { Dinâmica -- comu- } \\
\text { nicação sem fala; Apre- } \\
\text { sentação de vídeos de } \\
\text { alunos usando CAA; } \\
\text { Manuseio de acio- } \\
\text { nador, prancha fácil, } \\
\text { mouse adaptado, tecla- } \\
\text { do adaptado. }\end{array}$ & $\begin{array}{l}\text { Sete professoras } \\
\text { consideraram o } \\
\text { encontro ótimo; } \\
\text { Três consideraram } \\
\text { o curso muito bom, } \\
\text { porém ressaltaram } \\
\text { negativamente a } \\
\text { questão de local e } \\
\text { da aplicabilidade } \\
\text { do curso em seus } \\
\text { trabalhos diários; } \\
\text { Demanda por } \\
\text { continuidade dos } \\
\text { encontros mais } \\
\text { frequentemente, } \\
\text { com o enfoque para } \\
\text { a construçáo de } \\
\text { materiais. }\end{array}$ \\
\hline $09 / 11 / 16$ & & $\begin{array}{l}\text { PEI } \\
\text { Recursos CAA } \\
\text { Jogos }\end{array}$ & $\begin{array}{l}\text { Elaboração do PEI } \\
\text { coletivo; } \\
\text { Apresentação de } \\
\text { material de CAA } \\
\text { para crianças com } \\
\text { Síndrome de Down } \\
\text { e de vídeos de alunos } \\
\text { das professoras com } \\
\text { o objetivo de pensar } \\
\text { atividades; } \\
\text { Oficina de jogos - } \\
\text { Jogo da velha no } \\
\text { "prancha fácil". }\end{array}$ & $\begin{array}{l}\text { As participantes } \\
\text { avaliariam o en- } \\
\text { contro como muito } \\
\text { bom, principal- } \\
\text { mente em relação à } \\
\text { elaboração do PEI. }\end{array}$ \\
\hline
\end{tabular}




\section{SALAS ABERTAS COORDENADAS PELAS PROFESSORAS ANETE E KARLA}

\begin{tabular}{|c|c|c|c|c|}
\hline 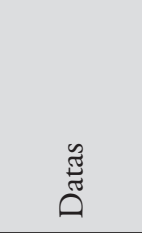 & 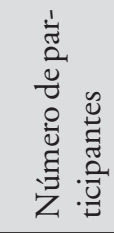 & $\underset{\overparen{E}}{\overparen{E}}$ & 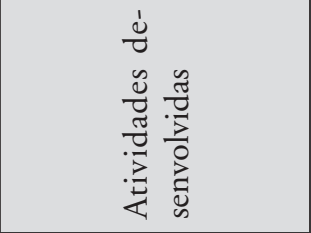 & 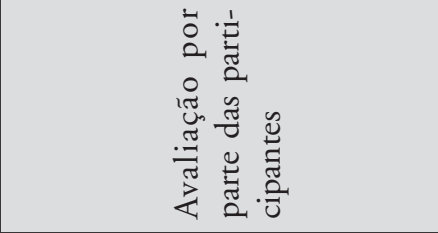 \\
\hline $09 / 09 / 15$ & 12 & $\begin{array}{l}\text { CAA } \\
\text { Materiais } \\
\text { adaptados }\end{array}$ & $\begin{array}{l}\text { Apresentação de } \\
\text { slides; } \\
\text { Dinâmica de grupo. }\end{array}$ & $\begin{array}{l}\text { Nove professoras relataram sa- } \\
\text { tisfação com o curso dado, } \\
\text { principalmente pela troca de } \\
\text { experiêncas, pela confecção de } \\
\text { materiais adaptados e pela doa- } \\
\text { ção de alguns; } \\
\text { Não houve relatos de pontos } \\
\text { negativos; } \\
\text { Interesse por adaptações curri- } \\
\text { culares, alfabetização e palestra } \\
\text { com fonoaudiólogas. }\end{array}$ \\
\hline $13 / 07 / 16$ & 13 & $\begin{array}{l}\text { Interação } \\
\text { com alu- } \\
\text { nos com } \\
\text { autismo }\end{array}$ & $\begin{array}{l}\text { Dinâmica sobre o li- } \\
\text { vro Com amor, Antony } \\
\text { para discussão; } \\
\text { Análise de vídeos de } \\
\text { professoras ensinando } \\
\text { alunos com autismo } \\
\text { relacionando com } \\
\text { suas práticas. }\end{array}$ & $\begin{array}{l}\text { Dez professoras consideraram } \\
\text { o encontro muito bom e três } \\
\text { consideraram o encontro bom; } \\
\text { Demanda por parte mais prática, } \\
\text { como a confecção de materiais } \\
\text { adaptados, o manuseio de apli- } \\
\text { cativos e, ainda, como iniciar o } \\
\text { processo de CAA. }\end{array}$ \\
\hline $09 / 11 / 16$ & 11 & Jogos & $\begin{array}{l}\text { Dinâmica com inter- } \\
\text { pretação dos emojis; } \\
\text { Confecção de jogos; } \\
\text { Discussão sobre ava- } \\
\text { liações. }\end{array}$ & $\begin{array}{l}\text { As participantes consideraram o } \\
\text { encontro muito bom, relatando } \\
\text { a falta de espaço para troca de } \\
\text { experiências e que esse encontro } \\
\text { a supriu; } \\
\text { As participantes solicitaram um } \\
\text { encontro ainda este ano para } \\
\text { tratar de adaptaçóes curriculares. }\end{array}$ \\
\hline
\end{tabular}




\begin{tabular}{|c|c|c|c|c|}
\hline \multicolumn{5}{|c|}{ SALAS ABERTAS COORDENADAS PELA PROFESSORA DANI } \\
\hline 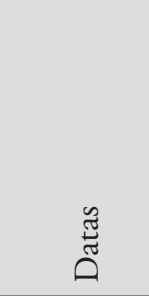 & 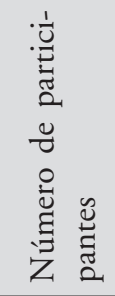 & 胥 & 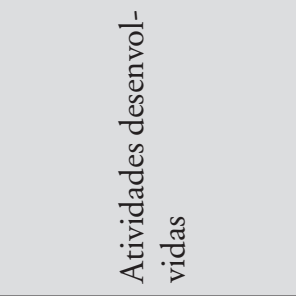 & 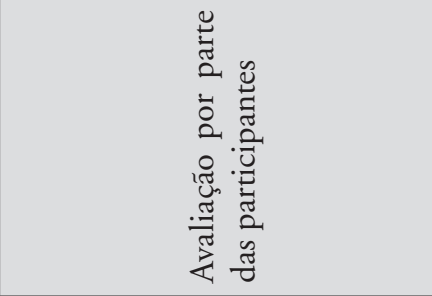 \\
\hline $09 / 09 / 15$ & 11 & $\begin{array}{l}\text { Projeto da } \\
\text { formação } \\
\text { de pro- } \\
\text { fessoras } \\
\text { da SRM } \\
\text { Materiais } \\
\text { adaptados } \\
\text { CAA }\end{array}$ & $\begin{array}{l}\text { Abertura (boas-vin- } \\
\text { das); } \\
\text { Informes; } \\
\text { Apresentação do Pro- } \\
\text { jeto de Pesquisa; } \\
\text { Dinâmica sobre os } \\
\text { vídeos; } \\
\text { Relatos sobre alunos } \\
\text { das professoras; } \\
\text { Avaliação do encon- } \\
\text { tro; } \\
\text { Exposição de mate- } \\
\text { riais; } \\
\text { Lanche. }\end{array}$ & $\begin{array}{l}\text { Duas delas acharam o encon- } \\
\text { tro muito bom; Três acharam } \\
\text { excelente; } \\
\text { Duas avaliaram como de extre- } \\
\text { ma importância; } \\
\text { Uma avaliou como proveitoso; } \\
\text { Uma gostou da troca de expe- } \\
\text { riência; } \\
\text { Uma avaliou como esclarecedor. }\end{array}$ \\
\hline $09 / 11 / 16$ & 12 & $\begin{array}{l}\text { CAA } \\
\text { Autosco- } \\
\text { pia }\end{array}$ & $\begin{array}{l}\text { Abertura; } \\
\text { Informes; } \\
\text { Apresentação em } \\
\text { Power Point sobre os } \\
\text { assuntos abordados } \\
\text { no encontro anterior; } \\
\text { Apresentação do pro- } \\
\text { cesso de autoscopia; } \\
\text { Apresentação de ví- } \\
\text { deos de alunos usan- } \\
\text { do CAA; } \\
\text { Adaptações de provas; } \\
\text { Lanche. }\end{array}$ & $\begin{array}{l}\text { As professoras participantes } \\
\text { consideraram o encontro pro- } \\
\text { veitoso e produtivo, com ênfase } \\
\text { na troca de experiências. }\end{array}$ \\
\hline
\end{tabular}




\begin{tabular}{|c|c|c|c|c|}
\hline $\begin{array}{l}\widetilde{\pi} \\
\tilde{\Xi} \\
0\end{array}$ & 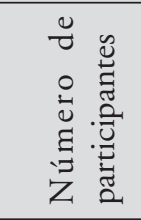 & 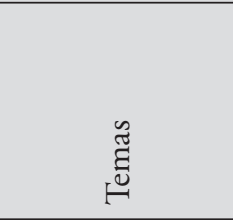 & 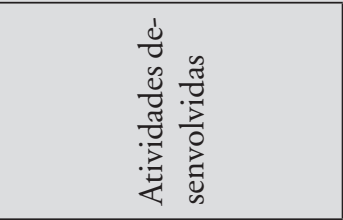 & 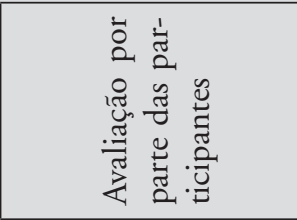 \\
\hline $09 / 09 / 15$ & 13 & $\begin{array}{l}\text { Tecnologia As- } \\
\text { sistiva } \\
\text { Uso da CAA } \\
\text { dentro e fora da } \\
\text { escola }\end{array}$ & $\begin{array}{l}\text { Apresentação oral e de } \\
\text { vídeos; } \\
\text { Dinâmica: comuni- } \\
\text { car por meio de uma } \\
\text { prancha projetada no } \\
\text { quadro. }\end{array}$ & $\begin{array}{l}\text { Uma professora ava- } \\
\text { liou como bom; } \\
\text { Quatro avaliaram } \\
\text { como muito bom; } \\
\text { Cinco avaliaram } \\
\text { como ótimo. }\end{array}$ \\
\hline
\end{tabular}




\begin{tabular}{|c|c|c|c|c|}
\hline 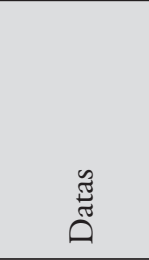 & 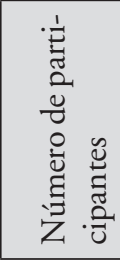 & 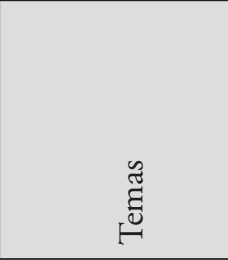 & 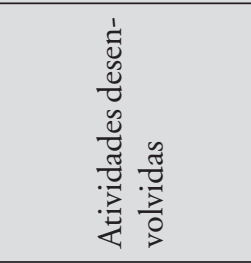 & 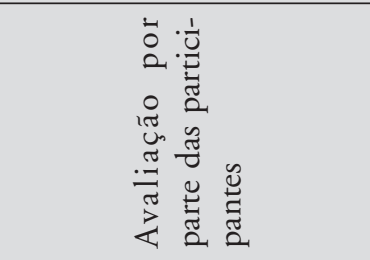 \\
\hline $13 / 07 / 16$ & 12 & CAA & $\begin{array}{l}\text { Boas-vindas da } \\
\text { direção; } \\
\text { Informes; } \\
\text { Apresentação de } \\
\text { slides e vídeos; } \\
\text { Divisão do grupo } \\
\text { de debate; } \\
\text { Lanche. }\end{array}$ & $\begin{array}{l}\text { Todas as participantes ava- } \\
\text { liaram o encontro positiva- } \\
\text { mente; } \\
\text { Três consideraram produ- } \\
\text { tivo; } \\
\text { Duas acharam interessante; } \\
\text { Duas gostaram; } \\
\text { Uma achou construtivo; } \\
\text { Uma considerou como es- } \\
\text { clarecedor; } \\
\text { Uma, como rico e engran- } \\
\text { decedor; } \\
\text { Uma vislumbrou novas pos- } \\
\text { sibilidades de comunicação; } \\
\text { Professoras reconheceram } \\
\text { a importância e as possibi- } \\
\text { lidades da CAA. }\end{array}$ \\
\hline $09 / 11 / 16$ & 12 & $\begin{array}{l}\text { CAA } \\
\text { Conversação } \\
\text { com o emprego } \\
\text { de CAA }\end{array}$ & $\begin{array}{l}\text { Dinâmica sobre } \\
\text { CAA de baixa e } \\
\text { alta tecnologias; } \\
\text { Estratégias; } \\
\text { Apresentação do } \\
\text { vídeo da Lívia } \\
\text { (uma moça não } \\
\text { oralizada) conver- } \\
\text { sando com uso da } \\
\text { CAA; } \\
\text { Estudos de casos. }\end{array}$ & $\begin{array}{l}\text { As professoras participantes } \\
\text { consideraram o encontro } \\
\text { muito bom, principalmente } \\
\text { pela troca de experiências. }\end{array}$ \\
\hline
\end{tabular}




\begin{tabular}{|c|c|c|c|c|}
\hline \multicolumn{5}{|c|}{ SALAS ABERTAS COORDENADAS PELA PROFESSORA JULIANA } \\
\hline 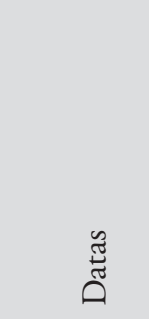 & 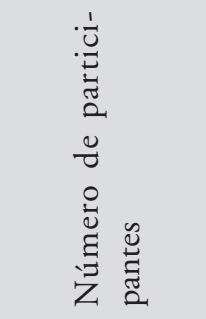 & $\underset{\mathscr{E}}{\tilde{E}}$ & 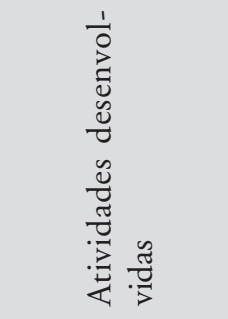 & 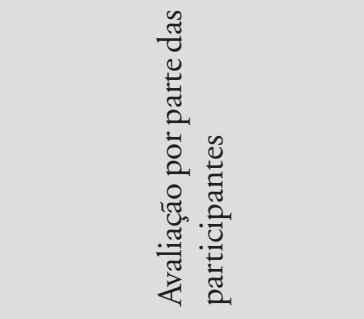 \\
\hline $13 / 07 / 16$ & $\begin{array}{l}16\left(7 \text { no } 1 .^{\circ}\right. \\
\text { turno e } 9 \text { no } \\
\left.2 .^{\circ} \text { turno }\right)\end{array}$ & $\begin{array}{l}\text { Salas Aber- } \\
\text { tas } \\
\text { CAA } \\
\text { Constru- } \\
\text { ção do co- } \\
\text { nhecimen- } \\
\text { to } \\
\text { Interação } \\
\text { do aluno }\end{array}$ & $\begin{array}{l}\text { Apresentação da } \\
\text { proposta das Sa- } \\
\text { las Abertas; } \\
\text { Apresentação } \\
\text { de slides e víde- } \\
\text { os com alguns } \\
\text { alunos que utili- } \\
\text { zam a CAA e de } \\
\text { alguns recursos } \\
\text { que a professora } \\
\text { Juliana utiliza. }\end{array}$ & $\begin{array}{l}\text { As professoras, em geral, } \\
\text { consideraram o encontro } \\
\text { bom, sobretudo pela troca } \\
\text { de experiências; } \\
\text { Ressaltaram como ponto } \\
\text { negativo a duração curta } \\
\text { do encontro; } \\
\text { No próximo encontro, a } \\
\text { professora espera ensinar a } \\
\text { produção de cartões e fazer } \\
\text { discussão sobre a importân- } \\
\text { cia de uma comunicação } \\
\text { funcional, tendo como base } \\
\text { o PEI. }\end{array}$ \\
\hline $09 / 11 / 16$ & $\begin{array}{l}15 \text { ( } 8 \text { no } 1 .^{\circ} \\
\text { turno e } 7 \text { no } \\
2 .^{\circ} \text { turno) }\end{array}$ & CAA & $\begin{array}{l}\text { Em ambos os } \\
\text { turnos: resumo } \\
\text { do encontro } \\
\text { anterior, expo- } \\
\text { sição do tema } \\
\text { "Comunicação } \\
\text { Alternativa no } \\
\text { Contexto das } \\
\text { Salas de Recur- } \\
\text { sos Multifuncio- } \\
\text { nais"; Avaliação. }\end{array}$ & $\begin{array}{l}\text { Nove consideraram como } \\
\text { muito bom; } \\
\text { Seis consideraram esclare- } \\
\text { cedor; } \\
\text { Uma considerou ser pro- } \\
\text { dutivo. }\end{array}$ \\
\hline
\end{tabular}




\begin{tabular}{|c|c|c|c|c|}
\hline \multicolumn{5}{|c|}{ SALAS ABERTAS COORDENADAS PELA PROFESSORA MARIANA } \\
\hline ָే & 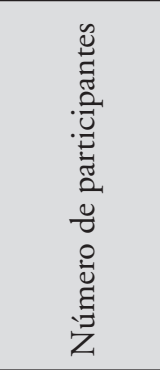 & 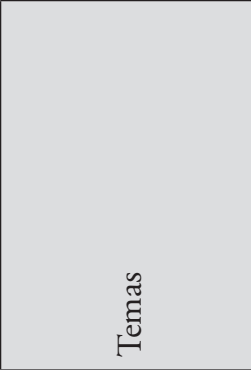 & 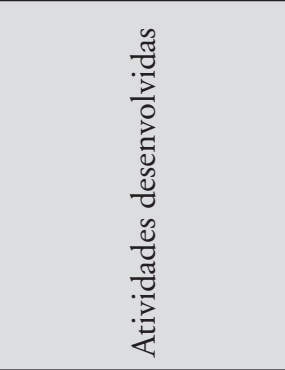 & 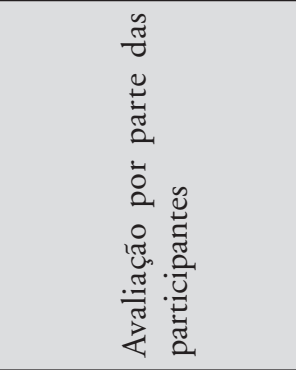 \\
\hline $13 / 07 / 16$ & $\begin{array}{l}23 \text { (12 do } \\
1^{\circ} \text { turno e } \\
11 \text { do } 2^{\circ} \\
\text { turno) }\end{array}$ & $\begin{array}{l}\text { Processos de Co- } \\
\text { municação: emis- } \\
\text { sor e receptor } \\
\text { Co mu u icação } \\
\text { sem fala }\end{array}$ & $\begin{array}{l}\text { Apresentação do } \\
\text { vídeo Processos de } \\
\text { Comunicação, que } \\
\text { explica o modelo } \\
\text { de comunicação de } \\
\text { Shannon-Weaver; } \\
\text { Dinâmica de grupo } \\
\text { para demonstrar a } \\
\text { codificação e a de- } \\
\text { codificação da men- } \\
\text { sagem; } \\
\text { Apresentação de } \\
\text { slides sobre a CAA, } \\
\text { diversidade de } \\
\text { pranchas e uso das } \\
\text { pranchas para jogar } \\
\text { "Cara a cara". }\end{array}$ & $\begin{array}{l}13 \text { consideraram o } \\
\text { encontro excelente e } \\
\text { dinâmico e uma con- } \\
\text { siderou o encontro } \\
\text { bom; } \\
\text { Demanda de encon- } \\
\text { tro voltado à parte } \\
\text { mais teórica e, ainda, } \\
\text { oficinas que englo- } \\
\text { bem tais aplicati- } \\
\text { vos, como: Arasaac, } \\
\text { Boardmaker e PECS- } \\
\text {-Adaptado. }\end{array}$ \\
\hline
\end{tabular}




\begin{tabular}{|c|c|c|c|c|}
\hline \multicolumn{5}{|c|}{ SALAS ABERTAS COORDENADAS PELA PROFESSORA MARIANA } \\
\hline 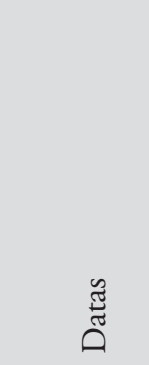 & 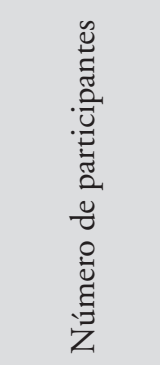 & 胥 & 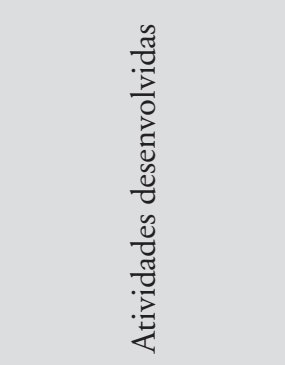 & 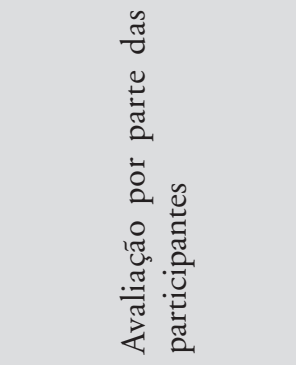 \\
\hline $09 / 11 / 16$ & $\begin{array}{l}24 \text { (13 do } \\
1^{\circ} \text { turno e } \\
11 \text { do } 2^{\circ} \\
\text { turno) }\end{array}$ & $\begin{array}{l}\text { Acessibilidade } \\
\text { CAA } \\
\text { Pranchas } \\
\text { Processos de co- } \\
\text { municação; } \\
\text { Construção de } \\
\text { mensagem em } \\
\text { prancha de CAA }\end{array}$ & $\begin{array}{l}\text { 1. }{ }^{\circ} \text { Turno: exibição } \\
\text { da animação Por que } \\
\text { Heloísa?; } \\
\text { Debate sobre o tema } \\
\text { da animação (acessi- } \\
\text { bilidade); } \\
\text { Apresentação de } \\
\text { slides sobre a CAA; } \\
\text { Montagem de ima- } \\
\text { gens com palavras; } \\
\text { Oficina de prancha } \\
\text { de CAA. } \\
\text { 2. }{ }^{\circ} \text { turno: exibição } \\
\text { do vídeo Processos de } \\
\text { Comunicação; } \\
\text { Debate sobre o ví- } \\
\text { deo; } \\
\text { Dinâmica; } \\
\text { Apresentação de sli- } \\
\text { des sobre CAA; } \\
\text { Construção de men- } \\
\text { sagem em prancha } \\
\text { de CAA. }\end{array}$ & $\begin{array}{l}\text { Quatro acharam im- } \\
\text { portante; Cinco dis- } \\
\text { seram que tiveram } \\
\text { grande aprendizado; } \\
\text { Cinco ficaram satis- } \\
\text { feitas; Duas acharam } \\
\text { esclarecedor. }\end{array}$ \\
\hline
\end{tabular}




\section{Capítulo 14 - Os encontros de Salas Abertas e seus desdobramentos}

Majui Menezes de Souza ${ }^{1}$ Carolina Rizzotto Schirmer ${ }^{2}$

Entre todas as atividades realizadas no curso "Salas de Recursos Multifuncionais de Referência”, os encontros de Salas Abertas mostraram ser particularmente importantes, pois possibilitaram, mediante uma extensa troca de informações entre os professores, a ampliação das ações inclusivas dentro das escolas e da interação entre os profissionais de AEE (Atendimento Educacional Especializado).

Já em minha primeira experiência, no dia 13 de julho de 2016, o encontro ficou marcado por diversos pontos positivos. Houve bastantes trocas de informações, debates, dinâmicas de grupo e, principalmente, muitas trocas de experiências entre os trinta participantes (divididos em dois turnos).

A primeira atividade foi a apresentação do vídeo Processos de Comunica$c_{c} a o^{3}$, produzido para o curso de Especialização em Coordenação Pedagógica da UFSC, na Sala Práticas e Espaços de Comunicação, pela professora D. K.

1 Secretaria Municipal de Educação do Rio de Janeiro. E-mail: majuisouza@yahoo.com.br.

2 Professora adjunta da Faculdade de Educação da UERJ. E-mail: ead.carolina@gmail. com.

3 Processos de Comunicação. Disponível em: https://www.youtube.com/watch?v=_ C3AmzKpJbQ\&t=100s. 
R., com o apoio do Laboratório de Novas Tecnologias (Lantec)/Centro de Ciências da Educação (CED), e disponibilizado publicamente por meio da internet. Trata-se de um stop-motion que explica o modelo de comunicação de Shannon-Weaver. O modelo descreve, entre outras coisas, o ruído, "termo que se refere a possíveis interferências que podem diferenciar a mensagem enviada da mensagem recebida”. Esse ponto foi amplamente discutido após a apresentação do vídeo. Observou-se, de forma muito pertinente, que até mesmo indivíduos sem prejuízo na comunicação estão sujeitos a essas falhas.

Após a exibição do vídeo, demos início à dinâmica de grupo, atividade essencial para desenvolver o tema abordado. A ideia central era de demonstrar, na prática, a codificação e a decodificação da mensagem a ser veiculada, a influência do ruído e como a utilização de uma ferramenta pode suprimir falhas e facilitar a comunicação, quando o ruído é particularmente expressivo, como, por exemplo, no caso de pessoas com prejuízo na comunicação.

A dinâmica de grupo foi feita da seguinte forma: dividiu-se o grupo em duplas em que um seria o emissor e o outro o receptor. $\mathrm{O}$ emissor recebeu uma mensagem simples, desconhecida pelo receptor, e deveria, utilizando-se apenas de movimentos muito limitados, comunicar a mensagem ao receptor sem fazer gestos óbvios. Dessa forma, simula-se uma situação na qual o emissor tem um prejuízo enorme na comunicação, como no caso de um indivíduo com paralisia cerebral. Como resultado, os receptores entenderam erroneamente ou não compreenderam de forma alguma as mensagens recebidas.

Após essa atividade, foram apresentados os slides sobre a CAA - Comunicação Alternativa Ampliada -, nos quais foi demonstrada a enorme diversidade de pranchas que podem ser usadas em cada caso, e alguns vídeos de atendimentos feitos pela Oficina Vivencial, mostrando a importância da comunicação para o aluno, suas inúmeras formas de se comunicar e as várias maneiras de ampliar essa comunicação. Em um desses vídeos, uma aluna com deficiência intelectual e prejuízo na oralidade participava do jogo conhecido como Cara a cara, no qual os participantes reúnem informações dadas pelo adversário para descobrir qual é o personagem, por meio de uma filtragem, com base nas características físicas dele. A aluna em questão, inicialmente não conseguiu comunicar as informaçóes pretendidas para o decorrer do jogo, escolhendo um personagem que era da sua preferência e não aquele oculto pelo adversário. Entretanto, ao reiniciar a atividade utilizando a prancha de CAA, ela foi perfeitamente capaz de comunicar as informações necessárias, 
e o jogo transcorreu de acordo com as regras. A prancha utilizada continha figuras com diversas características físicas, como cor dos olhos, cabelos, sexo do personagem, roupas etc. A aluna, então, pôde apontar para as figuras que representavam a característica a ser comunicada e, com isso, foi capaz de transmitir a mensagem pretendida. Ao final da exibição dos slides e de todo o debate, as duplas da dinâmica de grupo feita na abertura do encontro foram reunidas novamente, porém, utilizando pranchas de CAA para transmitirem um ao outro a mensagem combinada no início da atividade; dessa vez, obtendo melhores resultados.

Durante a primeira parte da dinâmica, os emissores de cada dupla relataram que, durante a tentativa de comunicação sem a prancha de CAA, sentiram-se ansiosos e angustiados ao tentarem transmitir a mensagem ao receptor que era incapaz de compreendê-la. Ao fazê-lo utilizando as pranchas, os resultados foram satisfatórios. Todos os receptores conseguiram compreender o que era transmitido pelos emissores, demonstrando a importância de tais ferramentas na comunicação. Os emissores, por sua vez, relataram que a prancha facilitou muito a comunicação, de modo que, mesmo com movimentos limitados, a informação era facilmente transmitida ao receptor, e o feedback era positivo.

Durante as pausas na apresentação dos vídeos e dos slides, houve muita troca de informações entre os professores presentes. Estes tiveram a oportunidade de relatar experiências, elucidar dúvidas, fazer suas colocaçóes, complementações e sugestões. Experiências positivas com calendário de antecipação foram relatadas, bem como outros tipos de prancha. Uma dúvida muito pertinente surgida durante o debate foi sobre a utilização de fotos ou gravuras e desenhos nas pranchas: concluiu-se que o uso da CAA pode ser iniciado com fotos, passando para figuras maiores e, depois, reduzidas, ou, dependendo do grau de autonomia do aluno, pode-se pular essa transição e utilizar diretamente os símbolos, universalizando o uso da prancha.

O resultado do segundo encontro, realizado no dia 9 de novembro de 2016 e integrado por 22 participantes, também divididos em dois turnos, foi igualmente enriquecedor. Debatemos e problematizamos o fato de que existe um hábito de se associar a CAA apenas a Transtornos do Espectro Autista, deixando de contemplar as muitas outras causas para o prejuízo da comunicação, como a paralisia cerebral. 
Foi apresentado o vídeo Por que Heloisa? ${ }^{4}$, produzido pela Secretaria dos Direitos da Pessoa com Deficiência do Estado de São Paulo e disponibilizado na internet. Ele conta a história de uma menina com paralisia cerebral durante seus primeiros contatos com uma nova escola. A animação aborda, entre outros temas, a acessibilidade e a inclusão, mas não fala sobre a CAA, apesar de o prejuízo da comunicação de Heloísa ser claramente demonstrado em diversas situações. Foi nesse ponto que surgiu a oportunidade de levantar essa questão de forma objetiva pelo grupo.

Algumas das situaçóes vividas pela personagem, em que a comunicação era difícil, foram prontamente identificadas pelo grupo, que também apontou a prática das pranchas de CAA como solução. A única referência à comunicação alternativa foi a utilização de um acionador por meio do qual Heloísa comunicou que desejava um lápis da cor amarela. Porém, nos diversos ambientes em que Heloísa precisava interagir, não havia nenhum calendário ou dispositivo móvel com aplicativo de CAA que pudesse facilitar sua comunicação.

Foi falado também sobre acessibilidade e inclusão, temas centrais no filme, bem como a importância do estímulo para que a pessoa com deficiência tenha sempre mais autonomia na realização de suas tarefas. Dúvidas que também surgiram no debate, como algumas dificuldades em se elaborar uma prancha, foram discutidas.

Finalizando o debate, houve a apresentação de slides, na qual foi demonstrada a importância da utilização da CAA para qualquer aluno com prejuízo na comunicação. Foi abordada também a atuação do professor de Sala de Recursos nesse processo.

Falamos sobre o programa de computador para elaboração de pranchas de CAA chamado Boardmaker, um recurso caro e de utilização restrita a uma única licença de usuário. Isso faz com que, para muitas escolas, esse recurso torne-se inacessível, embora seja extremamente eficaz. Além disso, é um programa pouco intuitivo, havendo complexidade na utilização de suas funções. Uma alternativa ao Boardmaker demonstrada foi o portal ARASAAC, uma ferramenta online e gratuita para a elaboração de pranchas. Foi então que se levantou o problema da falta de sinal de internet em muitas das escolas da

4 Por que Heloisa?. Disponível em: https://www.youtube.com/watch?v=f5vNAwmgZU4. 
rede municipal, o que impossibilita até mesmo a utilização dessa ferramenta inteiramente gratuita.

Em seguida, foi apresentado um organograma com palavras, expressões e situaçôes relacionadas ao PEI - Planejamento Educacional Individualizado -, que devem ser levadas em consideração para a elaboração desse documento. Concluiu-se que o PEI visa a promover um conhecimento aprofundado do histórico do aluno, suas características, habilidades e necessidades, garantindo, assim, um currículo adaptado que deve ser elaborado em conjunto com toda a equipe pedagógica que atende o aluno incluído, para que este possa ser avaliado de forma coerente.

Finalmente, realizamos uma oficina de pranchas de CAA, com imagens relacionadas ao ambiente escolar, na qual os professores puderam elaborar suas pranchas. Estas foram plastificadas, e cada professor pôde levar consigo seu material para a utilização em sala de aula, quando necessário.

Durante a apresentação dos slides, os professores apontaram dificuldades que surgem ao se elaborar uma prancha de CAA e aproveitaram para tirar dúvidas sobre isso e sobre a utilização do Portal ARASAAC. Também foi demonstrado o tutorial do portal e, então, puderam conhecer melhor a plataforma.

\section{Conclusão}

Os eventos das Salas Abertas possibilitaram uma troca enorme de informações entre os participantes. Métodos, dúvidas, experiências, sugestôes e dificuldades foram discutidos amplamente, bem como as políticas públicas para a educação especial. Ficou bastante claro, durante o evento, que, na maioria das vezes, a inclusão ainda é vista como um problema, e não como uma solução. O tema nem sempre é ponto pacífico e, frequentemente, o professor da Sala de Recursos se sente solitário em seu trabalho dentro da escola. E, por meio de um trabalho de conscientização, essa situação está se desconstruindo. Ações como o dia da conscientização do autismo, dia da conscientização da Síndrome de Down, capacitações oferecidas pelo IHA Instituto Helena Antipoff (que também abrangem coordenadores e professo- 
res de sala comum com alunos incluídos etc.) -, entre outras, visam a mitigar esse problema e criar uma cultura inclusiva na rede educacional.

A convergência e consequente troca de experiências entre tantos profissionais da educação especial mostrou-se como sendo o ponto mais importante do encontro. São pessoas que estão separadas fisicamente nos seus trabalhos e que, devido à diversidade e amplitude do tema, aumentam exponencialmente sua capacidade de atuação com esse tipo de interação. Cada aluno tem suas peculiaridades, e cada caso é um desafio. É durante encontros como esse que horizontes se ampliam, novas possibilidades surgem, e o maior beneficiado é o aluno. 


\section{Capítulo 15 - Linguagem, interação e comunicação: competências para o desenvolvimento da criança com deficiência não oralizada}

Debora Deliberato ${ }^{1}$

\section{Introdução}

Nos últimos anos, há uma crescente preocupação por parte dos profissionais e dos pesquisadores em entender a diversidade humana. A literatura tem discutido as diferentes possibilidades em relação às habilidades de comunicação entre as pessoas, principalmente quando: a) a fala não é adquirida na sua totalidade, b) a fala não é adquirida durante o desenvolvimento infantil, e c) a fala foi adquirida e desenvolvida para representar ideias, desejos, intençôes nas diferentes complexidades, mas, por alguma interferência, a pessoa pode perdê-la ou tornar-se impossibilitada de utilizá-la com diferentes pessoas.

Quando as pessoas se deparam com crianças, jovens e adultos que não falam, a interação pode não ocorrer e, com isso, a comunicação não se efetiva. É uma situação que pode surgir no dia a dia das pessoas, como, por exemplo,

1 Docente do Departamento de Educação Especial e do Programa de Pós-Graduação em Educação da Unesp de Marília. Pesquisadora do CNPq. Livre-Docente em Comunicação Alternativa. E-mail: delibera@marilia.unesp.br. 
no ambiente escolar, quando na sala de aula há um aluno com deficiência sem oralidade (ausência da fala).

Interação e comunicação fazem parte da rotina escolar. O professor deve estar atento à rotina de seus alunos para promover situações e atividades nas quais todos possam participar. Além da importância da interação e comunicação na rotina de sala de aula, o docente deve estar atento para a função da fala no processo da aprendizagem da leitura e da escrita, principalmente quando se trabalha com uma língua de natureza alfabética, como no caso da língua portuguesa. Entender o processo de aquisição de um idioma e da função da fala faz parte de uma função de complexidade maior, que é a linguagem.

Pesquisadores discutiram a necessidade de o professor entender a aquisição da linguagem e sua importância para as habilidades de comunicação, interação e aprendizagem da leitura e da escrita. Deliberato et al., (2014) alertaram que, quando o professor entende a função da linguagem para o desenvolvimento da comunicação e interação, a sua mediação poderá ser adequada para as diferentes especificidades dos alunos da sala de aula.

A linguagem é uma função mental superior que nos possibilita captar informações do meio ambiente por meio dos canais sensoriais e, em seguida, a pessoa pode processar esses estímulos recebidos nas diferentes regiōes cerebrais. Após todo processo de entrada de informações, há um complexo intercâmbio com outras funções mentais, tais como atenção, percepção, memória e cognição, que permitem ampliar todo o conteúdo da linguagem de forma dinâmica (Luria, 1981).

Assim, é por meio da percepção, integração e organização da informação recebida do meio ambiente que o indivíduo vai organizar seu pensamento mediante um sistema simbólico, linguístico, de alta complexidade. Esse sistema linguístico tem dependência com a língua, o idioma, da comunidade à qual pertence o indivíduo. Cada língua tem suas características: semântica, lexical, sintática, morfológica, fonológica e pragmática. Sendo assim, a linguagem comporta duas faces: organização de um idioma (língua: processo mental) e as habilidades de externalizar todo o conteúdo pensado e organizado mentalmente, por meio da linguagem externa, que pode ser a fala e $a$ escrita (Saussure, 1991). 
A fala ou linguagem oral é a habilidade mais utilizada e esperada no desenvolvimento da criança, quando se pensa nas habilidades de comunicação no contexto da modalidade oral. A fala é uma habilidade complexa que necessita de várias outras funçôes para que a criança possa se apropriar e transmitir seu pensamento e ideia com intencionalidade. A fala é a expressão do conteúdo organizado por meio do idioma aprendido. A criança precisa compartilhar, vivenciar as normas da língua/idioma durante as situações dialógicas, ou seja, nas diferentes interações, a criança pode e deve compartilhar com os interlocutores competentes o uso do idioma aprendido.

Comunicação é a capacidade que o ser humano tem de trocar informações aprendidas e pretendidas com diferentes pessoas. É um processo que envolve um receptor e um emissor, ou seja, uma pessoa emite uma mensagem, e a outra recebe a mensagem e a interpreta para responder com coesão e coerência. Durante o processo de comunicação, é importante o uso de um sistema linguístico compartilhado, ou seja, ambos os parceiros de comunicação devem utilizar o mesmo idioma para que possam transmitir e compartilhar uma mensagem. A comunicação humana torna-se possível por meio da compreensão dos diferentes signos compartilhados pela comunidade, ou seja, a comunicação será efetivada por meio do uso de um sistema de representação compartilhado no grupo.

A comunicação é mais efetiva quanto maior e melhor o sistema compartilhado entre os interlocutores: parceiros de comunicação.

\section{Aspectos gerais a respeito da competência comunicativa}

As experiências que as crianças e jovens têm durante seu desenvolvimento são dependentes da mediação e do suporte oferecido pelo meio de que participam. A família e a escola fazem parte desse cenário, facilitando e proporcionando acesso ao conhecimento. A participação das crianças em diferentes situações pode favorecer a ampliação do vocabulário, assim como propiciar a vivência no contexto cultural com a língua, o idioma da sua comunidade, como no caso da língua portuguesa.

Argyle (1976), em seus estudos, argumentou que a linguagem emerge na interação social, e os "componentes linguísticos" tornam-se importantes 
para a transmissão e a coordenação do pensamento individual e para o desenvolvimento e a transmissão de cultura. Segundo o autor, para duas pessoas se comunicarem por meio da linguagem, é necessário que elas usem as palavras da mesma forma, convencionadas pela língua vinculada à sua cultura: "A língua real aprendida é aquela que se desenvolveu, durante um longo período de desenvolvimento cultural, na cultura da criança" (Argyle, 1976, p. 77).

A aquisição e o domínio da língua portuguesa fazem parte de um processo de experiências vividas no meio cultural, no qual a criança passa, de agente passivo, à medida que absorve o que escuta, a agente ativo, construindo suas ideias, intenções e desejos. A partir dessa construção e elaboração interna, organizada por meio das regras do idioma, a criança expressa uma ideia com conteúdo e estrutura que pode ser compreendida por um adulto ou por uma outra criança em pleno desenvolvimento.

A troca de experiências entre as crianças com os diferentes interlocutores, mediada e assistida nas situações dialógicas, propicia o acesso destes ao conhecimento e permite às crianças e aos jovens o constante uso do idioma da comunidade em que vive. Quanto mais a criança participa das situaçôes dialógicas, mais ela compartilha experiências em relação ao seu idioma e suas regras: semântica, fonológica, sintática, morfológica e pragmática.

À medida que o desenvolvimento da criança acontece, diferentes habilidades são conquistadas e novas competências são adquiridas. Toda criança tem capacidade de aprender novas habilidades, mas elas dependem da mediação oferecida no meio ambiente que participam. $\mathrm{O}$ incentivo e o reforço oferecidos por diferentes pessoas podem proporcionar às crianças avanços nas aquisições das diferentes competências para o desenvolvimento global e da linguagem.

A ampliação do vocabulário e o entendimento em relação ao uso da língua portuguesa acontece na relação com o outro, ou seja, durante as situações dialógicas: é no momento em que a criança recebe a informação do outro (receptor) que ela pode elaborar e expressar uma resposta com intenção (emissor). Nesse movimento que ocorre durante a interação com o outro, há troca de informações, ou seja, existe a comunicação e a criança aprende a usar um sistema linguístico que representa seus sentidos, suas intenções. Quanto mais experiências e oportunidades a criança vivenciar durante os primeiros anos de vida com diferentes interlocutores, mais competências serão adquiridas em relação às habilidades de comunicação e expressão. 
Toda criança deve receber o suporte do meio ambiente para que possa adquirir e desenvolver as diferentes competências. A capacidade que cada criança apresenta pode ser explorada e ampliada para ter sua função nas diferentes atividades vivenciadas.

A família, sem dúvida, é a base para o início, o acompanhamento e os avanços no desenvolvimento de seus filhos e deve ser o parceiro fundamental no momento da entrada da criança na escola. É no meio familiar que os primeiros modelos e suportes são oferecidos às crianças, nos diferentes aspectos, em relação aos desenvolvimentos motor, cognitivo, linguístico, afetivo e social. A entrada da criança na escola amplia as possibilidades do desenvolvimento, e cabe a esse estabelecimento de ensino oferecer recursos e procedimentos para o aprendizado da leitura e da escrita.

A criança que inicia o processo escolar com competências já adquiridas anteriormente pode ter mais habilidades no entendimento em relação às estratégias utilizadas na medição do professor no processo de ensino dos diferentes conteúdos e em relação ao entendimento da palavra impressa (Deliberato e Nunes, 2015).

\section{Competência comunicativa em relação à criança com deficiência não oralizada}

Quando se discute a mediação em relação à criança com deficiência, os pais devem estar atentos às especificidades do seu filho para que o modelo a ser oferecido no momento das situaçóes dialógicas possa de fato proporcionar a aquisição de competências. A criança com deficiência pode ter habilidades diferentes em relação ao esperado e, dessa forma, as pessoas podem não perceber as diferentes capacidades de cada uma delas.

As crianças com deficiência podem ter capacidades para desenvolver habilidades diferentes das esperadas no desenvolvimento infantil em razão das suas especificidades sensoriais, perceptivas, motoras, cognitivas e linguísticas. Seria possível observar crianças com deficiência desenvolvendo outras habilidades de comunicação no momento das situações dialógicas, como, por exemplo, olhar, gestos, expressóes corporais, vocalizaçóes, uso de objetos, imagens pictográficas e até o uso da escrita como forma de expressar suas 
intenções, quando não conseguem utilizar a fala (Deliberato, 2015; Nunes, 2003; Limongi, 2002).

Entender e participar da diversidade de habilidades comunicativas compartilhadas entre as pessoas pode ampliar a construção de um sistema linguístico mais estruturado e favorecer o desenvolvimento das competências das crianças com deficiência. Nesse contexto, a família e a escola exercem papéis fundamentais.

Von Tetzchner et al. (2005) discutiram que a escola, principalmente a educação infantil, pode ser o ambiente favorecedor para dar suporte às linguagens alternativas. Na escola, a criança com deficiência pode ter a oportunidade de vivenciar com diferentes interlocutores o uso de sistemas que representam sentidos nas situações dialógicas, nas diferentes tarefas previstas na rotina de sala de aula.

A literatura discutiu que, quanto mais diversificado o vocabulário da criança com deficiência, mais possibilidades e oportunidades de ela entender a rotina de atividades da sua sala de aula e o conteúdo previsto no planejamento diário. $\mathrm{O}$ professor deve estar atento em relação às etapas do desenvolvimento de seu aluno para poder planejar e adequar o conteúdo do seu programa de ensino (Schirmer e Nunes, 2011).

Quando a criança com deficiência não conquista a fala como habilidade de expressar suas intenções, desejos e ideias, a ampliação do vocabulário e a organização desses elementos em estruturas mais organizadas, como frases, orações e textos, podem estar prejudicados.

Grande parte das crianças e jovens com deficiência e sem a oralidade acaba desenvolvendo, no seu meio social, outras habilidades de expressar suas ideias. Isso pode acontecer com diferentes crianças com deficiência que utilizam o olhar, expressão facial, sons vocais (vocalização) e gestos não padronizados, que normalmente são compreendidos por interlocutores familiarizados com as habilidades e com o contexto de uso. Essas habilidades são importantes para o desenvolvimento da linguagem, da comunicação e da interação, mas não são suficientes para a complexidade da função da linguagem (Romski e Sevcik, 2005).

A literatura argumentou o quanto é importante a família incentivar diferentes habilidades de comunicação para que as crianças com deficiência, não oralizadas, possam participar das situaçôes de interação com diferentes interlocutores; entretanto, Harwood et al., (2002) também argumentaram a 
necessidade da aquisição de estruturas mais complexas para a criança e para o jovem com deficiência conquistar as diferentes funçôes da linguagem.

Deliberato (2009, 2015) e Sameshima e Deliberato (2007) evidenciaram que crianças e jovens com deficiência, principalmente aqueles com deficiência neuromotora, mais especificamente com a paralisia cerebral, utilizam gestos, expressões faciais e vocalizaçôes como sendo as únicas possibilidades reais de comunicação, mesmo que em ambientes preestabelecidos, como no caso da rotina. Nesse contexto, eles acabam não participando das situações dialógicas de forma mais efetiva com diferentes interlocutores, ou seja, são passivos nas situações de interação e dependem de outro interlocutor competente no entendimento de suas habilidades para fazer a mediação.

A área da Comunicação Suplementar (Ampliada) e Alternativa instrumentaliza a pessoa com deficiência não oralizada nas situações de interação e comunicação. Perante o uso dos sistemas suplementares e alternativos de comunicação, a pessoa com deficiência pode compreender diferentes conteúdos e organizá-los para expressá-los de forma mais estruturada e, assim, pode interagir e ampliar a comunicação com diferentes interlocutores. Sendo assim, o uso dos sistemas suplementares e alternativos de comunicação são utilizados para diferentes pessoas com deficiência a fim de ampliar as questões de compreensão, elaboração e produção de novas ideias (Von Teztchner, 2009; Rothschild e Norris, 2001).

Light e McNaughton (2013) destacaram a relevância dos sistemas de comunicação suplementar e alternativo não só ao propiciarem uma variedade de funçôes pragmáticas, mas também ao desenvolverem um potencial para a aquisição e aprimoramento da linguagem e facilitarem as competências subjacentes à compreensão e à produção da linguagem gerada.

Sevcik, Romski e Wilkinson (1991) discutiram que a aquisição de símbolos faculta à criança o acesso para representar o meio externo internamente, além de proporcionar significados para compartilhar percepções internas e sentimentos com os outros. Ainda nessa direção, pesquisadores como Iacono et al. (1993) discutiram que a comunicação pode ocorrer por meio de múltiplas modalidades e, embora seja importante esse fato para se destacar, a interação humana é caracterizada pela comunicação simbólica, isto é, envolve o uso de símbolos arbitrários que representam ideias, estados afetivos, objetos, ações, relações e eventos. A capacidade de utilizar símbolos permite 
ao indivíduo tanto a comunicação a respeito de ideias e sentimentos quanto sobre temas que estão temporal e espacialmente distantes.

Para Millikin (1997), as pessoas combinam estratégias verbais e não verbais no momento da comunicação, favorecendo, dessa maneira, mensagens comunicativas que tenham sentido para o ouvinte. Segundo a autora, a pessoa com deficiência que usa sistemas suplementares e alternativos de comunicação pode transmitir mensagens por intermédio de sistemas de representação e elementos não verbais.

Em relação aos sistemas suplementares e alternativos de comunicação, Millikin (1997) padronizou uma estrutura de modelo no contexto das categorias dos métodos para a linguagem verbal: com auxílio (auxiliada) e sem auxílio (não auxiliada). Uma técnica de comunicação verbal auxiliada envolve a presença de um objeto físico externo, como papel, lápis, computador, pranchas com figuras ou ainda um dispositivo eletrônico para comunicação suplementar e alternativa (vocalizador ou comunicador). A comunicação verbal não auxiliada está associada à técnica que não precisa de objetos externos, como no caso da fala e da linguagem de sinais.

A autora ainda estabeleceu duas subcategorias para a comunicação verbal com auxílio e comunicação verbal sem auxílio: vocal e não vocal. Considerou a comunicação verbal, sem auxílio e vocal, a fala, enquanto a língua de sinais seria a comunicação verbal sem auxílio e não vocal. A comunicação verbal com auxílio e vocal trata-se do uso de sistemas de comunicação com voz digitalizada ou sintetizada, vocalizadores com voz digitalizada e sintetizada. Já a comunicação verbal com auxílio e não vocal engloba a linguagem escrita, as pranchas com alfabeto e as pranchas com figuras.

Ambas as modalidades de comunicação verbal, auxiliada e não auxiliada, apresentam um grupo ou um sistema de símbolos para a elaboração e transmissão das mensagens, ou seja, o termo verbal está relacionado com um referente simbólico específico. No caso de indivíduos para quem os referentes são ações e comportamentos que comunicam mensagens específicas, mas não representam referentes específicos, Millikin (1997) designou como comunicação não verbal. Para essa categoria, a autora elegeu duas subcategorias: vocal (choro, vocalização, variação de entonações, risada) e não vocal (apontar, gestos, expressões faciais e linguagem corporal).

Lloyd e Karlan (1984) salientaram que gestos, linguagem corporal e vocalizações, designados como comunicação não verbal por Millikin (1997), 
estão ligados a um grupo de símbolos, e não a um sistema de símbolos, isto é, tais grupos de símbolos são relativamente finitos e determinados, e faltam regras específicas ligadas à possibilidade de combinação, restringindo as mensagens que um indivíduo poderia ser capaz de transmitir.

\section{Ler e escrever: questões em relação à criança com deficiência que usa a Comunicação Alternativa}

Sandberg (2016) argumentou que ler e escrever estão entre as habilidades adquiridas mais importantes na nossa sociedade, permitindo-nos o acesso à informação independentemente da distância e do tempo. A autora ainda reforçou que a aquisição das habilidades da leitura e da escrita permitem às pessoas: a) participar de forma mais ativa na sociedade; b) obter mais informações; c) conquistar e ampliar a comunicação; d) ser educada; e) desenvolver atividades vocacionais; e f) desenvolver atividades de lazer. Sendo assim, a aprendizagem da leitura e da escrita é uma das principais conquistas do desenvolvimento da criança.

A literatura tem discutido que o uso da escrita pode ser um caminho para que as pessoas com deficiência, usuárias da Comunicação Alternativa, acessem o vocabulário ilimitado da sua comunidade e, assim, tenham a possibilidade de participar das diferentes situações dialógicas e do processo escolar (Nunes et al., 2011; Schirmer e Nunes, 2011; Smith, 2003). A mesma literatura e a experiência prática com professores e familiares de crianças e jovens que usam os sistemas suplementares e alternativos de comunicação indicaram dificuldades no caminho para a aquisição e para o desenvolvimento da leitura e da escrita dessas crianças e jovens (Deliberato, 2009; Lund e Light, 2006; Smith, 2003).

A literatura destacou que o professor deve ter o conhecimento a respeito da complexidade da relação entre a linguagem escrita e a linguagem oral: a primeira trata-se de sistemas de signos que representam a linguagem oral de forma gráfica e permanente, como, por exemplo, a escrita logográfica, quando o signo gráfico representa uma palavra; a escrita de sílaba, quando o signo escrito representa uma sílaba falada, e a alfabética, quando a combinação de signos corresponde aos sons da linguagem falada (Sandberg, 2016). 
Sendo assim, a linguagem escrita tem um vínculo fundamental com a linguagem oral e requer da criança um alto grau de abstração e poder de análise para converter os sons, fonemas e, nas representações gráficas, os grafemas. Além da tarefa de codificar e decodificar os fonemas e grafemas, a criança precisa compreender o sentido da "palavra" falada ou escrita. No processo de aquisição da leitura e da escrita, as pessoas podem utilizar duas estratégias para decodificar as palavras: ortográfica e fonológica. Na estratégia ortográfica, a pessoa pode visualizar a palavra impressa e entender seu significado, principalmente porque já tem o conhecimento do vocabulário e da representação entre os fonemas e grafemas. Mas, quando as palavras não são familiares, há necessidade da estratégia fonológica.

$\mathrm{Na}$ rota fonológica, as letras precisam ser reconhecidas na sua forma fonológica, ou seja, como fonemas: cada letra tem a correspondência do som (relação fonema/grafema). As experiências fonológicas são armazenadas na memória de curto prazo, e são as diferentes experiências entre a constituição da produção dos fonemas durante o uso na fala que vão constituindo a memória fonológica. É a relação entre a produção oral e a experiência com os sons da língua, ou seja, a criança vai aprendendo a emitir e a ouvir, a discriminar e a ter a consciência de cada som - consciência dos fonemas da sua língua.

No momento da aprendizagem da leitura e escrita, devem ser considerados vários fatores: a) experiência e uso do idioma da comunidade a que pertence a criança; b) cognição; c) memória visual e auditiva; e d) diferentes aspectos da linguagem, como: vocabulário, conhecimento da organização sintática e aspectos fonológicos e pragmáticos.

Pesquisadores advertem que a criança e o jovem que usam a Comunicação Alternativa acabam apresentando dificuldades no processo de aprender a ler e a escrever em decorrência de: a) vocabulário limitado; b) falta de vivência com as estruturas do idioma da comunidade das quais participam; c) falta de vivência da produção e da articulação dos fonemas do idioma; d) falta de retroalimentação entre sua produção e monitoramento auditivo do fonema; e) ausência de correspondência entre o input do idioma vivenciado e o uso dos sistemas gráficos utilizados por eles; e f) ausência de parceiros de comunicação competentes para usarem os sistemas gráficos a partir da estrutura do idioma compartilhado. A falta de suporte constante nas situações dialógicas pode interferir nas experiências das crianças e dos jovens que usam 
a Comunicação Alternativa com os elementos linguísticos necessários para a constituição da linguagem.

Os estudos a respeito da aprendizagem da leitura e da escrita em crianças e jovens que usam a Comunicação Alternativa ainda possuem número restrito de participantes e são resultados baseados em estudo de casos (Light e MacNaughton, 2013). Esses estudos tratam a respeito das dificuldades em relação à decodificação e à compreensão da palavra impressa e discutem a interferência ou não da habilidade da consciência fonológica (Sandberg, 2016; Van Balkom e Verhoeven, 2010).

Embora a literatura tenha discutido fatores individuais que possam interferir no processo de aquisição e desenvolvimento da leitura e da escrita, autores advertem que a escrita é uma invenção cultural e, como tal, é transmitida no contexto cultural e social. Nesse sentido, as pesquisas discutiram que crianças que exploram a escrita desde muito cedo, que participam de leituras de livros e crianças cujas famílias proporcionam experiências com a leitura podem apresentar expectativas diferenciadas em relação à aquisição e ao desenvolvimento da leitura e da escrita (Soto et al., 2008; Guarda e Deliberato, 2006).

Sendo assim, cabe aos profissionais da educação e da saúde terem o cuidado de avaliar e acompanhar as habilidades de seus alunos, bem como entender a história de vida construída durante as diferentes etapas do desenvolvimento. Os estudos demonstraram a necessidade de programas individualizados em razão da diversidade de habilidades e características identificadas em crianças e jovens que usam a Comunicação Alternativa. Além das questôes de recursos e procedimentos direcionados à consciência fonológica, decodificação e compreensão da palavra impressa, o uso da tecnologia também tem sido apontado como um instrumento favorecedor no processo de aprendizagem, como, por exemplo, nos recursos com saída de voz sintetizada ou digitalizada. Mas a literatura também tem alertado para a necessidade de intervenção para cuidar dos aspectos socioculturais, de motivação e de atenção das crianças e jovens que usam a Comunicação Alternativa (Light e McNaughton, 2014, 2015; Rocha et al. 2015). 


\section{Considerações finais}

A linguagem é uma função mental de alta complexidade, pois interage com outras funções mentais, como a memória e a cognição, e está intimamente relacionada com as ações do meio ambiente - suporte do interlocutor. Os profissionais que atuam com crianças e jovens com deficiência necessitam entender a respeito da aquisição e do desenvolvimento da linguagem e das diferentes possibilidades de a pessoa com deficiência expressar seus desejos, suas intenções e ideias. A construção da linguagem e a vivência com o idioma são compartilhados nas situaçôes dialógicas. Cabe ao interlocutor competente no idioma da comunidade oferecer o suporte em relação às linguagens alternativas. Nesse contexto, a escola é um ambiente favorável para inserir as linguagens alternativas e, com isso, as pessoas com deficiência podem ter acesso às situaçôes dialógicas e ter voz nas trocas comunicativas.

Vivenciar os elementos linguísticos da linguagem, por meio do suporte das açōes dos interlocutores competentes nas linguagens alternativas, motiva as pessoas com deficiência que usam a Comunicação Alternativa a emergir na aprendizagem da leitura e da escrita. $\mathrm{O}$ professor, compreendendo a função da linguagem, pode elaborar e adaptar seu currículo para a diversidade de alunos com deficiência sem oralidade e favorecer a aquisição da leitura e da escrita. 


\section{Capítulo 16 - PECS-Adaptado na sala de Atendimento Educacional Especializado}

Cátia Crivelenti de Figueiredo Walter ${ }^{l}$

As dificuldades de comunicação apresentadas pelos alunos com Transtorno do Espectro Autista (TEA) incluídos nas salas de aula do ensino fundamental são apontadas pelos professores como sendo um fator muito desfavorável ao sucesso escolar. Ausência de fala funcional, vocabulário restrito, ecolalia, falha ao responder ou fazer perguntas e solicitar algo desejado, enfim, dificuldade em estabelecer contato com seus pares e com os professores são caraterísticas comumente encontradas nessa população. $\mathrm{O}$ prejuízo linguístico no TEA envolve dificuldades na comunicação não verbal, nos processos simbólicos, na produção da fala, nos aspectos pragmáticos da linguagem (Prizant e Rydell, 2000), nas habilidades que precedem a linguagem, na compreensão da fala e no uso de gestos simbólicos e das mímicas (Perissinoto, 2003; Tomazelo, 2003; Von Tetzchner et al., 2004).

Este capítulo descreve o uso do PECS-Adaptado (Pessoas Engajadas Comunicando-se Socialmente) como um programa eficaz de Comunicação Alternativa (CA) indicado para alunos com TEA que frequentam as Salas de Recursos Multifuncionais (SRM), onde é oferecido o Atendimento Educacional Especializado (AEE) a todos os alunos incluídos, no contraturno do período escolar regular.

1 Professora adjunta da Faculdade de Educação e do Programa de Pós-Graduação em Educação da UERJ. Financiamento FAPERJ, Processo E-26/203.216/2015 - Bolsista Jovem Cientista do Nosso Estado. Universidade do Estado do Rio de Janeiro - UERJ. E-mail: catiawalter@gmail.com. 


\section{Os desafios da inclusão de alunos com TEA e o uso da CA}

A inclusão escolar de alunos com TEA tem apontado diferentes papéis que devem ser assumidos pelos professores. De um lado, temos os docentes das salas de aulas regulares procurando cumprir seus programas pedagógicos de forma satisfatória, mesmo sem saber, muitas vezes, como lidar com alunos que apresentam dificuldades comportamentais e comunicativas. De outro lado, temos os professores mais especializados da SRM. Esses professores assumem um papel de gestores especializados e realizam o planejamento de cada aluno de forma individualizada, pautado na complementação dos processos de escolarização desses discentes (Mendes et al., 2015). Sendo assim, é possível observar dois cenários no processo de inclusão escolar: um, no qual o número de alunos é menor, e o acompanhamento é individualizado, e outro, em que contamos com um número elevado de alunos em sala de aula, com um ensino proposto de forma generalista, priorizando o parâmetro de normalização.

Quando se trata de inclusão escolar de alunos com TEA, o processo tende a ser mais delicado e constitui um grande desafio para os professores tanto das salas comuns como das SRMs. O comprometimento na comunicação e na interação social e a presença de padrão restrito e repetitivo de comportamento podem acarretar prejuízos no sucesso do aluno na sala de aula comum (Camargo e Bosa, 2009; Braga, 2002). A inclusão de alunos com TEA é um processo complexo e ainda muito difícil de ser compreendido pelos docentes, pois muitos sentem-se incapazes de ensinar, comunicar e seguir de forma tranquila o planejamento acadêmico para tais discentes.

É muito comum nos depararmos com professores da sala comum com dúvidas sobre como utilizar programas de comunicação alternativa em sala de aula. Portanto, caberá ao professor da SRM propor inicialmente os programas especializados e as adaptaçôes necessárias para o sucesso do aluno na escola.

Muito frequentemente encontramos professores utilizando figuras ou fotos representativas de atividades acadêmicas ou de vida diária como indicativo de ordenação de rotinas, e não como forma de expressão, deixando, assim, de valorizar o potencial interativo e expressivo do aluno com TEA. Dessa forma, é preciso que os professores da SRM estejam atentos ao uso 
de tais cartôes de comunicação, a fim de que eles possam ser padronizados e convencionados como formas alternativas de comunicação, eficazes no processo de transmitir informações, sentimentos e desejos dos alunos que não conseguem se comunicar por meio da fala.

Ainda é presente a confusão em torno do assunto, visto que os professores ou profissionais especializados confundem métodos educacionais, que se estruturam com o uso de figuras, como é o caso do método TEACCH (Shopler, 2000), mas não são utilizados como programas de comunicação ou em situaçóes dialógicas. No caso dos sistemas de comunicação alternativa, podemos encontrar em salas de aula o uso de símbolos pictográficos Picture Communication Symbols - PCS (Mayer-Johnson, 2011), ARASAAC ${ }^{2}$, imagens públicas disponíveis na internet, desenhos, letras e, ainda, os gestos naturais e idiossincráticos. Como recursos alternativos de comunicação, os mais comuns são as pranchas de comunicação dispostas em pastas plastificadas, pranchas de madeira com velcros, tablets, álbuns e painéis de comunicação. Tais recursos são geralmente mais utilizados para favorecer a linguagem receptiva (compreensão da fala) do que para instigar a linguagem expressiva, ou seja, a solicitação ou manifestação de desejo ou sentimentos. Para ser considerado um programa de comunicação alternativa, este deverá ser apresentado com critérios de aplicabilidade e estrutura organizada em etapas nas quais o professor possa acompanhar cada fase do programa e seguir as formas de avaliação e evolução da comunicação de seus alunos. Lembrando que, quando necessário, o professor deverá solicitar apoio de uma avaliação fonoaudiológica para que possa sentir-se seguro e confiante no uso da CAA e poder contar com suporte de profissional especializado.

A literatura científica vem apontando resultados promissores na utilização de dois programas de CAA destinados às pessoas com TEA: o PECS (Bondy e Frost, 1994, 2001) e o PECS-Adaptado (Walter, 2000, 2006). É importante que os professores das SRMs conheçam muito bem os programas e possam utilizá-los de forma eficaz com seus alunos, incialmente no AEE e, posteriormente, introduzidos nas salas de aula comuns. Também é importante ficarem atentos às possíveis modificações que poderão ocorrer em cada caso, visto que crianças com TEA geralmente apresentam interesses

2 Sistema gráfico gratuito, desenvolvido pelo Governo de Aragon, Espanha, disponível no site: http://www.catedu.es/arasaac/descargas.php\#select. 
restritos e comportamentos peculiares, que deverão ser levados em consideração ao organizar um programa de comunicação pautado nas necessidades e nos desejos de cada aluno. O objetivo deste capítulo é descrever as fases do PECS-Adaptado e discutir as possíveis modificações que poderão ocorrer na sua implementação pelo professor da SRM.

\section{O PECS-Adaptado e suas fases evolutivas}

O PECS - The Picture Exchange Communication System (Bondy e Frost, 1994) - é um programa que foi desenvolvido para crianças com autismo e com déficit severo na comunicação oral e consiste no intercâmbio de figuras como uma forma interativa de transmitir uma mensagem a alguém. As crianças são motivadas a solicitar algo desejado entregando um cartão de comunicação à outra pessoa para obter o item desejado. Tal programa, que vem sendo utilizado em vários países e tem demonstrado sua eficácia, foi descrito inicialmente em sete fases, mas atualmente apresenta-se em seis fases de treinamento.

Uma versão desse sistema proposta no Brasil, com modificações em sua forma de instrução, nas fases do programa e nas formas de registro, foi denominada de PECS-Adaptado (Walter, 2000). As adaptaçóes propostas basearam-se na metodologia do Currículo Funcional Natural (Leblanc, 1991). O programa foi dividido em cinco fases de aplicação, sendo indicado para pessoas com TEA ou outros déficits severos na comunicação oral que apresentam dificuldades para iniciar um diálogo de forma espontânea ou inabilidades sociais graves. Por exemplo, o PECS-Adaptado é indicado para pessoas que apresentam comportamento de retirar os objetos das mãos das pessoas ou que não conseguem apontar ou mesmo indicar os itens desejados.

Para utilizar o PECS-Adaptado proposto por Walter (2000), é necessário que se compreendam as exigências estipuladas em cada fase do programa e que se valorize sempre o ato comunicativo como sendo o resultado mais importante, e não somente o ato de pegar um cartão e entregá-lo a outra pessoa. A autora destaca a finalidade de proporcionar aos indivíduos com TEA condiçóes de solicitar algo desejado ou necessário de uma forma mais clara e, assim, criar uma relação de confiança e afeto com seu interlocutor. Qualquer 
pessoa poderá utilizar o programa - professores, pais, fonoaudiólogos, pares e outros profissionais, enfim, quem se propuser a estabelecer interação e diálogo com a pessoa desprovida de fala funcional. O programa basicamente se divide nas fases descritas a seguir.

\section{Organização do material do PECS-Adaptado}

O emprego do PECS-Adaptado se inicia com atos funcionais que colocam a criança em contato com reforçadores naturalmente eficazes, ou seja, itens mais desejados e necessários, selecionados previamente pelos familiares e pelo professor. Para tanto, deverá ser preenchida pelos pais e professores, antes da implementação das fases que compóem o programa, uma lista de itens preferenciais da criança. Com o objetivo de selecionar as figuras correspondentes aos itens mais relevantes para cada aluno, os professores poderão checar se tais itens são, de fato, interessantes no momento em que estiverem interagindo com o aluno, ou seja, mesmo que tenha sido considerado relevante previamente, o item pode não ser do interesse do aluno posteriormente.

As figuras utilizadas no PECS-Adaptado podem ser desenhos, clip-arts, encartes ou figuras de softwares específicos ou sites que contenham pictogramas de comunicação alternativa. Os cartões de comunicação contendo o sistema gráfico determinado devem sempre vir acompanhados pela escrita (legenda) na parte superior. Os cartões podem ser impressos em preto e branco ou em cores, plastificados, e devem conter no verso um pequeno pedaço de velcro para permitir que sejam fixados nos painéis ou no álbum de comunicação. $\mathrm{O}$ tamanho dos cartões pode variar de acordo com a acuidade visual do aluno em questão. Walter (2000) sugere dois tamanhos: $5,5 \mathrm{~cm} \mathrm{em}$ um primeiro momento e, depois, reduzido para $2,2 \mathrm{~cm}$ na fase $3 \mathrm{~b}$, com o propósito de aumentar a disponibilidade de cartões em pranchas ou álbuns de comunicação, como ilustram as figuras 1, 2 e 3. 
Figura 1 - Figuras do PCS com os dois tamanhos, dispostas em pranchas e álbum de comunicação, e pochete utilizada no programa PECS-Adaptado

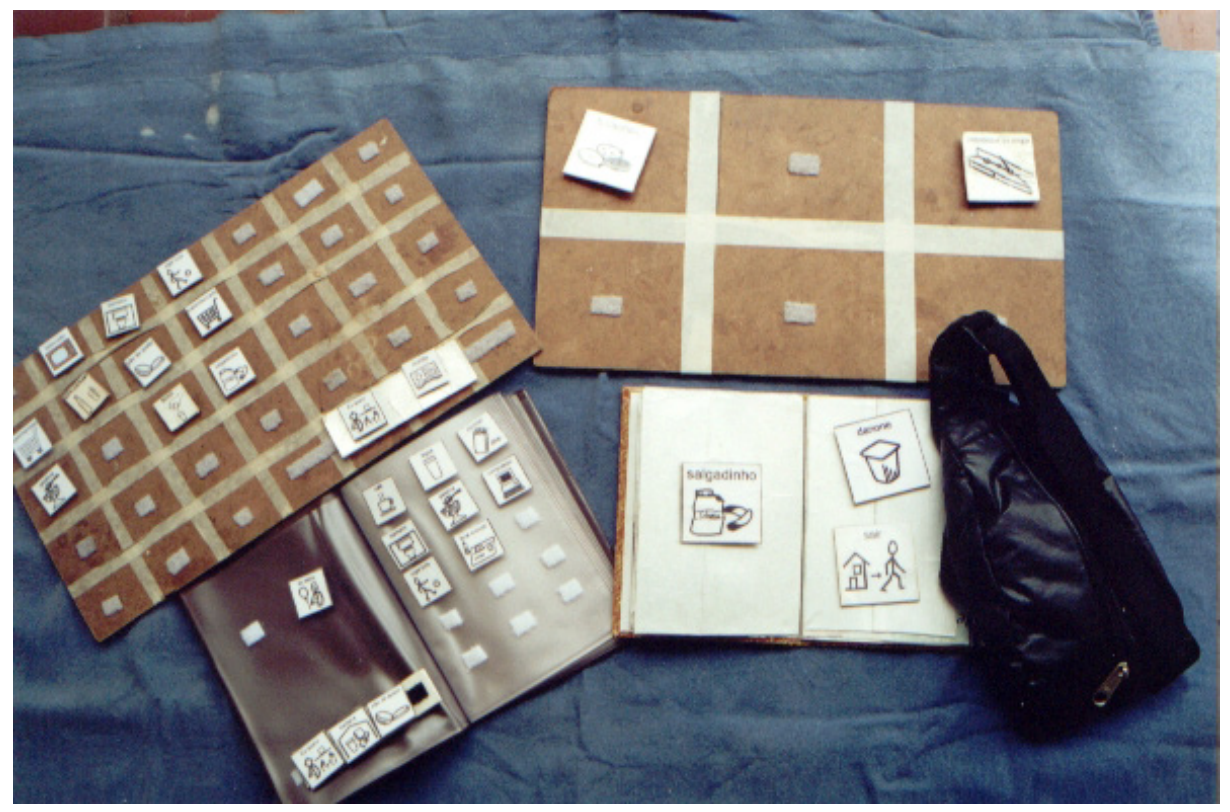

Fonte: Walter, 2000. 
Figura 2 - Modelo de uma prancha e de um álbum de comunicação (fase 5 do PECS-Adaptado) contendo cartões de comunicação impressos com o pictograma PCS $^{3}$
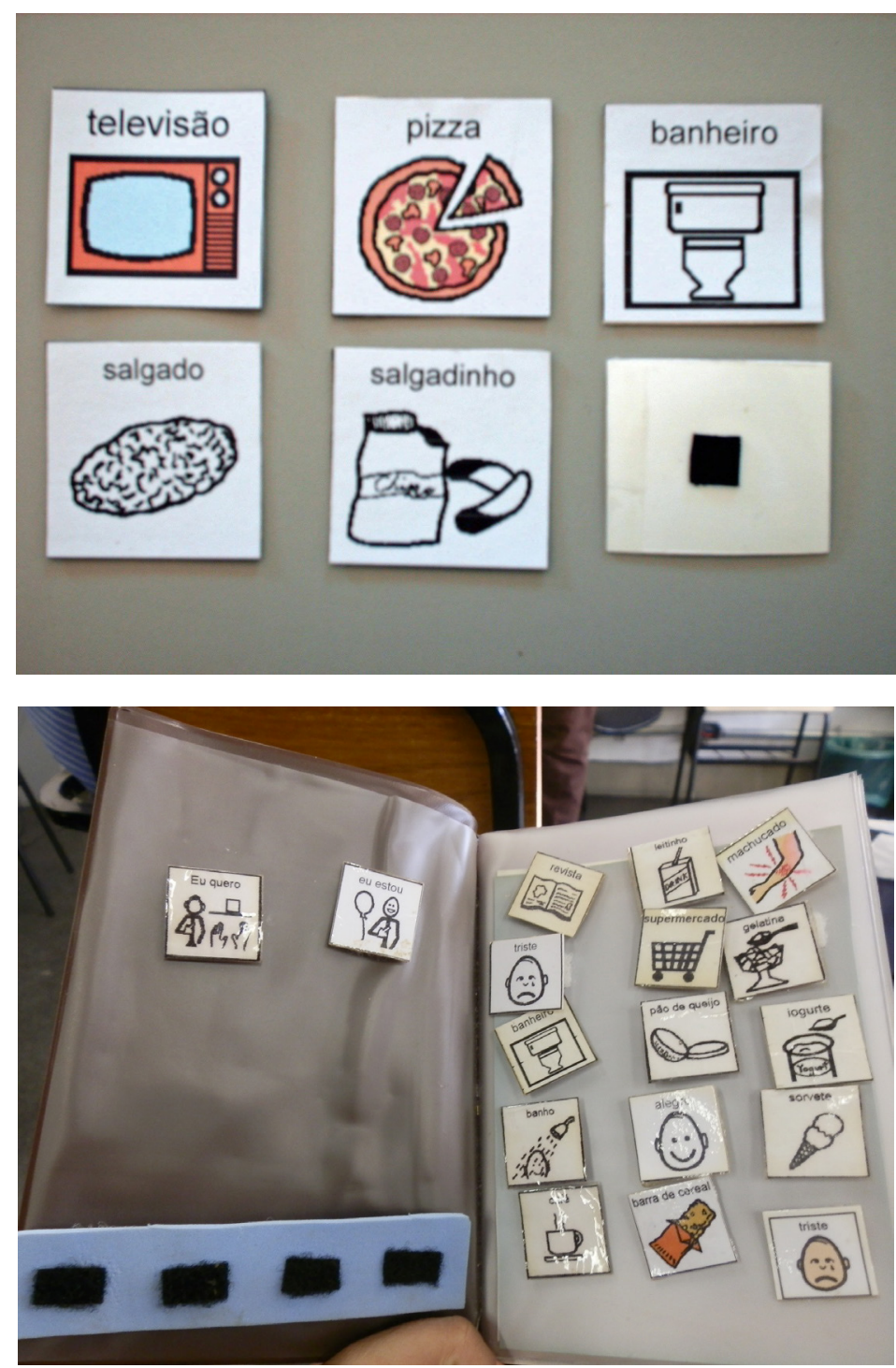

Fonte: Walter, 2006.

3 Picture Communication Symbols (Mayer-Johnson, 2011). 
Figura 3 - Painel de CA que poderá ser disposto na SRM

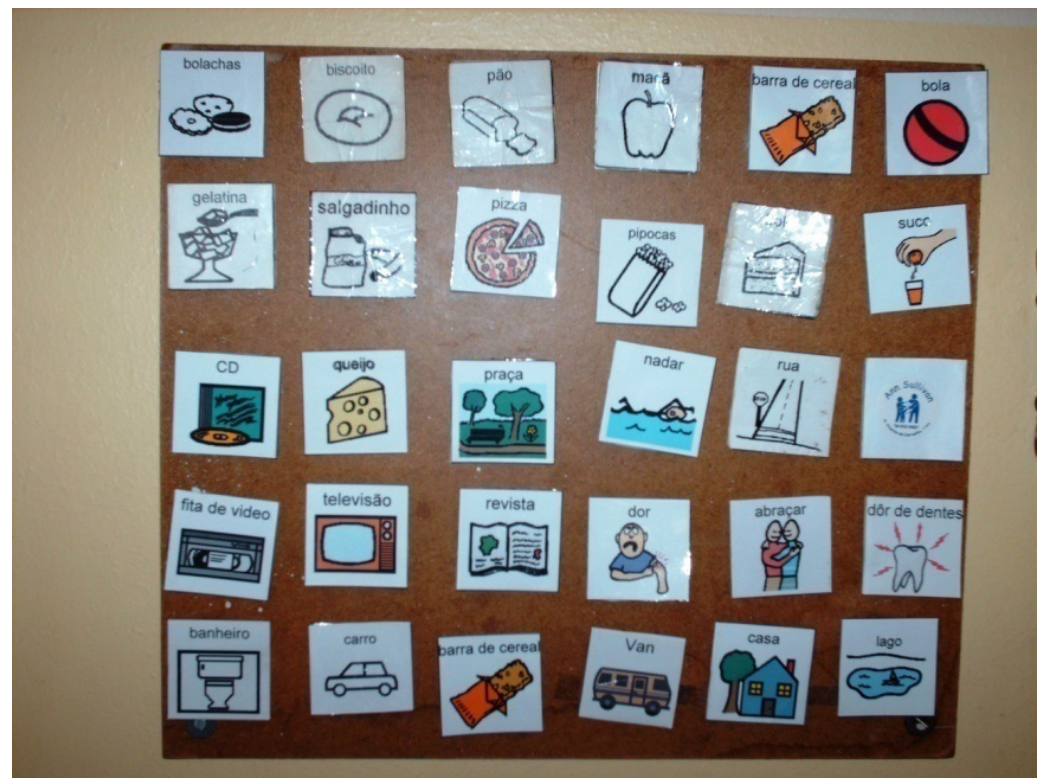

Fonte: Walter, 2006.

\section{Procedimentos gerais para o uso do PECS-Adaptado na SRM}

Depois de organizar os materiais, o professor da SRM terá de preencher as folhas de registro referentes aos níveis de apoio oferecido durante as fases do PECS-Adaptado. É preciso estar atento ao interesse e à motivação do aluno no ato comunicativo e proporcionar um ambiente harmonioso e amigável a fim de transformar uma simples solicitação em um envolvimento prazeroso e alegre.

Os níveis de apoio devem ser contabilizados mediante o número de tentativas de solicitação dos itens desejados pelo intercâmbio dos cartões de comunicação, obedecendo aos níveis de suporte ofertado ao aluno, seguindo o critério determinado por Walter e Almeida (2010) e adaptado para o contexto escolar. Assim, serão considerados os seguintes escores, pontuados pelo professor e contabilizados após análise das sessões filmadas: 
- 0 - Quando o aluno não faz uso da comunicação alternativa para solicitar ou informar algo que deseja ou retira das mãos da professora o item desejado;

- 1 - Quando é necessário o auxílio físico do professor ao tocar no aluno, direcionando sua mão para o cartão de comunicação disposto sobre a mesa, representando o item desejado;

- 2 - Quando é necessário oferecer auxílio verbal para que o aluno pegue o cartão de comunicação e o entregue na mão do professor, realizando a troca pelo item desejado;

- 3 - Quando o aluno necessita de supervisão por parte do professor, por exemplo: "Se você quiser algo, você pode me pedir/você deseja algo? Me diz o que deseja!";

- 4 - Quando o aluno pega o cartão do item desejado disposto sobre a mesa e comunica ao professor, sem ser instigado previamente, iniciando $\mathrm{o}$ ato comunicativo de forma espontânea.

A pontuação deve ser anotada na folha de registro (Walter, 2006) durante as fases do PECS-Adaptado em que o aluno se encontra, de acordo com o escore recebido na avaliação dos níveis de suporte que o aluno receber do professor. Por exemplo, se somar 20 pontos em 10 tentativas de comunicação, terá atingido $50 \%$ de acertos. Ao final da sessão, deve ser calculada a porcentagem média de apoio oferecido, considerando o número de tentativas. Quando o aluno obtiver uma porcentagem maior ou igual a 75\%, em três sessões consecutivas ou em cinco sessões alternadas, ele poderá avançar para a próxima fase do PECS-Adaptado. Tal procedimento de registro dependerá dos arranjos ambientais e do objetivo final descrito em cada fase do programa.

A forma de instrução do PECS-Adaptado (Walter, 2000) foi modificada a partir do programa PECS proposto por Bondy e Frost (1994), sendo explicado ao aluno previamente, ao início do programa, que se trata de uma nova forma de solicitar o que deseja, sem ter que retirar das mãos das pessoas o item desejado. Essa explicação dever ser dada ao aluno quando ele demons- 
trar desejo de obter um item do seu interesse, provavelmente no seu campo visual.

Em cada fase, há um objetivo final a ser alcançado, e será preciso anotar os tipos de apoio (explicado mais adiante) para que o professor da SRM possa acompanhar a evolução do seu aluno nas fases do PECS-Adaptado. Também é explicada ao aluno a forma como ele deverá realizar a troca da figura pelo item desejado e os benefícios que essa nova forma de comunicação trará na sua interação com as pessoas.

É importante que o professor deixe claro para o aluno que a troca do cartão de comunicação para solicitar itens desejados é a forma mais aceita e eficiente para expressar seus desejos, tornando suas solicitaçôes entendidas por todos. A instigação verbal é algo presente desde a primeira fase, por exemplo: "O que você quer?", "Eu posso te ajudar?", "Tente me dizer com essa figura o que deseja!", "Eu posso compreender melhor se você me pedir o que deseja entregando essa figura!" etc. É fundamental mostrar ao aluno a importância de manter um canal de comunicação comum e obter o reforço social naturalmente, decorrente da relação amiga e satisfatória por ter obtido algo desejado. Em todas as fases do PECS-Adaptado, o professor utilizará a fala em sua intervenção e sempre dará ênfase à nomeação em voz alta dos itens representados pelos cartões de comunicação.

O PECS-Adaptado vem sendo utilizado em ambiente escolar (Walter, 2016; Togashi e Walter, 2016; Walter e Nunes, 2013), e tem sido demonstrada a necessidade de adaptaçôes para tornar sua forma de instrução mais flexível. O professor poderá modificar a distância que mantém do aluno, a disposição dos itens, assim como seu posicionamento em relação ao discente durante $o$ ato comunicativo.

Aqui serão apresentadas as cinco fases do PECS-Adaptado, descrevendo o objetivo final de cada uma delas e seus arranjos ambientais. São de extrema importância as anotações e registros dos níveis de apoio oferecido em cada fase para que se possa avançar até a última fase do programa. 


\section{Fase 1 - Ensinando a solicitar algo pela troca da figura pelo item desejado}

Objetivo final: ao ver um item muito desejado na mão do professor, o aluno deve pegar o cartão de comunicação correspondente ao item desejado, disposto sobre a mesa, estender a mão e entregá-lo ao professor, de forma independente.

Arranjos ambientais: é necessário organizar o ambiente de acordo com a necessidade de cada aluno, porém algumas providências devem ser tomadas, como:

- Manter a presença de duas pessoas (facultativo) e o ambiente organizado (em mesa de preferência);

- Iniciar o ato comunicativo com enfoque amigo, como já descrito anteriormente;

- Apresentar o cartão de comunicação, de alta relevância e motivador, um de cada vez para o aluno, disposto à sua frente, para que ele solicite o item por meio do intercâmbio do cartão;

- Empregar o programa em locais avaliados previamente (sala de aula, refeitório, corredor etc.), de preferência na SRM;

- Receber em todas as suas tentativas de comunicação um retorno muito positivo e afetivo por parte do professor. Por exemplo: "Que bom, estou compreendendo o que está me pedindo!";

- Ser avaliado sempre quanto aos níveis de suporte recebido para utilizar o álbum de comunicação e avançar para a fase seguinte quando estiver mais independente. 
Figura 4 - Professora da SRM sentada ao lado do aluno (adaptação que fez durante a fase 1 do PECS-Adaptado) para ensiná-lo a solicitar biscoito por meio do intercâmbio do cartão de comunicação

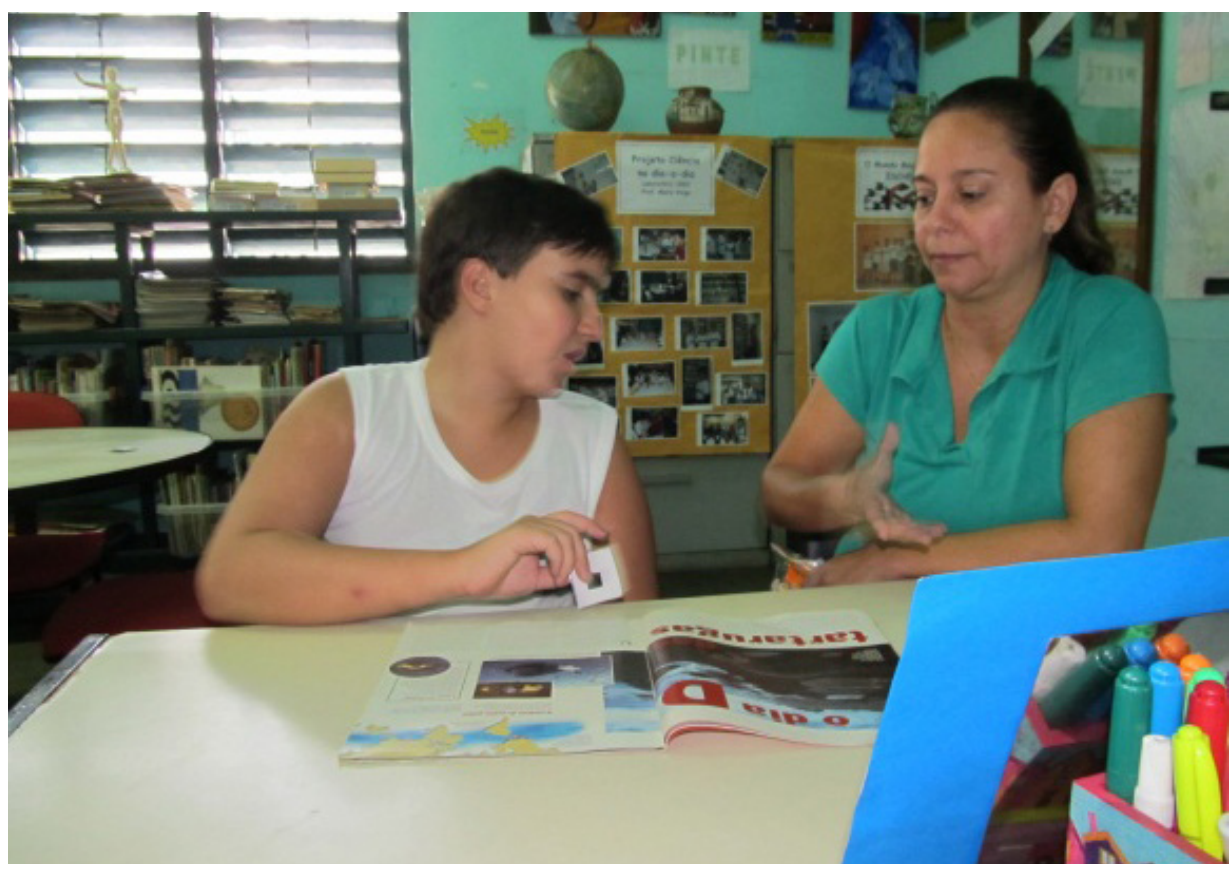

Fonte: A autora.

\section{Fase 2 - Aprendendo a pedir o que deseja para diferentes pessoas}

Objetivo final: o aluno deve retirar a figura da prancha ou do álbum de comunicação disposto próximo a ele, caminhar a distância necessária e entregá-la à pessoa que estiver de posse do item desejado, a fim de solicitá-lo de forma espontânea e independente.

Arranjos Ambientais: o professor deverá ir se distanciando do aluno, deixar a prancha ou álbum de comunicação sempre próximos a este e permitir sua ida para outros ambientes, com outros professores. O professor deverá seguir algumas etapas: 
- Introduzir a prancha de comunicação e dispor um cartão de comunicação de cada vez;

- Afastar-se gradativamente do aluno, permitindo que este caminhe até o professor para entregar o cartão de comunicação;

- Motivar o aluno a solicitar seu item de interesse para outras pessoas e em outros ambientes da escola;

- Introduzir o uso do álbum de comunicação para que o aluno o carregue sempre consigo, contendo ainda somente um cartão de comunicação;

- Organizar a SRM e proporcionar atividades comunicativas sempre que possível para que o aluno tenha muitas oportunidades de solicitar algo por meio dos cartões de comunicação;

- Sempre deixar os cartões de comunicação visíveis e de fácil acesso ao aluno;

- Utilizar um cartão de comunicação por vez, podendo, contudo, trocar o item e o cartão sempre que necessário (mudança de interesse);

- Sempre utilizar a fala com o aluno e enfatizar os nomes dos itens desejados quando solicitados por meio do cartão de comunicação e, se possível, motivar o aluno a repetir o nome do item;

- Avaliar o aluno sempre quanto aos níveis de suporte recebido para utilizar o álbum de comunicação e avançar para a fase seguinte quando estiver mais independente. 
Figura 5 - Aluno solicitando um item desejado para a mediadora, motivado pela professora da SRM

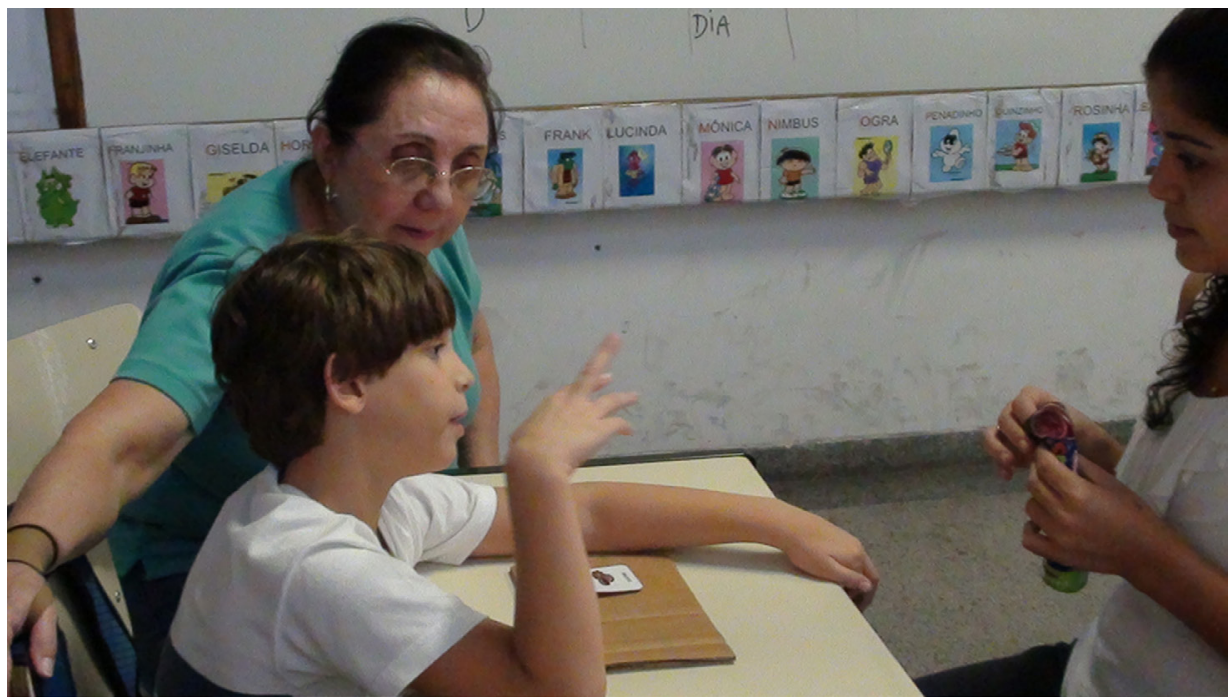

Fonte: A autora.

Fase 3 - Discriminando o pictograma e sua representação (Fase 3a) e diminuição do tamanho dos cartões de comunicação (Fase $3 b)$

Objetivo final: o aluno deve escolher o cartão de comunicação representativo do item desejado, entre vários outros dispostos na prancha ou no seu álbum de comunicação, dirigindo-se espontaneamente às pessoas para entregá-lo e obter, assim, o seu item desejado, estando ou não disposto à sua frente. $\mathrm{Na}$ Fase 3b, o cartão de comunicação será reduzido ao tamanho de 2,2 $\mathrm{cm}$, e o professor apresenta um cartão de comunicação por vez, mostrando para o aluno que é o mesmo cartão utilizado anteriormente por ele, só que em tamanho menor.

Arranjos ambientais: o professor deve utilizar a prancha de comunicação para dispor o cartão de comunicação do item muito desejado e, em outro ponto da prancha, um cartão contendo um pictograma de item nada rele- 
vante para o aluno. Assim, é possível observar se o aluno está relacionando o pictograma ao item desejado ou se ainda não associa o pictograma ao item e escolhe o item irrelevante. $\mathrm{O}$ professor tem que ter alguns itens irrelevantes na SRM, como: pregador de roupa, pano de prato, colher de pau, clipes, presilhas etc., e deve procurar organizar o ambiente, esperando que o aluno:

- Selecione o cartão de comunicação correspondente ao item muito desejado x item irrelevante;

- Retorne sempre o cartão de comunicação para a prancha após efetivar sua solicitação;

- Preste atenção ao local correto onde o professor colocou o cartão correspondente ao item desejado, pois ele deve alterar as posiçóes deste na prancha de comunicação;

- Discrimine o cartão correspondente ao item muito desejado em oposição aos outros itens menos desejados e, posteriormente, entre os diversos itens muito desejados, conseguindo associar de forma correta os pictogramas aos itens desejados;

- Amplie seu acervo pictográfico, utilizando cada dia um número maior de cartôes de comunicação, ampliando, assim, seu vocabulário expressivo;

- Observe que os cartões de comunicação serão diminuídos de tamanho, mas serão iguais aos maiores, sendo exigida mais atenção ao escolher os cartões na prancha ou álbum de comunicação;

- Seja avaliado sempre quanto aos níveis de suporte recebido para utilizar o álbum de comunicação e avançar para a fase seguinte quando estiver mais independente;

É importante capacitar o professor da sala de aula regular e os pares, motivando o aluno a utilizar seu álbum de comunicação na sala de aula comum. 
Figura 6 - Aluno escolhendo entre dois cartões de comunicação, o que contém o pictograma com seu item desejado e outro irrelevante (pregador de roupa)

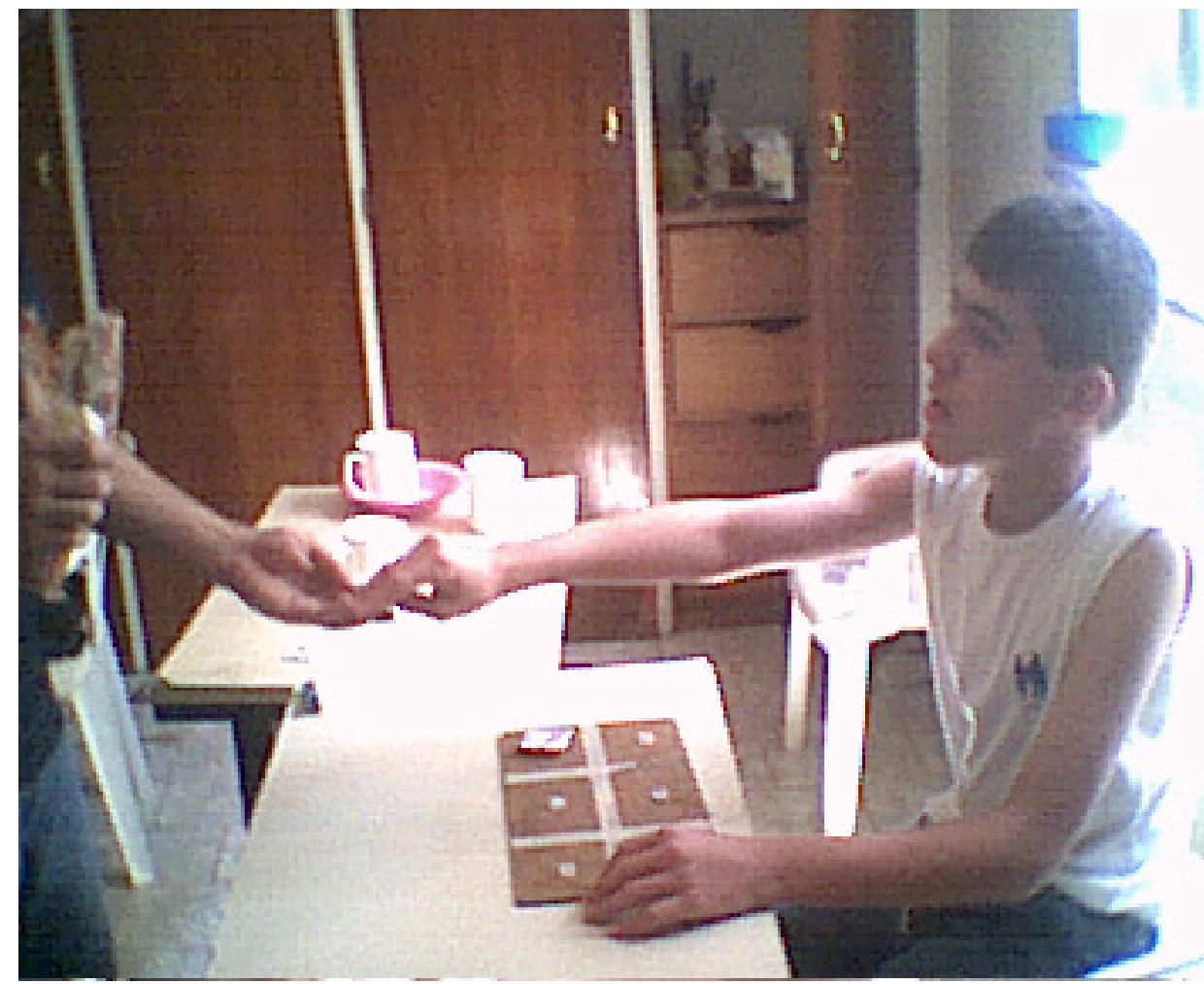

Fonte: A autora.

\section{Fase 4 - Formando sentenças simples e expressando sentimentos}

Objetivo final: o aluno deve solicitar os itens desejados, estando ou não presentes no ambiente, como também informar sobre seus sentimentos por meio dos cartóes com figuras-frases dispostas em destaque no seu álbum de comunicação. Para tanto, o aluno deve escolher o cartão com as figuras-frases, como "Eu quero", "Eu estou", colocá-las na tira porta-frase, em seguida, escolher a figura representativa do seu desejo ou expressão de um sentimento 
e colocá-la em sequência na tira porta-frase, formando, assim, uma frase simples para ser entregue ao seu interlocutor. Ao final dessa fase, o aluno deve contar com 20 a 50 figuras no seu álbum de comunicação e ser capaz de se comunicar espontaneamente com várias pessoas e em várias situações.

Arranjos ambientais: organizar a estrutura frasal primeiramente na prancha de comunicação para que o aluno compreenda que deverá formar uma frase com dois cartôes pictográficos. Depois, o professor deverá motivar o aluno a utilizar seu álbum de comunicação na sala de aula comum, com outros professores e com seus pares, pois já é capaz de manter um diálogo simples. É importante permitir que o aluno organize seu álbum de comunicação sozinho, pois ele deve escolher onde retornar os cartões de comunicação utilizados para formar a sentença. Assim, o aluno deverá:

- Ser ensinado a ordenar os cartões pictográficos na tira porta-frase disposta na prancha de comunicação e entregar a tira porta-frase no momento de solicitar algo desejado para as pessoas;

- Compreender o uso dos cartôes contendo as figuras-frases "Eu quero" e depois ser motivado a expressar sentimentos com a figura "Eu estou", que estará sempre disposta em lugar de destaque na prancha e no álbum de comunicação;

- Ser motivado a incluir, na tira porta-frase apresentada à sua frente, o cartão correspondente ao item desejado, formando, assim, uma sentença simples, como, por exemplo: "Eu quero" + "biscoito";

- Ser motivado a informar ao professor seus sentimentos, utilizando os cartões com a figura-frase "Eu estou", somando os cartões de "triste", "feliz", "cansado" etc.;

- Procurar utilizar todos os cartôes de comunicação que constam em seu álbum, estando o professor atento aos cartôes novos que poderão ser adicionados mediante o interesse do aluno e outros que deverão ser retirados, por falta de uso;

- Ser avaliado sempre quanto aos níveis de suporte recebido para utilizar o álbum de comunicação e avançar para a fase seguinte quando estiver mais independente. 
Figura 7 - Modelo de uma sentença "Eu estou" + "alegre", organizada no álbum de comunicação por um aluno na fase 4 do PECS-Adaptado

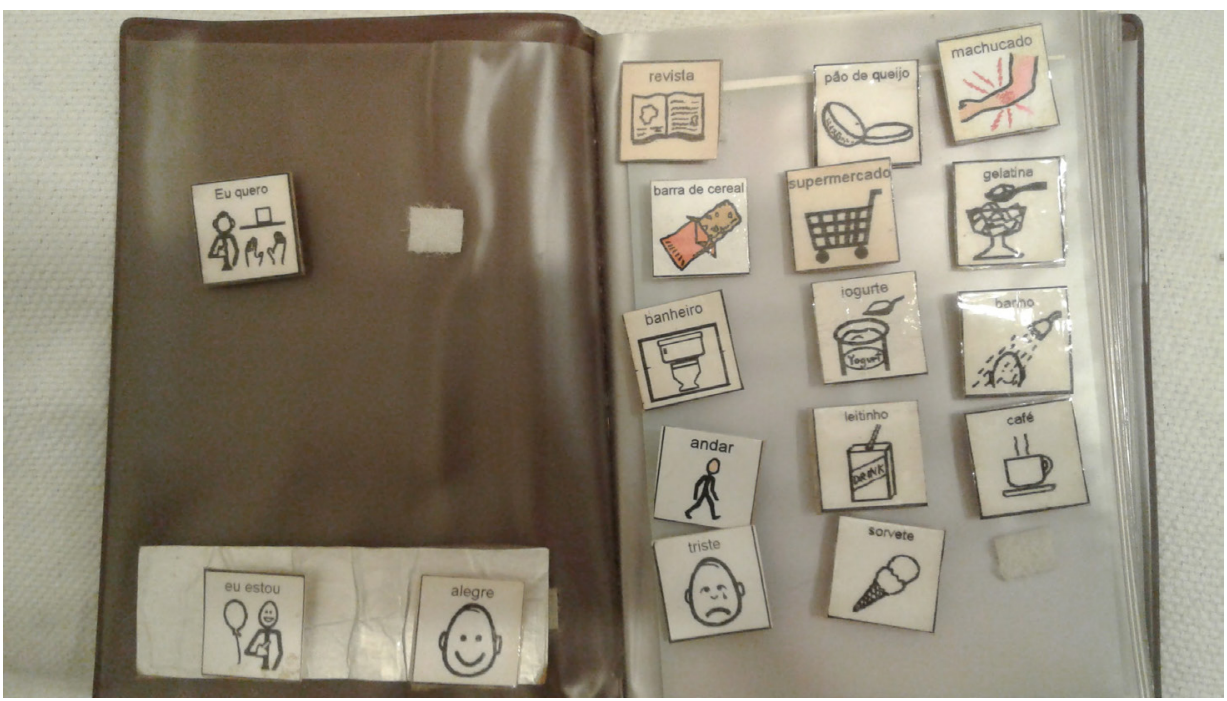

Fonte: A autora. 
Figura 8 - Um aluno com TEA formando a sentença "Eu quero" + "Billy" para solicitar brincar com o cachorro
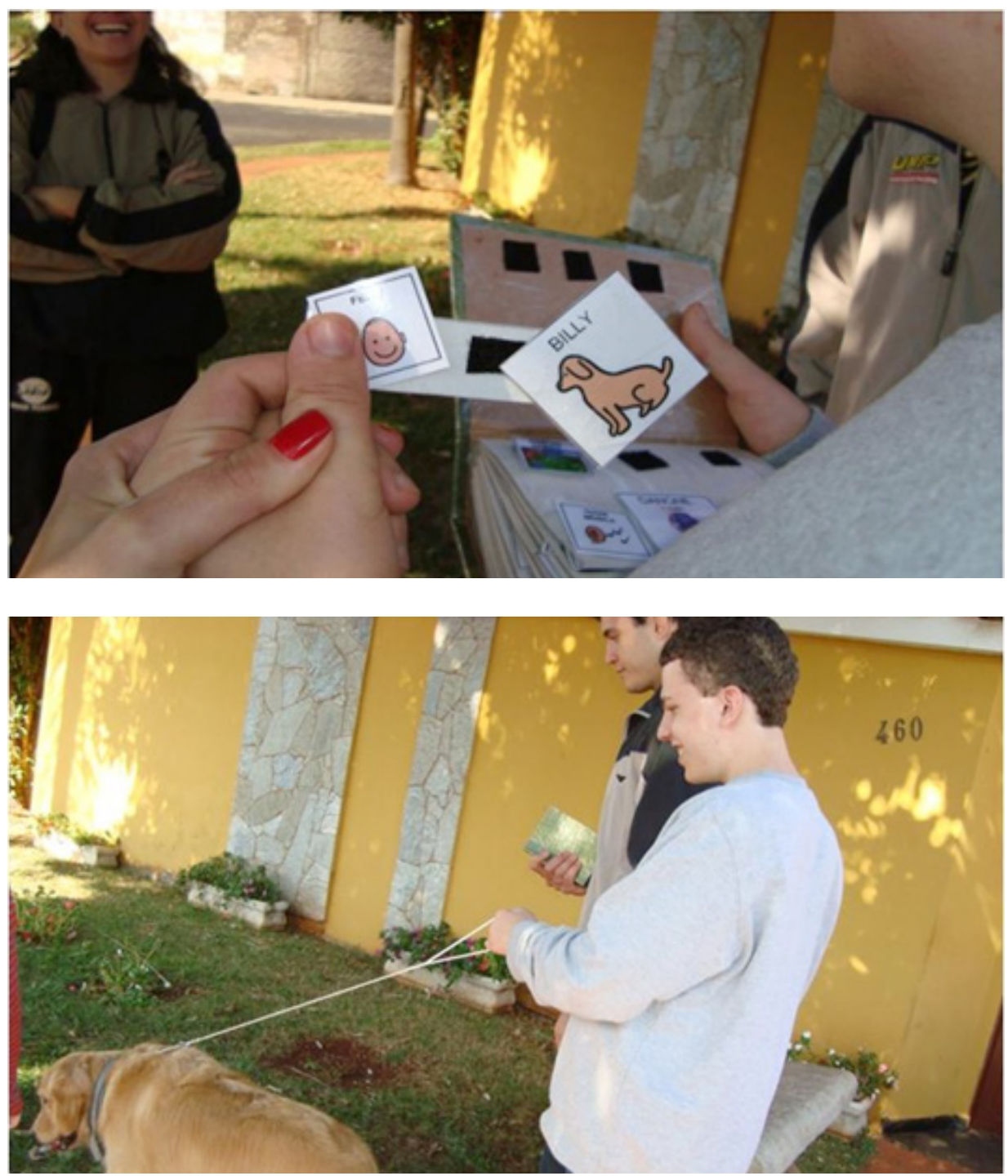

Fonte: A autora. 


\section{Fase 5 - Estruturando sentenças mais complexas e ampliando as condições para um diálogo mais elaborado}

Objetivo final: o aluno deve utilizar uma variedade de cartóes de comunicação para expressar seus sentimentos, desejos, solicitar informações, questionar, expressar opinião, enfim, ser capaz de manter um diálogo com os professores e pares no ambiente escolar. Igualmente, ele deve ser capaz de responder questôes acadêmicas, expressar suas necessidades de forma mais clara, utilizando uma linguagem funcional, em diferentes contextos sociais e linguísticos. $\mathrm{O}$ aluno deve realizar o mesmo procedimento da fase 4, portando seu álbum de comunicação, que deverá suportar um número elevado de cartōes, para serem utilizados em várias situaçōes como casa, escola, padaria, supermercado, casa de parentes etc.

Arranjos ambientais: os ambientes devem ser todos os frequentados pelo aluno, e o professor irá monitorar a necessidade de ampliar o seu vocabulário pictográfico, confeccionando mais cartôes de comunicação mediante a necessidade e o interesse do aluno. Agora, o discente poderá participar das atividades acadêmicas, respondendo às questôes dos professores da sala de aula comum e dos seus colegas de turma. O professor da SRM deve observar se o aluno necessita de suporte para continuar dialogando e sempre motivar as suas emissões orais. Quando ele for capaz de emitir palavras ou sentenças com função comunicativa, seus interlocutores devem elogiar e valorizar sempre sua fala, podendo utilizar de forma híbrida o programa, sendo necessário recorrer aos cartôes de comunicação quando sua fala não for clara. $\mathrm{O}$ professor deverá:

- Aumentar o número de cartóes comunicativos gradativamente no álbum de comunicação do aluno;

- Explicar as variações e combinações dos cartões dispostos na tira porta-frase, mostrando a versatilidade da linguagem e suas possíveis combinações semânticas;

- Iniciar o uso de cartóes que remetam ao questionamento, mostrando que o aluno poderá, nesse momento, solicitar informações aos interlocutores, com o uso dos seguintes cartóes: quem, qual, onde e quando; 
- Instigar o aluno a usar frases mais complexas - "Eu quero" + "supermercado" + "comprar" + "biscoito" - ou utilizar conceitos adicionais de linguagem, como: "Eu quero" + "beber" + "leite" + "chocolate" + "gelado";

- Reavaliar temporariamente o uso funcional do álbum de comunicação. Verificar se o aluno está conseguindo manuseá-lo bem e se está sendo útil para dialogar com seus pares e professores na sala de aula comum.

Figura 9 - Álbum de comunicação com sentença mais elaborada, expressando desejo de ir ao supermercado comprar iogurte e depois tomar banho

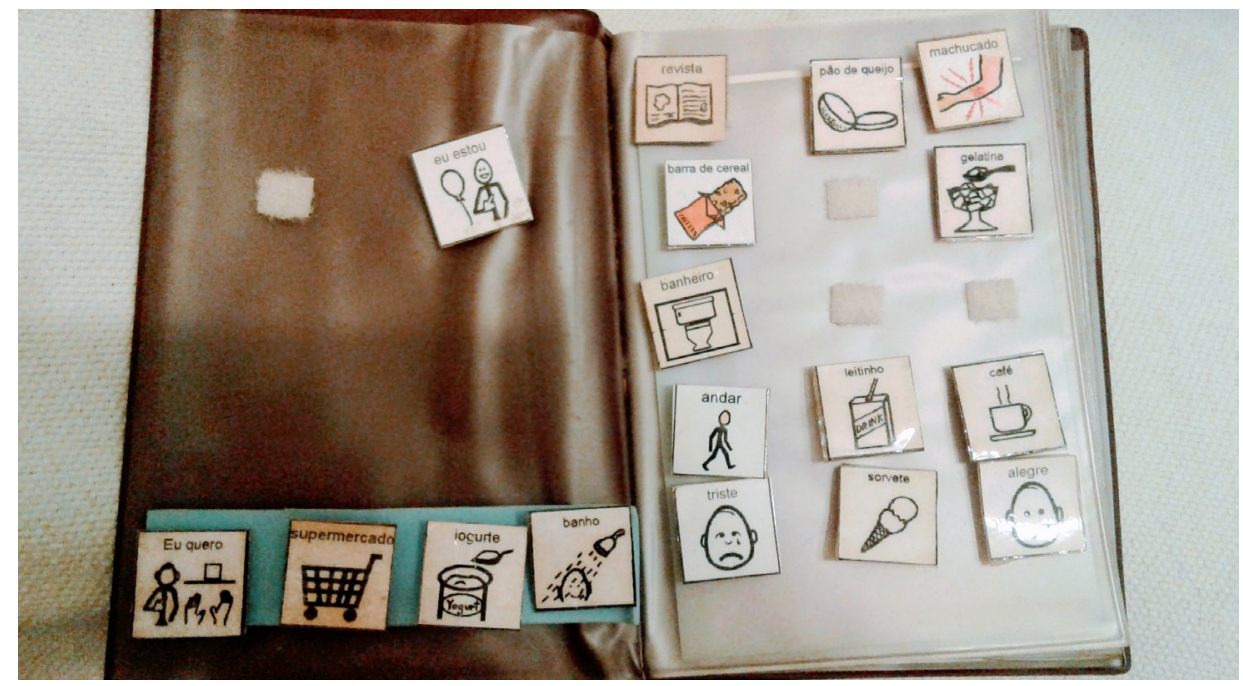

Fonte: A autora.

O PECS-Adaptado pode ser utilizado pelos professores do ensino comum, do AEE, do ensino especial, por familiares, assim como por profissionais especialistas em diferentes contextos, pois a pessoa com autismo carrega com ela seu próprio álbum de comunicação, favorecendo, assim, o processo comunicativo com seus interlocutores. É importante ressaltar a necessidade 
de o professor do AEE iniciar o programa na SRM primeiro, para que, depois da fase 3, ele possa utilizá-lo na sala de aula comum.

\section{Considerações Finais}

Estudos envolvendo a comunicação alternativa utilizada por alunos com TEA incluídos na escola regular ainda são escassos no Brasil, o que faz com que muitos alunos desprovidos da fala ou sem fala funcional permaneçam em silêncio e enclausurados em formas bizarras de comunicação. Ainda prevalece o mito entre professores e familiares de que o uso da CAA pode prejudicar o desenvolvimento da fala. Contudo, as pesquisas revelam justamente o oposto: a comunicação alternativa se mostra eficaz e promissora para o aparecimento da fala funcional e sua organização sintática e semântica. A falta de informação ainda é geral e, por isso, é preciso que as pesquisas sobre métodos e práticas que promovam a comunicação de alunos com TEA sejam mais difundidas no meio educacional (Walter e Nunes, 2013). O programa PECS-Adaptado vem se mostrando eficaz para facilitar a comunicação de alunos com autismo no ambiente escolar, e sua flexibilização é um ponto positivo, uma vez que todos podem modificar, adaptar e experimentar novas versões do programa.

É importante destacar ainda que nem todos os aspectos da comunicação podem ser substituídos quando a CAA é utilizada. Portando, o professor deve considerar os atos comunicativos como muito mais relevantes do que qualquer programa ou cartão de comunicação e lembrar que eles são um meio para "dar voz" a quem vive em um mundo sem palavras. Assim, qualquer recurso utilizado para intermediar o diálogo é valioso e relevante, mas é preciso destacar o tempo e a dedicação que dispensamos ao outro e a consideração que se deve ter pela "pessoa" com quem nos relacionamos. 


\section{Referências}

ARAÚJO, C. A. G. O ensino colaborativo favorecendo a inclusão de alunos com deficiência física e transtorno global do desenvolvimento nas escolas municipais do Rio de Janeiro (dissertação). UERJ, 2012.

ARAÚJO, R. C. T. e MANZINI, E. J. "Recursos de ensino na escolarização do aluno deficiente físico". In MANZINI E. J. (org.). Linguagem, cognição e ensino do aluno com deficiência. Marília: UNESP, 2001, pp. 1-11.

ARGYLE, M. A interação social: relaçōes interpessoais e comportamento social. Trad. Márcia Bandeira de Mello Leite Nunes. Rio de Janeiro: Zahar Editores, 1976.

ASCENÇÃO, M. J. L. Ajudas técnicas no atendimento ao aluno com deficiência matriculado na rede regular de ensino de educação infantil (monografia). UNESP, 2007.

BARDIN, L. Análise de conteúdo. Trad. Luís Reto e Augusto Pinheiro. Lisboa: Ediçôes 70, 1997.

BASIL, C. "Social interaction and learned helplessness in severely disabled children”. Augmentative and Alternative Communication, v. 8, pp. 188-99, 1992.

BATISTA, N. et al. "O enfoque problematizador na formação de profissionais da saúde”. Rev. Saúde Pública. São Paulo, v. 39, n. 2, pp. 231-37, abr. 2005. 
BERBEL, N. A. N. "A problematização e a aprendizagem baseada em problemas.” Interface - Comunicação, Saúde, Educação, v. 2, pp. 139-54, 1998.

(org.). "A metodologia da problematização e os ensinamentos de Paulo Freire: uma relação mais que perfeita." Metodologia da problematização: fundamentos e aplicaçôes. Londrina: EDUEL, 1999, pp. 1-28.

. Conhecer e intervir: o desafio da metodologia da problematização. Londrina: EDUEL, 2001, p. 184.

BERE, A. "A comparative study of student experiences of ubiquitous learning via mobile devices and learner management systems at a South African university". Proceedings of the 14th Annual Conference on World Wide Web Applications. Durban, pp. 7-9, nov. 2012.

BERSCH, R. “Tecnologia Assistiva”. In SCHIRMER, C. R. et al. Atendimento Educacional Especializado: deficiência fisica. São Paulo: MEC/SEESP, 2007 v. 1, pp. 31-7 .

. Tecnologia assistiva: metodologia para estruturação de serviço em escolas públicas (dissertação). UFRGS, 2009.

e PELOSI, M. B. Portal para ajudas técnicas. Tecnologia Assistiva: recursos de acessibilidade ao computador. Brasília: MEC/SEESP, 2007, p. 66.

BEYER, H. O. "A educação inclusiva: incompletudes escolares e perspectivas de ação." Cadernos de Educação Especial, Santa Maria, v. 2, n. 22, pp. 3344, 2003.

BLACKSTONE, S. et al. "Key principles underlying research and practice". Augmentative and Alternative Communication, v. 23, n. 3p. 191-203, 2007.

e . PECS: The Picture Exchange Communication System. Cherry Hill, NJ: Pyramid Educational Consultants, Inc., 1994. 
BONDY, A. e FROST, L. "The Picture Exchange Communication System." Behavior Modification, v. 25, pp. 725-44, 2001.

BRAGA, M. C. B. A interação professor-aluno em classe inclusiva: um estudo exploratório com criança autista (dissertação). UNESP, 2002.

BRANDO, A. et al. "Utilizando materiais de baixa tecnologia para promover a comunicação em atividades pedagógicas em sala de aula". In NUNES, L. R. et al. Comunicar é preciso: em busca das melhores práticas na educação do aluno com deficiência. Marília: ABPEE, 2011, pp. 107-14.

. Senado Federal. Constituição da República Federativa do Brasil. Brasília, 1988. Disponível em: http://www.planalto.gov.br/ccivil_03/Constituicao/ Constituicao.htm. Acesso em: 16 set. 2014.

. Senado Federal. Lei de Diretrizes e Bases da Educação Nacional n. ${ }^{\circ}$ 9394/96. Brasília, 1996. Disponível em: http://www2.camara.leg.br/ documentos-pesquisa/publicacoes/edicoes/paginas-individuais-dos-livros/ lei-de-diretrizes-e-bases-da-educacao-nacional. Acesso em: 16 set. 2014.

BRASIL. Diretrizes Nacionais para a Educação Especial na Educação Básica. Brasília: SEESP, 2001.

- O acesso de alunos com deficiência às escolas e classes comuns da rede regular. Ministério Público Federal: Fundação Procurador Pedro Jorge de Melo e Silva (org.). 2 ed., rev. atualiz. Brasília, 2004b. 60 p. 2008.

Ministério da Educação. Secretaria da Educação Especial. Política Nacional de Educação Especial na Perspectiva da Educação Inclusiva. Brasília, 2008. Disponível em: http://portal.mec.gov.br/arquivos/pdf/politicaeducespecial.pdf. Acesso em: 16 set. 2014. 
- Ministério da Educação. Secretaria da Educação Especial. Resolução n. 4, de 02 de outubro de 2009. Brasília, 2009.

- Nota Técnica n. ${ }^{\circ} 11$, de 7 de maio de 2010. Orientaçôes para a institucionalização da oferta do Atendimento Educacional Especializado - AEE em Salas de Recursos Multifuncionais, implantadas nas escolas regulares. Brasília: SEESP/GAB, 2010.

- Presidência da República. Casa Civil. Subchefia para Assuntos Jurídicos. Lei Brasileira de Inclusão da Pessoa com Deficiência (Estatuto da Pessoa com Deficiência), n. 13.146/2015. Brasília, 2015. Disponível em: http:// www.planalto.gov.br/ccivil_03/_Ato2015-2018/2015/Lei/L13146.htm. Acesso em: 16 mar. 2016.

BUENO, J. G. S. "A educação inclusiva e as novas exigências para a formação de professores: algumas considerações." In BICUDO, M. A. e SILVA Jr., C. A. (orgs.). Formação de educadores e avaliação educacional. São Paulo: UNESP, 1999, pp. 149-64.

CAMARGO, S. P. H. e BOSA, C. A. "Competência social, inclusão escolar e autismo: revisão crítica da literatura.” Psicol. Soc., Florianópolis, v. 21, n. 1, pp. 65-74, abr. 2009.

CANDAU, V. M. F. "Formação continuada de professores: tendências atuais." In REALI, A. M. M. e MIZUKAMI, M. G. N. (orgs.). Formação de professores: tendências atuais. São Carlos: EDUFSCar, 2003, pp. 140.

CASTELLS, M. A galáxia internet, reflexôes sobre internet, negócios e sociedade. Lisboa: Fundação Calouste Gulbenkian, 2004.

CAT. Ata da Reunião VII, de dezembro de 2007. Comitê de Ajudas Técnicas, Secretaria Especial dos Direitos Humanos da Presidência da República (CORDE/SEDH/PR). Disponível em: http://www.mj.gov.br/sedh/ct/ corde/dpdh/corde. Acesso em: 01 jan. 2017. 
CHUN, R. Y. "Comunicação suplementar e/ou alternativa: favorecimento da linguagem de um sujeito não falante.” Pró-fono, v. 15, n. 1, pp. 55-64, 2003.

COLOMBO, A. A. e BERBEL, N. A. "A Metodologia da Problematização com o Arco de Maguerez e sua relação com os saberes de professores." Semina: Ciências Sociais e Humanas, Londrina, v. 28, n. 2, pp. 121-46, jul.-dez. 2007.

COOK, Albert e HUSSEY, J. Assistive Tecnologies: principles and pratice. Missouri: Mosby-Year Book, 1995.

CORREA NETTO, M. M. F. A Comunicação Alternativa e a aprendizagem de crianças com autismo, Asperger e Angelman: formação continuada de profissionais de educação e saúde (dissertação). UERJ, 2012.

CORREIA, L. M. Alunos com necessidades educativas especiais nas classes regulares. Porto, Portugal: Porto, 1999.

CORREIA, S. "Ferramentas de Comunicação Aumentativa e Alternativa: escrevendo com símbolos e InterComm.” In NUNES, L. R et al. (orgs.). Um retrato da Comunicação Alternativa no Brasil: relatos de pesquisas e experiências. Rio de Janeiro: Quatro Pontos/FINEP, 2007, pp. 189-98.

CORTELAZZO, I. et al. "Formação de professores para educação especial: educação inclusiva com o apoio das Tecnologias Assistivas." Anais do IV Congresso Brasileiro Multidisciplinar de Educação Especial. Londrina, 2007.

COUNCIL OF CHIEF STATE SCHOOL OFFICERS. Education leadership policy standards: ISLLC 2008. Washington, DC, 2008.

CUNHA, M. I. et al. "Inovações pedagógicas na formação inicial de professores.” In FERNANDES, C. M. B. e GRILLO, M. (orgs.). Educação superior: travessias e atravessamentos. Canoas: ULBRA, 2001, pp. 33-90. 
CYRINO, E. G. e TORALLES-PEREIRA, M. L. “Trabalhando com estratégias de ensino-aprendizado por descoberta na área da saúde: a problematização e a aprendizagem baseada em problemas." Cad. Saúde Pública, v. 20, n. 3, Rio de Janeiro, pp. 780-88, maio-jun. 2004.

DELIBERATO, D. "Comunicação alternativa na escola: habilidades comunicativas e o ensino da leitura e escrita." In et al. (orgs.). Comunicação alternativa: teoria, prática, tecnologias e pesquisa. São Paulo: Memnon Ediçōes Científicas, 2009, pp. 235-43.

. "Questôes a respeito da comunicação do aluno com deficiência." In e MANZINI, Eduardo José (orgs.). Instrumentos para avaliação de alunos com deficiência sem oralidade. 1 ed. São Carlos: Marquezine e Manzini, ABPEE, 2015, v. 1, pp. 11-22.

e NUNES, L. R. D. P. "Use of graphic systems in the routine of a regular classroom with a disabled student." Archivos Analiticos de Politicas Educativas/Education Policy Analysis Archives, v. 23, pp. 1-26, 2015.

e PAURA, A. C. et al. "Comunicação suplementar e ou alternativa no contexto da música: recursos e procedimentos para favorecer o processo de inclusão de alunos com deficiência." In PINHO, S. Z. e SAGLIETE J. R. (orgs.). Núcleos de Ensino da UNESP. São Paulo: Cultura Acadêmica, 2007, pp. 366-78.

et al. "Comunicação suplementar e alternativa no contexto da música." In NUNES, L. R. O. P. et al. (orgs.). Um retrato da comunicação alternativa no Brasil. Rio de Janeiro: 4 Pontos, v. 1, 2007, pp. 77-81.

et al. "Linguagem e comunicação alternativa: caminhos para a interação e comunicação.” In ALMEIDA, M. A. e MENDES, E. G. (eds.). A escola e o público-alvo da educação especial: apontamentos atuais. São Carlos: ABPEE/Marquezine \& Manzini, 2014, pp. 197-210. 
DOWNING, J. E. “Assessment of early communication skills.” In SOTO, G. e ZANGARI, C. Practically speaking: language, literacy and academic development for students with AAC needs. Baltimore: Paul H. Brookes, 2009, pp. 27-46.

DUEK, V. P. e MARTINS, L. A. R. "Formação de professores para a educação inclusiva: casos de ensino como instrumentos de análise da prática”. Anais do IV Congresso Brasileiro de Educação Especial, 2010.

FERREIRA, A. A. e SILVA, B. D. "Comunidade de prática on-line: uma estratégia para o desenvolvimento profissional dos professores de História." Educ. rev., Belo Horizonte, v. 30, n. 1, pp. 37-64, mar. 2014.

FEUERSTEIN, R. Instrumental enrichment. Baltimore: University Park Press, 1980.

FOGEL, A. Developing through relationships: origins of communication, self, and culture. Chicago: The University of Chicago Press, 1993.

FONTES, R. S. et al. "Estratégias pedagógicas para a inclusão de alunos com deficiência mental no ensino regular.” In GLAT, R. (org.). Educação inclusiva: cultura e cotidiano escolar. Rio de Janeiro: Sette Letras, 2007, pp. 79-89.

FREIRE, P. Professora sim, tia não: cartas a quem ousa ensinar. São Paulo: Olho D’água, 1997.

GALVÃO FILHO, T. A. Tecnologia Assistiva para uma escola inclusiva: apropriação, demandas e perspectivas (tese). Universidade Federal da Bahia, 2009.

GIVIGI, R. C. "Criando novas práticas inclusivas com o trabalho colaborativo.” In MENDES, E. G. e ALMEIDA, M. A. Almeida (orgs.). A pesquisa sobre inclusão escolar em suas múltiplas dimensões: teoria, política e formação. Marília: ABPEE, 2012, pp. 263-79. 
GLAT, R. A integração social dos portadores de deficiências: uma reflexão. Rio de Janeiro: Sette Letras, 1995.

GOMES, C. e BARBOSA, A. J. "Inclusão escolar do portador de paralisia cerebral: atitudes de professores do ensino fundamental. " Revista Brasileira de Educação Especial, v. 12, n. 1, pp. 85-100, Marília, jan.-abr. 2006.

GOMES, M. Estudo descritivo de uma prática interativo-reflexiva para professores em formação inicial: subsidios para formação de professores de crianças surdocegas e aquelas com deficiência múltipla (dissertação). UERJ, 2006.

GUARDA, N. S. e DELIBERATO, D. “Caracterização dos enunciados de um aluno não-falante usuário de recurso suplementar de comunicação durante a construção de histórias." Revista Brasileira de Educação Especial, v. 12, pp. 269-88, 2006.

HARWOOD, K. et al. "The importance of responsivity in developing contingent exchanges with beginning communicators." In REICHLE, J. et al. (org.). Augmentative and alternative communication series: exemplary practices for beginning communicators: implications for $A A C$. Baltimore: Paul H. Brookes Publishing, 2002, pp. 59-95.

HETZRONI, O. E. AAC and literacy. Disability and Rehabilitation, v. 26, pp. 1305-12, 2004.

HIGGINBOTHAM, J. et al. "Access to AAC: present, past, and future." Augmentative and Alternative Communication, v. 23, n. 3, pp. 243-57, sep. 2007.

IACONO, T. et al. "Comparison of unimodal and multimodal for children with intellectual disabilities." Augmentative and Alternative Communication, v. 9, n. 2, pp. 83-93, 1993. 
JOHNSON, R. M. Guia dos Símbolos de Comunicação Pictórica - The Picture Communication Symbols Guide (PCS). Porto Alegre: Clik - Recursos Tecnológicos para Educação, Comunicação e Facilitação, 1998.

KING, T. Assistive technology: essential human factors. Needham Heights, MA: Allyn e Bacon, 1999.

LAUAND, G. Fontes de informação sobre Tecnologia Assistiva para favorecer a inclusão escolar de alunos com necessidades especiais (tese). UFSCar, 2005.

LAURO, B. R. et al. "Construindo uma educação infantil inclusiva." In MARQUEZINE, Maria Cristina et al. (orgs.). Inclusão. Londrina: Editora da Universidade de Londrina, 2003, pp.79-88.

LEBLANC, J. M. "El curriculum funcional en la educación de la persona con retardo mental." Anais do Simpósio Internacional COANIL, Santiago, Chile, nov. 1991.

LEITE, S. A. S. "Afetividade nas práticas pedagógicas." Temas em Psicologia, v. 20, n. 2, pp. 355-68, 2012.

LÉVY, P. Cibercultura. São Paulo: Editora 34, 1999.

LIDZ, C. S. Practitioner's Guide to Dynamic Assessment. New York: The Guilford Press, 1991.

LIGHT, J. e DRAGER, K. "AAC to improve language, literacy, and communication outcomes for young children with complex communication needs". Augmentative and Alternative Communication, v. 23, n. 3, pp. 204-16, 2007.

e . "Communicative competence for individuals who require augmentative and alternative communication: a new definition for a new era of communication?". Augmentative and Alternative Communication, v. 30, n. 1, pp. 1-18, 2014. 
e

"Designing AAC research and intervention to improve outcomes for individuals with Complex Communication Needs". Augmentative and Alternative Communication, v. 31, n. 2, pp. 85-96, 2015.

e MCNAUGHTON, D. "Evidence-based literacy intervention for individuals who require AAC". Proceedings of the $5^{\text {th }}$ Biennial Conference of the International Society for Augmentative and Alternative Communication, Philadelphia, 1992.

e MCNAUGHTON, D. "Putting people first: re-thinking the role of technology in Augmentative and Alternative Communication intervention". Augmentative and Alternative Communication, v. 29, n. 4, pp. 299-309, 2013.

LIMONGI, S. C. O. "A construção da linguagem na criança paralítica cerebral." Paralisia cerebral: processo terapêutico em linguagem e cognição: pontos de vista e abrangência. São Paulo: Pró-Fono, 2000, pp. 119-42.

LLOYD L. L. e KARLAN, G. R. "Nonspeech communication symbols: where have we been and where are we going?." Journal of Mental Deficiency Research, v. 28, pp. 3-20, 1984.

LOURENÇO, G. F. Avaliação de um programa de formação sobre recursos de Alta Tecnologia Assistiva e Escolarização (tese). UFSCar, 2012.

LUCENA, S. "Culturas digitais e tecnologias móveis na educação". Educar em Revista, n. 59, pp. 277-90, Curitiba, jan.-mar. 2016.

LUND, S. e LIGHT, J. "Long-term outcomes for individuals who use AAC: part I - What is a 'good' outcome?.” Augmentative and Alternative Communication, n. 22, pp. 284-99, 2006. 
e . "Long-term outcomes for individuals who use augmentative and alternative communication: part II - communication interaction." Augmentative and Alternative Communication, v. 23, n. 1, pp. 1-15, 2007.

LURIA, A. R. Fundamentos de neuropsicologia. São Paulo: EDUSP, 1981.

MACEDO, N. "Formação de professores em uma perspectiva inclusiva: possíveis contribuições advindas do curso de pedagogia." Anais do VSeminário Nacional de Pesquisa em Educação Especial: Formação de professores em foco. CD. São Paulo, 2009.

MACHADO, O. V. M. "Novas práxis educativas no ensino de Ciências.” In CAPPELLETTI, I. F. e LIMA, L. A. N. (orgs.). Formação de educadores: pesquisas e estudos qualitativos. São Paulo: Olho D’Água, 1999, pp. 95-127.

MAIA, M. V. C. M. Criar e brincar: o lúdico no processo de ensino e aprendizagem. Rio de Janeiro: WAK, 2014.

. "Um estudo sobre as pesquisas em comunicação alternativa na pós-graduação brasileira”. In DELIBERATO, D. et al. Comunicação alternativa: teoria, prática, tecnologias e pesquisa. São Paulo: Memnon, 2009, v. 1, pp. 264-75.

- "Formação do professor para trabalhar com recursos de tecnologia assistiva: um estudo de caso em Mato Grosso.” Educação e Fronteiras, v. 2, pp. 98-113, UFGD, 2012.

MANZINI, E. J. "Formação do professor para o uso de tecnologia assistiva." Cadernos de Pesquisa em Educação PPGE-UFES, v. 18, pp. 11-36, 2013.

MARTINS, L. A. "Prática da educação para a inclusão: aprendendo a viver juntos”. In MARQUEZINE, M. C. et al. (orgs.). Inclusão. Londrina: Universidade de Londrina, 2003, pp. 23-31. 
MASSARO, M. et al. "Augmentative and alternative communication resources in song interpreting and storytelling activities for disabled students". Biennial Conference of The International Society for Augmentative and Alternative Communication, Proceedings 14 $4^{\text {th }}$, Barcelona. 2010.

MAYER-JOHNSON, R. Boardmaker com Speaking Dynamically Pro. Versão 6. Software para aprendizagem e comunicação alternativa, com acessibilidade e geração de voz. 2011.

MENDES, E. G. e CIA, F. "Constituição de uma rede colaborativa de pesquisa: Observatório Nacional de Educação Especial (Oneesp)”. Ciências Humanas e Sociais em Revista, v. 34, n. 12, pp.13-29, 2012.

$\mathrm{e}$ - "O Observatório Nacional de Educação Especial". Inclusão Escolar e o Atendimento Educacional. Série Observatório Nacional de Educação Especial, v. 1. São Carlos: Marquezine \& Manzini: ABPEE, 2014, pp. 15-27.

et al. Ensino colaborativo como apoio à inclusão escolar: unindo esforços entre educação comum e especial. São Carlos: EdUFSCar, 2014.

et al. (orgs.). Inclusão escolar em foco: organização e funcionamento do Atendimento Educacional Especializado. São Carlos: Marquezine \& Manzini: ABPEE, 2015.

et al. (orgs.). Inclusão escolar e os desafios para a formação de professores em Educação Especial. São Carlos: Marquezine \& Manzini: ABPEE, 2015.

et al. "A formação de professores para atuação nas Salas de Recursos Multifuncionais: breve contextualização." Inclusão escolar e os desafios para a formação de professores em Educação Especial. São Carlos: Marquezine \& Manzini: ABPEE, 2015, pp. 25-38. 
MILLIKIN, C. "Symbol system and vocabulary selection strategies." In GLENNEN, S. e DeCOSTE, D. C. (Ed.). The handbook of augmentative and alternative comunication. San Diego: Singular Publishing Group, 1997, pp. $97-148$.

MISKULIN, R. G. S. et al. "Comunidade de Prática Virtual: possíveis contribuições para a formação de professores de matemática.” In FIORENTINI, D. et al. (orgs.). Práticas de formação e de pesquisa de professores que ensinam matemática. Campinas: Mercado de Letras, 2009, pp. 257-76.

MONTEIRO DA CRUZ, M. e MONTEIRO, A. "Acessibilidade cognitiva para o letramento de jovens com deficiência intelectual”. Dossiê Educação de Jovens e Adultos - Arquivos Analíticos de Políticas Educativas, v. 21, n. 74. Disponível em: http://epaa.asu.edu/ojs/article/view/1326.

MORAES, K. C. e BERBEL N. A. "O uso da metodologia da problematização para a investigação sobre avaliação da aprendizagem. O que há de específico para o ensino superior?”. Semina: Ciências Sociais e Humanas, v. 27, n. 2, pp. 169-86, jul.-dez. 2006.

MORI, N. N. R. "Alunos especiais inseridos em classes regulares." In MARQUEZINE, M. C. et al. (orgs.). Inclusão. Londrina: Editora da Universidade de Londrina, 2003, pp. 173-90.

NGALEKA, A. e UYS, W. "M-learning with WhatsApp: a conversation analysis." Proceedings of the 8th International Conference on E-Learning Cape Peninsula University of Technology, Cape Town, South Africa, 2013.

NÓVOA, A. "Concepções e práticas da formação contínua de professores": In (org.). Formação contínua de professores: realidade e perspectivas. Portugal: Universidade de Aveiro, 1991.

(org.). Os professores e sua formação. Lisboa: Publicaçōes Dom Quixote, 1992, pp. 117-38. 
. "O passado e o presente dos professores". In (org.). Profissão professor. 2 ed. Porto, Portugal: Porto Editora, 1992, pp. 13-34.

NUNES, D. R. e GOMES, R. "Interações comunicativas entre uma professora e um aluno com autismo na escola regular: uma proposta de intervenção.” Educação e Pesquisa, v. 40, pp. 143-61, 2014.

e SANTOS, L. B. "Promovendo a comunicação em autistas: mesclando práticas em CAA”. In PASSERINO, L. et al. (orgs.). Comunicar para incluir. Porto Alegre: CRBF, 2013, pp. 145-57.

NUNES, L. R. O. P. "Linguagem e comunicação alternativa: uma introdução". In (org.). Favorecendo o desenvolvimento da comunicação em crianças e jovens com necessidades educacionais especiais. Rio de Janeiro: Dunya, 2003, pp. 1-13.

. "Modelos teóricos na comunicação alternativa e ampliada". In (org.). Favorecendo o desenvolvimento da comunicação em crianças e jovens com necessidades educacionais especiais. Rio de Janeiro: Dunya, 2003, p. 15-48.

- Promovendo a inclusão comunicativa de alunos não oralizados com paralisia cerebral e deficiência múltipla. Relatório de Pesquisa financiado pelo CNPq, 2009.

. "Dando a voz através de imagens: comunicação alternativa para indivíduos com deficiência”. Relatório de pesquisa aprovado pela FAPERJ, 2009.

- "Acessibilidade comunicativa para alunos com deficiência: formação inicial e continuada de professores". Relatório de pesquisa aprovado pela FAPERJ, 2010.

e DANELON, M. C. "A pesquisa na sala de aula: um caminho acidentado". In BAPTISTA, C. e JESUS, M. (orgs.). Conhecimento e margens: 
ação pedagógica e pesquisa em educação especial. Porto Alegre: Mediação, 2009, pp. 123-39.

e . "Pesquisa experimental em educação especial." In

(org.). Novas trilhas no modo de fazer pesquisa em educação especial. São Carlos: Marquezine \& Manzini: ABPEE, 2014, pp. 27-52.

e WALTER, C. C. F. "A Comunicação Alternativa para além das Tecnologias Assistivas." Dossiê Educação Especial: diferenças, currículo e processos de ensino e aprendizagem - Arquivos Analiticos de Politicas Educativas, v. 22, n. X, 2014. Disponível em: http://epaa.asu.edu/epaa/v22.

et al. "Comunicação alternativa e interação social em sala de aula. Texto a ser publicado no livro pós-congresso.” Anais Do V Congresso Brasileiro Multidisciplinar De Educação Especial. Londrina: Universidade Estadual de Londrina, 2009.

et al. Comunicar é preciso: em busca das melhores práticas na educação do aluno com deficiência. Marília: ABPEE, 2011.

et al. "A prática pedagógica de mediadoras de alunos com deficiência física e dificuldades na comunicação em escolas do Rio de Janeiro.” In GLAT, R. e PLETSCH, M. Estratégias educacionais diferenciadas para alunos com necessidades especiais. Rio de Janeiro: EDUERJ/PROESP, 2013, pp. 65-90.

et al. "Formação de professores e pesquisadores em educação na Universidade do Estado do Rio de Janeiro: a contribuição da Comunicação Alternativa.” In PASSERINO, L. et al. (orgs.). Comunicar para incluir. Porto Alegre: CRBF, 2013, pp. 239-54.

OLIVEIRA, A. A. S. "Educação inclusiva: concepções teóricas e relato de experiência.” In MARQUEZINE, M. C. et al. (orgs.). Inclusão. Londrina: Editora da Universidade de Londrina, 2003, pp. 33-43. 
OLIVEIRA, E. e MACHADO, K. S. "Adaptações curriculares: caminho para uma educação inclusiva”. In GLAT, R. (org.). Educação inclusiva: cultura e cotidiano escolar. Rio de Janeiro: Sette Letras, 2007, pp. 36-52.

OLIVEIRA, E. D. S. et al. "Estratégias de uso do WhatsApp como um ambiente virtual de aprendizagem em um Curso de Formação de Professores e Tutores”. Anais do Simpósio Internacional de Educação a Distância. São Carlos: Universidade Federal de São Carlos, 2014.

PAUL, R. "Facilitating transitions in language development for children using AAC." Augmentative and Alternative Communication, v. 13, n. 3, pp. 141-8, 1997.

PAURA, A. C. e DELIBERATO, D. "Comunicação Alternativa e/ou Suplementar como recurso de apoio no ensino do conteúdo pedagógico de criança deficiente incluída". Anais do Congresso Brasileiro de Comunicação Alternativa - ISAAC/BRASIL, Campinas, 2007.

PELOSI, M. B. A comunicação alternativa e ampliada nas escolas do Rio de Janeiro: formação de professores e caracterização dos alunos com necessidades educacionais especiais (dissertação). UERJ, 2000.

. Inclusão e Tecnologia Assistiva (tese). UERJ, 2008.

e SOUZA, V. L. V. "O funcionamento das salas multifuncionais e o perfil de seus professores.” In MENDES. E. G. e ALMEIDA, M. A. (orgs.). A pesquisa sobre inclusão escolar em suas múltiplas dimensões: teoria, politica e formação. Marília: ABPEE, 2012, pp. 197-218.

et al. "O Centro de Terapia Ocupacional do Rio de Janeiro como centro de referência na área de comunicação alternativa.” In NUNES, L. $\mathrm{R}$. et al. Um retrato da comunicação alternativa no Brasil. Rio de Janeiro: Quatro Pontos, 2007, v.2, pp. 234-38. 
PERISSINOTO, J. “Linguagem da criança com autismo.” In et al. (orgs.). Conhecimentos essenciais para atender bem a criança com autismo. São José dos Campos: Pulso Editorial, 2003, pp. 23-7.

PLETSCH, M. Repensando a inclusão escolar de pessoas com deficiência mental: diretrizes politicas, currículo e práticas pedagógicas (tese). Universidade do Estado do Rio de Janeiro, Rio de Janeiro, 2009.

- "A formação de professores para a Educação Inclusiva: legislação, diretrizes políticas e resultados de pesquisa." Educar em Revista, v. 33, pp. 143-56, Paraná, UFPR, 2009.

Repensando a inclusão escolar: diretrizes políticas, práticas curriculares e deficiência intelectual. Rio de Janeiro: Nau: Edur, 2010.

PRIZANT, W. e RYDELL, P. "Communication intervention issues for young children with autism spectrum disorders.” In WETHERBY, A. M. e PRIZANT, B. M. (eds.). Autism spectrum disorders: a developmental, transactional perspective. Baltimore, MD: Paul Brookes, 2000, pp. 193-224.

QUITERIO, P. L. "O processo de inclusão de alunos com paralisia cerebral através de recursos da comunicação alternativa de baixo custo.” In NUNES, L. et al. (org.). Compartilhando experiências: ampliando a Comunicação Alternativa. Marília: ABPEE, 2011, pp. 209-19.

RAMBE, P. e CHIPUNZA, C. "Using mobile devices to leverage student access to collaboratively-generated resources: a case of WhatsApp instant messaging at a South African university.” Proceedings International Conference on Advanced ICT13. Hainan, China: Atlantis Press, 2013.

REILY, L. "Comunidades de prática como paisagem da formação em Comunicação Alternativa e Ampliada no Brasil.” In CHUN, R. Y. et al (orgs.). Comunicação Alternativa: ocupando territórios. São Carlos: Marquezine \& Manzini: ABPEE, 2015, pp. 51-67. 
ROCHA, A. N. e DELIBERATO, D. "Tecnologia Assistiva para a criança com paralisia cerebral na escola: identificação das necessidades.” Revista Brasileira de Educação Especial, v.18, pp. 71-92, 2012.

et al. "Procedimentos para a prescrição dos recursos de tecnologia assistiva para alunos da educação infantil com paralisia cerebral". Revista Educação Especial, v. 28, pp. 691-707, 2015.

ROCHA, E. F. et al. "Reflexões sobre as possíveis contribuições da terapia ocupacional nos processos de inclusão escolar." Revista de Terapia Ocupacional da Universidade de São Paulo, v. 14, n. 2, pp. 72-8, maio-ago. 2003.

RODRIGUES, C. L. e ROSE, T. M. S. "Formação de professores: articulação teoria e prática no ensino sobre motivação para aprender." Anais do IV Congresso Brasileiro de Educação Especial, S. Carlos, 2010.

ROMSKI, M. A. e SEVCIK, R. A. "Augmentative Communication and early intervention: myths and realities." Infants \& Young Children, v. 18, n. 3, pp. 174-85, jul.-set. 2005.

ROTHSCHILD, N. e NORRIS, L. Augmentative and Alternative Communication: management of severe communication disorders in children and adults. Brasil: Workshop, 2001.

SADALLA, A. M. F. A. Com a palavra, a professora: suas crenças e suas açōes (tese). UNICAMP, 1997.

e LAROCCA, P. "Autoscopia: um procedimento de pesquisa e de formação”. Educação e Pesquisa, v. 30, n. 3, pp. 419-33, set.-dez. 2004.

SAMESHIMA, F. S. Capacitação de professores no contexto de sistemas de comunicação suplementar e alternativa (tese). UNESP, 2011. 
e DELIBERATO, D. "Identificação das habilidades expressivas utilizadas por um grupo de alunos não-falantes durante atividades de jogos." In MANZINI, E. J. (org.). Inclusão do aluno com deficiência na escola: os desafios continuam. Marília: ABPEE, 2007, pp. 37-50.

SANDBERG, A. D. "Literacy learning and aided communication." In SMITH, M. M. e MURRAY, J. (eds.). The silent partner?: language, intervention and aided communication. Guildford: J \&R Press Ltd., 2016, pp. 159-73.

SAUSSURE, F. Curso de Linguistica Geral. Trad. Antônio Chelini, José Paulo Paes e Izidoro Blikstein. São Paulo: Cultrix, 2006.

SCHIRMER, C. R. "A comunicação alternativa na escola.” In NUNES, L. R.; Pelosi, M. (orgs.). Compartilhando experiências: ampliando a comunicação alternativa. Marília: ABPEE, 2011, pp. 183-96.

. "Comunidade on-line de professores das salas de recursos multifuncionais de referência.” In NUNES, L. R. e SCHIRMER, C. R. Salas Abertas: formação de professores e práticas pedagógicas em comunicação alternativa e ampliada nas salas de recursos multifuncionais. Rio de Janeiro: EdUERJ

- Comunicação Alternativa e formação inicial de professores para a Escola Inclusiva (tese). Universidade do Estado do Rio de Janeiro, 2012.

e BERSCH, R. “Comunicação Aumentativa e Alternativa.” In SCHIRMER, C. R. et al. Atendimento Educacional Especializado: deficiência física. São Paulo: MEC/SEESP, 2007.

e NUNES, L. R. "Introdução à comunicação alternativa em classes comuns de ensino.” In NUNES, L. R. et al. (eds.). Comunicar é preciso: em busca das melhores práticas na educação do aluno com deficiência. Marília: ABPEE, 2011, pp. 81-91. 
e . "A formação continuada de professores das Salas Recursos Multifuncionais do Rio de Janeiro em Tecnologia Assistiva.” Projeto de Pesquisa aprovado pela FAPERJ, 2013.

et al. "Comunicação para Todos - em busca da inclusão social e escolar.” In NUNES, L. R. ; Pelosi, M. Um retrato da Comunicação Alternativa no Brasil: relato de pesquisas e experiências. Rio de Janeiro: 4 Pontos /FINEP, v. 2, pp. 130-35, 2007.

et al. "Formação em serviço de professores para introdução da Comunicação Alternativa em sala de aula." Anais em CDROM do III Congresso Brasileiro de Educação Especial. São Carlos: UFSC, 2008.

et al. "Formação continuada de professores em comunicação alternativa - trabalhando em equipe." Anais do IX Encontro de Pesquisa em Educação da Região Sudeste. Marília: Kubo Multimídia, 2009.

et al. "Formação continuada em serviço de professores para uso da Tecnologia Assistiva e Comunicação Alternativa em sala de aula”. In NUNES, L. R. et al. (orgs.). Compartilhando experiências: ampliando a comunicação alternativa. Marília: ABPEE, 2011, pp. 161-73.

SCHOMMER, P. C. Comunidades de prática e articulação de saberes na relação entre universidade e sociedade (tese). FGV, 2005.

SCHÖN, D. "Formar professores como profissionais reflexivos." In NÓVOA, A. (org.). Os professores e sua formação. Lisboa: Publicações Dom Quixote, 1995, pp. 77-91.

SCHOPLER, E. (ed.). "International priorities for developing autism services via the TEACCH model”. International Journal of Mental Health, p. 29, 2000 . 
SEVCIK, R. A. e ROMSKI, M. A. "The role of language comprehension in establishing early augmented conversation.” In REICHLE, J. et al. (org.). Augmentative and alternative communication series: exemplary practices for beginning communicators: implications for $A A C$. Baltimore: Paul $\mathrm{H}$. Brookes, 2002, pp. 453-76.

SILVA, B. “Tecnologias, ecologias da comunicação e contextos educacionais”. In MARTINS, M. e PINTO, M. (orgs.). Comunicação e cidadania: Actas 5. ${ }^{\circ}$ Congresso da Associação Portuguesa de Ciências da Comunicação. Braga: Centro de Estudos de Comunicação e Sociedade (Universidade do Minho), 2008, pp. 1908-20.

SILVA, T. M. A autoscopia como ferramenta para a formação continuada de professores de Sala de Recursos Multifuncionais (dissertação). UERJ, 2016.

SIMPSON, R. L. et al. "Inclusion of learners with autism spectrum disorders in general education settings". Top. Lang. Disorders, v. 23, n. 2, 2003.

SMITH, M. M. "Environmental influences on aided language development: the role of partner adaptation.” In VON TETZCHNER, S. e GROVE, N. (eds.). Augmentative and alternative communication: developmental issues. London: Whurr, 2003, pp. 155-75.

SOTO, G. et al. "Effectiveness of multifaceted narrative intervention on the stories told by a 12-year-old girl who use AAC." Augmentative and Alternative Communication, v. 24, n. 1, pp. 76-87, 2008.

SOUZA, V. L. V. e PELOSI, M. B. "Pranchas estáticas e dinâmicas construídas com símbolos ARASAAC em softwares de livre acesso." Cadernos de Terapia Ocupacional da UFSCar, v. 22, pp. 301-06, 2014.

et al. "Comunicação Alternativa: comparação de softwares gratuitos elaborados com os símbolos Arasaac: projecto TICO, Araboard e in-tic." Anais do V Congresso Brasileiro de Comunicação Alternativa. Gramado, 2013. 
STRUM, J. et al. "Literacy development of children who use AAC." In BEUKELMAN, D. R. e MIRENDA, P. Augmentative and alternative communication: supporting children \& adults with complex communication needs. Baltimore, MD: Paul H. Brookes, 2005, pp. 351-89.

SUPLINO, M. Currículo Funcional Natural. Guia prático para a educação na área de autismo e deficiência mental. Brasília, 2005.

TOGASHI, C. M. A Comunicação Alternativa e Ampliada e suas contribuições para o processo de inclusão de um aluno com Transtorno do Espectro do Autismo com distúrbios na comunicação (dissertação). UERJ, 2014.

TOMAZELLO, M. Origens culturais da aquisição do conhecimento humano. São Paulo: Martins Fontes, 2003.

TORRES, P. L. et al. "Uma proposta de aprendizagem colaborativa para o processo ensino aprendizagem.” Revista Diálogo Educacional, 9, v. 4, n. 13, pp.129-45, set.-dez. 2004.

TREVIZOR, T. T. e CHUN R. Y. "O desenvolvimento da linguagem por meio do sistema pictográfico de comunicação.” Pro-fono, v. 16, n. 3, pp. 323-32, 2004.

VAN BALKOM, H. e VERHOEVEN, L. "Literacy learning is users of AAC: a neurocognitive perspective". Augmentative and Alternative Communication, n. 26, pp. 149-57, 2010.

VAVOULA, G. N. D4.4: a study of mobile learning practices: internal report of MOBIlearn Project, 2005.

VELTRONE, A. A. e MENDES, E. G. "Caracterização dos profissionais responsáveis pela identificação da deficiência intelectual em escolares.” Revista Educação Especial, v. 24, n. 39, pp. 61-76, Santa Maria, jan.-abr. 
2011. Disponível em: http://www.ufsm.br/revistaeducacaoespecial. Acesso em: 22 dez. 2011.

VERUSSA, E. O. e MANZINI, E. J. “Tecnologia Assistiva para o ensino de alunos com deficiência: um estudo com professores do ensino fundamental." Anais do V Congresso Brasileiro Multidisciplinar de Educação Especial, Londrina, 2009.

VIGOTSKI, L. S. Imaginação e criatividade na infância. São Paulo: Martins Fontes, 2014, p. 31.

VILARONGA, C. A. R. e MENDES, E. G. "Ensino colaborativo para o apoio à inclusão escolar: práticas colaborativas entre os professores.” Revista Brasileira de Estudos Pedagógicos [online], v. 95, n. 239, pp. 139-51, Brasília, jan.-abr. 2014. Disponível em: http://www.scielo.br. Acesso em: 09 jan. 2017.

VON TETZCHNER S. "The contexts of early aided language acquisition." Proceedings of 7th Biennial Conference of the International Society for Augmentative and Alternative Communication, Vancouver, Canadá, 1996.

. "Suporte ao desenvolvimento da comunicação suplementar e alternativa." Comunicação alternativa: teoria, prática, tecnologias e pesquisa. São Paulo: Memnon, 2009, pp. 14-25.

e MARTINSEN, H. Introdução à Comunicação Aumentativa e Alternativa. Porto: Porto Editora, 2002.

et al. "Preliminaries to a comprehensive model of augmentative and alternative communication." In e JENSEN, M. H. (eds.). Augmentative and alternative communication: European perspectives. London, UK: Whurr, 1996, pp. 19-36. 
et al. "Acquisition of graphic communication by a young girls without comprehension of spoken language." Disability and Rehabilitation, v. 26, n. 2, pp. 1335-46, 2004.

et al. "Inclusão de crianças em educação pré-escolar regular utilizando comunicação suplementar e alternativa." Revista Brasileira de Educação Especial, v. 11, n. 2, pp. 151-84, 2005.

WALTER, C. C. F. Os efeitos da adaptação do PECS ao curriculum funcional natural em pessoas com autismo infantil (dissertação). UFSCar, 2000.

Avaliação de um programa de comunicação alternativa e ampliada para mães de adolescentes com autismo (tese). UFSCar, 2006.

. "Comunicação alternativa para pessoas com autismo: o que as pesquisas revelam sobre o uso do PECS por pessoas com autismo.” In DELIBERATO, D et al. Comunicação alternativa: teoria, prática, tecnologia e pesquisa. São Paulo: Memnon, 2009, pp. 96-106.

e ALMEIDA, M. A. "Avaliação de um programa de comunicação alternativa e ampliada para mães de adolescentes com autismo.” Revista Brasileira de Educação Especial [online], v. 16, n. 3, 2010.

e NUNES, L. R. P. “Comunicação alternativa para alunos com autismo no ensino regular." Revista Educação Especial, v. 26, n. 47, pp. 587-602, Santa Maria, set.-dez. 2013.

WENGER, E. Communities of practice: learning, meaning and identity. Cambridge, England: Cambridge University Press, 1998.

ZANATA, E. M. Planejamento de práticas pedagógicas inclusivas para alunos surdos numa perspectiva colaborativa (tese). UFSCar, 2005. 
ZEICHNER, K. "Novos caminhos para o practicum: uma perspectiva para os anos 90.” In NÓVOA, A. (org.). Os professores e sua formação. Lisboa: Publicações Dom Quixote, 1992, pp. 117-38.

. "Action research: personal renewal and social reconstruction". Educational Action Research, v. 1, n. 2, pp. 199-219, 1993.

ZILBOVICIUS, M. et al. "Autismo: neuroimagem". Revista Brasileira de Psiquiatria, pp. 21-8, 2006.

ZUTTIN, F. S. Tecnologia assistiva na educação: consideraçôes sobre os recursos pedagógicos adaptados (monografia). UNESP, 2008. 